\title{
INFLUÊNCIA DA ÉPOCA DE PLANTIO E CORTE NA PRODUTIVIDADE DA CANA-DE-AÇÚCAR
}

\author{
LUIS FERNANDo SANGLADE MARCHIORI
}

Tese apresentada à Escola Superior de Agricultura "Luiz de Queiroz", Universidade de São Paulo, para obtenção do título de Doutor em Agronomia, Área de Concentração: Fitotecnia.

P I R A C IC A B A

Estado de São Paulo - Brasil

Julho - 2004 


\title{
INFLUÊNCIA DA ÉPOCA DE PLANTIO E CORTE NA PRODUTIVIDADE DA CANA-DE-AÇÚCAR
}

\author{
LUIS FERNANDO SANGLADE MARCHIORI
}

Engenheiro Agrônomo

Orientador: Prof. Dr. GIL MIGUEL DE SOUSA CÂMARA

Tese apresentada à Escola Superior de Agricultura "Luiz de Queiroz", Universidade de São Paulo, para obtenção do título de Doutor em Agronomia, Área de Concentração: Fitotecnia.

P I R A C IC A B A

Estado de São Paulo - Brasil

Julho - 2004 
Dados Internacionais de Catalogação na Publicação (CIP)
DIVISÃO DE BIBLIOTECA E DOCUMENTAÇÃO - ESALQ/USP

Marchiori, Luis Fernando Sanglade

Influência da época de plantio e corte na produtividade de cana-de-açúcar / Luis

Fernando Sanglade Marchiori. - - Piracicaba, 2004.

$273 p$.

Tese (doutorado) - - Escola Superior de Agricultura Luiz de Queiroz, 2004.

Bibliografia.

1. Cana-de-açúcar 2. Época de colheita 3. Época de plantio 4. Mudas I. Título

CDD 633.61

"Permitida a cópia total ou parcial deste documento, desde que citada a fonte - 0 autor" 
DEDICO

a minha esposa e filho,

Célia e Lucas

OFEREÇO

a minha Família, 


\section{AGRADECIMENTOS}

À Escola Superior de Agricultura "Luiz de Queiroz" - Universidade de São Paulo e Departamento de Produção Vegetal pela oportunidade de realizar o curso.

Ao amigo Prof. Dr. Edgar Gomes Ferreira de Beauclair, pela orientação, apoio, ensinamentos de vida e por compartilhar suas experiências.

Ao amigo Prof. Dr. Gil Miguel de Sousa Câmara, por toda colaboração.

A Prof ${ }^{a} \operatorname{Dr}^{a}$ Sonia Maria de Stefano Piedade pelas análises estatísticas e orientações.

Aos colegas Engenheiros Agrônomos João Carlos Tardivo e Maximiliano Scarpari, pela ajuda e contribuições ao trabalho.

Ao Sr. Celso José Negretti pela ajuda e incentivo.

Aos funcionários da Fazenda Areão da ESALQ pelo companheirismo.

À minha família, pela paciência e compreensão, obrigado pelo amor e carinho...

Enfim..., a todos que colaboraram e enviaram boas energias para este trabalho! 


\section{SUMÁRIO}

Página

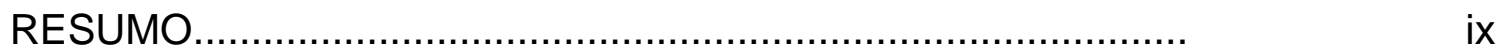

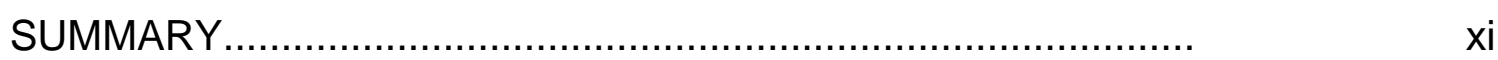

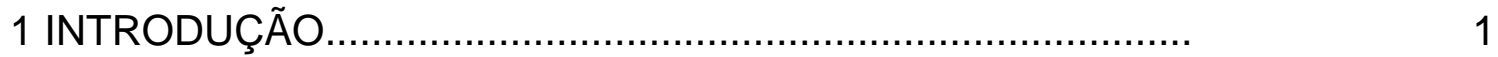

2 REVISÃO DE LITERATURA...................................... 5

2.1 Clima, crescimento e desenvolvimento da cana-de-açúcar no Brasil............................................. 10

2.1.1 Ecofisiologia da cana-de-açúcar................................. 10

2.2 Manejo dos canaviais............................................ 12

2.3 Fatores ecológicos que atuam direta ou indiretamente no crescimento e desenvolvimento da cana-de-açúcar.............. 15

2.3.1 Influência da temperatura..................................... 19

2.3.2 Influência da luz................................................ 22

2.3.3 Influência da radiação solar......................................... 24

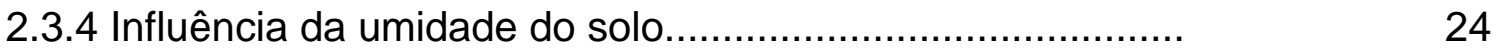

2.3.5 Influência da fertilidade dos solos............................... 26

2.3.6 Influência da evapotranspiração.................................. 28

2.3.7 Balanço hídrico................................................. 29

2.4 Tratos Culturais................................................

2.4 .1 Plantio.......................................................... 30

2.4.2 Influência das épocas de plantio................................ 31

2.4.2.1 Efeitos do estresse hídrico.................................. 36

2.4.3 Plantio convencional e de cana inteira.......................... 38 
2.4.3.1 Influência do comprimento dos toletes no

plantio de cana-de-açúcar.............................................. 40

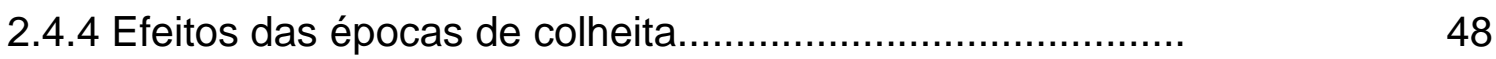

3 MATERIAL E MÉTODOS ...............................................

3.1 Delineamento experimental e modelo matemático utilizados. 55

3.2 Variedades utilizadas.......................................................

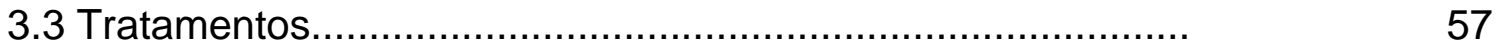

3.3.1 Parcelas - épocas de plantio........................................... 57

3.3.2 Subparcelas em faixas - épocas de corte........................... 57

3.3.3 Sub-subparcelas - picação das mudas..............................

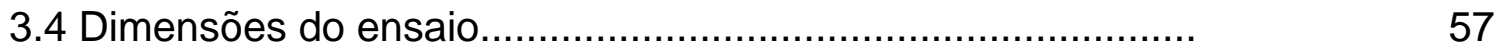

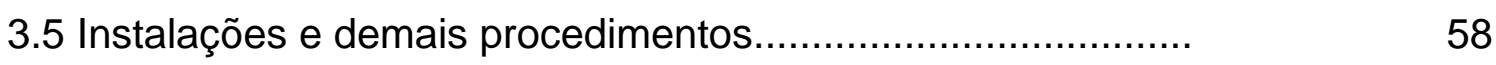

3.5.1 Preparo do solo, sulcação, adubação e plantio.................... 58

3.5.2 Épocas de plantio e corte................................................ 58

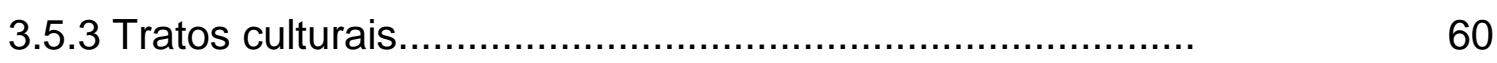

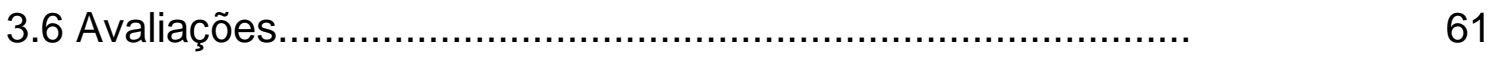

3.6.1 Avaliação de produtividades agrícola e industrial................. 61

3.6.2 Informações meteorológicas.................................................. 62

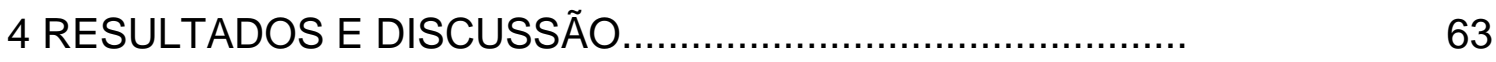

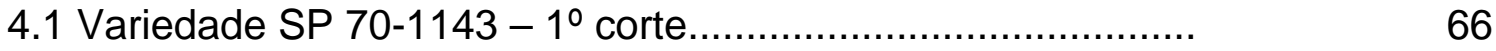

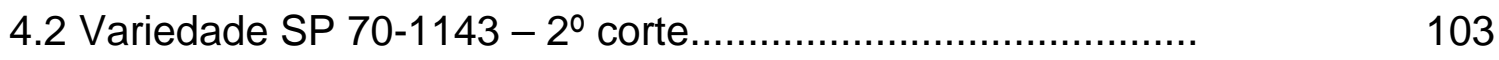

4.3 Variedade NA 56-79 $-1^{\circ}$ corte............................................. 133

4.4 Variedade NA 56-79 - 20 corte.......................................... 166

4.5 Variedade SP 71-1406 $-1^{\circ}$ corte ........................................ 197

4.6 Variedade SP 71-1406 $-2^{\circ}$ corte........................................ 232

4.7 Resumo das variedades SP 70-1143, NA 56-79 e

SP $71-1406-1{ }^{\circ}$ e $2^{\circ}$ cortes................................................

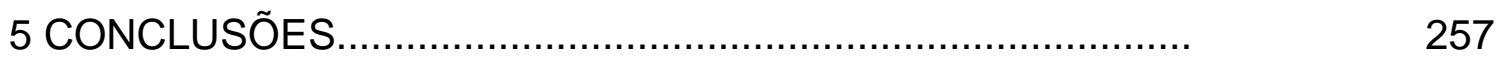

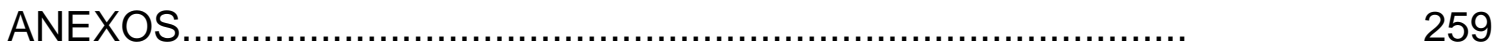

REFERÊNCIAS BIBLIOGRÁFICAS...................................... 261 


\title{
INFLUÊNCIA DA ÉPOCA DE PLANTIO E CORTE NA PRODUTIVIDADE DA CANA-DE-AÇÚCAR
}

\author{
Autor: LUIS FERNANDO SANGLADE MARCHIORI \\ Orientador: Prof. Dr. GIL MIGUEL DE SOUSA CÂMARA
}

\section{RESUMO}

O planejamento de colheita na cultura da cana-de-açúcar busca otimizar o retorno econômico, baseado no conceito de que a cana tem uma época, durante o ano, onde ocorre máxima concentração de sacarose nos colmos. Realizaram-se neste trabalho estudos enfocando as influências dos fatores edafo-climáticos sobre o rendimento e açúcares totais recuperáveis. Foram testadas as hipóteses de que há interação entre as épocas de plantio e corte, bem como a hipótese de que há interação do tratamento muda inteira e picada com cada época de plantio. Utilizaram-se dados de pesquisa conduzida, no Campo de experimentação da COPERSUCAR - Piracicaba/SP, num solo Latossol Vermelho Eutrófico. O delineamento utilizado foi blocos ao acaso, com parcelas subdivididas em faixas e sub-subparcelas dentro das faixas. Os tratamentos foram épocas de plantio (Novembro, Janeiro, Março, Maio), as faixas foram épocas de corte (Maio, julho, Setembro, Novembro), e os subsubtratamentos foram mudas picada e inteira. Mediram-se as variáveis: toneladas de colmos (TCH) e toneladas de açúcar por hectare (TAH), e açúcar total recuperável (ATR). A soqueira foi avaliada da mesma forma que o $1^{\circ}$ corte, aos (12) meses de idade. Foram instalados três experimentos, cada um com uma variedade, SP 70-1143, NA 56-79 e SP 71-1406. Os experimentos foram instalados e repetidos em três anos-safra, 1983/84, 1984/85 e 1985/86, com 
colheitas nas safras dos anos de 1985 até 1988, obtendo-se assim, rendimentos de estágios iguais em anos diferentes e estágios diferentes no mesmo ano. Concluiu-se que as épocas de plantio afetaram TCH, ATR e TAH do $1^{\circ}$ corte; épocas de plantio interagiram com os tipos de mudas na cana planta; épocas de corte afetaram TCH, ATR e TAH nas canas planta e soqueiras; ATR sempre evoluiu do início para o final da safra, com os picos nos meses de setembro e novembro; plantios tardios atrasam a maturação; os valores de TAH acompanham as curvas de ATR sendo influenciados por $\mathrm{TCH}$. Para a variedade SP 70-1143 no primeiro corte o clima influenciou os resultados de épocas de plantio e de tipos de mudas; os menores valores de $\mathrm{TCH}$ foram obtidos nas épocas de plantio Maio com mudas de cana picada e nas demais épocas de plantio não houve diferenças, indicando que se podem plantar mudas de cana inteiras em qualquer época; nos dois cortes estudados, os maiores valores de ATR foram obtidos na colheita de Setembro e os menores valores foram obtidos na época de plantio de Maio indicando que o pico de maturação ocorre no mês de setembro. Para a variedade NA 56-79 os valores de $\mathrm{TCH}$ das mudas picadas e inteiras não mostraram diferenças indicando que se pode plantar cana inteira; os maiores valores de ATR e TAH foram obtidos a partir das colheitas de Julho. Para a variedade SP 71-1406, no primeiro corte, houve superioridade para mudas picadas sendo o melhor manejo, os menores valores de $\mathrm{TCH}$ foram obtidos no plantio de Maio e o maior valor de ATR foi obtido na colheita de Novembro; nos dois cortes os valores de TAH e de ATR indicaram que a colheita deve ser feita partir de setembro. 


\title{
INFLUENCE OF PLANTING AND HARVESTING SEASON ON SUGARCANE PRODUCTIVITY
}

\author{
Author: LUIS FERNANDO SANGLADE MARCHIORI \\ Advisor: Prof. GIL MIGUEL DE SOUSA CÂMARA, Ph.D.
}

\section{ABSTRACT}

Harvest planning in sugarcane attempts to optimize the crop's economic return based on the concept that sugarcane presents, along the cropping season, a period during which the maximum concentration of sucrose occurs in the stalks. This work consisted of studies that focused on the influences of edaphic-climatic factors on yield and total recoverable sugars. The hypothesis was tested that an interaction exists between the planting and harvesting seasons, as well as the hypothesis that an interaction exists between the whole-stalk and the bud seedling treatments with each planting season. Data from a research conducted at COPERSUCAR's Experimental Field Piracicaba/SP, in a Red Eutrophic Latosol, were used. A random blocks design with strip split-plots was used, where sub-subplots were allocated within strips. Treatments were planting seasons (November, January, March, May), with harvesting seasons represented by strips (May, July, September, November), while sub-subtreatments consisted of bud and whole-stalk seedlings. The variables measured were: tons of sugarcane stalks (TSS) and tons of sugar per hectare (TSH), and total recoverable sugar (TRS). The ratoon (second cut) was evaluated in the same manner as the $1^{\text {st }}$ cut, when sugarcane was 12 months old. Three experiments were installed, each consisting of one variety: SP 701143, NA 56-79, and SP 71-1406. The experiments were installed and 
replicated in three cropping years: 1983/84, 1984/85, and 1985/86, with harvests in the cropping seasons from 1985 through 1988; therefore, yields for the same stage in different years, and yields for different stages in the same year were obtained. It was concluded that planting seasons affected TSS, TRS, and TSH in the $1^{\text {st }}$ cut; planting seasons interacted with seedling types in one-year-old sugarcane; harvesting seasons affected TSS, TRS, and TSH in one-year-old and ratoon sugarcane; TRS always progressed from the beginning to the end of the cropping season, with peaks in the months of September and November; late plantings delayed maturation; TSH values followed the TRS curves, and were influenced by TSS. In the first cut of variety SP 70-1143, climate influenced the planting season and seedling type results; the smallest TSS values were obtained in the May planting seasons with bud seedlings, while no differences were observed in the other planting seasons, indicating that whole-stalk seedlings can be planted in any season; in both cuts under study, the highest TRS values were obtained for the September harvesting, and the smallest values were obtained for the May planting season, indicating that peak maturity occurs in the month of September. In variety NA 56-79, the TSS values for bud and whole-stalk seedlings did not show differences, indicating that whole-stalk cane can be planted; the highest TRS and TSH values were obtained from harvests made in July. In the first cut of variety SP 71-1406, the best management consisted of bud seedlings, which were superior; the smallest TSS values were obtained for the May planting and the highest TRS value was obtained for the November harvesting; in both cuts, the TSH and TRS values indicated that harvesting should be done beginning in September. 


\section{INTRODUÇÃO}

O planejamento de colheita na cultura da cana-de-açúcar busca otimizar o retorno econômico da cultura, baseado no conceito de que a cana tem uma época, durante o ano, onde ocorre máxima concentração de sacarose nos colmos, mais propícia para colheita. Segundo a Cooperativa Central dos Produtores de Açúcar e Álcool do Estado de São Paulo (COPERSUCAR) (1982) o objetivo primordial da agroindústria sucro-alcooleira é a recuperação máxima da sacarose da cana-de-açúcar ao menor custo possível. Para se atingir este objetivo, depende-se diretamente da produtividade e da qualidade tecnológica da matéria prima a ser processada, aliada às características e à eficiência da unidade industrial.

O acúmulo de sacarose ao longo da safra, descrito em termos de quilogramas de açúcar por tonelada de cana, é um processo bastante detalhado em diversos trabalhos relacionados ao manejo de variedades e da cultura em geral, e sofre também, efeito do clima, à semelhança do rendimento agrícola (Van Dillewijn, 1952; Humbert, 1968; Alexander, 1973; Nascif et al., 1981; Ahmed \& Mariotti, 1983; Orlando Filho, 1983; COPERSUCAR, 1983; Beauclair \& Penteado, 1984; Paranhos, 1987).

Os estímulos ambientais promovem diferentes resultados nas plantas de acordo com o estádio fenológico em que se encontram; assim, a suficiente disponibilidade de água na fase de perfilhamento das plantas de cana-deaçúcar vai resultar em abundante perfilhamento e a mesma situação na fase de maturação fisiológica vai desencadear processos de inversão da sacarose o que não seria interessante em época de colheita (Van Dillewijn, 1952; Humbert, 1968; Alexander, 1973). 
Diversos fatores podem interferir na produtividade e na qualidade tecnológica da cana-de-açúcar, que no final representa a integração das diferentes condições a que ficou submetida à cultura (Orlando Filho, 1983; COPERSUCAR, 1983).

O ciclo de desenvolvimento da cana-de-açúcar varia desde 10 meses na Luisiana, até 2 anos no Hawai, Peru e África do Sul. Nos demais países produtores é de 14 a 18 meses para cana planta e 12 meses para soca (Humbert, 1968). A cada ciclo, a cultura é submetida durante o seu desenvolvimento, a diferentes condições ambientais (clima, solo), sendo o rendimento agrícola afetado diretamente por estas condições, como também, pelo manejo empregado em relação à época de plantio, variedade, tipo de muda, época de corte e estágio de desenvolvimento da cultura (Humbert, 1968). Em função de todas estas causas de variação ao longo do ciclo, surge a necessidade de se prever as respostas da cultura aos diferentes estímulos para fins de planejamento.

Beauclair \& Penteado (1984) estabelecem a programação do corte de uma lavoura de cana-de-açúcar como uma atividade fundamental na rentabilidade do empreendimento, pois pode aumentá-la praticamente sem custo adicional. Ressaltam porém, que existem poucos trabalhos que tratam o assunto do ponto de vista gerencial com o objetivo de auxiliar a tomada de decisões sobre o cronograma de corte das áreas próprias, de forma a produzir o máximo de sacarose. Os mesmos autores citam, ainda, que trabalhos realizados na Austrália permitiram que o planejamento de corte durante a safra fosse alterado, maximizando a rentabilidade da cultura. Nestes trabalhos, a diferença varietal apesar de evidente, não se traduziu em mudanças nas respostas ao ambiente, ao se variar épocas de plantio e de corte, ou seja, ocorreram semelhanças no comportamento das variedades, mesmo com ciclos de maturação distintos, apenas diferenciando-se quanto à intensidade dos eventos. 
A prática da picação das mudas é comum em todo Estado de São Paulo, mas não vem sendo utilizada em outros locais do mundo, como Taiwan e U.S.A (Louisiana). Existe a crença em nosso meio, de que as mudas vergam mais ou menos de acordo com as condições de umidade e a época de plantio. Esta prática, que também possui poucas referências nas condições do Estado de São Paulo, foi testada neste trabalho em diferentes épocas.

Experimentos realizados pela COPERSUCAR em Piracicaba no Centro de Tecnologia de Piracicaba (CTEP), indicaram os meses de janeiro/fevereiro como os mais favoráveis para o plantio, mas estes resultados são comumente contestados por técnicos de outras regiões. Mesmo levando-se em consideração que as dificuldades operacionais do plantio em grandes áreas, normalmente provocam o alongamento das épocas de plantio, pretendeu-se com este estudo, gerar informações que justificassem uma possível ênfase nas operações de plantio nas épocas favoráveis, e possibilitassem com o manejo da época de corte, determinar as práticas mais rentáveis. Estudos que elevem os índices de produtividade agrícola sem aumento dos custos de produção tornamse necessários e indispensáveis. Assim, este trabalho justificou-se por existir grande polêmica quanto ao assunto, com poucas referências técnicas.

Neste trabalho estudaram-se aspectos do sistema de produção de cana-de-açúcar, com o objetivo de determinar as épocas de plantio e corte mais adequados para cana de ano e meio na região de Piracicaba, Estado de São Paulo. O enfoque foi o estudo das influências dos fatores edafo-climáticos sobre o rendimento e ATR (açúcares totais recuperáveis, calculado a partir de dados de pol da cana e açúcares redutores da cana) da cultura da cana, que, em resumo, são os dados que definem seu valor comercial e industrial.

Este trabalho se realizou baseado nas hipóteses de que há interação entre as épocas de plantio ou brotação e corte, que sofrem influência dos fatores ambientais e seus estímulos, assim cada época de plantio poderia como conseqüência influenciar os resultados de $\mathrm{TCH}$ (toneladas de cana por ha) e cada época de corte poderia influenciar os resultados de ATR (açúcar total 
recuperável por tonelada de cana), bem como a hipótese de que há interação dos tratamentos com mudas de cana inteira e picada com cada época de plantio.

Dessa forma, espera-se através da coleta dos dados relativos ao desempenho da cana-de-açúcar, determinar as épocas de plantio e colheita mais adequadas, e também o melhor manejo das mudas. 


\section{REVISÃO DE LITERATURA}

Desde o ano de 1900, a cana-de-açúcar é um dos maiores cultivos em 69 países dos trópicos e o açúcar, artigo principal do comércio internacional para esses países (Humbert, 1968).

Segundo Doorembos \& Kassam (1979), a cana-de-açúcar tem como origem a Ásia, provavelmente a nova Guiné. A maior parte da cana-de-açúcar comercial é produzida entre as latitudes $35^{\circ} \mathrm{N}$ e $35^{\circ} \mathrm{S}$. A temperatura ótima para o brotamento das mudas é de 32 a $38^{\circ} \mathrm{C}$. Para um ótimo crescimento o ambiente deve apresentar médias de temperaturas diurnas entre 22 e $30^{\circ} \mathrm{C}$, abaixo de $20^{\circ} \mathrm{C}$ diminui a taxa de crescimento, porém para a maturação e colheita, se faz necessário a redução da temperatura para 10 a $20^{\circ} \mathrm{C}$ com isso, ocorre diminuição na taxa de crescimento e maior acúmulo de sacarose, produto mais nobre da cana e objetivo da indústria sucro-alcooleira.

Magalhães (1987), cita que a cana-de-açúcar é cultivada numa ampla faixa de latitudes, desde aproximadamente $35^{\circ} \mathrm{N}$ a $30^{\circ} \mathrm{S}$, e em altitudes que variam desde o nível do março até mil metros. É cultivada em 79 países em uma área de cerca de 12 milhões de hectares.

Há países que avaliam o rendimento da cana pela massa de colmos produzida por unidade de área, que gira em torno de $60 \mathrm{t} \mathrm{ha}^{-1}$ na média mundial (Production Yearbook, 1994), há outros que a avaliam pela quantidade de sacarose obtida por unidade de área, sendo que os colmos possuem em média 7 a 13\% de sacarose e 11 a $16 \%$ de fibra, (Magalhães, 1987).

Para a economia do Brasil e particularmente do Estado de São Paulo, a cultura da cana-de-açúcar é de suma importância, uma vez que foi a primeira lavoura introduzida e explorada no país e, atualmente é uma das principais 
culturas exploradas no Estado de São Paulo (Orlando Filho, 1983; COPERSUCAR, 1983).

O Brasil produziu no ano de 1999, segundo estatística do Agrianual (1999), 335.857 mil toneladas de colmos de cana-de-açúcar, ocupando a primeira posição mundial em termos de produção de açúcar. No Estado de São Paulo, em 1999, a produção de colmos de cana-de-açúcar foi de 199.451 mil toneladas, representando $59,4 \%$ da produção nacional.

Certas áreas, segundo Barbieri \& Villa Nova (1977), possuem clima ideal para a cultura da cana-de-açúcar, sem restrição alguma, ao passo que outras apresentam restrições térmicas e/ou hídricas moderadas, que permitem a produção econômica da cultura sem exigir recursos e técnicas especiais. Entretanto, há aquelas, em que as restrições são limitantes, onde somente o cultivo das variedades selecionadas e o emprego de recursos especiais, podem corrigir deficiências hídricas, ou a adoção de técnicas culturais adequadas previne os efeitos do frio, permitindo a lavoura canavieira econômica.

Em sua publicação da Coordenadoria Regional-Sul, para caracterização da área canavieira, Barbieri \& Villa Nova (1977), cita que a cana-de-açúcar é cultivada em quase todos os 21 estados do Brasil, mas as grandes zonas canavieiras restringem-se principalmente à área costeira, entre as latitudes $8^{\circ}$ e $23^{\circ} \mathrm{S}$. A temperatura média anual é de $20^{\circ} \mathrm{C}$ na região Centro - Sul e $26^{\circ} \mathrm{C}$ na região Norte - Nordeste. A precipitação média anual é de 1.250 a $1.750 \mathrm{~mm}$ no centro - Sul, de 750 a $1.250 \mathrm{~mm}$ no Nordeste e de 1.750 a $2.500 \mathrm{~mm}$ no extremo norte. Cita ainda que, como se observa no quadro 1 , a região Centro-Sul apresenta boas condições climáticas para o desenvolvimento e maturação da cana-de-açúcar. Nessa região, o principal problema climático é a ocorrência de geadas, principalmente nas áreas situadas entre os meridianos $49^{\circ} 40^{\prime} \mathrm{W}$ e $52^{\circ} 00^{\prime} \mathrm{W}$ e paralelos $22^{\circ}$ e $24^{\circ} \mathrm{S}$, (Sul do Estado de São Paulo e norte do Estado do Paraná), situadas no Vale do rio Paranapanema. Essas geadas são causadas por invasões de massas de ar frio proveniente do Sul do 
continente que às vezes atingem grandes extensões mesmo acima do paralelo $22^{\circ} \mathrm{S}$.

\begin{tabular}{|c|c|c|}
\hline $\begin{array}{c}\text { REGIÃO } \\
\text { CANAVIEIRA }\end{array}$ & \begin{tabular}{|c|} 
TIPO \\
CLIMÁTICO \\
(KOEPPEN)
\end{tabular} & $\begin{array}{l}\text { CARACTERÍSTICAS } \\
\text { REGIONAIS DO CLIMA }\end{array}$ \\
\hline $\begin{array}{c}\text { MATO } \\
\text { GROSSO }\end{array}$ & Aw & $\begin{array}{l}\text { Clima tropical, com seca nos meses de Jun. Jul. Ago. Meses } \\
\text { mais chuvosos Jan. Fev. Mar. Precipitação anual em torno de } \\
1.500 \mathrm{~mm} \text {. Temperatura média anual em torno de } 24^{\circ} \mathrm{C} \text {. }\end{array}$ \\
\hline GOIÁS & Aw & $\begin{array}{l}\text { Clima tropical com seca nos meses de Jun. Jul. Ago. Meses } \\
\text { mais chuvosos Dez. Jan. Fev. Precipitação anual em torno de } \\
1.500 \text { mm. Temperatura média anual em torno de } 22^{\circ} \mathrm{C} \text {. }\end{array}$ \\
\hline \multirow[t]{2}{*}{$\begin{array}{l}\text { MINAS } \\
\text { GERAIS }\end{array}$} & Cwa & $\begin{array}{l}\text { Clima subtropical, seco no inverno (meses de Jun. Jul. Ago.), e } \\
\text { verão chuvoso (meses Nov. Dez. Jan.). Precipitação anual de } \\
1.250 \mathrm{~mm} \text { a } 1.750 \mathrm{~mm} \text {. Temperatura do mês mais quente } \\
\text { superior a } 22^{\circ} \mathrm{C} \text {. }\end{array}$ \\
\hline & Cwbl & $\begin{array}{l}\text { Clima temperado, seco no inverno (meses de Jun. Jul. Ago.) } \\
\text { Verão chuvoso Nov. Dez. Jan. Precipitação anual em torno de } \\
1.500-1.750 \mathrm{~mm} \text {. Temperatura do mês mais quente inferior a } \\
22^{\circ} \mathrm{C} \text {. }\end{array}$ \\
\hline SÃO PAULO & Cwa & $\begin{array}{l}\text { Clima subtropical com seca no inverno (meses de Jun. Jul } \\
\text { Ago.) e verão chuvoso (meses Nov. Dez. Jan.). Temperatura } \\
\text { do mês mais quente superior a } 22^{\circ} \mathrm{C} \text {. Precipitação anual entre } \\
1.250 \mathrm{~mm} \text { e } 1.500 \mathrm{~mm} \text {. Temperatura média anual entre } 20^{\circ} \text { e } \\
22^{\circ} \mathrm{C} \text {. }\end{array}$ \\
\hline PARANÁ & Cfa & $\begin{array}{l}\text { Clima subtropical sempre úmido. Temperatura do mês mais } \\
\text { quente superior a } 22^{\circ} \mathrm{C} \text {. Meses mais secos Jun. Jul. Ago., e } \\
\text { meses mais chuvosos Dez. Jan. e Fev. Precipitação anual em } \\
\text { torno de } 1.250 \mathrm{~mm} \text {. Temperatura média anual em torno de } 20^{\circ} \\
\text { C. }\end{array}$ \\
\hline $\begin{array}{c}\text { SANTA } \\
\text { CATARINA }\end{array}$ & Cfa & $\begin{array}{l}\text { Clima subtropical sempre úmido. Temperatura do mês mais } \\
\text { quente superior a } 22^{\circ} \mathrm{C} \text {. Meses mais secos Jun. Jul. Ago., e } \\
\text { meses mais chuvosos Dez. Jan. e Fev. Precipitação anua } \\
\text { entre de } 1.500 \text { e } 2.000 \mathrm{~mm} \text {. Temperatura média anual entre } \\
18^{\circ} \text { e } 20^{\circ} \mathrm{C} \text {. }\end{array}$ \\
\hline $\begin{array}{l}\text { RIO GRANDE } \\
\text { DO SUL }\end{array}$ & $C f b$ & $\begin{array}{l}\text { Clima subtropical sempre úmido. Temperatura do mês mais } \\
\text { quente inferior a } 22^{\circ} \mathrm{C} \text {. Meses mais secos Nov. Dez. Jan., e } \\
\text { meses mais chuvosos Ago. Set. Out. Precipitação anual em } \\
\text { torno de } 1.500 \mathrm{~mm} \text {. Temperatura média anual entre } 18^{\circ} \text { e } 20^{\circ} \\
\text { C. }\end{array}$ \\
\hline
\end{tabular}

Quadro 1 - Clima da Região Canavieira Centro-Sul do Brasil

Fonte: Barbieri \& Villa Nova, 1977

A temperatura, a insolação e a umidade são fatores determinantes do clima para o desenvolvimento da cana-de-açúcar, planta tropical que se desenvolve melhor em lugares quentes e ensolarados. O clima é o fator que 
mais influencia na produtividade da cana-de-açúcar (Humbert, 1968; Alexander, 1973; Ometo, 1978, 1981; Ide \& Banchi, 1984; Ide \& Oliveira, 1986; Barbieri, 1993), os modelos que não particularizam este efeito podem, no máximo, representar uma fração da variação total (Beauclair, 1994). Segundo Barbieri (1993), de uma ou de outra forma, estes modelos pretendem correlacionar os efeitos dos dados meteorológicos com a produção e rendimento das culturas. Porém, em alguns trabalhos o clima foi isolado e estudou-se o efeito de outros fatores, como atributos do solo em Beauclair (1991 e 1994), medidas de crescimento e análises da planta com relação a determinar níveis adequados da cada nutriente para a cultura (Zambello Júnior \& Orlando Filho, 1980; Beaufils, 1973).

Magalhães (1987) cita que dos fatores ambientais é a temperatura, provavelmente, o de maior significância para o desempenho da cana. Temperaturas altas, geralmente, são bem toleradas pela cultura, desde que haja irrigação, ou umidade no solo. Porém, nas temperaturas baixas (menores que $21^{\circ} \mathrm{C}$ ) a cultura sofre diminuição na taxa de alongamento dos colmos e acúmulo de sacarose.

Castro (1999), afirma que a maturação é considerada um dos aspectos mais importantes na produção da cana-de-açúcar, e que as características varietais são fator de importância no processo de acúmulo de sacarose, que é executado às custas de energia no carregamento ativo da sacarose no vacúolo celular.

Alexander (1973) citando Clements, descreve maturação como a culminação das fases dos processos fisiológicos. A primeira fase termina quando a folha velha se separar de seu internódio; a segunda fase inclui todos os eventos subseqüentes relativos à acumulação de açúcar nos internódios completamente expandidos. Deve-se sempre considerar que o processo de maturação completa está intimamente ligado aos fatores varietais, culturais e ecológicos que influenciaram períodos iniciais da vida da planta 
Gheller (1999), citando Arias (1986) e Alexander (1973) escreve que os canavicultores perceberam que para o acúmulo de mais açúcar, as plantas de cana-de-açúcar deveriam retardar seu ritmo de crescimento, o que geralmente ocorria em condições naturais específicas de combinação de temperatura ambiente e umidade do solo. E, descreve que o processo de maturação fisiológica da cana-de-açúcar consiste em frear a taxa de desenvolvimento vegetativo, sem porém afetar significativamente o processo fotossintético, de maneira que haja maior saldo de produtos fotossintetizados e transformados em açúcares para armazenamento nos tecidos da planta.

Gemente et al. (1986) definem o clima como determinante principal das restrições impostas pelo ambiente físico, constituído pela interação dos componentes clima, solo e planta, que influenciam respectivamente, a época de colheita, o número programado de cortes e a eleição de variedades.

De acordo com Pinazza (1985), a elevação dos índices de produtividade agrícola é beneficiada ou prejudicada pela ação de quatro fatores básicos: físicos, estruturais, institucionais e de desenvolvimento. Os fatores físicos representam as condições edafo-climáticas de uma determinada região e a aptidão para a exploração deste ou daquele produto agrícola, enquanto os institucionais envolvem a ação governamental através das políticas agrícolas implantadas (preço, crédito, comercialização, contingenciamento, incentivos, etc.). Já o fator de desenvolvimento manifesta-se através do sistema de pesquisa, face à capacidade dos conhecimentos gerados possibilitarem incrementos na produtividade. O fator estrutural, é o sistema gerencial adotado, e influi decisivamente no desempenho operacional e estratégico de uma empresa. 


\subsection{Clima, crescimento e desenvolvimento da cana-de-açúcar no Brasil}

\subsubsection{Ecofisiologia da cana-de-açúcar}

Segundo Magalhães (1987), a cana-de-açúcar é uma gramínea perene que perfilha abundantemente na sua fase inicial de desenvolvimento. Quando se estabelece como uma cultura, a competição intra-específica por luz (auto-sombreamento) induz uma inibição no perfilhamento e uma aceleração do crescimento do colmo principal. Este crescimento em altura continua até a ocorrência de temperaturas baixas, ou ainda devido ao florescimento. Em culturas comerciais, o florescimento é uma ocorrência indesejável.

Informações referentes ao comportamento futuro da cultura da canade-açúcar em termos de maturação (acúmulo de sacarose), podem definir o manejo de variedades e até a época ideal de colheita. A colheita da cana tem como diretriz a retirada do campo de cultivo de colmos com o maior conteúdo possível de sacarose, em maturação fisiológica completa ou bastante avançada (COPERSUCAR, 1983). Segundo Gheller (1999), a capacidade de acumulação de açúcar nos colmos, em condições naturais, depende da associação de alguns fatores que induzirão às plantas a acumular sacarose nos colmos. Individualmente, os fatores são:

a. Umidade do solo, que proporciona a absorção dos nutrientes do solo, fundamentais para o desenvolvimento das plantas e em última instância produção de açúcar. A diminuição da umidade no solo, ou uma seca moderada, reduz o crescimento dos entrenós mais jovens e favorece o acúmulo de açúcares nos colmos. Alexander (1973), cita que em 1939, Hartt fez o seguinte comentário sobre os resultados de seu trabalho com água e a maturação da cana: "As plantas de cana providas com água definitivamente eram melhores produtoras de açúcar que as plantas privadas de água, as folhas das primeiras continham dez vezes mais sacarose que as folhas das posteriores, as folhas 
verdes das canas supridas em água continham uma grande quantia de sacarose enquanto as outras perderam sacarose, e o suco extraído das folhas secas de cana das anteriores teve uma relação de qualidade melhor que das posteriores". E subseqüentemente: "O terceiro estudo de água e maturação da cana confirma as conclusões dos primeiros dois estudos: uma provisão abundante de água é essencial para a formação de sacarose nas folhas, para seu transporte para o talo, e para a expressão de açúcar no caldo";

b. Temperatura, que alguns autores (Humbert, 1968; Alexander, 1973; Ometo, 1978, 1981; Ide \& Banchi, 1984; Ide \& Oliveira, 1986; Barbieri, 1993) definem como fator de maior importância para a maturação fisiológica da cana, porque além de afetar a absorção de água e nutrientes através do fluxo transpiratório, é um condicionante não controlável. Para que ocorram os maiores acúmulos de açúcar pela cana-de-açúcar são necessárias oscilações de temperaturas associadas a período de seca moderada;

c. Luminosidade, diretamente ligada ao processo de síntese fotossintética e cuja fonte de energia é a radiação solar; a redução na luminosidade determina menor armazenamento de açúcares e acumulação de amido nas folhas, portanto altera todo o processo de síntese, prejudicando a eficiência das plantas de cana (Humbert, 1968; Alexander, 1973; Ometto, 1978, 1981; Ide \& Banchi, 1984; Ide \& Oliveira, 1986; Barbieri, 1993);

d. Nutrientes minerais, influenciam a maturação da cana de acordo com a época em que estão disponíveis às plantas. assim, as ofertas tardias de nitrogênio favorecem o desenvolvimento vegetativo ao invés do acúmulo de sacarose desejado para esta fase da cultura. Segundo Orlando Filho (1983), o nitrogênio para a cana-de-açúcar é crucial no período de formação da cultura, ou seja, no estágio que se inicia imediatamente após a germinação e termina no fechamento do canavial, o que normalmente ocorre em torno de 3 a 5 
meses. É nessa época que se dá a formação dos perfilhos e, para tanto, é necessária suficiente disponibilidade de nitrogênio no solo. Aproximadamente a partir do fechamento do canavial, a cultura entra num período de crescimento acelerado, desde que haja boas condições de temperatura e umidade. Se o nível de nitrogênio no solo e, conseqüentemente, na cultura, durante o estágio de formação, é baixo, o número de perfilhos que participará do crescimento acelerado também será baixo. Posteriormente, mesmo que haja formação de outros perfilhos, estes não terão condições de serem aproveitados para a moagem na época da colheita;

e. Floração, a transformação da gema apical de vegetativa para reprodutiva, em resposta aos fatores ambientais, interrompe a formação de novos entrenós, impede parcialmente o crescimento da planta, e proporciona condições para o acúmulo de sacarose (Gheller, 1999).

\subsection{Manejo dos canaviais}

Segundo Doorembos \& Kassam (1979), a cana-de-açúcar tem como origem a Ásia, provavelmente a nova Guiné. A maior parte da cana-de-açúcar comercial é produzida entre as latitudes $35^{\circ} \mathrm{N}$ e $35^{\circ} \mathrm{S}$. A temperatura ótima para o brotamento das mudas é de 32 a $38^{\circ} \mathrm{C}$. Para um ótimo crescimento o ambiente deve apresentar médias de temperaturas diurnas entre 22 e $30^{\circ} \mathrm{C}$, abaixo de $20^{\circ} \mathrm{C}$ diminui a taxa de crescimento, porém para a maturação e colheita, se faz necessário à redução da temperatura para 10 a $20^{\circ} \mathrm{C}$ com isso, ocorre diminuição na taxa de crescimento e maior acúmulo de sacarose, produto mais nobre da cana e objetivo da indústria sucro-alcooleira.

Castro (1999), descreve que a curva que caracteriza o crescimento da cana-de-açúcar de primeiro corte é simétrica para cana de ano, mostrando-se bimodal em cana de ano e meio (figura 1). 


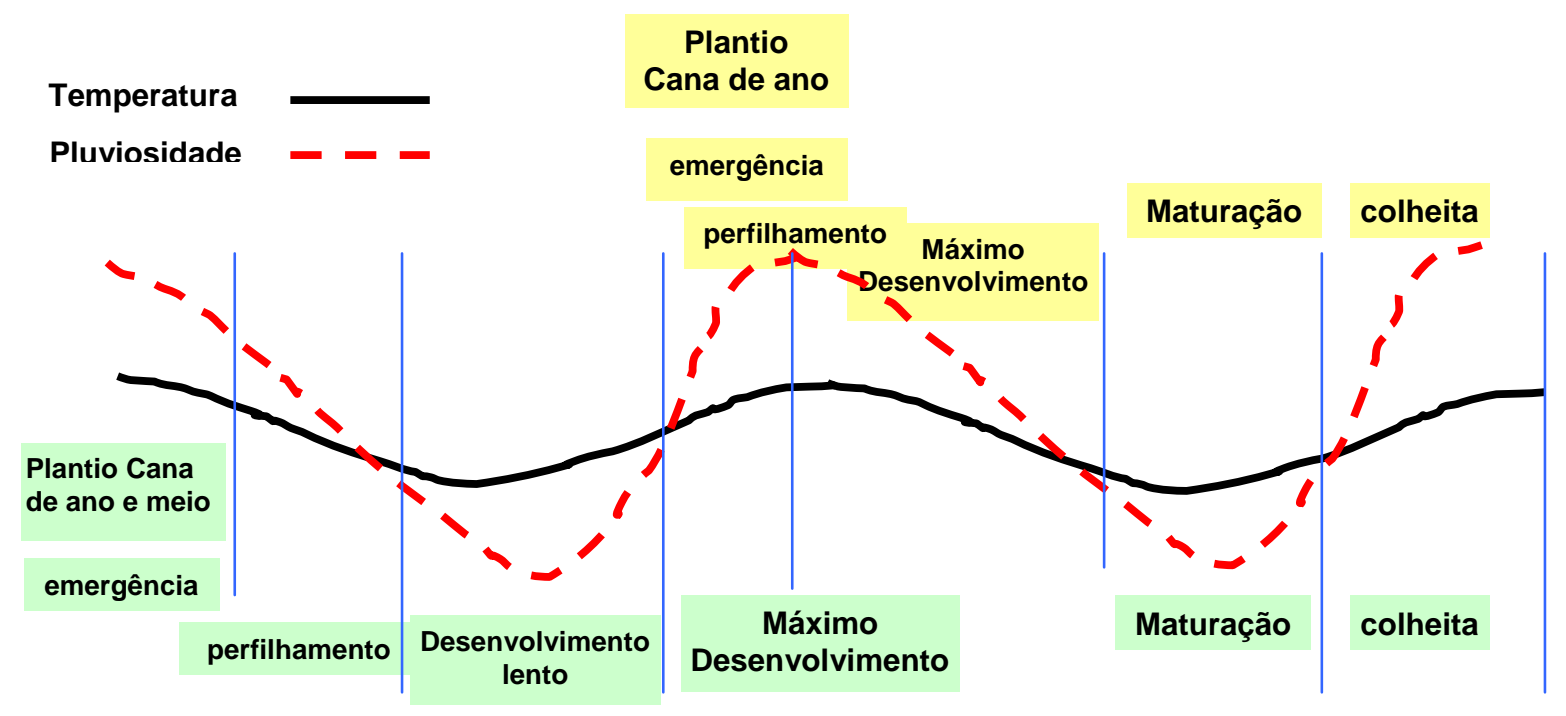

Jan FevMar Abr Mai Jun Jul Aqo Set OutNov Dez Jan FevMar Abr Mai Jun Jul AqoSet Out Nov Dez

Figura 1 - Ciclos da cana-de-açúcar e variações na temperatura e pluviosidade da região centro-sul do Brasil

Fonte: Castro, 1999

Durante os meses iniciais de crescimento e desenvolvimento da canade-açúcar, os processos de armazenamento de açúcar operam em tecidos imaturos e nos colmos com pequeno número de nós com internódios completamente desenvolvidos perto da base do talo. Nessa fase, é o crescimento, ao invés de armazenamento de açúcar, a preocupação primária da planta. Na planta, foi criado previamente um potencial para acumulação de açúcar no tecido de armazenamento já formado. O estabelecimento deste potencial é descrito comumente como processo de maturação. Em condições fisiológicas, o processo de envelhecimento, maturação e amadurecimento não são sinônimos embora possam parecer ao observador casual. Maturidade tem significados diferentes as diferentes pessoas envolvidas com cana-de-açúcar. O significado mais correto pertence à conclusão botânica: colmos aptos a produzir novas plântulas a cada nó (Alexander, 1973). 
A cultura procedente da cana planta, por via de regra, vem seguida de duas a quatro culturas de rebrota (cana soca), podendo em certos casos ultrapassar os oito ciclos. No início o crescimento é lento, aumentando gradualmente até atingir uma taxa máxima de crescimento, após a qual diminui à medida que a cana começa a amadurecer devido ao frio e/ou seca, ou mesmo devido à floração (Doorembos \& Kassam, 1979).

O acúmulo de matéria seca apresenta a forma sigmóide (figura 1), podendo ser dividido em três fases: I) fase inicial, na qual o crescimento é lento; II) fase de rápido crescimento, onde 70 a $80 \%$ de toda matéria seca é acumulada, e; III) fase final, em que o crescimento é novamente lento, acumulando cerca de $10 \%$ da matéria seca total (Machado, 1987). Segundo Küpper, citado por Doorembos \& Kassam (1979), para a cana-de-açúcar, podem ser distinguidas quatro grandes fases de crescimento, conforme pode ser apreciado na figura 2, a seguir.

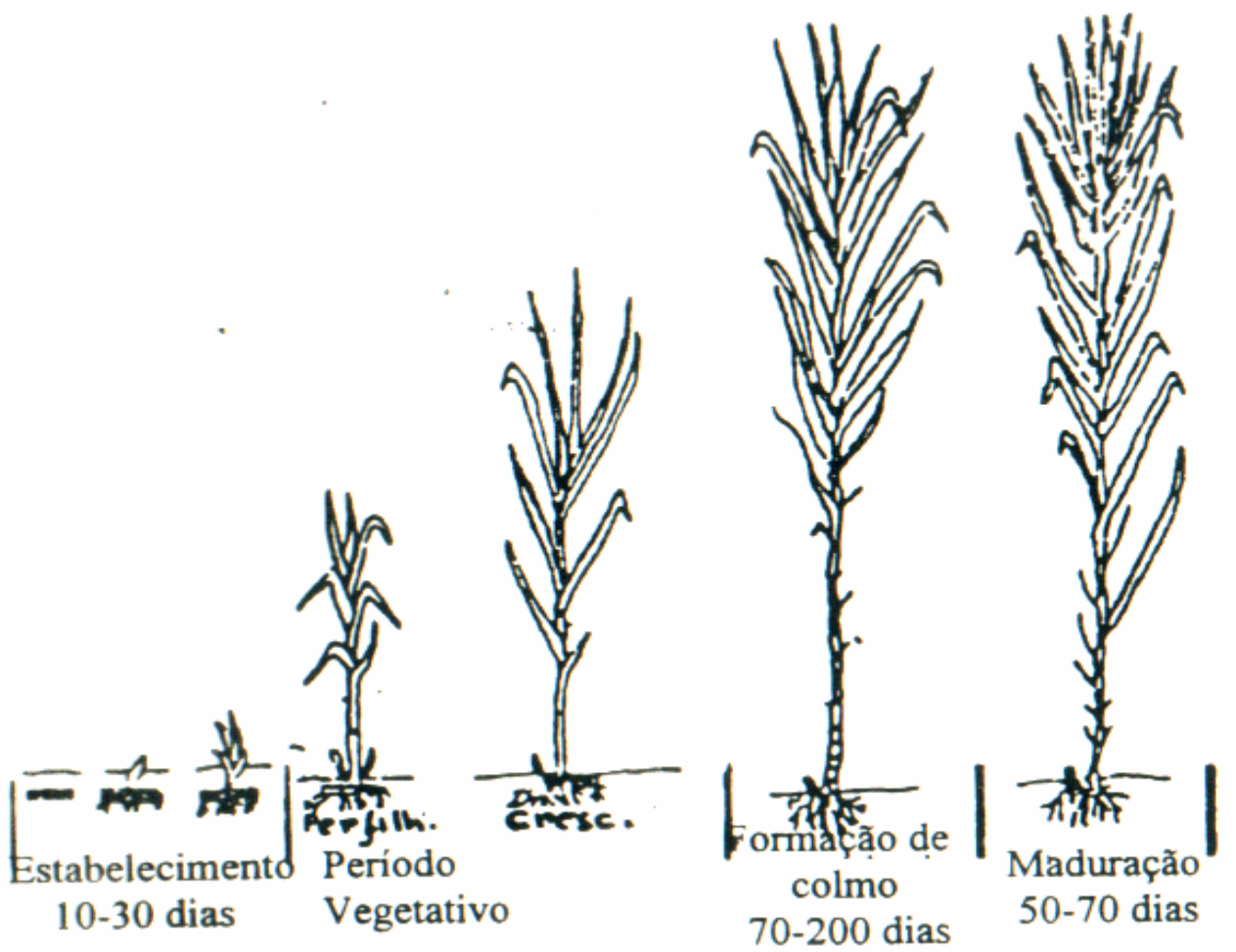

Figura 2 - Períodos de desenvolvimento da cana-de-açúcar

Fonte: Doorembos \& Kassam, 1979 
Outro aspecto importante desta cultura, diz respeito ao sistema radicular. Cada perfilho apresenta um sistema radicular próprio, de forma que, enquanto houver emissão de perfilhos, ocorre aumento no volume de raízes. Esse volume tende a se estabilizar, havendo posteriormente apenas uma renovação das raízes velhas, que vão morrendo. Após o corte da cana-deaçúcar, o sistema radicular antigo mantém-se ainda em atividade por algum tempo, quando tem início a sua substituição pelas raízes dos novos perfilhos da soqueira. Essa substituição é lenta e gradual, ocorrendo um período onde o sistema radicular antigo atua concomitantemente com o novo sistema em formação (Bacchi In: Orlando Filho, 1983).

Segundo Evans, citado por Van Dillewijn (1952), parece haver evidências que as raízes mais profundas atuam por períodos mais longos de tempo do que as superficiais. As raízes das soqueiras normalmente são mais superficiais que as da cana-planta, pelo fato de que os perfilhos das soqueiras brotam mais próximos da superfície do que os da cana-planta. Pelo mesmo fato, quanto maior o número de cortes, mais superficial torna-se o sistema radicular das soqueiras. Esta característica faz com que a cana seja tratada como uma cultura anual, quanto à disponibilidade de água no solo, em razão de que as raízes nascem e crescem gradualmente acompanhando o desenvolvimento da parte aérea da cultura (Camargo, 1976).

\subsection{Fatores ecológicos que atuam direta ou indiretamente sobre o crescimento e desenvolvimento da cana-de-açúcar}

Segundo Barbieri \& Villa Nova (1977), o crescimento da cana-deaçúcar é governado pelas potencialidades genéticas de origem hereditária e pelo meio ambiente. Para a cana-de-açúcar, as condições de todas as estações do ano afetam o desenvolvimento da planta e o sucesso da cultura, uma vez que se colhem colmos, e não frutos ou sementes, todo o período vegetativo no 
decorrer do ciclo está dependente de condições ambientais favoráveis para o seu pleno desenvolvimento.

Castro (1999), Classifica os fatores de produção vegetal que afetam direta e indiretamente os processos fisiológicos das plantas de acordo com o esquema demonstrado na figura 3 , a seguir.

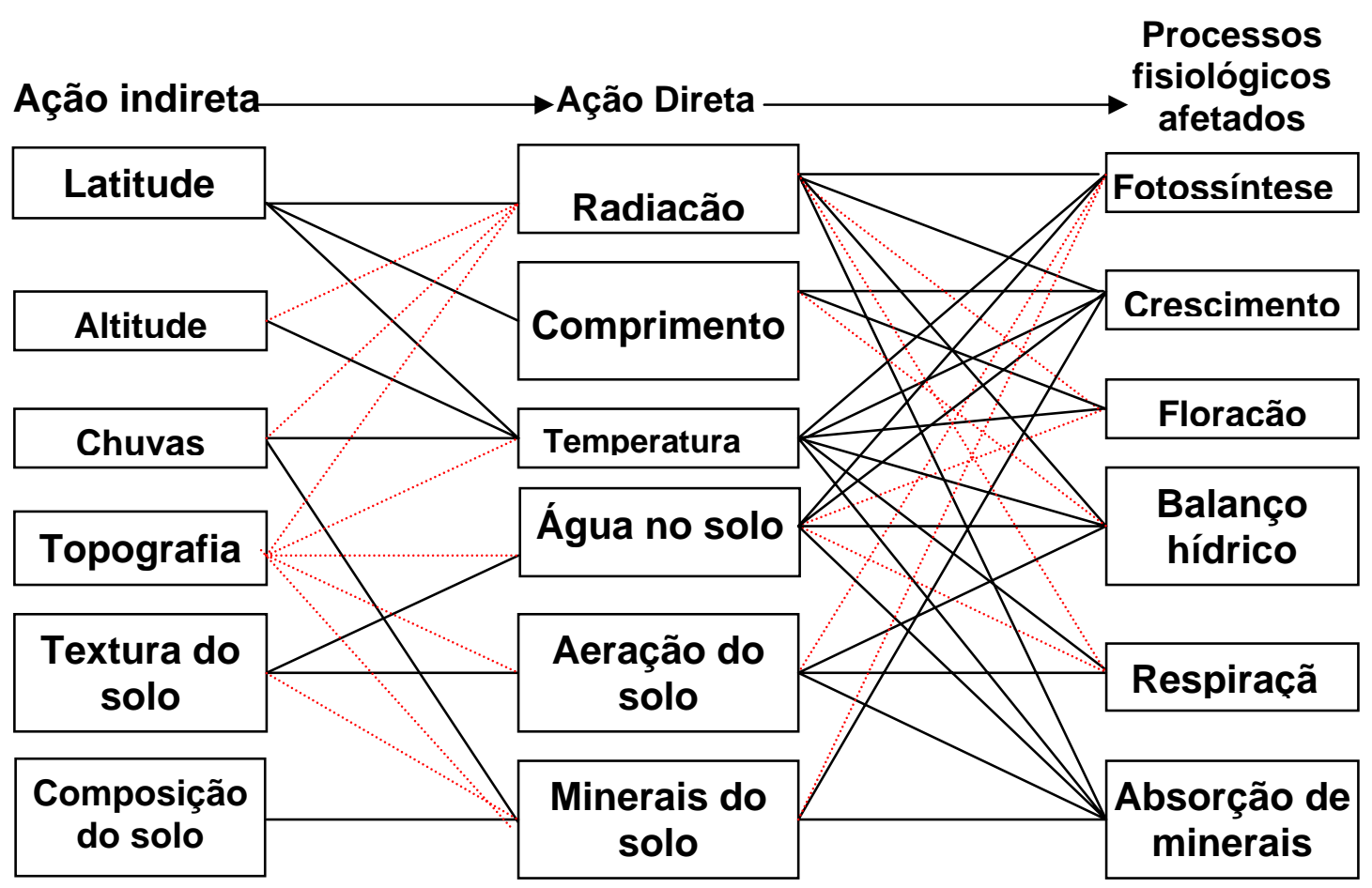

Figura 3 - Classificação dos fatores de produção vegetal que afetam direta e indiretamente os processos fisiológicos das plantas. Linhas cheias correspondem a uma ação mais efetiva do que as linhas interrompidas

Fonte: Castro, 1999

Magalhães (1987), cita que o rendimento econômico da cana-deaçúcar refere-se à produção de sacarose, o mais valioso componente, além de açúcares redutores que contribuem para a formação do melaço, e também a fibra, que pode ser utilizada como combustível alternativo na própria usina. O processamento industrial de cana-de-açúcar pode ser dirigido para a produção 
de combustível líquido para motores de combustão interna, fato que atualmente é rotina para os proprietários de carros movidos a álcool.

As exigências climáticas da lavoura canavieira, como afirmam Barbieri \& Villa Nova (1977), podem diferir bastante segundo a finalidade: açúcar, aguardente ou forragem. Normalmente, as lavouras com a finalidade de extração de açúcar são mais exigentes em clima. Como há necessidade de alta produção de sacarose, a planta precisa encontrar condições de temperatura e umidade adequadas para o seu pleno desenvolvimento na fase vegetativa, seguida de certa restrição hídrica e/ou térmica, para forçar o repouso e enriquecimento em sacarose na época do corte. O ambiente ideal é aquele onde a irrigação ou a precipitação é bem distribuída durante o período de crescimento da planta, seguido de um período relativamente seco antes da colheita, com bastante luminosidade durante toda a estação, pois, segundo os mesmos autores, há correlação entre a incidência luminosa e a produção de açúcar.

Para evitar invernos muito rigorosos, onde pode ocorrer período de hibernação longo, afetando a fase vegetativa, a cultura situa-se nas faixas intertropicais, com poucas incursões na faixa de latitudes mais elevadas da zona subtropical, onde ocorrem temperaturas abaixo de $15^{\circ} \mathrm{C}$, forçando um manejo com variedades precoces e resistentes ao frio, (Barbieri \& Villa Nova, 1977).

A figura 4, a seguir, mostra o regime hídrico e o desenvolvimento da cana-de-açúcar. 


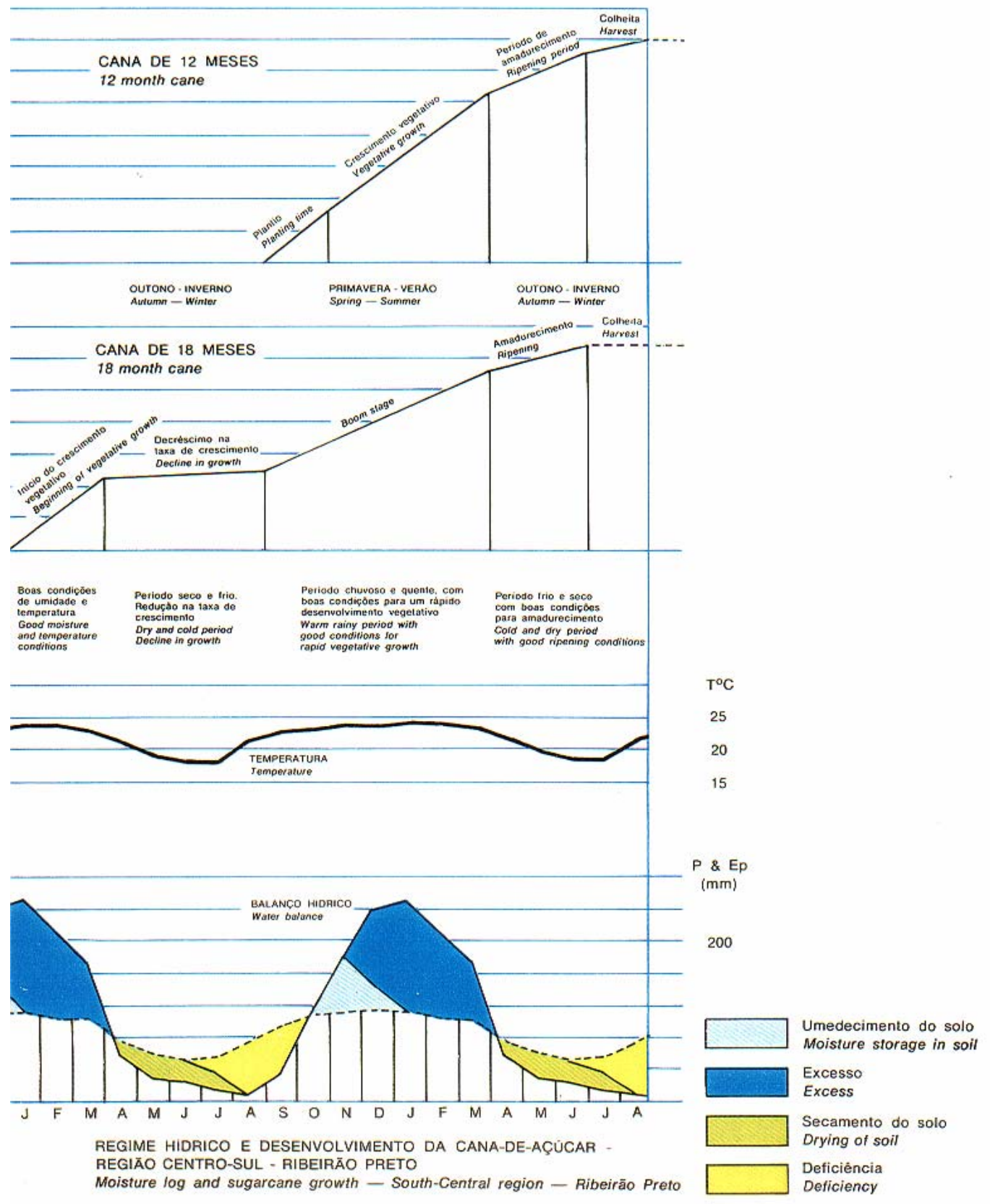

Figura 4 - Regime hídrico e desenvolvimento da cana-de-açúcar Fonte: Barbieri \& Villa Nova, 1977 


\subsubsection{Influência da temperatura}

Os bons rendimentos em açúcar só são observados com o processo de maturação completo da cana-de-açúcar antes do corte. A primeira condição é retardar o crescimento e os agentes mais efetivos são: as baixas temperaturas e a seca moderada. A temperatura é talvez o fator mais efetivo para a cana-de-açúcar acumular sacarose. O tempo frio retarda o desenvolvimento e melhora o teor de sacarose. Ocorrendo o aumento de temperatura, o crescimento recomeça e o processo de acúmulo de sacarose cessa (Humbert, 1968).

A temperatura noturna influi mais no crescimento que a diurna. Quando as noites são frias, o desenvolvimento é lento e há maior concentração de sacarose. O crescimento da cana-de-açúcar está relacionado com a temperatura ambiente, segundo Fauconier \& Bassereau (1975), a temperatura de crescimento máximo para a cana está entre 30 e $34^{\circ} \mathrm{C}$, enquanto que abaixo de $25^{\circ} \mathrm{C}$ e acima de $38^{\circ} \mathrm{C}$ o crescimento é muito lento. Barbieri et al. (1979), estabelecem a temperatura basal para cana em torno de $20^{\circ} \mathrm{C}$, e escrevem que nas várias fases fenológicas, a temperatura assume grande importância, assim para germinação, segundo vários autores, a temperatura ótima é de $32^{\circ} \mathrm{C}$ e a basal de $21^{\circ} \mathrm{C}$. O florescimento da cana está diretamente ligado à temperatura, comprimento do dia, umidade do solo e variedade.

Quando ocorrem temperaturas noturnas acima de $18^{\circ} \mathrm{C}$, baixa umidade e comprimento do dia próximo há 12 horas, há, na maioria dos casos e dependendo da variedade exposta, estímulo do florescimento.

Para Alexander (1973), virtualmente, sob condições satisfatórias todas plantas de cana-de-açúcar produzirão flores, o "estímulo" ao florescimento se origina nas folhas e é definido pelo ambiente.

Paliatseas \& Chilton, citados por Alexander (1973), sugerem em pesquisa executada antes de 1956 que o controle do florescimento estava em efeito apontando para o controle da indução. Estes autores mostram que o 
florescimento é uma sucessão de processos fisiológicos distintos, e os fatores ambientais têm efeitos diferentes nas várias fases. Foram reconhecidas quatro fases distintas: (a) iniciação dos primórdios florais; (b) organização floral; (c) maturação floral e (d) aparecimento de borla. A iniciação floral geralmente é considerada a fase mais importante

Segundo Castro (1999), a florescência da cana-de-açúcar é controlada por um complexo de fatores, envolvendo principalmente 0 fotoperíodo e a temperatura, além da umidade e da radiação solar, assim, observou-se que cinco noites com temperatura abaixo de $18^{\circ} \mathrm{C}$ não afetam a florescência mas dez noites a prejudicam, e mais de dez noites a inibem. $O$ processo de florescência é bastante complexo, envolvendo fitocromos, processos metabólicos, hormônios, ácidos nucléicos e fatores diversos (Figura $5)$.

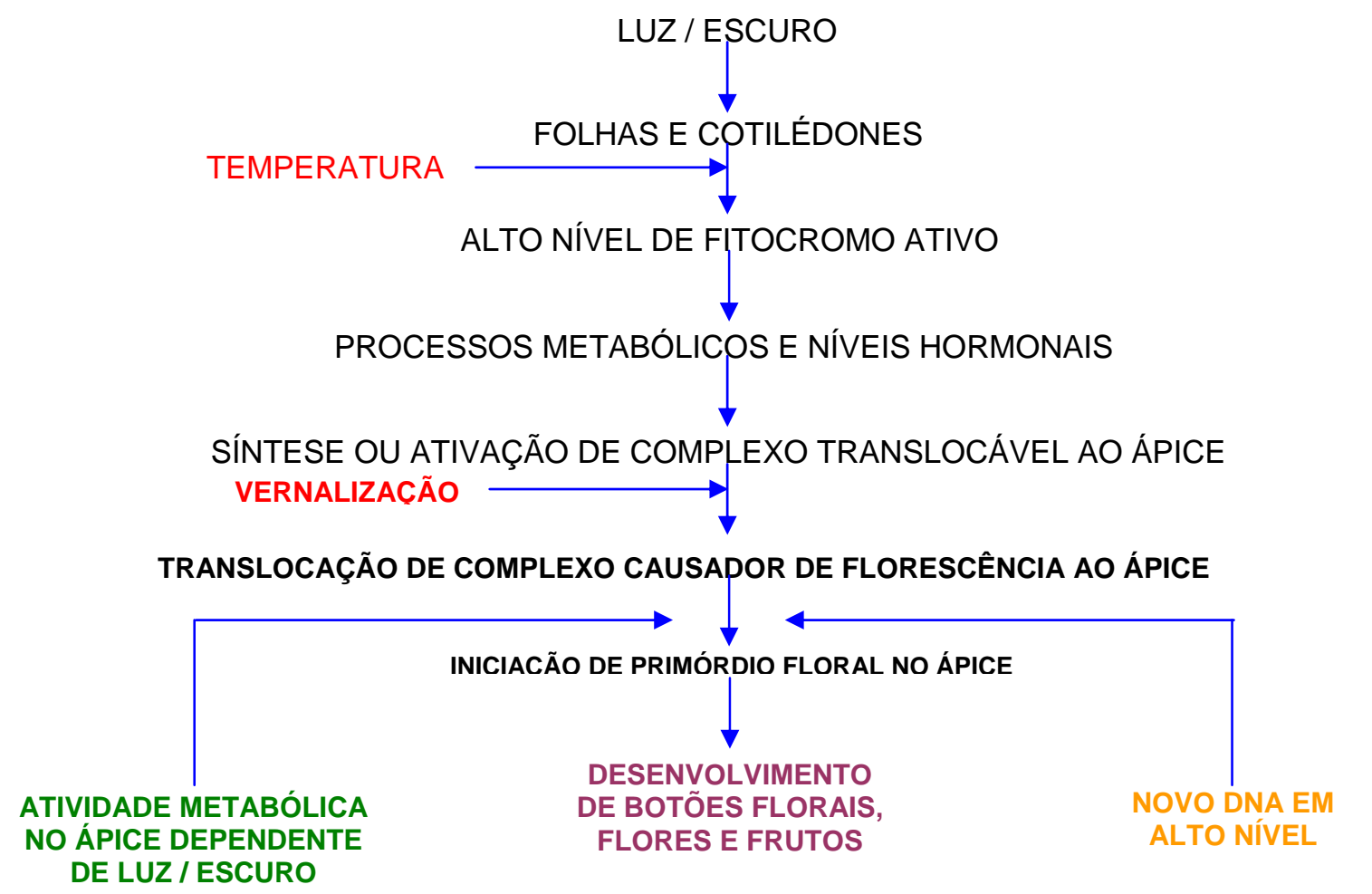

Figura 5 - Representação esquemática da seqüência de eventos que levam ao processo de florescimento Fonte: Castro, 1999 
Bacchi (in Orlando Filho, 1983) escreve que artificialmente o florescimento pode ser controlado através do manejo de água e de nutriente, bem como através de variações na época de plantio e de corte.

Villa Nova et al. (1972), citam que o melhor método para correlacionar o desenvolvimento dos vegetais e a temperatura é o método dos Graus-dia (área compreendida entre a temperatura base, abaixo da qual o desenvolvimento é considerado nulo, e a curva da temperatura diária). Já, Barbieri et al. (1979), propuseram a seguinte fórmula para o cálculo de Grausdia:

\section{Para $\mathrm{TM}>\mathrm{TB}>\mathrm{Tm}$}

$$
\mathrm{GDC}=\frac{(\mathrm{TM}-\mathrm{TB})^{2}+(\mathrm{TM}-25)^{2}}{2(\mathrm{TM}-\mathrm{Tm})} \mathrm{f}
$$

\section{Para $\mathrm{TB}<\mathrm{Tm}$}

$$
\mathrm{GDC}=\mathrm{Tm}-\mathrm{TB}+\frac{\mathrm{TM}-\mathrm{Tm}}{2}+\frac{(\mathrm{TM}-25)^{2}}{2(\mathrm{TM}-\mathrm{Tm})} \mathrm{f}
$$

Sendo:

$$
\mathrm{f}=\left(\frac{\mathrm{N}^{2}}{24}-N\right)^{2}
$$

$\mathrm{N}=$ comprimento do dia em horas; 


\section{$\mathrm{Tm}=$ Temperatura mínima média mensal $\left({ }^{\circ} \mathrm{C}\right)$}

\section{TB $=$ Temperatura Base $\left({ }^{\circ} \mathrm{C}\right)$}

\subsubsection{Influência da luz}

Segundo Fauconnier \& Basserau (1975), a cana-de-açúcar, no seu estágio de máximo desenvolvimento, apresenta uma área foliar que corresponde aproximadamente a 7 vezes à área de solo ocupada. Essa característica confere à cultura grande capacidade fotossintética e grande capacidade de troca de substâncias (água, gases e nutrientes) com a atmosfera.

Segundo Barbieri et al. (1979), o comprimento dos internódios da cana-de-açúcar, em geral, aumenta com o comprimento do dia $(\mathrm{N})$, até um máximo que para algumas variedades pode ser de 16 a 18 horas, onde o crescimento é reduzido. Por ser espécie do grupo $\mathrm{C}_{4}$, a cana está entre as espécies de maior eficiência fotossintética, cujo ponto de saturação lumínica é um dos mais altos, assim, quanto maior for a intensidade luminosa, maior será a fotossíntese e o crescimento, até os limites da cultura.

Os parâmetros ambientais que afetam de maneira mais marcante a bioconversão de energia na cana-de-açúcar são: luz (intensidade e qualidade), concentração de $\mathrm{CO}_{2}$, disponibilidade de água e nutrientes e temperatura. A fotossíntese em cana-de-açúcar eleva-se linearmente com o aumento da irradiância, entre 0,2 a $0,6 \mathrm{cal} . \mathrm{cm}^{-2} \cdot \mathrm{min}^{-1}$, ocorrendo à saturação acima de 0,9 cal.cm ${ }^{-2} \cdot \mathrm{min}^{-1}$ (Waldron et al., 1967).

A cana-de-açúcar, é a planta mais eficiente para armazenar a energia solar aproveitando ao máximo sua potencialidade. E para isso, requer-se que a relação solo-planta, assim como os demais fatores que intervêm no desenvolvimento da cana-de-açúcar, se integrem ao ótimo (Humbert, 1968). 
Magalhães (1987), confirma tal fato, ao escrever que a cana-deaçúcar é uma planta considerada de alta eficiência na conversão de energia radiante em energia química, com taxas fotossintéticas calculadas em até 100 $\mathrm{mg}$ de $\mathrm{CO}_{2}$ fixado por $\mathrm{dm}^{2}$ de área foliar por hora. Entretanto, alta eficiência fotossintética não está diretamente associada com a elevada produtividade de biomassa. As evidências experimentais indicam que a grande capacidade da cana-de-açúcar para a produção de matéria orgânica reside na alta taxa de fotossíntese por unidade de terreno, que é influenciada pelo índice de área foliar (IAF). Por outro lado, o longo ciclo de crescimento da planta resulta em elevadas produções acumuladas de matéria seca.

Castro (1999) cita uma série de características genéticas, fisiológicas e morfológicas associadas à produtividade da cana-de-açúcar. A aquisição do ciclo de Hatch durante o processo evolutivo no melhoramento da cana, a arquitetura com folhas mais eretas e a força de dreno de sacarose no colmo, são algumas dessas características relacionadas com altas produções (Quadro 2).

\begin{tabular}{|c|c|c|}
\hline $\begin{array}{c}\text { PARTE DA } \\
\text { PLANTA }\end{array}$ & $\begin{array}{c}\text { CARACTERÍSTICA } \\
\text { DESEJÁVEL }\end{array}$ & $\begin{array}{c}\text { EFEITO NA FOTOSSíNTESE } \\
\text { E NA PRODUÇÃo }\end{array}$ \\
\hline Perfilhos & $\begin{array}{c}\text { Vertical } \\
\text { Grande quantidade }\end{array}$ & $\begin{array}{c}\text { Melhor penetração de luz } \\
\text { Substituição de plantas mortas } \\
\text { Desenvolvimento rápido do IAF }\end{array}$ \\
\hline Folha & $\begin{array}{c}\text { Espessa } \\
\text { Curta e pequena } \\
\text { Ereta }\end{array}$ & $\begin{array}{c}\text { Hábito mais ereto } \\
\text { Distribuição mais uniforme } \\
\text { Aumento na área iluminada com } \\
\text { IAF maiores }\end{array}$ \\
\hline Colmos & $\begin{array}{c}\text { Alta força de dreno de sacarose } \\
\text { Firmes }\end{array}$ & $\begin{array}{c}\text { Alta produtividade } \\
\text { Previne acamamento }\end{array}$ \\
\hline
\end{tabular}

Quadro 2 - Características morfológicas associadas à produtividade da cana-deaçúcar

Fonte: Castro, 1999 


\subsubsection{Influência da radiação solar}

Ortolani \& Paes de Camargo (1987), comentam que a distribuição da intensidade estacional da energia solar sobre o globo constitui a causa principal de todos os fenômenos meteorológicos, pois intervém parcial ou totalmente na origem e no desenvolvimento dos demais fatores do meio. A radiação solar intervém diretamente sobre o crescimento e o desenvolvimento da planta e indiretamente pelos efeitos no regime térmico, sendo fundamental à produção de biomassa. É igualmente importante no condicionamento da evaporação e da evapotranspiração. Em regiões úmidas a radiação solar global pode apresentar estreita relação com a evapotranspiração. A radiação líquida disponível ao meio, resultante do balanço energético, é a variável mais utilizada para estimativa da demanda hídrica.

\subsubsection{Influência da umidade do solo}

Menos de um por cento da água absorvida por uma planta é utilizado quimicamente em fotossíntese. Porém, os déficits internos de água das plantas que envolvem porcentagens muito maiores, também afetam a fotossíntese através de meios indiretos. Estes efeitos são normalmente associados com o fechamento dos estômatos, hidratação reduzida do protoplasma do clorênquima, e resistência na difusão de $\mathrm{CO}_{2}$ entre a atmosfera e os cloroplastos. Somado a isto, há a perda de água que foi utilizada para manter os processos de translocação, que transportam os solutos pelo tecido condutor (Alexander, 1973)

A retirada da água pelo sistema radicular da planta pressupõe que no equilíbrio hídrico do sistema solo-raiz reside um dos problemas fundamentais da agricultura. A água em excesso no solo altera processos químicos e biológicos, limitando a quantidade de oxigênio e acelerando a formação de compostos tóxicos á raiz. Por outro lado, a percolação intensa da água provoca 
remoção de nutrientes e inibição do crescimento normal da planta. Embora importantes, os excedentes hídricos não apresentam a mesma ordem de grandeza de problemas, quando comparados à seca. A deficiência hídrica, que se caracteriza por diferentes formas e intensidades, corresponde à causa principal de decréscimos de produtividade (Ortolani \& Paes de Camargo, 1987).

Barbieri \& Villa Nova (1977), citam que a cana requer boa quantidade de umidade no solo somente o período de crescimento, uma vez que a água tem papel fundamental na turgescência, translocação e na pressão de crescimento e de turgor, porém durante o período de maturação o ideal é que haja redução na água disponível, não drasticamente, mas o suficiente para reduzir o crescimento e induzir a maior concentração de açúcar nos colmos. Alguns autores citam que durante a safra ou até dois meses antes da época de maturação a produção de sacarose é inversamente proporcional a quantidade de chuva que ocorreu na região.

Barbieri \& Villa Nova, (1977), afirmam que no início do crescimento a evapotranspiração da cultura de cana-de-açúcar está em torno de 40 a 60\% do tanque classe "A", aumentando até aproximadamente 90\%, quando a cana cobriu totalmente o terreno (cana com 6 meses de idade). Citam, ainda, que Leme et al., estudando o consumo de água pela cana-de-açúcar e analisando de forma geral o comportamento do coeficiente kc (relação entre a evapotranspiração da cultura e a de um gramado) nos três ciclos da cultura, observou uma variação entre 0,36 a 1,17 com valor médio de 0,88. E, segundo os mesmos autores, resultados semelhantes foram encontrados por Campbell et al. e Cox et al. no Havaí, que determinaram um kc variando de 0,4 a 1,1.

A disponibilidade da água é evidenciada por Ometto (1980) citando os resultado de Hartt que verificou que folhas de cana supridas com água sintetizam dez vezes mais sacarose que folhas desprovidas de água e que a atividade fotossintética não cessa no ponto de murchamento ou abaixo dele mas permanece em razão extremamente baixa. O mesmo autor cita que em média a cana necessita de 1.200 a 1.500 mm de chuva bem distribuída por ano, 
sendo ideal que durante a época de maturação a precipitação seja menor que no período de crescimento.

\subsubsection{Influência da fertilidade dos solos}

A fertilidade dos solos, é um dos fatores que atuam diretamente sobre o crescimento da cana-de-açúcar, e representa o substrato onde as plantas vão desenvolver-se e dele retirar os nutrientes que necessitam (Orlando Filho, 1983).

Orlando Filho (1983) cita, também, que a extração dos nutrientes do solo pela cultura da cana-de-açúcar é influenciada por fatores como: idade das plantas - uma vez que durante o ciclo evolutivo da cultura as exigências nutricionais apresentam-se bastante variáveis; tipo de solo - que afeta a absorção, principalmente através da maior ou menor disponibilidade dos nutrientes; variedades - as exigências nutricionais são controladas geneticamente, ocorrendo, portanto, variação nas necessidades de nutrientes entre variedades. $E$, a ordem de extração de macronutrientes tanto para canaplanta como para cana-soca é: $\mathrm{K}>\mathrm{N}>\mathrm{Ca}>\mathrm{Mg}>\mathrm{P}$.

Segundo Orlando Filho (1983), a necessidade de nitrogênio pela cana-de-açúcar é crucial no período de formação da cultura, ou seja, no estágio que se inicia imediatamente após a germinação e termina no fechamento do canavial, o que normalmente ocorre em torno de 3 a 5 meses. É nessa época que se dá à formação dos perfilhos e, para tanto, é necessária suficiente disponibilidade de nitrogênio no solo. Aproximadamente a partir do fechamento do canavial, a cultura entra num período de crescimento acelerado, desde que haja boas condições de temperatura e umidade. Se o nível de nitrogênio no solo e, conseqüentemente, na cultura, durante o estágio de formação, é baixo, o número de perfilhos que participará do crescimento acelerado também será baixo. Posteriormente, mesmo que haja formação de outros perfilhos, estes não terão condições de serem aproveitados para a moagem na época da colheita. 
Está comprovado que a produtividade da cana aumenta com o incremento de doses de nitrogênio, porém essas canas apresentam maior conteúdo de umidade. Ocorre marcante correlação positiva entre a absorção de nitrogênio e a umidade, de modo que as canas com bom suprimento de água e nitrogênio, sendo os demais fatores favoráveis, terão maior crescimento e, até certo ponto, maior rendimento.

Orlando Filho (1983), cita que Hartt \& Burr verificaram para cana-deaçúcar que a deficiência em fósforo aos dois meses de idade diminui a atividade fotossintética mais que o nitrogênio ou o potássio. O fósforo tem importante participação na formação da sacarose. Hartt também verificou que em plantas deficientes em potássio ocorre aumento na porcentagem de açúcares redutores e diminuição na sacarose; que existem aumentos na atividade da invertase e amilase; que há aumento na taxa de respiração foliar; que ocorre diminuição da fotossíntese; que há redução no movimento da sacarose das folhas para os tecidos e diminuição da síntese e translocação de proteínas, causando ainda necrose do floema. Teores adequados do nutriente aumentam a sacarose na cana-de-açúcar.

Quanto ao cálcio, Orlando Filho (1983), cita é fundamental na composição salina do citoplasma, faz parte da parede celular dando estrutura às células e facilitando a absorção de água por sua elevada função plasmolítica.

Segundo Álvares, citado por Beauclair (1994), o magnésio é componente da molécula de clorofila, sendo entretanto encontrado em maior quantidade nos pontos de crescimento.

Beauclair (1994), cita que o enxofre foi encontrado em numerosos compostos das plantas, sendo as proteínas os mais importantes. Faz parte dos aminoácidos, tais como metionina (21 \% de S) e cistina (27\% de S), de reguladores de crescimento (tiamina, biotina e glutamina), que participam de reações de oxi-redução. Por ser constituinte das proteínas que entram na 
composição do protoplasma das plantas, a deficiência de enxofre provoca retardamento no crescimento.

Embora o silício não seja essencial às plantas, diversas funções são atribuídas a ele, Beauclair (1991) cita que Cheong et al., verificaram que, em folhas de canas ricas em silício, este preencheria os espaços interfibrilares, reduzindo o movimento da água através da parede celular, causando aumento de economia de água pela planta através da diminuição da taxa de transpiração foliar.

\subsubsection{Influência da evapotranspiração}

Thornthwaite et al., citados por Camargo (1962), introduziram o conceito de evapotranspiração potencial para definir a evapotranspiração que normalmente se verifica em um solo inteiramente vegetado, livremente exposto à atmosfera e às condições de capacidade de campo.

Somente a evapotranspiração realizada livremente, sem qualquer restrição pela deficiência de umidade do solo, condicionada exclusivamente pela disponibilidade de energia solar na superfície do solo, é que pode ser considerada potencial (Camargo,1962).

Pennman (1948) desenvolveu um método para estimar a evapotranspiração de superfícies vegetadas baseado em modelo aeroenergético, ou seja, apoiado em uma combinação do método do balanço de energia radiante e aerodinâmico. Situa-se entre os métodos de estimativa de evapotranspiração mais precisos. Entretanto, por ser a fórmula bastante complexa e trabalhosa e dependendo ainda de elementos meteorológicos menos freqüentemente observados, torna-se, na sua forma original, um método de aplicação restrita. 


\subsubsection{Balanço hídrico}

Pelo princípio da conservação de massa num volume de solo com vegetação, a equação do balanço hídrico é:

$$
P+I=\Delta M+D+E
$$

Onde:

$$
\begin{aligned}
& P=\text { precipitação pluviométrica } \\
& I=\text { irrigação } \\
& \Delta M=\text { variação no armazenamento } \\
& D=\text { drenagem profunda } \\
& E=\text { evapotranspiração }
\end{aligned}
$$

Segundo Ortolani \& Paes de Camargo (1987), o processo de contabilidade hídrica no solo mais utilizado para fins climatológicos é o método do balanço hídrico de Thornthwaite \& Mather (1955), que consiste no cotejo entre a precipitação pluviométrica e a evapotranspiração, considerando-se uma determinada capacidade de retenção de água no solo, segundo as características físicas dos solos, bem como em função do tipo de cobertura vegetal.

Além da evapotranspiração potencial, o balanço hídrico de Thornthwaite \& Mather (1955), possibilita estimar a evapotranspiração real, o excedente hídrico, que é a água que excede a capacidade máxima de retenção, sujeita à percolação e ao escoamento superficial, a deficiência hídrica, que é a quantidade de água que deixa de ser evapotranspirada pela falta de umidade, e as fases de reposição e retirada de água do solo, que representem a variação no armazenamento superficial, (Ortolani \& Paes de Camargo, 1987). 


\subsection{Tratos Culturais}

No Brasil, pela grande extensão do seu território, encontram-se as mais variadas condições climáticas para a lavoura canavieira. Possuindo duas estações diferentes e distintas durante o ano, o Brasil é possivelmente o único país no mundo com duas colheitas anuais: uma do Norte - Nordeste, que começa em setembro e continua até abril, e a outra na Região Centro - Sul, que vai de junho a dezembro (Barbieri \& Villa Nova, 1977).

A figura 6, a seguir, mostra as épocas em que são executadas as principais operações agrícolas no cultivo da cana-de-açúcar no Brasil.

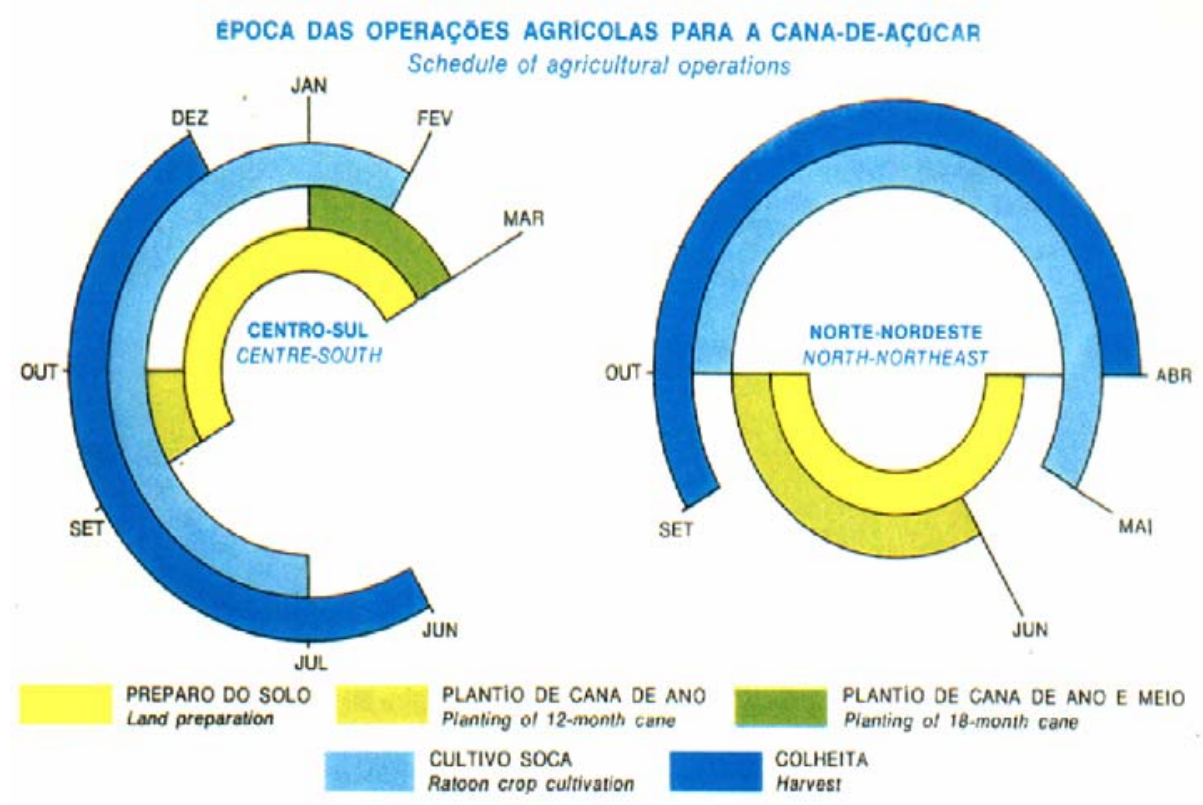

Figura 6 - Época das operações agrícolas para a cana-de-açúcar Fonte: Barbieri \& Villa Nova, 1977

\subsubsection{Plantio}

A multiplicação de cana-de-açúcar, devido ao fenômeno da dominância apical, é normalmente feita através de toletes, que são pedaços de 
colmos contendo duas ou três gemas no estado latente, que encontrando condições favoráveis, passam ao estado ativo de crescimento e desenvolvimento, devido às mudanças das reservas nutritivas pela atividade de enzimas e reguladores de crescimento (Van Dillewijn, 1952). O processo de brotação das gemas nos toletes de cana-de-açúcar depende de fatores endógenos e exógenos descritos entre outros por Van Dillewijn (1952), Humbert (1968) e Fauconnier \& Bassereau (1975).

Quintela (1996), afirma que a cana-de-açúcar inclui-se entre as plantas que são propagadas vegetativamente, portanto, o conhecimento do processo de brotação, bem como dos fenômenos que interferem no mesmo, reveste-se de grande importância para o sucesso da cultura, pelo fato de que o canavial deverá ser explorado por um período médio de cinco anos. Um canavial implantado sem os conhecimentos básicos de plantio, poderá ter reduzida a sua longevidade, determinando como conseqüência, elevação dos custos de produção.

\subsubsection{Influência das épocas de plantio}

A brotação das gemas na cana-de-açúcar é um dos processos que requer maior atenção nesta cultura, pois dele dependerá, em grande medida, a futura população de plantas no campo, (Plana et al., 1987).

Ricaud \& Cochran (1980), afirmaram que são as datas de plantio que determinam a baixa produção de colmos/ha em cana-de-açúcar.

O clima no Estado de São Paulo permite o plantio da cana-de-açúcar num largo período do ano. Normalmente, são recomendadas duas épocas de plantio. Uma menos ampla, ao início da primavera, e outra, mais longa, no verão, quando principalmente as condições de temperatura e umidade são favoráveis à boa e rápida emergência dos colmos. Sendo importante também considerar que, após a emergência dos colmos primários deve haver condições favoráveis a um máximo perfilhamento e a formação de touceiras vigorosas que 
vão fornecer quantidade maior de colmos por área e possivelmente permitindo maior número de cortes econômicos (Rocha, 1984).

Barbieri \& Villa Nova (1977), descrevem que o plantio da cana-deaçúcar na região Centro-Sul, é feito em duas épocas, conhecidas como "plantio de cana de ano" e "plantio de cana de ano e meio". O plantio feito em outubro, permite a colheita da cana com aproximadamente 12 meses (Set.-Out. do ano seguinte) e conhecida como "cana de ano". O plantio feito em Janeiro fevereiro, permite a colheita da cana com 18 meses (Set.-Out. do ano seguinte) e é conhecida como "cana de ano e meio". O número de ciclos vegetativos úteis varia de local para local, mas geralmente adota-se um regime de 3 a 4 cortes, ou seja, faz-se à renovação do canavial após o corte da segunda ou terceira soca. Nesse sistema, o agricultor reforma anualmente cerca de $25 \%$ a $33 \%$ da sua área cultivada, sendo necessário aproximadamente 1 ha de área de viveiros para cada 10 ha renovados.

Nas usinas do Estado de São Paulo, distinguem-se três tipos de sistema de produção, baseados no ciclo da cana: cana planta de ano, cana planta de ano e meio e soqueiras. A caracterização da cana planta de ano, nas condições do nosso Estado, em termos práticos, é aquela cana plantada de agosto a novembro e cuja colheita se efetua de onze e quatorze meses após o plantio. A cana de ano e meio é plantada de janeiro a março - às vezes prolongando-se até maio - e a colheita sendo feita de 15 a 20 meses após, (Calça et al., 1983).

$\mathrm{Na}$ figura 4 (Regime hídrico e desenvolvimento da cana-de-açúcar), se pode observar que a cana de ano, plantada em setembro - outubro, tem seu máximo desenvolvimento de novembro a abril, diminuindo em seguida, devido às condições climáticas adversas, podendo ser colhida, dependendo do cultivar, a partir de julho. A cana de ano e meio, plantada em janeiro - abril, tem taxa de crescimento restrita, em função do clima, de maio a setembro, desencadeando o maior desenvolvimento de outubro a abril, principalmente a partir de dezembro, sob condições favoráveis de precipitação (Castro, 1999). 
Rocha (1984), estudando o comportamento de 3 variedades de canade-açúcar (NA 56-79, CB 41-76 e IAC 51/205), através de plantios efetuados nas épocas a saber: cana-de-açúcar de ano, plantio em 11 de setembro e 05 de outubro de 1978; cana-de-açúcar de ano e meio, plantio em 05 de janeiro e 30 de março de 1979; analisando-se a emergência das plantas, a capacidade e o modo de perfilhamento, a produção de colmos industrializáveis por touceira e a influência das condições ambientais nessas características. Estas datas foram estabelecidas a fim de comparar plantios nos limites extremos de cada uma das épocas recomendadas. Os resultados obtidos permitiram as seguintes conclusões: As variedades responderam diferentemente às condições ambientais para emergência. Em idênticas condições de temperatura e umidade do solo, a emergência da variedade NA 56-79 deu-se posteriormente a das variedades CB 41-76 e IAC 51/205; Na época de plantio da cana de ano, em setembro-outubro, houve um rápido e intenso perfilhamento porque os períodos ocorreram nas estações da primavera e verão, quando são maiores a radiação solar, a luminosidade e a precipitação. Quando se fez o plantio logo no início da época de janeiro-março, para a cana-de-ano e meio, período que coincide com as estações de final de outono e início de inverno, o perfilhamento foi menor e mais lento; Houve diferenças no modo de perfilhamento das variedades; Culturas originadas de plantios de cana-de-ano e meio, em janeiromarço, produzem na $1^{\circ}$ colheita colmos maiores, de maior diâmetro e mais pesados do que culturas de ano cujos plantios se efetuam em setembrooutubro.

Rocha (1984), cita ainda que o perfilhamento é influenciado pelas condições do solo, de cultivo e pelos elementos meteorológicos e dentre estes devem ser destacados os efeitos da radiação solar e temperatura que sofrem variações durante as estações do ano.

Van Dillewijn (1952), registrou que a tendência do processo de perfilhamento, bem como o número final de colmos industrializáveis, são influenciados pela data de plantio. Desde que o perfilhamento inicial é 
grandemente afetado pelo calor e luz, a influência da época de plantio seria mais marcante em regiões com maiores variações sazonais.

O plantio sazonal da cana-de-açúcar em Punjab (Índia) foi estudado por Singh \& Singh (1956), os quais observaram que, a fase de emergência da variedade de cana-de-açúcar Co 312, no caso dos plantios de outono e primavera, se completava em cerca de seis semanas, enquanto que no caso do plantio no início do verão era completado em 4 a 5 semanas. As gemas, no caso do plantio de inverno, permaneceram dormentes por cerca de 6 a 8 semanas. Registraram, ainda, que a temperatura do solo desempenha um importante papel na germinação das gemas. Uma faixa de temperatura do solo de $16,8^{\circ} \mathrm{C}$ a $30,2^{\circ} \mathrm{C}$ foi considerada ótima para a emergência de gemas.

Segundo Barnes (1964), as canas tropicais grossas usualmente têm um sistema de perfilhamento simples, descrito como brotos primários a, secundários b, terciários c e assim por diante. Barber (1919), citado pelo autor, achou uma espécie de Saccharum spontaneum, na Índia com a fórmula $a+8 b+23 c+31 d+3 e$, representando um total de 66 perfilhos. A extensão do perfilhamento e a sobrevivência dos perfilhos até a maturidade são de certa forma uma medida de caráter varietal, mas, é influenciada pelo clima, solo e condições nutricionais. Algumas variedades perfilham precoce e profusamente, porém, os perfilhos são tardios em elongação, enquanto outros se desenvolvem e formam colmos mais facilmente com uma menor produção de perfilhos. A fase de perfilhamento em grande parte determina a produtividade da cultura, mas nem todos os perfilhos sobrevivem.

Plana et al. (1987), verificaram interação entre as datas de plantio e as variedades em seu estudo sobre a influência das datas de plantio sobre a brotação de algumas variedades de cana, indicando que nem as variedades nem as datas de plantio separadamente provocaram um aumento na porcentagem de brotação. Os autores afirmam ainda, que em relação às datas de plantio, são lógicas as diferenças, uma vez que em função destas ocorrem diferentes condições de temperatura e umidade. 
Chen \& Tse (1969), em Taiwan, trabalhando com a variedade F 151, estudaram o efeito da época de plantio e densidade de plantio sobre o rendimento de cana-planta e soca, plantada no outono. O ensaio foi executado em 3 datas de plantio: 15 de julho, 30 de agosto e 15 de outubro. Dos resultados analisados concluíram: considerando a produção de diferentes datas de plantio, ambas, cana-planta e soca, tinham revelado diferenças significativas. As maiores produções foram achadas na cana-planta. Afirmaram que a emergência e perfilhamento da cana-de-açúcar são grandemente afetados pela temperatura e radiação solar, sua extensão diferindo conforme a data do plantio e característica varietal.

Panje et al. (1962), efetuaram estudos sobre a emergência da canade-açúcar, a fim de determinar os gradientes e interações na emergência de gemas ao Norte da Índia, utilizando toletes de 3 gemas da variedade Co 951. Conduziram os estudos pelo plantio em outubro e fevereiro. Constataram, que a média de emergência para os 2 plantios foi de $56,8 \%$. Observaram, ainda, que em geral a emergência da gema foi melhor em toletes derivados de canas jovens em outubro, com $58,8 \%$ do que daqueles derivados de cana 4 meses mais velhas, em fevereiro, com 54,7\%. Notaram, que a gema mediana ou intermediária tinha apresentado a mais alta emergência nas duas épocas de plantio, o que consideraram ser devido ao fato dessa gema ter os entre-nos intactos em ambos os lados da gema e conseqüentemente maior taxa de umidade, sendo sua perda menor do que das outras duas gemas. A porcentagem de emergência da gema apical é distintamente mais elevada do que da gema basal do tolete em ambas épocas de plantio, isto pode ser atribuído à dominância apical. Constataram, no plantio de fevereiro, que a associação entre a gema do topo e a mediana e, entre a gema mediana e a gema basal foram ambas negativas e altamente significativas. Isto significa que quando qualquer uma das duas adjacentes germinam, há uma tendência para a outra não germinar. Tal associação, entretanto, não existe entre a gema apical e a basal. 
Crescimento e qualidade de 4 variedades de cana-de-açúcar NCo 376, NCo 310, CP 29-116 e Co 462, influenciadas pela idade e estação, foram investigados por Lonsdale \& Gosnell (1976), na Rodésia. O plantio foi iniciado em novembro de 1967 e 18 parcelas das 4 variedades foram plantadas nos meses consecutivos de tal modo que a primeira parcela tinha 18 meses de idade quando a última foi plantada. Medições de altura, contagens de colmos e de folhas foram feitas semanalmente. A cada semana efetuavam contagens de colmos para cada mês de plantio. Nos estádios iniciais de crescimento, a população foi influenciada principalmente pela estação. A população de colmos aumentou rapidamente quando a cana foi plantada ou sua rebrota se deu na primavera e verão (setembro-dezembro), mostrando-se relativamente lenta com cana-planta e soca de março e junho. Inversamente, a população se manteve por mais tempo e com mortalidade de perfilhos mais tardia na cana-planta e soca de março e junho. Houve uma significativa diferença entre as variedades em população de colmos. A NCo 376 mostrou consideravelmente mais colmos que as demais, seguida pela NCo 310, Co 462 e CP 29-116.

\subsubsection{Efeitos do estresse hídrico}

Os efeitos do estresse hídrico nas plantas incluem, além de outros, redução nas taxas de assimilação de $\mathrm{CO} 2$, tamanho das células foliares, taxa de transpiração, potencial de água na planta, taxa de crescimento e abertura estomática (Hsiao, 1973).

Além da sua interferência no florescimento, as relações hídricas desempenham um papel importante na elongação dos perfilhos e altura final dos colmos em cana-de-açúcar (Gascho \& Shih, 1983; Chang et al., 1968), sendo os tecidos de alongamento e meristemáticos encontrados em maior grau nos internódios em expansão, os mais severamente afetados (Hartt, 1967). 
A disponibilidade de água também afeta a taxa de fotossíntese, sendo que próximo ao ponto de murchamento permanente, essa redução pode atingir de $30 \%$ a $50 \%$ (Hartt \& Burr, 1967).

Os períodos de déficit hídrico podem ocorrer durante todo o ciclo da cultura, mas seu efeito sobre a produtividade de cana-de-açúcar varia muito em função da interação entre a época do ano em que ocorrem e a fase do ciclo fenológico da cultura (Shaw \& Innes, 1965; Thompsom, 1976; Doorembos \& Pruitt, 1975).

Vazquez (1970), estudando época de irrigação em Porto Rico, concluiu que para as condições de variedade e climas do estudo seria possível economizar até $250 \mathrm{~mm} / a n o$ suspendendo a irrigação 5 meses antes da colheita, sem redução significativa na produção.

Já, autores como Doorembos \& Pruitt (1975), citam como épocas mais críticas apenas os períodos de perfilhamento e início de elongação dos colmos.

Van Dillewijn, citado por Mongelard \& Nickell (1971), observou serem conhecidos os efeitos benéficos proporcionados por um adequado suprimento de água no início do crescimento e perfilhamento da cana.

Rosenfeld (1984), estudando o período crítico de deficiência hídrica em cana planta, concluiu que o início do estágio de máximo desenvolvimento da cana planta foi o período mais sensível a déficit hídrico; Para cana plantada em fevereiro e junho, o período mais crítico foi do $4^{\circ}$ ao $8^{\circ}$ meses de idade; Para canas plantadas em outubro, o período mais critico foi do $8^{\circ}$ ao $11^{\circ}$ meses; As maiores reduções de produção foram provocadas por períodos secos durante o verão em canas com idade de 4 a 8 meses; O período crítico de deficiência hídrica para o crescimento da cana planta foi do $4^{\circ}$ ao $8^{\circ}$ meses de idade.

A redução de produção de açúcar na cana com deficiência hídrica pode resultar do alto conteúdo de fibra, em decorrência da restrição no 
comprimento dos entrenós, da maior transpiração, e do crescimento atrofiado dos colmos (Madrazo, 1968; citado por Naqvi \& Qayyum, 1973).

Segundo Tabayoyong et al. (1959), citado por Naqvi \& Qayyum (1973), o caldo de colmos que sofreram um período de seca prolongado apresentou menor conteúdo de sacarose e maior brix, e, conseqüentemente, menor pureza, alem da dificuldade de extração e processamento.

A perda de peso dos colmos por deficiência de água disponível foi mencionada por Nickell (1968), Chang et al. (1968) e Thompson (1976).

Carlucci \& Ramos (1989), testando a deficiência de água no solo após a indução floral observaram que não houve alteração no número de entrenós formados, mas sim em seu crescimento, diminuindo, conseqüentemente, o comprimento final dos colmos; O peso dos colmos foi mais afetado nos terços médio e superior, principalmente quando a restrição hídrica ocorreu durante a iniciação floral; Nas parcelas tratadas houve uma diminuição na pol, brix e pureza do caldo extraído, assim como no açúcar teórico recuperável, porém essa tendência foi marcante quando a falta de água ocorreu durante a iniciação floral; Em resumo, a deficiência de água no solo após a indução floral é uma pratica não recomendável na produção comercial da cana, pelas reduções que traz ao seu crescimento e produção de açúcar.

\subsubsection{Plantio convencional e de cana inteira}

Segundo observações de Wood (1976), o seccionamento dos colmos no sulco de plantio, além de aumentar o custo da mão de obra, pode afetar a brotação devido à podridão que se instala a partir das superfícies de corte. Em condições de ambiente quente e úmido, os colmos seccionados deterioram mais rapidamente que os colmos inteiros.

A secção é realizada visando garantir uma boa percentagem de brotação, uma vez que toletes com maior número de gemas tem percentagem de brotação diminuída em decorrência da dominância apical. Assim que ocorre 
a brotação, esta induz a formação de auxina, fazendo com que as demais gemas não brotem ou o façam com atraso, o que resulta numa menor percentagem de brotação, quando comparada com o uso de toletes com menor número de gemas, Van Dillewijn (1952), Malavolta (1964).

O corte da cana em toletes, seja antes do plantio (Região Nordeste) ou no sulco (Região Centro-Sul), é uma prática tradicional na cultura canavieira, Lee et al. (1984 e 1986).

Recentemente, o plantio de canas inteiras tornou-se comum em Taiwan, devido à falta de mão-de-obra, Hsu \& Kao, (1981). Esta técnica também foi testada em vários locais, como a Louisiana (Arcenaux, 1948) e Rodésia (Lonsdale, 1978), mas os resultados foram variáveis. No Brasil, o plantio deste tipo foi testado algumas vezes pelos departamentos técnicos de usinas, mas apenas em caráter exploratório, sem a preocupação de se correlacionar o estado fisiológico da muda e as condições de campo, com os resultados obtidos. Além disto, geralmente os testes foram abandonados depois das avaliações de germinação, sem se esperar os resultados finais de produtividade. Como um canavial plantado seguindo esta técnica apresenta, quando não apropriadamente realizada, mais falhas e maior índice de levantamento de pontas, esta prática não tem sido utilizada. Entretanto, pequenos fornecedores algumas vezes têm obtido "stands" considerados igualmente satisfatórios em canaviais onde este método foi empregado (Lee, 1984).

A operação de corte em toletes no plantio é prática onerosa, que demanda muita mão-de-obra. Além disto, quando se pica a cana dentro do sulco, uma grande quantidade de gemas é danificada, sendo necessário colocar mais gemas por metro para compensar esta perda. Ainda, o corte dos toletes facilita muito a ação dos agentes patogênicos, que também contribuem para o decréscimo na germinação da cana picada, Lee et al. (1984).

Van Dillewijn (1952), abordando o tema das influências do tamanho do tolete na brotação das gemas, relatou o uso de toletes com uma, duas ou no 
máximo três gemas para plantios realizados comumente em diversos países; entretanto, independente de associação com podridões dos toletes, considerou que em condições de plantio menos favoráveis, o comprimento dos toletes deve ser adequadamente aumentado, destacando que sob condições favoráveis de crescimento, é preferível plantar toletes de cana-de-açúcar com 4 a 6 gemas e de menores comprimentos.

De acordo com Camargo (1968), o comprimento do material a ser propagado é ditado pela qualidade da cana-muda, pelo crescimento dos colmos e pela idade da muda. Segundo o autor, embora o normal seja toletes com três gemas, pode-se em função das características mencionadas, utilizar estacas maiores.

O Instituto do Açúcar e do Álcool (IAA), juntamente com várias usinas, desde 1982 vem instalando diversos experimentos para estudar a possibilidade de se plantar cana inteira. Os resultados até agora obtidos, demonstraram que esta técnica tem produzido resultados iguais ou até melhores do que o plantio de cana picada, Lee et al. (1984).

\subsubsection{Influência do comprimento dos toletes no plantio de cana-de- açúcar}

Lonsdale (1978) considerou que agricultores rodesianos, num esforço de economizar mão-de-obra, plantaram canas em colmos inteiros, obtendo boas brotações iniciais.

Nota-se que a grande tendência na conclusão dos trabalhos sobre a brotação inicial da cana-de-açúcar, é considerar-se preferível o seccionamento do colmo em toletes não maiores que 3 gemas. Algumas informações, entretanto, sinalizam para a oportunidade de utilizarem-se toletes maiores (Lonsdale, 1978; Chow, 1949; Arceneaux, 1948; Van Dillewijn, 1952).

O seccionamento dos colmos em toletes de 3 gemas foi recomendação e aplicação tradicional no Brasil, como também em todo o 
mundo canavieiro, fundamentado no efeito da dominância apical existente entre as gemas distribuídas ao longo do colmo da cana, (Gheller, 1995). Van Dillewijn (1952), abordou as questões da brotação inicial nos toletes, citando que quando se plantam toletes de mais de uma gema, entra em jogo um fator adicional na forma da dominância apical. Tal fator é ativo nos colmos inteiros e em qualquer secção de colmo com mais de uma gema, casos em que a gema apical mais jovem brotará rapidamente e ao mesmo tempo retardará, e até inibirá, o desenvolvimento das gemas inferiores, dando como resultado uma porcentagem de brotação média menor quando comparado com toletes mais curtos.

Arceneaux (1948), em ensaio conduzidos na Louisiana (USA), comprovou que toletes de 5 gemas são os que melhores rendimentos de produção proporcionaram no plantio de outono. Estas afirmações foram confirmadas por Chow (1949) em Formosa, onde observou que em caso de severas condições de crescimento, toletes de 4 a 6 gemas são preferíveis àqueles mais curtos.

Ainda, Van Dillewijn (1952), comentou ser o comprimento mínimo dos toletes determinado principalmente pela qualidade da muda e pelas condições de crescimento. Em Java onde tais fatores são favoráveis, utilizam-se toletes com duas ou apenas uma gema desenvolvida. Em regiões com condições menos favoráveis, o comprimento dos toletes tem que ser aumentado adequadamente, como nos plantios de outono nas regiões temperadas, onde as condições de brotação são ruins.

Lee (1984), também notou que quando ocorre um período de déficit hídrico, o plantio de cana inteira em comparação com toletes de três gemas, apresenta falhas menores e o "stand" final melhor. No caso estudado, ocorreram 30 dias de seca após o plantio, acrescido de altas temperaturas, nestas condições, a perda de umidade em toletes de três gemas é bem maior do que em cana inteira. 
Gheller (1995), estudando técnicas culturais para o controle da podridão abacaxi em cana-de-açúcar, concluiu que a podridão-abacaxi, em condições de clima favoráveis à sua ocorrência, infecciona severamente os toletes de cana-de-açúcar plantados, caso tenham sido seccionados à maneira convencional (3 gemas), diminuindo sua intensidade (\%) de infecção à medida que se aumenta o tamanho do tolete plantado, de valores próximos a $100 \%$ (toletes de 3 gemas) para valores ao redor de 38\% (cana plantada inteira). 0 efeito da doença foi maior na cana planta, e os maiores rendimentos agrícolas ocorreram nos tratamentos com menor número de seccionamentos dos colmos plantados, isto é, procedendo-se a apenas um seccionamento, ou nenhum, em colmos de no máximo 12 meses de idade, houve, além de ganhos no rendimento agrícola (t/ha), melhor qualidade de plantio, comparado ao sistema tradicional.

Santos (1983), desenvolveu um trabalho sobre brotação e desenvolvimento inicial da cana-de-açúcar, influenciados pelo ambiente, tempo de armazenamento e tamanho das estacas. Foi observado que a resistência das mudas ao armazenamento aumentou com o tamanho da estaca, enquanto a eficiência da germinação foi reduzida em razão do tempo em que permaneceram armazenadas.

$\mathrm{Na}$ Índia, Kanwar et al. (1975), conduziram um ensaio por dois anos, no qual estudaram o efeito do tamanho de toletes e do tratamento com fungicida, sobre a germinação e produção de cana-de-açúcar. Os resultados mostraram que toletes com duas, três, quatro ou cinco gemas deram maior percentagem de brotação e perfilhamento que toletes com seis gemas e colmo inteiro, mas as diferenças na população de colmos e na produção não foram significativas.

Tomer (1969), citando Thakor \& Jaiswal, reportou que ambos conduziram ensaio em Pusa (Índia) para estudar a produção por área e teores de sacarose da BO 32 em relação a diferentes tamanhos de toletes na época de plantio, foram usados toletes de 1, 3 e 6 gemas e colmos inteiros. Os toletes 
de 3 gemas deram o rendimento máximo por área, o qual foi 45,0\%,6\% e $22,0 \%$ maior do que aqueles obtidos de 1 gema, 6 gemas e colmos inteiros, respectivamente.

Em Taiwan, Chow (1949), investigando a porcentagem de emergência, taxa de crescimento e rendimento de colmos, verificou: a) maior porcentagem de emergência $(84,1 \%)$ em toletes de 1 gema e a mais baixa $(66,6 \%)$ em toletes de 6 gemas. Em geral a porcentagem de emergência se revelou negativamente correlacionada com o número de gemas por toletes; b) constatou que a maior porcentagem de brotos primários (mãe) mortos $(17,2 \%)$ foi observada em toletes de 1 gema; os toletes de 2 gemas apresentaram 8,4\%, os toletes de 3 gemas 13,4\%, os toletes de 4 gemas $13,9 \%$ e os de 6 gemas 13,55\%; c) o mais alto número de colmos sobreviventes por parcela no estádio inicial de crescimento foi verificado no tratamento toletes de 1 gema e o mais baixo em toletes de 6 gemas; d) constatou que o comprimento médio dos colmos é significativamente mais alto em toletes com mais gemas do que em toletes com menos gemas.

Em Taiwan, Pao \& Shiah (1962), observaram maior porcentagem de brotação e velocidade de emergência em estacas com uma gema, quando comparadas com aquela de duas ou quatro gemas, embora o crescimento subseqüente da planta tenha sido menos vigoroso. Também Worden (1962), nas Filipinas, verificou que toletes de uma gema embora aumentando a brotação, proporcionaram plantas de menor perfilhamento, afetando a produtividade de cana-de-açúcar. A percentagem de brotação e mais do que ela, o desenvolvimento inicial da planta, depende da reserva contida nos toletes.

Yang et al. (1981), não encontraram diferença significativa no número de colmos e comprimentos dos colmos, entre plantas crescidas a partir de plantio de canas inteiras e em toletes de duas gemas.

Ma (1980), sugeriu que o uso de colmos inteiros ao invés de toletes com duas gemas, tem as seguintes vantagens: economia de mão-de-obra; 
redução da deficiente "germinação" induzida por alta precipitação e alto nível de umidade no solo; perfilhamento precoce com benefício para o crescimento da planta em estágio posterior; aumento no número de colmos industrializáveis; redução dos custos de plantio. Entretanto, cuidados devem ser tomados para a qualidade das mudas, tais como: controle fitossanitário; é mais aplicável para canas eretas e com 8-10 meses e 10-12 gemas por colmo.

Quintela (1996), avaliando o plantio convencional e de cana inteira, com e sem desponte, e a compactação pós-cobertura, em duas variedades de cana-de-açúcar, concluiu que para as duas variedades estudadas, a percentagem de brotação e a velocidade de emergência, foram maiores no plantio de toletes com três gemas do que no plantio de cana inteira com ou sem desponte; O plantio de cana inteira, com desponte, proporcionou um maior arqueamento de mudas do que o plantio de cana inteira sem desponte e o plantio de toletes com três gemas; Como as características químicotecnológicas da cana, assim como os rendimentos de colmos das duas variedades não foram influenciados pelo plantio de cana inteira com ou sem desponte, e nem pela compactação das mudas pós-plantio, pode-se fazer o plantio de cana inteira sem desponte.

Lee (1984), conduziu um experimento onde testou a viabilidade do plantio de cana inteira da variedade NA 56-79, plantio de cana de ano, onde estudou comparativamente a brotação, o crescimento e o rendimento de colmos provenientes de plantio convencional de toletes com três gemas, picadas no sulco de plantio, com o plantio de cana inteira com e sem pontas e com e sem cartucho foliar, realizado no mês de setembro; concluiu-se que a brotação e o desenvolvimento da cana-de-açúcar a partir de mudas de cana inteira, de sete a oito meses de idade, foram iguais ou melhores do que as mudas com três gemas picadas no sulco, e que os rendimentos de cana-de-açúcar também foram semelhantes nos dois métodos. A percentagem de falhas foi maior nas parcelas de cana inteira (plantadas na razão de 12 gemas por metro linear), porém sem afetar o rendimento final observado, situando-se tais falhas entre 8 
a 9,6\% para canas inteiras contra $3,4 \%$ para o tratamento convencional de 3 gemas, entretanto, segundo o autor, este problema pode ser amenizado aumentando para 15 ou 20 gemas por metro linear de sulco. Observou ainda, que o arqueamento de mudas foi mais numeroso quando se utilizou mudas de cana inteira, recomendando, entretanto o plantio de cana inteira com o cartucho foliar, visando diminuir este problema. Também verificou que o arqueamento de mudas não oferece impedimento quando da realização dos subseqüentes tratos culturais.

O índice de falhas inferior a 10\% (das falhas maiores que $50 \mathrm{~cm}$ ) é classificado por Stolf (1983) como de excelente qualidade de plantio. Stolf (1983; 1986) e Stolf et al. (1986 e 1991), propôs a avaliação da qualidade do plantio em relação às falhas em cana planta e socas, da forma como mostra o quadro 3,a seguir:

\begin{tabular}{|cl|}
\hline \% FALHA $>0,5 \mathrm{~m}$ & Avaliação do Plantio \\
\hline $0-10$ & Excelente $^{\star}$ \\
$11-20$ & Bom $^{\star \star}$ \\
$21-35$ & médio \\
$36-50$ & Ruim \\
$>50$ & Péssimo \\
\hline
\end{tabular}

Quadro 3 - Avaliação da qualidade do plantio da cultura da cana-de-açúcar em relação às falhas no plantio Fonte: Stolf, 1983

(*) Para 15 gemas por metro e condições excepcionais de brotação

$(\star \star)$ normal - tipo mais encontrado

Em outros experimentos conduzidos em diversas localidades do Estado de São Paulo, Lee et al. (1986) confrontaram o plantio convencional de cana picada com o plantio de canas inteiras e recomendaram o seguinte procedimento para a utilização da cana inteira no plantio: utilizar mudas com 810 meses de idade para cana plantada, e no máximo 9 meses caso utilizar-se 
de cana soca; não descartar o palmito da muda, mantendo-se todas as bainhas das folhas do palmito, para evitar-se o levantamento de pontas; plantar as canas com pé e ponta bem cruzados; evitar a cobertura da cana com muita terra, sendo $5 \mathrm{~cm}$ a quantidade ideal; utilizar variedades que se apresentem eretas quando da coleta de mudas.

Lee \& Silva (1987), conduziram um experimento com o objetivo de verificar se o pré-tratamento de mudas para plantio de cana inteira, aumentaria a taxa de brotação de cana com mais de 11 meses de idade. Foram utilizadas mudas da variedade NA 56-79, com 11,5 meses de idade, os colmos foram cortados, despalhados e despontados e deixados no campo em montes por um período de 1 a 9 dias. Depois desse período essas canas e outras recém cortadas foram plantadas numa densidade de 15 gemas por metro de sulco, utilizando-se tanto o sistema de plantio de cana inteira como o de toletes com três gemas. Concluíram os referidos autores que, utilizando-se mudas com mais de 11 meses de idade para o plantio de cana inteira, em pré-tratamento constituído pelo repouso das canas no campo, por um período de 4 a 6 dias, houve um aumento na brotação na ordem 30 a 35\%. Entretanto, o repouso muito longo pode resultar num efeito negativo, devido a constante perda de água sofrida pelas canas e a ocorrência de brotação lateral acentuada durante o pré-tratamento.

Clements (1940), trabalhando com toletes de 1 e 5 gemas, verificou que a melhor emergência se deu com os que tinham 1 gema. No tocante ao comportamento de toletes de 1 gema, advindos de colmos inteiros, constatou que a melhor emergência ocorreu no terceiro nó a partir do topo e que decresceu desse ponto para a base do colmo, havendo, portanto, um gradiente de emergência que decresce do topo para a base do colmo, fato esse confirmado posteriormente por Van Dillewijn (1952). Observou, ainda, que quando as gemas são colocadas em posição lateral, a emergência é consideravelmente melhor. 
Arceneaux (1948), na Louisiana, EUA, em experimentos plantados no inicio de outubro, admitiu que a taxa de emergência poderia ser aumentada substancialmente pela redução do tamanho dos toletes. Na média de todos os testes, toletes de 5 gemas registraram os mais altos rendimentos de cana-deaçúcar por área. O uso de toletes menores, embora aumentasse a taxa de emergência, resultou numa queda em rendimento de cana-de-açúcar, quando comparada com toletes maiores. O aumento da exposição de partes pequenas de colmos a podridão teria sido um importante fator.

Mourão (1991), estudando a influência do número de gemas por toletes na produção de cana-de-açúcar, verificou não haver diferença entre toletes com quatro ou duas gemas, utilizando-se mudas da variedade NA 56-79, com doze meses de idade.

Brito (1988), estudando o plantio convencional (3-4 gemas/tolete) com sistemas de meia cana com e sem desponte e cana inteira com e sem desponte, nas variedades NA 56-79 e CB 45-3 em plantio feito em março, concluiu que não foram afetados o rendimento agrícola e as características tecnológicas da cana-de-açúcar, nos sistemas analisados. Também, observou que houve diferenças significativas para os parâmetros número de colmos colhidos por hectare, peso médio dos colmos, diâmetro médio dos colmos, arqueamento das mudas e \% de área falhada nos diferentes sistemas de plantio, que entretanto, não influenciaram a produção de cana por área (t/ha) e açúcar por área (t açúcar/ha). Informou com tais observações, ser possível sugerir-se a utilização de colmos inteiros no plantio da cana-de-açúcar. No mesmo trabalho, o autor observou que a qualidade de plantio foi considerada excelente para o sistema convencional, e média para os sistemas com meia cana e canas inteiras despontadas ou não. Para a análise de porcentagem de falhas, observou-se pela metodologia proposta por Stolf et al. (1986) que houve falhas ao redor de $2,6 \%$ para o sistema convencional contra 20 a 31\% para os demais sistemas de plantio estudados. Estes dados divergem um pouco daqueles de Lee (1984), que encontrou qualidade excelente de plantio com 
canas inteiras, porém em plantio de canas de ano, com falhas na ordem de $10 \%$ apenas. Deve-se considerar que em ambos os trabalhos, utilizaram-se números de gemas plantadas por metro linear de sulco inferiores aos plantios comerciais (20 a 25 gemas/metro), o que ajudaria a minimizar o fato.

Quanto ao arqueamento das mudas e conseqüente levantamento das pontas, Brito (1988) concluiu não haver diferença significativa entre o sistema convencional (3 a 4 gemas) e os sistemas de meia cana e cana inteira sem desponte. Analisou-se que a presença da gema apical mais o efeito mecânico das folhas deva ter contribuído para reduzir o arqueamento. Nos sistemas de meia cana e cana inteira com desponte, houve diferenças significativas para os demais tratamentos no arqueamento das mudas plantadas. Estas conclusões estão em acordo com as observações de Lee (1984); ambos autores definiram não ter havido comprometimento dos rendimentos agrícola e industrial pelo fato terem ocorrido diferentes níveis de arqueamento das mudas.

\subsubsection{Efeitos das épocas de colheita}

O período de safra da cana-de-açúcar no Brasil atinge cerca de 150 dias (Brieger \& Paranhos, 1964). Tal período é determinado em função de diversos fatores, destacando-se, entre eles, os teores de sacarose e os de açúcar redutores, contidos no caldo (Van Dillewjn, 1952, Bonnet, 1962; Alexander, 1973; Brieger \& Paranhos, 1964; Brás, 1982). Por essa razão, não se recomenda iniciar a colheita para a produção de açúcar, enquanto as canas não atingirem os padrões tecnológicos mínimos para a sua industrialização, (COPERSUCAR, 1980).

Silva et al. (1986) citando dados dos censos agropecuários da FUNDAÇÃO GETÚLIO VARGAS (FGV) (1979), em São Paulo observa que o plantio de cana-de-açúcar acontece nos meses de janeiro, fevereiro e março para a cana de ano e meio, e em outubro para a cana de ano; esses plantios 
serão colhidos no ano subseqüente, com a colheita concentrando-se nos meses de junho, julho, agosto e setembro.

Entre as inúmeras medidas de manejo que podem permitir reais ganhos de produtividade da lavoura canavieira, a época de colheita tem merecido especial atenção por influir diretamente neste aspecto (Segalla et al., 1981; Segalla \& Tokeshi, 1981; Nunes \& Schouchana, 1984).

Segundo o esquema de Tuler (1979), o rendimento da cana-de-açúcar seria afetado pelo regime pluviométrico de 27 meses consecutivos. Um $1^{\circ}$ período, de outubro a maio, correspondendo à fase de preparo do solo e plantio de novos canaviais que responderiam por mais de $30 \%$ das canas moídas em cada safra; seriam necessárias nessa fase chuvas normais, com excessos prejudicando as operações de preparo e plantio. $\mathrm{O} 2^{\circ}$ período se estenderia de junho a dezembro, compreendendo o processamento de canas plantadas no ano anterior, que dariam origem à soca da safra subseqüente; também aqui são necessárias chuvas normais para o desenvolvimento das canas plantadas e das socas, com excesso prejudicando o processo de colheita, ocasionando maior compactação do solo e prejudicando o rendimento. Um $3^{\circ}$ período cobriria os meses de janeiro a maio, coincidindo com o maior desenvolvimento cultural, época em que deficiências de chuvas causariam grandes prejuízos. A partir de junho, até dezembro, estender-se-ia o $4^{\circ}$ período que cobriria basicamente a colheita, onde poucas chuvas seriam ideais, com excessos dificultando a colheita e estimulando a continuação do crescimento, atrasando o amadurecimento e induzindo o perfilhamento, o que se refletiria em menores rendimentos culturais.

Durante o ciclo da cultura, considera-se que $850 \mathrm{~mm}$ anuais de evapotranspiração real é o mínimo valor compatível com um bom desenvolvimento (Bacchi, 1978).

A ocorrência de geadas tem sido relatada como potencialmente prejudicial à cana-de-açúcar, porém os danos variam não apenas pela intensidade do fenômeno mas também de acordo com idade do canavial e 
variedades utilizadas (Fernandes \& Furco, 1983; Bastos et al., 1983; Mendonça et al., 1983; COPERSURCAR, 1976). Em canas que serão colhidas no ano em que ocorram geadas, o efeito danoso do fenômeno pode ser minorado com a antecipação da colheita, já que a deterioração das plantas atingidas se inicia algum tempo depois da gema - entre 20 e 75 dias - dependendo da variedade e das condições de tempo posteriores (Ferrari et al., 1984; Lee et al., 1983). Nos canaviais mais novos atingidos por geadas,as recomendações variam de acordo com a idade das plantas, indo desde quebrar, cortar ou queimar, até não adotar nenhum procedimento (Bacchi, 1982; Lee, 1983).

Mendes et al. (1987), estudando a viabilidade de ampliação do período de safra da cana-de-açúcar para a produção de etanol, concluíram que para as condições em que foram conduzidos os ensaios, é possível, técnica e economicamente, iniciar-se a colheita das canas, para a produção de etanol antes do inicio do período de safra normalmente estabelecido para a produção de açúcar.

Lima et al. (1990), pesquisando o comportamento das socas de quinze variedades de cana-de-açúcar, entre elas NA 56-79, SP 70-1143 e SP 71-1406, oriundas de um ensaio de competição de variedades, onde a canaplantada foi colhida em três épocas: inicio de safra (junho), meio (agosto) e fim de safra (outubro), no município de Dumont-SP, em relação à ocorrência de déficits hídricos no período de desenvolvimento, observaram diferenças significativas entre variedades, épocas e interações entre ambas, em relação à produção de açúcar; para a cana-planta cortada nas três épocas (junho, agosto e outubro). Concluíram que a produção de açúcar por área das socas, foi afetada significativamente pelas diferenças que ocorreram entre variedades, épocas de corte e interação variedades versus época de corte; Independentemente da época de corte da cana-planta, de um modo geral, todas as socas das variedades atingiram o máximo de rendimento industrial no mês de setembro; Sem levar em consideração o rendimento agrícola, detectaram queda de rendimento industrial em socas oriundas da cana-planta 
cortadas no início de safra (junho) e que passaram por longo período com baixa precipitação; Os meses de outubro, dezembro e maio apareceram como os de maior influência sobre o rendimento da cana-de-açúcar e não se detectaram efeito significativo de geadas sobre a produtividade.

Silva et al. (1986), ao estudarem os efeitos das condições do tempo sobre a produtividade da cana-de-açúcar no Estado de São Paulo concluíram que nas condições médias do estado de São Paulo, outubro, dezembro e maio apareceram como os meses do ano-safra que mais influenciaram a cultura.

Mendonça et al. (1984), estudando diferentes épocas de corte em cana-de-açúcar, onde foram comparadas as curvas de ganho de massa verde e sacarose ao longo do ano em 19 variedades em 8 diferentes épocas e em duas safras, observaram importantes diferenças tanto entre variedades quanto entre épocas de corte, apontando comportamentos contrastantes entre variedades floríferas e não floríferas e grandes e fracas produtoras de colmos, com reflexos nas reais curvas de ganho de sacarose por unidade de área. Ressaltaram a importância de avaliar pontos ótimos de colheita sempre de maneira relativa, considerando o conjunto de variedades disponíveis na lavoura e não apenas curvas isoladas de maturação.

Mendonça et al. (1984) afirmam ainda, que do correto manejo do crescente número de variedades que vão se incorporando à lavoura, cada qual com características próprias de crescimento e maturação, depende o sucesso de sua utilização, particularmente agora que o pagamento da cana é baseado em seu conteúdo de sacarose e não mais apenas por seu peso. De modo geral, as variedades apresentam a mesma tendência de progressivo acúmulo de sacarose de abril a novembro, em termos de ATR ( $\mathrm{kg} / \mathrm{t})$, com picos de agosto (35\%), setembro (30\%), outubro (25\%) e novembro (10\%). Analisando-se as curvas de maturação, as canas altamente produtivas como a variedade SP 701143, que são grandes produtoras de massa verde, apresentam curvas de toneladas de açúcar por hectare (TAH), em geral acentuadamente mais inclinadas que as de açúcar total recuperável (ATR), tanto na fase ascendente 
quanto na descendente, por este motivo nem sempre ocorre à coincidência dos respectivos pontos de máxima destas curvas, já que os fatores ambientais que determinam o crescimento vegetativo da cana-de-açúcar agem de maneira aproximadamente inversa em relação à marcha de acúmulo de sacarose nos colmos. Observa-se uma tendência de antecipação do ponto ótimo de colheita (TAH) destas variedades em relação ao indicado pela curva de ATR.

Mendonça et al. (1984), citam também que, quando a variedade se destaca tanto pela sua riqueza em sacarose quanto por sua produção agrícola e não floresce, sua curva de ATR mostra sua real maturação do ponto de vista prático. Se florescer, entretanto, deve haver uma antecipação de sua colheita em relação a seu pico de ATR por um período variável em cada caso, não sendo entretanto, necessário colher tão logo ocorra o florescimento. Toda medida que vise à liberação de talhões para corte deve ser baseada na comparação conjunta de todas as variedades de cana-de-açúcar disponíveis para tanto, avaliadas tanto para seu conteúdo de sacarose como para sua tonelagem de colmos por unidade de área e não na observação de curvas isoladas de maturação destas variedades.

A influência da época de colheita na qualidade da variedade de canade-açúcar RB 72454 florescida, foi estudada por Pires et al. (1987). Nas análises os autores consideraram tanto os colmos como suas brotações laterais. Os resultados mostraram que nas três épocas de corte estudadas os colmos colhidos sem as brotações laterais não apresentaram diferenças significativas na produtividade agrícola e nem na produção de açúcar/ha, embora tenha havido um aumento no teor de sacarose nas duas últimas épocas. Quando os colmos foram colhidos com suas brotações laterais, também não houve diferenças significativas na produtividade agrícola, mas houve uma superioridade das duas últimas épocas sobre a primeira em açúcar/ha, assim como no teor de sacarose. Mostrando que houve uma vantagem em se colher a variedade RB 72454 florescida na última das três épocas estudadas, pois além de não prejudicar a produção de açúcar/ha 
provocou uma diminuição na probabilidade de ocorrência de florescimento nas socas subseqüentes.

Beauclair \& Penteado (1984), afirmam que o procedimento usual para determinar a época ideal de corte para as áreas cultivadas, consiste inicialmente na seleção de áreas a serem amostradas para análise tecnológica, nas quais os parâmetros de maturação são considerados. Em seguida escolhem-se para o corte, os locais com os maiores valores de açúcar teoricamente recuperável (ATR). Também consideram que a maior preocupação é a conseqüência da época de corte sobre a produtividade da cana na safra seguinte, sendo, para o cronograma de corte, considerado o dimensionamento da frota, bem como as variedades, idade, estágio, solo, clima, adubação, tratos culturais, entre outros. 



\section{MATERIAL E MÉTODOS}

Este trabalho utilizou dados de pesquisa conduzida, no CTEP Campo de experimentação da COPERSUCAR localizado na rodovia SP 127 , em Piracicaba - SP.

O tipo de solo utilizado foi o Latossol Vermelho Eutrófico (EMBRAPA, 1999) que não possuía graves problemas de erosão, já que limitaria o plantio nos meses de maior precipitação.

\subsection{Delineamento experimental e modelo matemático utilizados}

O delineamento utilizado foi blocos ao acaso, em faixas com parcelas subdivididas. Foram instalados três experimentos, cada um com uma variedade. Cada experimento teve cinco repetições. O experimento foi conduzido nas safras 1983/84, 1984/85, 1985/86, 1986/87 para a soqueira da safra de 1985/86.

O modelo matemático utilizado na análise, obtido por dedução, foi:

$$
y_{i k l j}=b_{j}+a_{i}+a b_{i j}+c_{k}+c b_{k j}+d_{l}+a c_{i k}+a d_{i l}+c d_{k l}+a c d_{i k l}+e_{i k l j}
$$

onde:

$y_{i k l j}=$ Valor observado na parcela da i-ésima época de colheita na k-ésima época de plantio no l-ésimo tratamento e j-ésimo bloco;

$b_{j}=$ Efeito aleatório do j-ésimo bloco, $b_{j} \stackrel{\text { iid }}{\sim} \mathrm{N}\left(0, \delta_{b}^{2}\right)$;

$a_{i}=$ Efeito da i-ésima época de colheita; 
$a b_{i j}=$ Efeito aleatório da interação entre a i-ésima época de colheita e o j-ésimo bloco, (resíduo "a"), $a b_{i j} \stackrel{i i d}{\sim} \mathrm{N}\left(0, \delta_{a b}^{2}\right)$;

$c_{k}=$ Efeito da k-ésima época de plantio;

$c b_{k j}=$ Efeito aleatório da interação entre a k-ésima época de plantio e o j-ésimo bloco, (resíduo "b"), $c b_{k j} \stackrel{i i d}{\sim} \mathrm{N}\left(0, \delta_{c b}^{2}\right)$;

$d_{l}=$ Efeito do l-ésimo tratamento;

$a c_{i k}=$ Efeito da interação entre a i-ésima época de colheita e a k-ésima época plantio;

$a d_{i l}=$ Efeito da interação entre a i-ésima época de colheita e o l-ésimo tratamento;

$c d_{k l}=$ Efeito da interação entre a k-ésima época de plantio e o l-ésimo tratamento;

$a c d_{i k l}=$ Efeito da interação entre a i-ésima época de colheita com a k-ésima época de plantio e o l-ésimo tratamento;

$e_{i k l j}=$ erro experimental;

iid = independente e identicamente distribuído;

\subsection{Variedades utilizadas}

Experimento 1 - SP 70-1143

Experimento 2 - NA 56-79 


\section{Experimento 3 - SP 71-1406}

\subsection{Tratamentos}

\subsubsection{Parcelas - Épocas de plantio}

$$
\begin{aligned}
& 1 \text { - Novembro } \\
& 2 \text { - Janeiro } \\
& 3 \text { - Março } \\
& 4 \text { - Maio }
\end{aligned}
$$

\subsubsection{Subparcelas em faixas - Épocas de corte}

$$
\begin{aligned}
& 1 \text { - Maio } \\
& 2 \text { - julho } \\
& 3 \text { - Setembro } \\
& 4 \text { - Novembro }
\end{aligned}
$$

\subsubsection{Sub- subparcelas - picação das mudas}

$$
\begin{aligned}
& \text { 1-Muda picada } \\
& \text { 2-Muda inteira }
\end{aligned}
$$

\subsection{Dimensões do ensaio}

As parcelas tiveram oito ruas de $50 \mathrm{~m}$, divididas em 4 subparcelas com $10 \mathrm{~m}$ de comprimento, separadas por $2 \mathrm{~m}$ de cana, inclusive no início e no final da parcela. 
Por sua vez, as subparcelas foram divididas em duas subsubparcelas, cada uma com quatro ruas. Em toda extensão da parcela, a $1^{a} \mathrm{e}$ $8^{\mathrm{a}}$ linhas foram bordaduras nas avaliações finais.

Tamanho da parcela: $8 m \times 1,4 m \times 50 m=560 m^{2}$

Tamanho de 1 experimento: $\frac{560 \times 4 \times 5}{10.000}=1,12 \mathrm{ha}$

Área do conjunto de três experimentos: $1,12 h a \times 3=3,36 h a$

Obs.: número de ruas de $50 \mathrm{~m}$ por experimento: 160 ruas

\subsection{Instalação e demais procedimentos}

\subsubsection{Preparo do solo, sulcação, adubação e plantio}

Foi feito preparo de solo convencional. A sulcação só foi realizada momentos antes do plantio. Na distribuição das mudas colocaram-se sempre dois colmos corridos no sulco de plantio, com uma densidade mínima de 12 gemas/m.

A adubação foi feita normalmente junto com a sulcação, na dosagem recomendada.

\subsection{2 Épocas de plantio e corte}

O ano safra inicia-se no mês de maio e finaliza-se no mês de abril do ano subseqüente, dessa forma os plantios realizaram-se numa safra e foram colhidos após um ano safra em formação, buscando caracterizar canas com no mínimo 12 meses de ciclo e no máximo 24 meses. 
As épocas de plantio utilizadas foram programadas para cobrir todo o período de plantio da cana-de-açúcar usado no Estado de São Paulo, assim, houve plantios para cada ano de repetição do experimento, como mostram o quadro 4 e a figura 7 a seguir:

\begin{tabular}{|c|c|c|c|c|c|}
\hline \multicolumn{2}{|c|}{$\begin{array}{c}\text { Plantio } \\
\text { ano safra 1983/84 }\end{array}$} & \multicolumn{2}{|c|}{$\begin{array}{c}1^{\circ} \text { corte } \\
\text { ano safra } 1985 / 86\end{array}$} & \multicolumn{2}{|c|}{$\begin{array}{c}2^{\circ} \text { corte (12 meses após) } \\
\text { ano safra } 1986 / 87\end{array}$} \\
\hline Mês & Ano & Mês & Ano & Mês & Ano \\
\hline \multirow{4}{*}{ Novembro } & \multirow{4}{*}{1983} & Maio & 1985 & Maio & 1986 \\
\hline & & Julho & 1985 & Julho & 1986 \\
\hline & & Setembro & 1985 & Setembro & 1986 \\
\hline & & Novembro & 1985 & Novembro & 1986 \\
\hline \multirow{4}{*}{ Janeiro } & \multirow{4}{*}{1984} & Maio & 1985 & Maio & 1986 \\
\hline & & Julho & 1985 & Julho & 1986 \\
\hline & & Setembro & 1985 & Setembro & 1986 \\
\hline & & Novembro & 1985 & Novembro & 1986 \\
\hline \multirow{4}{*}{ Março } & \multirow{4}{*}{1984} & Maio & 1985 & Maio & 1986 \\
\hline & & Julho & 1985 & Julho & 1986 \\
\hline & & Setembro & 1985 & Setembro & 1986 \\
\hline & & Novembro & 1985 & Novembro & 1986 \\
\hline \multirow{4}{*}{ Maio } & \multirow{4}{*}{1984} & Maio & 1985 & Maio & 1986 \\
\hline & & Julho & 1985 & Julho & 1986 \\
\hline & & Setembro & 1985 & Setembro & 1986 \\
\hline & & Novembro & 1985 & Novembro & 1986 \\
\hline
\end{tabular}

Quadro 4 - Épocas de plantio e corte utilizadas

Este procedimento foi repetido no ano safra 1984/85 e 1985/86, com a instalação de ovos experimentos idênticos visando a repetição de estágios iguais em anos-safra diferentes e diferentes estágios dentro do mesmo anosafra. 

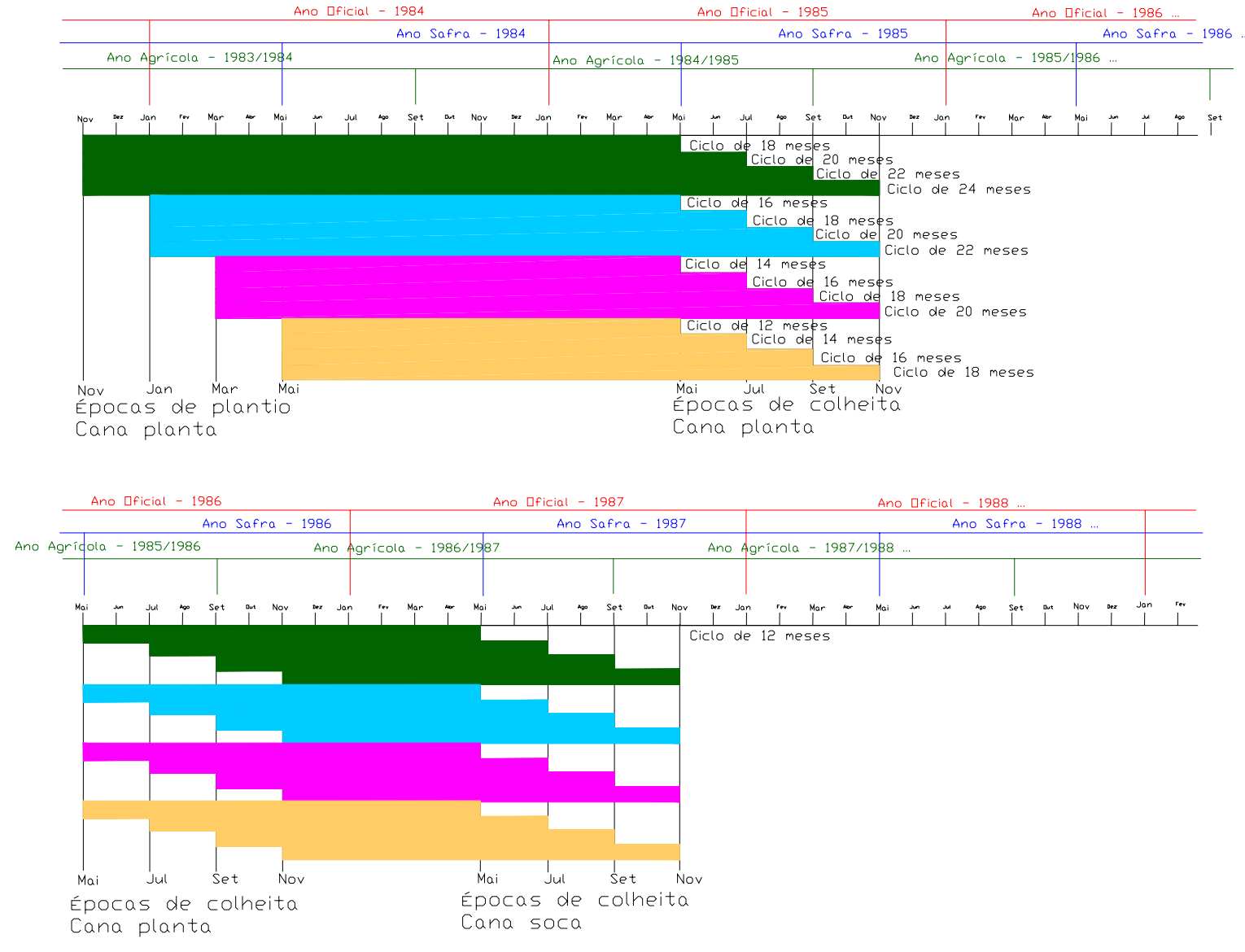

Figura 7 - Épocas de plantio e corte utilizadas

\subsubsection{Tratos culturais}

Os tratos culturais foram normais, com aplicação de herbicida após plantio e cultivo mecânico com complementação de $50 \mathrm{Kg} \mathrm{N} / \mathrm{ha}$ no fechamento da cultura, conforme resultado obtido no programa COPI (COPERSUCAR, 1982; Maia \& Beauclair, 1984). Desta forma, as parcelas receberam complementação nitrogenada em épocas distintas, aproximadamente aos 3 meses de idade. 


\subsection{Avaliações}

\subsubsection{Avaliação de produtividades agrícola e industrial}

As causas de variação a serem avaliadas são: efeito do ano, variedade, época de plantio, época de corte, tipo de muda e repetição (blocos), para cada uma das variáveis avaliadas.

Foram medidas as variáveis de produção: toneladas de colmos por ha (TCH), açúcar total recuperável (ATR), e toneladas de açúcar por ha (TAH).

As parcelas ao serem cortadas, tiveram a massa das seis ruas centrais avaliada individualmente por subparcela sendo três ruas de $10 \mathrm{~m}$ para cada uma. Foram calculados então os rendimentos equivalentes em toneladas de cana por hectare $(\mathrm{TCH})$, e utilizadas nas análises de variância.

$\mathrm{Na}$ ocasião da colheita, em cada subparcela foram retiradas três amostras de 10 canas seguidas no sulco, para análise tecnológica e estimativa de rendimento industrial. A massa das amostras foi acrescentada à massa das subparcelas.

Para a análise tecnológica e estimativa de rendimento industrial utilizaram-se os procedimentos segundo CONSECANA (2002).

Conhecidos a pol da cana (PC) e os açúcares redutores da cana (ARC), o ATR foi calculado pela equação:

$$
A T R=10 * P C * 1,0526 * 0,88+10 * A R C * 0,88(6)
$$

Onde:

10 * PC $=$ pol por tonelada de cana

1,0526 = coeficiente estequiométrico para a conversão de pol em açúcares redutores

$0,88=$ coeficiente de recuperação, para uma perda industrial de $12 \%$ (doze por cento) 
10 * ARC = açúcares redutores por tonelada de cana.

A soqueira das subparcelas foi avaliada da mesma forma que o $1^{\circ}$ corte, aos (12) meses de idade.

\subsubsection{Informações meteorológicas}

Foram utilizados os dados do posto meteorológico da estação experimental para estudo de seus efeitos sobre as avaliações obtidas com os diversos tratamentos e elaboração do balanço hídrico nos anos equivalentes ao estudo.

Através da repetição dos procedimentos por três anos seguidos no mesmo local, foram feitas inferências dos efeitos climáticos sobre cada ciclo e estágio. 


\section{RESULTADOS E DISCUSSÃO}

Os valores de TCH, ATR e TAH gerados para as épocas de plantio e de colheita nos tratamentos com muda de cana picada e inteira no sulco de plantio, em cada ano e estágio para as três variedades utilizadas, foram submetidos à análise de variância e suas médias comparadas pelo teste de Tukey.

Os dados climáticos são apresentados a seguir nas figuras 08 e 09, em forma de gráfico, representando o balanço hídrico segundo Thornthwaite \& Mather (1955) para o período de Julho/1983 até Dezembro/1989, e temperaturas médias mensais, para o mesmo período.

Como se pode observar na figura 08 o $1^{\circ}$ semestre de 1984 foi seco, com déficit a partir de fevereiro de 1984 até agosto. O ano de 1985 apresentou boa quantidade de chuva no $1^{\circ}$ semestre e grande déficit em outubro ( $2^{\circ}$ semestre). Em 1986 ocorreu pouco déficit no $2^{\circ}$ semestre. O ano de 1987 foi um relativamente chuvoso. Em 1988 ocorreu déficit durante a safra (colheita) e 1989 se apresentou praticamente sem déficit hídrico.

$\mathrm{Na}$ figura 09 se pode observar eu os anos de 1985 e 1988 apresentaram as mais baixas temperaturas nos meses de julho favorecendo a maturação. 


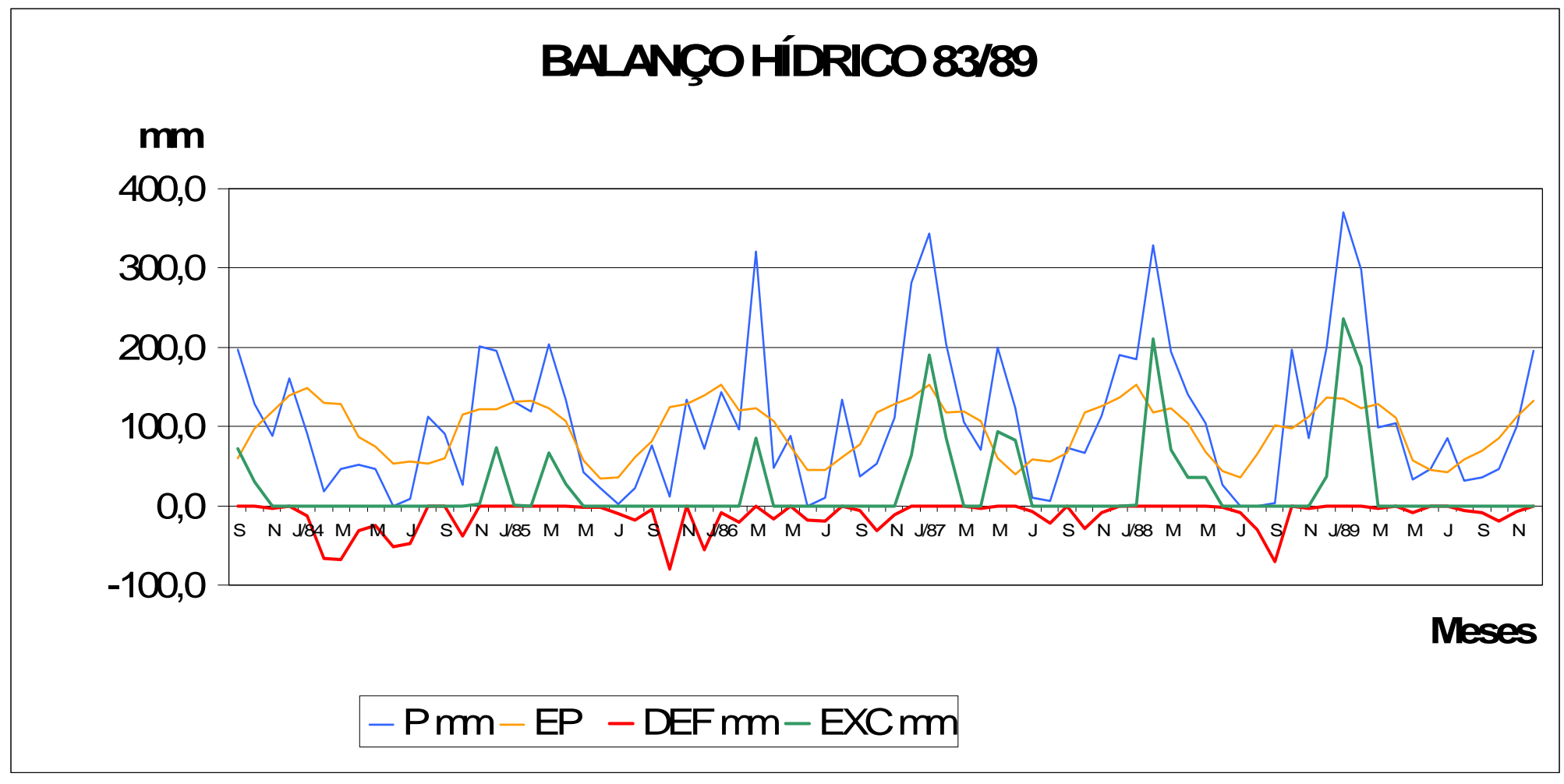

Figura 8 - Balanço Hídrico, segundo Thornthwaite \& Mather (1955), para o período entre julho/1983 e dezembro/1989, de acordo com os dados do posto meteorológico da estação experimental 


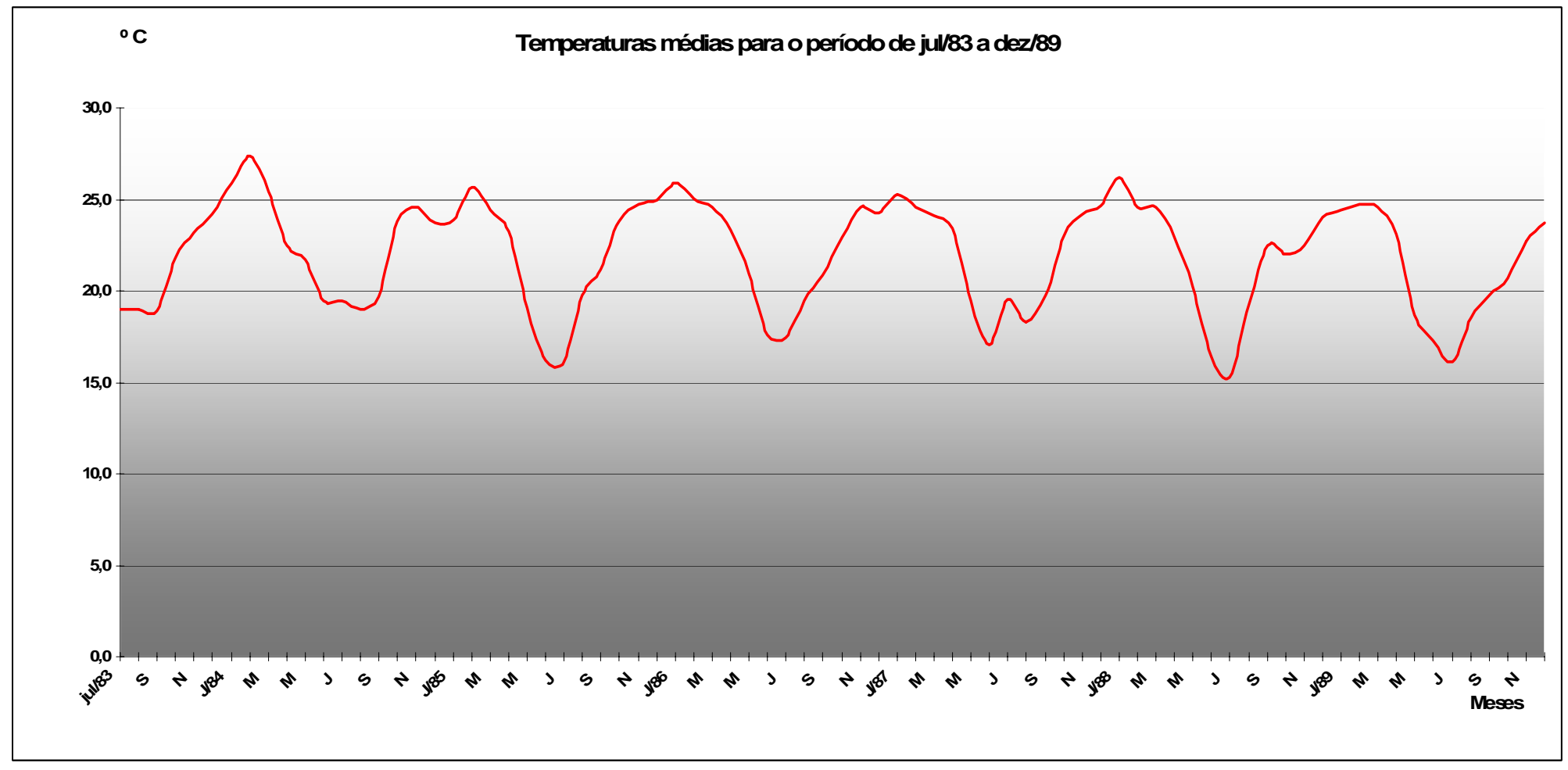

Figura 9 - Temperaturas Médias Mensais $\left({ }^{\circ} \mathrm{C}\right)$ para o período entre julho/83 e dezembro/89, de acordo com os dados do posto meteorológico da estação experimental 


\section{1 Variedade SP $70-1143-1^{\circ}$ corte}

São apresentados na tabela 1, a seguir, os resultados obtidos no primeiro corte nas safras de 1985, 1986 e 1987, para toneladas de cana por ha (TCH), açúcar total recuperável (ATR) em kg de açúcar por tonelada de cana e (TAH) toneladas de açúcar por ha, para a variedade SP 70-1143.

Tabela 1. Valores obtidos de TCH, ATR e TAH para a variedade SP 70-1143, no primeiro corte e nas safras de 1985, 1986 e 1987, em várias combinações de épocas de plantio e de colheita e sob os tratamentos muda picada e inteira no sulco de plantio

\begin{tabular}{|c|c|c|c|c|c|c|c|c|c|c|c|}
\hline \multicolumn{12}{|c|}{ SP 70-1143 } \\
\hline \multirow[b]{2}{*}{$\begin{array}{l}\text { Ep } \\
\mathrm{PI}\end{array}$} & \multirow[b]{2}{*}{$\begin{array}{l}\text { Ep } \\
\text { Colh }\end{array}$} & \multirow[b]{2}{*}{ Trat } & \multicolumn{3}{|c|}{ Safra 1985 - corte 1} & \multicolumn{3}{|c|}{ Safra 1986 - corte 1} & \multicolumn{3}{|c|}{ Safra 1987 - corte 1} \\
\hline & & & $\begin{array}{l}\text { Rend } \\
\text { Cana } \\
\text { (TCH) }\end{array}$ & ATR & $\begin{array}{l}\text { Rend } \\
\text { açúcar } \\
\text { (TAH) }\end{array}$ & $\begin{array}{l}\text { Rend } \\
\text { Cana } \\
\text { (TCH) }\end{array}$ & ATR & $\begin{array}{l}\text { Rend } \\
\text { açúcar } \\
\text { (TAH) }\end{array}$ & $\begin{array}{l}\text { Rend } \\
\text { Cana } \\
\text { (TCH) }\end{array}$ & ATR & $\begin{array}{l}\text { Rend } \\
\text { açúcar } \\
\text { (TAH) }\end{array}$ \\
\hline Nov & Mai & Picada & 94,45 & 131,69 & 12,40 & 84,31 & 123,35 & 10,42 & 145,19 & 122,65 & 17,81 \\
\hline Nov & Mai & Inteira & 94,50 & 124,44 & 11,74 & 91,26 & 123,92 & 11,31 & 153,43 & 121,35 & 18,61 \\
\hline Nov & Jul & Picada & 95,24 & 152,31 & 14,51 & 100,67 & 150,77 & 15,18 & 142,29 & 157,51 & 22,42 \\
\hline Nov & Jul & Inteira & 95,57 & 150,46 & 14,38 & 94,26 & 143,03 & 13,37 & 133,15 & 155,87 & 20,71 \\
\hline Nov & Set & Picada & 79,07 & 158,12 & 12,45 & 93,05 & 159,23 & 14,82 & 146,15 & 162,52 & 23,72 \\
\hline Nov & Set & Inteira & 79,33 & 158,15 & 12,53 & 95,67 & 155,11 & 14,80 & 143,81 & 164,48 & 23,66 \\
\hline Nov & Nov & Picada & 87,69 & 162,10 & 14,21 & 101,05 & 147,67 & 14,93 & 134,91 & 152,82 & 20,55 \\
\hline Nov & Nov & Inteira & 84,57 & 162,65 & 13,76 & 89,24 & 145,47 & 12,98 & 138,15 & 153,48 & 21,19 \\
\hline Jan & Mai & Picada & 93,45 & 127,53 & 11,91 & 94,62 & 115,75 & 10,95 & 137,96 & 124,91 & 17,17 \\
\hline Jan & Mai & Inteira & 97,91 & 127,04 & 12,43 & 87,72 & 113,51 & 9,96 & 142,43 & 123,20 & 17,51 \\
\hline Jan & Jul & Picada & 101,03 & 153,02 & 15,44 & 101,17 & 146,35 & 14,80 & 124,67 & 153,77 & 19,19 \\
\hline Jan & Jul & Inteira & 108,31 & 151,29 & 16,35 & 93,81 & 148,28 & 13,91 & 138,57 & 151,28 & 20,97 \\
\hline Jan & Set & Picada & 91,45 & 158,73 & 14,46 & 99,43 & 155,51 & 15,44 & 141,43 & 161,88 & 22,94 \\
\hline Jan & Set & Inteira & 87,98 & 162,64 & 14,32 & 97,14 & 153,93 & 14,97 & 146,34 & 163,94 & 24,00 \\
\hline Jan & Nov & Picada & 93,86 & 160,87 & 15,03 & 94,62 & 138,45 & 13,04 & 147,96 & 152,43 & 22,58 \\
\hline Jan & Nov & Inteira & 98,17 & 159,63 & 15,66 & 88,34 & 133,02 & 11,76 & 134,15 & 149,53 & 20,05 \\
\hline Mar & Mai & Picada & 96,62 & 114,56 & 11,03 & 84,69 & 95,32 & 8,06 & 124,48 & 107,97 & 13,47 \\
\hline Mar & Mai & Inteira & 95,95 & 114,21 & 10,96 & 87,76 & 97,99 & 8,59 & 121,15 & 107,63 & 13,03 \\
\hline Mar & Jul & Picada & 105,22 & 147,57 & 15,48 & 94,45 & 133,49 & 12,62 & 119,62 & 145,70 & 17,41 \\
\hline Mar & Jul & Inteira & 106,69 & 148,36 & 15,84 & 92,41 & 137,93 & 12,76 & 129,67 & 144,75 & 18,76 \\
\hline Mar & Set & Picada & 90,10 & 158,07 & 14,26 & 93,72 & 161,68 & 15,14 & 132,05 & 159,76 & 21,07 \\
\hline Mar & Set & Inteira & 89,64 & 155,31 & 13,90 & 93,95 & 161,65 & 15,19 & 134,53 & 155,64 & 20,94 \\
\hline Mar & Nov & Picada & 113,31 & 160,10 & 18,15 & 89,29 & 145,39 & 12,98 & 119,38 & 148,02 & 17,67 \\
\hline Mar & Nov & Inteira & 111,05 & 160,66 & 17,85 & 85,67 & 144,47 & 12,37 & 119,53 & 151,03 & 18,03 \\
\hline Mai & Mai & Picada & 85,24 & 88,47 & 7,49 & 71,31 & 80,20 & 5,72 & 99,86 & 90,02 & 8,99 \\
\hline Mai & Mai & Inteira & 97,00 & 84,81 & 8,20 & 81,62 & 81,23 & 6,63 & 102,10 & 90,84 & 9,29 \\
\hline Mai & Jul & Picada & 92,93 & 128,20 & 11,91 & 79,60 & 129,73 & 10,31 & 100,67 & 138,00 & 13,90 \\
\hline Mai & Jul & Inteira & 109,38 & 128,81 & 14,04 & 89,72 & 129,53 & 11,62 & 102,81 & 130,87 & 13,44 \\
\hline Mai & Set & Picada & 87,10 & 155,67 & 13,53 & 82,48 & 159,41 & 13,15 & 121,05 & 148,88 & 17,98 \\
\hline Mai & Set & Inteira & 96,05 & 146,95 & 14,14 & 87,05 & 160,55 & 13,97 & 109,86 & 144,40 & 15,86 \\
\hline Mai & Nov & Picada & 75,88 & 164,27 & 12,46 & 81,91 & 148,11 & 12,12 & 122,62 & 150,26 & 18,43 \\
\hline Mai & Nov & Inteira & 93,17 & 158,20 & 14,73 & 87,91 & 146,72 & 12,87 & 100,38 & 152,18 & 15,31 \\
\hline
\end{tabular}


Tabela 2. Resumo dos quadros de análise de variância dos dados obtidos para a variedade SP $70-1143$, no primeiro corte com plantio no ano de 1983/84, em relação às variáveis dependentes TCH, ATR e TAH em várias combinações de épocas de plantio e de colheita e sob os tratamentos muda picada e inteira no sulco de plantio

\begin{tabular}{lcccc}
\hline & & TCH & ATR & TAH \\
\multicolumn{1}{c}{ C. Variação } & $G L$ & $Q M$ & $Q M$ & $Q M$ \\
\hline BLOCO & 4 & -- & -- & -- \\
EPCOL & 3 & $1346,212^{* *}$ & $17970,263^{* *}$ & $159,991^{* *}$ \\
Resíduo (a) & 12 & 282,879 & 108,966 & 3,959 \\
EPPLA & 3 & $1139,216^{* *}$ & $2925,482^{* *}$ & $58,395^{* *}$ \\
Resíduo (b) & 12 & 276,676 & 36,448 & 5,354 \\
TRAT & 1 & $613,207^{*}$ & 119,491 & 5,860 \\
EPCOL ${ }^{*}$ EPPLA & 9 & $356,786^{*}$ & $742,263^{* *}$ & $15,665^{* *}$ \\
EPCOL ${ }^{*}$ TRAT & 3 & 42,855 & 9,738 & 1,307 \\
EPPLA ${ }^{*} T R A T$ & 3 & $448,411^{*}$ & 42,196 & 5,937 \\
EPCOL ${ }^{*}$ EPPLA ${ }^{*}$ TRAT & 9 & 20,760 & 28,149 & 0,573 \\
Resíduo (c) & $10 \odot$ & 154,960 & 31,809 & 3,595 \\
Total & 159 & -- & -- & -- \\
\hline
\end{tabular}

A tabela 2, apresentada, mostra os valores da análise de variância, para as variáveis ATR, TCH e TAH, da variedade SP 70-1143, no primeiro corte e ano de plantio 1983/84. Como se pode observar, para as variáveis TCH, ATR e TAH houve efeito significativo de época de corte e época de plantio. O tratamento muda picada e inteira no sulco de plantio apresentou efeito significativo apenas para a variável TCH.

Houve interação de épocas de plantio dentro de épocas de colheita para as três variáveis estudadas, indicando efeito significativo das épocas de plantio sobre cada época de colheita. Para TCH houve, ainda, interação de tratamentos (muda picada e inteira no sulco de plantio) dentro de épocas de plantio, indicando efeito significativo do tipo de muda sobre cada época de plantio. 
Tabela 3. Valores médios de TCH para a variedade SP 70-1143 nas interações de épocas de plantio dentro de época de colheita, no ano de 1983/84, no $1^{\circ}$ corte

\begin{tabular}{ccrl}
\hline EPPLA & EPCOL & \multicolumn{2}{c}{$T C H$ MÉDIA } \\
\hline Mar & Nov & 112,18 & a \\
Mar & Jul & 105,95 & ab \\
Jan & Jul & 104,67 & ab \\
Mai & Jul & 101,16 & abc \\
Mar & Mai & 96,29 & abcd \\
Jan & Nov & 96,01 & abcd \\
Jan & Mai & 95,68 abcd \\
Nov & Jul & 95,41 & abcd \\
Nov & Mai & 94,48 & abcd \\
Mai & Set & 91,57 & bcd \\
Mai & Mai & 91,12 & bcd \\
Mar & Set & 89,87 & bcd \\
Jan & Set & 89,72 & bcd \\
Nov & Nov & 86,13 & cd \\
Mai & Nov & 84,53 & cd \\
Nov & Set & 79,20 & d
\end{tabular}

Médias seguidas das mesmas letras não diferiram estatisticamente entre si.

$\mathrm{Na}$ tabela 3, observa-se que para a variedade SP 70-1143, plantada em 1983/84 e no primeiro corte, houve diferença estatisticamente significativa entre as médias das épocas de plantio dentro das épocas de colheita.

A época de plantio Março com colheita em Novembro, obteve melhor rendimento que as épocas de plantio Novembro com colheita em Novembro, Maio com colheita em Novembro e Novembro com colheita em Setembro. 
Tabela 4. Valores médios de TCH para a variedade SP 701143 nas interações de Tratamentos dentro de épocas de plantio, no ano de 1983/84, no $1^{\circ}$ corte

\begin{tabular}{clr}
\hline EPPLA & Tratamento & TCH MÉDIA \\
\hline Mar & Muda Picada & $101,31 \mathrm{a}$ \\
Mar & Muda Inteira & $100,83 \mathrm{ab}$ \\
Mai & Muda Inteira & $98,90 \mathrm{abc}$ \\
Jan & Muda Inteira & $98,09 \mathrm{abc}$ \\
Jan & Muda Picada & $94,95 \mathrm{abc}$ \\
Nov & Muda Picada & $89,12 \mathrm{bc}$ \\
Nov & Muda Inteira & $88,50 \mathrm{C}$ \\
Mai & Muda Picada & $85,29 \quad \mathrm{~d}$ \\
\hline
\end{tabular}

Médias seguidas das mesmas letras não diferiram estatisticamente entre si.

$\mathrm{Na}$ tabela 4, observa-se que para a variedade SP 70-1143, plantada em 1983/84 e no primeiro corte, houve diferença estatisticamente significativa entre as médias dos tratamentos muda picada e inteira no sulco de plantio dentro das épocas de plantio.

A época de plantio Março obteve melhor rendimento de cana que as épocas de plantio Novembro e Maio. A época de plantio Maio com muda de cana picada apresentou o menor valor de $\mathrm{TCH}$. Ainda, para as épocas de plantio Março, Janeiro e Novembro, não houve diferença estatisticamente significativa entre os tratamentos muda picada e inteira, mas para a época de plantio Maio houve diferença entre os tratamentos, sendo significativamente superior o desempenho da cana plantada inteira. As figuras 10, 11, 12 e 13, a seguir, mostram a evolução de TCH para cada época de plantio onde se pode verificar o efeito das épocas de colheita sobre os valores observados.

A figura 08 mostra que a partir do mês de abril até julho ocorreram baixas precipitações e queda na temperatura (figura 09), considerando que Maio é uma época de plantio com condições climáticas menos favoráveis para a cana, caracterizada por declínio na temperatura e déficit hídrico, estes resultados sugerem que nesta época deva-se plantar a cana inteira. Lee et al. (1984), 
também notaram que quando ocorre um período de déficit hídrico, o plantio de cana inteira em comparação com toletes de três gemas apresenta falhas menores e o "stand" final melhor. No caso estudado, ocorreram 30 dias de seca após o plantio, acrescido de altas temperaturas, nestas condições, a perda de umidade em toletes de três gemas é bem maior do que em cana inteira. Van Dillewijn (1952), comentou ser o comprimento mínimo dos toletes determinado principalmente pela qualidade da muda e pelas condições de crescimento. Em regiões com condições favoráveis, utilizam-se toletes com duas ou apenas uma gema desenvolvida. Em regiões com condições menos favoráveis, o comprimento dos toletes tem que ser aumentado adequadamente, como nos plantios de outono nas regiões temperadas, onde as condições de brotação são ruins.

\section{Resultados de TCH- Safra 1985 \\ corte 1 - época de plantio Novembro}

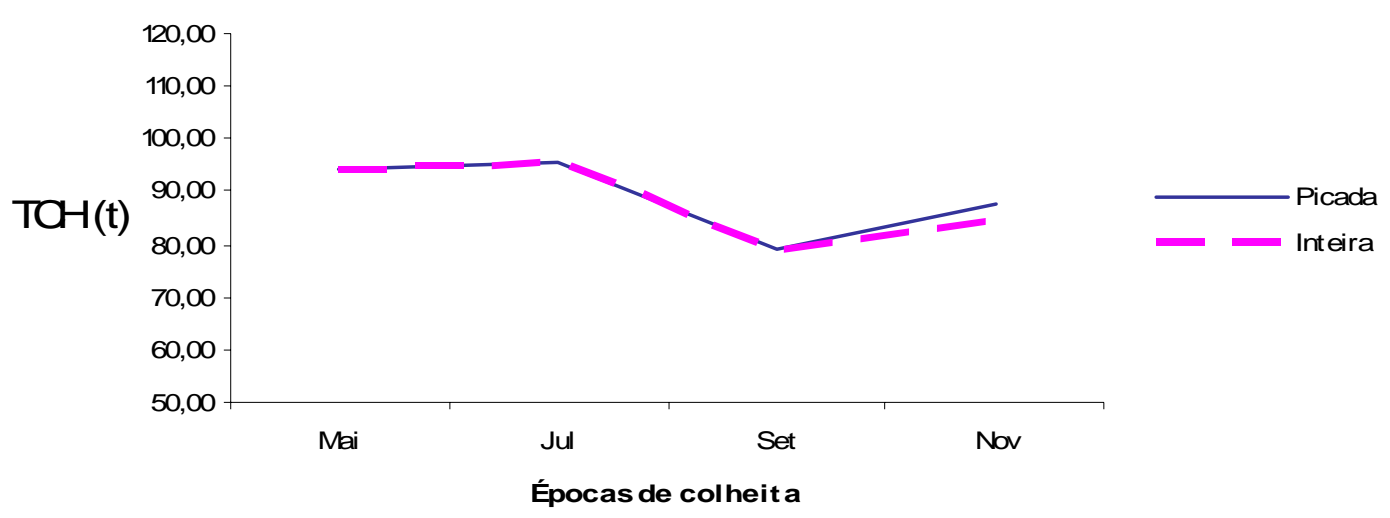

Figura 10 - Resultados de TCH para a variedade SP 70-1143 na safra 1985 , no $1^{\circ}$ corte e época de plantio Novembro 
Resultados de TCH- Safra 1985

corte 1 - época de plantio Janeiro

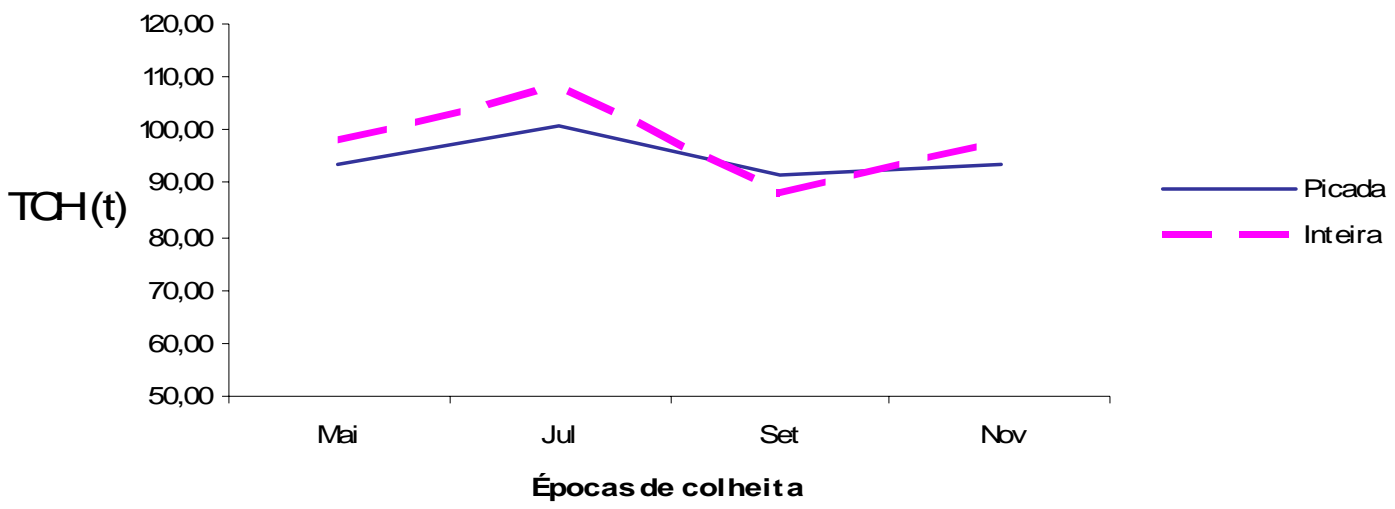

Figura 11 - Resultados de TCH para a variedade SP 70-1143 na safra 1985, no $1^{\circ}$ corte e época de plantio Janeiro

Resultados de TCH-Safra 1985

corte 1 - época de plantio Março

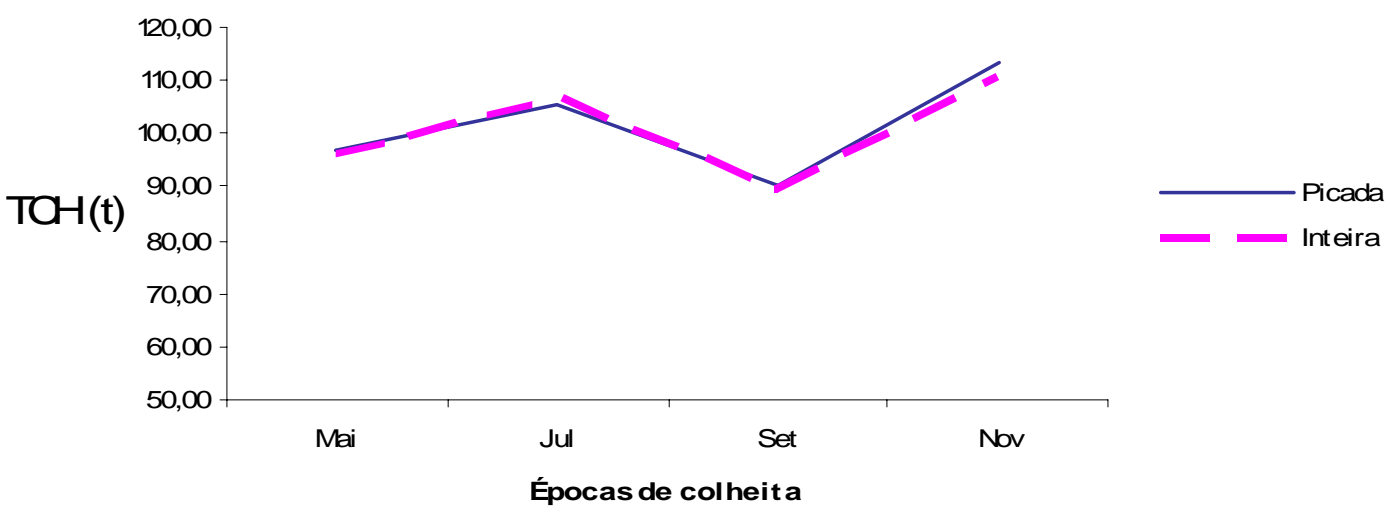

Figura 12 - Resultados de TCH para a variedade SP 70-1143 na safra 1985, no $1^{\circ}$ corte e época de plantio Março 
Resultados de TCH- Safra 1985

corte 1 - época de plantio Maio

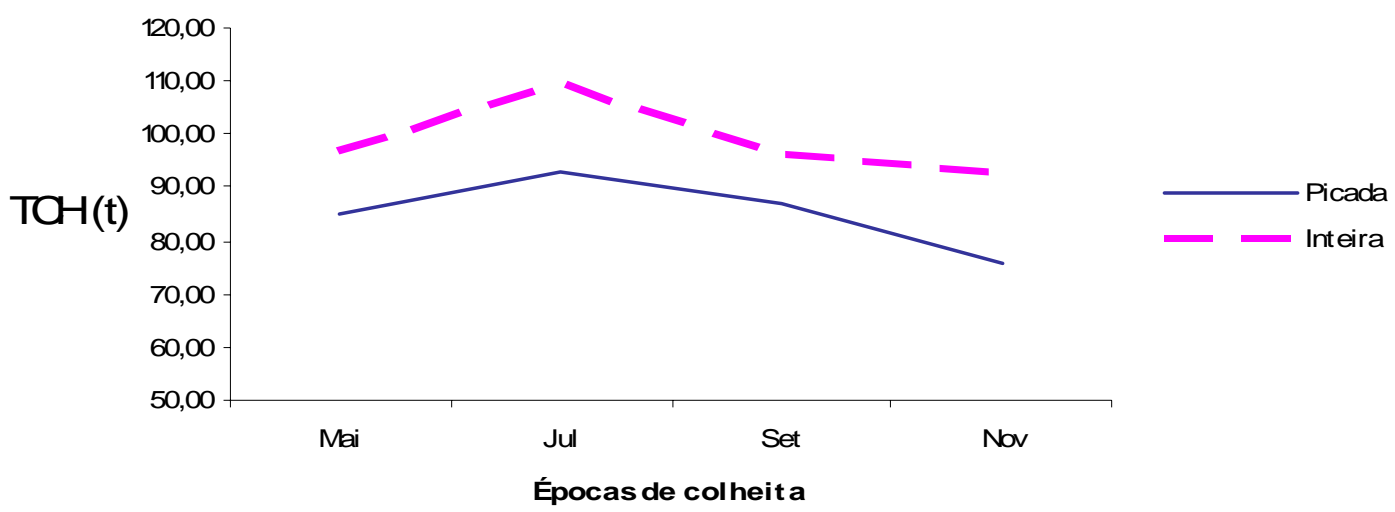

Figura 13 - Resultados de TCH para a variedade SP 70-1143 na safra 1985, no $1^{\circ}$ corte e época de plantio Maio

Tabela 5. Valores médios de ATR para a variedade SP 70-1143 nas interações de épocas de plantio dentro de épocas de colheita, no ano de $1983 / 84$, no $1^{\circ}$ corte

\begin{tabular}{cccc}
\hline EPPLA & EPCOL & ATR (MÉDIA) \\
\hline Nov & Nov & 162,38 a & \\
Mai & Nov & 161,24 & a \\
Jan & Set & 160,69 & ab \\
Mar & Nov & 160,38 ab \\
Jan & Nov & 160,25 ab & \\
Nov & Set & 158,13 abc \\
Mar & Set & 156,69 abcd \\
Jan & Jul & 152,16 & bcd \\
Nov & Jul & 151,38 & cd \\
Mai & Set & 151,31 & cd \\
Mar & Jul & 147,97 & $\mathrm{~d}$ \\
Mai & Jul & 128,51 & $\mathrm{e}$ \\
Nov & Mai & 128,07 & $\mathrm{e}$ \\
Jan & Mai & 127,28 & $\mathrm{e}$ \\
Mar & Mai & 114,38 & $\mathrm{f}$ \\
Mai & Mai & 86,64 & $\mathrm{~g}$ \\
\hline Médias seguidas das mesmas letras não diferiram estatisticamente entre si.
\end{tabular}


$\mathrm{Na}$ tabela 5, observa-se que para a variedade SP 70-1143, plantada em 1983/84 e no primeiro corte, houve diferença estatisticamente significativa entre as médias das épocas de plantio dentro das épocas de colheita.

Os resultados mostram que em relação à variável ATR para qualquer época de plantio, a época de colheita Novembro apresentou os maiores valores seguidos pela época de colheita Setembro. A época de plantio Maio com colheita em Maio apresentou o menor valor de ATR.

As figuras 14, 15, 16 e 17, a seguir, mostram a evolução de ATR para cada época de plantio, verifica-se que as épocas de colheita afetam os valores observados; os valores de ATR sempre se mostram crescentes do início para o final da safra, o que coincide com os resultados de Lima et al. (1990), Mendonça et al. (1984), Pires et al. (1987). Nota-se uma redução dos valores iniciais de ATR da época de plantio Novembro para Janeiro e Março com os menores valores observados para a época Maio. O tipo de muda (inteira ou picada) apresentou variações pequenas ou nulas nos resultados de ATR.

Resultados de ATR- Safra 1985

corte 1 - época de plantio Novembro

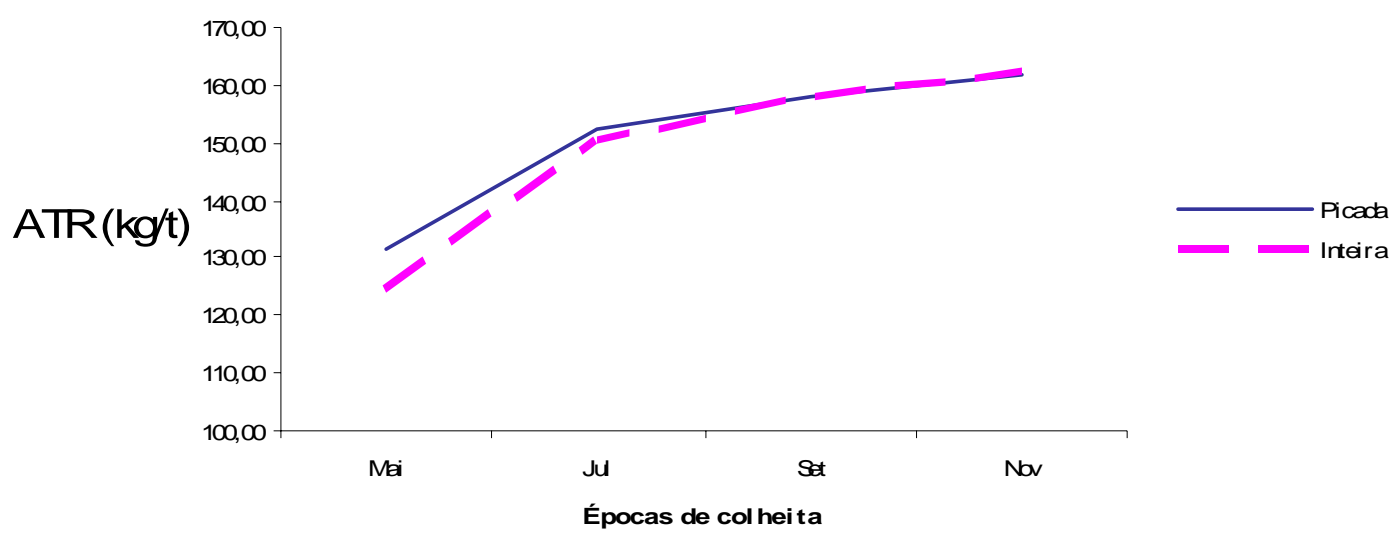

Figura 14 - Resultados de ATR para a variedade SP 70-1143 na safra 1985, no $1^{\circ}$ corte e época de plantio Novembro 
Resultados de ATR- Safra 1985

corte 1 - época de plantio Janeiro

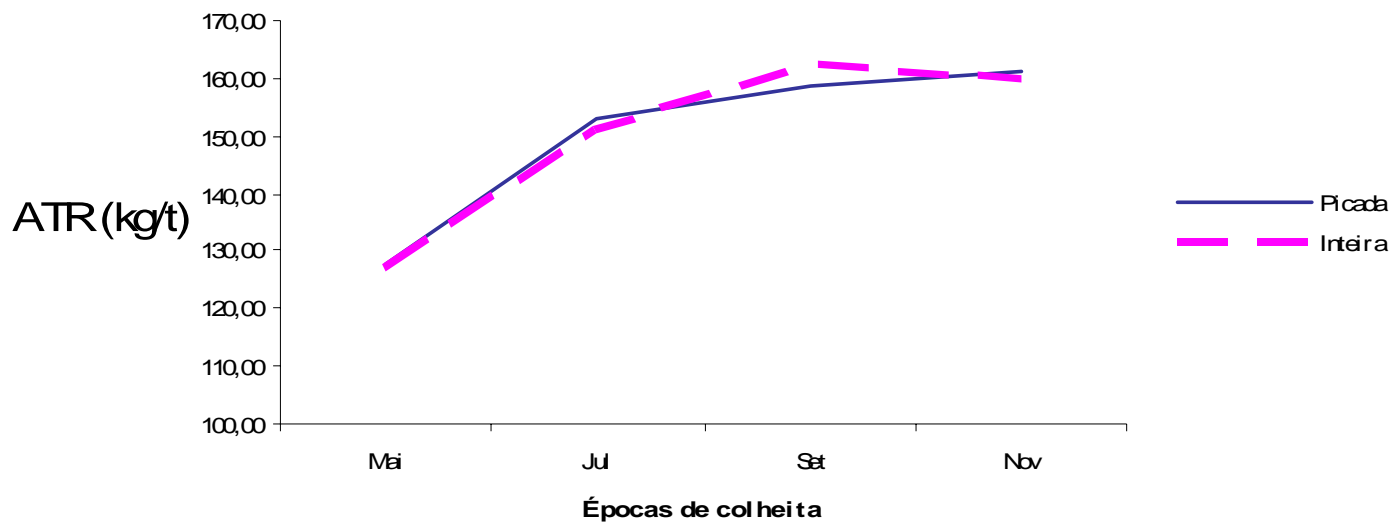

Figura 15 - Resultados de ATR para a variedade SP 70-1143 na safra 1985, no $1^{\circ}$ corte e época de plantio Janeiro

Resultados de ATR- Safra 1985

corte 1 - época de plantio Março

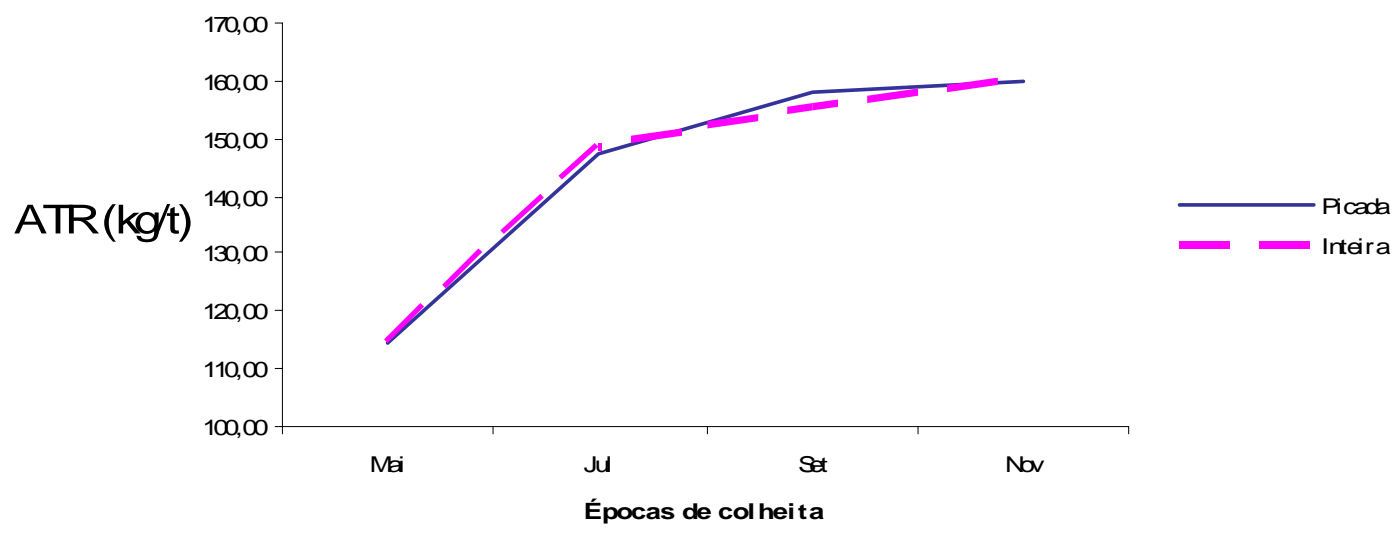

Figura 16 - Resultados de ATR para a variedade SP 70-1143 na safra 1985, no $1^{\circ}$ corte e época de plantio Março 


\section{Resultados de ATR- Safra 1985 corte 1 - época de plantio Maio}

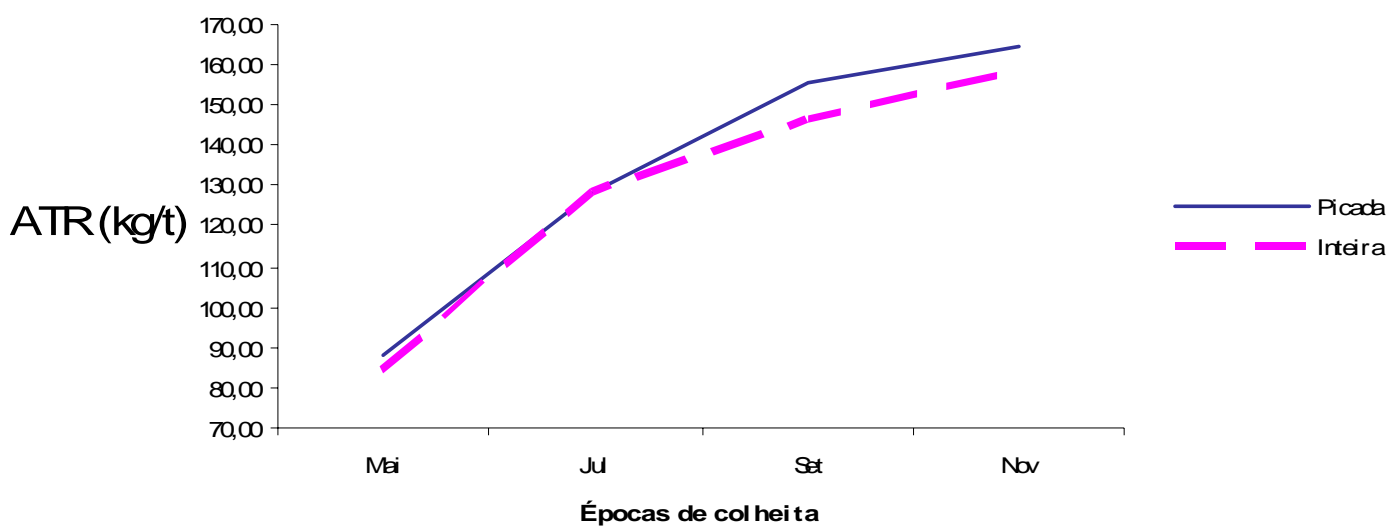

Figura 17 - Resultados de ATR para a variedade SP 70-1143 na safra 1985 , no $1^{\circ}$ corte e época de plantio Maio

Tabela 6. Valores médios de TAH para a variedade SP 70-1143 nas interações de épocas de plantio dentro de épocas de colheita, no ano de $1983 / 84$, no $1^{\circ}$ corte

\begin{tabular}{cccc}
\hline EPPLA & EPCOL & \multicolumn{2}{c}{ TAH MÉDIA } \\
\hline Mar & Nov & 18,00 & a \\
Jan & Jul & 15,89 & ab \\
Mar & Jul & 15,66 & ab \\
Jan & Nov & 15,34 & abc \\
Nov & Jul & 14,45 & bcd \\
Jan & Set & 14,39 & bcd \\
Mar & Set & 14,08 & bcd \\
Nov & Nov & 13,99 & bcd \\
Mai & Set & 13,84 & bcde \\
Mai & Nov & 13,60 & bcde \\
Mai & Jul & 12,98 & bcde \\
Nov & Set & 12,49 & cde \\
Jan & Mai & 12,17 & de \\
Nov & Mai & 12,07 & de \\
Mar & Mai & 10,99 & e \\
Mai & Mai & 7,84 & $\mathrm{f}$ \\
\hline
\end{tabular}

Médias seguidas das mesmas letras não diferiram estatisticamente entre si. 
$\mathrm{Na}$ tabela 6, observa-se que para a variedade SP 70-1143, plantada em 1983/84 e no primeiro corte, houve diferença estatisticamente significativa entre as médias das épocas de plantio dentro das épocas de colheita para a variável TAH.

As épocas de plantio Janeiro e Março com colheita em Novembro e Julho, obtiveram os maiores resultados que as épocas de plantio Maio, Março, Novembro e Janeiro combinados com a época de colheita Maio.

As figuras 18, 19, 20 e 21, a seguir, mostram a evolução de TAH para cada época de plantio evidenciando o efeito das épocas de colheita sobre os valores observados.

Resultados deTAH- Safra 1985

corte 1 - época de plantio Novembro

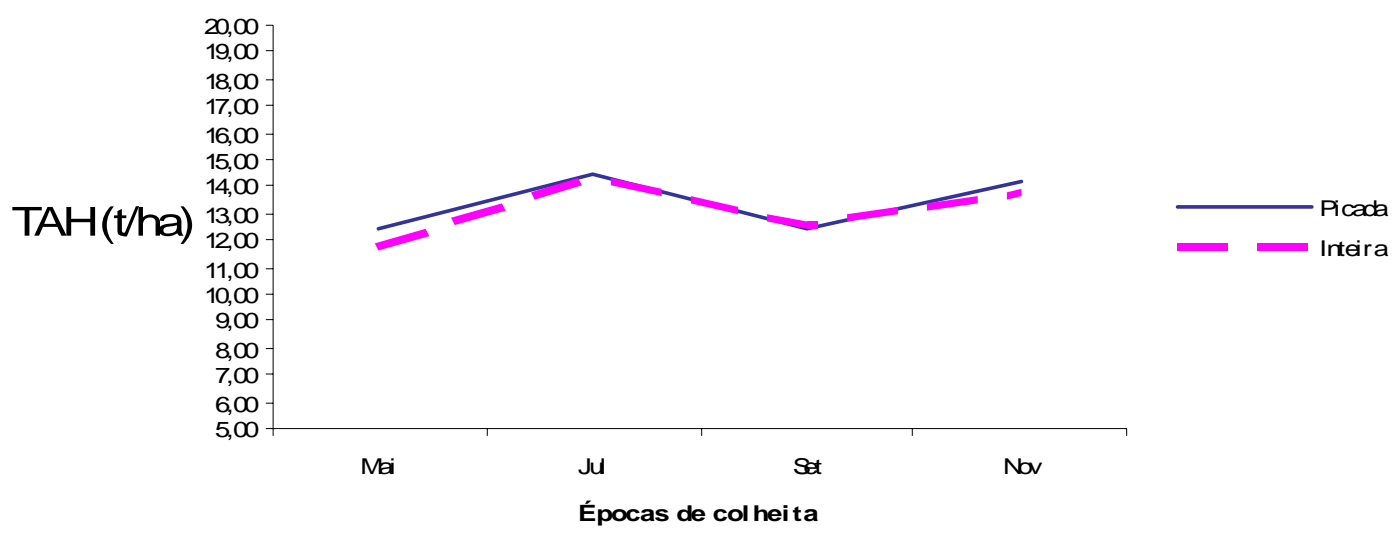

Figura 18 - Resultados de TAH para a variedade SP 70-1143 na safra 1985 , no $1^{\circ}$ corte e época de plantio Novembro 
Pesultados deTAH- Safra 1985 corte 1 - época de plantio Janeiro

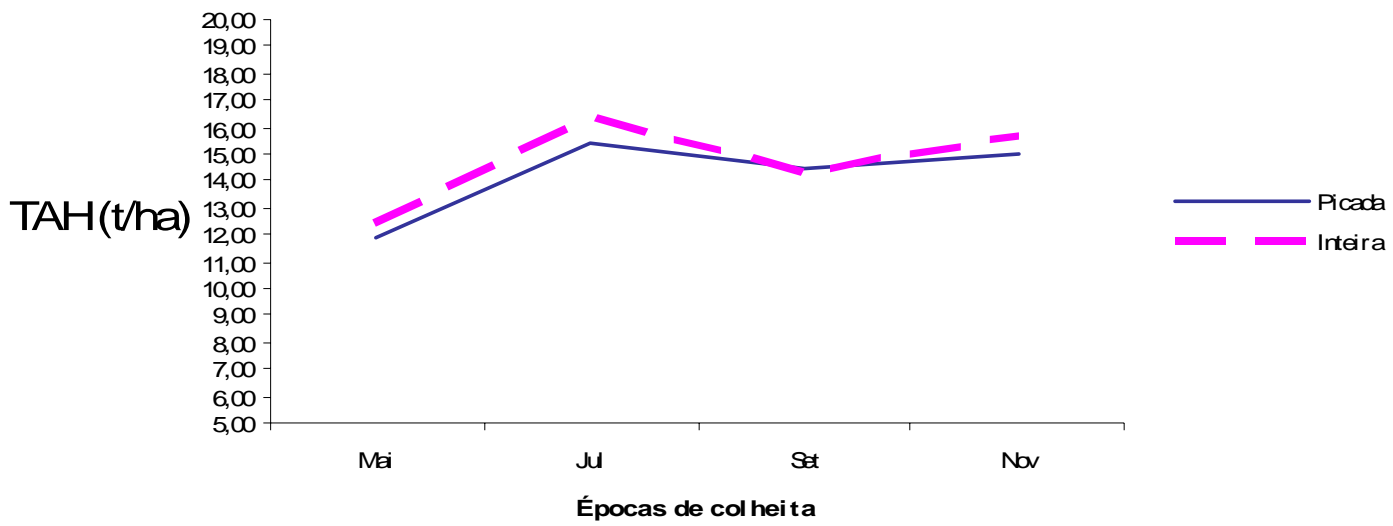

Figura 19 - Resultados de TAH para a variedade SP 70-1143 na safra 1985 , no $1^{\circ}$ corte e época de plantio Janeiro

\section{Resultados deTAH- Safra 1985 corte 1 - época de plantio Março}

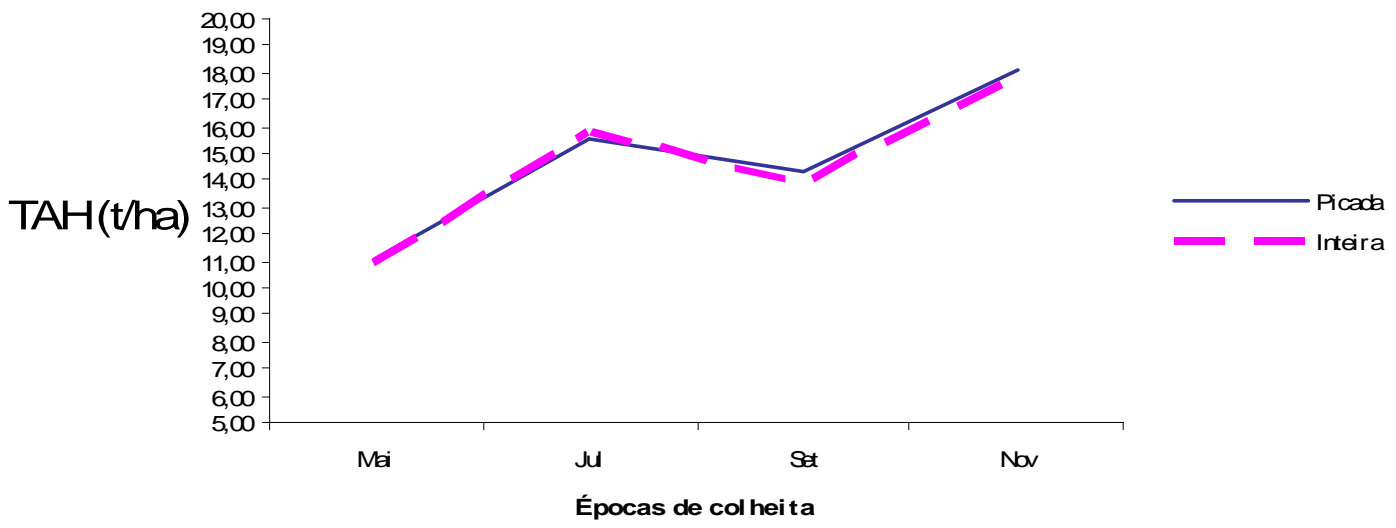

Figura 20 - Resultados de TAH para a variedade SP 70-1143 na safra 1985 , no $1^{\circ}$ corte e época de plantio Março 


\section{Resultados deTAH- Safra 1985 \\ corte 1 - época de plantio Maio}

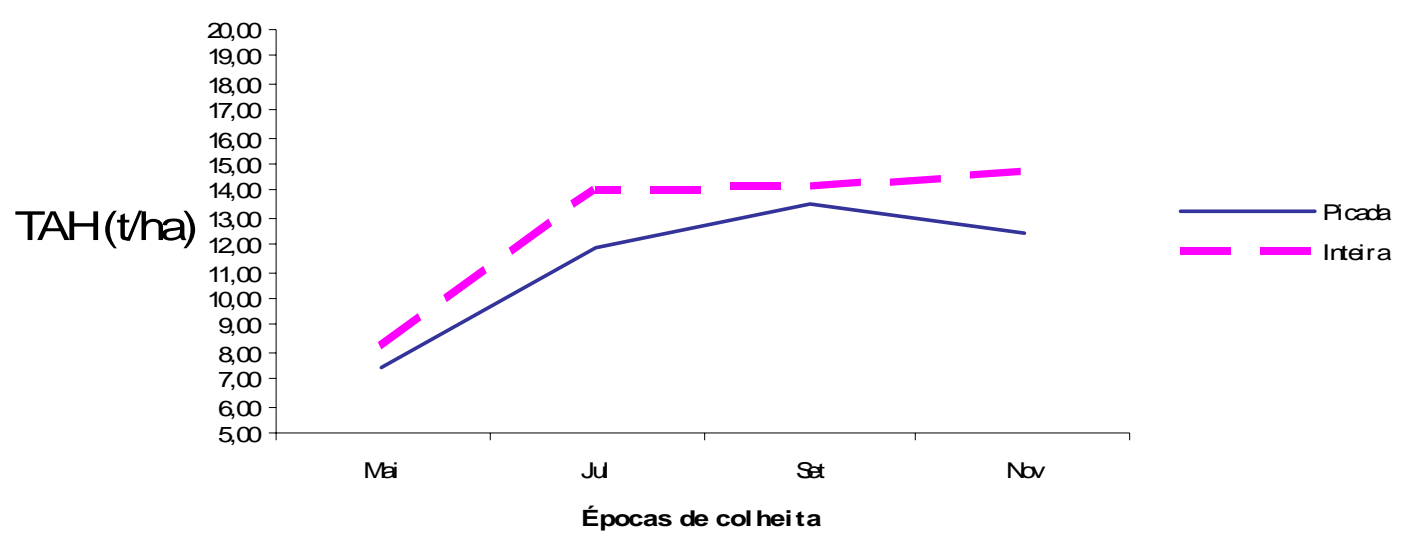

Figura 21 - Resultados de TAH para a variedade SP 70-1143 na safra 1985 , no $1^{\circ}$ corte e época de plantio Maio

Tabela 7. Resumo dos quadros de análise de variância dos dados obtidos para a variedade SP 70-1143, no primeiro corte e com plantio no ano de 1984/85, em relação às variáveis dependentes ATR, TCH e TAH em várias combinações de épocas de plantio e de colheita e sob os tratamentos cana picada e inteira no sulco de plantio

\begin{tabular}{|c|c|c|c|c|}
\hline C. Variação & $G L$ & $\begin{array}{c}\mathrm{TCH} \\
Q M\end{array}$ & $\begin{array}{c}\text { ATR } \\
Q M\end{array}$ & $\begin{array}{c}\mathrm{TAH} \\
\mathrm{QM}\end{array}$ \\
\hline BLOCO & 4 & -- & -- & -- \\
\hline EPCOL & 3 & $523,344 * *$ & $21386,006 * *$ & $237, \odot 82$ ** \\
\hline Resíduo (a) & 12 & 57,548 & 35,618 & 1,511 \\
\hline EPPLA & 3 & $1171,040 * *$ & $1406,833^{* *}$ & 56,697 ** \\
\hline Resíduo (b) & 12 & 189,604 & 25,375 & 4,070 \\
\hline TRAT & 1 & 1,250 & 30,800 & 1,081 \\
\hline$E P C O L{ }^{\star} E P P L A$ & 9 & 40,829 & $1127,427^{* *}$ & 8,955 ** \\
\hline$E P C O L{ }^{*} T R A T$ & 3 & $10 \odot, 856$ & 16,025 & 2,372 \\
\hline$E P P L A * T R A T$ & 3 & $325,260 * *$ & 46,691 & 7,143 ** \\
\hline$E P C O L{ }^{\star} E P P L A{ }^{\star} T R A T$ & 9 & 45,258 & 18,631 & 1,149 \\
\hline Resíduo (c) & 100 & 48,208 & 26,252 & 1,135 \\
\hline Total & 159 & -- & -- & -- \\
\hline
\end{tabular}


A tabela 7, apresentada, mostra os valores da análise de variância, para as variáveis TCH, ATR e TAH, da variedade SP 70-1143, no primeiro corte e com plantio no ano de 1984/85.

Como se pode observar, para as variáveis TCH, ATR e TAH houve efeito significativo de época de corte e época de plantio. O tratamento muda picada e inteira no sulco de plantio não apresentou efeito significativo para as variáveis estudadas, pois ao contrário do ano anterior, ocorreu menor déficit hídrico.

Houve interação de épocas de plantio dentro de épocas de colheita para as variáveis ATR e TAH, indicando diferenças significativas entre as épocas de plantio para cada época de colheita. Houve, ainda, interação de tratamentos (muda picada e inteira no sulco de plantio) dentro de épocas de plantio para $\mathrm{TCH}$ e TAH, indicando efeito do tipo de muda (picada ou inteira) nas épocas de plantio.

Tabela 8. Valores médios de TCH para a variedade SP 70-1143 nas interações de Tratamentos dentro de épocas de plantio, com plantio no ano de $1984 / 85$, no $1^{\circ}$ corte

\begin{tabular}{cll}
\hline EPPLA & \multicolumn{1}{c}{ Trat } & TCH MÉDIA \\
\hline Jan & Muda Picada & $97,461 \mathrm{a}$ \\
Nov & Muda Picada & $94,770 \mathrm{ab}$ \\
Nov & Muda Inteira & $92,609 \mathrm{abc}$ \\
Jan & Muda Inteira & $91,752 \mathrm{abc}$ \\
Mar & Muda Picada & $90,538 \mathrm{bc}$ \\
Mar & Muda Inteira & $89,949 \mathrm{bc}$ \\
Mai & Muda Inteira & $86,574 \mathrm{C}$ \\
Mai & Muda Picada & $78,822 \mathrm{~d}$ \\
\hline
\end{tabular}

Médias seguidas das mesmas letras não diferiram estatisticamente entre si.

Na tabela 8, observa-se que para a variável TCH na variedade SP 701143, plantada em 1984/85 e no primeiro corte, houve diferença estatisticamente significativa entre as médias dos tratamentos dentro das épocas de plantio. 
Para a variável $\mathrm{TCH}$ os tratamentos mudas picadas ou inteiras não mostraram diferenças estatísticas nas épocas de plantio Janeiro, Novembro e Março, apresentando os maiores valores, por outro lado, os valores obtidos para os plantios no mês de Maio foram os menores, sendo que nessa época houve significativa superioridade do tratamento muda inteira no sulco de plantio. Considerando que os resultados apresentados na tabela 04 assemelham-se aos da tabela 10, já apresentadas, bem como os dados climáticos desses anos também se assemelham (figuras 8 e 9), reforça-se a sugestão de que nesta época devam-se plantar mudas de cana inteiras. Ainda, considerando as afirmações de Lee (1984), e que não ocorreram diferenças significativas nas demais épocas entre os tipos de mudas e devido a redução de custos operacionais que essa prática resulta, pode ser recomendado como manejo do plantio o uso de mudas de cana inteiras em qualquer época, principalmente em Maio.

Tabela 9. Valores médios de TCH para a variedade SP 70-1143 nas épocas de colheita, com plantio no ano de $1984 / 85$, no $1^{\circ}$ corte

\begin{tabular}{|c|c|c|}
\hline EPCOL & \multicolumn{2}{|c|}{ TCH MÉDIA } \\
\hline Jul & 101,796 & $a$ \\
\hline Nov & 94,713 & $a b$ \\
\hline Mai & 94,392 & $a b$ \\
\hline Set & 87,591 & $\mathrm{~b}$ \\
\hline
\end{tabular}

Médias seguidas das mesmas letras não diferiram estatisticamente entre si.

Na tabela 9, observa-se que para a variável TCH na variedade SP 701143, plantada em 1984/85 e no primeiro corte, houve diferença estatisticamente significativa entre as médias das épocas de colheita.

Os valores obtidos na época de colheita Julho foram superiores aos da época de colheita Setembro. 
A figura 22, a seguir, mostra a evolução de $\mathrm{TCH}$ para cada época de plantio, observa-se o efeito do tipo de muda (inteira ou picada) sobre os valores de épocas de plantio.

\section{Resultados de TCH \\ Safra 86 - corte 1}

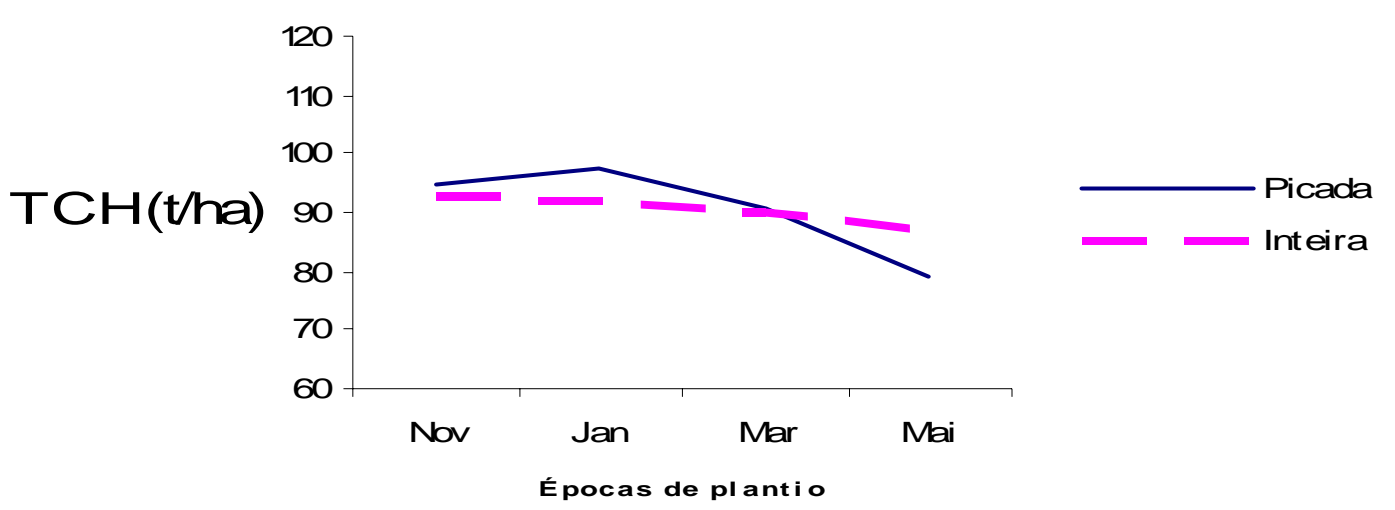

Figura 22 - Resultados de TCH para a variedade SP 70-1143 na safra 1986, no $1^{\circ}$ corte nas épocas de plantio

A figura 23, a seguir, mostra a evolução de $\mathrm{TCH}$ para cada época de colheita. 


\section{Resultados de TCH \\ Safra 86 - corte 1}

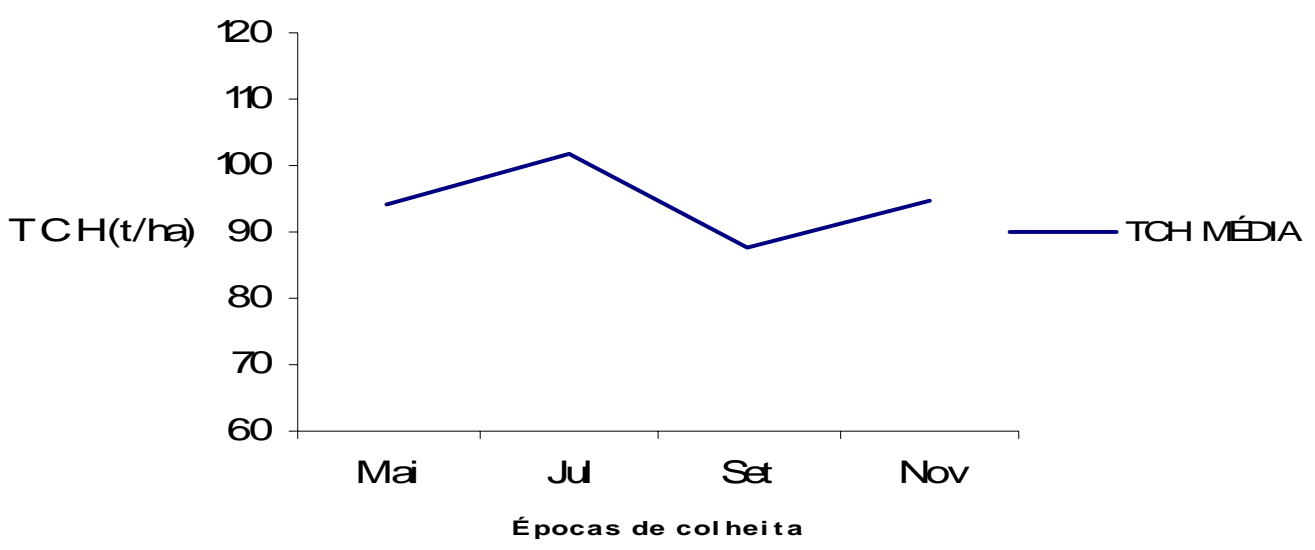

Figura 23 - Resultados de TCH para a variedade SP 70-1143 na safra 1986, no $1^{\circ}$ corte nas épocas de colheita

Tabela 10. Valores médios de ATR para a variedade SP 70-1143 nas interações de épocas de plantio dentro de épocas de colheita, com plantio no ano de $1984 / 85$, no $1^{\circ}$ corte

\begin{tabular}{|c|c|c|c|}
\hline EPPLA & EPCOL & \multicolumn{2}{|c|}{ ATR (MÉDIA) } \\
\hline Mar & Set & $161.668 \mathrm{c}$ & \\
\hline Mai & Set & 159.980 a & \\
\hline Nov & Set & 157.170 a & \\
\hline Jan & Set & 154.720 a & \\
\hline Mai & Nov & 147.413 & bc \\
\hline Jan & Jul & 147.317 & bc \\
\hline Nov & Jul & 146.900 & bc \\
\hline Nov & Nov & 146.566 & c \\
\hline Mar & Nov & 144.928 & C \\
\hline Jan & Nov & 135.733 & d \\
\hline Mar & Jul & 135.712 & d \\
\hline Mai & Jul & 129.629 & de \\
\hline Nov & Mai & 123.632 & e \\
\hline Jan & Mai & 114.630 & $f$ \\
\hline Mar & Mai & 96.651 & g \\
\hline Mai & Mai & 80.717 & h \\
\hline
\end{tabular}

Médias seguidas das mesmas letras não diferiram estatisticamente entre si. 
Na tabela 10, observa-se que para a variável ATR na variedade SP 70-1143, plantada em 1984/85 e no primeiro corte, houve diferença estatisticamente significativa entre as médias das épocas de plantio dentro das épocas de colheita. Os resultados mostram que as combinações de épocas de plantio e colheita que apresentaram os maiores valores foram: colheitas em Setembro com plantios em Março, Maio, Novembro e Janeiro. Os menores valores foram observados nas colheitas de Maio com plantios em Maio, Março, Janeiro.

As figuras 24, 25, 26 e 27, a seguir, mostram a evolução de ATR para cada época de plantio nota-se o efeito das épocas de colheita sobre os valores observados.

\section{Resultados de ATR- Safra 1986 \\ corte 1 - época de plantio Novembro}

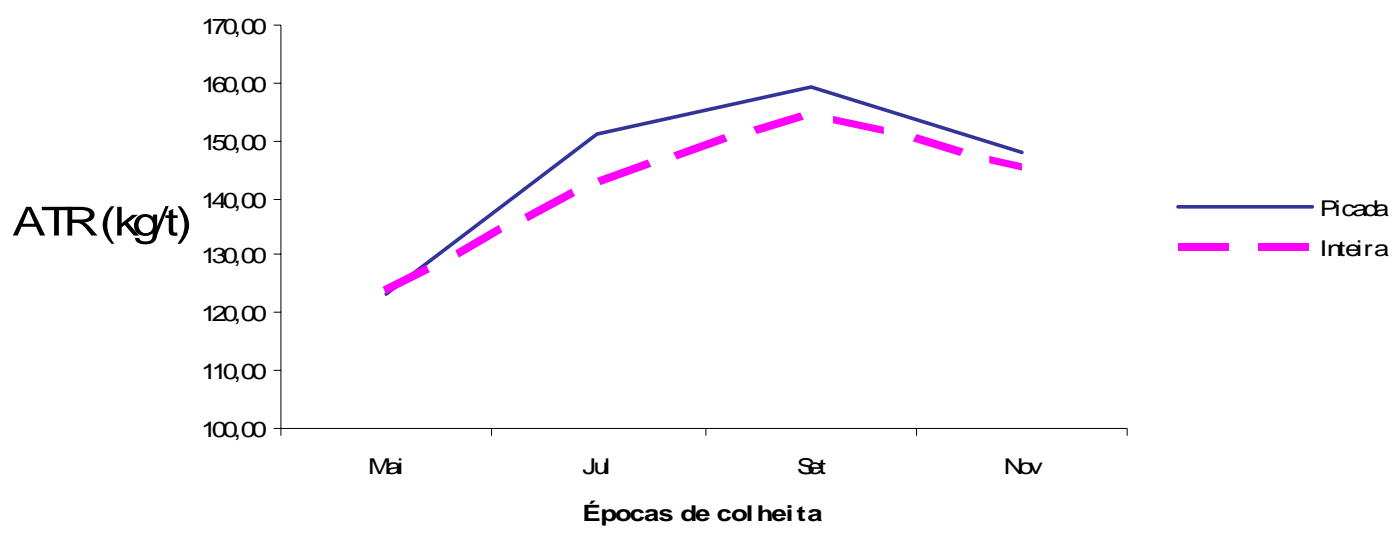

Figura 24 - Resultados de ATR para a variedade SP 70-1143 na safra 1986, no $1^{\circ}$ corte e época de plantio Novembro 
Resultados de ATR- Safra 1986

corte 1 - época de plantio Janeiro

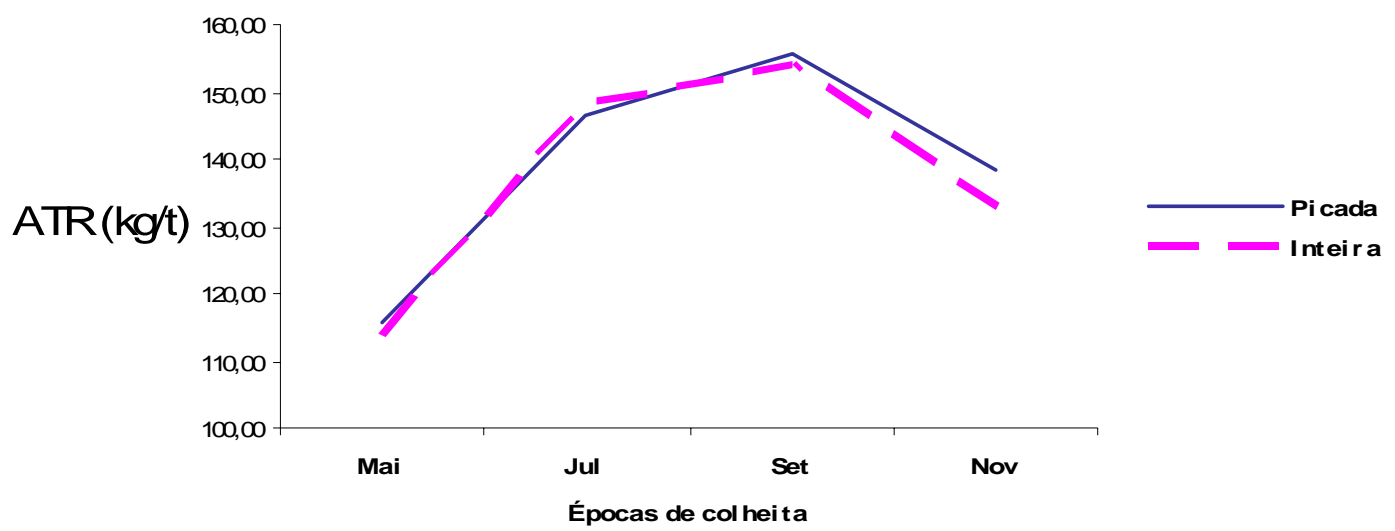

Figura 25 - Resultados de ATR para a variedade SP 70-1143 na safra 1986, no $1^{\circ}$ corte e época de plantio Janeiro

Resultados de ATR- Safra 1986

corte 1 - época de plantio Março

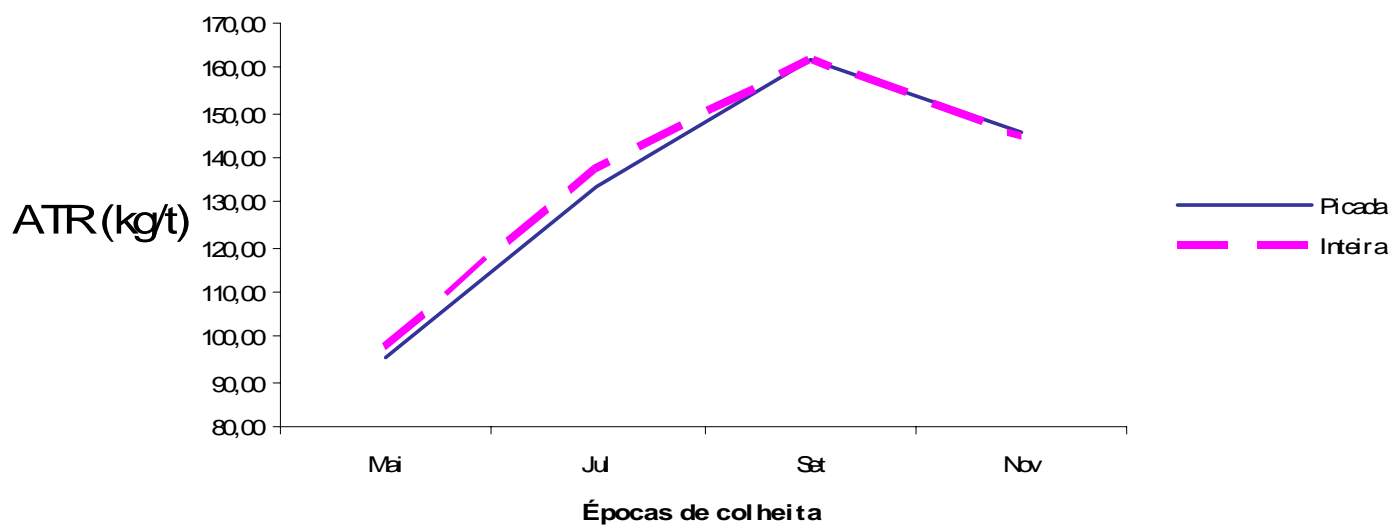

Figura 26 - Resultados de ATR para a variedade SP 70-1143 na safra 1986, no $1^{\circ}$ corte e época de plantio Março 


\section{Resultados de ATR- Safra 1986 corte 1 - época de plantio Maio}

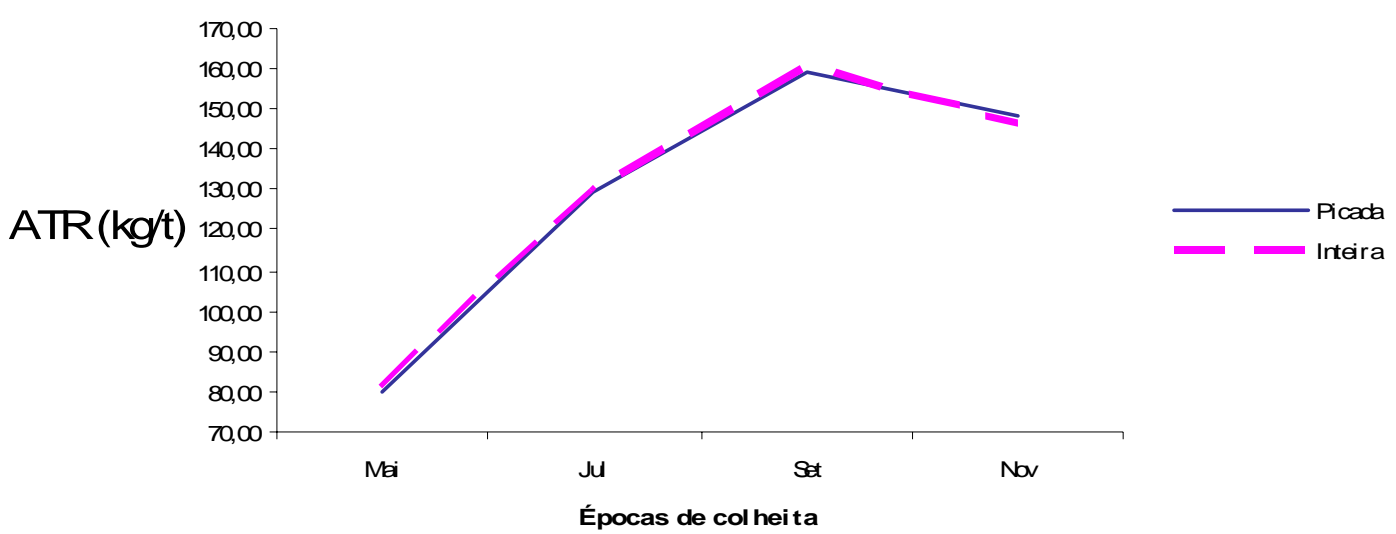

Figura 27 - Resultados de ATR para a variedade SP 70-1143 na safra 1986, no $1^{\circ}$ corte e época de plantio Maio

Tabela 11. Valores médios de TAH para a variedade SP 70-1143 nas interações de épocas de plantio dentro de épocas de colheita, com plantio no ano de $1984 / 85$, no $1^{\circ}$ corte

\begin{tabular}{|c|c|c|c|}
\hline EPPLA & EPCOL & TAH (MÉ & DIA) \\
\hline Jan & Set & 15,208 & $a$ \\
\hline Mar & Set & 15,165 & a \\
\hline Nov & Set & 14,809 & a \\
\hline Jan & Jul & 14,356 & $a b$ \\
\hline Nov & Jul & 14,276 & $a b c$ \\
\hline Nov & Nov & 13,954 & abcd \\
\hline Mai & Set & 13,562 & abcd \\
\hline Mar & Jul & 12,692 & bcd \\
\hline Mar & Nov & 12,674 & $\mathrm{~cd}$ \\
\hline Mai & Nov & 12,493 & de \\
\hline Jan & Nov & 12,397 & de \\
\hline Mai & Jul & 10,966 & ef \\
\hline Nov & Mai & 10,864 & ef \\
\hline Jan & Mai & 10,455 & $f$ \\
\hline Mar & Mai & 8,325 & g \\
\hline Mai & Mai & 6,173 & \\
\hline
\end{tabular}

Médias seguidas das mesmas letras não diferiram estatisticamente entre si. 
$\mathrm{Na}$ tabela 11, observa-se que para a variável TAH na variedade SP 70-1143, plantada em 1984/85 e no primeiro corte, houve diferença estatisticamente significativa entre as médias das épocas de plantio dentro das épocas de colheita. Observa-se que os maiores valores de TAH foram obtidos nas colheitas de Setembro com plantios em Janeiro, Março, Novembro e Maio; colheitas em Julho com plantios em Janeiro e Novembro e, ainda, colheitas em Novembro com plantios em Novembro. Os menores valores foram obtidos nas colheitas de Maio com plantios em Maio, Março, Janeiro e Novembro.

Tabela 12. Valores médios de TAH para a variedade SP 70-1143 nas interações de Tratamentos dentro de épocas de plantio, com plantio no ano de $1984 / 85$, no $1^{\circ}$ corte

\begin{tabular}{cll}
\hline EPPLA & Trat & TAH MÉDIA \\
\hline Nov & Muda Picada & $13,840 \mathrm{a}$ \\
Jan & Muda Picada & $13,557 \mathrm{ab}$ \\
Nov & Muda Inteira & $13,112 \mathrm{abc}$ \\
Jan & Muda Inteira & $12,651 \quad$ bc \\
Mar & Muda Inteira & $12,229 \quad$ cd \\
Mar & Muda Picada & $12,200 \quad$ cd \\
Mai & Muda Inteira & $11,273 \quad \mathrm{~d}$ \\
Mai & Muda Picada & $10,325 \quad \mathrm{e}$ \\
\hline
\end{tabular}

Médias seguidas das mesmas letras não diferiram estatisticamente entre si.

$\mathrm{Na}$ tabela 12, observa-se que para a variável TAH na variedade SP 70-1143, plantada em 1984/85 e no primeiro corte, houve diferença estatisticamente significativa entre as médias dos tratamentos dentro das épocas de plantio.

Esses resultados mostram que as maiores produções foram obtidas nos plantios de Novembro e Janeiro e as menores produções foram obtidas nos plantios de Maio. Considerando que os tipos de mudas de cana (picadas ou inteiras no sulco de plantio) não apresentaram diferenças estatisticamente significativas dentro de cada época, nas épocas de plantio Novembro, Janeiro e 
Março, mas em Maio houve superioridade das mudas inteiras, e ainda que os dados climáticos mostraram-se semelhantes nessa época (figuras 08 e 09) e também que Lee (1984), observou resultados até melhores em plantios de mudas de cana inteira, bem como a redução de custos operacionais que essa prática resulta, reforça-se a recomendação do manejo do plantio com uso de mudas de cana inteiras em qualquer época.

As figuras 28, 29, 30 e 31, a seguir, mostram a evolução de TAH para cada época de plantio onde se verifica o efeito das épocas de colheita e dos tipos de mudas sobre os valores observados.

\section{Resultados deTAH- Safra 1986 corte 1 - época de plantio Nbvembro}

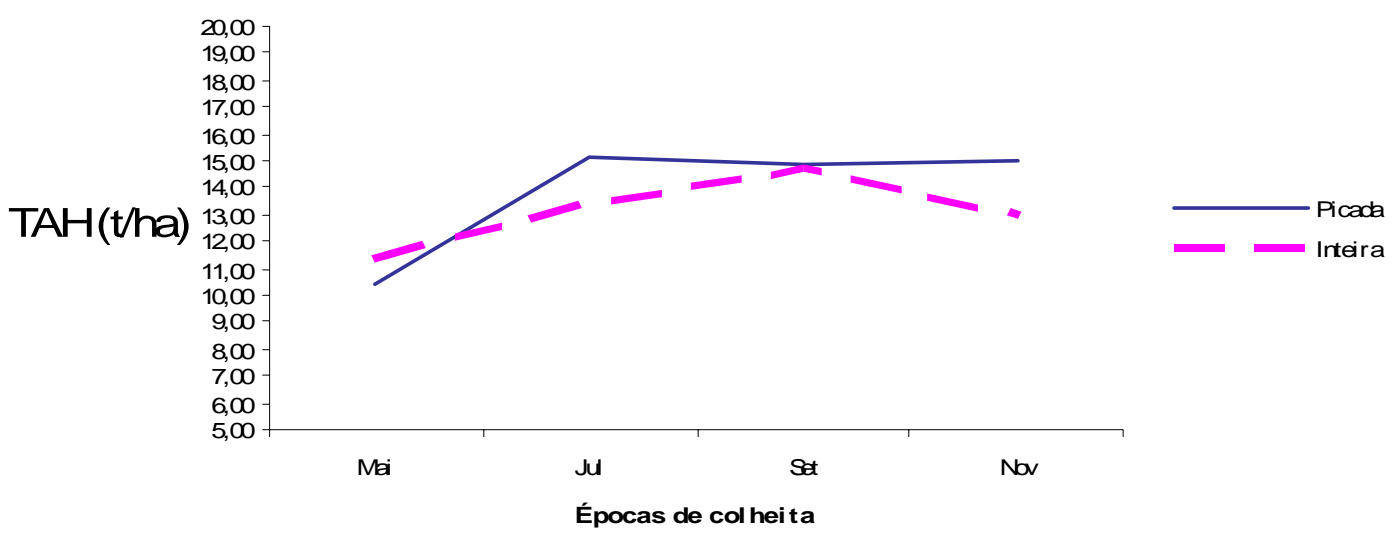

Figura 28 - Resultados de TAH para a variedade SP 70-1143 na safra 1986 , no $1^{\circ}$ corte e época de plantio Novembro 
Resultados deTAH- Safra 1986

corte 1 - época de plantio Janeiro

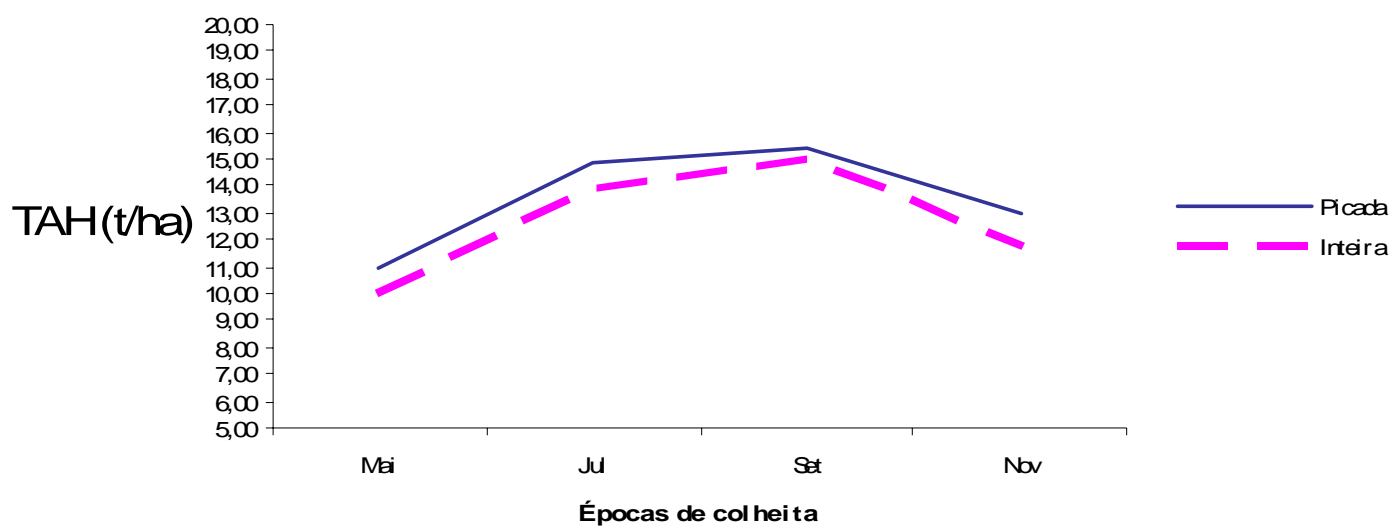

Figura 29 - Resultados de TAH para a variedade SP 70-1143 na safra 1986, no $1^{\circ}$ corte e época de plantio Janeiro

Resultados deTAH- Safra 1986

corte 1 - época de plantio Março

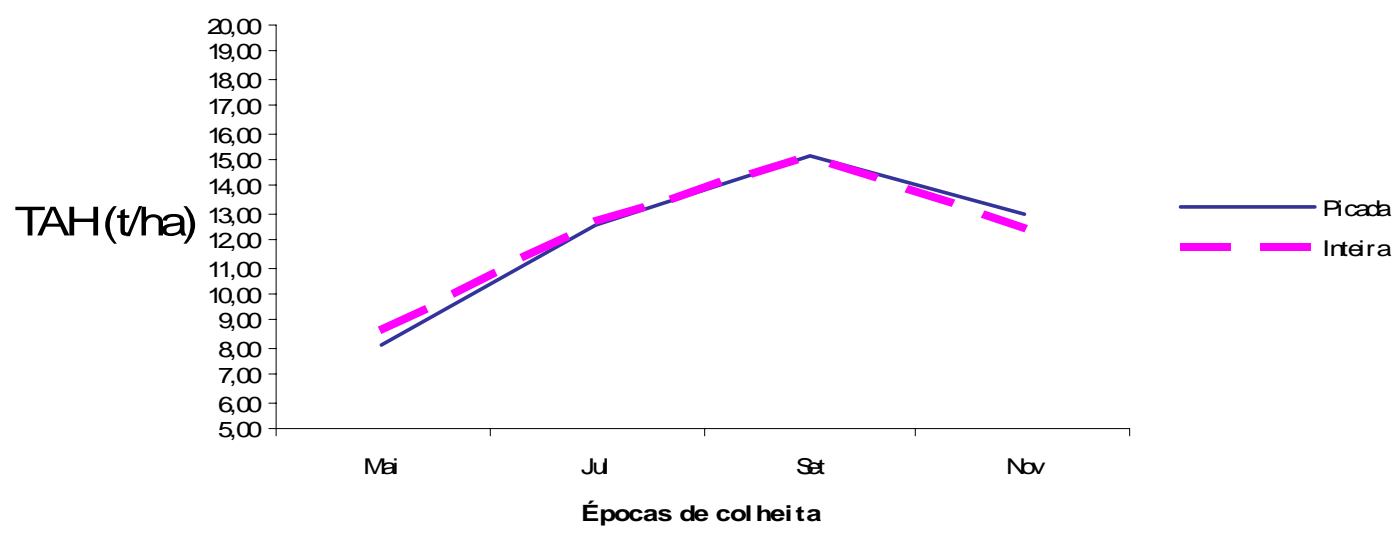

Figura 30 - Resultados de TAH para a variedade SP 70-1143 na safra 1986, no $1^{\circ}$ corte e época de plantio Março 
Resultados deTAH- Safra 1986

corte 1 - época de plantio Maio

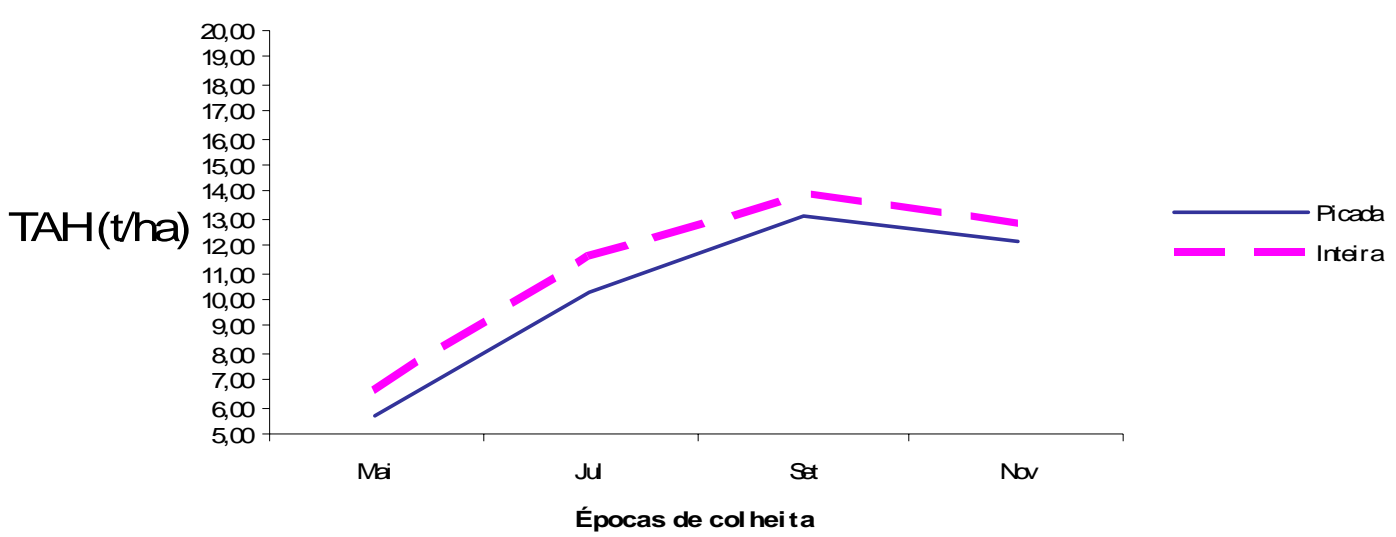

Figura 31 - Resultados de TAH para a variedade SP 70-1143 na safra 1986, no $1^{\circ}$ corte e época de plantio Maio

Tabela 13. Resumo dos quadros de análise de variância dos dados obtidos para a variedade SP 70-1143, no primeiro corte e com plantio no ano de 1985/86, em relação às variáveis dependentes TCH, ATR e TAH em várias combinações de épocas de plantio e de colheita e sob os tratamentos cana picada e inteira no sulco de plantio

\begin{tabular}{|c|c|c|c|c|}
\hline C. Variação & $G L$ & $\begin{array}{c}\mathrm{TCH} \\
Q M\end{array}$ & $\begin{array}{c}\text { ATR } \\
Q M\end{array}$ & $\begin{array}{c}\mathrm{TAH} \\
Q M\end{array}$ \\
\hline$B L O C O$ & 4 & -- & -- & -- \\
\hline EPCOL & 3 & $767,948^{* *}$ & 17529,924 * * & $323,309 * *$ \\
\hline Resíduo (a) & 12 & 136,806 & 60,356 & 4,071 \\
\hline$E P P L A$ & 3 & $10085,127^{* *}$ & 2799,716 ** & $407,857^{* *}$ \\
\hline Resíduo (b) & 12 & $6 \odot 2,081$ & 57,204 & 13,304 \\
\hline TRAT & 1 & 16,320 & 43,254 & 2,418 \\
\hline$E P C O L{ }^{\star} E P P L A$ & 9 & 248,160 & $399,899 * *$ & $10,235^{* *}$ \\
\hline$E P C O L{ }^{*} T R A T$ & 3 & 312,683 & 23,867 & 4,437 \\
\hline$E P P L A^{*} T R A T$ & 3 & 207,133 & 8,495 & 5,632 \\
\hline$E P C O L{ }^{\star} E P P L A{ }^{*} T R A T$ & 9 & 197,959 & 21,268 & 5,109 \\
\hline Resíduo (c) & 100 & 141,324 & 34,922 & 3,328 \\
\hline Total & 159 & -- & -- & -- \\
\hline
\end{tabular}


A tabela 13, mostra os valores da análise de variância para as variáveis TCH, ATR e TAH da variedade SP 70-1143, no primeiro corte e ano de plantio 1985/86.

Como se pode observar, para as variáveis TCH, ATR e TAH houve efeito significativo de época de corte e época de plantio. O tratamento muda picada e inteira no sulco de plantio não apresentou efeito significativo para as variáveis estudadas.

Houve interação de épocas de plantio dentro de épocas de colheita para as variáveis ATR e TAH, indicando diferenças significativas entre as épocas de plantio para cada época de colheita. Não houve qualquer outra interação.

Tabela 14. Valores médios de TCH para a variedade SP 70-1143 das médias de épocas de plantio, com plantio no ano de $1985 / 86$, no $1^{\circ}$ corte

\begin{tabular}{cc}
\hline EPPLA & $T C H \quad(M E ́ D I A)$ \\
\hline Nov & 142,134 a \\
Jan & 139,187 ab \\
Mar & $125,051 \quad$ b \\
Mai & $107,419 \quad \mathrm{C}$ \\
\hline $\begin{array}{l}\text { Médias seguidas das mesmas letras não diferiram estatisticamente entre } \\
\text { si. }\end{array}$
\end{tabular}

$\mathrm{Na}$ tabela 14, observa-se que para a variedade SP 70-1143, no primeiro corte e ano de plantio 1985/86, houve diferença estatisticamente significativa entre as médias de $\mathrm{TCH}$ nas épocas de plantio. Os resultados mostraram que as maiores produções foram obtidas nos plantios feitos em Novembro e Janeiro e as menores produções nos plantios feitos em Maio. Os dados climáticos já apresentados (figuras 08 e 09) mostram que na melhor época houve condições favoráveis ao bom desempenho da cultura e que a 
época de plantio Maio foi marcada por declínio nas precipitações e nas temperaturas.

A figura 32, a seguir, mostra a evolução de $\mathrm{TCH}$ para as épocas de plantio.

\section{Resultados de $\mathrm{TOH}$}

Safra 87 - corte 1

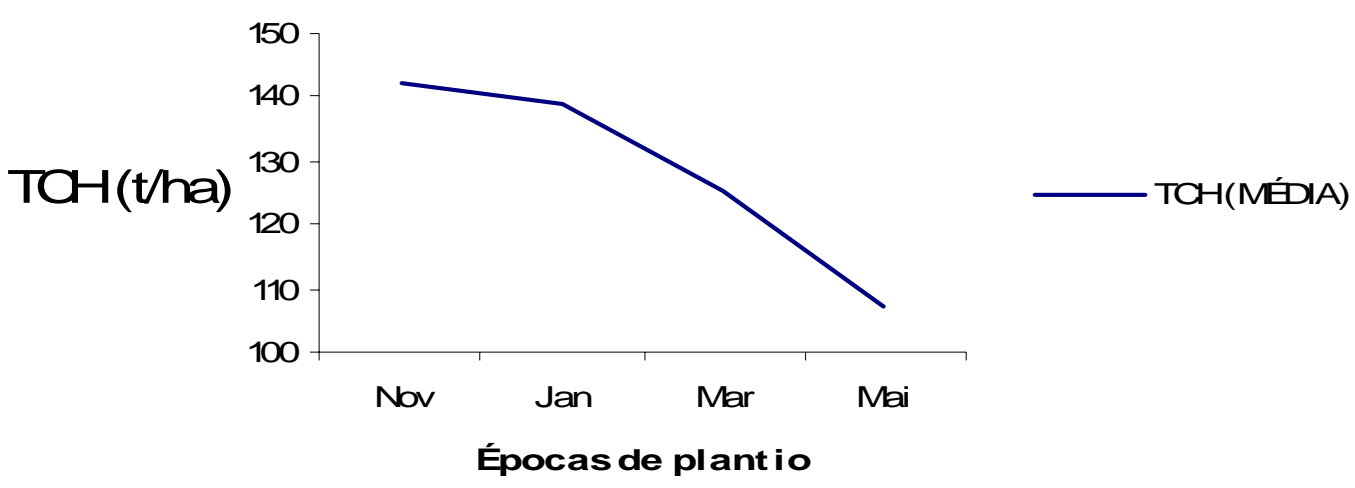

Figura 32 - Resultados de TCH para a variedade SP 70-1143 na safra 1987, no $1^{\circ}$ corte e nas épocas de plantio

Tabela 15. Valores médios de TCH para a variedade SP 70-1143 das médias de épocas de colheita, com plantio no ano de 1985/86, no $1^{\circ}$ corte

\begin{tabular}{cc}
\hline EPCOL & $T C H(M E ́ D I A)$ \\
\hline Set & 134,402 a \\
Mai & 128,324 ab \\
Nov & 127,134 ab \\
Jul & $123,931 \quad$ b \\
\hline Médias seguidas das mesmas letras não diferiram estatisticamente entre si.
\end{tabular}

Médias seguidas das mesmas letras não diferiram estatisticamente entre si. 
$\mathrm{Na}$ tabela 15, observa-se que para a variedade SP 70-1143, no primeiro corte e ano de plantio 1985/86, houve diferença estatisticamente significativa entre as médias de $\mathrm{TCH}$ nas épocas de colheita. Os resultados mostraram que os maiores valores de $\mathrm{TCH}$ foram obtidos nas colheitas feitas em setembro e os menores nas colheitas feitas em Julho.

A figura 33, a seguir, mostra a evolução de $\mathrm{TCH}$ para as épocas de colheita.

\section{Resultados de $\mathrm{TOH}$ Safra 87 - corte 1}

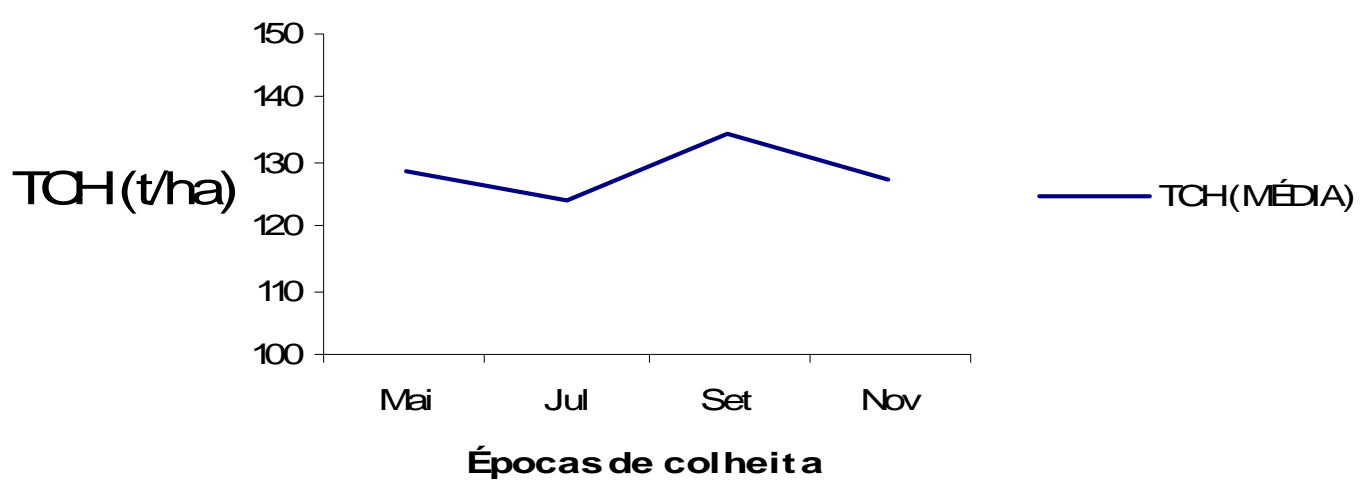

Figura 33 - Resultados médios de TCH para a variedade SP 70-1143 na safra 1987, no $1^{\circ}$ corte e nas épocas de colheita

A tabela 16, mostrada a seguir, contém os valores médios de ATR para a variedade SP 70-1143 nas interações de épocas de plantio dentro de épocas de colheita, no plantio do ano de 1985/86 e no $1^{\circ}$ corte; observa-se que houve diferença estatisticamente significativa entre as médias para a interação épocas de plantio dentro das épocas de colheita. Os maiores valores de ATR foram obtidos nas épocas de colheita de Setembro com plantios em Novembro, Janeiro e Março e, ainda, colheitas em Julho com plantios em Novembro. Os 
menores valores foram observados nas épocas de colheita Maio com plantios em Maio, Março, Novembro e Janeiro.

Tabela 16. Valores médios de ATR para a variedade SP 70-1143 nas interações de épocas de plantio dentro de épocas de colheita, com plantio no ano de 1985/86, no $1^{\circ}$ corte

\begin{tabular}{|c|c|c|c|}
\hline$E P P L A$ & EPCOL & \multicolumn{2}{|c|}{ ATR (MÉDIA) } \\
\hline Nov & Set & 163,497 & \\
\hline Jan & Set & 162,907 & \\
\hline Mar & Set & 157,700 & \\
\hline Nov & Jul & 156,692 & \\
\hline Nov & Nov & 153,152 & bc \\
\hline Jan & Jul & 152,525 & bc \\
\hline Mai & Nov & 151,220 & bc \\
\hline Jan & Nov & 150,978 & bc \\
\hline Mar & Nov & 149,528 & bc \\
\hline Mai & Set & 146,640 & c \\
\hline Mar & Jul & 145,227 & C \\
\hline Mai & Jul & 134,432 & d \\
\hline Jan & Mai & 124,055 & e \\
\hline Nov & Mai & 121,999 & e \\
\hline Mar & Mai & 107,799 & $f$ \\
\hline Mai & Mai & 90,430 & g \\
\hline
\end{tabular}

Médias seguidas das mesmas letras não diferiram estatisticamente entre si.

As figuras 34, 35, 36 e 37, a seguir, mostram a evolução de ATR para cada época de plantio onde se verifica o efeito das épocas de colheita sobre os valores observados. 


\section{Resultados de ATR- Safra 1987 \\ corte 1 - época de plantio Novembro}

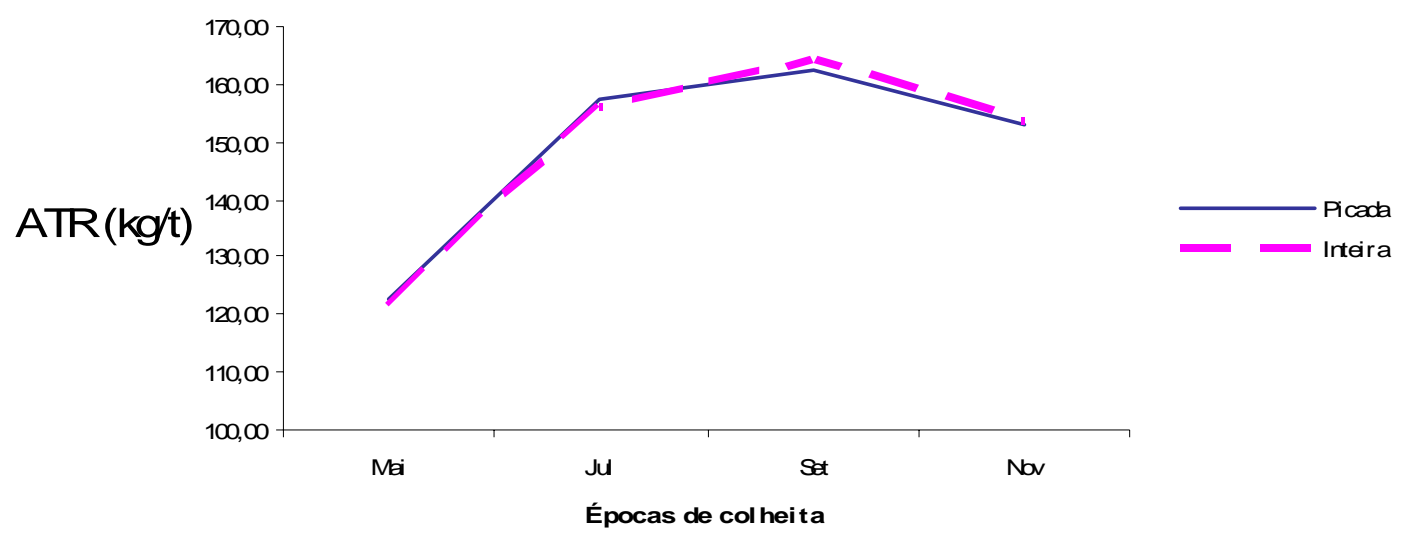

Figura 34 - Resultados de ATR para a variedade SP 70-1143 na safra 1987, no $1^{\circ}$ corte e época de plantio Novembro

Resultados de ATR- Safra 1987

corte 1 - época de plantio Janeiro

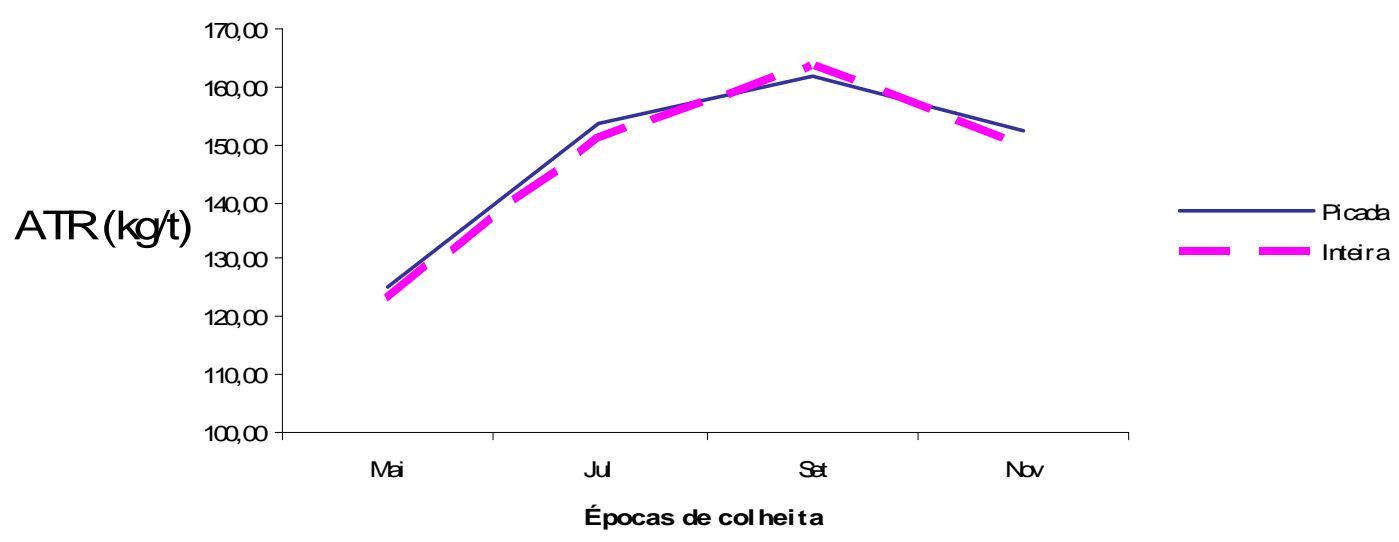

Figura 35 - Resultados de ATR para a variedade SP 70-1143 na safra 1987, no $1^{\circ}$ corte e época de plantio Janeiro 
Resultados de ATR- Safra 1987 corte 1 - época de plantio Março

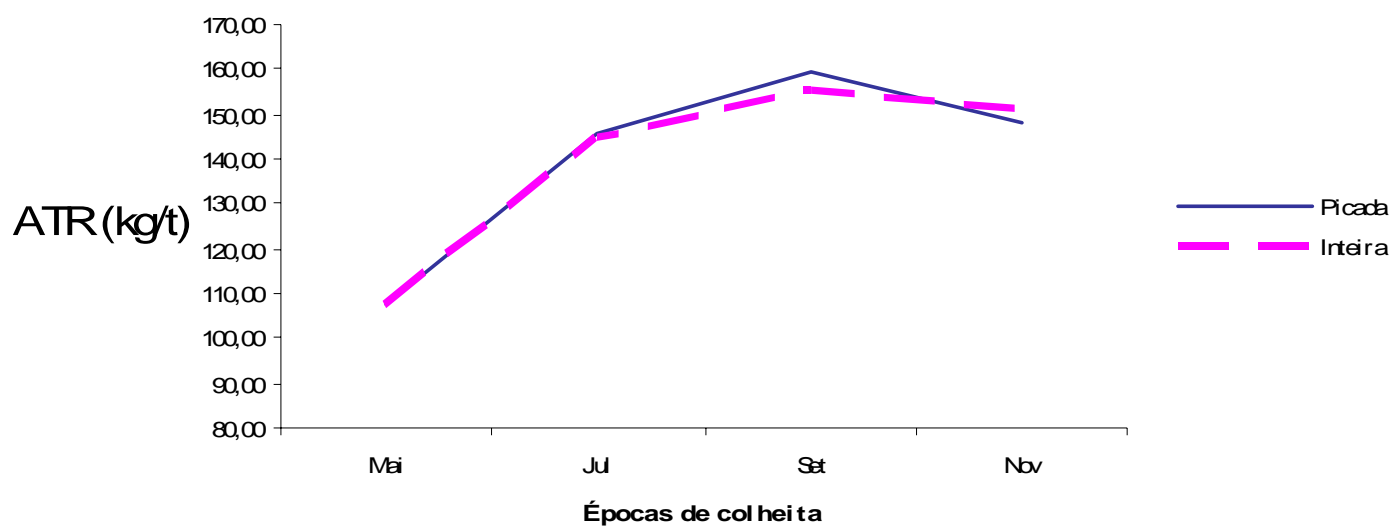

Figura 36 - Resultados de ATR para a variedade SP 70-1143 na safra 1987, no $1^{\circ}$ corte e época de plantio Março

\section{Resultados de ATR- Safra 1987 \\ corte 1 - época de plantio Maio}

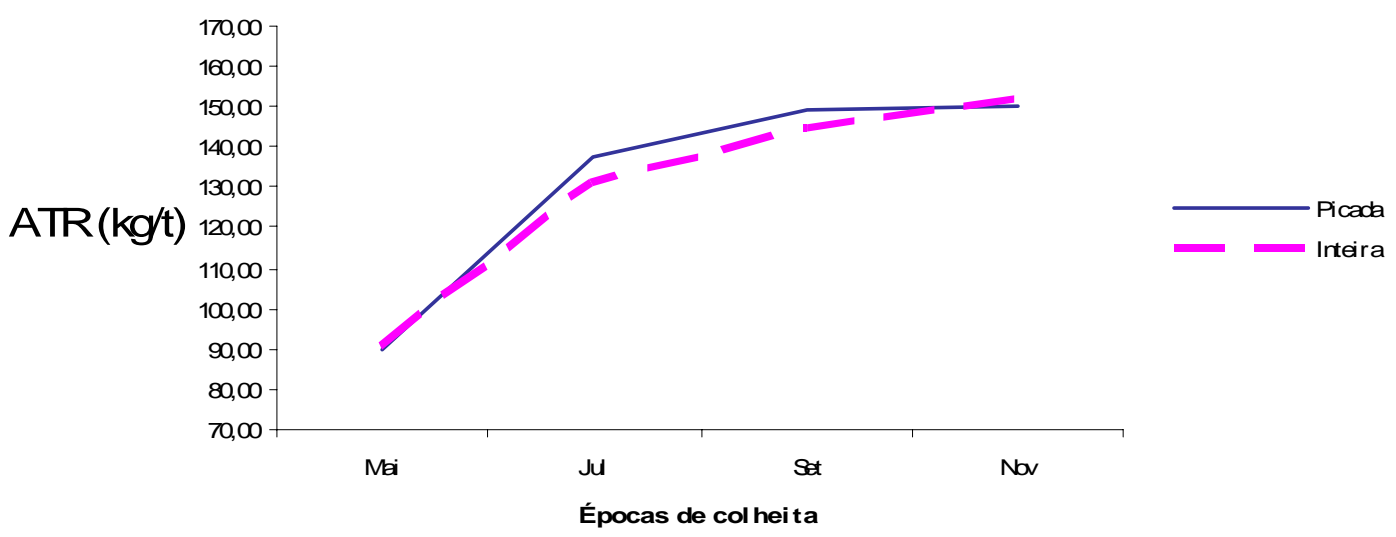

Figura 37 - Resultados de ATR para a variedade SP 70-1143 na safra 1987, no $1^{\circ}$ corte e época de plantio Maio 
Tabela 17. Valores médios de TAH para a variedade SP 70-1143 nas interações de épocas de plantio dentro de épocas de colheita, com plantio no ano de $1985 / 86$, no $1^{\circ}$ corte

\begin{tabular}{|c|c|c|c|}
\hline EPPLA & EPCOL & \multicolumn{2}{|c|}{$T A H$ (MÉDIA) } \\
\hline Nov & Set & \multicolumn{2}{|c|}{$23,694 \mathrm{a}$} \\
\hline Jan & Set & \multicolumn{2}{|c|}{$23,466 \mathrm{a}$} \\
\hline Nov & Jul & \multicolumn{2}{|c|}{$21,564 a b$} \\
\hline Jan & Nov & \multicolumn{2}{|c|}{$21,310 a b$} \\
\hline Mar & Set & \multicolumn{2}{|c|}{21,008 abc } \\
\hline Nov & Nov & \\
\hline Jan & Jul & \multicolumn{2}{|c|}{$\begin{array}{l}20,871 \text { abcd } \\
20080 \text { bcde }\end{array}$} \\
\hline Nov & Mai & 18,209 & cdef \\
\hline Mar & Jul & 18,089 & def \\
\hline Mar & Nov & 17,848 & ef \\
\hline Jan & Mai & 17,338 & ef \\
\hline Mai & Set & 16,923 & $\mathrm{f}$ \\
\hline Mai & Nov & 16,869 & $f$ \\
\hline Mai & Jul & 13,669 & $\mathrm{~g}$ \\
\hline Mar & Mai & 13,251 & $\mathrm{~g}$ \\
\hline Mai & Mai & 9,140 & 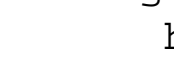 \\
\hline
\end{tabular}

Médias seguidas das mesmas letras não diferiram estatisticamente entre si.

$\mathrm{Na}$ tabela 17, observa-se que para a variedade SP 70-1143, no primeiro corte e ano de plantio 1985/86, houve diferença estatisticamente significativa entre as médias de TAH para a interação épocas de plantio dentro das épocas de colheita. As maiores produções de açúcar por ha foram obtidas nas épocas de colheita Setembro com plantios em Novembro, Janeiro e Março; colheitas de Novembro com plantios em Janeiro e Novembro, e, ainda, colheitas de Julho com plantios em Novembro. As menores produções foram obtidas nos plantios em Maio com colheitas em Maio, Julho, Novembro e Setembro.

As figuras 38, 39, 40 e 41 a seguir, mostram a evolução de TAH para cada época de plantio onde se verifica o efeito das épocas de colheita sobre os valores observados. Verifica-se que os valores são ascendentes de Maio até Setembro com queda brusca de Setembro para Novembro, apenas o plantio de Maio não se comporta assim, mas com valores ascendentes até Novembro. 
Resultados deTAH- Safra 1987

corte 1 - época de plantio Nbvembro

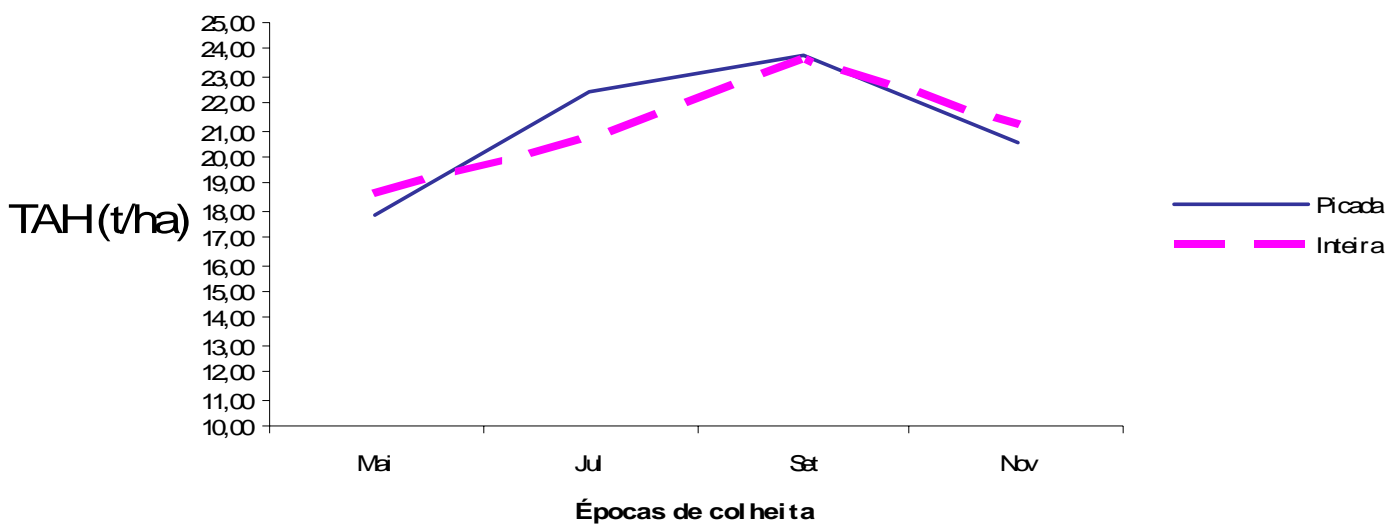

Figura 38 - Resultados de TAH para a variedade SP 70-1143 na safra 1987, no $1^{\circ}$ corte e época de plantio Novembro

Resultados deTAH- Safra 1987

corte 1 - época de plantio Janeiro

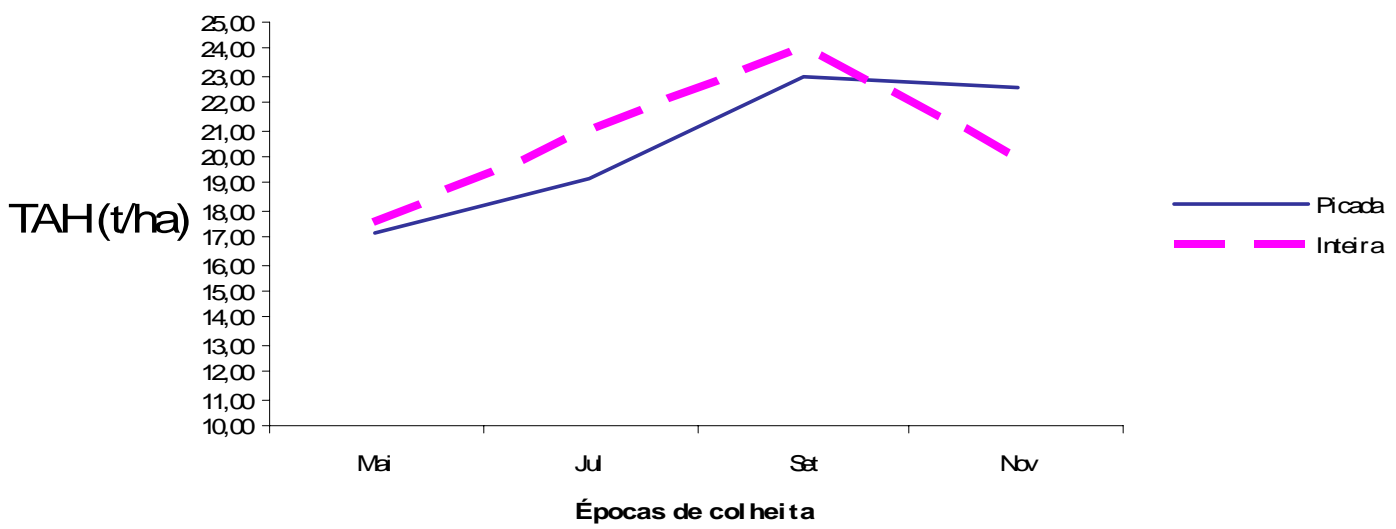

Figura 39 - Resultados de TAH para a variedade SP 70-1143 na safra 1987 , no $1^{\circ}$ corte e época de plantio Janeiro 


\section{Resultados deTAH- Safra 1987 \\ corte 1 - época de plantio Março}

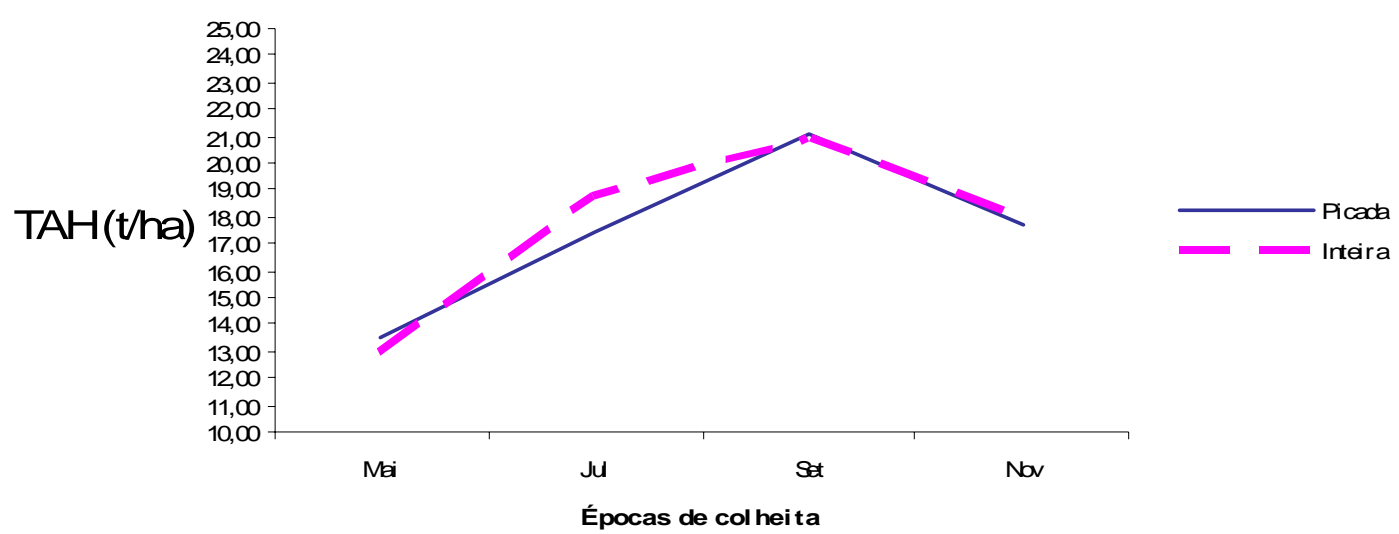

Figura 40 - Resultados de TAH para a variedade SP 70-1143 na safra 1987, no $1^{\circ}$ corte e época de plantio Março

Resultados deTAH- Safra 1987

corte 1 - época de plantio Maio

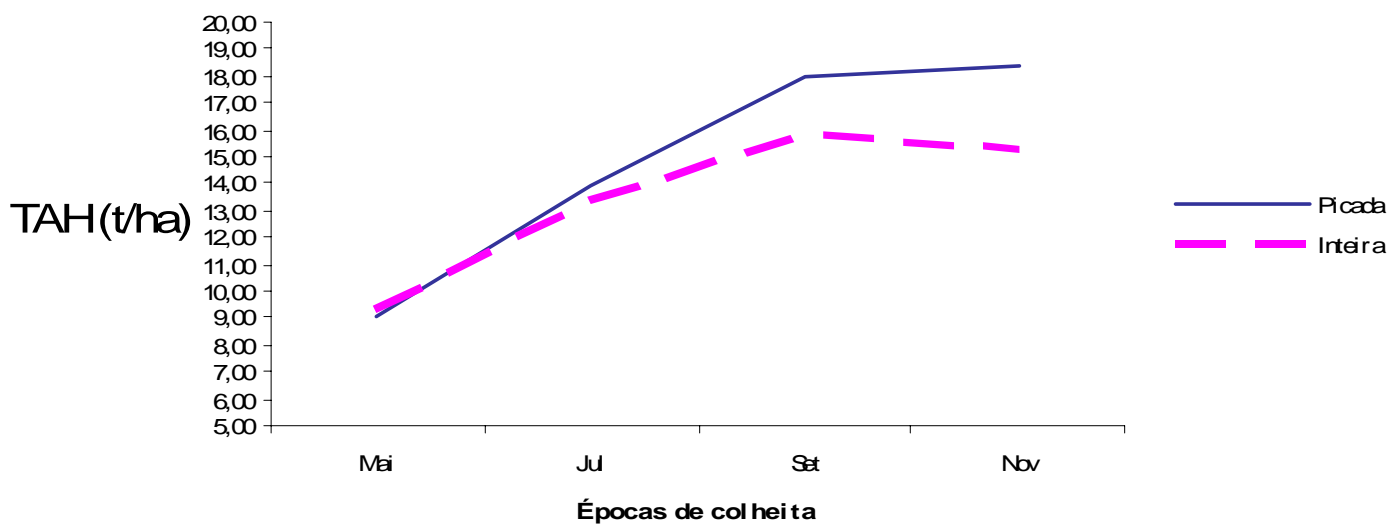

Figura 41 - Resultados de TAH para a variedade SP 70-1143 na safra 1987, no $1^{\circ}$ corte e época de plantio Maio 
$\mathrm{Na}$ tabela 18, a seguir, mostram-se os valores médios das safras de 1985, 1986 e 1987 para TCH, ATR e TAH da variedade SP 70-1143, no primeiro corte, nas várias combinações de épocas de plantio e de colheita e nos tratamentos muda picada e inteira no sulco de plantio. Comparando as os resultados ano a ano, observa-se que no ano de plantio 1983/84 houve efeito significativo de época de corte e época de plantio para as variáveis TCH, ATR e $\mathrm{TAH}$. O tratamento muda picada e inteira no sulco de plantio apresentou efeito significativo apenas para a variável TCH. Houve interação de épocas de plantio dentro de épocas de colheita para as três variáveis estudadas. Para TCH houve, ainda, interação de tratamentos (muda picada e inteira no sulco de plantio) dentro de épocas de plantio.

No ano de plantio 1984/85, houve efeito significativo de época de corte e época de plantio para as variáveis TCH, ATR e TAH, mas, o tratamento muda picada e inteira no sulco de plantio não apresentou efeito significativo para as variáveis estudadas. Houve interação de épocas de plantio dentro de épocas de colheita para as variáveis ATR e TAH. Houve, ainda, interação de tratamentos (muda picada e inteira no sulco de plantio) dentro de épocas de plantio para $\mathrm{TCH}$ e $\mathrm{TAH}$.

No ano de plantio 1985/86, houve efeito significativo de época de corte e época de plantio para as variáveis TCH, ATR e TAH. O tratamento muda picada e inteira no sulco de plantio, como no ano de plantio anterior, não apresentou efeito significativo para as variáveis estudadas. Houve interação de épocas de plantio dentro de épocas de colheita somente para as variáveis ATR e TAH.

Para os três anos estudados a variedade SP 70-1143, apresentou efeito significativo de épocas de plantio e corte para as variáveis TCH, ATR e $\mathrm{TAH}$. O tratamento muda picada e inteira no sulco de plantio apresentou efeito significativo somente para a variável TCH e apenas no ano de plantio 1983/84 quando também houve interação de épocas de plantio dentro de épocas de colheita para as três variáveis estudadas. Nesse ano ocorreu deficiência hídrica 
desde o mês de janeiro de 1984 até o mês de julho como se pode observar no gráfico de Balaço Hídrico (figura 8), fato que se mostrou decisivo para a ocorrência de destes resultados uma vez que no ano de plantio 1984/85 não ocorreu deficiência hídrica neste período não ocorrendo também efeito do tipo de muda, mas ocorreu efeito de interação de época de plantio com o tipo de muda. No ano de plantio 1985/86, as deficiências e excessos hídricos mostraram valores intermediários em relação aos anos anteriores, gerando efeitos também intermediários com interação de épocas de plantio dentro de épocas de colheita para ATR e TAH, como no ano anterior, mas sem efeito de interação de tratamentos (muda picada e inteira no sulco de plantio) dentro de épocas de plantio para TCH e TAH.

Assim, em todos os anos estudados, os resultados de ATR sempre evoluíram do início para o final da safra com os picos localizados no mês de setembro e ligeira queda no mês de novembro com destaque para a época de plantio Maio que sempre apresentou os menores valores iniciais. TAH sempre acompanhou as curvas de ATR sendo influenciado por TCH. Ainda, a época de plantio Maio sempre apresentou os menores valores para todas as variáveis estudadas comprovando que esta época de plantio deve ser evitada. 
Tabela 18. Valores médios de TCH, ATR e TAH para a variedade SP 70-1143, no primeiro corte e nas safras de 1985, 1986 e 1987, em várias combinações de épocas de plantio e de colheita e sob os tratamentos muda picada e inteira no sulco de plantio

\begin{tabular}{|c|c|c|c|c|c|}
\hline \multirow{4}{*}{$\begin{array}{l}\text { Ep } \\
\text { PI }\end{array}$} & \multicolumn{4}{|c|}{$\begin{array}{r}\text { SP } 70-1143 \\
\end{array}$} & \multirow{4}{*}{$\begin{array}{l}\text { Rend } \\
\text { açúcar } \\
\text { (TAH) }\end{array}$} \\
\hline & & & Rend & & \\
\hline & $\mathrm{Ep}$ & & Cana & & \\
\hline & Colh & Trat & $(\mathrm{TCH})$ & ATR & \\
\hline$\overline{N o v}$ & Mai & Picada & 107,99 & 125,89 & 13,54 \\
\hline Nov & Mai & Inteira & 113,07 & 123,24 & 13,88 \\
\hline Nov & Jul & Picada & 112,73 & 153,53 & 17,37 \\
\hline Nov & Jul & Inteira & 107,66 & 149,79 & 16,16 \\
\hline Nov & Set & Picada & 106,09 & 159,96 & 17,00 \\
\hline Nov & Set & Inteira & 106,27 & 159,25 & 17,00 \\
\hline Nov & Nov & Picada & 107,88 & 154,20 & 16,57 \\
\hline Nov & Nov & Inteira & 103,99 & 153,87 & 15,98 \\
\hline Jan & Mai & Picada & 108,68 & 122,73 & 13,34 \\
\hline Jan & Mai & Inteira & 109,35 & 121,25 & 13,30 \\
\hline Jan & Jul & Picada & 108,95 & 151,05 & 16,48 \\
\hline Jan & Jul & Inteira & 113,57 & 150,29 & 17,08 \\
\hline Jan & Set & Picada & 110,77 & 158,71 & 17,61 \\
\hline Jan & Set & Inteira & 110,49 & 160,17 & 17,76 \\
\hline Jan & Nov & Picada & 112,15 & 150,58 & 16,88 \\
\hline Jan & Nov & Inteira & 106,88 & 147,39 & 15,82 \\
\hline Mar & Mai & Picada & 101,93 & 105,95 & 10,85 \\
\hline Mar & Mai & Inteira & 101,62 & 106,61 & 10,86 \\
\hline Mar & Jul & Picada & 106,43 & 142,26 & 15,17 \\
\hline Mar & Jul & Inteira & 109,59 & 143,68 & 15,79 \\
\hline Mar & Set & Picada & 105,29 & 159,84 & 16,82 \\
\hline Mar & Set & Inteira & 106,04 & 157,53 & 16,68 \\
\hline Mar & Nov & Picada & 107,33 & 151,17 & 16,27 \\
\hline Mar & Nov & Inteira & 105,41 & 152,05 & 16,08 \\
\hline Mai & Mai & Picada & 85,47 & 86,23 & 7,40 \\
\hline Mai & Mai & Inteira & 93,57 & 85,63 & 8,04 \\
\hline Mai & Jul & Picada & 91,07 & 131,98 & 12,04 \\
\hline Mai & Jul & Inteira & 100,64 & 129,74 & 13,03 \\
\hline Mai & Set & Picada & 96,87 & 154,65 & 14,89 \\
\hline Mai & Set & Inteira & 97,65 & 150,64 & 14,66 \\
\hline Mai & Nov & Picada & 93,47 & 154,21 & 14,33 \\
\hline Mai & Nov & Inteira & 93,82 & 152,37 & 14,30 \\
\hline
\end{tabular}

As figuras 42, 43 e 44 a seguir, mostram a evolução de TCH média das safras 1985/86/87 para as épocas de plantio e colheita onde se verifica o efeito das épocas sobre os valores observados. 
Resultados de TCH - Média das Safras 1985/86/87 corte 1- épocas de plantio e colheita

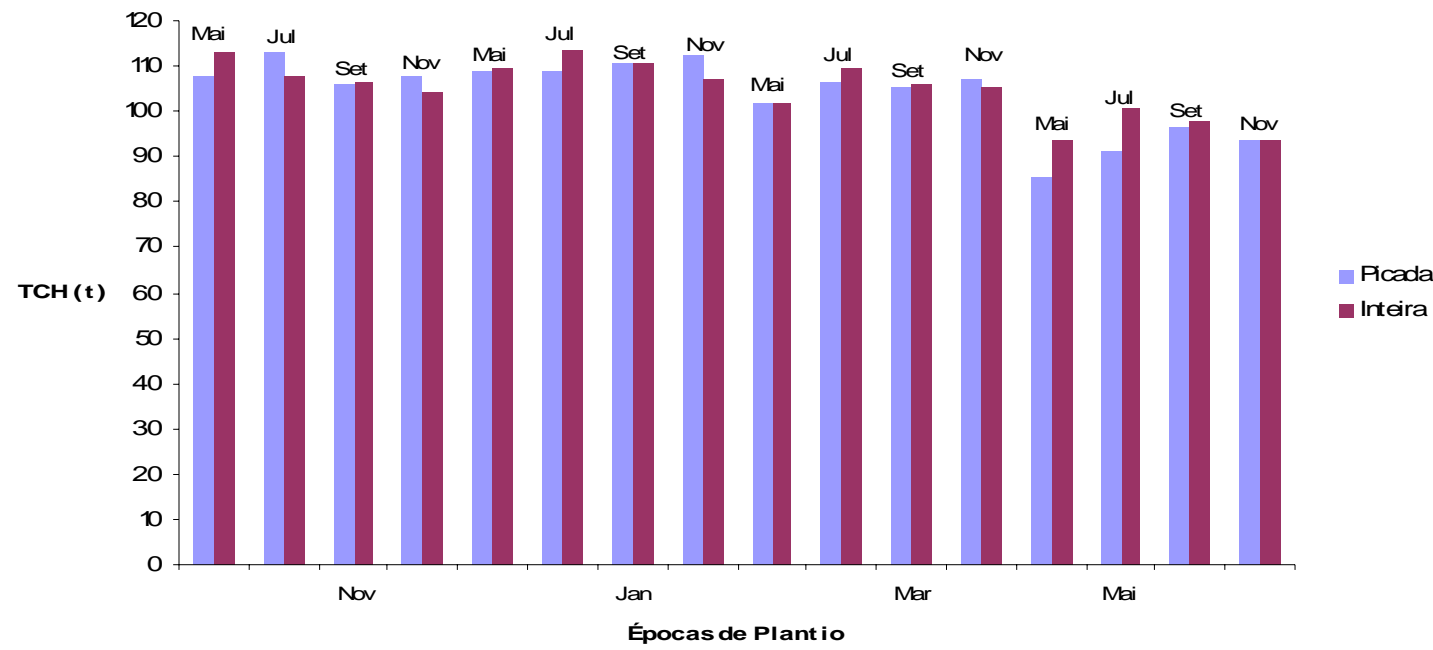

Figura 42 - Resultados médios de TCH para a variedade SP 70-1143 nas safras 1985/86/87, no $1^{\circ}$ corte nas épocas de plantio e colheita

Resultados de ATR - Média das Safras 1985/86/87 corte 1- épocas de plantio e colheita

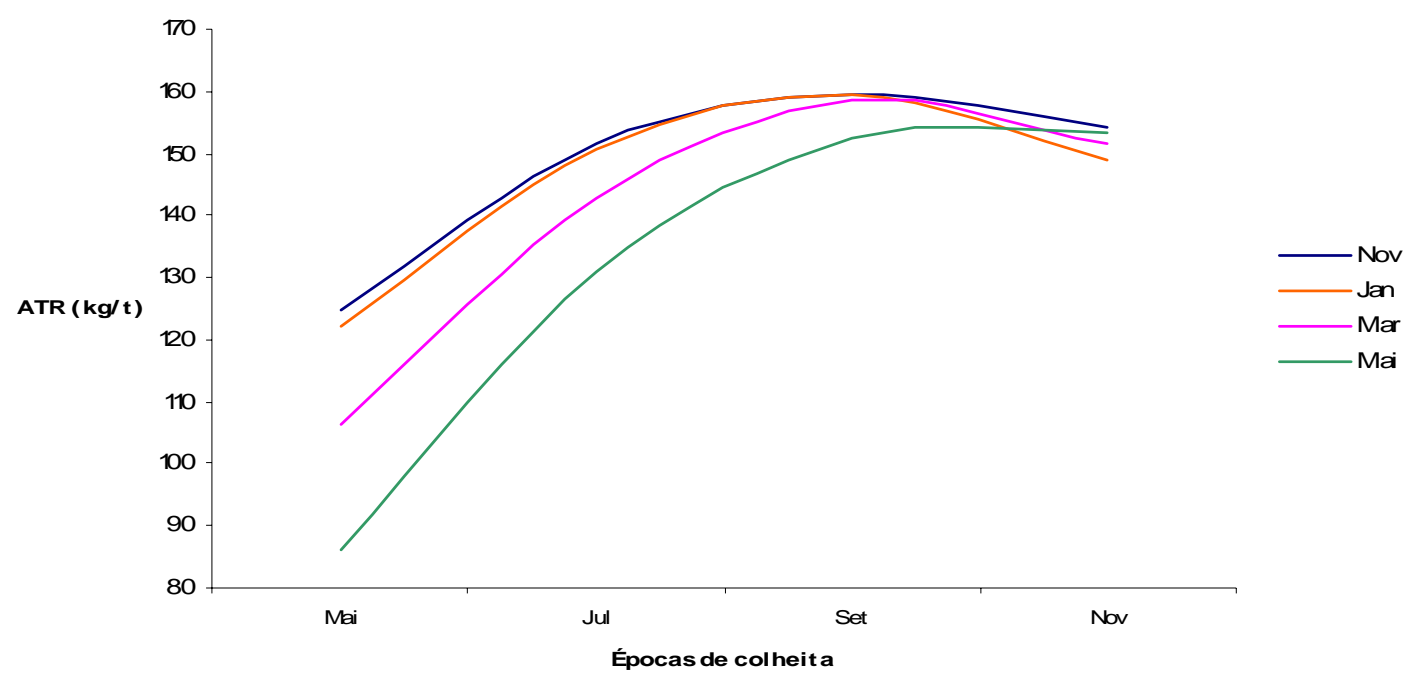

Figura 43 - Resultados médios de ATR para a variedade SP 70-1143 nas safras 1985/86/87, no $1^{\circ}$ corte nas épocas de plantio e colheita 
Resultados de TAH - Média das Safras 1985/86/87 corte 1- épocas de plantio e colheita

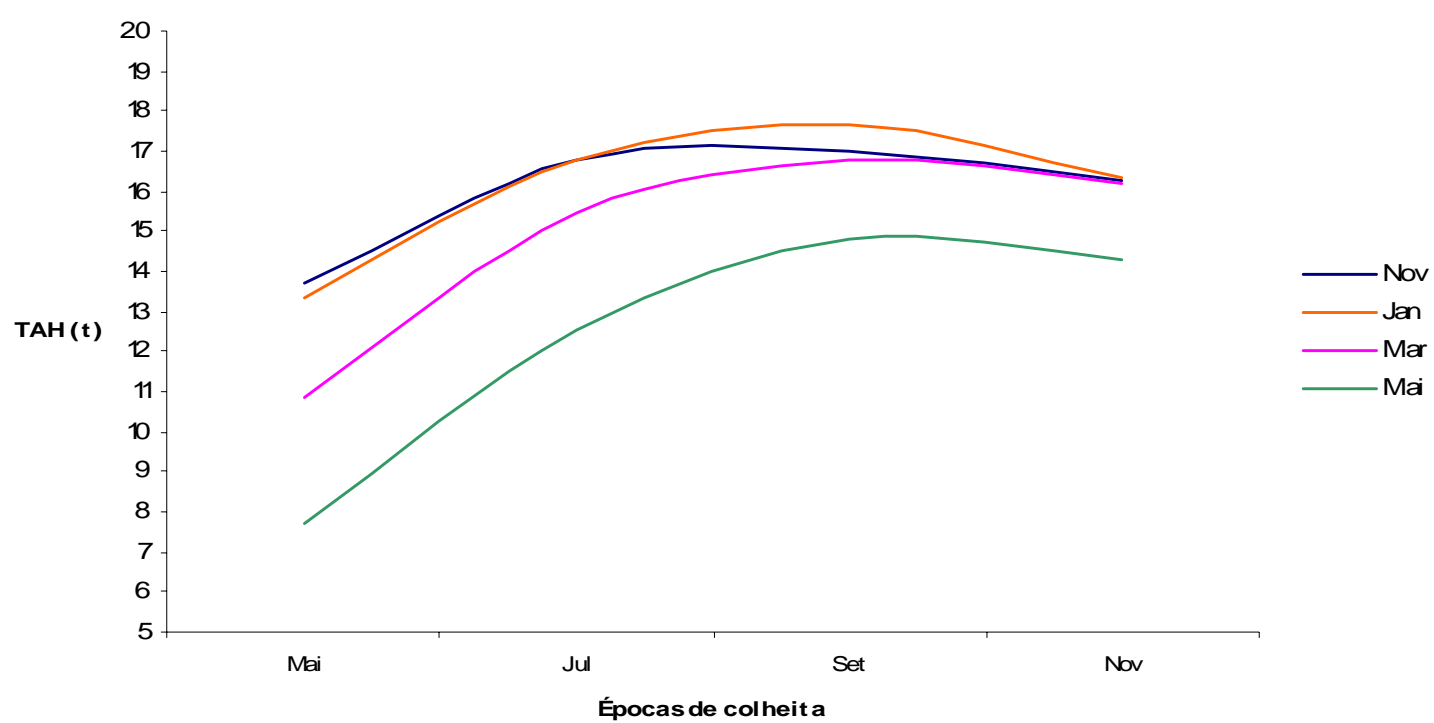

Figura 44 - Resultados médios de TAH para a variedade SP 70-1143 nas safras 1985/86/87, no $1^{\circ}$ corte nas épocas de plantio e colheita

\subsection{Variedade SP $70-1143-2^{\circ}$ corte}

São apresentados na tabela 19, a seguir, os resultados obtidos no segundo corte nas safras de 1986, 1987 e 1988, para toneladas de cana por ha (TCH), açúcar total recuperável (ATR) em kg de açúcar por tonelada de cana e (TAH) toneladas de açúcar por ha, para a variedade SP 70-1143. 
Tabela 19. Valores obtidos de TCH, ATR e TAH para a variedade SP 70-1143, no segundo corte e nas safras de 1986, 1987 e 1988, em várias combinações de épocas de plantio e de colheita e sob os tratamentos muda picada e inteira no sulco de plantio

\begin{tabular}{|c|c|c|c|c|c|c|c|c|c|c|c|}
\hline \multicolumn{12}{|c|}{ SP 70-1143 } \\
\hline \multirow[b]{2}{*}{$\begin{array}{l}\text { Ep } \\
\mathrm{PI}\end{array}$} & \multirow[b]{2}{*}{$\begin{array}{c}\text { Ep } \\
\text { Colh }\end{array}$} & \multirow[b]{2}{*}{ Trat } & \multicolumn{3}{|c|}{ Safra 1986 - corte 2} & \multicolumn{3}{|c|}{ Safra 1987 - corte 2} & \multicolumn{3}{|c|}{ Safra 1988 - corte 2} \\
\hline & & & $\begin{array}{l}\text { Rend } \\
\text { Cana } \\
\text { (TCH) }\end{array}$ & ATR & $\begin{array}{l}\text { Rend } \\
\text { açúcar } \\
\text { (TAH) }\end{array}$ & $\begin{array}{l}\text { Rend } \\
\text { Cana } \\
\text { (TCH) }\end{array}$ & ATR & $\begin{array}{l}\text { Rend } \\
\text { açúcar } \\
\text { (TAH) }\end{array}$ & $\begin{array}{l}\text { Rend } \\
\text { Cana } \\
\text { (TCH) }\end{array}$ & ATR & $\begin{array}{l}\text { Rend } \\
\text { açúcar } \\
\text { (TAH) }\end{array}$ \\
\hline Nov & Mai & Picada & 77,76 & 100,20 & 7,76 & 76,10 & 107,83 & 8,22 & 82,81 & 117,17 & 9,70 \\
\hline Nov & Mai & Inteira & 82,93 & 101,48 & 8,39 & 77,29 & 108,17 & 8,36 & 86,43 & 113,11 & 9,77 \\
\hline Nov & Jul & Picada & 58,79 & 143,27 & 8,41 & 80,14 & 147,10 & 11,78 & 87,38 & 137,83 & 12,05 \\
\hline Nov & Jul & Inteira & 62,79 & 144,80 & 9,07 & 83,24 & 146,16 & 12,17 & 86,24 & 139,75 & 12,05 \\
\hline Nov & Set & Picada & 79,95 & 152,07 & 12,17 & 89,95 & 159,05 & 14,31 & 76,95 & 162,40 & 12,50 \\
\hline Nov & Set & Inteira & 79,14 & 151,49 & 11,99 & 86,86 & 156,42 & 13,59 & 76,19 & 162,42 & 12,38 \\
\hline Nov & Nov & Picada & 73,53 & 129,21 & 9,49 & 85,43 & 140,96 & 12,02 & 67,62 & 159,29 & 10,76 \\
\hline Nov & Nov & Inteira & 70,29 & 129,00 & 9,04 & 82,10 & 137,00 & 11,19 & 65,57 & 157,55 & 10,33 \\
\hline Jan & Mai & Picada & 78,22 & 95,92 & 7,46 & 91,05 & 113,46 & 10,30 & 96,62 & 120,52 & 11,64 \\
\hline Jan & Mai & Inteira & 80,67 & 103,40 & 8,34 & 88,91 & 107,56 & 9,56 & 91,34 & 120,37 & 10,99 \\
\hline Jan & Jul & Picada & 64,50 & 146,15 & 9,42 & 77,19 & 143,73 & 11,06 & 100,00 & 138,59 & 13,86 \\
\hline Jan & Jul & Inteira & 65,88 & 149,27 & 9,84 & 85,86 & 149,51 & 12,83 & 96,05 & 138,76 & 13,32 \\
\hline Jan & Set & Picada & 77,76 & 152,80 & 11,88 & 97,00 & 155,03 & 15,03 & 89,76 & 163,25 & 14,64 \\
\hline Jan & Set & Inteira & 78,81 & 151,48 & 11,95 & 94,10 & 156,48 & 14,73 & 89,43 & 160,43 & 14,34 \\
\hline Jan & Nov & Picada & 75,95 & 131,01 & 9,96 & 93,48 & 137,29 & 12,81 & 72,38 & 158,28 & 11,45 \\
\hline Jan & Nov & Inteira & 72,10 & 133,38 & 9,69 & 93,29 & 142,18 & 13,27 & 70,38 & 158,47 & 11,13 \\
\hline Mar & Mai & Picada & 71,45 & 104,38 & 7,45 & 91,81 & 102,90 & 9,45 & 93,57 & 115,70 & 10,79 \\
\hline Mar & Mai & Inteira & 74,05 & 99,35 & 7,35 & 88,34 & 107,75 & 9,50 & 93,86 & 121,19 & 11,35 \\
\hline Mar & Jul & Picada & 52,95 & 149,52 & 7,93 & 82,19 & 148,15 & 12,18 & 90,48 & 137,01 & 12,38 \\
\hline Mar & Jul & Inteira & 55,81 & 150,80 & 8,42 & 82,24 & 141,51 & 11,65 & 90,91 & 139,85 & 12,71 \\
\hline Mar & Set & Picada & 74,57 & 151,72 & 11,31 & 95,76 & 156,11 & 14,95 & 82,86 & 161,46 & 13,37 \\
\hline Mar & Set & Inteira & 72,95 & 153,27 & 11,20 & 98,81 & 158,41 & 15,62 & 89,48 & 163,11 & 14,60 \\
\hline Mar & Nov & Picada & 70,95 & 133,40 & 9,45 & 94,53 & 142,47 & 13,43 & 71,05 & 157,82 & 11,20 \\
\hline Mar & Nov & Inteira & 74,19 & 137,44 & 10,19 & 95,34 & 139,63 & 13,35 & 73,05 & 155,12 & 11,35 \\
\hline Mai & Mai & Picada & 76,38 & 99,18 & 7,55 & 87,95 & 106,22 & 9,35 & 97,86 & 114,22 & 11,17 \\
\hline Mai & Mai & Inteira & 77,55 & 99,53 & 7,70 & 79,81 & 106,48 & 8,50 & 96,00 & 116,48 & 11,14 \\
\hline Mai & Jul & Picada & 58,05 & 146,29 & 8,48 & 88,76 & 146,50 & 12,96 & 98,10 & 140,20 & 13,71 \\
\hline Mai & Jul & Inteira & 59,69 & 148,97 & 8,88 & 86,91 & 150,17 & 13,07 & 98,48 & 144,09 & 14,20 \\
\hline Mai & Set & Picada & 84,34 & 152,26 & 12,85 & 95,24 & 152,62 & 14,51 & 89,72 & 163,21 & 14,64 \\
\hline Mai & Set & Inteira & 79,38 & 152,05 & 12,08 & 93,76 & 157,66 & 14,76 & 81,53 & 163,87 & 13,36 \\
\hline Mai & Nov & Picada & 75,29 & 145,88 & 10,98 & 93,48 & 138,54 & 12,89 & 75,00 & 156,60 & 11,74 \\
\hline Mai & Nov & Inteira & 75,00 & 142,00 & 10,66 & 90,19 & 141,03 & 12,75 & 73,86 & 159,04 & 11,76 \\
\hline
\end{tabular}


Tabela 20. Resumo dos quadros de análise de variância dos dados obtidos para a variedade SP 70-1143, no segundo corte e com plantio no ano de 1983/84, em relação às variáveis dependentes TCH, ATR e TAH em várias combinações de épocas de plantio e de colheita e sob os tratamentos cana picada e inteira no sulco de plantio

\begin{tabular}{|c|c|c|c|c|}
\hline C. Variação & $G L$ & $\begin{array}{c}\mathrm{TCH} \\
Q M\end{array}$ & $\begin{array}{c}\text { ATR } \\
Q M\end{array}$ & $\begin{array}{c}\mathrm{TAH} \\
Q M\end{array}$ \\
\hline$B L O C O$ & 4 & -- & -- & -- \\
\hline EPCOL & 3 & 2931,209 * * & $21815,315^{* *}$ & 127,778 ** \\
\hline Resíduo (a) & 12 & 338,082 & 101,513 & 5,246 \\
\hline$E P P L A$ & 3 & 276,546 * * & $154,893^{* *}$ & $4,409 * *$ \\
\hline Resíduo (b) & 12 & 56,586 & 43,475 & 1,872 \\
\hline TRAT & 1 & 18,137 & 32,725 & $\odot, 756$ \\
\hline$E P C O L{ }^{\star} E P P L A$ & 9 & 58,968 * & $110,581^{* *}$ & 2,294 * * \\
\hline$E P C O L{ }^{*} T R A T$ & 3 & 53,199 & 9,220 & 1,270 \\
\hline$E P P L A^{*} T R A T$ & 3 & 11,275 & 19,150 & $\odot, 359$ \\
\hline$E P C O L{ }^{*} E P P L A^{*} T R A T$ & 9 & 13,828 & 27,331 & 0,411 \\
\hline Resíduo (c) & 100 & 24,354 & 22,278 & $\odot, 583$ \\
\hline Total & 159 & -- & -- & -- \\
\hline
\end{tabular}

A tabela 20, apresentada, mostra os valores da análise de variância, para as variáveis TCH, ATR e TAH, da variedade SP 70-1143, no segundo corte e com plantio no ano de 1983/84.

Como se pode observar, para as variáveis TCH, ATR e TAH houve efeito significativo de época de corte e época de plantio. $\mathrm{O}$ tratamento muda picada e inteira no sulco de plantio não apresentou efeito significativo para as variáveis estudadas.

Houve interação de épocas de plantio dentro de épocas de colheita para todas as variáveis estudadas, indicando diferenças significativas entre as épocas de plantio para cada época de colheita. Não houve qualquer outra interação. 
Tabela 21. Valores médios de TCH para a variedade SP 70-1143 nas interações de épocas de plantio dentro de épocas de colheita, com plantio no ano de $1983 / 84$, no $2^{\circ}$ corte

\begin{tabular}{|c|c|c|}
\hline$E P P L A$ & EPCOL & $T C H$ (MÉDIA) \\
\hline Mai & Set & $81,857 \mathrm{a}$ \\
\hline Nov & Mai & $80,347 a b$ \\
\hline Nov & Set & $79,549 \mathrm{abc}$ \\
\hline Jan & Mai & 79,443 abc \\
\hline Jan & Set & 78,287 abc \\
\hline Mai & Mai & $76,965 \mathrm{abc}$ \\
\hline Mai & Nov & 75,143 abc \\
\hline Jan & Nov & 74,025 bc \\
\hline Mar & Set & 73,764 bc \\
\hline Mar & Mai & $72,752 \mathrm{bcd}$ \\
\hline Mar & Nov & 72,575 \\
\hline Nov & Nov & 71,907 \\
\hline Jan & Jul & 65,192 \\
\hline Nov & Jul & 60,786 \\
\hline Mai & Jul & 58,870 \\
\hline Mar & Jul & 54,381 \\
\hline
\end{tabular}

Médias seguidas das mesmas letras não diferiram estatisticamente entre si.

$\mathrm{Na}$ tabela 21, observa-se que para a variedade SP 70-1143, plantada em 1983/84 e no segundo corte, em relação a variável TCH, houve diferença estatisticamente significativa entre as médias das épocas de plantio dentro das épocas de colheita. As maiores produções foram obtidas nas épocas de colheita Setembro com plantio em Maio e Novembro e colheita em Maio com plantio em Novembro, Janeiro e Maio. As menores produções foram obtidas na época de colheita Julho com plantio em Março, Maio, Novembro e Janeiro.

As figuras 45, 46, 47 e 48, a seguir, mostram a evolução de TCH na safra 1986 para cada época de plantio onde se verifica o efeito das épocas de colheita sobre os valores observados. 


\section{Resultados de TCH- Safra 1986 \\ $2^{\circ}$ corte - época de plantio Novembro}

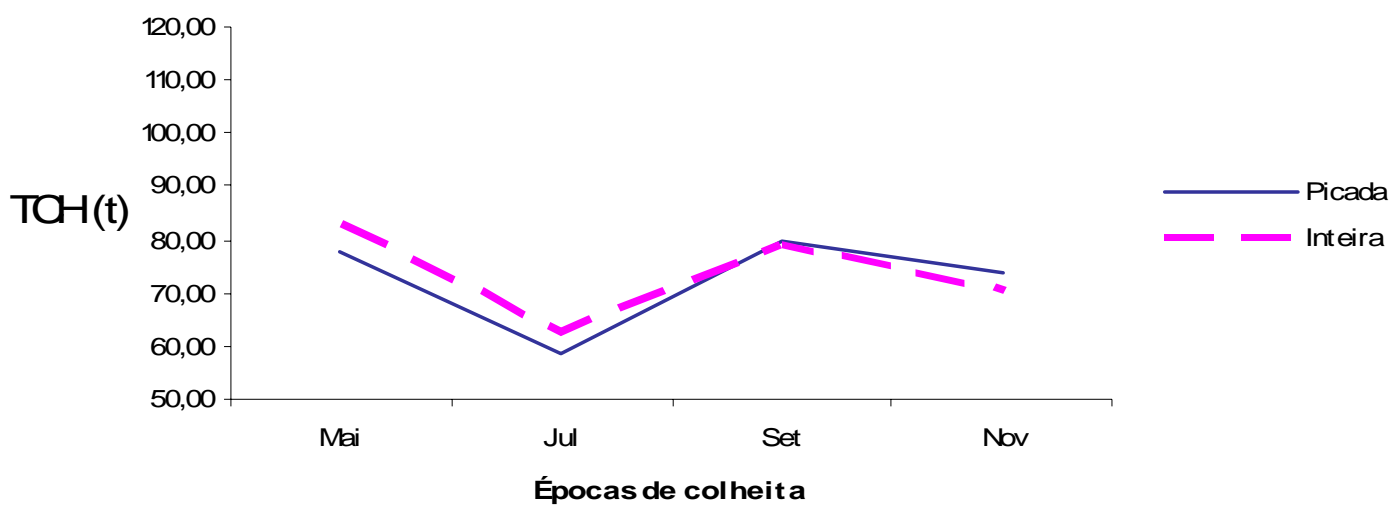

Figura 45 - Resultados de TCH para a variedade SP 70-1143 na safra 1986 , no $2^{\circ}$ corte e época de plantio Novembro

\section{Resultados de TCH-Safra 1986 \\ $2^{\circ}$ corte - época de plantio Janeiro}

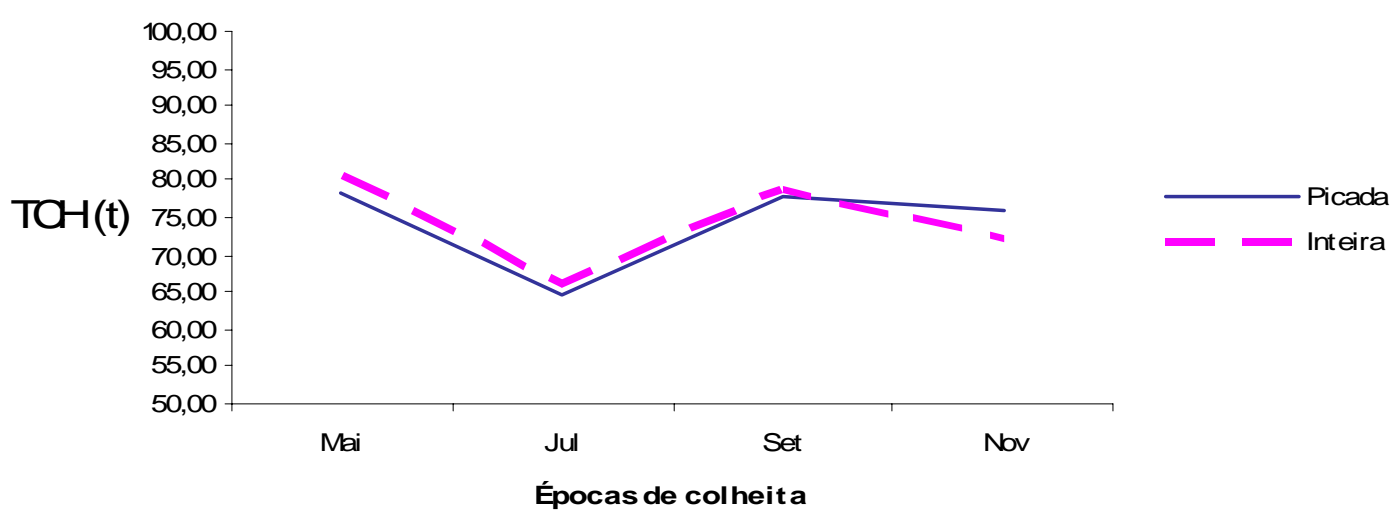

Figura 46 - Resultados de TCH para a variedade SP 70-1143 na safra 1986 , no $2^{\circ}$ corte e época de plantio janeiro 


\section{Resultados de TCH- Safra 1986 \\ $2^{\circ}$ corte - época de plantio Março}

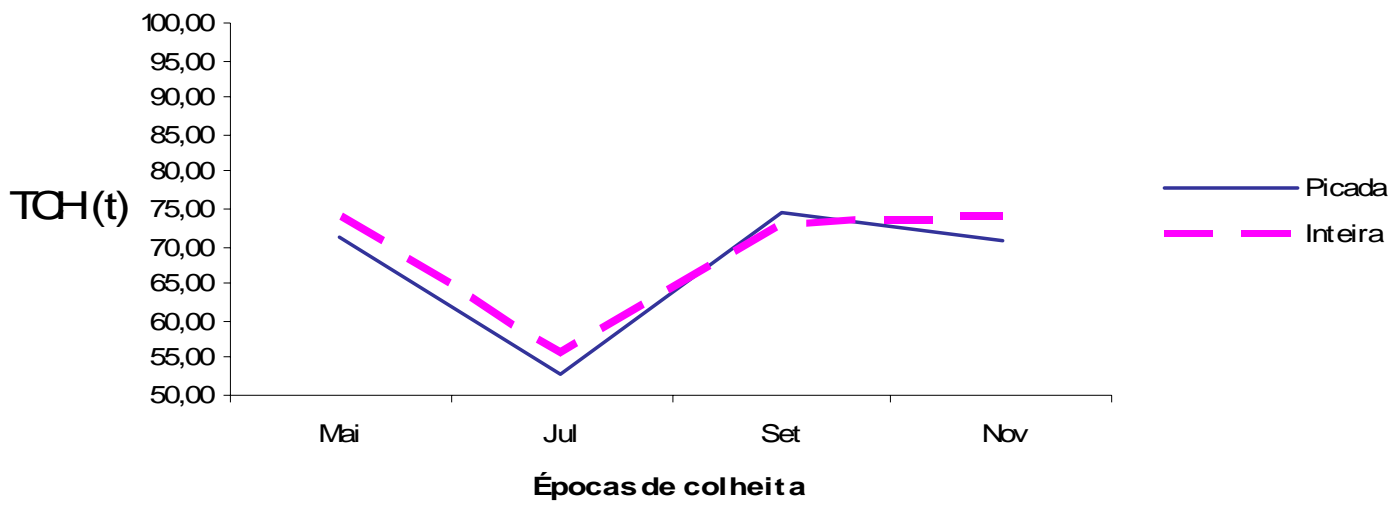

Figura 47 - Resultados de TCH para a variedade SP 70-1143 na safra 1986, no $2^{\circ}$ corte e época de plantio Março

Resultados de TCH- Safra 1986

$2^{\circ}$ corte - época de plantio Maio

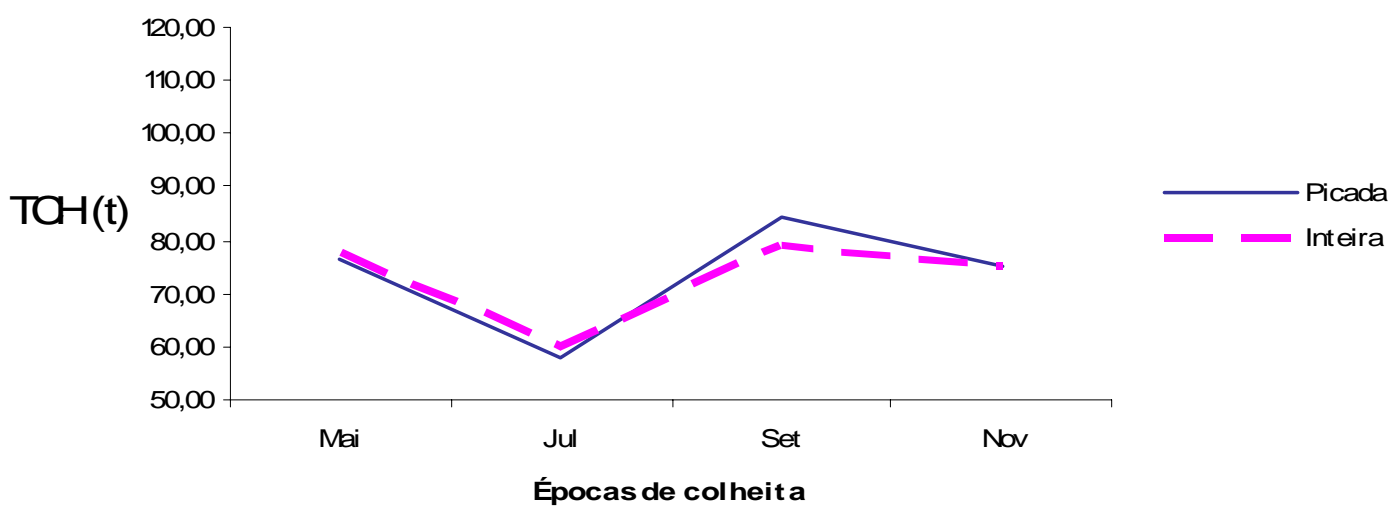

Figura 48 - Resultados de TCH para a variedade SP 70-1143 na safra 1986 , no $2^{\circ}$ corte e época de plantio Maio 
Tabela 22. Valores médios de ATR para a variedade SP 70-1143 nas interações de épocas de plantio dentro de épocas de colheita, com plantio no ano de $1983 / 84$, no $2^{\circ}$ corte

\begin{tabular}{|c|c|c|c|}
\hline EPPLA & EPCOL & ATR (MÉDI & \\
\hline Mar & Set & 152,495 & $a$ \\
\hline Mai & Set & 152,152 & a \\
\hline Jan & Set & 152,138 & $\mathrm{a}$ \\
\hline Nov & Set & 151,780 & $\mathrm{a}$ \\
\hline Mar & Jul & 150,158 & $a b$ \\
\hline Mai & Jul & 150,158 & $a b$ \\
\hline Jan & Jul & 147,711 & $a b$ \\
\hline Nov & Jul & 144,033 & b \\
\hline Mai & Nov & 143,939 & $b$ \\
\hline Mar & Nov & 135,420 & c \\
\hline Jan & Nov & 132,193 & c \\
\hline Nov & Nov & 129,100 & c \\
\hline Mar & Mai & 101,867 & d \\
\hline Nov & Mai & 100,844 & d \\
\hline Jan & Mai & 99,661 & d \\
\hline Mai & Mai & 99,357 & d \\
\hline
\end{tabular}

Médias seguidas das mesmas letras não diferiram estatisticamente entre si.

$\mathrm{Na}$ tabela 22, observa-se que para a variedade SP 70-1143, plantada em 1983/84 e no segundo corte, houve diferença estatisticamente significativa entre as médias das épocas de plantio dentro das épocas de colheita. Desses resultados pode-se concluir que para a variável ATR, o tratamento época de colheita mostrou maior influência, apresentando os maiores valores nas épocas de colheita Setembro e Julho com plantio em Março, Maio, Janeiro e Novembro.

Os piores valores foram obtidos nas épocas de colheita Maio com plantios em Maio, Janeiro, Novembro e Março.

As figuras 49, 50, 51 e 52, a seguir, mostram a evolução de ATR na safra 1986 para cada época de plantio onde se verifica o efeito das épocas de colheita sobre os valores observados. 


\section{Resultados de ATR- Safra 1986 \\ $2^{\circ}$ corte - época de plantio Nbvembro}

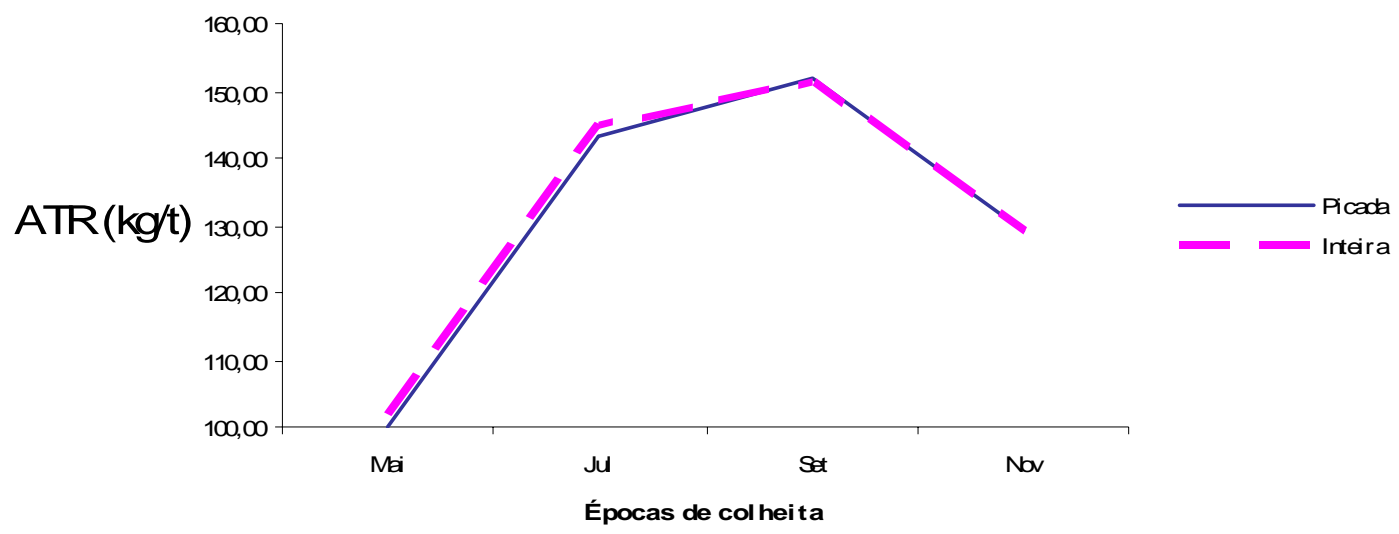

Figura 49 - Resultados de ATR para a variedade SP 70-1143 na safra 1986 , no $2^{\circ}$ corte e época de plantio Novembro

Resultados de ATR- Safra 1986

$2^{\circ}$ corte - época de plantio Janeiro

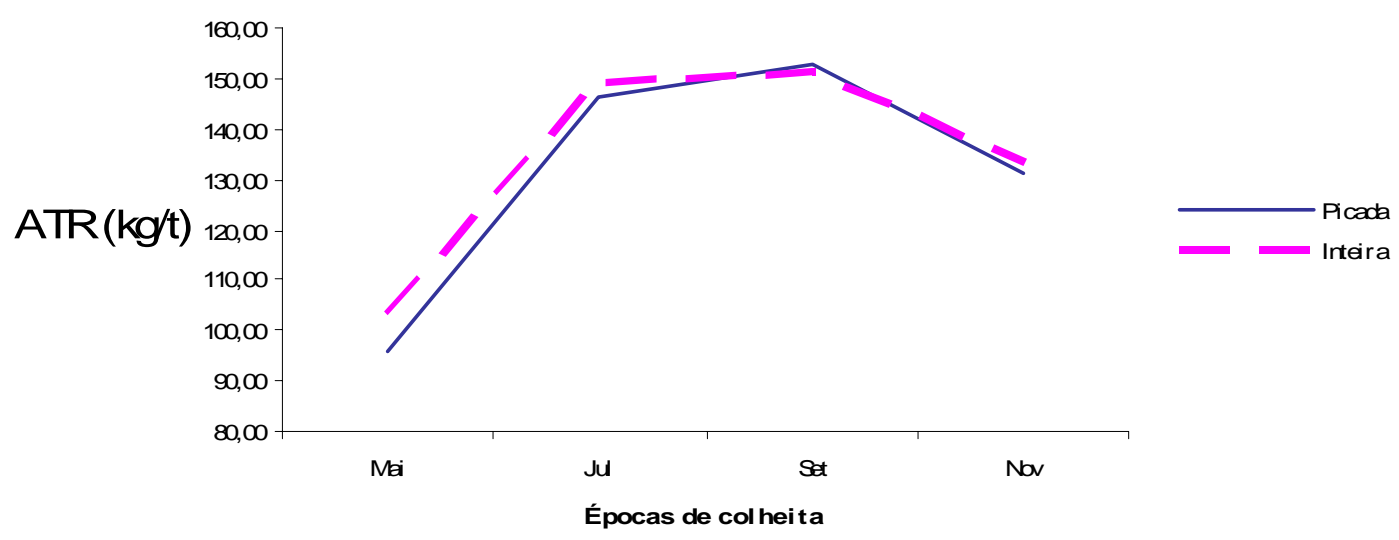

Figura 50 - Resultados de ATR para a variedade SP 70-1143 na safra 1986 , no $2^{\circ}$ corte e época de plantio Janeiro 
Resultados de ATR- Safra 1986

$2^{\circ}$ corte - época de plantio Março

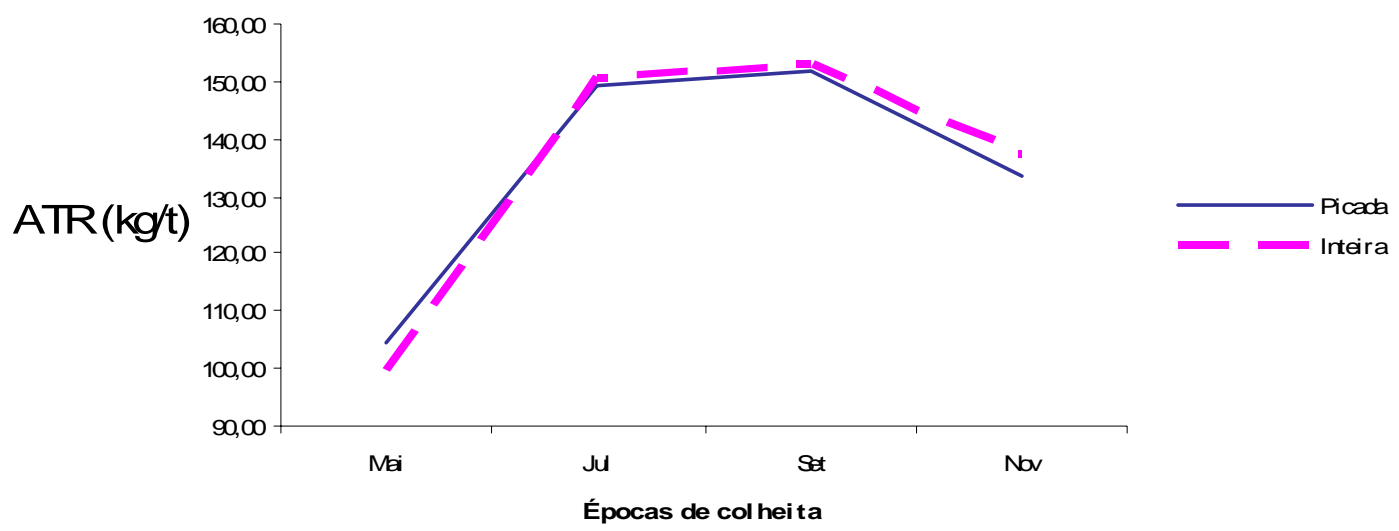

Figura 51 - Resultados de ATR para a variedade SP 70-1143 na safra 1986, no $2^{\circ}$ corte e época de plantio Março

Resultados de ATR- Safra 1986

$2^{\circ}$ corte - época de plantio Maio

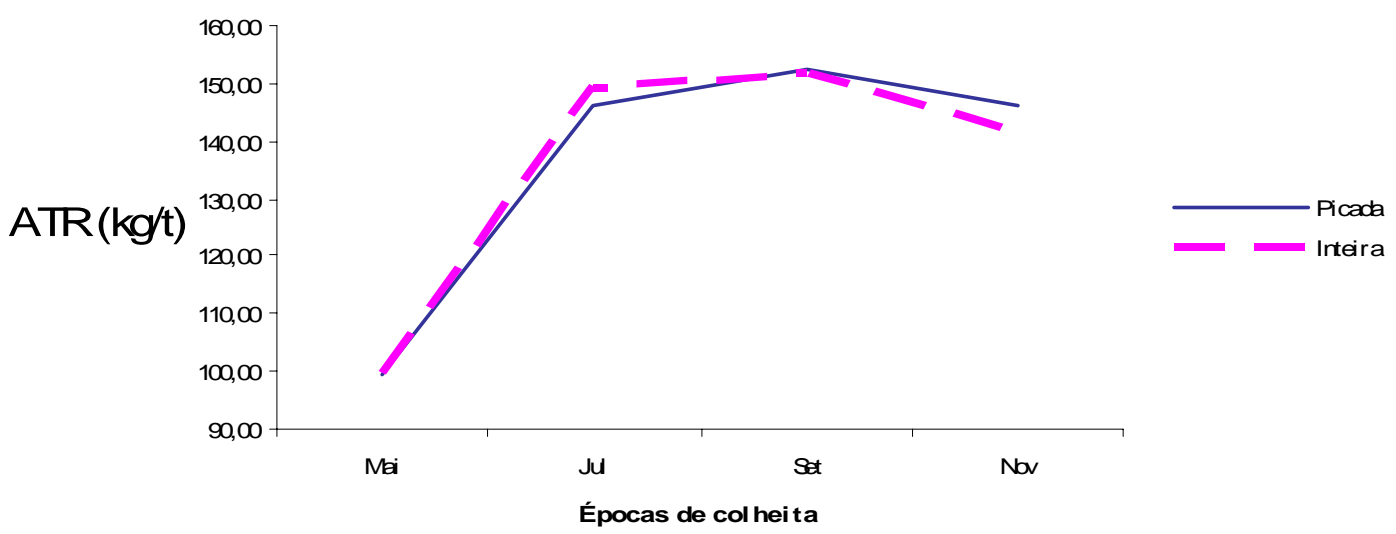

Figura 52 - Resultados de ATR para a variedade SP 70-1143 na safra 1986, no $2^{\circ}$ corte e época de plantio Maio 
Tabela 23. Valores médios de TAH para a variedade SP 70-1143 nas interações de épocas de plantio dentro de épocas de colheita, no ano de 1983/84, no $2^{\circ}$ corte

\begin{tabular}{cccc}
\hline EPPLA & EPCOL & TAH (MÉDIA) \\
\hline Mai & Set & $12,464 \mathrm{a}$ & \\
Nov & Set & $12,084 \mathrm{ab}$ & \\
Jan & Set & $11,913 \mathrm{abc}$ & \\
Mar & Set & $11,254 \quad \mathrm{bc}$ \\
Mai & Nov & $10,819 \mathrm{~cd}$ \\
Jan & Nov & 9,827 & $\mathrm{~d}$ \\
Mar & Nov & 9,818 & $\mathrm{~d}$ \\
Jan & Jul & 9,631 & $\mathrm{~d}$ \\
Nov & Nov & 9,262 & de \\
Nov & Jul & 8,740 & def \\
Mai & Jul & 8,681 & def \\
Mar & Jul & 8,176 & efg \\
Nov & Mai & 8,074 & efg \\
Jan & Mai & 7,900 & $\mathrm{fg}$ \\
Mai & Mai & 7,625 & $\mathrm{fg}$ \\
Mar & Mai & 7,402 & $\mathrm{~g}$ \\
\hline Médias seguidas das mesmas letras não diferiram estatisticamente entre si. &
\end{tabular}

Médias seguidas das mesmas letras não diferiram estatisticamente entre si.

$\mathrm{Na}$ tabela 23, observa-se que para a variedade SP 70-1143, plantada em 1983/84 e no segundo corte, em relação a variável TAH, houve diferença estatisticamente significativa entre as médias das épocas de plantio dentro das épocas de colheita. Os maiores valores foram obtidos na época de colheita Setembro com plantio em Maio, Novembro, Janeiro e Março. Os menores valores apareceram na época de colheita Maio com plantios em Março, Maio, Janeiro e Novembro.

As figuras 53, 54, 55 e 56, a seguir, mostram a evolução de TAH na safra 1986 para cada época de plantio onde se verifica o efeito das épocas de colheita sobre os valores observados. 
Resultados de TAH- Safra 1986

$2^{\circ}$ corte - época de plantio Novembro

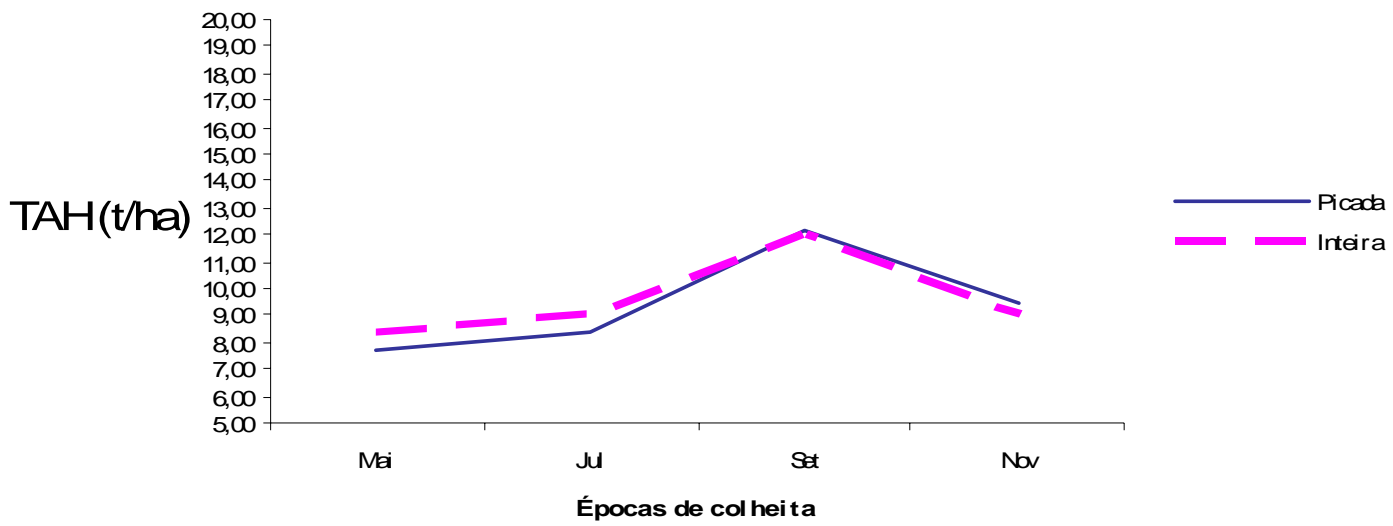

Figura 53 - Resultados de TAH para a variedade SP 70-1143 na safra 1986 , no $2^{\circ}$ corte e época de plantio Novembro

Resultados de TAH- Safra 1986

$2^{\circ}$ corte - época de plantio Janeiro

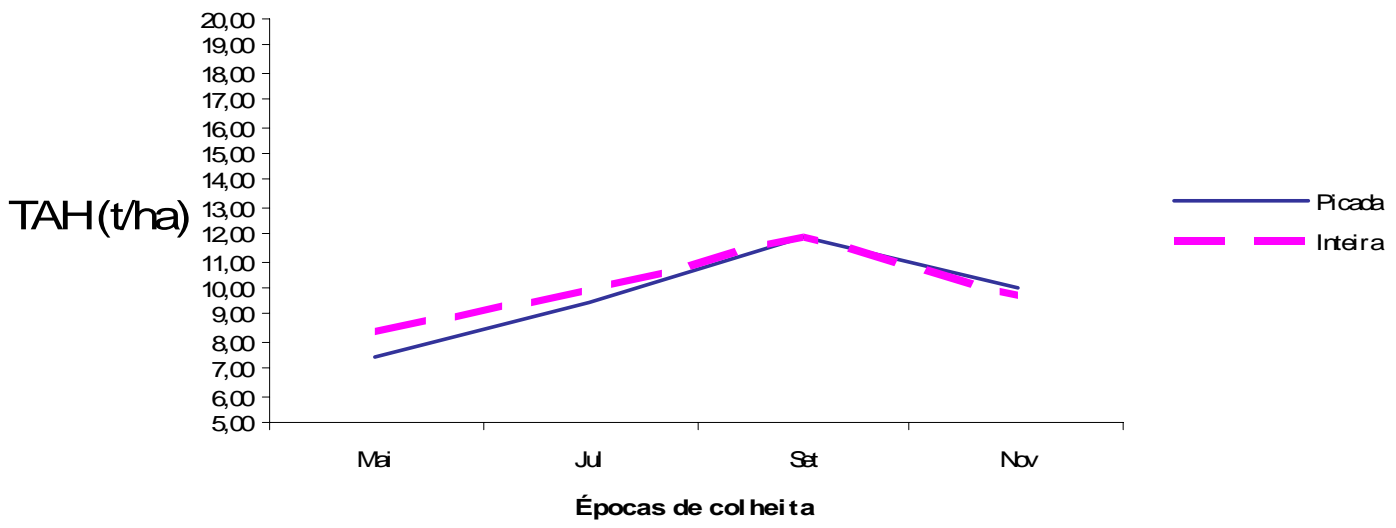

Figura 54 - Resultados de TAH para a variedade SP 70-1143 na safra 1986 , no $2^{\circ}$ corte e época de plantio Janeiro 
Resultados de TAH- Safra 1986

$2^{\circ}$ corte - época de plantio Março

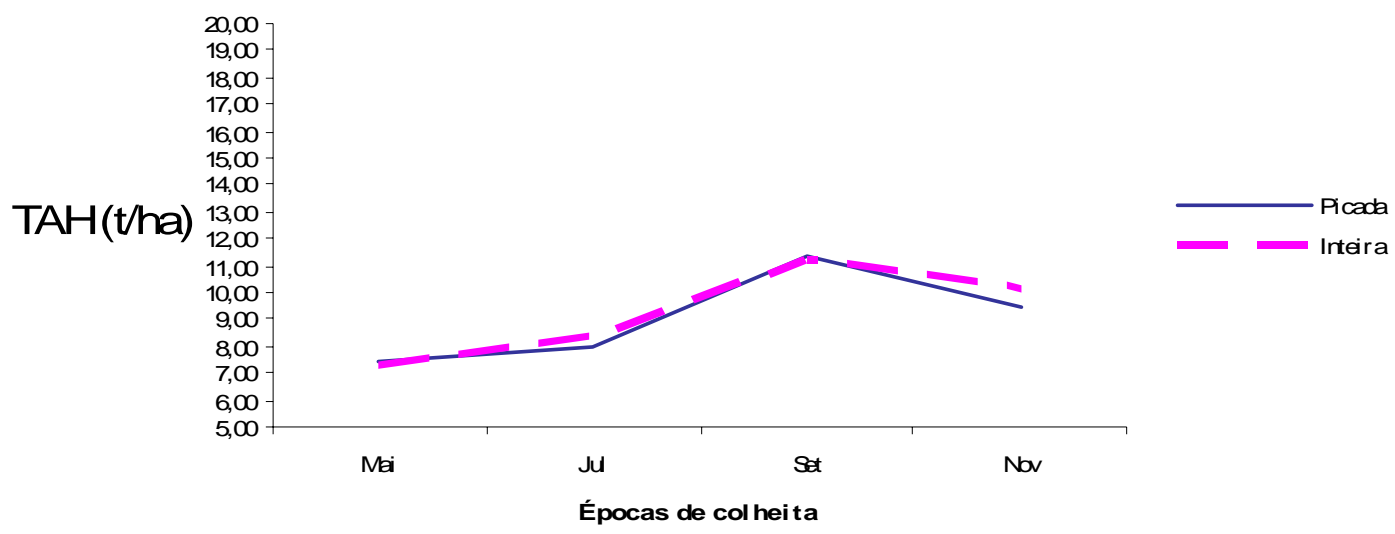

Figura 55 - Resultados de TAH para a variedade SP 70-1143 na safra 1986 , no $2^{\circ}$ corte e época de plantio Março

Resultados de TAH- Safra 1986

$2^{\circ}$ corte - época de plantio Maio

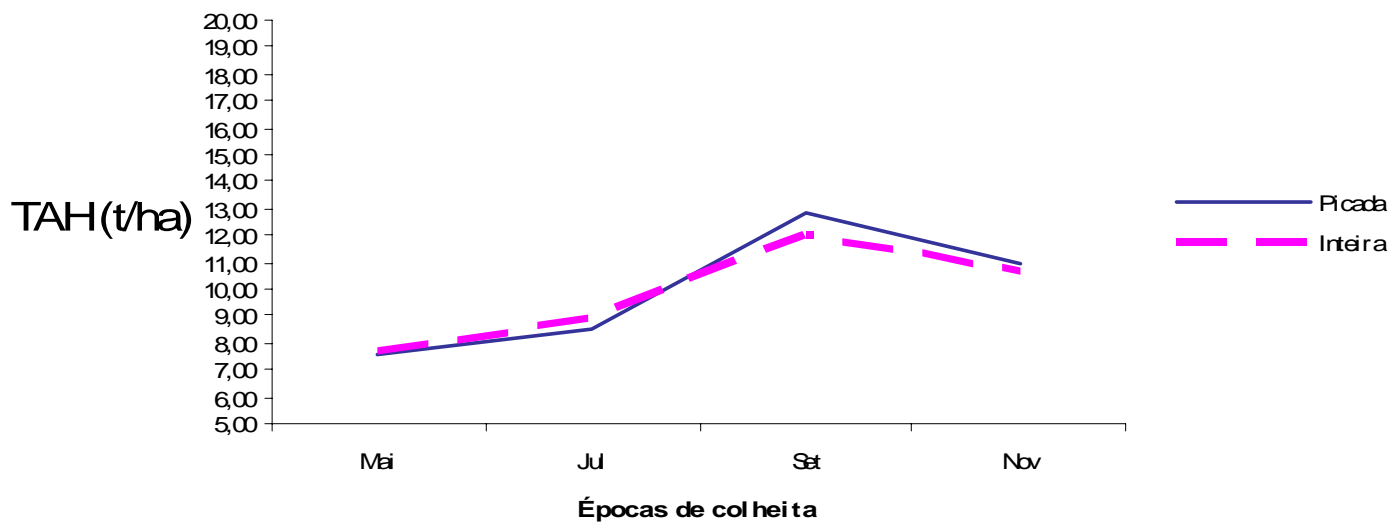

Figura 56 - Resultados de TAH para a variedade SP 70-1143 na safra 1986, no $2^{\circ}$ corte e época de plantio Maio 
Tabela 24. Resumo dos quadros de análise de variância dos dados obtidos para a variedade SP 70-1143, no segundo corte e com plantio no ano de 1984/85, em relação às variáveis dependentes TCH, ATR e TAH em várias combinações de épocas de plantio e de colheita e sob os tratamentos cana picada e inteira no sulco de plantio

\begin{tabular}{|c|c|c|c|c|}
\hline C. Variação & $G L$ & $\begin{array}{c}\mathrm{TCH} \\
Q M\end{array}$ & $\begin{array}{c}\text { ATR } \\
Q M\end{array}$ & $\begin{array}{c}\mathrm{TAH} \\
Q M\end{array}$ \\
\hline$B L O C O$ & 4 & -- & -- & -- \\
\hline EPCOL & 3 & 981,840 * * & $17942,817^{* *}$ & 209,537 ** \\
\hline Resíduo (a) & 12 & 91,025 & 19,928 & 2,075 \\
\hline$E P P L A$ & 3 & 597,049 & 8,425 & $9,855^{* *}$ \\
\hline Resíduo (b) & 12 & 253,469 & 51,186 & 4,573 \\
\hline TRAT & 1 & 26,585 & 10,517 & $\bullet, 017$ \\
\hline$E P C O L{ }^{\star} E P P L A$ & 9 & 97,743 & 28,544 & $2,405^{\star}$ \\
\hline$E P C O L{ }^{*} T R A T$ & 3 & 56,339 & 5,306 & $1, \odot 91$ \\
\hline$E P P L A^{*} T R A T$ & 3 & 39,968 & 43,815 & $\odot, 588$ \\
\hline$E P C O L{ }^{*} E P P L A{ }^{*} T R A T$ & 9 & 27,363 & 50,246 & 1,355 \\
\hline Resíduo (c) & 100 & 55,064 & 32,611 & 1,106 \\
\hline Total & 159 & -- & -- & -- \\
\hline
\end{tabular}

A tabela 24, apresentada, mostra os valores da análise de variância, para as variáveis TCH, ATR e TAH, da variedade SP 70-1143, no segundo corte e com plantio no ano de 1984/85.

Como se pode observar, para as variáveis TCH, ATR e TAH houve efeito significativo de época de corte; para época de plantio houve efeito significativo apenas para a variável TAH. O tratamento muda picada e inteira no sulco de plantio não apresentou efeito significativo para as variáveis estudadas.

Houve interação de épocas de plantio dentro de épocas de colheita apenas para a variável TAH, indicando diferenças significativas entre as épocas de plantio para cada época de colheita. Não houve qualquer outra interação. 
Tabela 25. Valores médios de TCH para a variedade SP 701143 das médias de épocas de colheita, com plantio no ano de $1984 / 85$, no $2^{\circ}$ corte

\begin{tabular}{cc}
\hline$E P C O L$ & $T C H(M E ́ D I A)$ \\
\hline Set & 93,937 a \\
Nov & 90,978 ab \\
Mai & 85,156 bc \\
Jul & $83,318 \quad$ C
\end{tabular}

Médias seguidas das mesmas letras não diferiram estatisticamente entre si.

A tabela 25, mostra que para a variedade SP 70-1143, no segundo corte e ano de plantio 1984/85, houve diferença estatisticamente significativa entre as médias $\mathrm{TCH}$ nas épocas de colheita. Observou-se então que as maiores produções foram obtidas nas colheitas de Setembro e as menores produções foram obtidas nas colheitas de Julho.

A figura 57, a seguir, mostra a evolução de TCH na safra 1987 para as épocas de colheita.

\section{Resultados de $\mathrm{TaH}$ Safra 87 - corte 2}

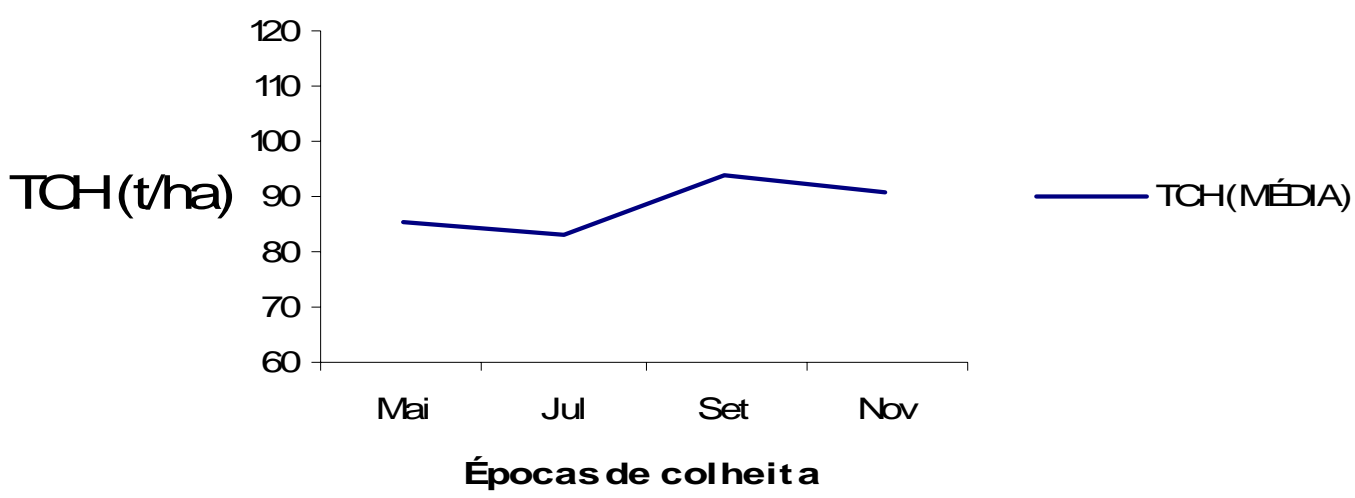

Figura 57 - Resultados de TCH para a variedade SP 70-1143 na safra 1987, no $2^{\circ}$ corte nas épocas de colheita 
Tabela 26. Valores médios de ATR para a variedade SP 701143 das médias de épocas de colheita, com plantio no ano de $1984 / 85$, no $2^{\circ}$ corte

\begin{tabular}{cc}
\hline$E P C O L$ & $A T R(M E ́ D I A)$ \\
\hline Set & 156,473 a \\
Jul & $146,604 \quad$ b \\
Nov & $139,887 \quad$ c \\
Mai & $107,546 \quad$ d
\end{tabular}

Médias seguidas das mesmas letras não diferiram estatisticamente entre si.

$\mathrm{Na}$ tabela 26, observa-se que para a variedade SP 70-1143, no segundo corte e ano de plantio 1984/85, houve diferença estatisticamente significativa entre as médias de ATR nas épocas de colheita. O maior valor de ATR foi observado na época de colheita Setembro e o menor na época de colheita Maio.

A figuras 58, a seguir, mostra a evolução de ATR na safra 1987 para as épocas de colheita.

\section{Resultados de ATR}

Safra 87 - corte 2

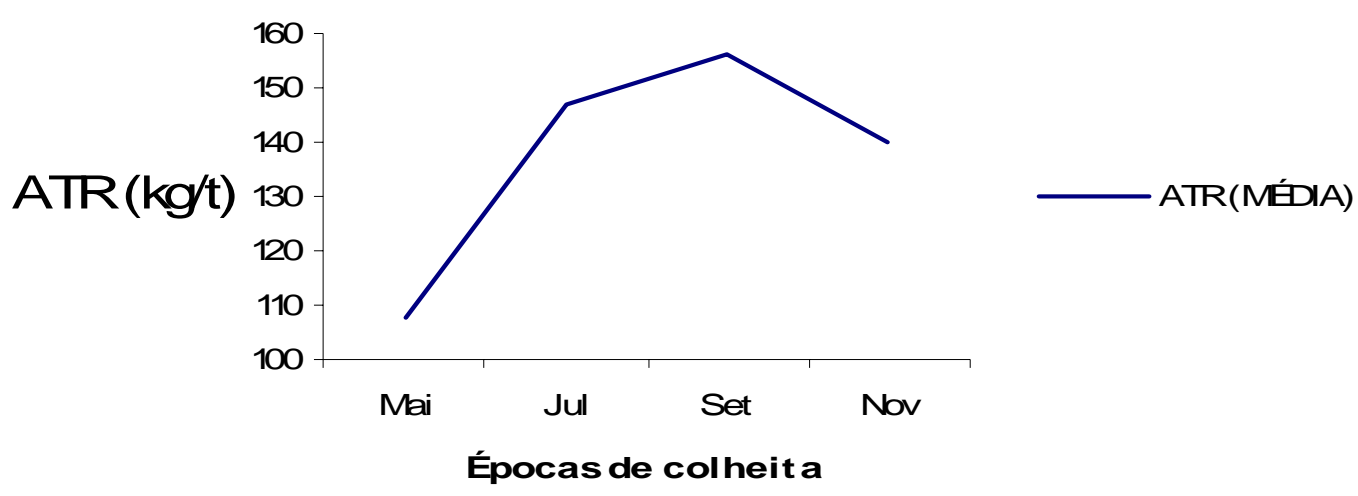

Figura 58 - Resultados de ATR para a variedade SP 70-1143 na safra 1987, no $2^{\circ}$ corte nas épocas de colheita 
Tabela 27. Valores médios de TAH para a variedade SP 70-1143 nas interações de épocas de plantio dentro de épocas de colheita, com plantio no ano de $1984 / 85$, no $2^{\circ}$ corte

\begin{tabular}{|c|c|c|c|c|}
\hline EPPLA & EPCOL & \multicolumn{2}{|c|}{ TAH (MÉDIA) } & MÉDIA $N^{O}$ \\
\hline Mar & Set & 15,281 & $\mathrm{a}$ & 11 \\
\hline Jan & Set & 14,879 & $a b$ & 10 \\
\hline Mai & Set & 14,635 & $a b c$ & 12 \\
\hline Nov & Set & 13,949 & abcd & 9 \\
\hline Mar & Nov & 13,394 & bcde & 15 \\
\hline Jan & Nov & 13,040 & cdef & 14 \\
\hline Mai & Jul & 13,015 & cdef & 8 \\
\hline Mai & Nov & 12,819 & def & 16 \\
\hline Nov & Jul & 11,977 & ef & 5 \\
\hline Jan & Jul & 11,941 & ef & 6 \\
\hline Mar & Jul & 11,914 & ef & 7 \\
\hline Nov & Nov & 11,605 & $f$ & 13 \\
\hline Jan & Mai & 9,932 & g & 2 \\
\hline Mar & Mai & 9,476 & $\mathrm{~g}$ & 3 \\
\hline Mai & Mai & 8,926 & g & 4 \\
\hline Nov & Mai & 8,287 & $\mathrm{~g}$ & 1 \\
\hline
\end{tabular}

Médias seguidas das mesmas letras não diferiram estatisticamente entre si.

$\mathrm{Na}$ tabela 27, observa-se para a variedade SP 70-1143, no segundo corte e ano de plantio 1984/85, que houve diferença estatisticamente significativa entre as médias de TAH para as interações de épocas de plantio dentro das épocas de colheita. As maiores produções foram obtidas nas colheitas de Setembro com plantios em Março, Janeiro, Maio e Novembro. As menores produções foram obtidas nas colheitas de Maio com plantios em Novembro, Maio, Março e Janeiro.

As figuras 59, 60, 61 e 62, a seguir, mostram a evolução de TAH na safra 1987 para cada época de plantio onde se verifica o efeito das épocas de colheita sobre os valores observados. 


\section{Resultados de TAH- Safra 1987 \\ $2^{\circ}$ corte - época de plantio Nbvembro}

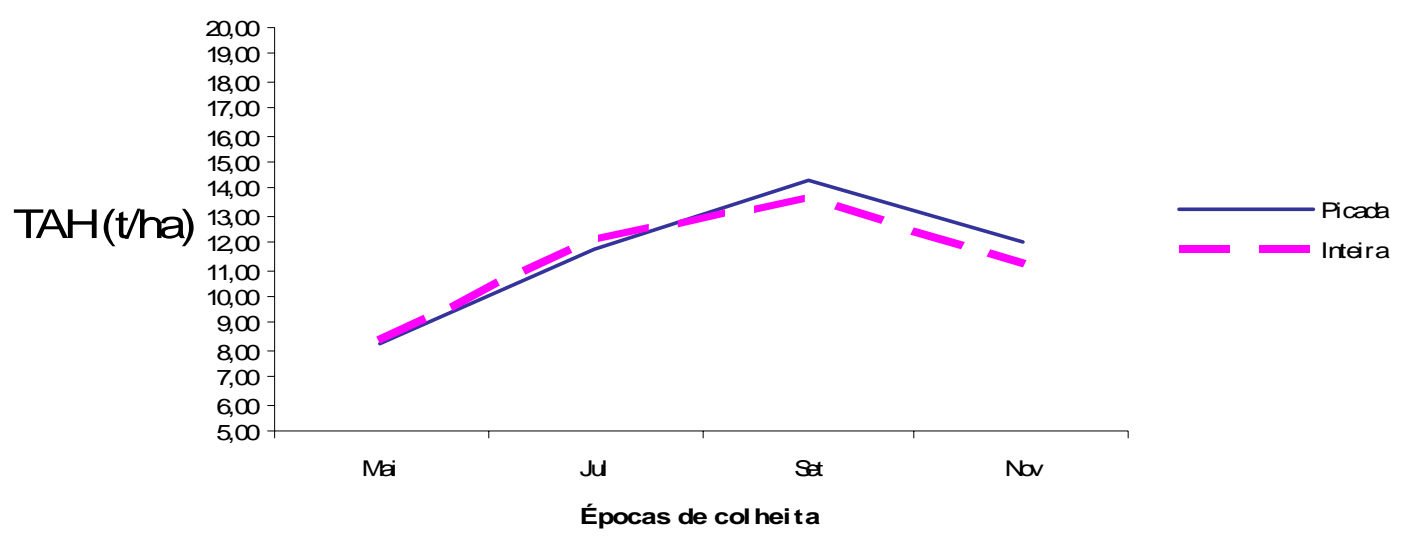

Figura 59 - Resultados de TAH para a variedade SP 70-1143 na safra 1987 , no $2^{\circ}$ corte e época de plantio Novembro

Resultados de TAH- Safra 1987

$2^{\circ}$ corte - época de plantio Janeiro

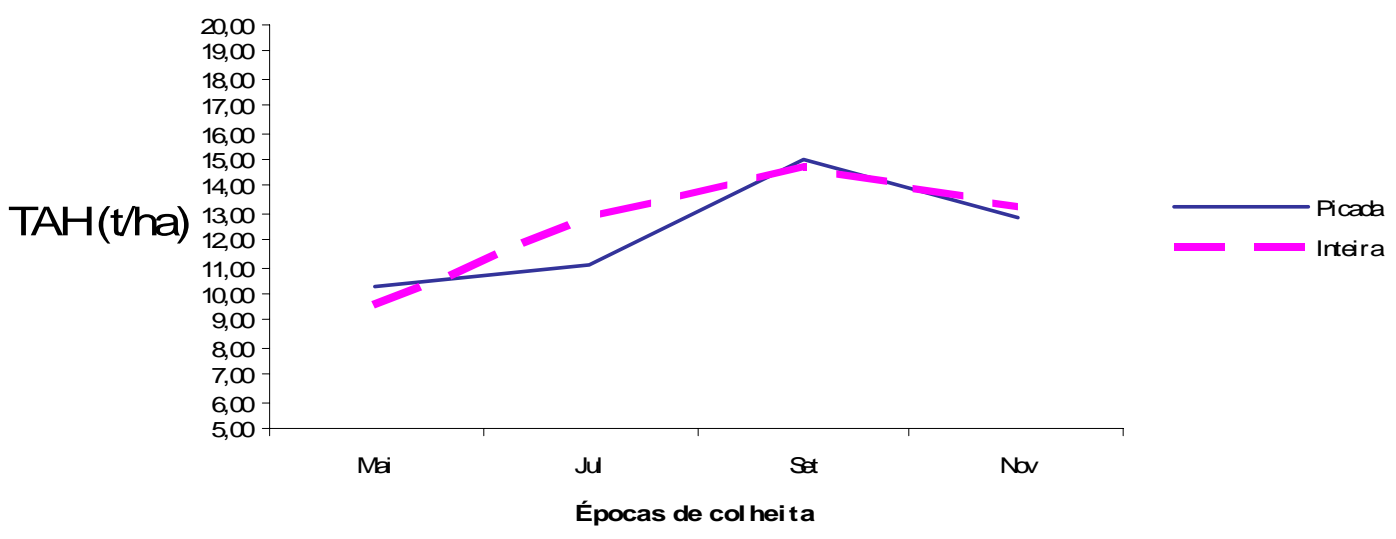

Figura 60 - Resultados de TAH para a variedade SP 70-1143 na safra 1987, no $2^{\circ}$ corte e época de plantio Janeiro 
Resultados de TAH- Safra 1987

$2^{\circ}$ corte - época de plantio Março

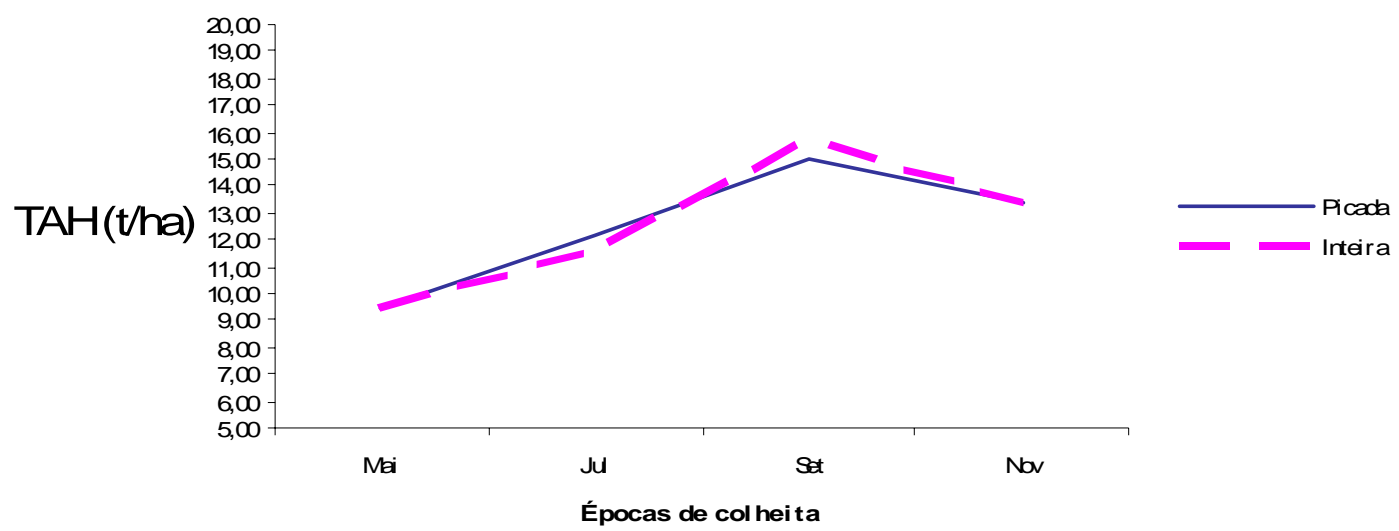

Figura 61 - Resultados de TAH para a variedade SP 70-1143 na safra 1987 , no $2^{\circ}$ corte e época de plantio Março

Resultados de TAH- Safra 1987

$2^{\circ}$ corte - época de plantio Maio

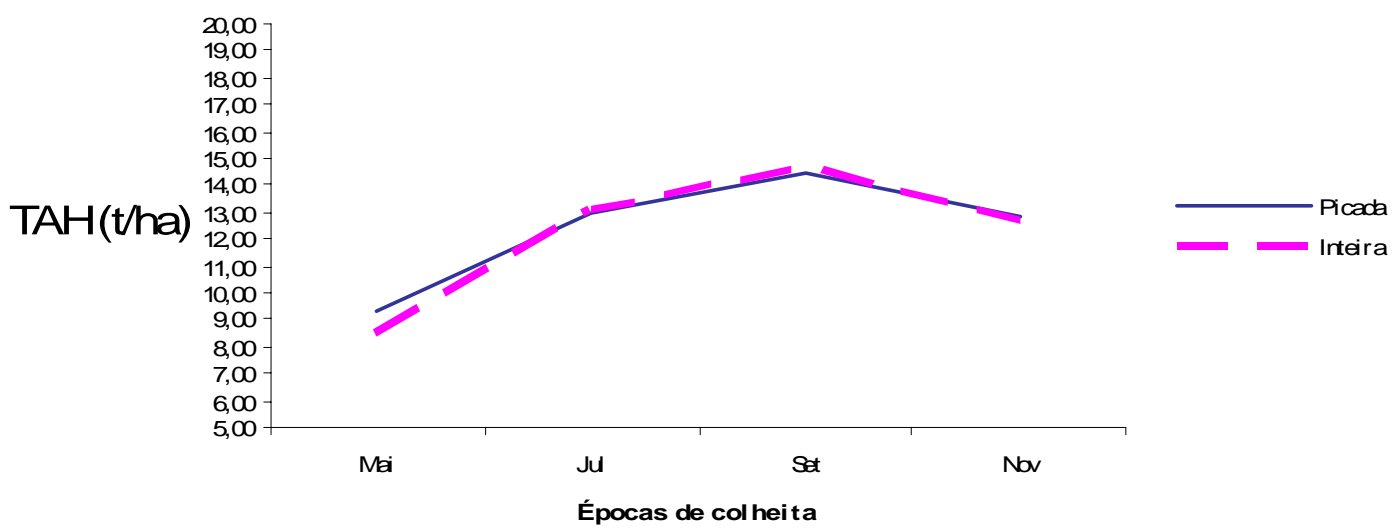

Figura 62 - Resultados de TAH para a variedade SP 70-1143 na safra 1987 , no $2^{\circ}$ corte e época de plantio Maio 
Tabela 28. Resumo dos quadros de análise de variância dos dados obtidos para a variedade SP 70-1143, no segundo corte e com plantio no ano de 1985/86, em relação às variáveis dependentes TCH, ATR e TAH em várias combinações de épocas de plantio e de colheita e sob os tratamentos cana picada e inteira no sulco de plantio

\begin{tabular}{|c|c|c|c|c|}
\hline C. Variação & $G L$ & $\begin{array}{l}\text { TCH } \\
Q M\end{array}$ & $\begin{array}{c}\text { ATR } \\
\text { QM }\end{array}$ & $\begin{array}{l}\text { TAH } \\
Q M\end{array}$ \\
\hline$B L O C O$ & 4 & -- & -- & -- \\
\hline EPCOL & 3 & 4233,407 * & 16837,522 ** & 78,802 ** \\
\hline Resíduo (a) & 12 & 80,611 & 65,223 & 1,114 \\
\hline EPPLA & 3 & 871,654 * * & 13,130 & 19,988 * * \\
\hline Resíduo (b) & 12 & 69,497 & 25,853 & 1,487 \\
\hline TRAT & 1 & 27,956 & 15,832 & $\odot, 106$ \\
\hline$E P C O L{ }^{\star} E P P L A$ & 9 & 49,916 & 32,334 * & 1,197 \\
\hline$E P C O L{ }^{*} T R A T$ & 3 & $\odot, 289$ & 14,210 & 0,101 \\
\hline$E P P L A * T R A T$ & 3 & 61,063 & 28,173 & 1,908 \\
\hline$E P C O L{ }^{\star} E P P L A{ }^{\star} T R A T$ & 9 & 28,365 & 13,602 & $\odot, 695$ \\
\hline Resíduo (c) & 100 & 38,254 & 14,513 & $\odot, 855$ \\
\hline Total & 159 & - & - & - \\
\hline
\end{tabular}

Na tabela 28, mostram-se os valores da análise de variância para as variáveis TCH, ATR e TAH da variedade SP 70-1143, no segundo corte e ano de plantio 1985/86.

Como se pode observar, para as variáveis TCH, ATR e TAH houve efeito significativo de épocas de corte e, para as variáveis TCH e TAH houve efeito significativo de épocas de plantio. O tratamento muda picada e inteira no sulco de plantio não apresentou efeito significativo para as variáveis estudadas.

Houve interação de épocas de plantio dentro de épocas de colheita apenas para a variável ATR, indicando diferenças significativas entre as épocas de plantio para cada época de colheita. Não houve qualquer outra interação. 
Tabela 29. Valores médios de TCH para a variedade SP 70-1143 das médias de épocas de plantio, com plantio no ano de $1985 / 86$, no $2^{\circ}$ corte

\begin{tabular}{cc}
\hline EPPLA & $T C H(M E ́ D I A)$ \\
\hline Mai & $88,817 \mathrm{a}$ \\
Jan & $88,246 \mathrm{a}$ \\
Mar & $85,657 \mathrm{a}$ \\
Nov & $78,651 \quad \mathrm{~b}$ \\
\hline Médias seguidas das mesmas letras não diferiram estatisticamente entre si.
\end{tabular}

$\mathrm{Na}$ tabela 29, observa-se que para a variedade SP 70-1143, no segundo corte e ano de plantio 1985/86, houve diferença estatisticamente significativa entre as médias de $\mathrm{TCH}$ nas épocas de plantio. Os maiores rendimentos foram obtidos nos plantios feitos em Maio, Janeiro e Março e os menores foram obtidos nos plantios feitos em Novembro.

Tabela 30. Valores médios de TCH para a variedade SP 70-1143 das médias de épocas de colheita, com plantio no ano de $1985 / 86$, no $2^{\circ}$ corte

\begin{tabular}{cc}
\hline EPCOL & $T C H$ (MÉDIA) \\
\hline Jul & $93,454 \mathrm{a}$ \\
Mai & $92,311 \mathrm{a}$ \\
Set & $84,490 \quad \mathrm{~b}$ \\
Nov & $71,115 \quad \mathrm{C}$ \\
\hline Médias seguidas das mesmas letras não diferiram estatisticamente entre si.
\end{tabular}

$\mathrm{Na}$ tabela 30 , observa-se que para a variedade SP $70-1143$, no segundo corte e ano de plantio 1985/86, houve diferença estatisticamente significativa entre as médias de $\mathrm{TCH}$ nas épocas de colheita. Os maiores rendimentos foram obtidos nas épocas de colheita Julho e Maio e os menores foram obtidos na época Novembro.

As figuras 63 e 64, a seguir, mostram, respectivamente, a evolução de TCH na safra 1988, segundo corte, para as épocas de plantio e de colheita. 


\section{Resultados de $\mathrm{TOH}$}

Safra 88 - corte 2

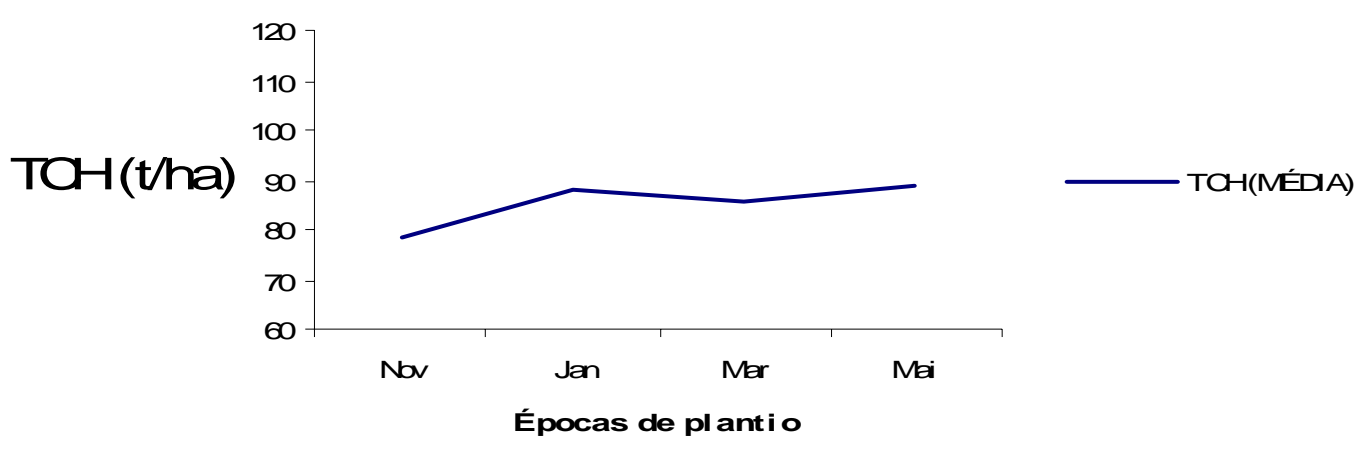

Figura 63 - Resultados de TCH para a variedade SP 70-1143 na safra $1988,2^{\circ}$ corte nas épocas de plantio

Resultados de $\mathrm{TOH}$

Safra 88 - corte 2

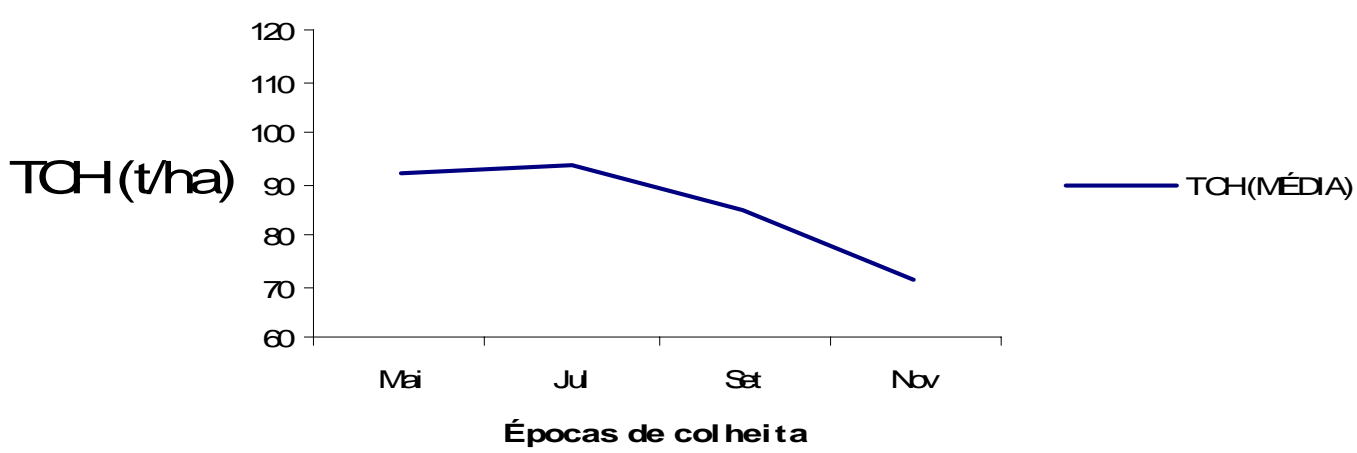

Figura 64 - Resultados de TCH para a variedade SP 70-1143 na safra $1988,2^{\circ}$ corte nas épocas de colheita 
Tabela 31. Valores médios de ATR para a variedade SP 70-1143 nas interações de épocas de plantio dentro de épocas de colheita, com plantio no ano de $1985 / 86$, no $2^{\circ}$ corte

\begin{tabular}{|c|c|c|c|}
\hline EPPLA & EPCOL & \multicolumn{2}{|c|}{ ATR (MÉDIA) } \\
\hline Mai & Set & 163,540 & $\mathrm{a}$ \\
\hline Nov & Set & 162,407 & $a b$ \\
\hline Mar & Set & 162,286 & $a b$ \\
\hline Jan & Set & 161,839 & $a b$ \\
\hline Nov & Nov & 158,421 & $a b$ \\
\hline Jan & Nov & 158,376 & $a b$ \\
\hline Mai & Nov & 157,818 & $a b$ \\
\hline Mar & Nov & 156,470 & b \\
\hline Mai & Jul & 142,145 & c \\
\hline Nov & Jul & 138,786 & c \\
\hline Jan & Jul & 138,675 & C \\
\hline Mar & Jul & 138,430 & c \\
\hline Jan & Mai & 120,449 & $d$ \\
\hline Mar & Mai & 118,441 & d \\
\hline Mai & Mai & 115,354 & d \\
\hline Nov & Mai & 115,142 & d \\
\hline
\end{tabular}

Médias seguidas das mesmas letras não diferiram estatisticamente entre si.

$\mathrm{Na}$ tabela 31, observa-se que para a variedade SP 70-1143, no segundo corte e ano de plantio 1985/86, houve diferença estatisticamente significativa entre as médias de ATR para a interação épocas de plantio dentro das épocas de colheita. Os maiores valores de ATR ocorreram nas colheitas de Setembro e Novembro com plantios em Novembro, Janeiro, Março e Maio. As épocas com menores valores ocorreram nas colheitas de Maio com plantios em Novembro, Maio, Março e Janeiro.

As figuras 65, 66, 67 e 68, a seguir, mostram a evolução de ATR na safra 1988 para cada época de plantio onde se verifica o efeito das épocas de colheita sobre os valores observados. 
Resultados de ATR- Safra 1988

$2^{\circ}$ corte - época de plantio Novembro

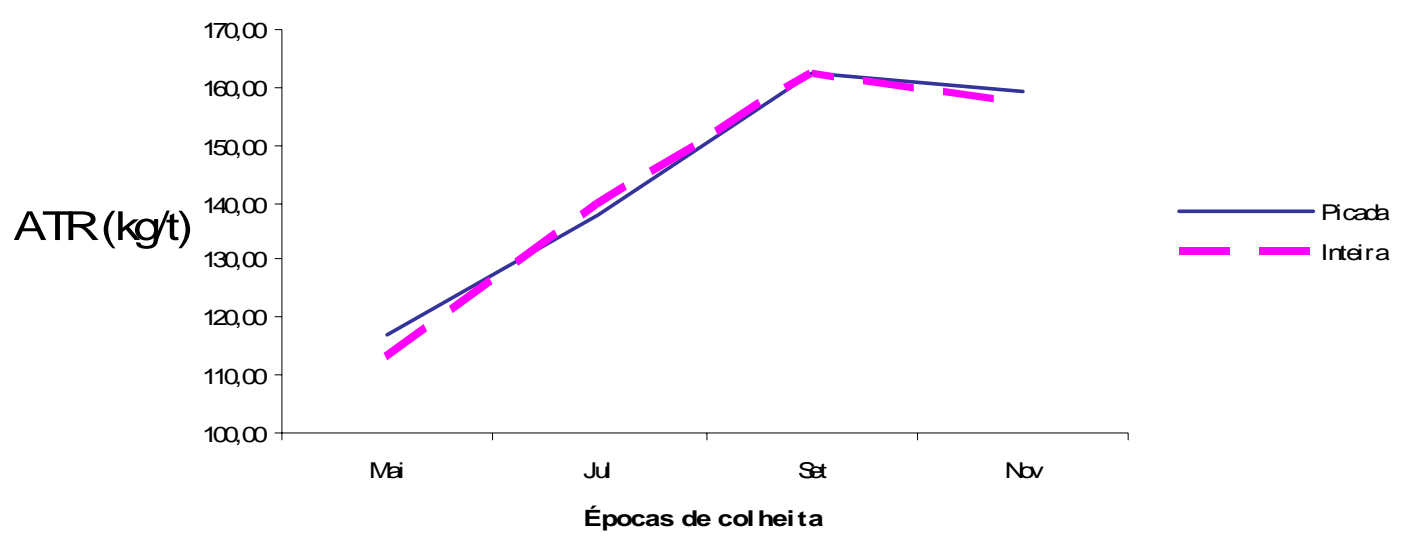

Figura 65 - Resultados de ATR para a variedade SP 70-1143 na safra 1988 , no $2^{\circ}$ corte e época de plantio Novembro

Resultados de ATR- Safra 1988

$2^{\circ}$ corte - época de plantio Janeiro

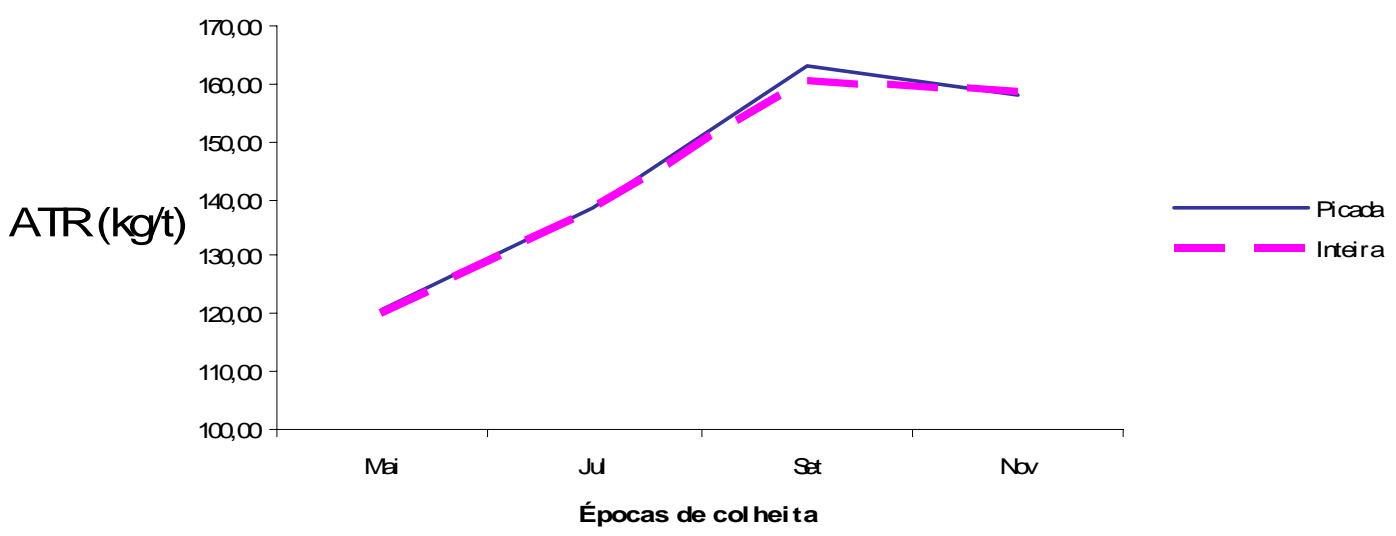

Figura 66 - Resultados de ATR para a variedade SP 70-1143 na safra 1988 , no $2^{\circ}$ corte e época de plantio Janeiro 
Resultados de ATR- Safra 1988

$2^{\circ}$ corte - época de plantio Março

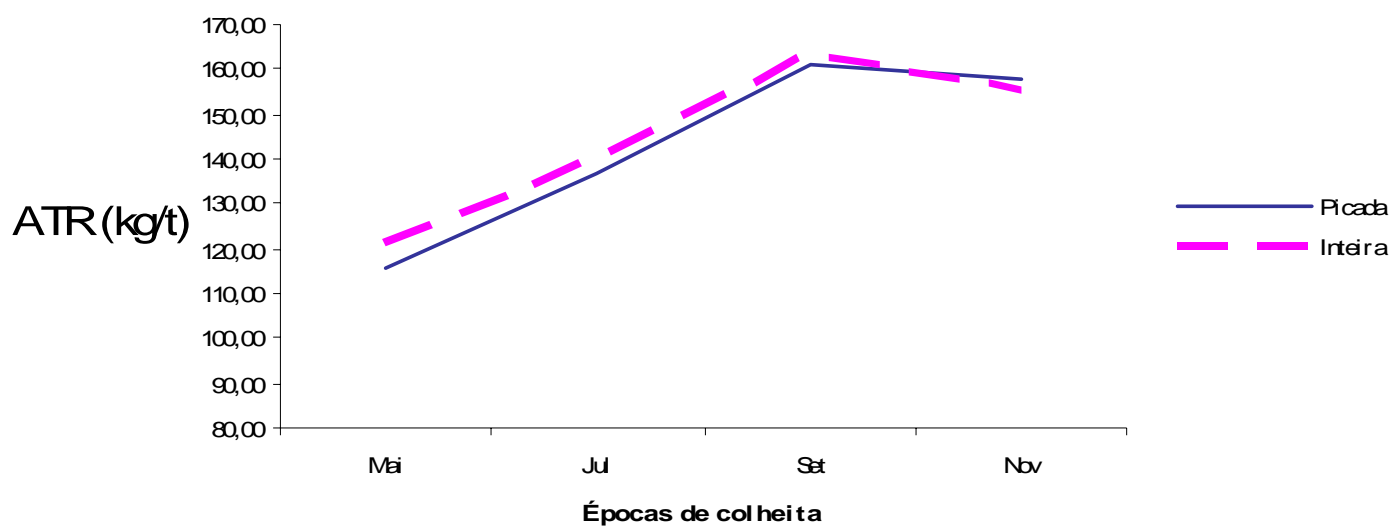

Figura 67 - Resultados de ATR para a variedade SP 70-1143 na safra 1988 , no $2^{\circ}$ corte e época de plantio Março

Resultados de ATR- Safra 1988

$2^{\circ}$ corte - época de plantio Maio

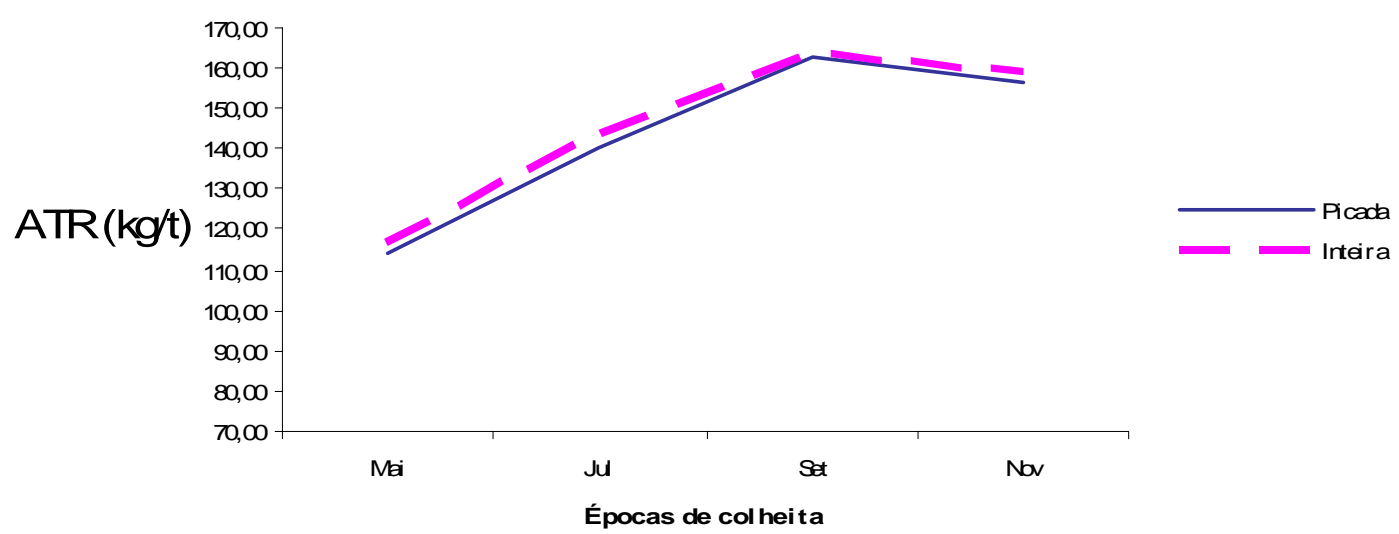

Figura 68 - Resultados de ATR para a variedade SP 70-1143 na safra 1988, no $2^{\circ}$ corte e época de plantio Maio 
Tabela 32. Valores médios de TAH para a variedade SP 70-1143 das médias de épocas de plantio, com plantio no ano de $1985 / 86$, no $2^{\circ}$ corte

\begin{tabular}{cc}
\hline EPPLA & TAH (MÉDIA) \\
\hline Mai & $12,714 \mathrm{a}$ \\
Jan & $12,671 \mathrm{a}$ \\
Mar & $12,218 \mathrm{a}$ \\
Nov & $11,194 \quad \mathrm{~b}$ \\
\hline Médias seguidas das mesmas letras não diferiram estatisticamente entre si.
\end{tabular}

$\mathrm{Na}$ tabela 32, observa-se que para a variedade SP 70-1143, no segundo corte e ano de plantio 1985/86, houve diferença estatisticamente significativa entre as médias de TAH nas épocas de plantio. Os maiores rendimentos foram obtidos nos plantios de Maio, Janeiro e Março e os menores foram obtidos nos plantios de Novembro.

Tabela 33. Valores médios de TAH para a variedade SP 70-1143 das médias de épocas de colheita, com plantio no ano de $1985 / 86$, no $2^{\circ}$ corte

\begin{tabular}{cc}
\hline EPCOL & $T A H(M E ́ D I A)$ \\
\hline Set & $13,728 \mathrm{a}$ \\
Jul & $13,035 \mathrm{a}$ \\
Nov & $11,214 \mathrm{~b}$ \\
Mai & $10,819 \quad \mathrm{~b}$ \\
\hline Médias seguidas das mesmas letras não diferiram estatisticamente entre si.
\end{tabular}

$\mathrm{Na}$ tabela 33, observa-se que para a variedade SP 70-1143, no segundo corte e ano de plantio 1985/86, houve diferença estatisticamente significativa entre as médias de TAH nas épocas de colheita. Os maiores rendimentos foram obtidos nas épocas de colheita Setembro e Julho e os menores foram obtidos na época Maio.

As figuras 69 e 70, a seguir, mostram a evolução de TAH na safra 1988, segundo corte, para as épocas de plantio e de colheita. 


\section{Resultados de TAH}

Safra 88 - corte 2

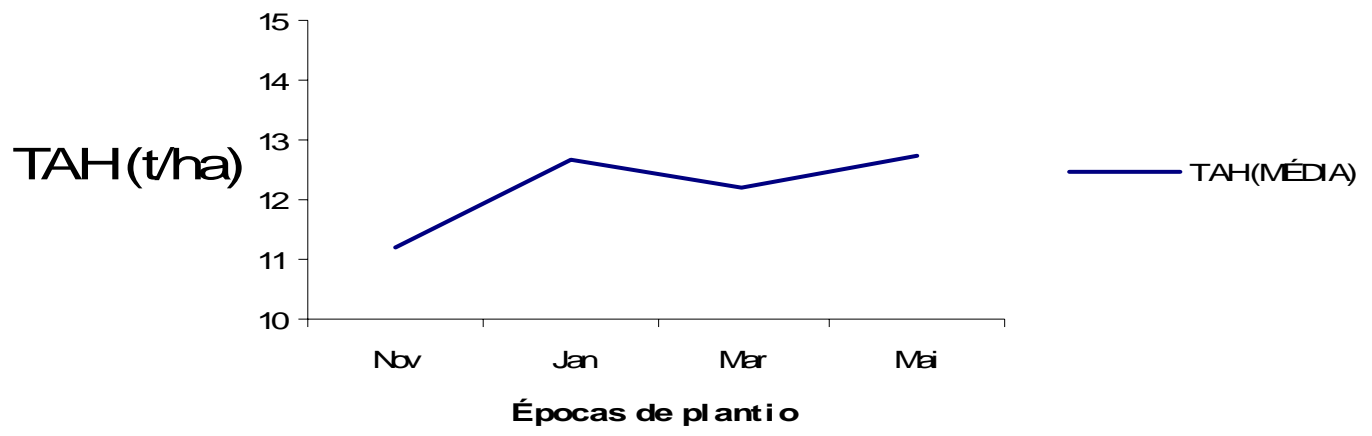

Figura 69 - Resultados de TAH para a variedade SP 70-1143 na safra $1988,2^{\circ}$ corte nas épocas de plantio

\section{Resultados de TAH}

Safra 88 - corte 2

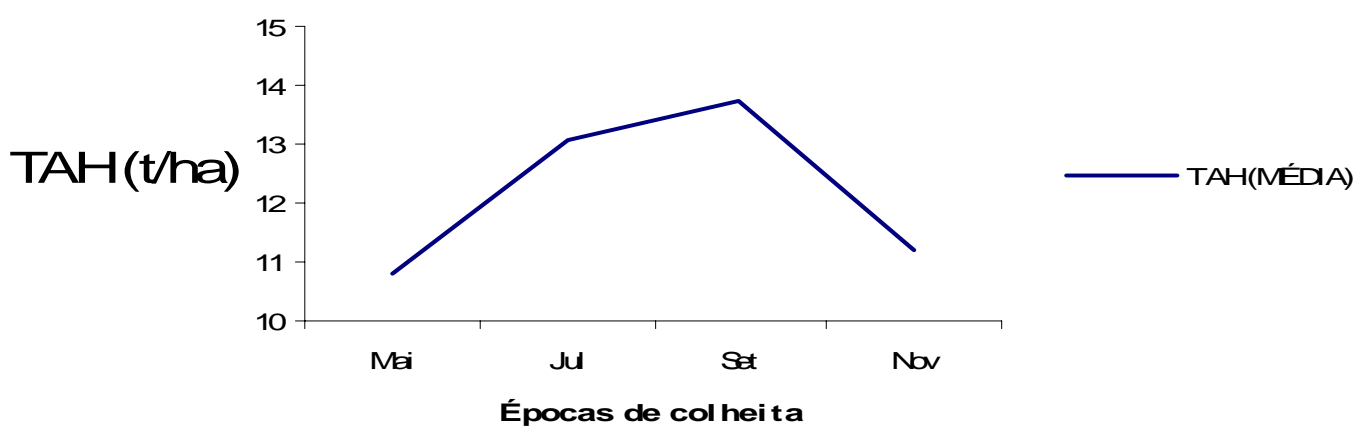

Figura 70 - Resultados de TAH para a variedade SP 70-1143 na safra 1988, $2^{\circ}$ corte nas épocas de colheita 
$\mathrm{Na}$ tabela 34, a seguir, mostram-se os valores médios das safras de 1986, 1987 e 1988 para TCH, ATR e TAH da variedade SP 70-1143, no segundo corte, nas várias combinações de épocas de plantio e de colheita e nos tratamentos muda picada e inteira no sulco de plantio.

Comparando as os resultados ano a ano, observa-se que no segundo corte e ano de plantio 1983/84, para as variáveis TCH, ATR e TAH houve efeito significativo de época de plantio e de corte. O tratamento muda picada e inteira no sulco de plantio não apresentou efeito significativo; houve interação de épocas de plantio dentro de épocas de colheita para todas as variáveis estudadas.

No ano de plantio 1984/85 segundo corte, houve efeito significativo de época de corte para as variáveis TCH, ATR e TAH; para época de plantio houve efeito significativo apenas para a variável TAH. O tratamento muda picada e inteira no sulco de plantio não apresentou efeito significativo; houve interação de épocas de plantio dentro de épocas de colheita somente para a variável TAH.

No ano de plantio 1985/86 segundo corte, houve efeito significativo de épocas de corte para TCH, ATR e TAH e, para as variáveis TCH e TAH houve efeito significativo de épocas de plantio. $\mathrm{O}$ tratamento muda picada e inteira no sulco de plantio não apresentou efeito significativo; houve interação de épocas de plantio dentro de épocas de colheita.

Para os três anos estudados, no segundo corte, a variedade SP 701143, apresentou efeito significativo de épocas de corte para as variáveis $\mathrm{TCH}$, ATR e TAH. Épocas de plantio provocaram efeito significativo para as três variáveis na safra 1986 (ano de plantio 1983/84), na safra 1987 (ano de plantio 1984/85) apenas para TAH e na safra 1988 (ano de plantio 1985/86) apenas pra as variáveis TCH e TAH. O tratamento muda picada e inteira no sulco de plantio não apresentou efeito significativo no segundo corte dessa variedade. 
As interações de épocas de plantio dentro de épocas de colheita provocaram efeito para as três variáveis estudadas na safra 1986, já na safra 1987 somente para a variável TAH e na safra 1988 apenas para a variável ATR.

No $2^{\circ}$ corte onde as idades foram igualadas, $\mathrm{TCH}$ mostrou-se mais influenciado pelas condições climáticas do ano do que pelo manejo em si.

O corte e avaliação das soqueiras mostraram que os efeitos das épocas de plantio não se restringem apenas ao primeiro corte se prolongando também pelo segundo corte. $O$ estudo das soqueiras mostrou que também em todos os anos estudados, os resultados de ATR sempre evoluíram do início para o final da safra com os picos localizados no mês de setembro e ligeira queda no mês de novembro, porém a época de plantio Maio já não mostrou os menores valores iniciais ficando semelhante as demais.

Novamente TAH sempre acompanhou as curvas de ATR sendo influenciado por $\mathrm{TCH}$. 
Tabela 34. Valores médios de TCH, ATR e TAH para a variedade SP 70-1143, no segundo corte e nas safras de 1986, 1987 e 1988, em várias combinações de épocas de plantio e de colheita e sob os tratamentos muda picada e inteira no sulco de plantio

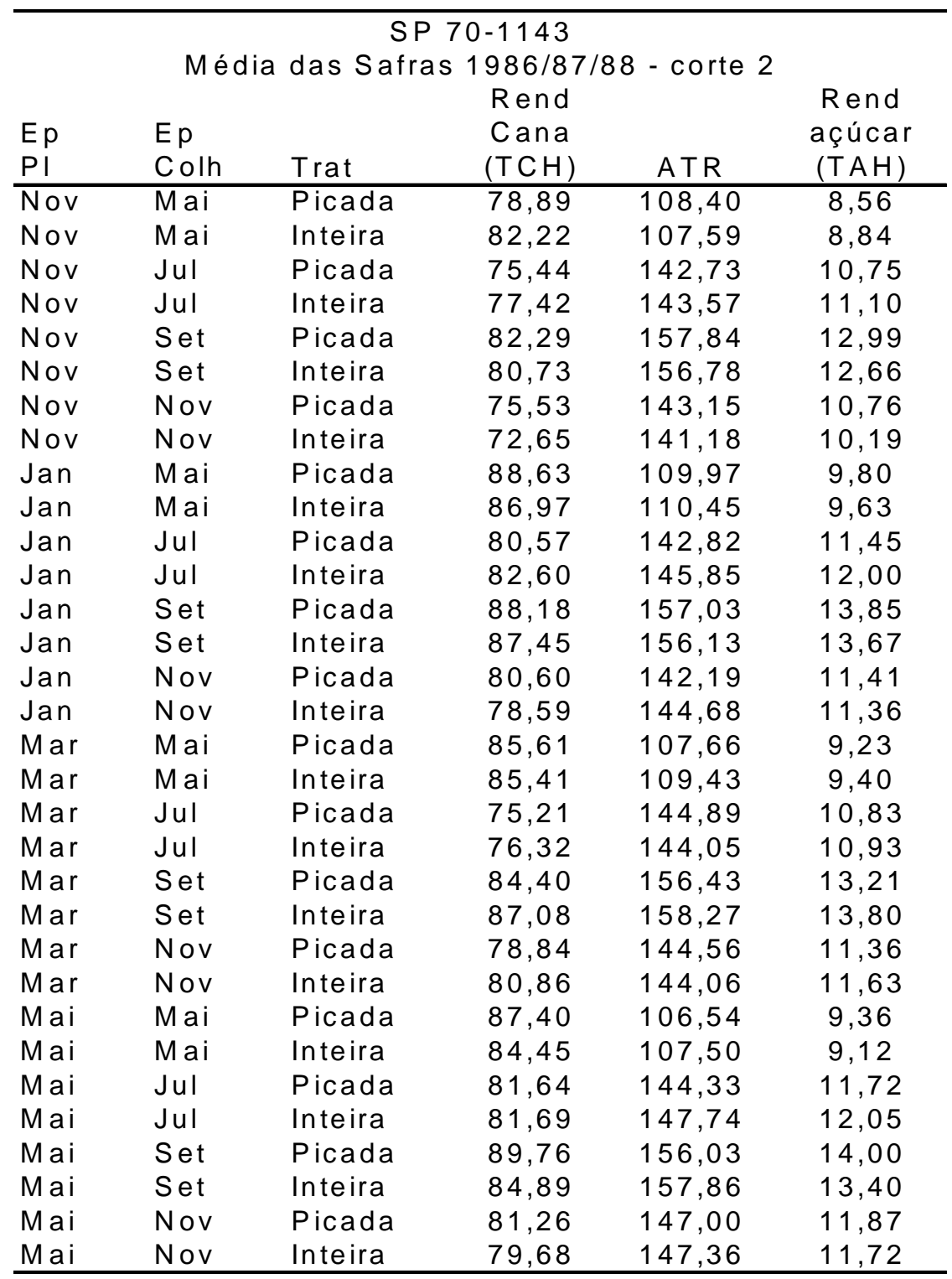

As figuras 71, 72 e 73, a seguir, mostram, respectivamente, a evolução de TCH, ATR e TAH médias das safras de 1986, 1987 e 1988 para as épocas de plantio e de colheita. 


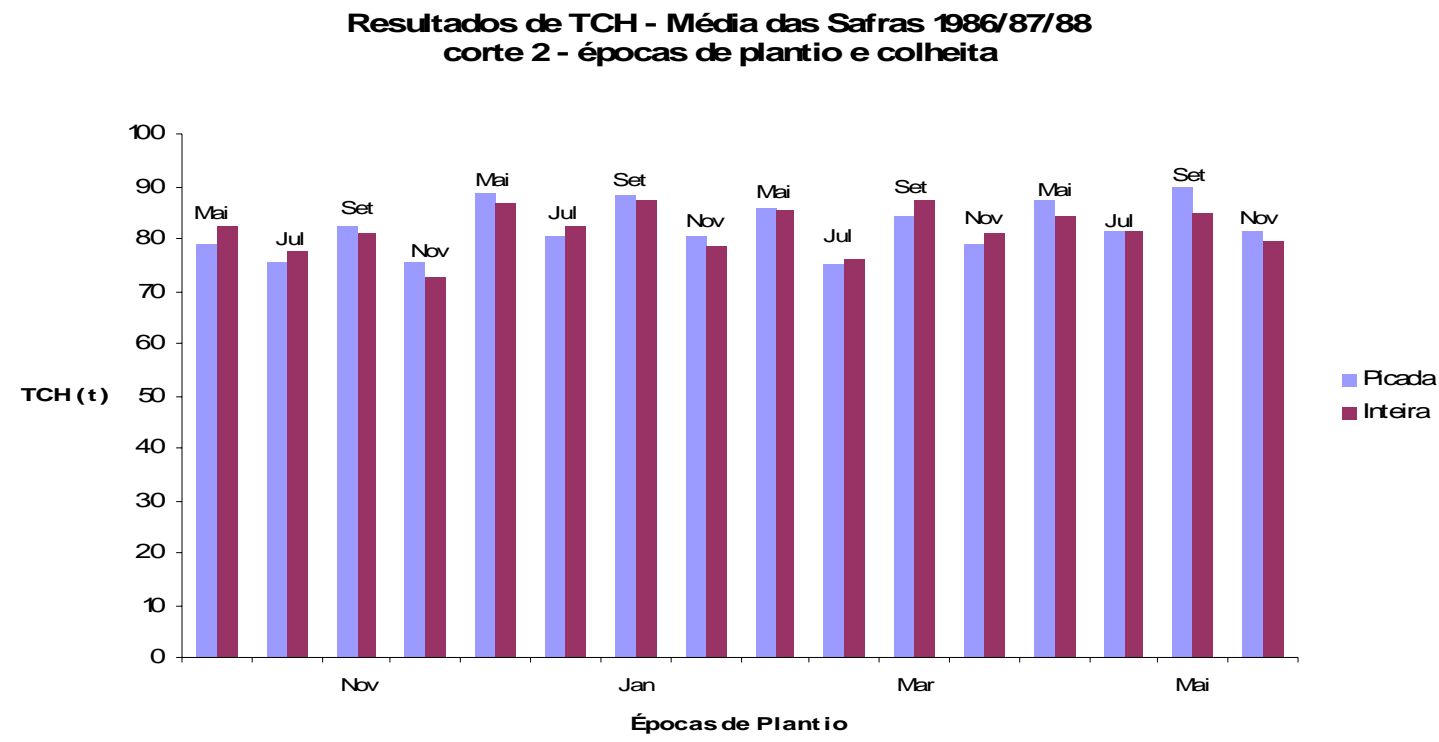

Figura 71 - Resultados médios de TCH para a variedade SP 70-1143 nas safras 1986/87/88, no $2^{\circ}$ corte e nas épocas de plantio e colheita

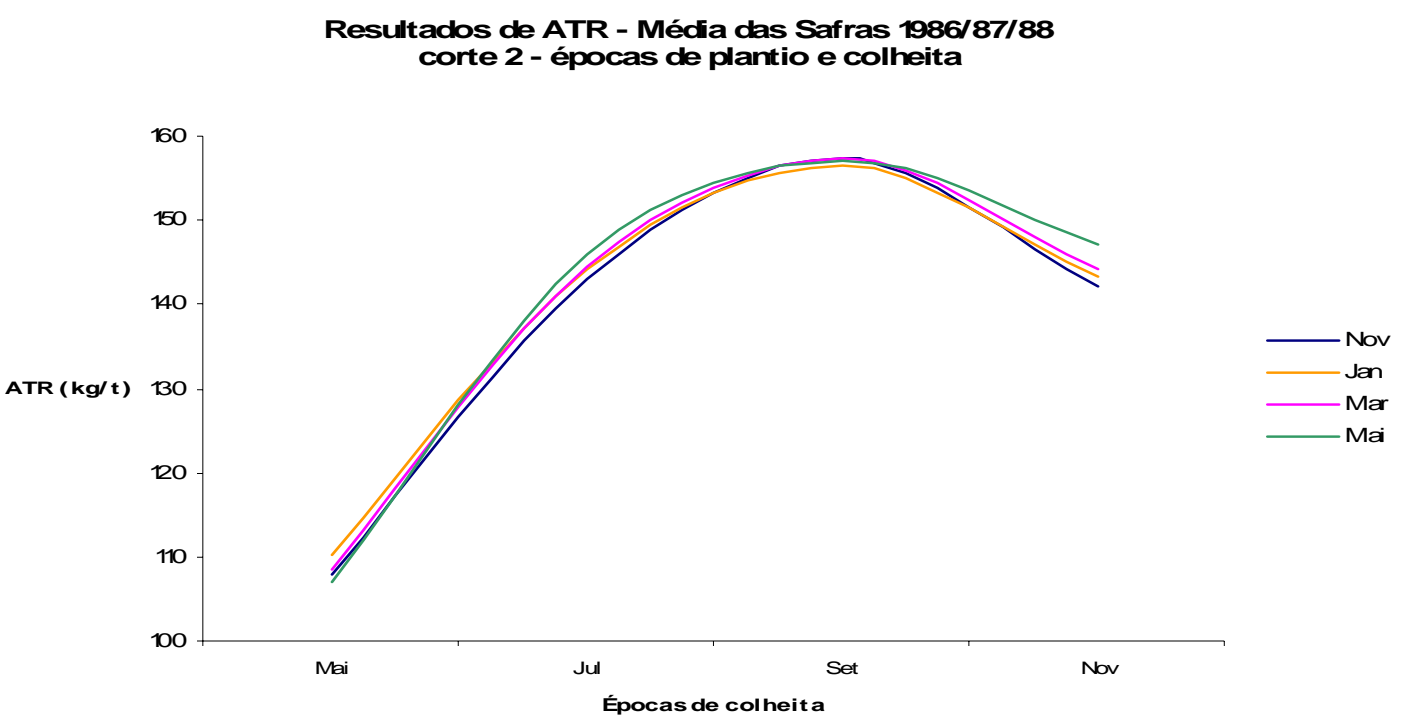

Figura 72 - Resultados médios de ATR para a variedade SP 70-1143 nas safras $1986 / 87 / 88$, no $2^{\circ}$ corte e nas épocas de plantio e colheita 
Resultados de TAH - Média das Safras 1986/87/88 corte 2 - épocas de plantio e colheita

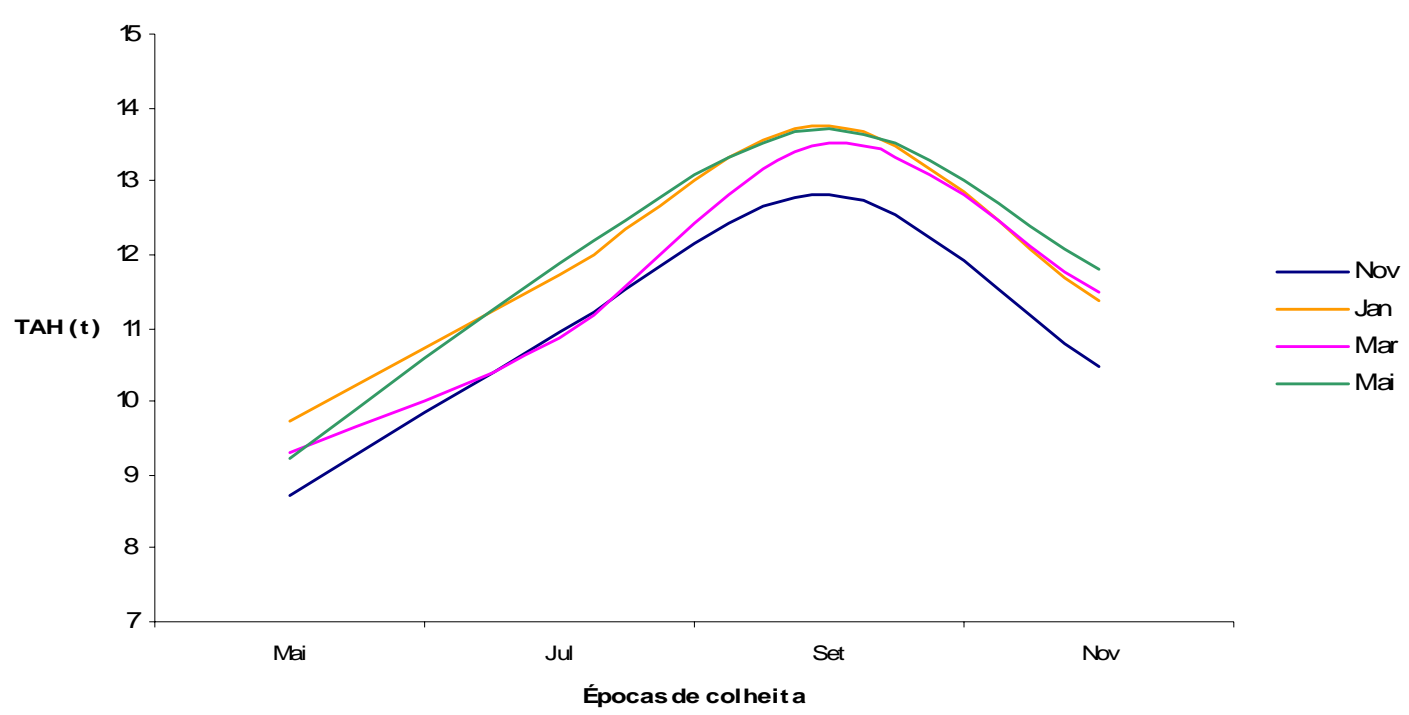

Figura 73 - Resultados médios de TAH para a variedade SP 70-1143 nas safras 1986/87/88, no $2^{\circ}$ corte e nas épocas de plantio e colheita

\subsection{Variedade NA $56-79-1^{\circ}$ corte}

São apresentados na tabela 35, a seguir, os resultados obtidos no primeiro corte nas safras de 1985, 1986 e 1987, para toneladas de cana por ha (TCH), açúcar total recuperável (ATR) em kg de açúcar por tonelada de cana e (TAH) toneladas de açúcar por ha, para a variedade NA 56-79. 
Tabela 35. Valores obtidos de TCH, ATR e TAH para a variedade NA 56-79, no primeiro corte e nas safras de 1985, 1986 e 1987, em várias combinações de épocas de plantio e de colheita e sob os tratamentos muda picada e inteira no sulco de plantio

\begin{tabular}{|c|c|c|c|c|c|c|c|c|c|c|c|}
\hline \multicolumn{12}{|c|}{ NA 56-79 } \\
\hline \multirow[b]{2}{*}{$\begin{array}{l}\text { Ep } \\
\text { PI }\end{array}$} & \multirow[b]{2}{*}{$\begin{array}{l}\text { Ep } \\
\text { Colh }\end{array}$} & \multirow[b]{2}{*}{ Trat } & \multicolumn{3}{|c|}{ Safra 1985 - corte 1} & \multicolumn{3}{|c|}{ Safra 1986 - corte 1} & \multicolumn{3}{|c|}{ Safra 1987 - corte 1} \\
\hline & & & $\begin{array}{l}\text { Rend } \\
\text { Cana } \\
(\mathrm{TCH})\end{array}$ & ATR & $\begin{array}{l}\text { Rend } \\
\text { açúcar } \\
\text { (TAH) }\end{array}$ & $\begin{array}{l}\text { Rend } \\
\text { Cana } \\
(\mathrm{TCH})\end{array}$ & ATR & $\begin{array}{l}\text { Rend } \\
\text { açúcar } \\
\text { (TAH) }\end{array}$ & $\begin{array}{l}\text { Rend } \\
\text { Cana } \\
(\mathrm{TCH})\end{array}$ & ATR & $\begin{array}{l}\text { Rend } \\
\text { açúcar } \\
\text { (TAH) }\end{array}$ \\
\hline Nov & Mai & Picada & 92,29 & 140,96 & 13,02 & 109,36 & 128,83 & 14,09 & 122,67 & 127,99 & 15,65 \\
\hline Nov & Mai & Inteira & 92,62 & 140,02 & 12,97 & 114,98 & 129,44 & 14,87 & 134,29 & 132,92 & 17,82 \\
\hline Nov & Jul & Picada & 96,19 & 150,73 & 14,49 & 115,88 & 140,22 & 16,23 & 112,24 & 146,18 & 16,41 \\
\hline Nov & Jul & Inteira & 99,41 & 149,41 & 14,87 & 126,91 & 138,00 & 17,45 & 119,05 & 148,20 & 17,63 \\
\hline Nov & Set & Picada & 90,50 & 150,88 & 13,66 & 121,43 & 143,05 & 17,34 & 122,86 & 151,61 & 18,65 \\
\hline Nov & Set & Inteira & 93,05 & 149,89 & 13,92 & 119,43 & 143,77 & 17,13 & 125,62 & 151,07 & 18,99 \\
\hline Nov & Nov & Picada & 94,62 & 151,62 & 14,35 & 106,19 & 131,61 & 13,95 & 112,72 & 144,70 & 16,23 \\
\hline Nov & Nov & Inteira & 86,43 & 152,39 & 13,14 & 113,53 & 129,22 & 14,62 & 105,38 & 137,35 & 14,47 \\
\hline Jan & Mai & Picada & 103,41 & 141,34 & 14,58 & 101,76 & 120,08 & 12,15 & 135,34 & 135,63 & 18,34 \\
\hline Jan & Mai & Inteira & 103,60 & 139,74 & 14,46 & 102,29 & 127,30 & 13,03 & 124,86 & 130,04 & 16,22 \\
\hline Jan & Jul & Picada & 101,19 & 149,71 & 15,15 & 113,72 & 140,76 & 16,00 & 123,48 & 149,39 & 18,45 \\
\hline Jan & Jul & Inteira & 103,64 & 149,37 & 15,49 & 114,26 & 141,62 & 16,18 & 121,24 & 146,62 & 17,77 \\
\hline Jan & Set & Picada & 92,03 & 154,00 & 14,24 & 110,34 & 139,82 & 15,42 & 134,34 & 152,04 & 20,44 \\
\hline Jan & Set & Inteira & 91,53 & 155,18 & 14,21 & 102,24 & 139,59 & 14,28 & 130,19 & 151,88 & 19,79 \\
\hline Jan & Nov & Picada & 105,62 & 155,98 & 16,43 & 101,34 & 123,82 & 12,58 & 124,95 & 141,44 & 17,69 \\
\hline Jan & Nov & Inteira & 109,74 & 154,01 & 16,89 & 99,76 & 124,90 & 12,43 & 123,72 & 145,02 & 17,93 \\
\hline Mar & Mai & Picada & 101,14 & 134,68 & 13,63 & 91,98 & 118,65 & 10,92 & 97,43 & 130,70 & 12,74 \\
\hline Mar & Mai & Inteira & 114,10 & 136,61 & 15,59 & 89,62 & 121,07 & 10,83 & 100,29 & 133,67 & 13,36 \\
\hline Mar & Jul & Picada & 121,50 & 150,86 & 18,33 & 89,64 & 138,06 & 12,36 & 106,72 & 148,49 & 15,85 \\
\hline Mar & Jul & Inteira & 110,93 & 148,47 & 16,47 & 93,48 & 138,86 & 12,98 & 105,72 & 147,23 & 15,59 \\
\hline Mar & Set & Picada & 116,26 & 149,85 & 17,47 & 91,48 & 135,95 & 12,42 & 115,38 & 154,75 & 17,86 \\
\hline Mar & Set & Inteira & 110,26 & 154,22 & 16,99 & 93,67 & 138,12 & 12,93 & 118,62 & 151,70 & 17,97 \\
\hline Mar & Nov & Picada & 130,12 & 143,87 & 18,73 & 88,76 & 124,59 & 11,05 & 116,72 & 136,54 & 15,93 \\
\hline Mar & Nov & Inteira & 112,57 & 144,76 & 16,31 & 82,14 & 127,95 & 10,51 & 120,43 & 130,43 & 15,61 \\
\hline Mai & Mai & Picada & 98,34 & 119,43 & 11,77 & 74,83 & 100,57 & 7,56 & 97,53 & 121,62 & 11,85 \\
\hline Mai & Mai & Inteira & 103,86 & 119,38 & 12,37 & 81,05 & 103,28 & 8,37 & 91,76 & 115,47 & 10,52 \\
\hline Mai & Jul & Picada & 112,65 & 139,48 & 15,71 & 80,74 & 136,57 & 11,04 & 95,14 & 142,34 & 13,53 \\
\hline Mai & Jul & Inteira & 111,17 & 139,03 & 15,46 & 77,36 & 136,99 & 10,59 & 90,43 & 142,50 & 12,88 \\
\hline Mai & Set & Picada & 108,74 & 150,24 & 16,33 & 80,38 & 137,03 & 11,02 & 105,95 & 152,16 & 16,11 \\
\hline Mai & Set & Inteira & 104,72 & 149,47 & 15,65 & 88,24 & 135,13 & 11,92 & 98,14 & 151,90 & 14,89 \\
\hline Mai & Nov & Picada & 109,05 & 142,84 & 15,54 & 76,38 & 123,35 & 9,40 & 105,76 & 144,56 & 15,27 \\
\hline Mai & Nov & Inteira & 117,10 & 147,14 & 17,20 & 76,19 & 125,27 & 9,56 & 102,53 & 141,01 & 14,46 \\
\hline
\end{tabular}


Tabela 36. Resumo dos quadros de análise de variância dos dados obtidos para a variedade NA 56-79, no primeiro corte e com plantio no ano de 1983/84, em relação às variáveis dependentes ATR, TCH e TAH em várias combinações de épocas de plantio e de colheita e sob os tratamentos muda picada e inteira no sulco de plantio

\begin{tabular}{|c|c|c|c|c|}
\hline C. Variação & $G L$ & $\begin{array}{c}\mathrm{TCH} \\
Q M\end{array}$ & $\begin{array}{c}\text { ATR } \\
Q M\end{array}$ & $\begin{array}{c}\mathrm{TAH} \\
Q M\end{array}$ \\
\hline BLOCO & 4 & - & - & - \\
\hline EPCOL & 3 & 538,032 & $2478,401^{* *}$ & $50,641^{* *}$ \\
\hline Resíduo (a) & 12 & 729,409 & 67,845 & 19,678 \\
\hline$E P P L A$ & 3 & 3398,446 * * & $1036,429 * *$ & 56,112 ** \\
\hline Resíduo (b) & 12 & 89,899 & 40,954 & 2,919 \\
\hline TRAT & 1 & 12,438 & 1,056 & 0,328 \\
\hline$E P C O L{ }^{\star} E P P L A$ & 9 & 200,881 & 187,819 * * & 8,236 ** \\
\hline$E P C O L{ }^{*} T R A T$ & 3 & 131,196 & 10,245 & 2,138 \\
\hline$E P P L A * T R A T$ & 3 & 111,843 & 9,180 & 2,065 \\
\hline$E P C O L{ }^{*} E P P L A{ }^{*} T R A T$ & 9 & 152,181 & 10,278 & 3,840 \\
\hline Resíduo (c) & 100 & 129,386 & 15,418 & 2,876 \\
\hline Total & 159 & -- & -- & -- \\
\hline
\end{tabular}

A tabela 36, apresentada, mostra os valores da análise de variância, para as variáveis TCH, ATR e TAH da variedade NA 56-79, no primeiro corte ano de plantio 1983/84.

Como se pode observar, para as variáveis TCH, ATR e TAH houve efeito significativo de época de plantio; para época de corte houve efeito significativo apenas para as variáveis ATR e TAH. O tratamento muda picada e inteira no sulco de plantio não apresentou efeito significativo para as variáveis estudadas.

Houve interação de épocas de plantio dentro de épocas de colheita apenas para as variáveis ATR e TAH, indicando diferenças significativas entre as épocas de plantio para cada época de colheita. Não houve qualquer outra interação. 
Tabela 37. Valores médios de TCH para a variedade NA 56-79 das épocas de plantio, no ano de $1983 / 84$, no $1^{\circ}$ corte

\begin{tabular}{cc}
\hline EPPLA & $T C H(M E ́ D I A)$ \\
\hline Mar & $114,512 \quad \mathrm{a}$ \\
Mai & $108,202 \quad \mathrm{~b}$ \\
Jan & $101,345 \quad \mathrm{C}$ \\
Nov & $93,138 \quad \mathrm{~d}$ \\
\hline Médias seguidas das mesmas letras não diferiram estatisticamente entre si.
\end{tabular}

Na tabela 37, observa-se que para a variedade NA 56-79, plantada em 1983/84 e no primeiro corte, houve diferença estatisticamente significativa entre as médias das épocas de plantio. O maior valor de $\mathrm{TCH}$ foi obtido na época de plantio Mar, seguido de Maio, Janeiro e Novembro, sendo que essas médias diferiram estatisticamente entre si.

A Figura 74 a seguir, mostra a evolução de $\mathrm{TCH}$, onde se pode verificar o efeito das épocas de plantio.

Resultados de TOH

Safra 1985 - corte 1

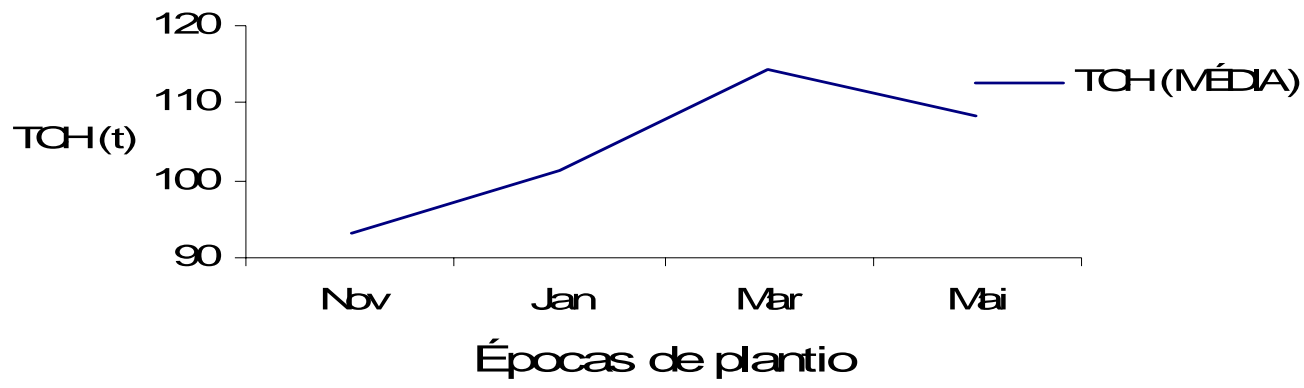

Figura 74 - Resultados de TCH para a variedade NA 56-79 na safra 1985, no $1^{\circ}$ corte e nas épocas de plantio 
Tabela 38. Valores médios de ATR para a variedade NA 56-79 nas interações de épocas de plantio dentro de épocas de colheita, com plantio no ano de $1983 / 84$, no $1^{\circ}$ corte

\begin{tabular}{|c|c|c|c|}
\hline$E P P L A$ & EPCOL & \multicolumn{2}{|c|}{ ATR (MÉDIA) } \\
\hline Jan & Set & 154,59 & $\mathrm{a}$ \\
\hline Jan & Nov & 154,00 & $\mathrm{a}$ \\
\hline Mar & Set & 152,04 & $\mathrm{a}$ \\
\hline Nov & Nov & 152,00 & $\mathrm{a}$ \\
\hline Nov & Set & 150,39 & $\mathrm{ab}$ \\
\hline Nov & Jul & 150,07 & $\mathrm{ab}$ \\
\hline Mai & Set & 149,86 & $\mathrm{ab}$ \\
\hline Mar & Jul & 149,66 & $a b$ \\
\hline Jan & Jul & 149,54 & $\mathrm{ab}$ \\
\hline Mai & Nov & 145,00 & bc \\
\hline Mar & Nov & 144,32 & bc \\
\hline Jan & Mai & 140,54 & $\mathrm{C}$ \\
\hline Nov & Mai & 140,49 & c \\
\hline Mai & Jul & 139,25 & c \\
\hline Mar & Mai & 135,64 & c \\
\hline Mai & Mai & 119,41 & d \\
\hline
\end{tabular}

Médias seguidas das mesmas letras não diferiram estatisticamente entre si.

$\mathrm{Na}$ tabela 38, observa-se que para a variedade NA 56-79, plantada em 1983/84 e no primeiro corte, houve diferença estatisticamente significativa entre as médias das épocas de plantio dentro das épocas de colheita.

Desses resultados pode-se concluir que para a variável ATR, os maiores valores ocorreram nas épocas de colheita Setembro com plantio em Janeiro, Março, Novembro e Maio; nas colheitas de Novembro com plantio em Janeiro e Novembro e, ainda, nas colheitas de Julho com plantio em Novembro.

Os menores valores ocorreram nos plantios dos meses de Maio, Março, Novembro e Janeiro com colheita em Maio. A variedade estudada atingiu sua maturação no mês de Julho com pequenos acréscimos em ATR de Julho para Novembro.

As figuras 75, 76, 77 e 78, a seguir, mostram a evolução de ATR onde se pode verificar o efeito das épocas de colheita sobre as épocas de plantio. 
Resultados de ATR- Safra 1985

corte 1 - época de plantio Novembro

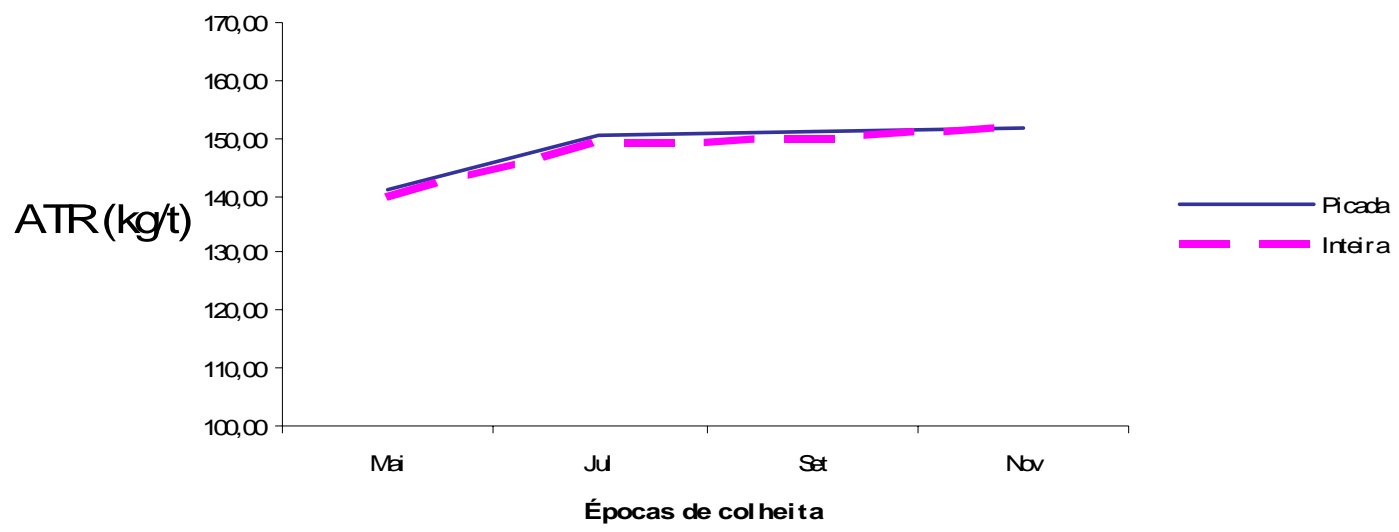

Figura 75 - Resultados de ATR para a variedade NA 56-79 na safra 1985, no $1^{\circ}$ corte e na época de plantio Novembro

Resultados de ATR- Safra 1985

corte 1 - época de plantio Janeiro

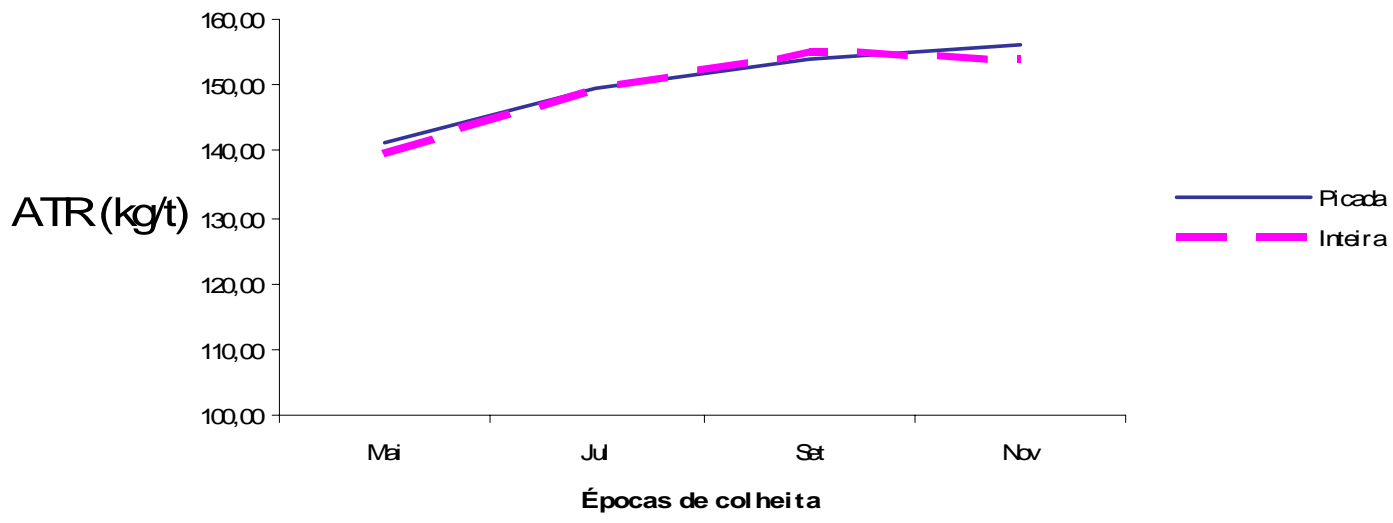

Figura 76 - Resultados de ATR para a variedade NA 56-79 na safra 1985, no $1^{\circ}$ corte e na época de plantio Janeiro 
Resultados de ATR- Safra 1985

corte 1 - época de plantio Março

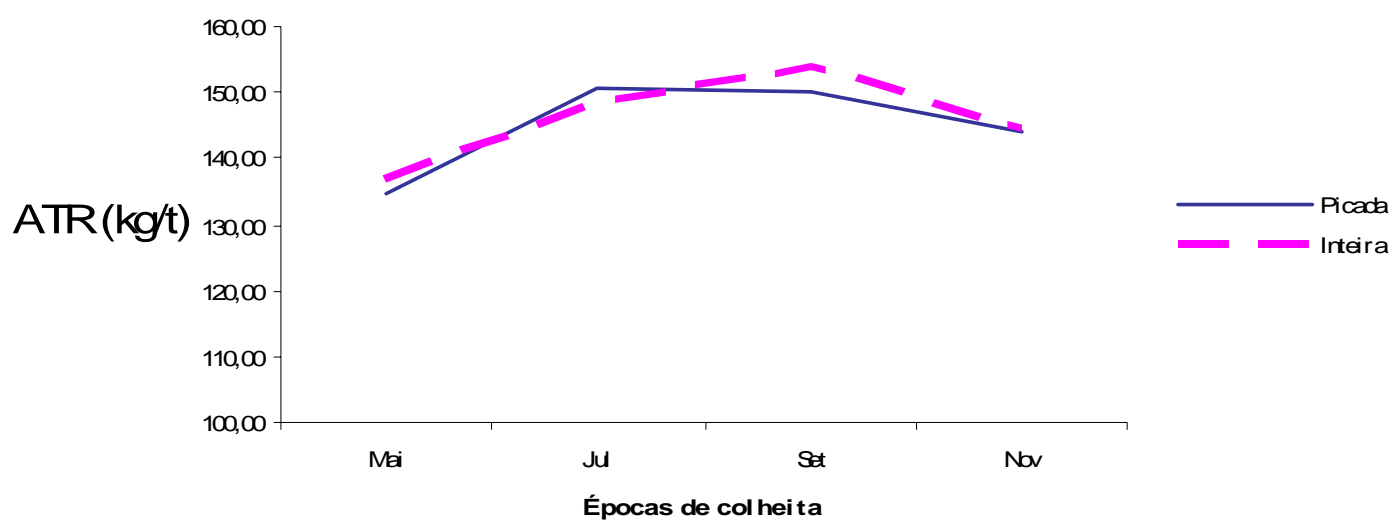

Figura 77 - Resultados de ATR para a variedade NA 56-79 na safra 1985, no $1^{\circ}$ corte e na época de plantio Março

Resultados de ATR- Safra 1985

corte 1 - época de plantio Maio

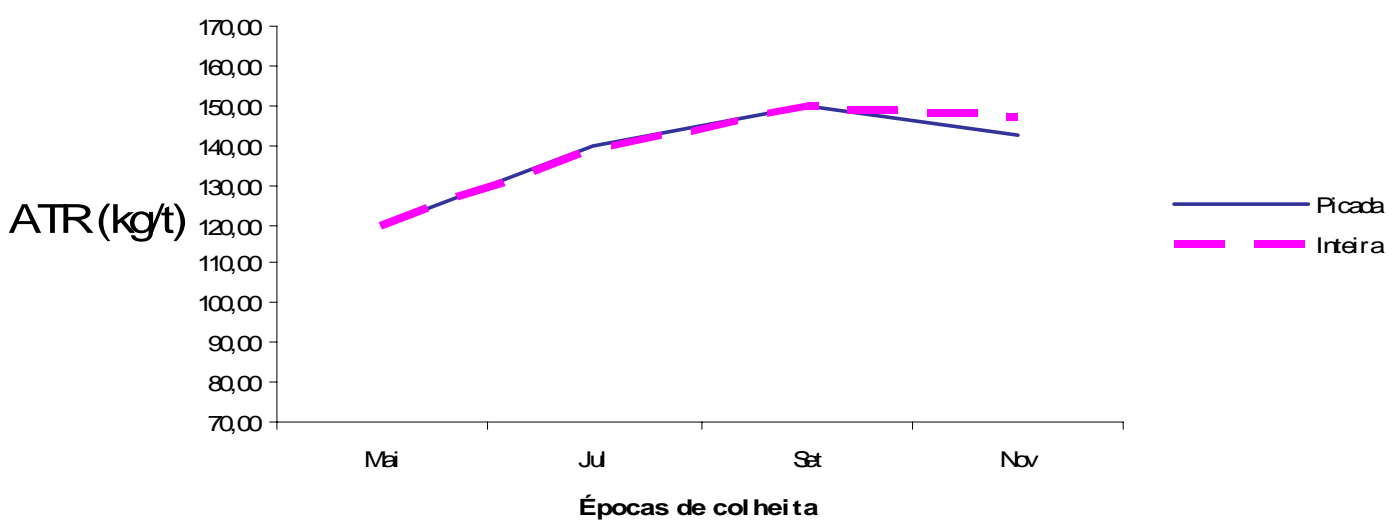

Figura 78 - Resultados de ATR para a variedade NA 56-79 na safra 1985, no $1^{\circ}$ corte e na época de plantio Maio 
Tabela 39. Valores médios de TAH para a variedade NA 56-79 nas interações de épocas de plantio dentro de épocas de colheita, no ano de $1983 / 84$, no $1^{\circ}$ corte

\begin{tabular}{|c|c|c|c|}
\hline$E P P L A$ & EPCOL & \multicolumn{2}{|c|}{ TAH MÉDIA } \\
\hline Mar & Nov & 17,52 & $a$ \\
\hline Mar & Jul & 17,40 & a \\
\hline Mar & Set & 17,23 & $a b$ \\
\hline Jan & Nov & 16,66 & $a b c$ \\
\hline Mai & Nov & 16,37 & $a b c d$ \\
\hline Mai & Set & 15,99 & $a b c d$ \\
\hline Mai & Jul & 15,58 & abcde \\
\hline Jan & Jul & 15,32 & abcde \\
\hline Nov & Jul & 14,68 & bcdef \\
\hline Mar & Mai & 14,61 & bcdef \\
\hline Jan & Mai & 14,52 & cdef \\
\hline Jan & Set & 14,22 & cdef \\
\hline Nov & Set & 13,79 & def \\
\hline Nov & Nov & 13,74 & def \\
\hline Nov & Mai & 13,00 & ef \\
\hline Mai & Mai & 12,07 & $f$ \\
\hline
\end{tabular}

Médias seguidas das mesmas letras não diferiram estatisticamente entre si.

$\mathrm{Na}$ tabela 39, observa-se que para a variedade NA 56-79, plantada em 1983/84 e no primeiro corte, houve diferença estatisticamente significativa entre as médias das épocas de plantio dentro das épocas de colheita.

As épocas de plantio Março com colheitas em Novembro, Julho e Setembro, apresentaram os maiores valores de TAH. Os menores valores foram obtidos nas épocas de plantio Maio com colheita em Maio e na época de plantio Novembro com colheita em Maio, Novembro e Setembro.

As figuras 79, 80, 81 e 82, a seguir, mostram a evolução de TAH onde se pode verificar o efeito das épocas de colheita sobre as épocas de plantio. 
Resultados deTAH- Safra 1985

corte 1 - época de plantio Novembro

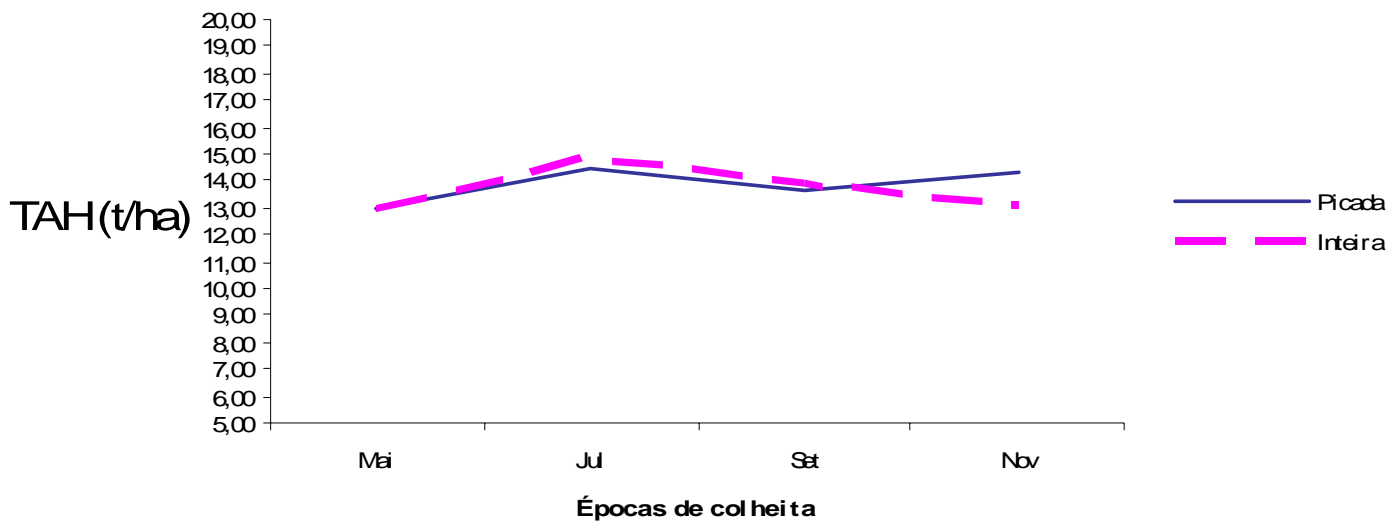

Figura 79 - Resultados de TAH para a variedade NA 56-79 na safra 1985, no $1^{\circ}$ corte e na época de plantio Novembro

\section{Resultados deTAH- Safra 1985 \\ corte 1 - época de plantio Janeiro}

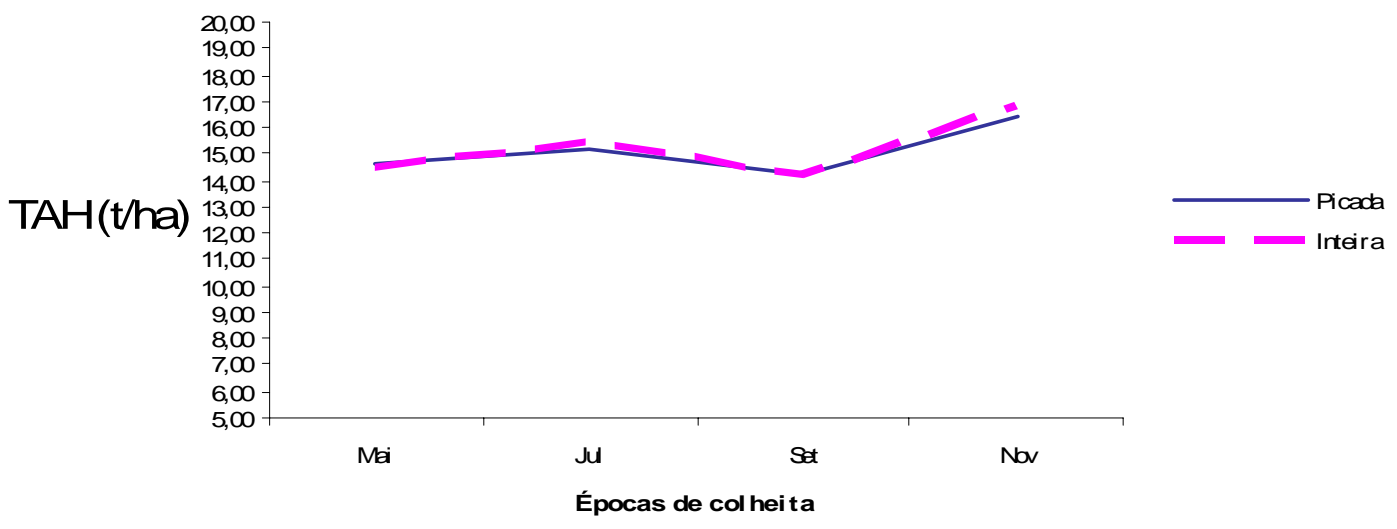

Figura 80 - Resultados de TAH para a variedade NA 56-79 na safra 1985, no $1^{\circ}$ corte e na época de plantio Janeiro 
Resultados deTAH- Safra 1985

corte 1 - época de plantio Março

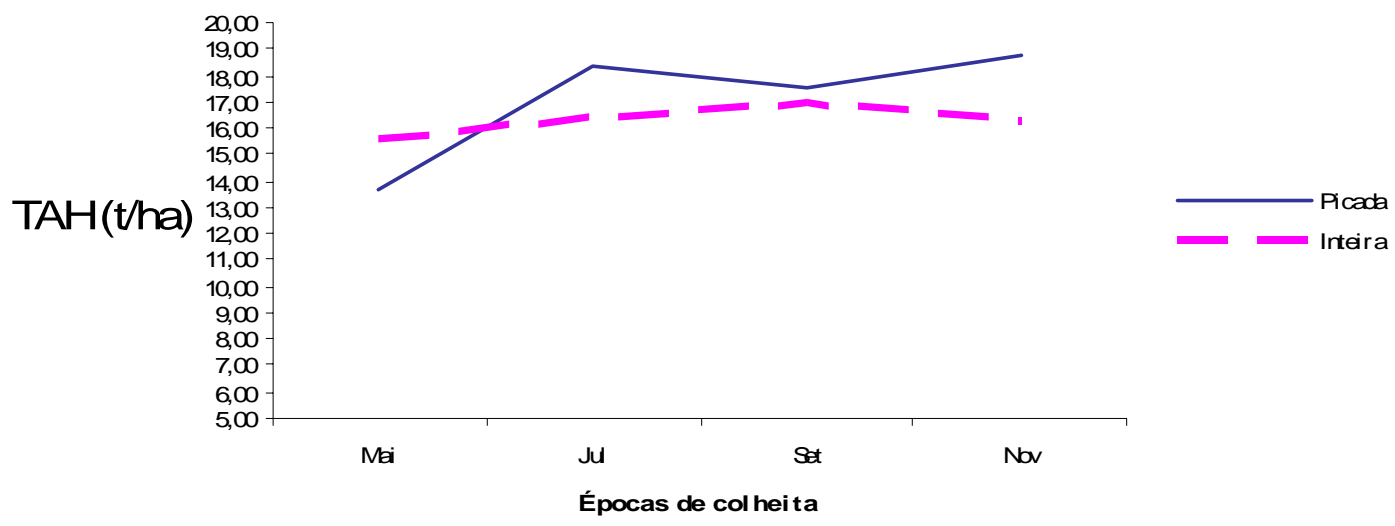

Figura 81 - Resultados de TAH para a variedade NA 56-79 na safra 1985, no $1^{\circ}$ corte e na época de plantio Março

Resultados deTAH- Safra 1985

corte 1 - época de plantio Maio

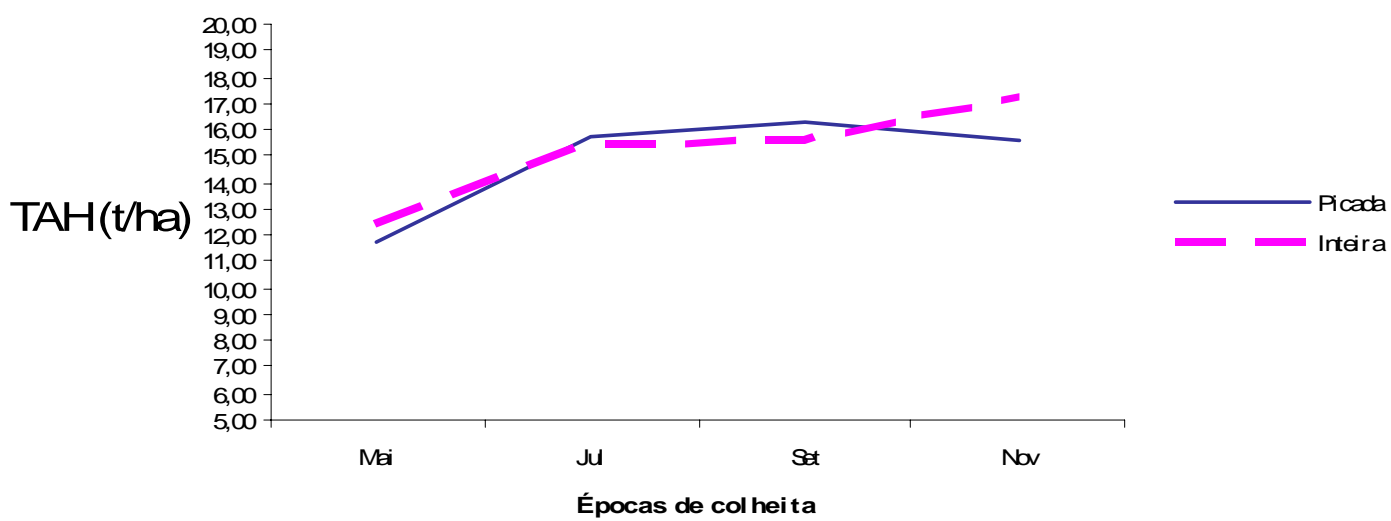

Figura 82 - Resultados de TAH para a variedade NA 56-79 na safra 1985, no $1^{\circ}$ corte e na época de plantio Maio 
Tabela 40. Resumo dos quadros de análise de variância dos dados obtidos para a variedade NA 56-79, no primeiro corte e com plantio no ano de 1984/85, em relação às variáveis dependentes TCH, ATR e TAH em várias combinações de épocas de plantio e de colheita e sob os tratamentos cana picada e inteira no sulco de plantio

\begin{tabular}{|c|c|c|c|c|}
\hline C. Variação & $G L$ & $\begin{array}{c}\mathrm{TCH} \\
Q M\end{array}$ & $\begin{array}{c}\text { ATR } \\
Q M\end{array}$ & $\begin{array}{c}\mathrm{TAH} \\
\mathrm{QM}\end{array}$ \\
\hline$B L O C O$ & 4 & -- & -- & - \\
\hline EPCOL & 3 & $670,073^{* *}$ & 4012,160 * * & 81,329 * * \\
\hline Resíduo (a) & 12 & 54,957 & 73,991 & 2,208 \\
\hline EPPLA & 3 & 10540,093 * * & $810,338^{* *}$ & $256,627^{* *}$ \\
\hline Resíduo (b) & 12 & 139,291 & 57,697 & 2,068 \\
\hline TRAT & 1 & 68,291 & 48,114 & 2,712 \\
\hline$E P C O L{ }^{\star} E P P L A$ & 9 & 84,022 & 267,080 * * & $3,030 * *$ \\
\hline$E P C O L{ }^{*} T R A T$ & 3 & 28,365 & 22,344 & $\odot, 806$ \\
\hline$E P P L A^{*} T R A T$ & 3 & 117,924 & 20,865 & $\odot, 858$ \\
\hline$E P C O L{ }^{\star} E P P L A{ }^{\star} T R A T$ & 9 & 71,421 & 8,823 & 1,194 \\
\hline Resíduo (c) & 100 & 52,503 & 25,850 & 1,023 \\
\hline Total & 159 & -- & -- & -- \\
\hline
\end{tabular}

A tabela 40, apresentada, mostra os valores da análise de variância, para as variáveis TCH, ATR e TAH, da variedade NA 56-79, no primeiro corte e com plantio no ano de 1984/85.

Como se pode observar, para as variáveis TCH, ATR e TAH houve efeito significativo de época de plantio e de épocas de colheita. $O$ tratamento muda picada e inteira no sulco de plantio não apresentou efeito significativo para as variáveis estudadas.

Houve interação de épocas de plantio dentro de épocas de colheita apenas para as variáveis ATR e TAH, indicando diferenças significativas entre as épocas de plantio para cada época de colheita. Não houve qualquer outra interação. 
Tabela 41. Valores médios de TCH para a variedade NA 56-79 das médias de épocas de plantio, com plantio no ano de $1984 / 85$, no $1^{\circ}$ corte

\begin{tabular}{cr}
\hline EPPLA & $T C H$ (MÉDIA) \\
\hline Nov & 115,964 a \\
Jan & 105,713 b \\
Mar & $90,097 \quad \mathrm{c}$ \\
Mai & $79,398 \quad \mathrm{~d}$ \\
\hline
\end{tabular}

Médias seguidas das mesmas letras não diferiram estatisticamente entre si.

$\mathrm{Na}$ tabela 41, observa-se que para a variedade NA 56-79, no primeiro corte e ano de plantio 1984/85, houve diferença estatisticamente significativa entre as médias $\mathrm{TCH}$ nas épocas de plantio.

Os resultados mostraram que as maiores produções foram obtidas nos plantios de Novembro, e as menores produções foram obtidas nos plantios de Maio.

Tabela 42. Valores médios de TCH para a variedade NA 56-79 das médias de épocas de colheita, com plantio no ano de $1984 / 85$, no $1^{\circ}$ corte

\begin{tabular}{cr}
\hline EPCOL & $T C H($ MÉDIA) \\
\hline Jul & 101,499 a \\
Set & 100,901 a \\
Mai & 95,734 b \\
Nov & 93,037 b \\
\hline
\end{tabular}

Médias seguidas das mesmas letras não diferiram estatisticamente entre si.

$\mathrm{Na}$ tabela 42, observa-se que para a variedade NA 56-79, no primeiro corte e ano de plantio 1984/85, houve diferença estatisticamente significativa entre as médias de TCH nas épocas de colheita.

Esses resultados mostram que para o ano agrícola estudado, as maiores produções foram obtidas nas colheitas de Julho e Setembro e as menores produções foram obtidas nas colheitas de Novembro e Maio. 
As figuras 83 e 84, a seguir, mostram, respectivamente, a evolução de TCH para épocas de plantio e colheita.

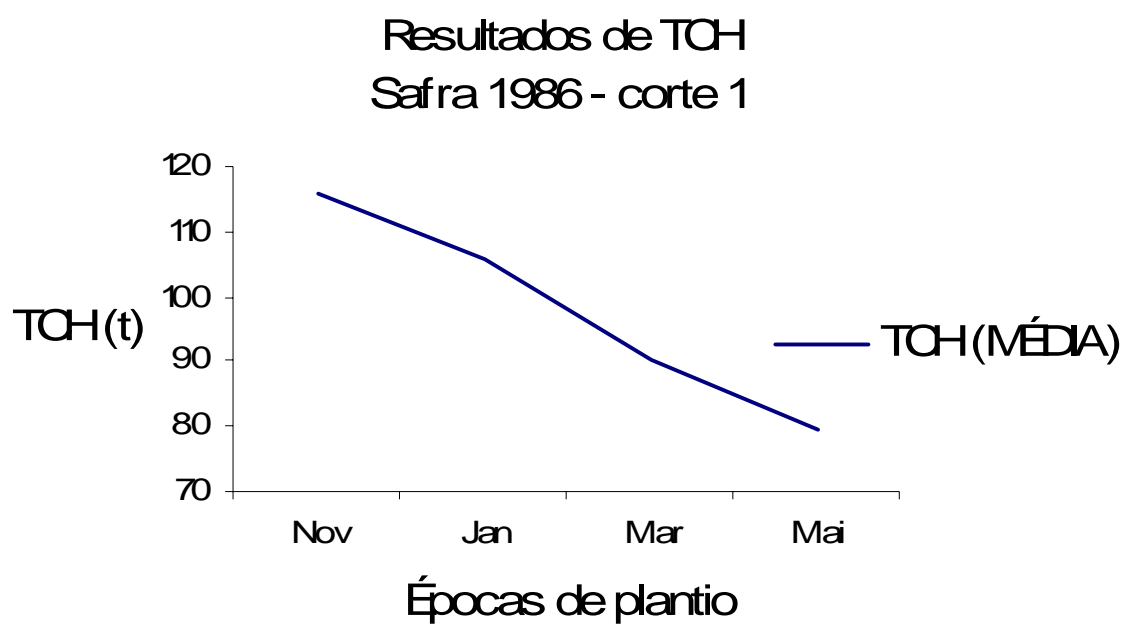

Figura 83 - Resultados de TCH para a variedade NA 56-79 na safra 1986, no $1^{\circ}$ corte e nas épocas de plantio

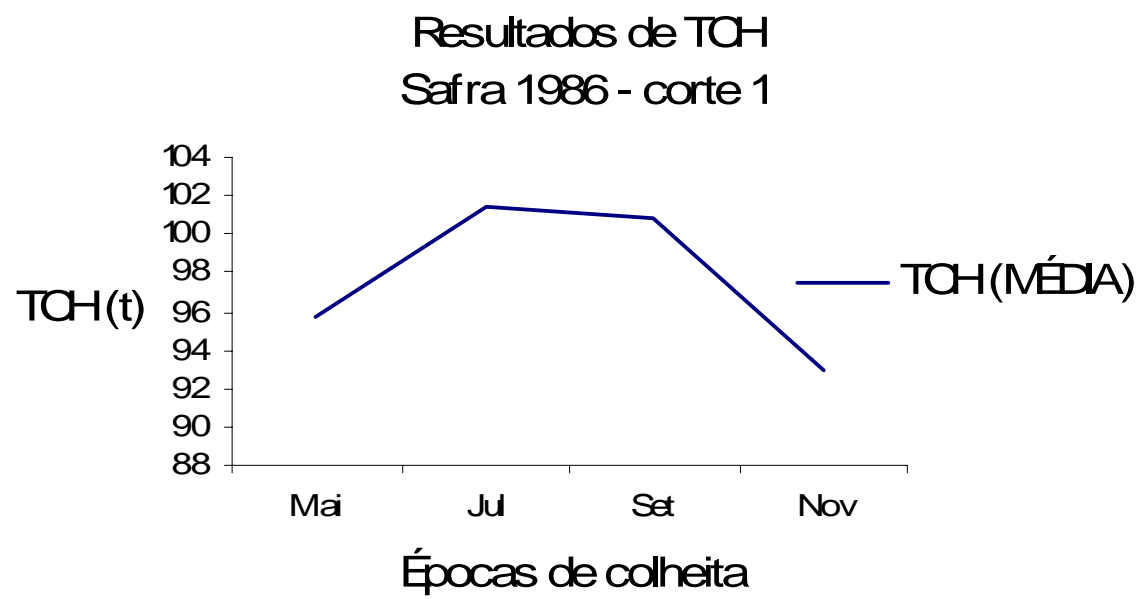

Figura 84 - Resultados de TCH para a variedade NA 56-79 na safra 1986, no $1^{\circ}$ corte e nas épocas de colheita 
Tabela 43. Valores médios de ATR para a variedade NA 56-79 nas interações de épocas de plantio dentro de épocas de colheita, com plantio no ano de 1984/85, no $1^{\circ}$ corte

\begin{tabular}{|c|c|c|c|}
\hline EPPLA & EPCOL & \multicolumn{2}{|c|}{$\overline{A T R}$ (MÉDIA) } \\
\hline Nov & Set & 143,410 & $a$ \\
\hline Jan & Jul & 141,192 & a \\
\hline Jan & Set & 139,699 & a \\
\hline Nov & Jul & 139,109 & $\mathrm{a}$ \\
\hline Mar & Jul & 138,461 & $\mathrm{a}$ \\
\hline Mar & Set & 137,037 & $a b$ \\
\hline Mai & Jul & 136,779 & $a b$ \\
\hline Mai & Set & 136,080 & $a b$ \\
\hline Nov & Nov & 130,415 & bc \\
\hline Nov & Mai & 129,139 & $b c$ \\
\hline Mar & Nov & 126,270 & $\mathrm{~cd}$ \\
\hline Jan & Nov & 124,359 & $\mathrm{~cd}$ \\
\hline Mai & Nov & 124,307 & $\mathrm{~cd}$ \\
\hline Jan & Mai & 123,693 & $\mathrm{~cd}$ \\
\hline Mar & Mai & 119,863 & d \\
\hline Mai & Mai & 101,929 & $e$ \\
\hline
\end{tabular}

Médias seguidas das mesmas letras não diferiram estatisticamente entre si.

$\mathrm{Na}$ tabela 43, observa-se que para a variedade NA 56-79, plantada em 1984/85 e no primeiro corte, houve diferença estatisticamente significativa entre as médias das épocas de plantio dentro das épocas de colheita.

Desses resultados pode-se concluir que para a variável ATR, os maiores valores foram observados nas épocas de colheita em Setembro com plantio em Novembro, Janeiro, Março e Maio e, ainda, colheita em Julho com plantio em Janeiro, Novembro, Março e Maio. Os menores valores foram observados nas épocas de colheita em Maio com plantio em Maio, Março e Janeiro.

As figuras 85, 86, 87 e 88, a seguir, mostram a evolução de ATR onde se pode verificar o efeito das épocas de colheita sobre as épocas de plantio. 
Resultados de ATR- Safra 1986

corte 1 - época de plantio Nbvembro

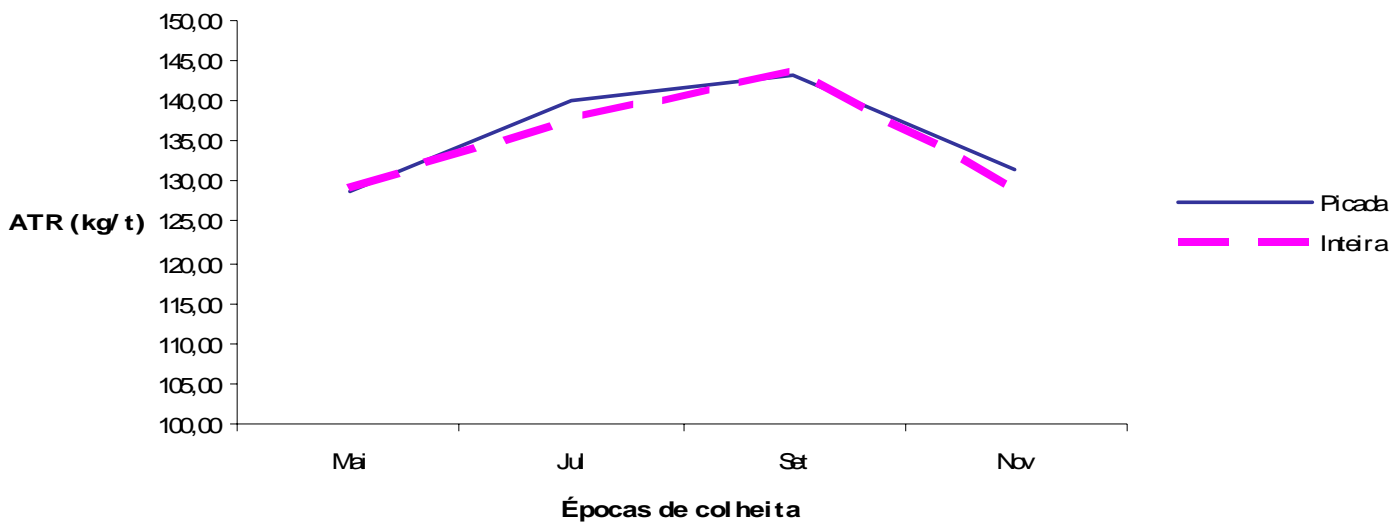

Figura 85 - Resultados de ATR para a variedade NA 56-79 na safra 1986, no $1^{\circ}$ corte e na época de plantio Novembro

Resultados de ATR- Safra 1986

corte 1 - época de plantio Janeiro

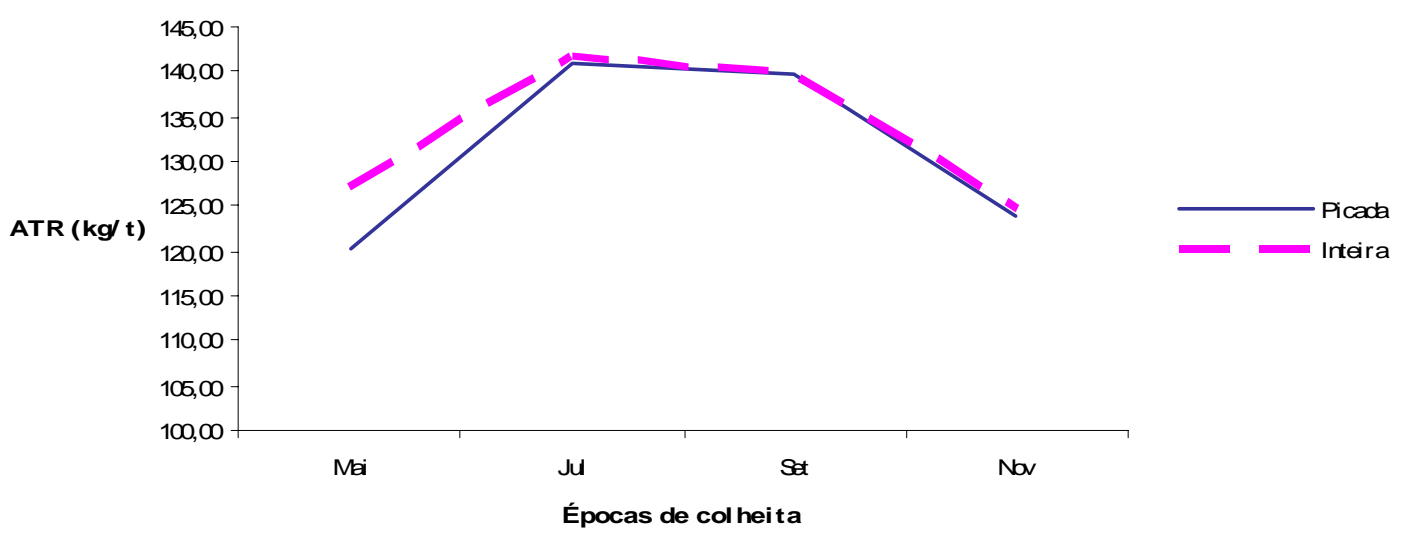

Figura 86 - Resultados de ATR para a variedade NA 56-79 na safra 1986, no $1^{\circ}$ corte e na época de plantio Janeiro 
Resultados de ATR- Safra 1986

corte 1 - época de plantio Março

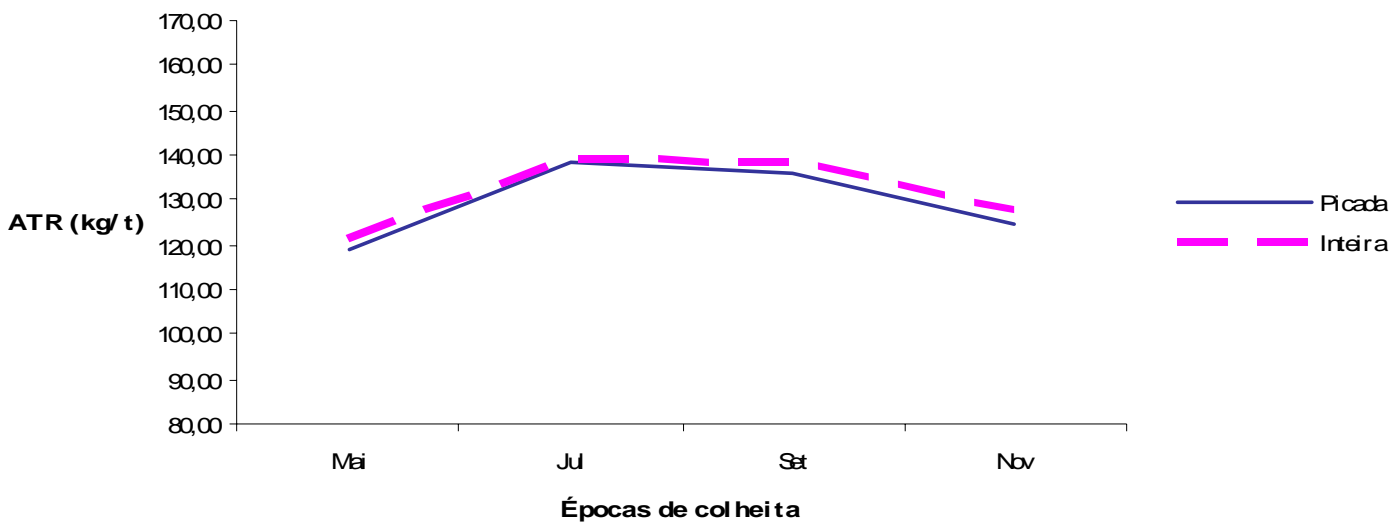

Figura 87 - Resultados de ATR para a variedade NA 56-79 na safra 1986, no $1^{\circ}$ corte e na época de plantio Março

\section{Resultados de ATR- Safra 1986}

corte 1 - época de plantio Maio

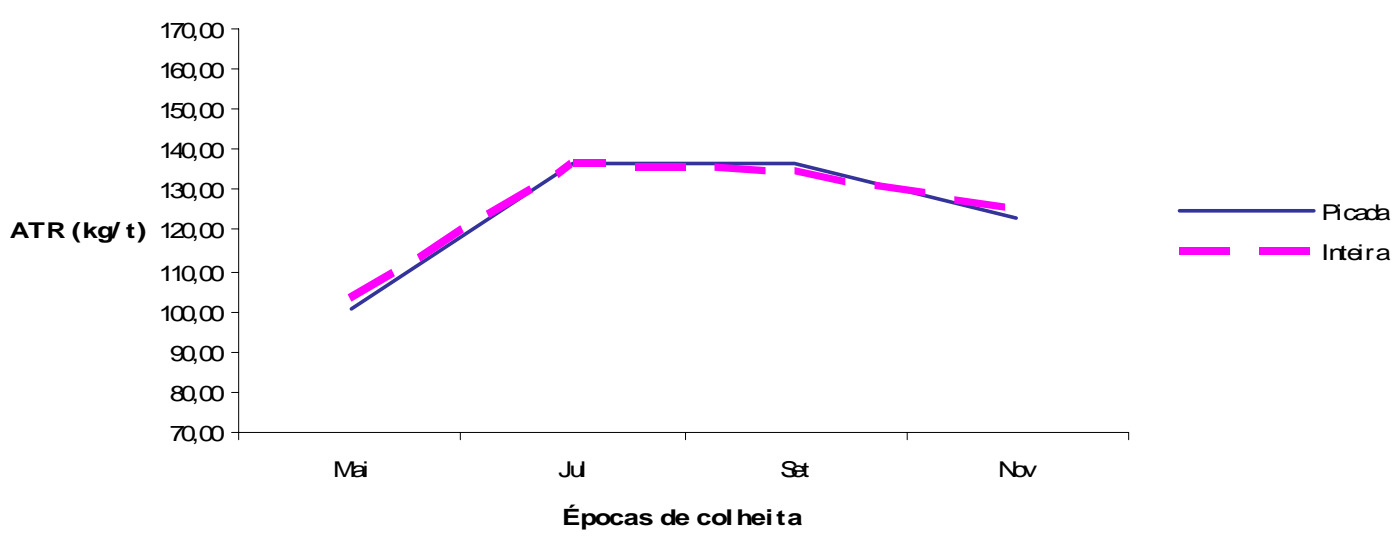

Figura 88 - Resultados de ATR para a variedade NA 56-79 na safra 1986, no $1^{\circ}$ corte e na época de plantio Maio 
Tabela 44. Valores médios de TAH para a variedade NA 56-79 nas interações de épocas de plantio dentro de épocas de colheita, com plantio no ano de 1984/85, no $1^{\circ}$ corte

\begin{tabular}{|c|c|c|c|}
\hline$E P P L A$ & $E P C O L$ & \multicolumn{2}{|c|}{ TAH (MÉDIA) } \\
\hline Nov & Set & 17,237 & $\mathrm{a}$ \\
\hline Nov & Jul & 16,841 & a \\
\hline Jan & Jul & 16,096 & $a b$ \\
\hline Jan & Set & 14,853 & bc \\
\hline Nov & Mai & 14,478 & c \\
\hline Nov & Nov & 14,284 & c \\
\hline Mar & Set & 12,673 & d \\
\hline Mar & Jul & 12,667 & d \\
\hline Jan & Mai & 12,590 & d \\
\hline Jan & Nov & 12,508 & d \\
\hline Mai & Set & 11,472 & de \\
\hline Mar & Mai & 10,879 & e \\
\hline Mai & Jul & 10,816 & e \\
\hline Mar & Nov & 10,783 & e \\
\hline Mai & Nov & 9,484 & et \\
\hline Mai & Mai & 7,960 & 1 \\
\hline
\end{tabular}

Médias seguidas das mesmas letras não diferiram estatisticamente entre si.

$\mathrm{Na}$ tabela 44, observa-se que para a variável TAH na variedade NA 56-79, plantada em 1984/85 e no primeiro corte, houve diferença estatisticamente significativa entre as médias das épocas de plantio dentro das épocas de colheita.

Desses resultados pode-se concluir que para a variável $T A H$, as maiores produções foram obtidas nas colheitas de Setembro e Julho com plantios em Novembro e Janeiro. As menores produções foram obtidas nas colheitas de Maio, Novembro, Julho e Setembro com plantios em Maio.

As figuras 89, 90, 91 e 92, a seguir, mostram a evolução de TAH onde se pode verificar o efeito das épocas de colheita sobre as épocas de plantio. 
Resultados deTAH- Safra 1986

corte 1 - época de plantio Novembro

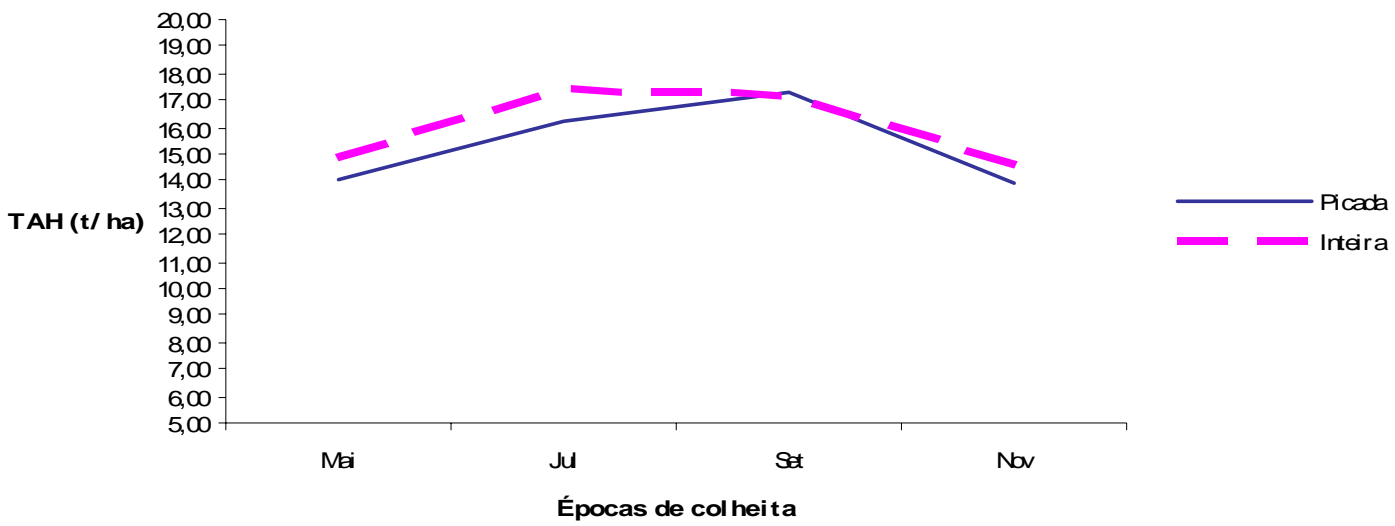

Figura 89 - Resultados de TAH para a variedade NA 56-79 na safra 1986, no $1^{\circ}$ corte e na época de plantio Novembro

\section{Resultados deTAH- Safra 1986}

corte 1 - época de plantio Janeiro

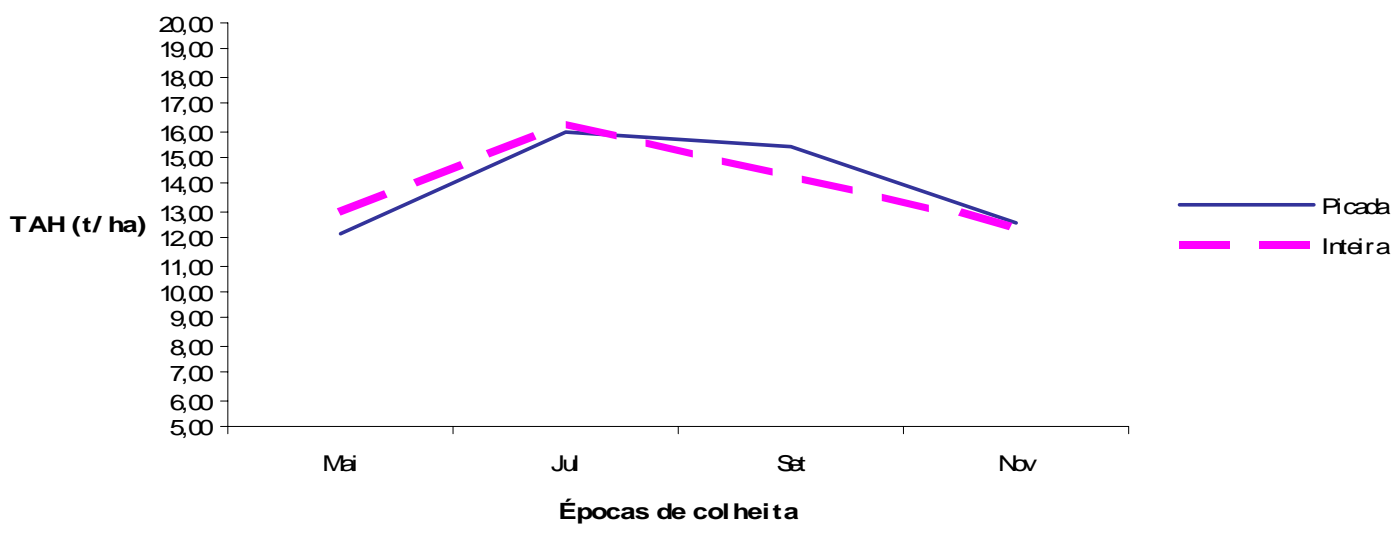

Figura 90 - Resultados de TAH para a variedade NA 56-79 na safra 1986, no $1^{\circ}$ corte e na época de plantio Janeiro 
Resultados deTAH- Safra 1986 corte 1 - época de plantio Março

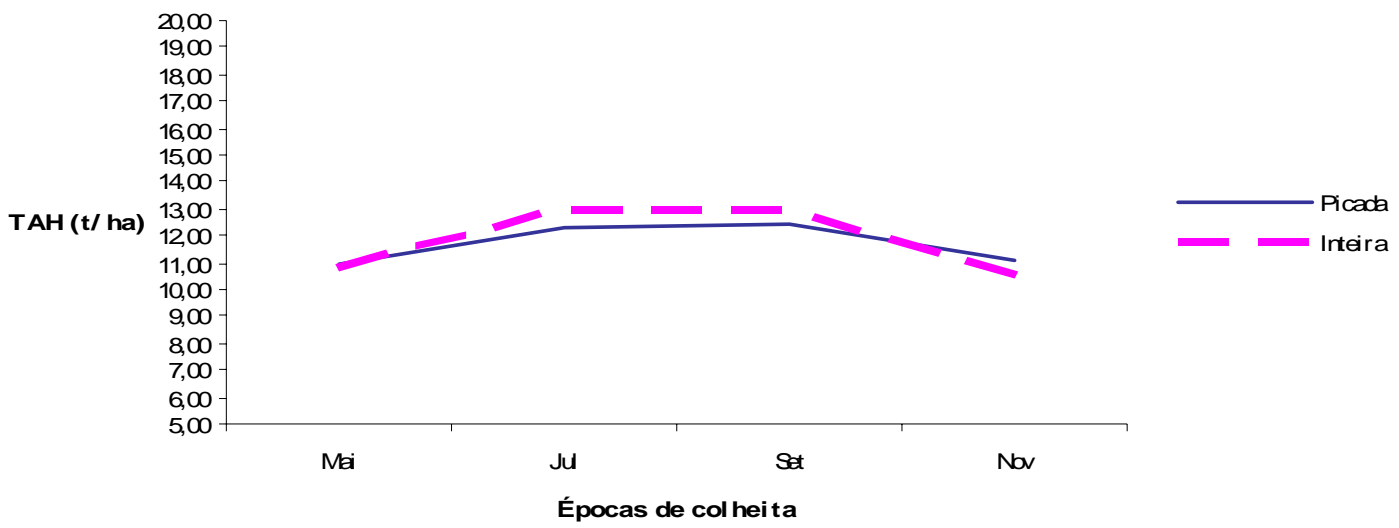

Figura 91 - Resultados de TAH para a variedade NA 56-79 na safra 1986, no $1^{\circ}$ corte e na época de plantio Março

Resultados deTAH- Safra 1986

corte 1 - época de plantio Maio

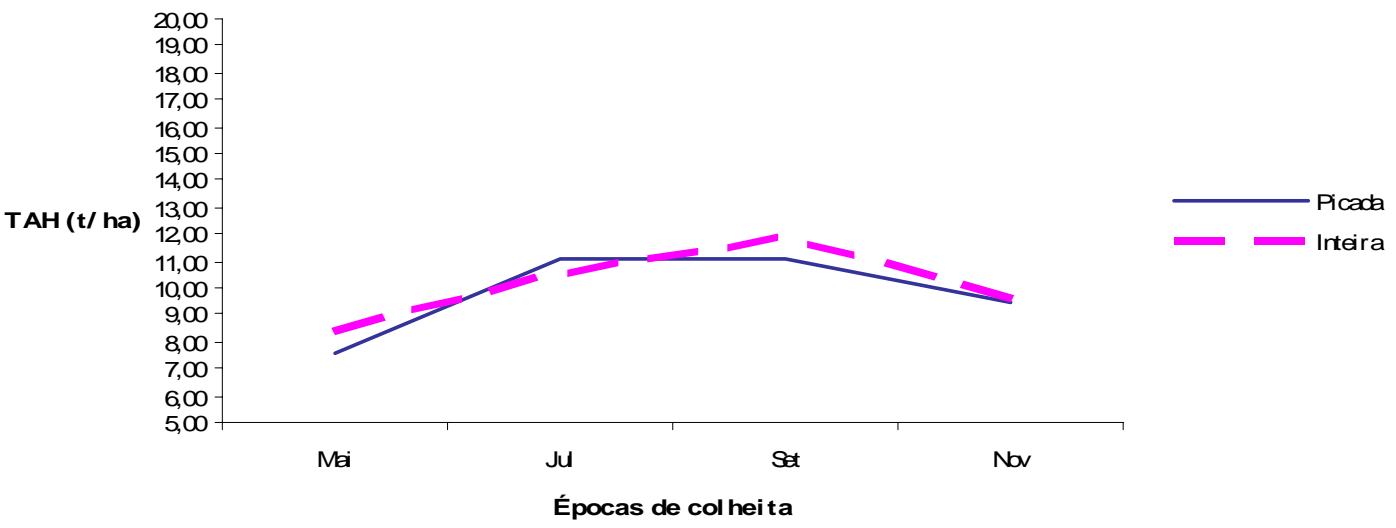

Figura 92 - Resultados de TAH para a variedade NA 56-79 na safra 1986, no $1^{\circ}$ corte e na época de plantio Maio 
Tabela 45. Resumo dos quadros de análise de variância dos dados obtidos para a variedade NA 56-79, no primeiro corte e com plantio no ano de 1985/86, em relação às variáveis dependentes TCH, ATR e TAH em várias combinações de épocas de plantio e de colheita e sob os tratamentos cana picada e inteira no sulco de plantio

\begin{tabular}{|c|c|c|c|c|}
\hline C. Variação & $G L$ & $\begin{array}{c}\mathrm{TCH} \\
Q M\end{array}$ & $\begin{array}{c}\text { ATR } \\
Q M\end{array}$ & $\begin{array}{c}\mathrm{TAH} \\
Q M\end{array}$ \\
\hline$B L O C O$ & 4 & -- & - & -- \\
\hline EPCOL & 3 & 629,807 * * & 4096,676 ** & 84,416 * * \\
\hline Resíduo (a) & 12 & 198,170 & 40,621 & 2,188 \\
\hline EPPLA & 3 & 6163,852 * * & 180,304 ** & 157,061 * * \\
\hline Resíduo (b) & 12 & 289,802 & 35,230 & 3,834 \\
\hline TRAT & 1 & 44,859 & 83,608 & 4,067 \\
\hline$E P C O L{ }^{\star} E P P L A$ & 9 & 507,296 * * & 184,326 * & $9,375^{* *}$ \\
\hline$E P C O L{ }^{*} T R A T$ & 3 & 6,989 & 16,755 & $\odot, 651$ \\
\hline$E P P L A^{*} T R A T$ & 3 & 205,996 & 8,976 & 4,967 \\
\hline$E P C O L{ }^{*} E P P L A * T R A T$ & 9 & 73,102 & 49,342 & 3,171 \\
\hline Resíduo (c) & 100 & 112,811 & 32,057 & 2,371 \\
\hline Total & 159 & -- & -- & -- \\
\hline
\end{tabular}

A tabela 45, mostra os valores da análise de variância para as variáveis ATR, TCH e TAH da variedade NA 56-79, no primeiro corte e ano de plantio 1985/86.

Como se pode observar, para as variáveis TCH, ATR e TAH houve efeito significativo de épocas de plantio e de épocas de colheita. $O$ tratamento muda picada e inteira no sulco de plantio não apresentou efeito significativo para as variáveis estudadas.

Houve interação de épocas de plantio dentro de épocas de colheita para as três variáveis estudadas, indicando diferenças significativas entre as épocas de plantio para cada época de colheita. Não houve qualquer outra interação. 
Tabela 46. Valores médios de TCH para a variedade NA 56-79 nas interações de épocas de plantio dentro de épocas de colheita, com plantio no ano de 1985/86, no $1^{\circ}$ corte

\begin{tabular}{ccc}
\hline EPPLA & EPCOL & $T C H \quad(M E ́ D I A)$ \\
\hline Jan & Set & $132,262 \mathrm{a}$ \\
Jan & Mai & $130,098 \mathrm{a}$ \\
Nov & Mai & $128,480 \mathrm{a}$ \\
Jan & Nov & $124,335 \mathrm{ab}$ \\
Nov & Set & $124,240 \mathrm{ab}$ \\
Jan & Jul & $122,361 \mathrm{abc}$ \\
Mar & Nov & $118,574 \mathrm{abcd}$ \\
Mar & Set & $117,003 \mathrm{abcd}$ \\
Nov & Jul & $115,646 \mathrm{abcd}$ \\
Nov & Nov & 109,050 bcde \\
Mar & Jul & 106,216 cde \\
Mai & Nov & $104,145 \quad$ de \\
Mai & Set & $102,051 \quad$ de \\
Mar & Mai & $98,860 \quad$ e \\
Mai & Mai & $94,646 \quad$ e \\
Mai & Jul & $92,787 \quad$ e \\
\hline
\end{tabular}

Médias seguidas das mesmas letras não diferiram estatisticamente entre si.

$\mathrm{Na}$ tabela 46, observa-se que para a variedade NA 56-79, no primeiro corte e ano de plantio 1985/86, houve diferença estatisticamente significativa entre as médias de TCH para a interação épocas de plantio dentro das épocas de colheita.

Os resultados mostraram que os maiores valores de $\mathrm{TCH}$ foram obtidos nos plantios feitos em Janeiro e Novembro com colheitas feitas em Setembro e Maio, e ainda, plantios em Janeiro com colheitas em Novembro e Julho. As menores produções foram obtidas nas colheitas feitas em Julho, Maio, Setembro e Novembro com plantios em Maio e, ainda, colheitas de Maio com plantios em Março.

As figuras 93, 94, 95 e 96, a seguir, mostram a evolução de TCH onde se pode verificar o efeito das épocas de colheita sobre as épocas de plantio. 


\section{Resultados de TCH- Safra 1987 \\ corte 1 - época de plantio Novembro}

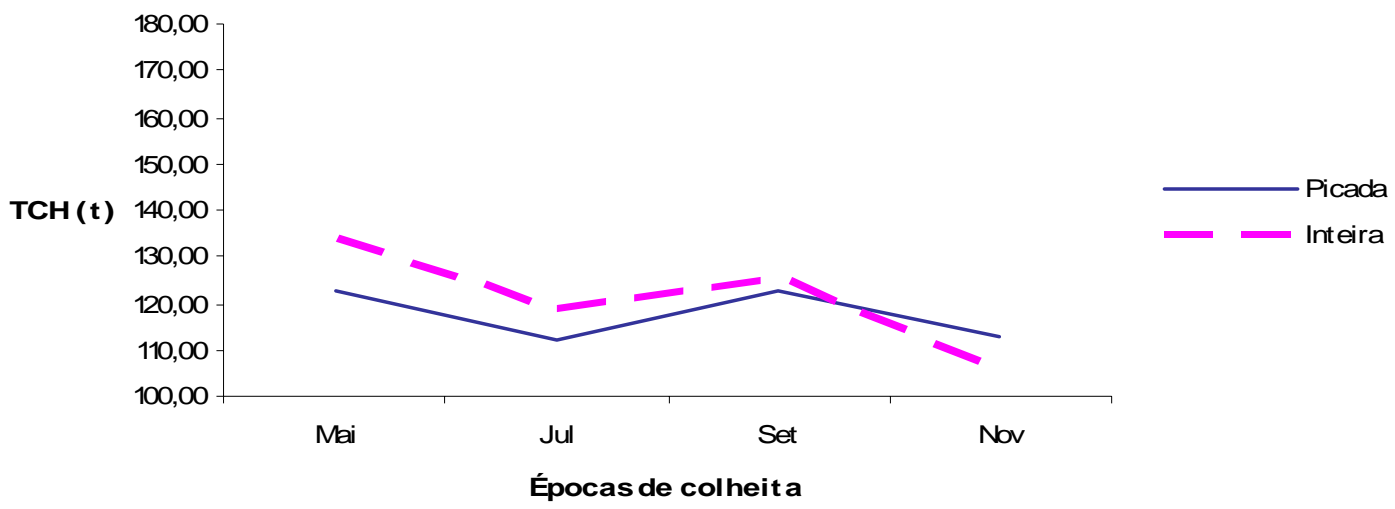

Figura 93 - Resultados de TCH para a variedade NA 56-79 na safra 1987, no $1^{\circ}$ corte e na época de plantio Novembro

Resultados de TCH- Safra 1987

corte 1 - época de plantio Janeiro

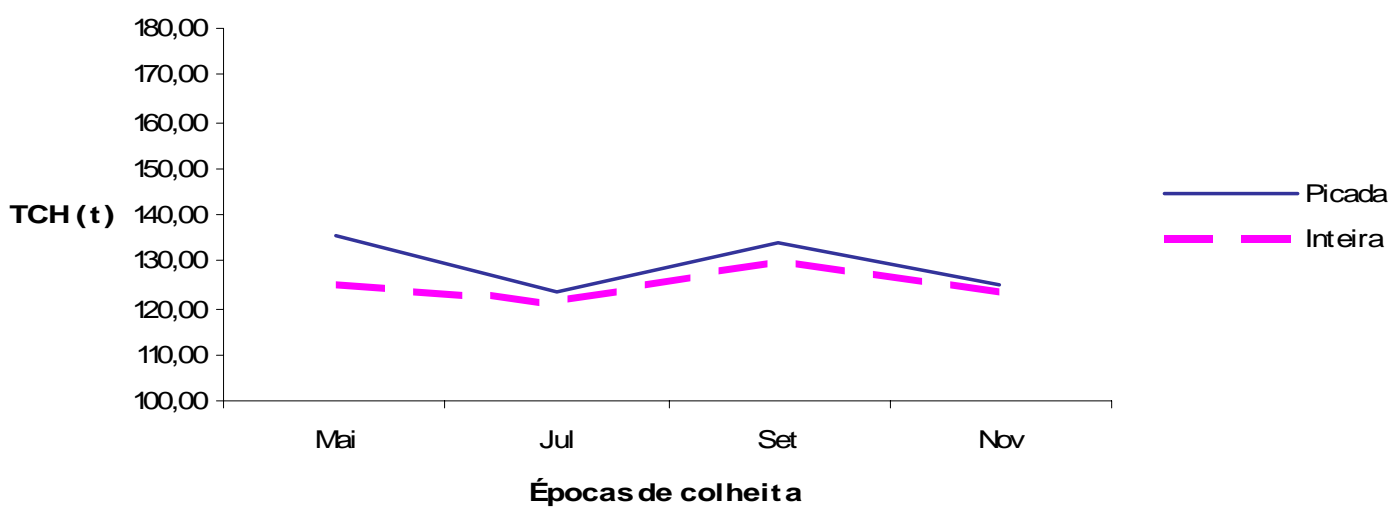

Figura 94 - Resultados de TCH para a variedade NA 56-79 na safra 1987, no $1^{\circ}$ corte e na época de plantio Janeiro 


\section{Resultados de TCH-Safra 1987 \\ corte 1 - época de plantio Março}

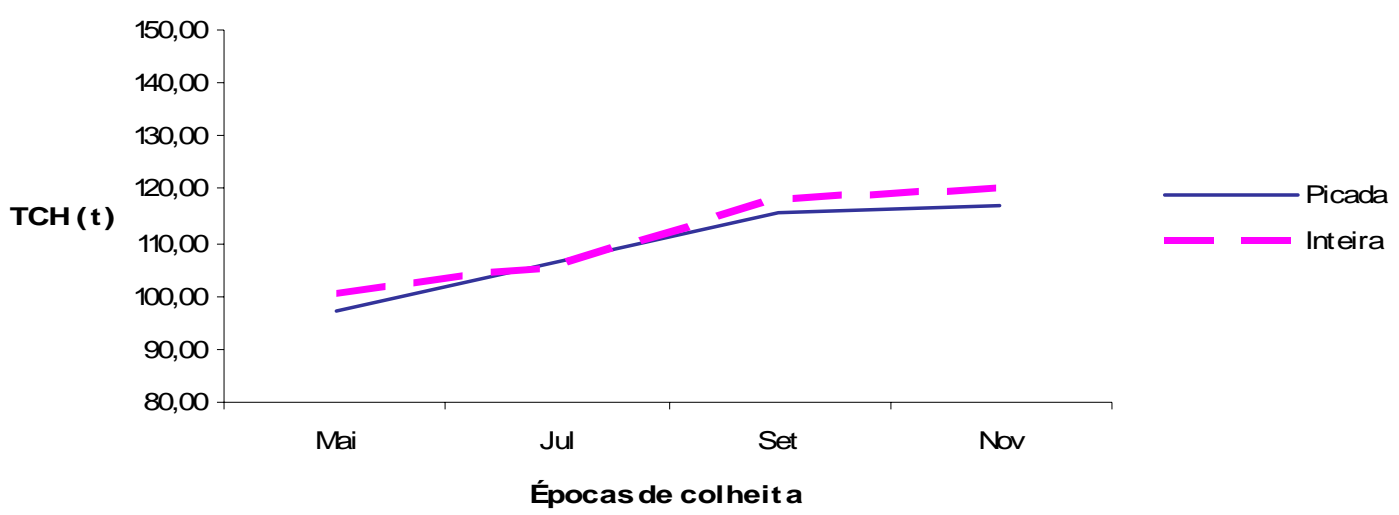

Figura 95 - Resultados de TCH para a variedade NA 56-79 na safra 1987, no $1^{\circ}$ corte e na época de plantio Março

Resultados de TCH- Safra 1987

corte 1 - época de plantio Maio

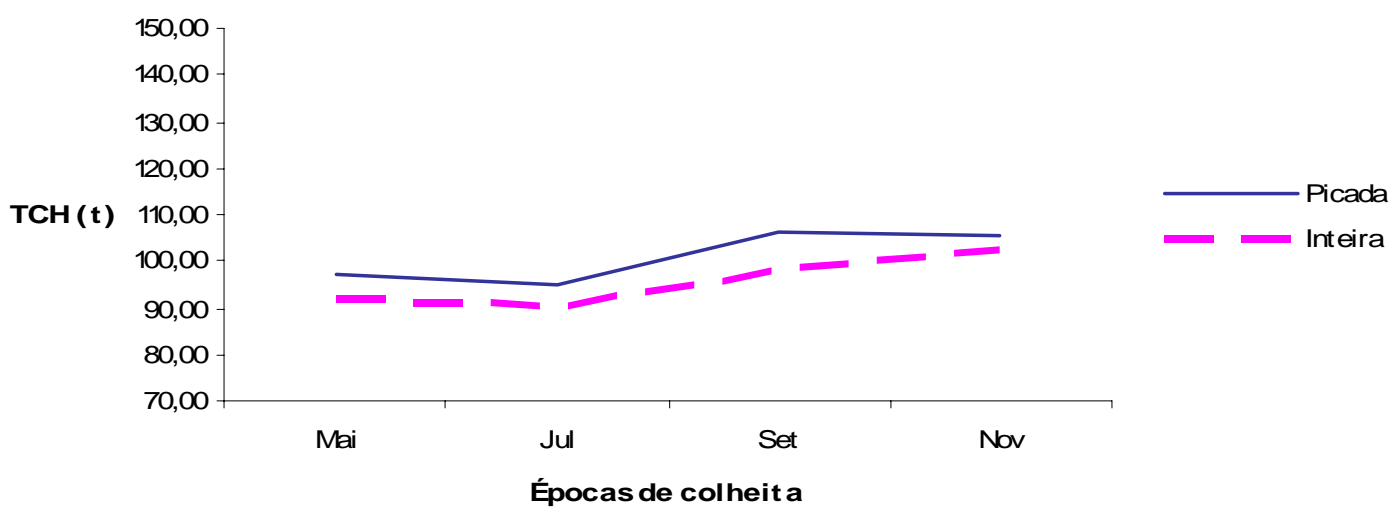

Figura 96 - Resultados de TCH para a variedade NA 56-79 na safra 1987, no $1^{\circ}$ corte e na época de plantio Maio 
Tabela 47. Valores médios de ATR para a variedade NA 56-79 nas interações de épocas de plantio dentro de épocas de colheita, com plantio no ano de $1985 / 86$, no $1^{\circ}$ corte

\begin{tabular}{|c|c|c|c|}
\hline EPPLA & $E P C O L$ & \multicolumn{2}{|c|}{ ATR (MÉDIA) } \\
\hline Mar & Set & \multicolumn{2}{|c|}{$153,224 \mathrm{a}$} \\
\hline Mai & Set & \multicolumn{2}{|c|}{$152,032 \mathrm{ab}$} \\
\hline Jan & Set & \multicolumn{2}{|c|}{$151.959 \mathrm{ab}$} \\
\hline Nov & Set & \multicolumn{2}{|c|}{$151,336 \mathrm{abc}$} \\
\hline Jan & Jul & \multicolumn{2}{|c|}{$148,002 \mathrm{abcd}$} \\
\hline Mar & Jul & \multicolumn{2}{|c|}{$147,860 \mathrm{abcd}$} \\
\hline Nov & Jul & \\
\hline Jan & Nov & \multicolumn{2}{|c|}{$\begin{array}{l}147,190 \text { abcd } \\
143,231 \text { bcd }\end{array}$} \\
\hline Mai & Nov & \multicolumn{2}{|c|}{$142,784 \quad \mathrm{~cd}$} \\
\hline Mai & Jul & \multicolumn{2}{|c|}{$142,421 \quad d$} \\
\hline Nov & Nov & \multicolumn{2}{|c|}{141,021 de } \\
\hline Mar & Nov & \multicolumn{2}{|c|}{133,483 ef } \\
\hline Jan & Mai & \multicolumn{2}{|c|}{132,837 ef } \\
\hline Mar & Mai & \multicolumn{2}{|c|}{132,187 ef } \\
\hline Nov & Mai & \multicolumn{2}{|c|}{$130,456 \quad f$} \\
\hline Mai & Mai & 118,545 & \\
\hline
\end{tabular}

Médias seguidas das mesmas letras não diferiram estatisticamente entre si.

$\mathrm{Na}$ tabela 47, observa-se que para a variedade NA 56-79, no primeiro corte e ano de plantio 1985/86, houve diferença estatisticamente significativa entre as médias de ATR para a interação épocas de plantio dentro das épocas de colheita. Os maiores valores de ATR foram obtidos nas épocas de colheita Setembro com plantios em Março, Maio, Janeiro e Novembro. Os menores valores ocorreram nas épocas de colheita Maio com plantios em Maio, Novembro, Março e Janeiro.

As figuras 97, 98, 99 e 100, a seguir, mostram a evolução de ATR onde se pode verificar o efeito das épocas de colheita sobre as épocas de plantio. 
Resultados de ATR- Safra 1987

corte 1 - época de plantio Nbvembro

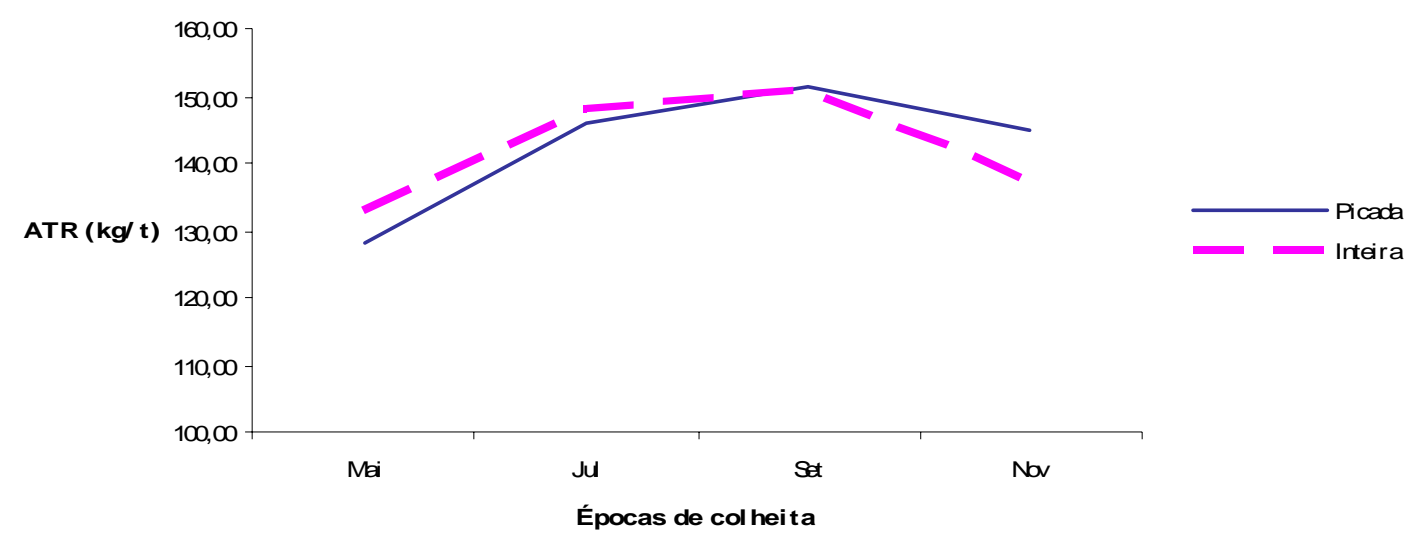

Figura 97 - Resultados de ATR para a variedade NA 56-79 na safra 1987, no $1^{\circ}$ corte e na época de plantio Novembro

\section{Resultados de ATR- Safra 1987 \\ corte 1 - época de plantio Janeiro}

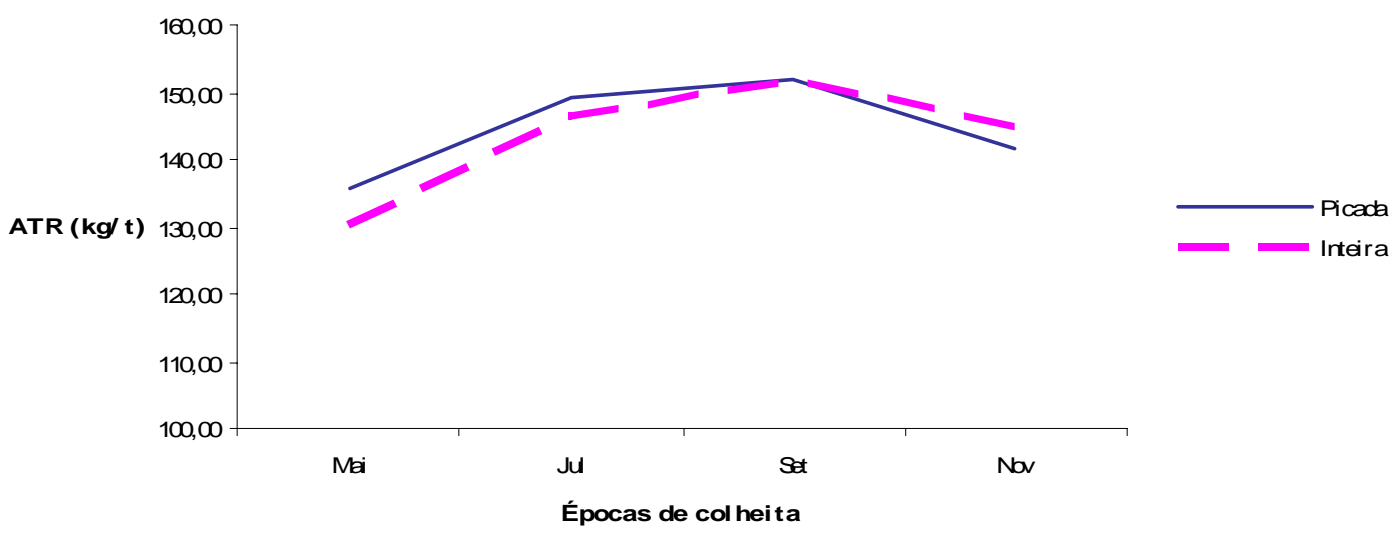

Figura 98 - Resultados de ATR para a variedade NA 56-79 na safra 1987, no $1^{\circ}$ corte e na época de plantio Janeiro 
Resultados de ATR- Safra 1987 corte 1 - época de plantio Março

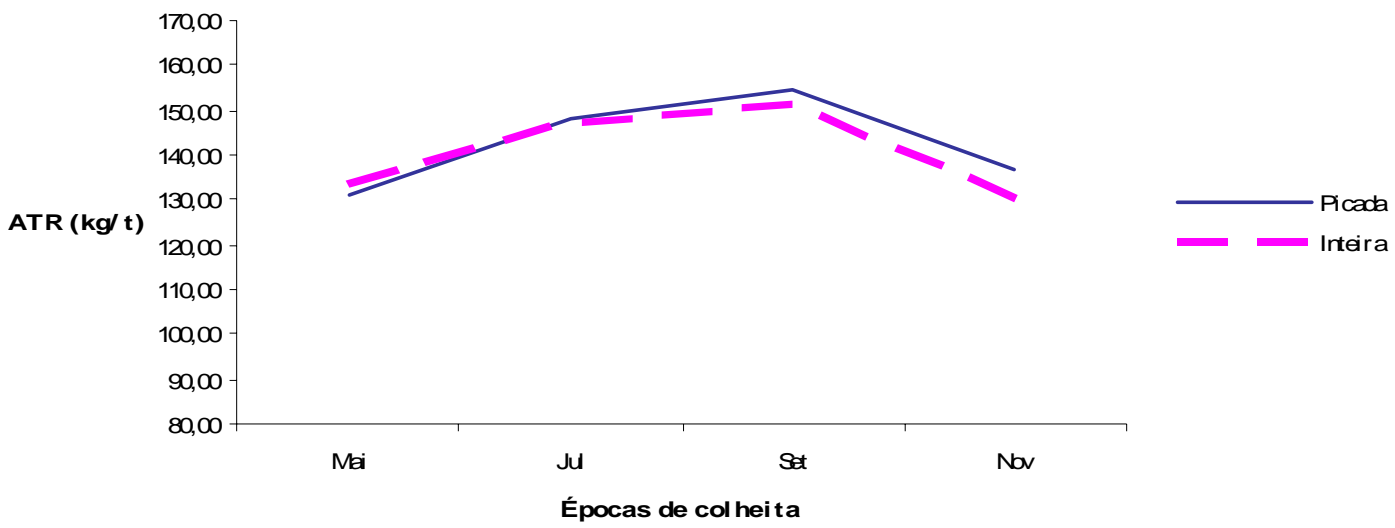

Figura 99 - Resultados de ATR para a variedade NA 56-79 na safra 1987, no $1^{\circ}$ corte e na época de plantio Março

\section{Resultados de ATR- Safra 1987 \\ corte 1 - época de plantio Maio}

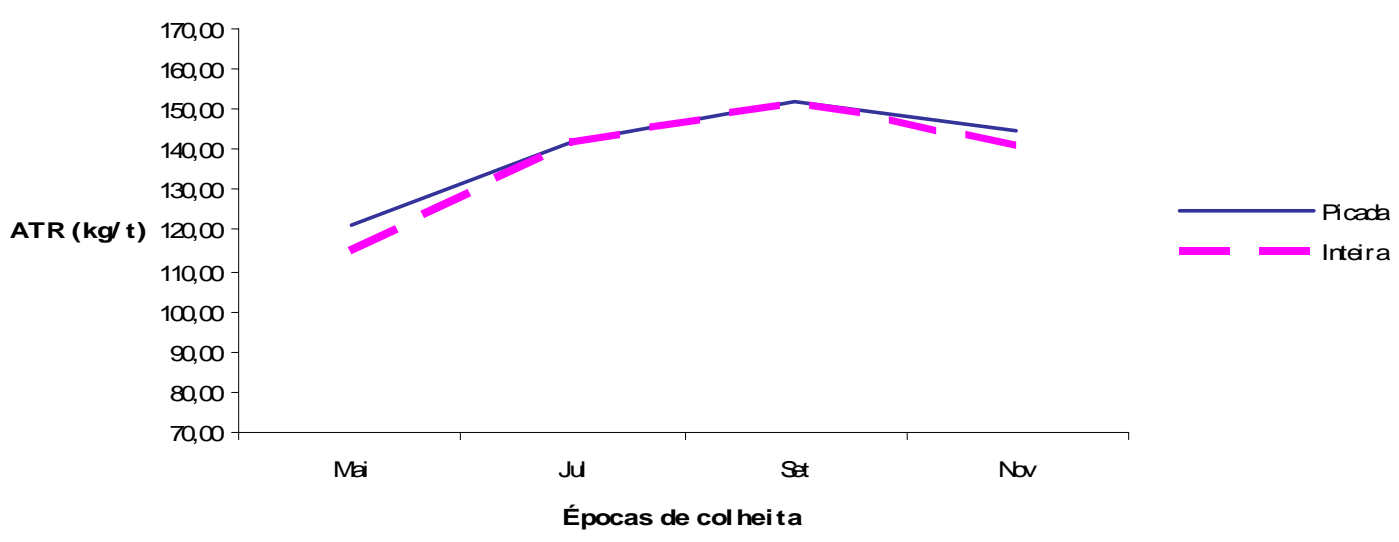

Figura 100 - Resultados de ATR para a variedade NA 56-79 na safra 1987, no $1^{\circ}$ corte e na época de plantio Maio 
Tabela 48. Valores médios de TAH para a variedade NA 56-79 nas interações de épocas de plantio dentro de épocas de colheita, com plantio no ano de $1985 / 86$, no $1^{\circ}$ corte

\begin{tabular}{|c|c|c|c|}
\hline$E P P L A$ & EPCOL & \multicolumn{2}{|c|}{ TAH (MÉDIA) } \\
\hline Jan & Set & 20,115 & \\
\hline Nov & Set & 18,816 & $a b$ \\
\hline Jan & Jul & 18,112 & $a b c$ \\
\hline Mar & Set & 17,917 & abcd \\
\hline Jan & Nov & 17,805 & abcd \\
\hline Jan & Mai & 17,283 & bcde \\
\hline Nov & Jul & 17,017 & bcdef \\
\hline Nov & Mai & 16,733 & bcdef \\
\hline Mar & Nov & 15,766 & cdef \\
\hline Mar & Jul & 15,716 & cdef \\
\hline Mai & Set & 15,502 & defg \\
\hline Nov & Nov & 15,347 & efgh \\
\hline Mai & Nov & 14,861 & fgh \\
\hline Mai & Jul & 13,204 & ghi \\
\hline Mar & Mai & 13,051 & hi \\
\hline Mai & Mai & 11,188 & i \\
\hline
\end{tabular}

Médias seguidas das mesmas letras não diferiram estatisticamente entre si.

$\mathrm{Na}$ tabela 48, observa-se que para a variedade NA 56-79, no primeiro corte e ano de plantio 1985/86, houve diferença estatisticamente significativa entre as médias de TAH para a interação épocas de plantio dentro das épocas de colheita.

Os maiores valores e TAH foram obtidos nas colheitas de Setembro, Julho e Novembro com plantios em Janeiro e colheitas de Setembro com plantios em Novembro e Março. Os menores valores foram obtidos nas colheitas de Maio, Julho e Novembro com plantios em Maio e, ainda, colheitas de Maio com plantios em Março.

As figuras 101, 102, 103 e 104, a seguir, mostram a evolução de TAH onde se pode verificar o efeito das épocas de colheita sobre as épocas de plantio. 
Resultados deTAH- Safra 1987

corte 1 - época de plantio Novembro

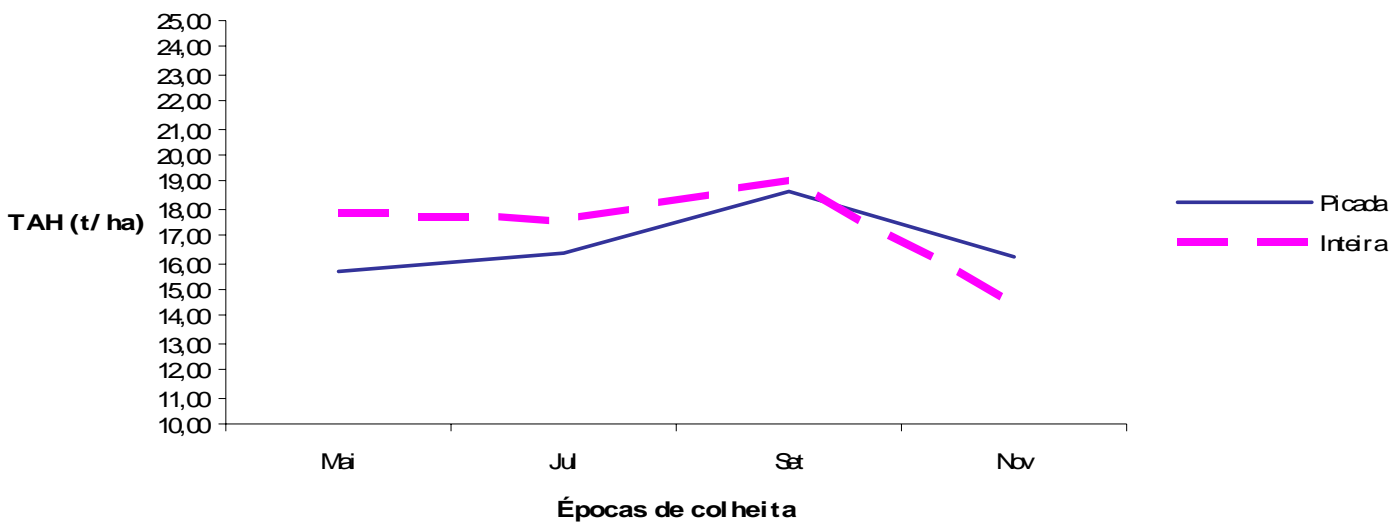

Figura 101 - Resultados de TAH para a variedade NA 56-79 na safra 1987, no $1^{\circ}$ corte e na época de plantio Novembro

\section{Resultados deTAH- Safra 1987 \\ corte 1 - época de plantio Janeiro}

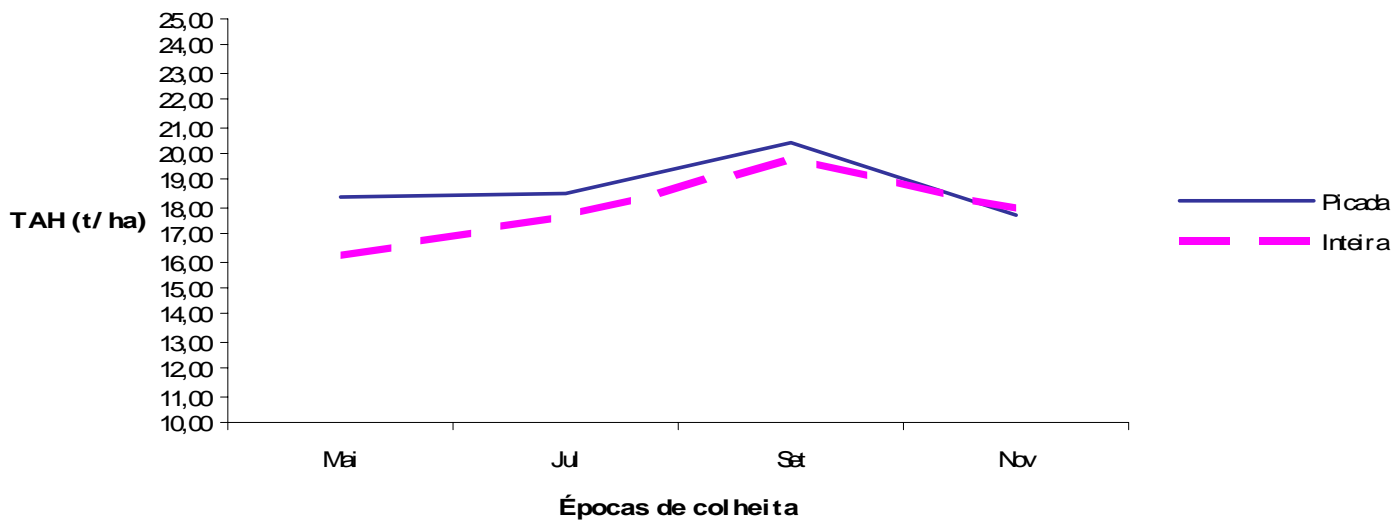

Figura 102 - Resultados de TAH para a variedade NA 56-79 na safra 1987 , no $1^{\circ}$ corte e na época de plantio Janeiro 
Resultados deTAH- Safra 1987 corte 1 - época de plantio Março

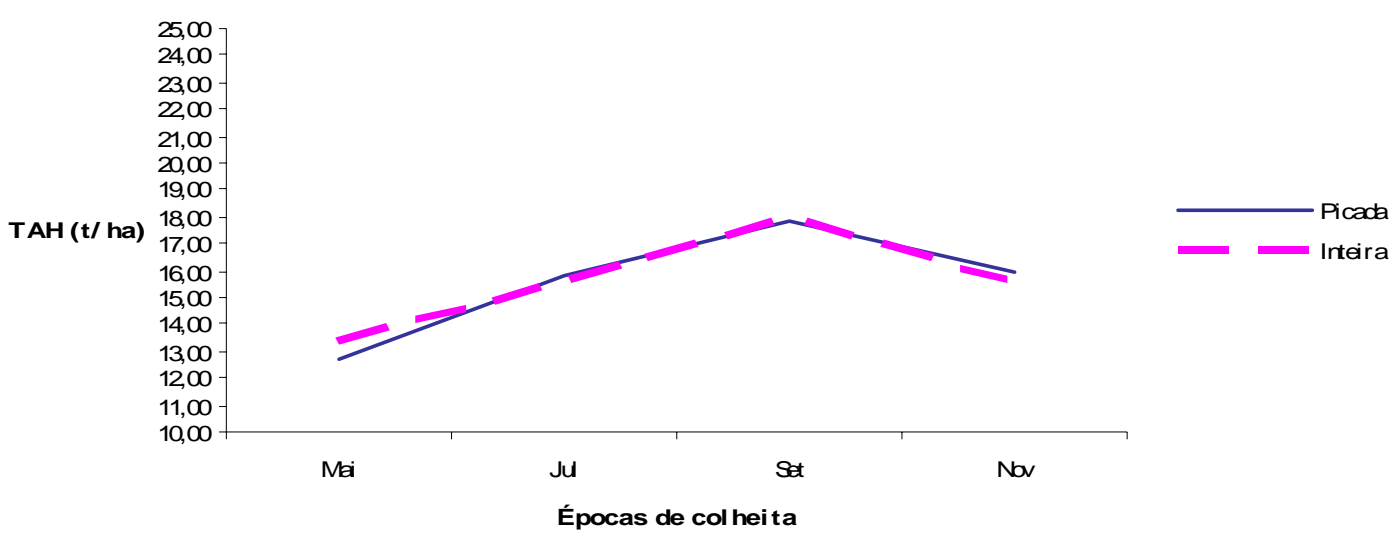

Figura 103 - Resultados de TAH para a variedade NA 56-79 na safra 1987, no $1^{\circ}$ corte e na época de plantio Março

Resultados deTAH- Safra 1987

corte 1 - época de plantio Maio

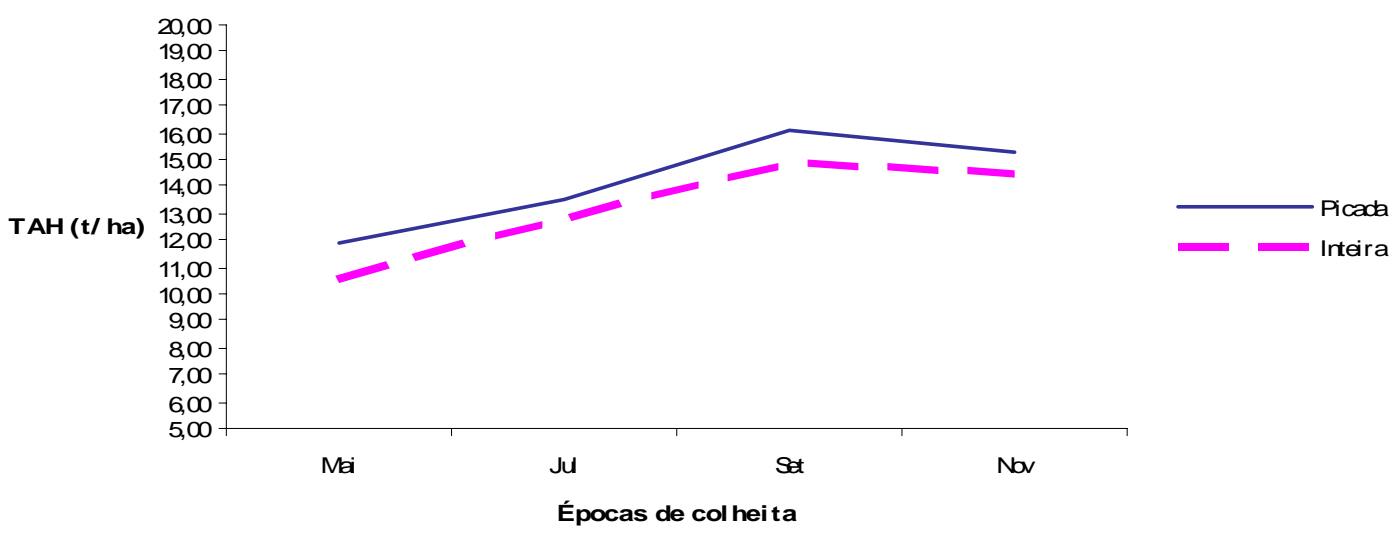

Figura 104 - Resultados de TAH para a variedade NA 56-79 na safra 1987, no $1^{\circ}$ corte e na época de plantio Maio 
$\mathrm{Na}$ tabela 49, a seguir, mostram-se os valores médios das safras de 1985, 1986, e 1987 para TCH, ATR e TAH da variedade NA 56-79, no primeiro corte, nas várias combinações de épocas de plantio e de colheita e nos tratamentos muda picada e inteira no sulco de plantio.

Comparando as os resultados ano a ano, observa-se que no ano de plantio 1983/84 houve efeito significativo de época de plantio para as três variáveis estudadas; para época de corte houve efeito significativo apenas para as variáveis ATR e TAH. O tratamento muda picada e inteira no sulco de plantio não apresentou efeito significativo, e houve interação de épocas de plantio dentro de épocas de colheita apenas para as variáveis ATR e TAH.

No ano de plantio 1984/85, para as variáveis TCH, ATR e TAH houve efeito significativo de época de plantio e de épocas de colheita. O tratamento muda picada e inteira no sulco de plantio não apresentou efeito significativo e houve interação de épocas de plantio dentro de épocas de colheita apenas para as variáveis ATR e TAH.

No ano de plantio 1985/86, houve efeito significativo de épocas de plantio e de épocas de colheita para as variáveis TCH, ATR e TAH. O tratamento muda picada e inteira no sulco de plantio não apresentou efeito significativo e houve interação de épocas de plantio dentro de épocas de colheita para as três variáveis estudadas.

Para os três anos estudados a variedade NA 56-79, apresentou efeito significativo de época de plantio para as variáveis TCH, ATR e TAH. No ano de plantio 1983/84, época de corte apresentou efeito significativo apenas para as variáveis ATR e TAH e nos anos de plantio 1984/85 e 1985/86, houve efeito significativo de épocas de colheita para as variáveis TCH, ATR e TAH.

O tratamento muda picada e inteira no sulco de plantio não apresentou efeito significativo para nenhuma das variáveis estudadas em nenhum dos anos.

Nos anos de plantio 1983/84 e 1984/85 houve interação de épocas de plantio dentro de épocas de colheita apenas para as variáveis ATR e TAH e no 
ano de plantio 1985/86 houve interação de épocas de plantio dentro de épocas de colheita para as três variáveis estudadas.

Em todos os anos estudados, os resultados de ATR sempre evoluíram do início para o final da safra com os picos localizados no mês de setembro e ligeira queda no mês de novembro com destaque para a época de plantio Maio que sempre apresentou os menores valores iniciais. TAH sempre acompanhou as curvas de ATR sendo influenciado por TCH. Ainda, a época de plantio Maio sempre apresentou os menores valores para todas as variáveis estudadas comprovando que esta época de plantio deve ser evitada. 
Tabela 49. Valores médios de TCH, ATR e TAH para a variedade NA 56-79, no primeiro corte e nas safras de 1985, 1986 e 1987, em várias combinações de épocas de plantio e de colheita e sob os tratamentos muda picada e inteira no sulco de plantio

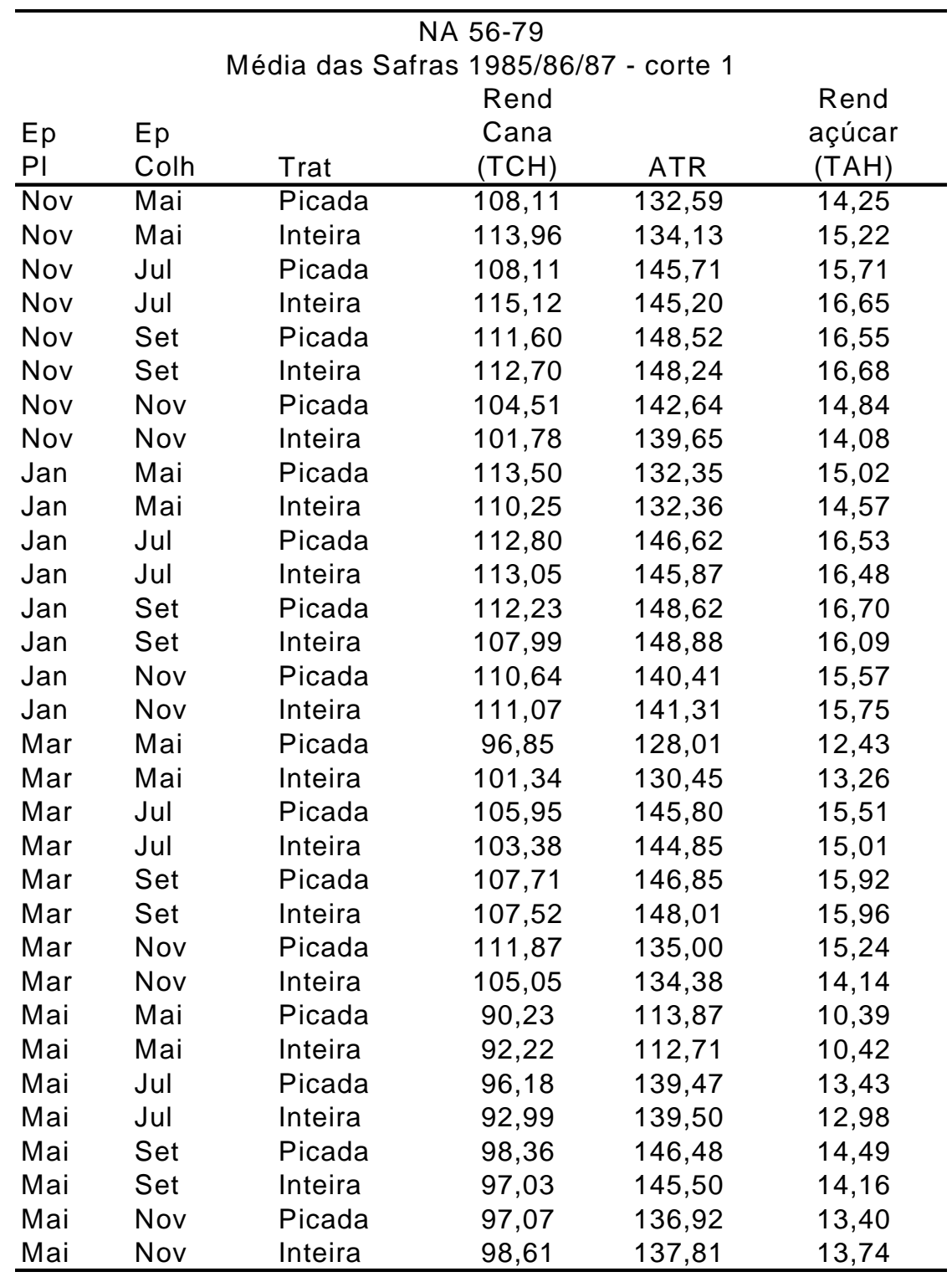

As figuras 105, 106 e 107, a seguir, mostram, respectivamente, a evolução de TCH, ATR e TAH médias das safras de 1985, 1986 e 1987 para as épocas de plantio e de colheita. 
Resultados de TCH - Média das Safras 1985/86/87 corte 1 - épocas de plantio e colheita

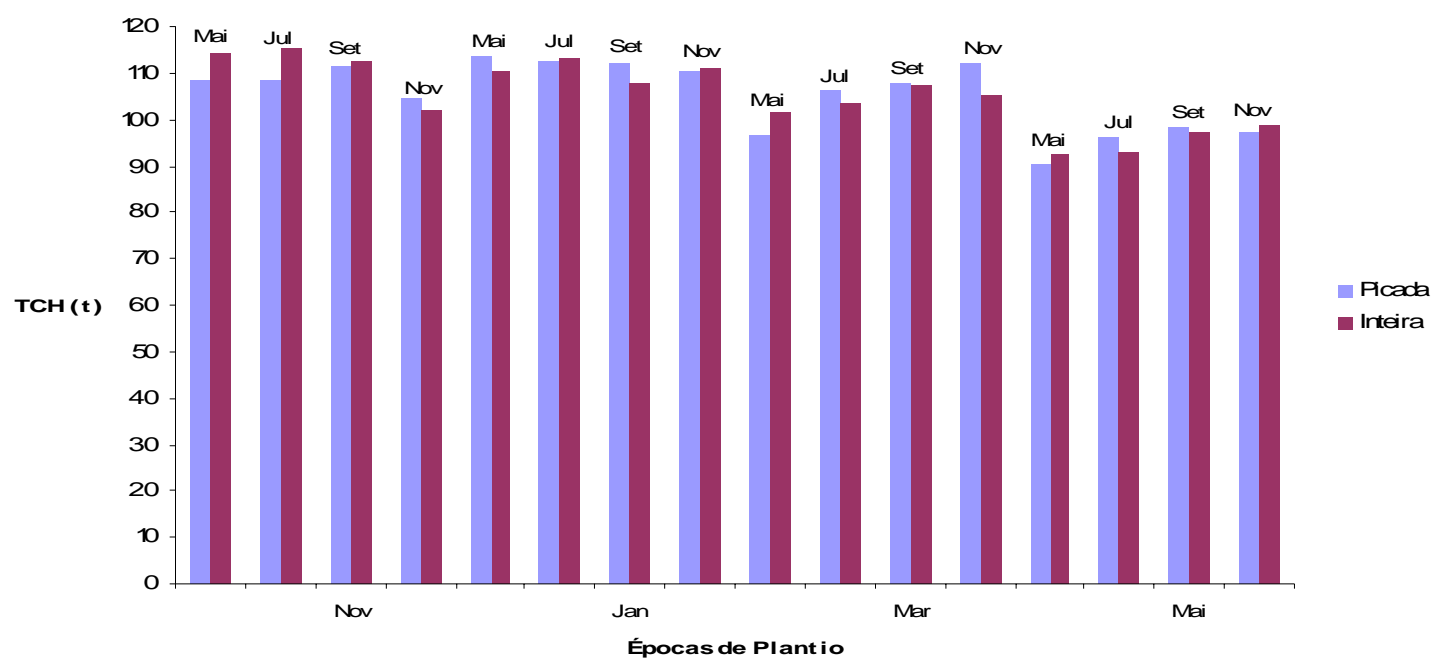

Figura 105 - Resultados médios de TCH para a variedade NA 56-79 nas safras 1985/86/87, no $1^{\circ}$ corte e nas épocas de plantio e colheita

\footnotetext{
Resultados de ATR - Média das Safras 1985/86/87 corte 1 - épocas de plantio e colheita
}

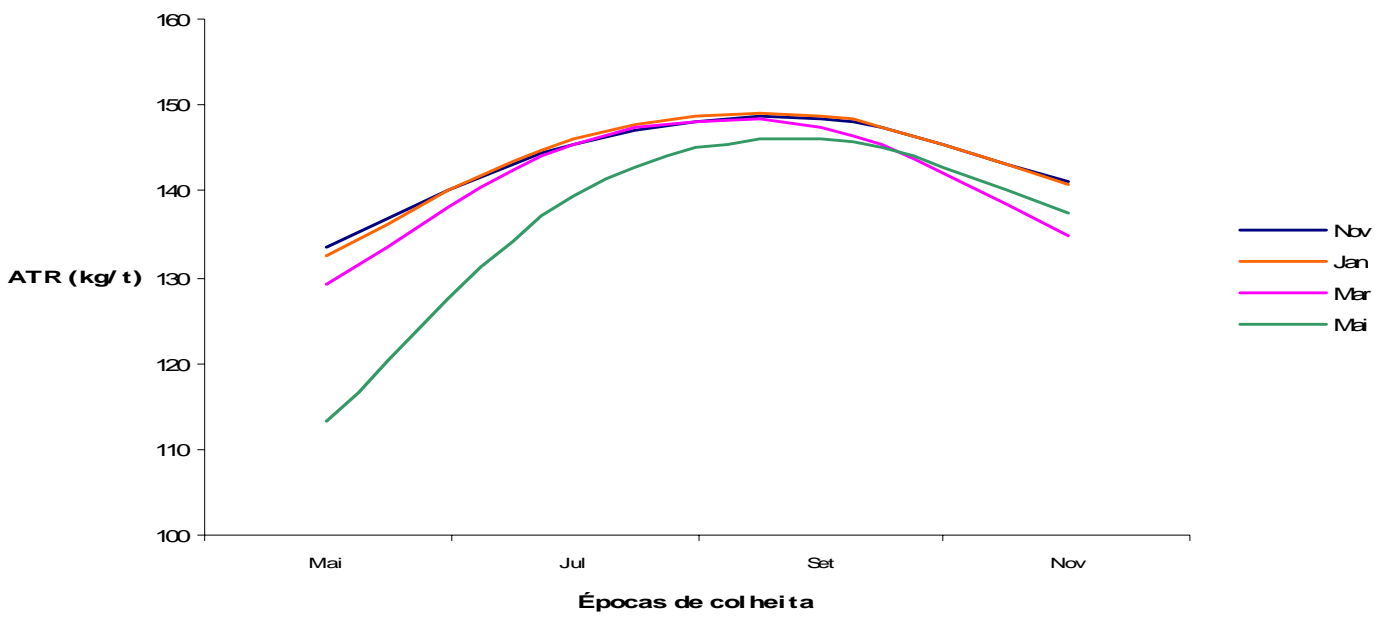

Figura 106 - Resultados médios de ATR para a variedade NA 56-79 nas safras 1985/86/87, no $1^{\circ}$ corte e nas épocas de plantio e colheita 
Resultados de TAH - Média das Safras 1985/86/87

corte 1- épocas de plantio e colheita

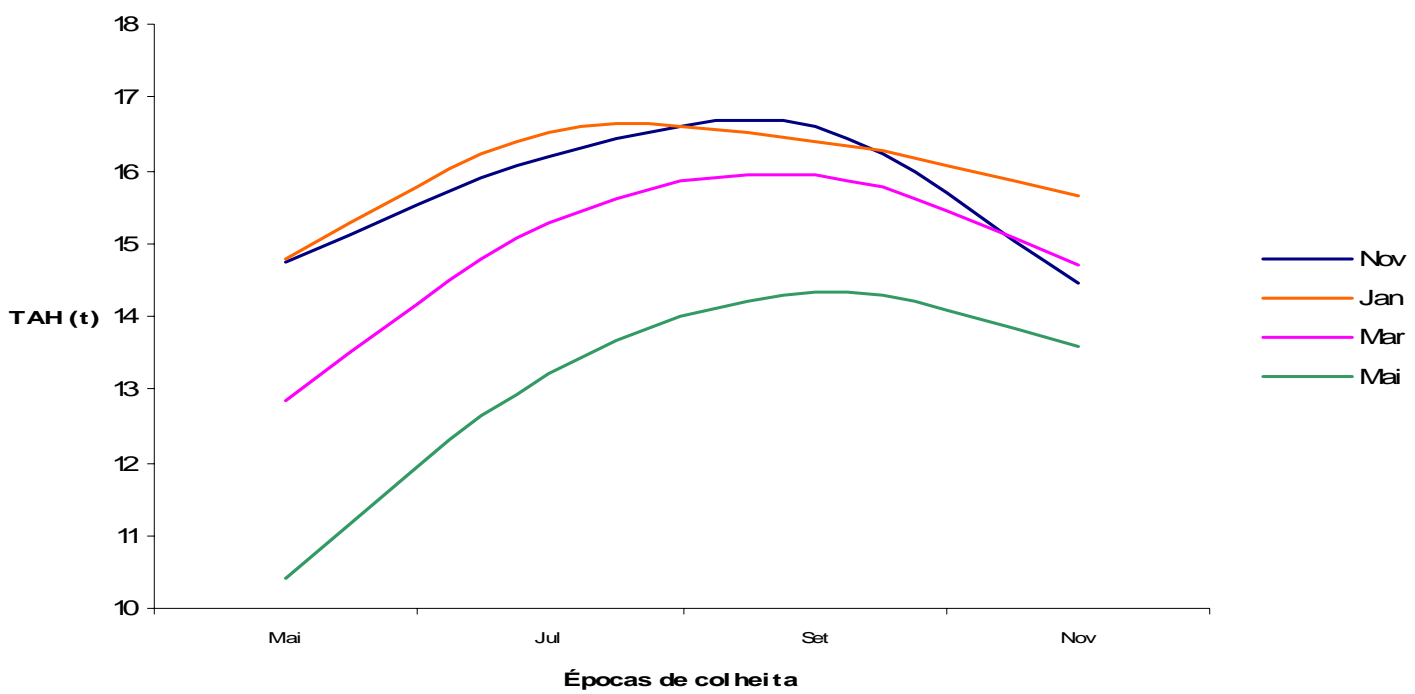

Figura 107 - Resultados médios de TAH para a variedade NA 56-79 nas safras 1985/86/87, no $1^{\circ}$ corte e nas épocas de plantio e colheita

\subsection{Variedade NA $56-79-2^{\circ}$ corte}

São apresentados na tabela 50, a seguir, os resultados obtidos no segundo corte nas safras de 1986, 1987 e 1988, para toneladas de cana por ha (TCH), açúcar total recuperável (ATR) em kg de açúcar por tonelada de cana e (TAH) toneladas de açúcar por ha, para a variedade NA 56-79. 
Tabela 50. Valores obtidos de TCH, ATR e TAH para a variedade NA 56-79, no segundo corte e nas safras de 1986, 1987 e 1988, em várias combinações de épocas de plantio e de colheita e sob os tratamentos muda picada e inteira no sulco de plantio

\begin{tabular}{|c|c|c|c|c|c|c|c|c|c|c|c|}
\hline \multicolumn{12}{|c|}{ NA 56-79 } \\
\hline \multirow[b]{2}{*}{$\begin{array}{l}\text { Ep } \\
\text { PI }\end{array}$} & \multirow[b]{2}{*}{$\begin{array}{c}\text { Ep } \\
\text { Colh }\end{array}$} & \multirow[b]{2}{*}{ Trat } & \multicolumn{3}{|c|}{ Safra 1986 - corte 2} & \multicolumn{3}{|c|}{ Safra 1987 - corte 2} & \multicolumn{3}{|c|}{ Safra 1988 - corte 2} \\
\hline & & & $\begin{array}{l}\text { Rend } \\
\text { Cana } \\
(\mathrm{TCH})\end{array}$ & ATR & $\begin{array}{l}\text { Rend } \\
\text { açúcar } \\
\text { (TAH) }\end{array}$ & $\begin{array}{l}\text { Rend } \\
\text { Cana } \\
(\mathrm{TCH})\end{array}$ & ATR & $\begin{array}{l}\text { Rend } \\
\text { açúcar } \\
\text { (TAH) }\end{array}$ & $\begin{array}{l}\text { Rend } \\
\text { Cana } \\
(\mathrm{TCH})\end{array}$ & ATR & $\begin{array}{l}\text { Rend } \\
\text { açúcar } \\
\text { (TAH) }\end{array}$ \\
\hline Nov & Mai & Picada & 67,19 & 116,43 & 7,84 & 75,72 & 134,68 & 10,19 & 90,86 & 131,20 & 11,93 \\
\hline Nov & Mai & Inteira & 56,81 & 111,71 & 6,34 & 81,81 & 134,44 & 11,00 & 89,48 & 131,31 & 11,75 \\
\hline Nov & Jul & Picada & 65,57 & 138,05 & 9,05 & 78,24 & 154,49 & 12,10 & 87,14 & 149,71 & 13,05 \\
\hline Nov & Jul & Inteira & 66,17 & 139,12 & 9,19 & 77,33 & 154,31 & 11,93 & 90,48 & 147,80 & 13,38 \\
\hline Nov & Set & Picada & 69,10 & 136,02 & 9,40 & 76,57 & 162,47 & 12,44 & 70,53 & 166,43 & 11,74 \\
\hline Nov & Set & Inteira & 70,38 & 137,58 & 9,66 & 74,14 & 160,00 & 11,86 & 68,86 & 162,66 & 11,21 \\
\hline Nov & Nov & Picada & 65,19 & 111,34 & 7,20 & 66,76 & 146,74 & 9,80 & 56,33 & 163,84 & 9,26 \\
\hline Nov & Nov & Inteira & 57,38 & 110,95 & 6,36 & 66,76 & 147,72 & 9,86 & 55,43 & 165,55 & 9,18 \\
\hline Jan & Mai & Picada & 79,48 & 111,58 & 8,90 & 76,00 & 134,32 & 10,21 & 90,48 & 133,92 & 12,12 \\
\hline Jan & Mai & Inteira & 81,91 & 114,24 & 9,35 & 74,43 & 137,35 & 10,22 & 80,00 & 132,82 & 10,60 \\
\hline Jan & Jul & Picada & 71,43 & 136,61 & 9,76 & 85,34 & 155,03 & 13,23 & 89,00 & 150,33 & 13,38 \\
\hline Jan & Jul & Inteira & 75,19 & 139,27 & 10,48 & 79,38 & 154,42 & 12,27 & 85,91 & 151,69 & 13,03 \\
\hline Jan & Set & Picada & 80,57 & 140,56 & 11,35 & 81,76 & 160,54 & 13,11 & 71,67 & 163,92 & 11,75 \\
\hline Jan & Set & Inteira & 79,72 & 137,90 & 11,00 & 75,72 & 160,85 & 12,17 & 67,14 & 164,54 & 11,05 \\
\hline Jan & Nov & Picada & 73,00 & 122,84 & 8,98 & 71,62 & 148,77 & 10,64 & 54,76 & 163,76 & 8,98 \\
\hline Jan & Nov & Inteira & 71,10 & 125,31 & 8,92 & 74,86 & 148,37 & 11,10 & 53,86 & 163,43 & 8,79 \\
\hline Mar & Mai & Picada & 72,79 & 111,73 & 8,18 & 82,72 & 135,20 & 11,19 & 83,95 & 131,74 & 11,06 \\
\hline Mar & Mai & Inteira & 77,22 & 115,96 & 8,97 & 81,33 & 136,59 & 11,12 & 86,24 & 135,36 & 11,66 \\
\hline Mar & Jul & Picada & 63,55 & 137,90 & 8,76 & 73,38 & 153,89 & 11,29 & 88,91 & 150,29 & 13,38 \\
\hline Mar & Jul & Inteira & 66,14 & 136,92 & 9,04 & 74,38 & 153,98 & 11,47 & 83,53 & 148,79 & 12,43 \\
\hline Mar & Set & Picada & 76,67 & 140,14 & 10,75 & 77,33 & 160,31 & 12,40 & 73,19 & 166,21 & 12,16 \\
\hline Mar & Set & Inteira & 76,67 & 138,03 & 10,58 & 77,38 & 160,13 & 12,39 & 74,48 & 163,99 & 12,22 \\
\hline Mar & Nov & Picada & 67,43 & 120,83 & 8,14 & 70,24 & 147,18 & 10,35 & 53,48 & 165,96 & 8,88 \\
\hline Mar & Nov & Inteira & 66,29 & 121,87 & 8,08 & 67,48 & 148,12 & 10,01 & 52,14 & 163,10 & 8,51 \\
\hline Mai & Mai & Picada & 69,22 & 108,48 & 7,50 & 79,29 & 135,17 & 10,73 & 101,14 & 130,96 & 13,25 \\
\hline Mai & Mai & Inteira & 68,57 & 109,30 & 7,49 & 74,57 & 135,31 & 10,10 & 99,38 & 129,33 & 12,86 \\
\hline Mai & Jul & Picada & 66,76 & 136,80 & 9,13 & 68,57 & 155,02 & 10,65 & 87,34 & 148,37 & 12,96 \\
\hline Mai & Jul & Inteira & 63,50 & 136,35 & 8,66 & 67,24 & 154,00 & 10,35 & 90,29 & 146,78 & 13,26 \\
\hline Mai & Set & Picada & 80,10 & 141,76 & 11,35 & 79,43 & 158,76 & 12,61 & 72,91 & 160,43 & 11,62 \\
\hline Mai & Set & Inteira & 75,14 & 140,87 & 10,59 & 75,38 & 154,39 & 11,63 & 73,00 & 164,60 & 12,01 \\
\hline Mai & Nov & Picada & 71,05 & 119,43 & 8,48 & 72,72 & 149,33 & 10,83 & 54,72 & 161,65 & 8,84 \\
\hline Mai & Nov & Inteira & 63,67 & 119,37 & 7,58 & 70,62 & 148,99 & 10,53 & 54,72 & 163,25 & 8,93 \\
\hline
\end{tabular}


Tabela 51. Resumo dos quadros de análise de variância dos dados obtidos para a variedade NA 56-79, no segundo corte e com plantio no ano de 1983/84, em relação às variáveis dependentes TCH, ATR e TAH em várias combinações de épocas de plantio e de colheita e sob os tratamentos cana picada e inteira no sulco de plantio

\begin{tabular}{lcccc}
\hline & & TCH & ATR & TAH \\
\multicolumn{1}{c}{ C. Variação } & $G L$ & $Q M$ & $Q M$ & $Q M$ \\
\hline BLOCO & 4 & -- & -- & -- \\
EPCOL & 3 & $738,618^{* *}$ & $7146,685^{* *}$ & $60,001^{* *}$ \\
Resíduo (a) & 12 & 37,745 & 42,711 & 0,765 \\
EPPLA & 3 & $941,634^{* *}$ & $91,166^{*}$ & $19,850^{* *}$ \\
Resíduo (b) & 12 & 49,946 & 26,556 & 0,783 \\
TRAT & 1 & 84,434 & 2,809 & 0,923 \\
EPCOL ${ }^{*} E P P L A$ & 9 & $86,401^{*}$ & $106,248^{* *}$ & $1,935^{*}$ \\
EPCOL ${ }^{*} T R A T$ & 3 & 51,931 & 7,462 & 0,723 \\
EPPLA ${ }^{*} T R A T$ & 3 & 91,866 & 6,870 & 1,686 \\
EPCOL ${ }^{*} E P P L A^{*} T R A T$ & 9 & 29,615 & 16,959 & 0,813 \\
Resíduo (c) & 100 & 36,452 & 23,629 & 0,673 \\
Total & 159 & -- & -- & -- \\
\hline
\end{tabular}

A tabela 51, apresentada, mostra os valores da análise de variância, para as variáveis ATR, TCH e TAH, da variedade NA 56-79, no segundo corte e com plantio no ano de 1983/84.

Como se pode observar, para as variáveis TCH, ATR e TAH houve efeito significativo de épocas de plantio e de épocas de colheita. $O$ tratamento muda picada e inteira no sulco de plantio não apresentou efeito significativo para as variáveis estudadas.

Houve interação de épocas de plantio dentro de épocas de colheita para as três variáveis estudadas, indicando diferenças significativas entre as épocas de plantio para cada época de colheita. Não houve qualquer outra interação. 


\section{Resultados de TCH- Safra 1986 \\ corte 2 - época de plantio Novembro}

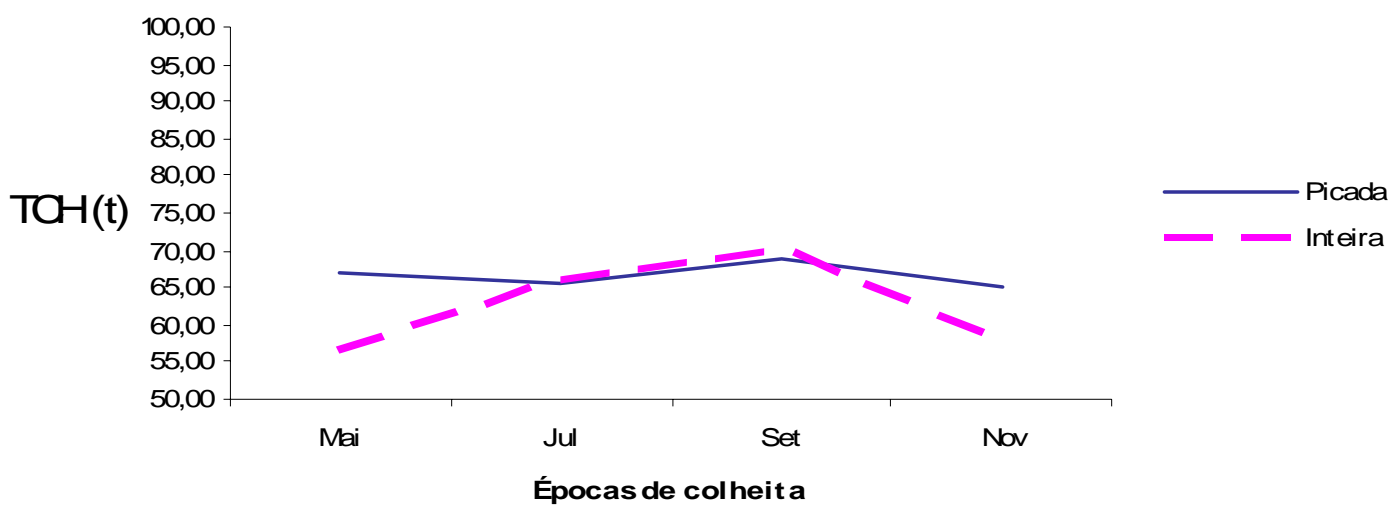

Figura 108 - Resultados de TCH para a variedade NA 56-79 na safra 1986 , no $2^{\circ}$ corte e época de plantio Novembro

Resultados de TCH- Safra 1986 corte 2 - época de plantio Janeiro

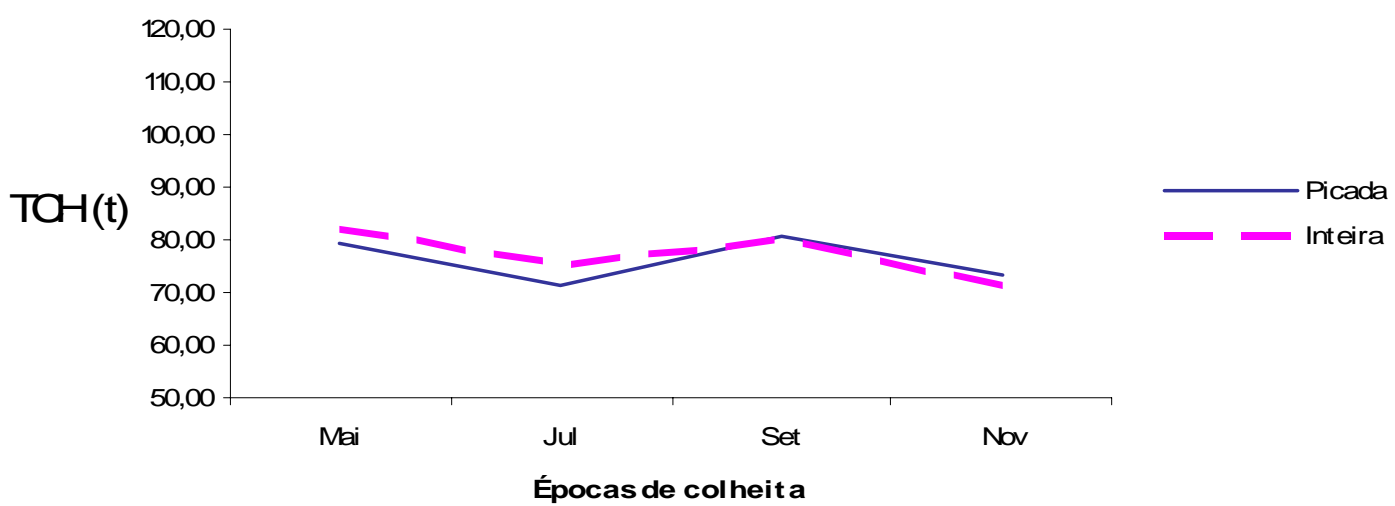

Figura 109 - Resultados de TCH para a variedade NA 56-79 na safra 1986 , no $2^{\circ}$ corte e época de plantio Janeiro 
Resultados de TCH- Safra 1986

corte 2 - época de plantio Março

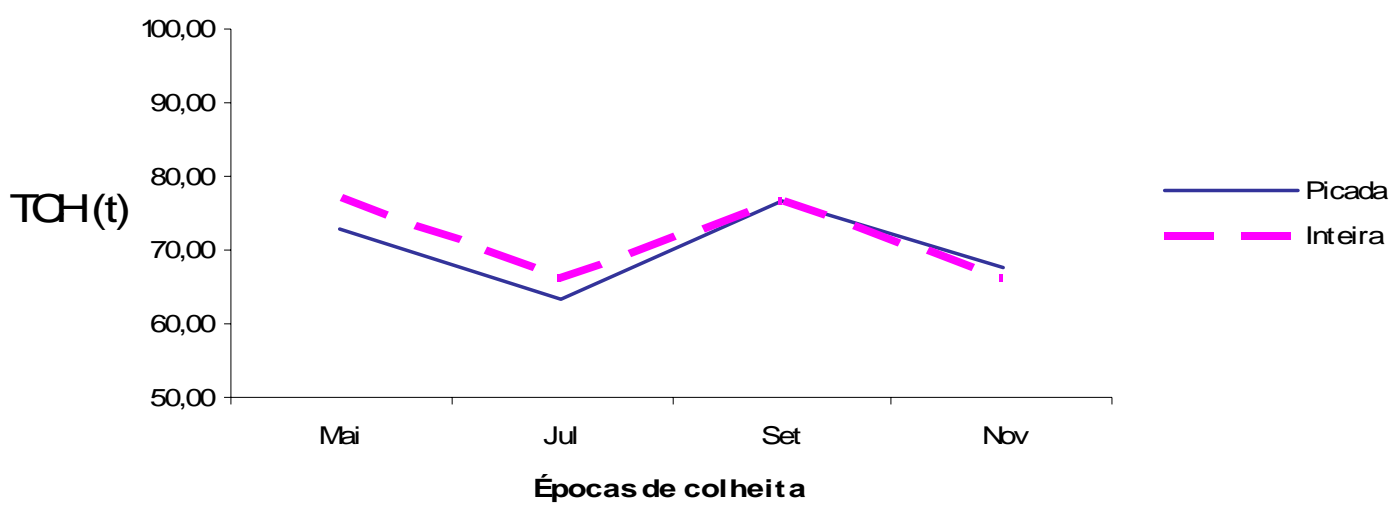

Figura 110 - Resultados de TCH para a variedade NA 56-79 na safra 1986 , no $2^{\circ}$ corte e época de plantio Março

Resultados de TCH- Safra 1986

corte 2- época de plantio Maio

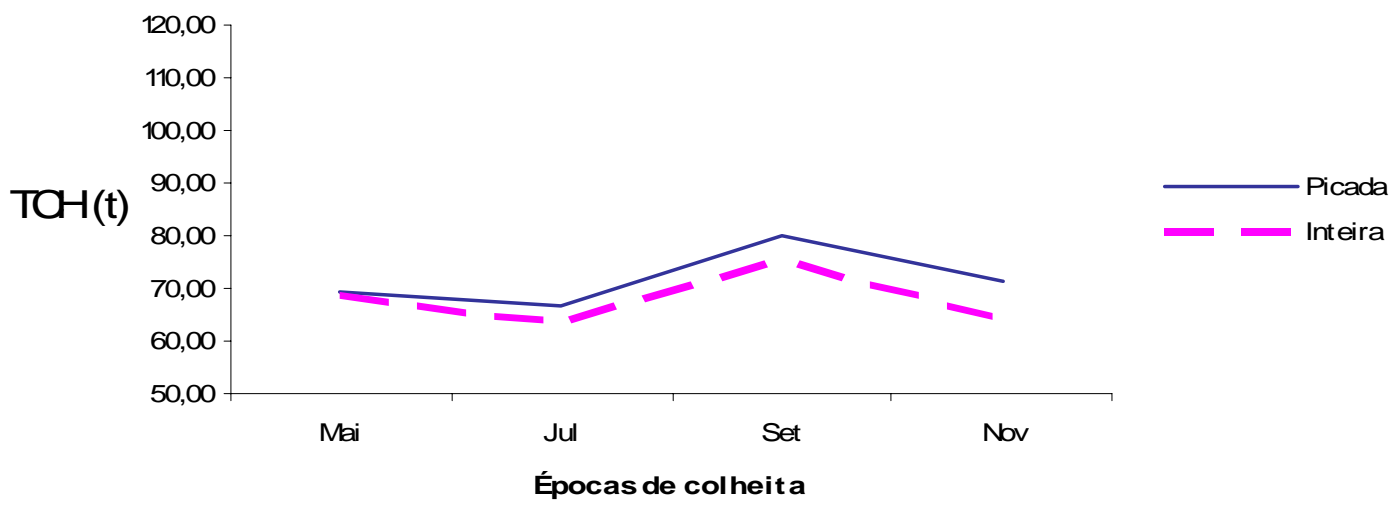

Figura 111 - Resultados de TCH para a variedade NA 56-79 na safra 1986 , no $2^{\circ}$ corte e época de plantio Maio 
Tabela 53. Valores médios de ATR para a variedade NA 56-79 nas interações de épocas de plantio dentro de épocas de colheita, no ano de $1983 / 84$, no $2^{\circ}$ corte

\begin{tabular}{cccc}
\hline EPPLA & EPCOL & \multicolumn{2}{l}{$A T R($ MÉDIA) } \\
\hline Mai & Set & 141,315 & $\mathrm{a}$ \\
Jan & Set & 139,225 & $\mathrm{a}$ \\
Mar & Set & 139,087 & $\mathrm{a}$ \\
Nov & Jul & 138,589 & $\mathrm{a}$ \\
Jan & Jul & 137,944 & $\mathrm{a}$ \\
Mar & Jul & 137,407 & $\mathrm{a}$ \\
Nov & Set & 136,798 & $\mathrm{a}$ \\
Mai & Jul & 136,576 & $\mathrm{a}$ \\
Jan & Nov & 124,074 & $\mathrm{~b}$ \\
Mar & Nov & 121,352 & $\mathrm{bc}$ \\
Mai & Nov & 119,398 & $\mathrm{bcd}$ \\
Nov & Mai & 114,070 & $\mathrm{cde}$ \\
Mar & Mai & 113,842 & $\mathrm{cde}$ \\
Jan & Mai & 112,910 & $\mathrm{de}$ \\
Nov & Nov & 111,146 & $\mathrm{e}$ \\
Mai & Mai & 108,889 & $\mathrm{e}$ \\
\hline
\end{tabular}

Médias seguidas das mesmas letras não diferiram estatisticamente entre si.

$\mathrm{Na}$ tabela 53, observa-se que para a variedade NA 56-79, plantada em 1983/84 e no segundo corte, houve diferença estatisticamente significativa entre as médias das épocas de plantio dentro das épocas de colheita.

Desses resultados pode-se concluir que para a variável ATR, o tratamento época de colheita mostrou maior influência, apresentando os valores mais altos nas épocas de colheita Setembro com plantio em Maio, Janeiro, Março e Novembro e colheita Julho com plantio em Novembro, Janeiro, Março e Maio. Os menores valores foram obtidos nas épocas de colheita Maio com plantio em Maio, Janeiro, Março e Novembro e colheita em Novembro com plantio em Novembro.

As figuras 112, 113, 114 e 115, a seguir, mostram a evolução de ATR para cada época de plantio onde se verifica o efeito das épocas de colheita sobre os valores observados. 
Resultados de ATR- Safra 1986

corte 2 - época de plantio Novembro

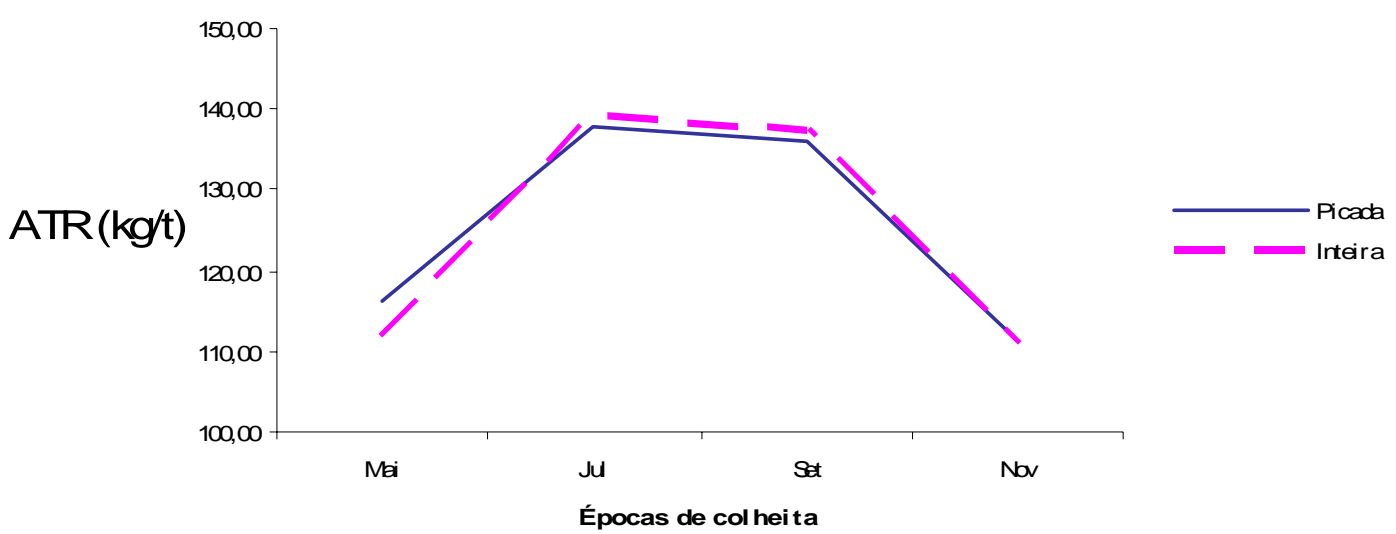

Figura 112 - Resultados de ATR para a variedade NA 56-79 na safra 1986 , no $2^{\circ}$ corte e época de plantio Novembro

Resultados de ATR- Safra 1986

corte 2 - época de plantio Janeiro

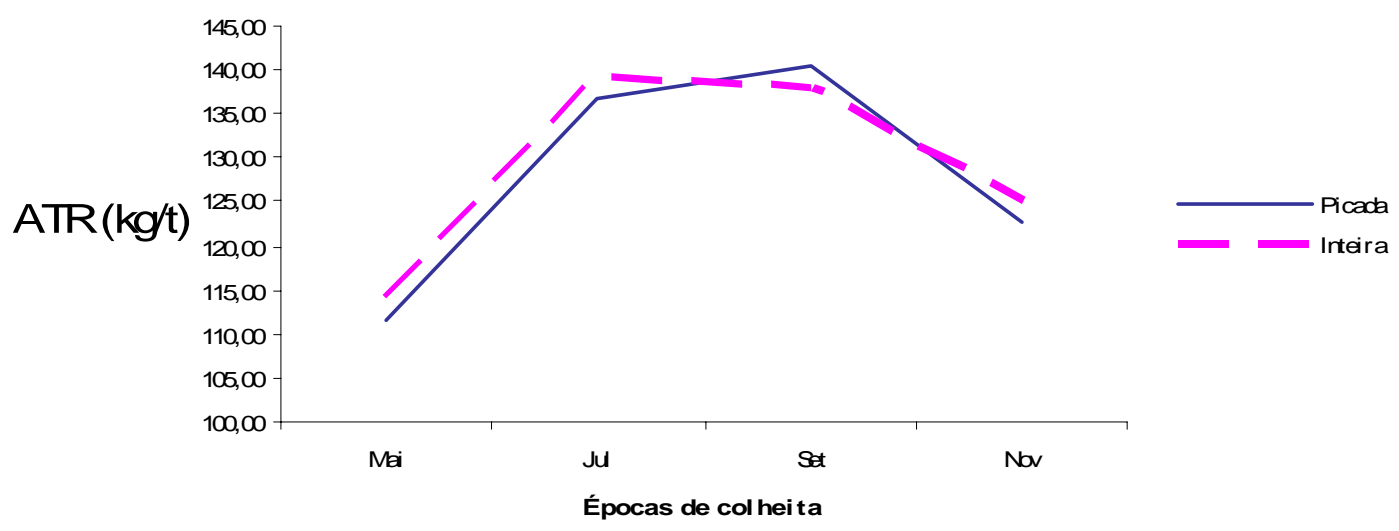

Figura 113 - Resultados de ATR para a variedade NA 56-79 na safra 1986 , no $2^{\circ}$ corte e época de plantio Janeiro 
Resultados de ATR- Safra 1986

corte 2 - época de plantio Março

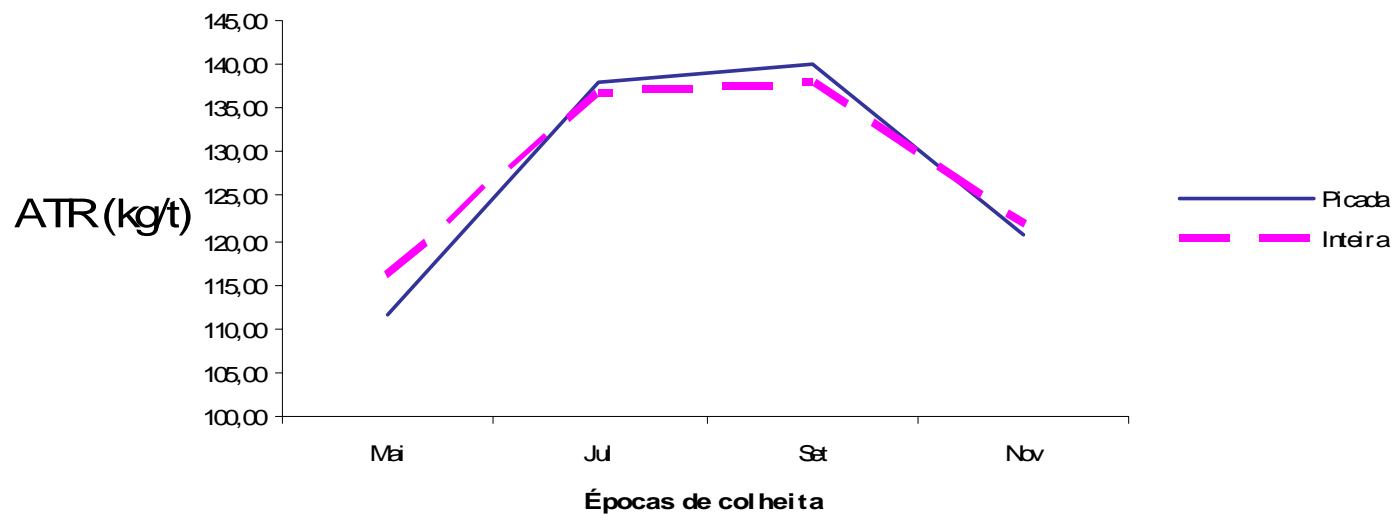

Figura 114 - Resultados de ATR para a variedade NA 56-79 na safra 1986 , no $2^{\circ}$ corte e época de plantio Março

Resultados de ATR- Safra 1986

corte 2 - época de plantio Maio

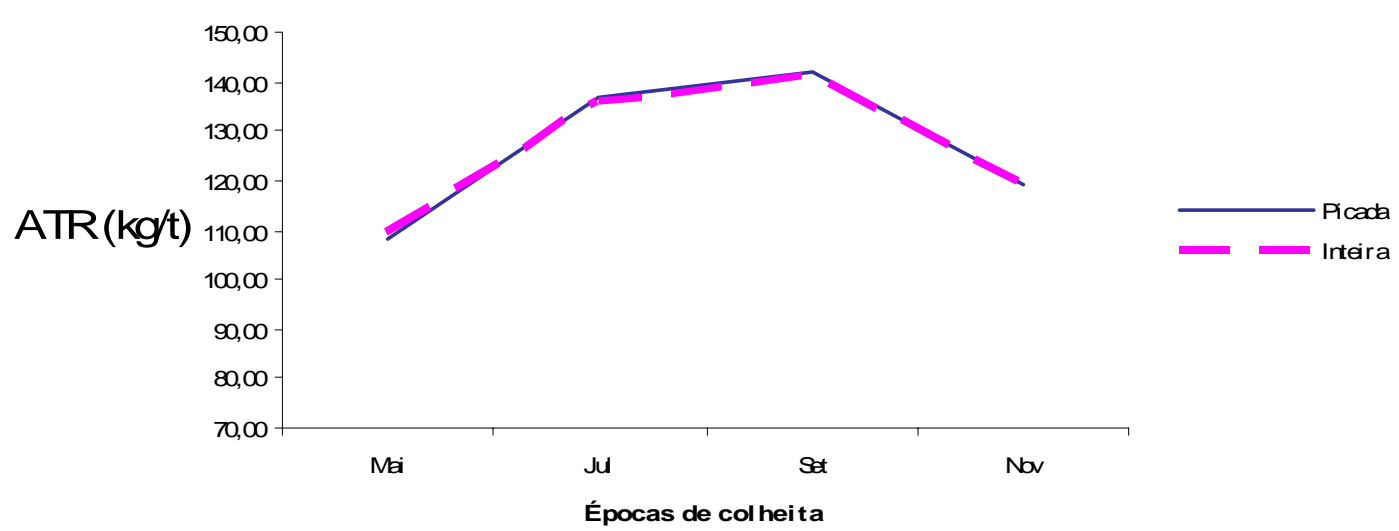

Figura 115 - Resultados de ATR para a variedade NA 56-79 na safra 1986 , no $2^{\circ}$ corte e época de plantio Maio 
Tabela 54. Valores médios de TAH para a variedade NA 56-79 nas interações de épocas de plantio dentro de épocas de colheita, no ano de $1983 / 84$, no $2^{\circ}$ corte

\begin{tabular}{|c|c|c|c|}
\hline$E P P L A$ & EPCOL & \multicolumn{2}{|c|}{ TAH (MÉDIA) } \\
\hline Jan & Set & 11,170 & \\
\hline Mai & Set & 10,969 & \\
\hline Mar & Set & 10,665 & \\
\hline Jan & Jul & 10,122 & $\mathrm{abc}$ \\
\hline Nov & Set & 9,531 & bcd \\
\hline Jan & Mai & 9,124 & cde \\
\hline Nov & Jul & 9,123 & cde \\
\hline Jan & Nov & 8,952 & cde \\
\hline Mar & Jul & 8,902 & cde \\
\hline Mai & Jul & 8,891 & cde \\
\hline Mar & Mai & 8,574 & def \\
\hline Mar & Nov & 8,112 & efg \\
\hline Mai & Nov & 8,031 & efgh \\
\hline Mai & Mai & 7,494 & fgh \\
\hline Nov & Mai & 7,089 & gh \\
\hline Nov & Nov & 6,780 & $\mathrm{~h}$ \\
\hline
\end{tabular}

Médias seguidas das mesmas letras não diferiram estatisticamente entre si.

$\mathrm{Na}$ tabela 54, observa-se que para a variável TAH na variedade NA 56-79, plantada em 1983/84 e no segundo corte, houve diferença estatisticamente significativa entre as médias das épocas de plantio dentro das épocas de colheita.

Os maiores valores foram obtidos na época de colheita Setembro com plantios em Janeiro, Maio, Março e Novembro e colheita em Julho com plantio em Janeiro. Os menores valores foram obtidos nas épocas de colheita Novembro e Maio com plantios em Novembro e Maio.

As figuras 116, 117, 118 e 119, a seguir, mostram a evolução de TAH para cada época de plantio onde se verifica o efeito das épocas de colheita sobre os valores observados. 
Resultados deTAH- Safra 1986

corte 2 - época de plantio Novembro

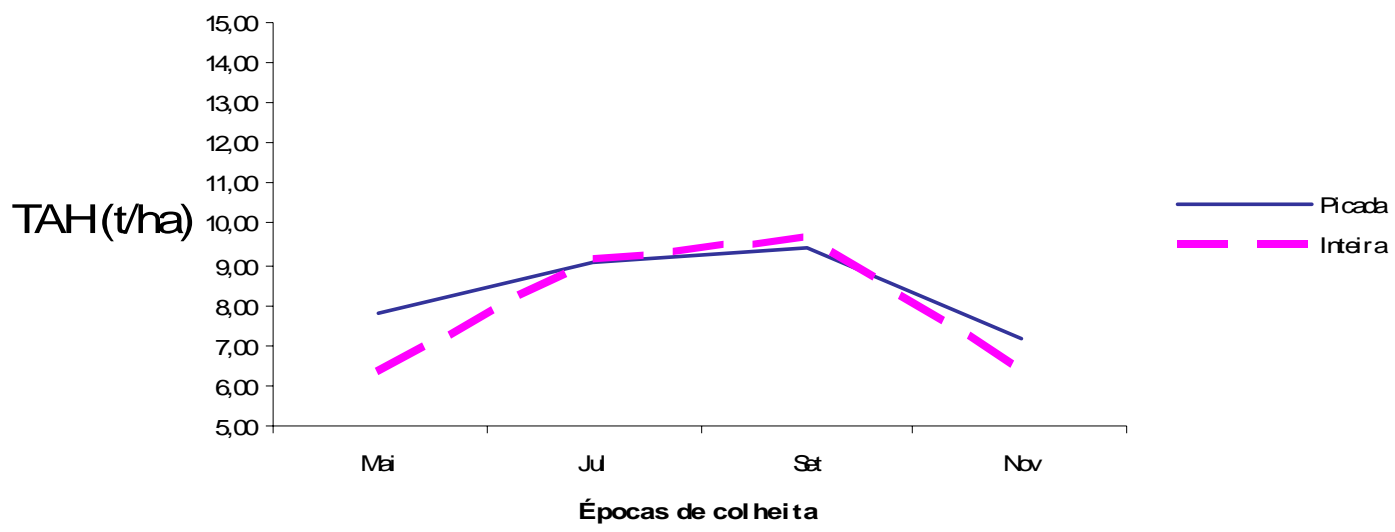

Figura 116 - Resultados de TAH para a variedade NA 56-79 na safra 1986 , no $2^{\circ}$ corte e época de plantio Novembro

\section{Resultados deTAH- Safra 1986}

corte 2 - época de plantio Janeiro

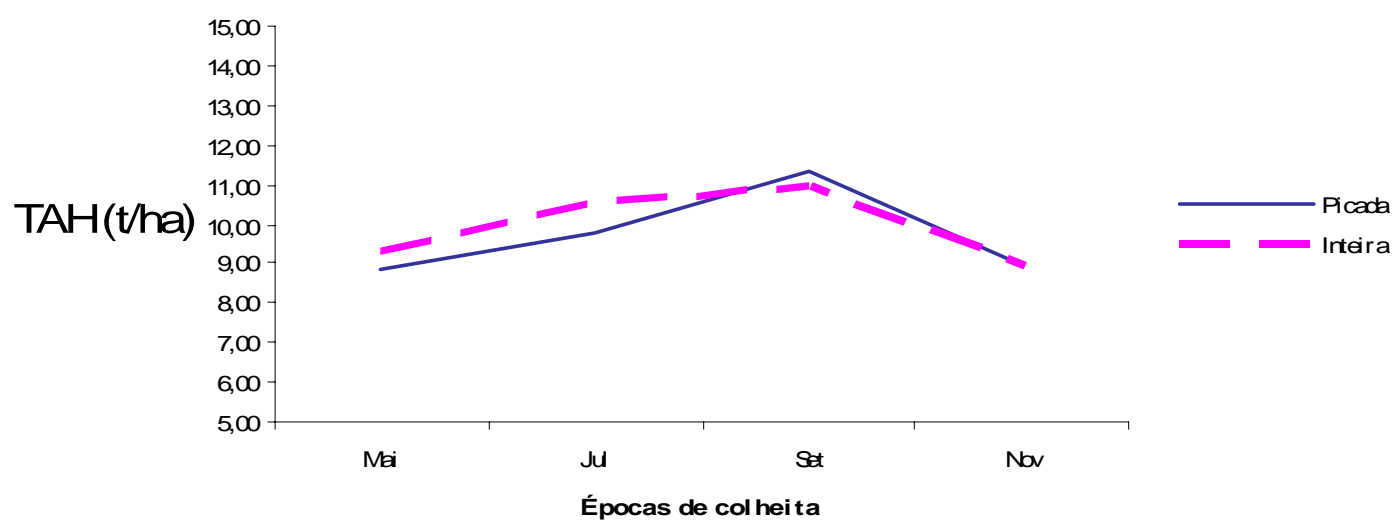

Figura 117 - Resultados de TAH para a variedade NA 56-79 na safra 1986 , no $2^{\circ}$ corte e época de plantio Janeiro 
Resultados deTAH- Safra 1986 corte 2 - época de plantio Março

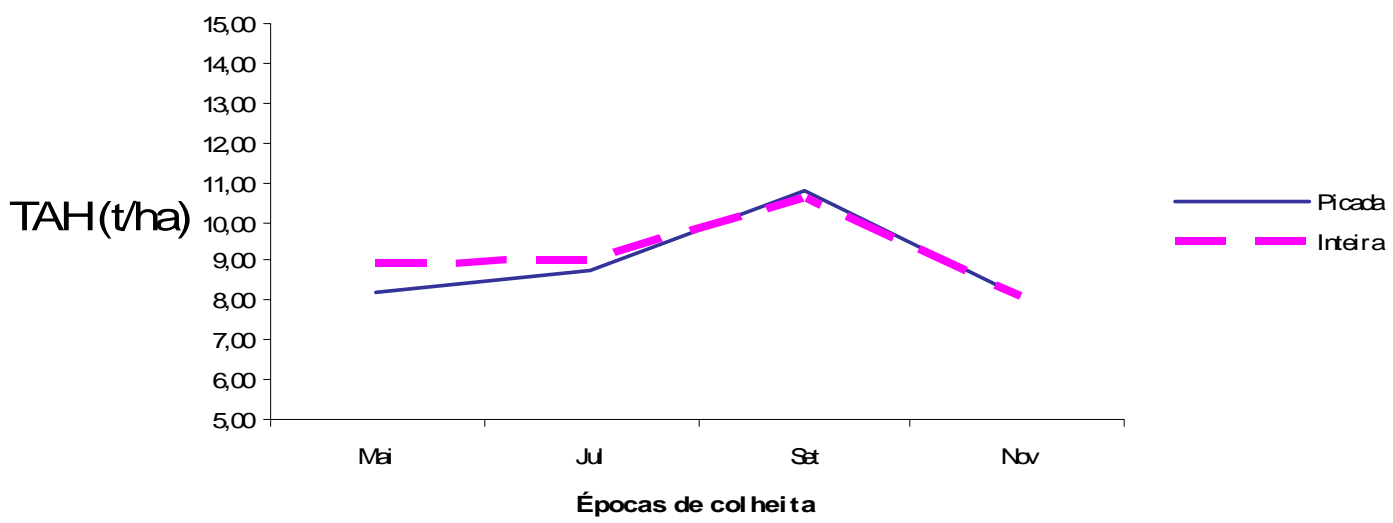

Figura 118 - Resultados de TAH para a variedade NA 56-79 na safra 1986 , no $2^{\circ}$ corte e época de plantio Março

Resultados deTAH- Safra 1986

corte 2 - época de plantio Maio

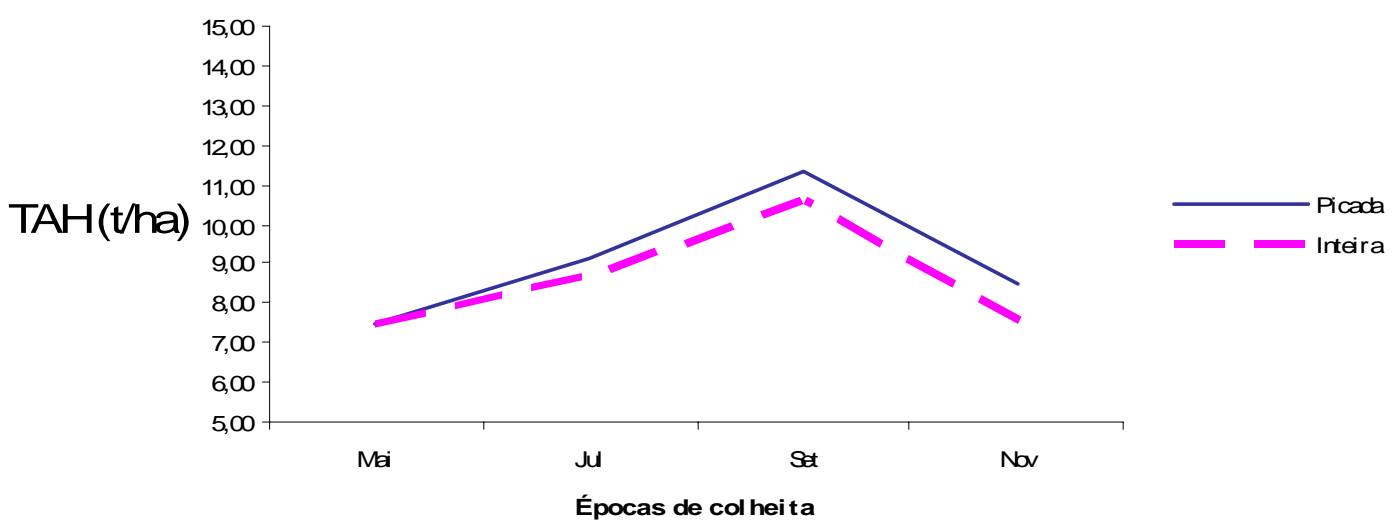

Figura 119 - Resultados de TAH para a variedade NA 56-79 na safra 1986 , no $2^{\circ}$ corte e época de plantio Maio 
Tabela 55. Resumo dos quadros de análise de variância dos dados obtidos para a variedade NA 56-79, no segundo corte e com plantio no ano de 1984/85, em relação às variáveis dependentes TCH, ATR e TAH em várias combinações de épocas de plantio e de colheita e sob os tratamentos cana picada e inteira no sulco de plantio

\begin{tabular}{|c|c|c|c|c|}
\hline C. Variação & $G L$ & $\begin{array}{c}\mathrm{TCH} \\
Q M\end{array}$ & $\begin{array}{c}\text { ATR } \\
Q M\end{array}$ & $\begin{array}{c}\mathrm{TAH} \\
Q M\end{array}$ \\
\hline$B L O C O$ & 4 & -- & - & - \\
\hline EPCOL & 3 & $520,194 * *$ & 4382,092 ** & $33,288 * *$ \\
\hline Resíduo (a) & 12 & 131,216 & 29,200 & 2,318 \\
\hline$E P P L A$ & 3 & 108,392 & 7,916 & $3,333^{*}$ \\
\hline Resíduo (b) & 12 & 150,179 & 21,742 & 3,462 \\
\hline TRAT & 1 & 81,639 & 1,358 & 2,216 \\
\hline$E P C O L{ }^{\star} E P P L A$ & 9 & $151,447^{* *}$ & 16,441 & 3,411 ** \\
\hline$E P C O L{ }^{*} T R A T$ & 3 & 17,060 & 13,738 & $\odot, 908$ \\
\hline$E P P L A^{*} T R A T$ & 3 & 29,568 & 8,984 & $\odot, 728$ \\
\hline$E P C O L{ }^{*} E P P L A{ }^{\star} T R A T$ & 9 & 26,548 & 3,432 & $\odot, 527$ \\
\hline Resíduo (c) & 100 & 40,377 & 14,744 & 1,130 \\
\hline Total & 159 & -- & -- & -- \\
\hline
\end{tabular}

A tabela 55, mostra os valores da análise de variância para as variáveis TCH, ATR e TAH da variedade NA 56-79, no segundo corte e ano de plantio 1984/85.

Como se pode observar, para a variável TAH houve efeito significativo de épocas de plantio; para as variáveis TCH, ATR e TAH houve efeito significativo de épocas de colheita $O$ tratamento muda picada e inteira no sulco de plantio não apresentou efeito significativo para as variáveis estudadas.

Houve interação de épocas de plantio dentro de épocas de colheita para as variáveis $\mathrm{TCH}$ e $\mathrm{TAH}$, indicando diferenças significativas entre as épocas de plantio para cada época de colheita. Não houve qualquer outra interação. 
Tabela 56. Valores médios de TCH para a variedade NA 56-79 nas interações de épocas de plantio dentro de épocas de colheita, com plantio no ano de $1984 / 85$, no $2^{\circ}$ corte

\begin{tabular}{ccc}
\hline EPPLA & EPCOL & TAH (MÉDIA) \\
\hline Jan & Jul & $82,357 \mathrm{a}$ \\
Mar & Mai & $82,026 \mathrm{a}$ \\
Nov & Mai & $78,762 \mathrm{ab}$ \\
Jan & Set & $78,739 \mathrm{ab}$ \\
Nov & Jul & $77,787 \mathrm{abc}$ \\
Mai & Set & $77,408 \mathrm{abc}$ \\
Mar & Set & $77,359 \mathrm{abc}$ \\
Mai & Mai & $76,930 \mathrm{abc}$ \\
Nov & Set & $75,359 \mathrm{abcd}$ \\
Jan & Mai & $75,216 \mathrm{abcd}$ \\
Mar & Jul & $73,882 \mathrm{abcd}$ \\
Jan & Nov & $73,240 \mathrm{abcd}$ \\
Mai & Nov & $71,667 \quad \mathrm{bcd}$ \\
Mar & Nov & $68,859 \mathrm{bcd}$ \\
Mai & Jul & $67,906 \quad \mathrm{~cd}$ \\
Nov & Nov & $66,762 ~ \mathrm{~d}$ \\
\hline
\end{tabular}

Médias seguidas das mesmas letras não diferiram estatisticamente entre si.

$\mathrm{Na}$ tabela 56, observa-se que para a variedade NA 56-79, no segundo corte e ano de plantio 1984/85, houve diferença estatisticamente significativa entre as médias de $\mathrm{TCH}$ para as interações épocas de plantio dentro das épocas de colheita.

Os resultados mostraram que os maiores valores de $\mathrm{TCH}$ foram obtidos nas colheitas de Julho com plantios em Janeiro; colheitas de Maio com plantios em Março e Novembro e, ainda, colheitas em Setembro com plantios em Janeiro. Os menores valores foram obtidos nas colheitas de Novembro com plantios em Novembro, Março e Maio e, ainda, colheitas de Julho com plantios em Maio.

As figuras 120, 121, 122 e 123, a seguir, mostram a evolução de TCH para cada época de plantio onde se verifica o efeito das épocas de colheita sobre os valores observados. 


\section{Resultados de TCH- Safra 1987 \\ corte 2 - época de plantio Novembro}

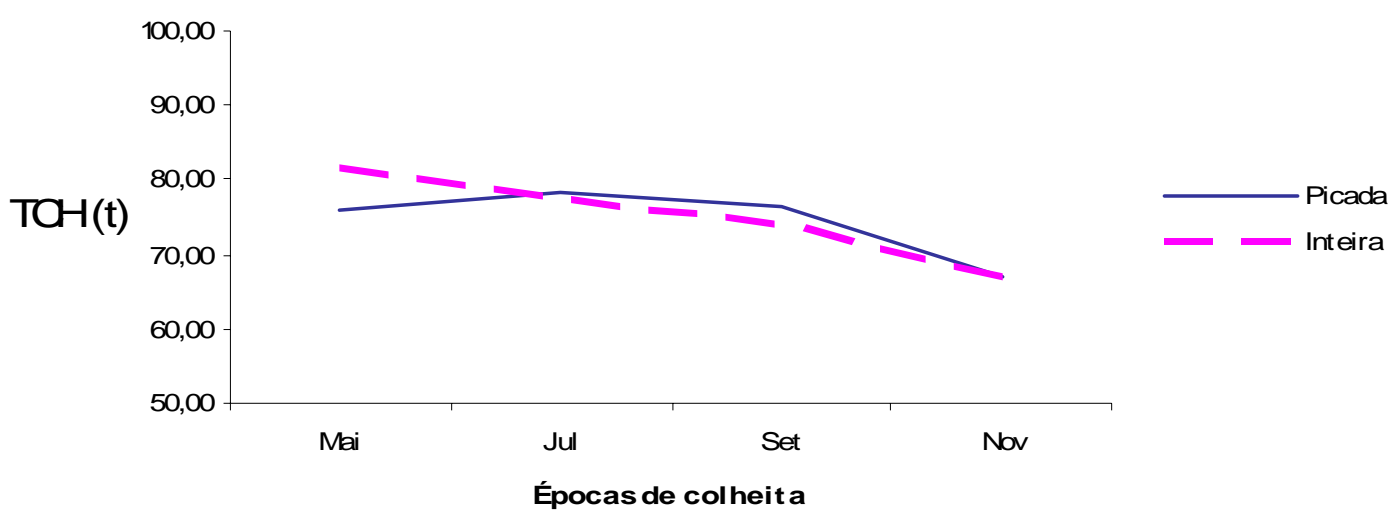

Figura 120 - Resultados de TCH para a variedade NA 56-79 na safra 1987, no $2^{\circ}$ corte e época de plantio Novembro

Resultados de TCH- Safra 1987 corte 2 - época de plantio Janeiro

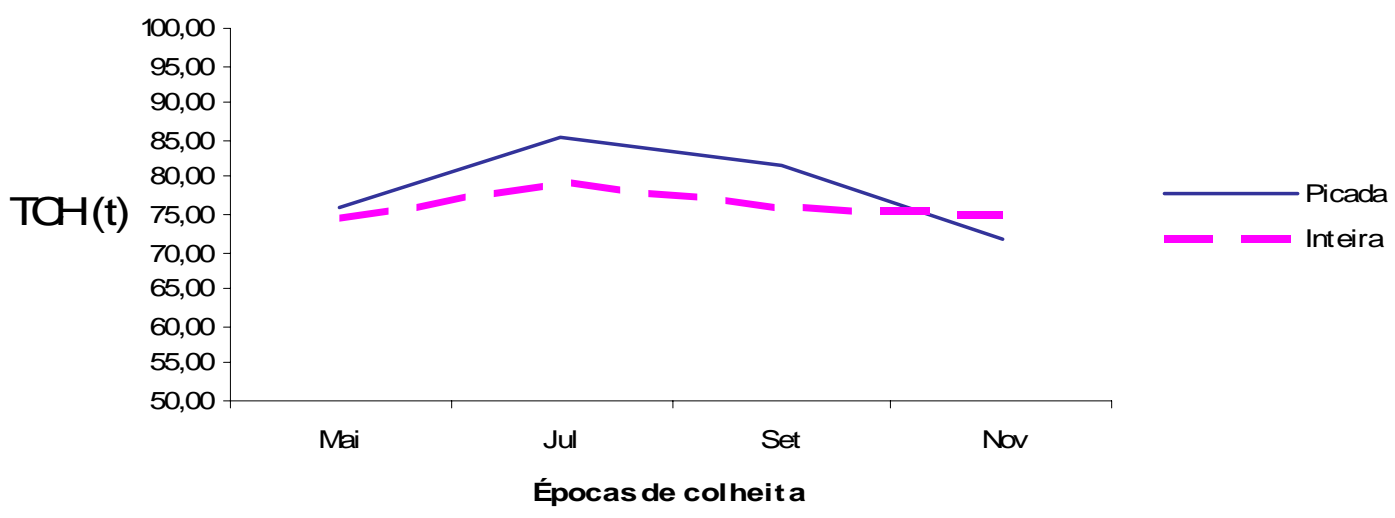

Figura 121 - Resultados de TCH para a variedade NA 56-79 na safra 1987, no $2^{\circ}$ corte e época de plantio Janeiro 


\section{Resultados de TCH- Safra 1987 \\ corte 2 - época de plantio Março}

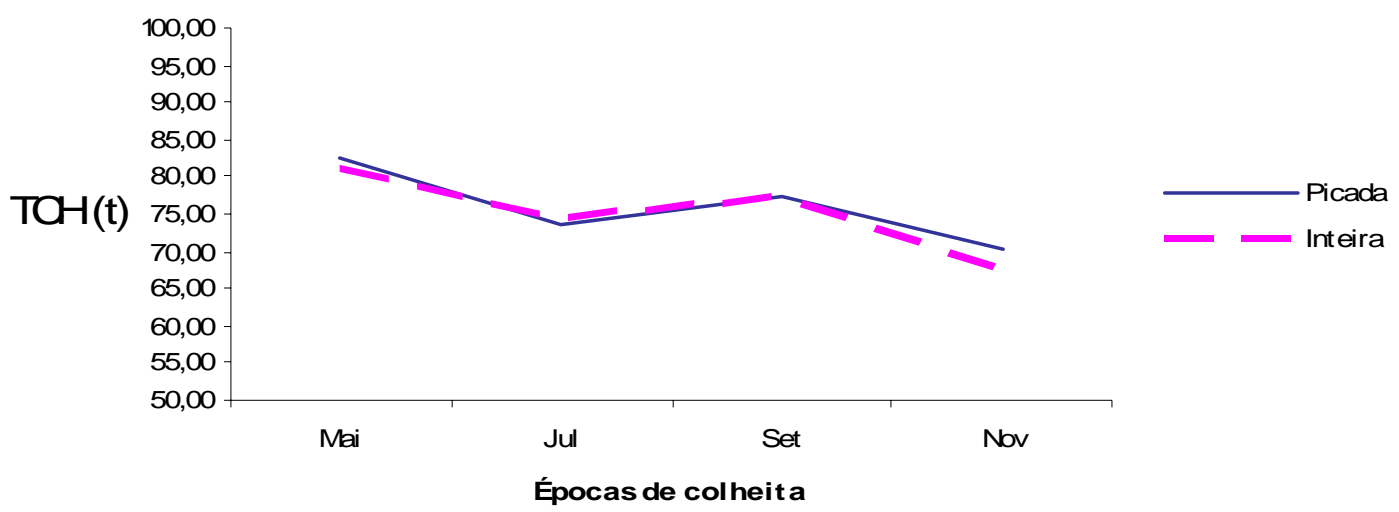

Figura 122 - Resultados de TCH para a variedade NA 56-79 na safra 1987, no $2^{\circ}$ corte e época de plantio Março

Resultados de TCH- Safra 1987

corte 2 - época de plantio Maio

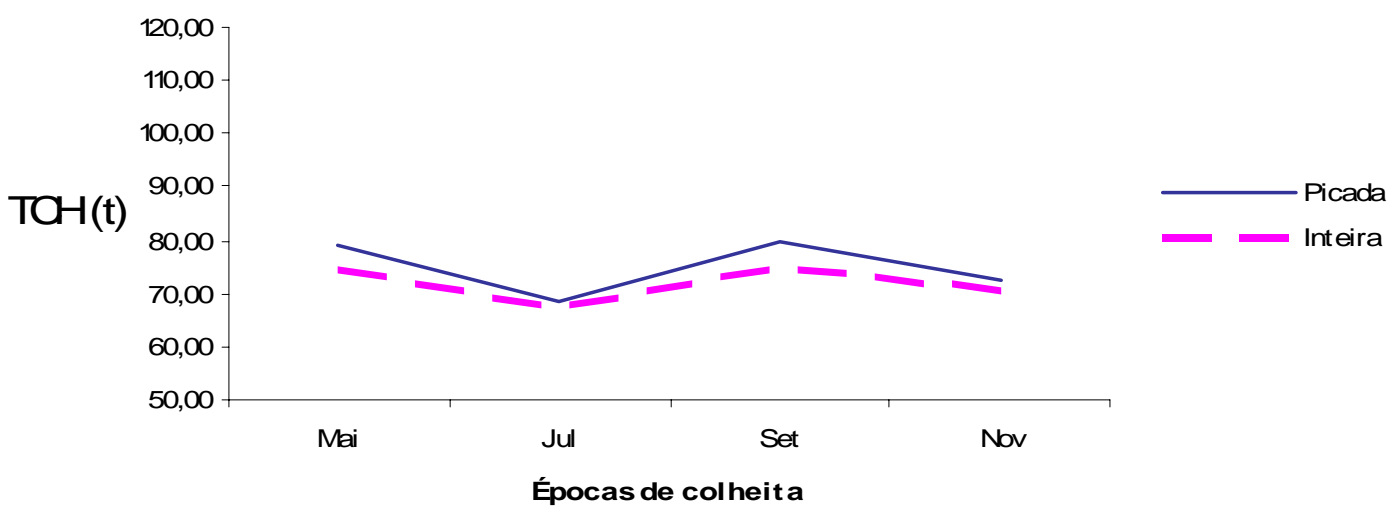

Figura 123 - Resultados de TCH para a variedade NA 56-79 na safra 1987 , no $2^{\circ}$ corte e época de plantio Maio 
Tabela 57. Valores médios de ATR para a variedade NA 56-79 das médias de épocas de colheita, com plantio no ano de 1984/85, no $2^{\circ}$ corte

\begin{tabular}{cc}
\hline EPCOL & ATR (MÉDIA) \\
\hline Set & 159,680 a \\
Jul & $154,393 \quad$ b \\
Nov & $148,153 \quad$ c \\
Mai & $135,383 \quad$ d \\
\hline Médias seguidas das mesmas letras nã diferiram estatisticamente entre
\end{tabular}
si.

A tabela 57, mostra que para a variedade NA 56-79, no segundo corte e ano de plantio 1984/85, houve diferença estatisticamente significativa entre as médias ATR das épocas de colheita. A época de colheita com maior valor de ATR foi Setembro e o menor valor foi observado na colheita de Maio.

A Figura 124 a seguir, mostra a evolução de ATR nas épocas de colheita.

Resultados de ATR

Safra 1987 - corte 2

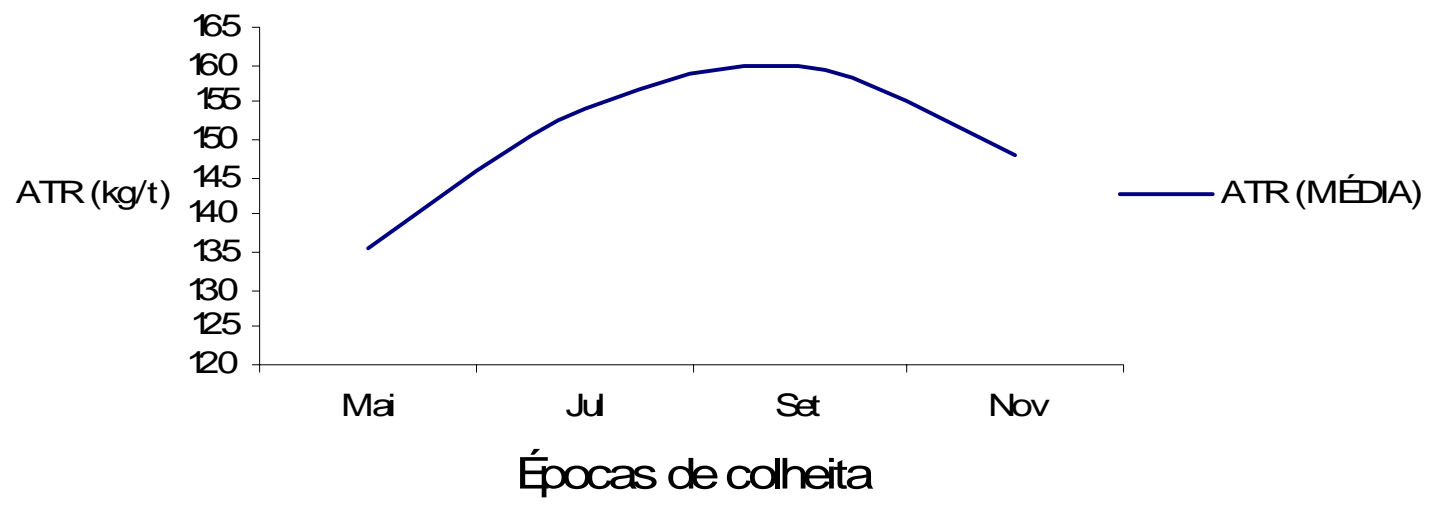

Figura 124 - Resultados de ATR para a variedade NA 56-79 na safra 1987, no $2^{\circ}$ corte e nas épocas de colheita 
Tabela 58. Valores médios de TAH para a variedade NA 56-79 nas interações de épocas de plantio dentro de épocas de colheita, com plantio no ano de 1984/85, no $2^{\circ}$ corte

\begin{tabular}{|c|c|c|}
\hline$E P P L A$ & EPCOL & $T A H$ (MÉDIA) \\
\hline Jan & Jul & $12,749 \mathrm{a}$ \\
\hline Jan & Set & $12,643 \mathrm{a}$ \\
\hline Mar & Set & $12,393 a b$ \\
\hline Nov & Set & $12,153 a b c$ \\
\hline Mai & Set & $12,119 a b c$ \\
\hline Nov & Jul & $12,013 \mathrm{abcd}$ \\
\hline Mar & Jul & 11,374 abcde \\
\hline Mar & Mai & 11,155 abcde \\
\hline Jan & Nov & 10,868 bcde \\
\hline Mai & Nov & 10,679 \\
\hline Nov & Mai & 10,596 \\
\hline Mai & Jul & 10,502 \\
\hline Mai & Mai & 10,415 \\
\hline Jan & Mai & 10,215 \\
\hline Mar & Nov & 10,180 \\
\hline Nov & Nov & 9,831 \\
\hline
\end{tabular}

Médias seguidas das mesmas letras não diferiram estatisticamente entre si.

$\mathrm{Na}$ tabela 58, observa-se que para a variedade NA 56-79, no segundo corte e ano de plantio 1984/85, houve diferença estatisticamente significativa entre as médias de TAH para as interações das épocas de plantio dentro das épocas de colheita.

Os maiores valores de TAH foram obtidos nas colheitas de Julho com plantios em Janeiro e, ainda, colheitas em Setembro com plantios em Janeiro, Março, Novembro e Maio. Os menores valores foram obtidos nas colheitas de Novembro com plantios em Novembro e Março e, ainda, nas colheitas em Maio com plantios em Janeiro e Maio.

As figuras 125, 126, 127e 128, a seguir, mostram a evolução de TAH para cada época de plantio onde se verifica o efeito das épocas de colheita sobre os valores observados. 
Resultados deTAH- Safra 1987

corte 2 - época de plantio Novembro

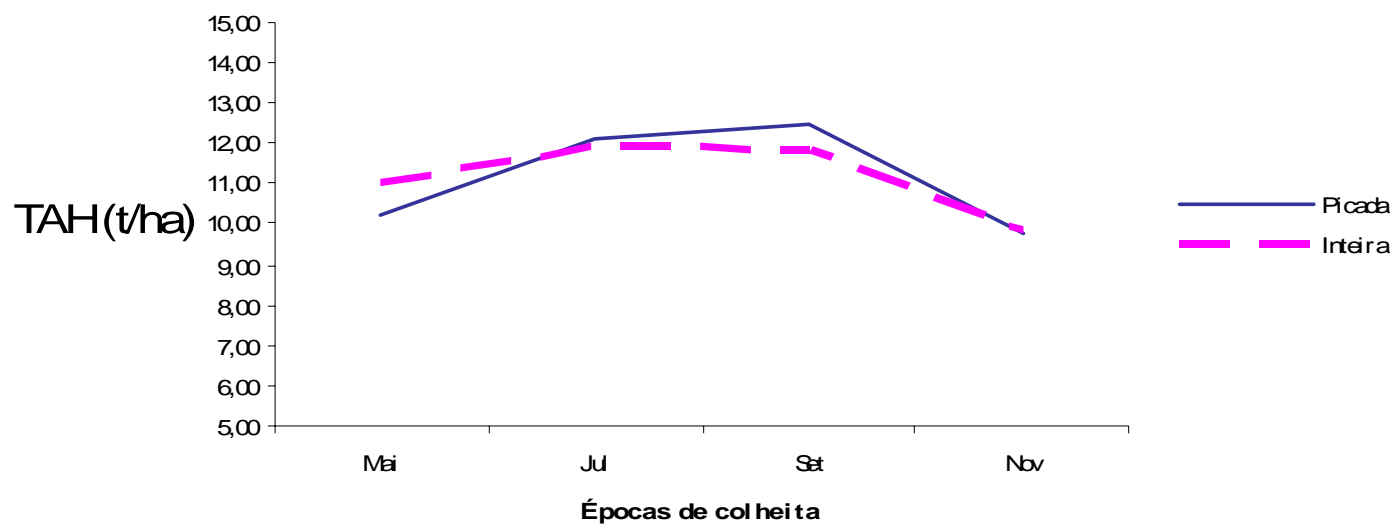

Figura 125 - Resultados de TAH para a variedade NA 56-79 na safra 1987 , no $2^{\circ}$ corte e época de plantio Novembro

\section{Resultados deTAH- Safra 1987}

corte 2 - época de plantio Janeiro

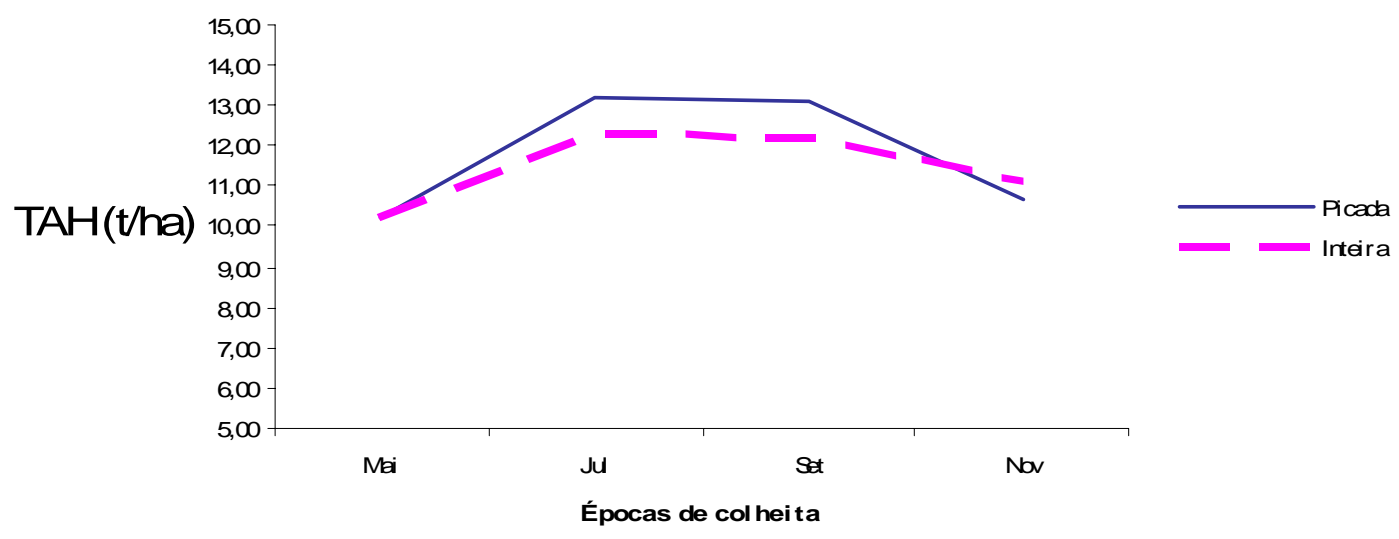

Figura 126 - Resultados de TAH para a variedade NA 56-79 na safra 1987, no $2^{\circ}$ corte e época de plantio Janeiro 
Resultados deTAH- Safra 1987 corte 2 - época de plantio Março

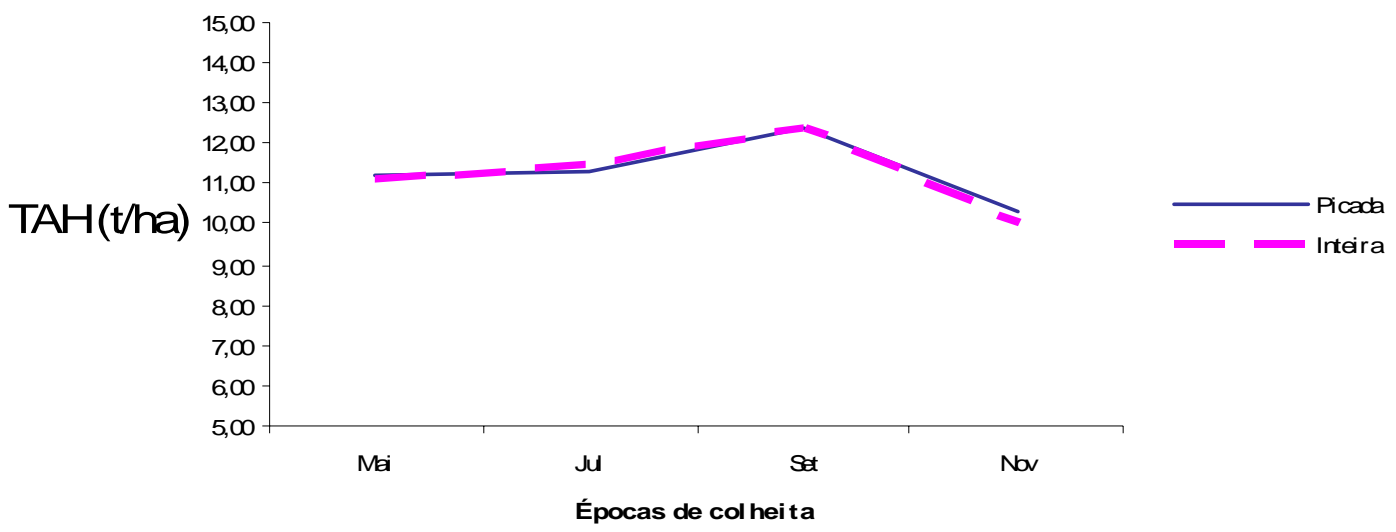

Figura 127 - Resultados de TAH para a variedade NA 56-79 na safra 1987 , no $2^{\circ}$ corte e época de plantio Março

Resultados deTAH- Safra 1987

corte 2 - época de plantio Maio

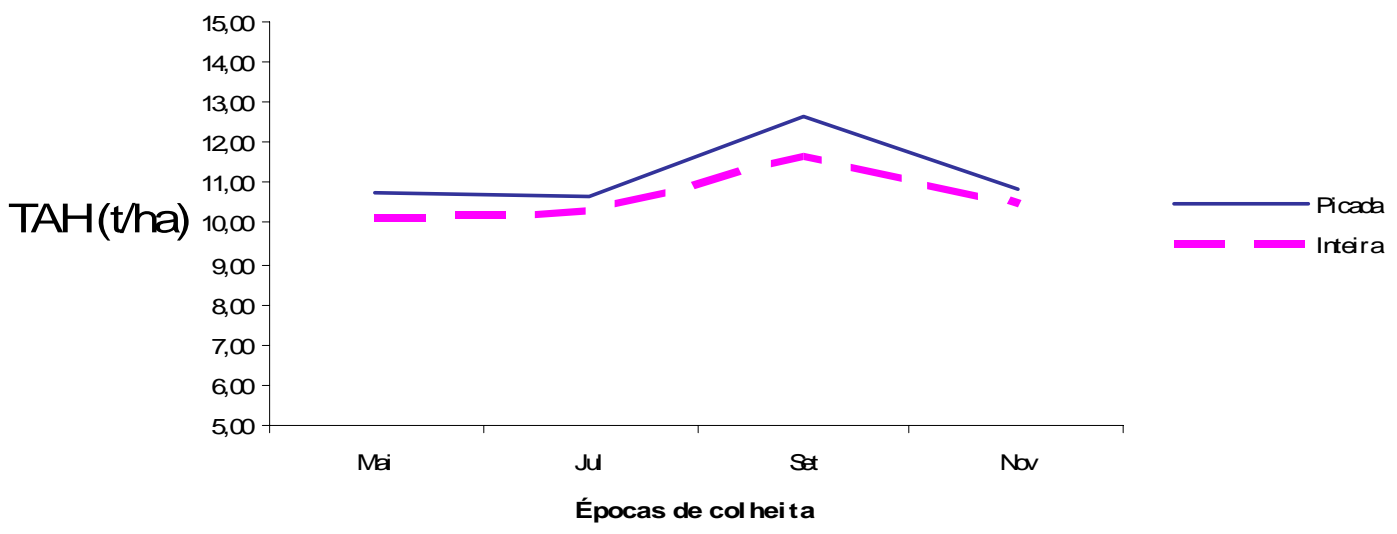

Figura 128 - Resultados de TAH para a variedade NA 56-79 na safra 1987, no $2^{\circ}$ corte e época de plantio Maio 
Tabela 59. Resumo dos quadros de análise de variância dos dados obtidos para a variedade NA 56-79, no segundo corte e com plantio no ano de 1985/86, em relação às variáveis dependentes TCH, ATR e TAH em várias combinações de épocas de plantio e de colheita e sob os tratamentos cana picada e inteira no sulco de plantio

\begin{tabular}{lcccc}
\hline \multicolumn{1}{c}{ C. Variação } & GL & TCH & ATR & TAH \\
\hline BLOCO & 4 & $Q M$ & QM & QM \\
EPCOL & 3 & $11026,206^{* *}$ & $9201,721^{* *}$ & $125,454^{* *}$ \\
Resíduo (a) & 12 & 68,313 & 34,857 & 1,558 \\
EPPLA & 3 & $213,998^{* *}$ & 53,139 & 1,967 \\
Resíduo (b) & 12 & 129,593 & 14,927 & 2,974 \\
TRAT & 1 & 72,079 & 2,186 & 1,903 \\
EPCOL ${ }^{*}$ EPPLA & 9 & $124,941^{* *}$ & 6,031 & $2,130^{*}$ \\
EPCOL ${ }^{*}$ TRAT & 3 & 10,618 & 2,543 & 0,114 \\
EPPLA*TRAT & 3 & 53,667 & 5,644 & 1,109 \\
EPCOL ${ }^{*} E P P L A * T R A T$ & 9 & 27,984 & 18,732 & 0,817 \\
Resíduo (c) & $10 \odot$ & 41,651 & 13,077 & 0,955 \\
Total & 159 & -- & -- & -- \\
\hline
\end{tabular}

A tabela 59, mostra os valores da análise de variância para as variáveis TCH, ATR e TAH da variedade NA 56-79, no segundo corte e ano de plantio 1985/86.

Como se pode observar, para a variável TCH houve efeito significativo de épocas de plantio; para as variáveis TCH, ATR e TAH houve efeito significativo de épocas de colheita. O tratamento muda picada e inteira no sulco de plantio não apresentou efeito significativo para as variáveis estudadas.

Houve interação de épocas de plantio dentro de épocas de colheita para as variáveis $\mathrm{TCH}$ e $\mathrm{TAH}$, indicando diferenças significativas entre as épocas de plantio para cada época de colheita. Não houve qualquer outra interação. 
Tabela 60. Valores médios de TCH para a variedade NA 56-79 nas interações de épocas de plantio dentro de épocas de colheita, com plantio no ano de 1985/86, no $2^{\circ}$ corte

\begin{tabular}{|c|c|c|c|}
\hline EPPLA & $E P C O L$ & \multicolumn{2}{|c|}{$T C H$ (MÉDIA) } \\
\hline Mai & Mai & 100,265 & \\
\hline Nov & Mai & 90,169 & \\
\hline Nov & Jul & 88,810 & $b$ \\
\hline Jan & Jul & 87,453 & $b$ \\
\hline Mar & Jul & 86,215 & $\mathrm{~b}$ \\
\hline Mai & Jul & 86,215 & b \\
\hline Jan & Mai & 85,241 & $b$ \\
\hline Mar & Mai & 85,098 & $b$ \\
\hline Mar & Set & 73,835 & c \\
\hline Mai & Set & 72,954 & c \\
\hline Nov & Set & 69,692 & c \\
\hline Jan & Set & 69,406 & c \\
\hline Nov & Nov & 55,883 & d \\
\hline Mai & Nov & 54,716 & d \\
\hline Jan & Nov & 54,312 & d \\
\hline Mar & Nov & 52,810 & d \\
\hline
\end{tabular}

Médias seguidas das mesmas letras não diferiram estatisticamente entre si.

Na tabela 60, observa-se que para a variedade NA 56-79, no segundo corte e ano de plantio 1985/86, houve diferença estatisticamente significativa entre as médias TCH das épocas de plantio dentro das épocas de colheita.

Os maiores valores de $\mathrm{TCH}$ foram obtidos nas épocas de colheita Maio e Julho com plantios em Novembro, Janeiro, Março e Maio. Os menores valores foram obtidos nas colheitas de Novembro com plantio em Março, Janeiro, Maio e Novembro.

As figuras 129, 130, 131 e 132, a seguir, mostram a evolução de TCH para cada época de plantio onde se verifica o efeito das épocas de colheita sobre os valores observados. 


\section{Resultados de TCH- Safra 1988 \\ corte 2 - época de plantio Novembro}

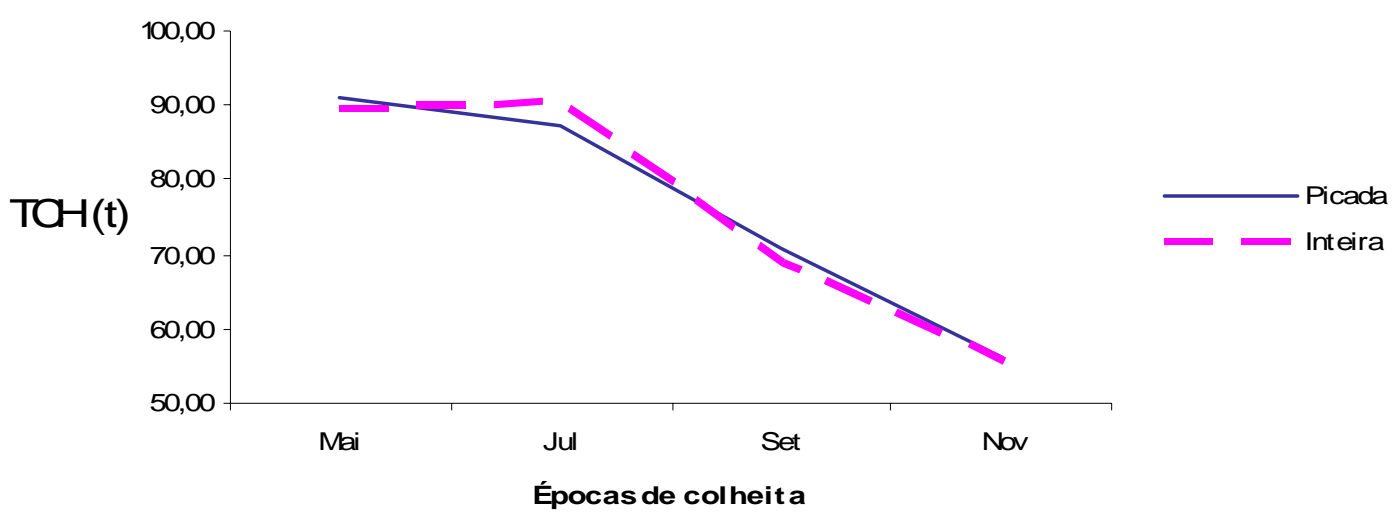

Figura 129 - Resultados de TCH para a variedade NA 56-79 na safra 1988, no $2^{\circ}$ corte e época de plantio Novembro

Resultados de TCH- Safra 1988 corte 2 - época de plantio Janeiro

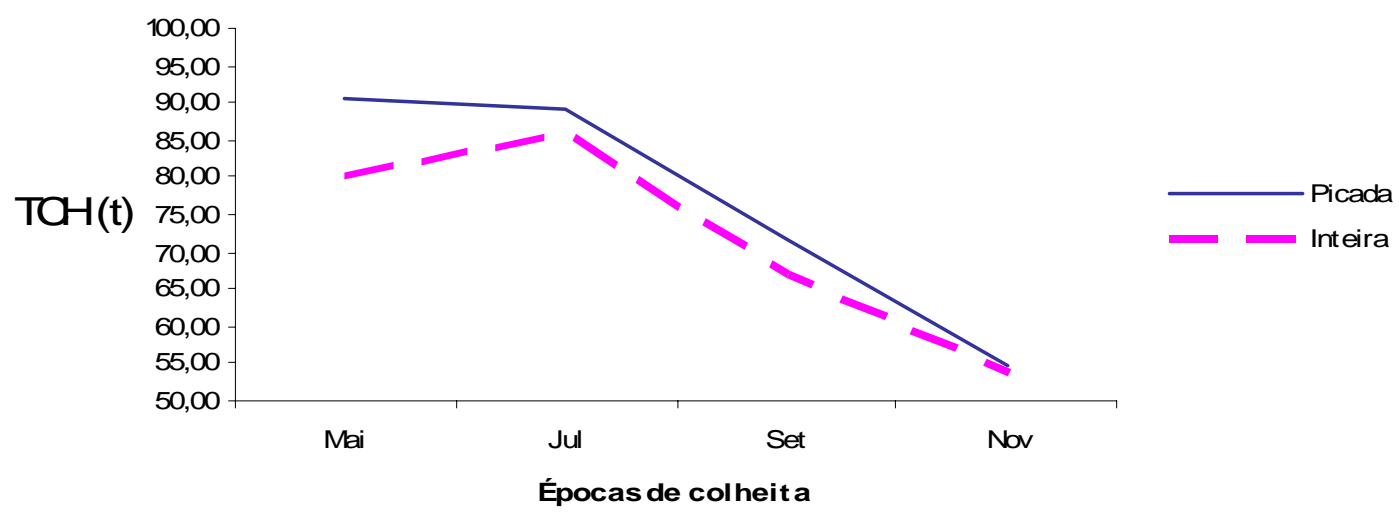

Figura 130 - Resultados de TCH para a variedade NA 56-79 na safra 1988 , no $2^{\circ}$ corte e época de plantio Janeiro 
Resultados de TCH- Safra 1988

corte 2 - época de plantio Março

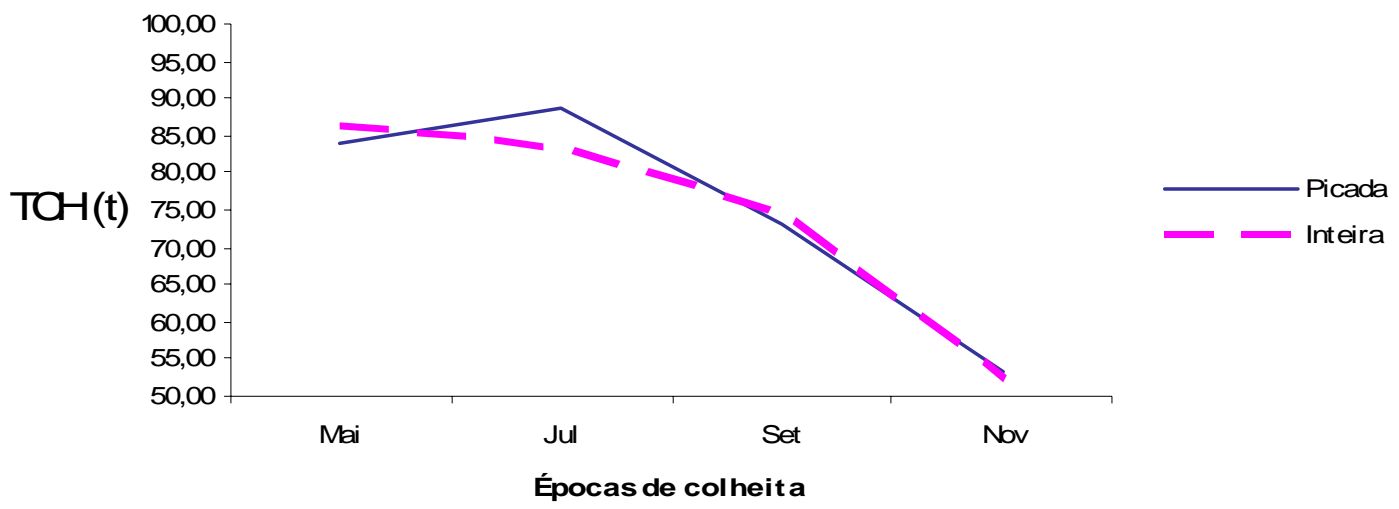

Figura 131 - Resultados de TCH para a variedade NA 56-79 na safra 1988 , no $2^{\circ}$ corte e época de plantio Março

Resultados de TCH- Safra 1988

corte 2 - época de plantio Maio

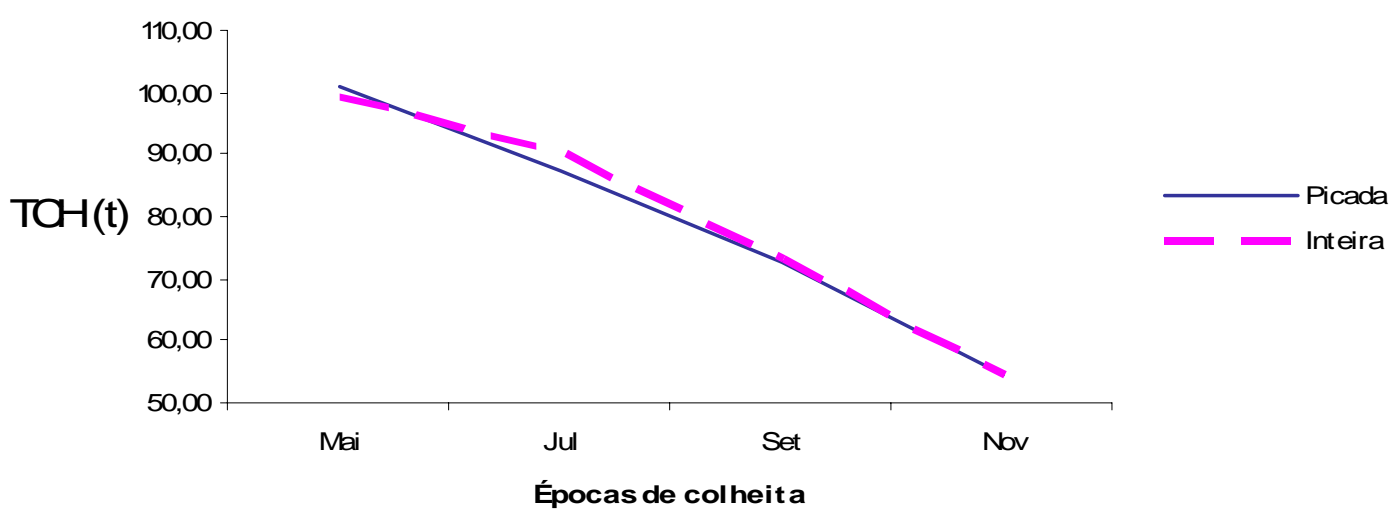

Figura 132 - Resultados de TCH para a variedade NA 56-79 na safra 1988 , no $2^{\circ}$ corte e época de plantio Maio 
Tabela 61. Valores médios de ATR para a variedade NA 56-79 das médias de épocas de colheita, com plantio no ano de $1985 / 86$, no $2^{\circ}$ corte

\begin{tabular}{cc}
\hline EPCOL & $A T R($ MÉDIA) \\
\hline Set & $164,097 \mathrm{a}$ \\
Nov & $163,818 \mathrm{a}$ \\
Jul & $149,221 \quad \mathrm{~b}$ \\
Mai & $132,081 \quad \mathrm{c}$ \\
\hline Médias seguidas das mesmas letras não diferiram estatisticamente entre si.
\end{tabular}

$\mathrm{Na}$ tabela 61, observa-se que para a variedade NA 56-79, no segundo corte e ano de plantio 1985/86, houve diferença estatisticamente significativa entre as médias de ATR nas épocas de colheita. Os maiores valores de ATR foram obtidos nas épocas de colheita Setembro e Novembro e os menores na época de colheita Maio.

A Figura 133 a seguir, mostra a evolução de ATR nas épocas de colheita.

\section{Resultados de ATR}

\section{Safra 1988 - corte 2}

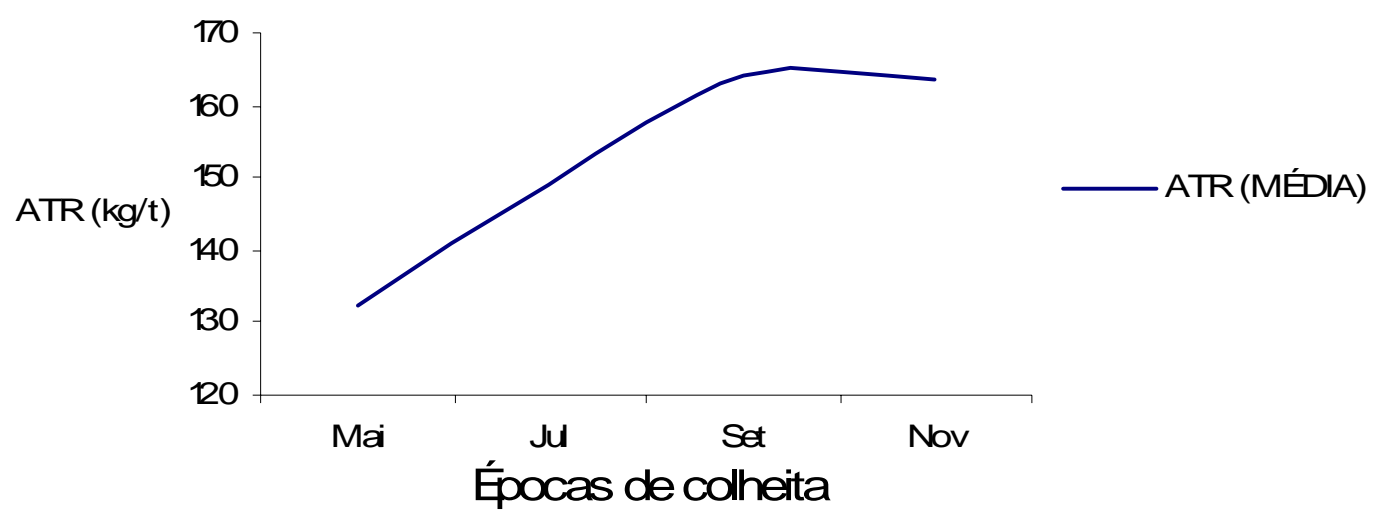

Figura 133 - Resultados de ATR para a variedade NA 56-79 na safra 1987 , no $2^{\circ}$ corte e nas épocas de colheita 
Tabela 62. Valores médios de TAH para a variedade NA 56-79 nas interações de épocas de plantio dentro de épocas de colheita, com plantio no ano de $1985 / 86$, no $2^{\circ}$ corte

\begin{tabular}{ccc}
\hline EPPLA & EPCOL & TAH (MÉDIA) \\
\hline Nov & Jul & $13,217 \mathrm{a}$ \\
Jan & Jul & $13,205 \mathrm{a}$ \\
Mai & Jul & $13,107 \mathrm{a}$ \\
Mai & Mai & $13,051 \mathrm{a}$ \\
Mar & Jul & $12,907 \mathrm{ab}$ \\
Mar & Set & $12,189 \mathrm{abc}$ \\
Nov & Mai & $11,842 \mathrm{abc}$ \\
Mai & Set & $11,813 \mathrm{abc}$ \\
Nov & Set & $11,473 \mathrm{bc}$ \\
Jan & Set & $11,395 \mathrm{bc}$ \\
Jan & Mai & $11,362 \mathrm{c}$ \\
Mar & Mai & $11,361 \quad \mathrm{c}$ \\
Nov & Nov & $9,221 \quad \mathrm{~d}$ \\
Mai & Nov & $8,888 \mathrm{~d}$ \\
Jan & Nov & $8,886 \quad \mathrm{~d}$ \\
Mar & Nov & $8,698 \quad \mathrm{~d}$ \\
\hline
\end{tabular}

Médias seguidas das mesmas letras não diferiram estatisticamente entre si.

Na tabela 62, observa-se que para a variedade NA 56-79, no segundo corte e ano de plantio 1985/86, houve diferença estatisticamente significativa entre as médias TAH nas épocas de plantio dentro das épocas de colheita. Os maiores valores foram obtidos nas colheitas de Julho com plantios em Novembro, Janeiro, Maio, e, ainda, colheitas de Maio com plantios em Maio. Os menores valores foram obtidos nas colheitas de Novembro com plantios em Março, Janeiro, Maio e Novembro.

As figuras 134, 135, 136 e 137, a seguir, mostram a evolução de TAH para cada época de plantio onde se verifica o efeito das épocas de colheita sobre os valores observados. 
Resultados deTAH- Safra 1988

corte 2 - época de plantio Novembro

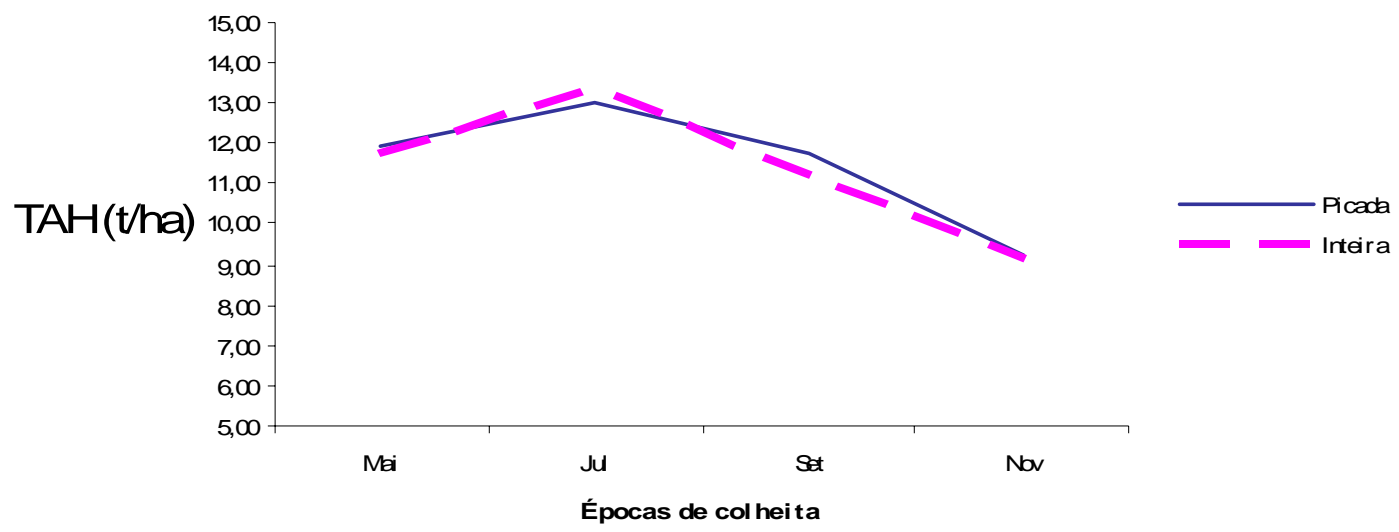

Figura 134 - Resultados de TAH para a variedade NA 56-79 na safra 1988 , no $2^{\circ}$ corte e época de plantio Novembro

\section{Resultados deTAH- Safra 1988}

corte 2 - época de plantio Janeiro

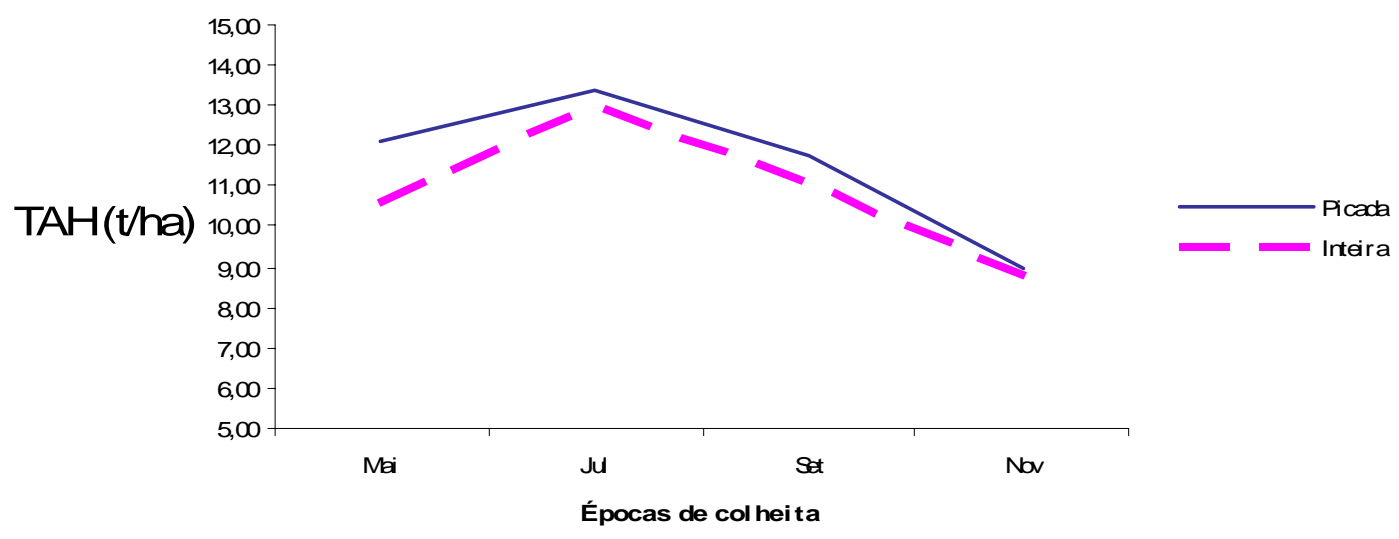

Figura 135 - Resultados de TAH para a variedade NA 56-79 na safra 1988 , no $2^{\circ}$ corte e época de plantio Janeiro 
Resultados deTAH- Safra 1988 corte 2- época de plantio Março

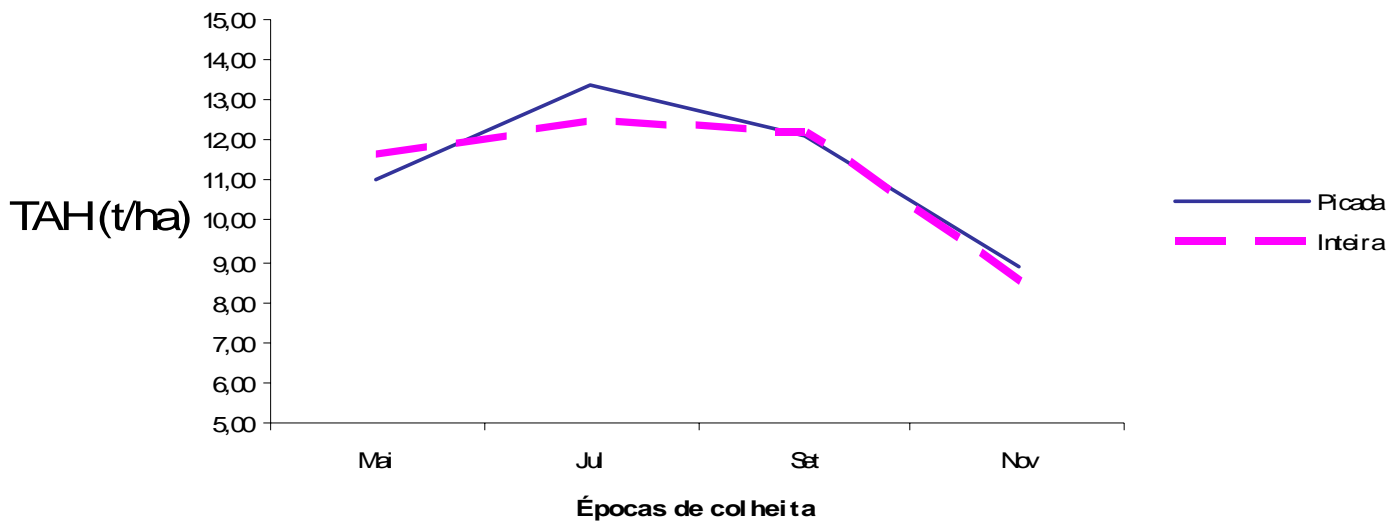

Figura 136 - Resultados de TAH para a variedade NA 56-79 na safra 1988 , no $2^{\circ}$ corte e época de plantio Março

\section{Resultados deTAH- Safra 1988}

corte 2 - época de plantio Maio

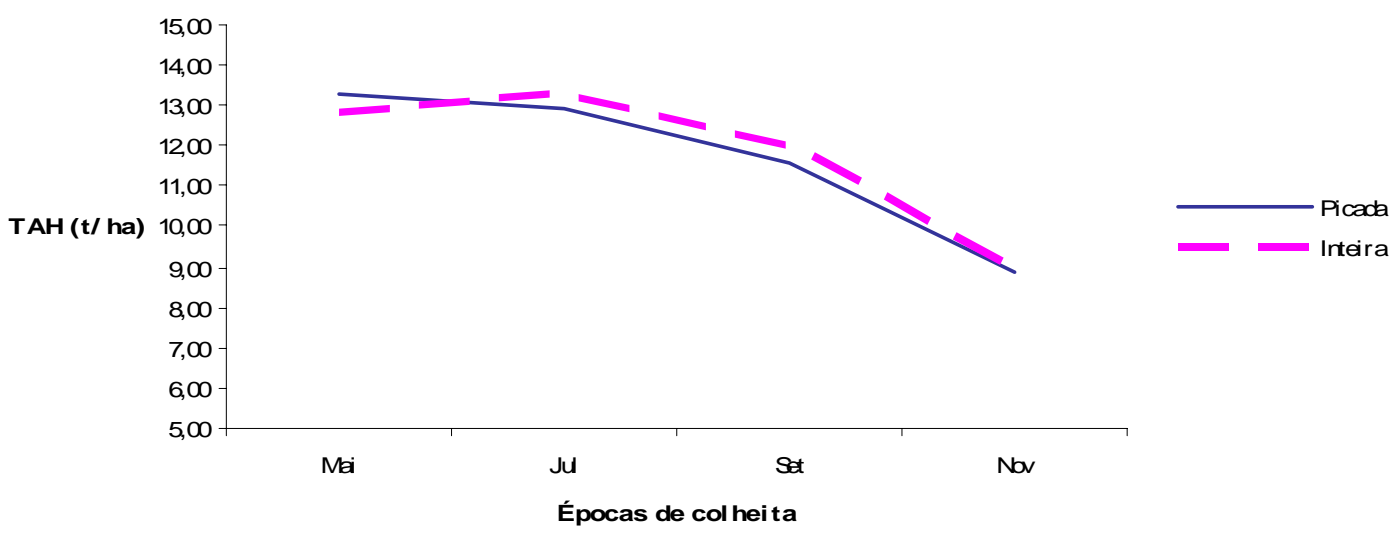

Figura 137 - Resultados de TAH para a variedade NA 56-79 na safra 1988 , no $2^{\circ}$ corte e época de plantio Maio 
$\mathrm{Na}$ tabela 63, a seguir, mostram-se os valores médios das safras de 1986, 1987 e 1988, para TCH, ATR e TAH da variedade NA 56-79, no segundo corte, nas várias combinações de épocas de plantio e de colheita e nos tratamentos muda picada e inteira no sulco de plantio.

Comparando as os resultados ano a ano, observa-se que na safra 86 , ano de plantio 1983/84, houve efeito significativo de época de plantio e de épocas de colheita para as variáveis TCH, ATR e TAH. O tratamento muda picada e inteira no sulco de plantio não apresentou efeito e, houve interação de épocas de plantio dentro de épocas de colheita para as três variáveis estudadas.

Na safra 87, ano de plantio 1984/85, houve efeito significativo de épocas de plantio para a variável TAH e, houve efeito significativo de épocas de colheita variáveis TCH, ATR e TAH. O tratamento muda picada e inteira no sulco de plantio não apresentou efeito significativo. Houve interação de épocas de plantio dentro de épocas de colheita para as variáveis TCH e TAH.

Na safra 88, ano de plantio 1985/86, houve efeito significativo de épocas de plantio para a variável $\mathrm{TCH}$; houve efeito significativo de épocas de colheita para as variáveis TCH, ATR e TAH. O tratamento muda picada e inteira no sulco de plantio não apresentou efeito significativo e, houve interação de épocas de plantio dentro de épocas de colheita para as variáveis TCH e TAH.

Para os três anos estudados a variedade NA 56-79, apresentou efeito significativo de época de colheita para as variáveis TCH, ATR e TAH. O efeito de épocas de plantio já não foi constante durante os anos de estudo. O tratamento muda picada e inteira no sulco de plantio não apresentou efeito significativo em nenhum dos anos estudados e, houve interação de épocas de plantio dentro de épocas de colheita para as variáveis TCH e TAH nos três anos estudados.

Novamente, no $2^{\circ}$ corte onde as idades foram igualadas, $\mathrm{TCH}$ mostrou-se mais influenciado pelas condições climáticas do ano do que pelo manejo em si. 
Em todos os anos estudados, os resultados de ATR sempre evoluíram do início para o final da safra com os picos localizados no mês de setembro e ligeira queda no mês de novembro. TAH sempre acompanhou as curvas de ATR sendo influenciado por TCH.

Tabela 63. Valores médios de TCH, ATR e TAH para a variedade NA 56-79, no segundo corte e nas safras de, 1986, 1987 e 1988, em várias combinações de épocas de plantio e de colheita e sob os tratamentos muda picada e inteira no sulco de plantio

\begin{tabular}{|c|c|c|c|c|c|}
\hline \multirow[b]{2}{*}{$\begin{array}{l}\text { Ep } \\
\text { Pl }\end{array}$} & Mé & das Saf & $\begin{array}{l}56-79 \\
1986 / 87 \\
\text { Rend }\end{array}$ & 8 - corte 2 & \multirow{2}{*}{$\begin{array}{l}\text { Rend } \\
\text { açúcar } \\
\text { (TA } \mathrm{A})\end{array}$} \\
\hline & $\begin{array}{l}\text { Ep } \\
\text { Colh }\end{array}$ & Trat & $\begin{array}{c}\mathrm{Cana} \\
(\mathrm{TCH})\end{array}$ & A T R & \\
\hline$\overline{\mathrm{Nov}}$ & $\mathrm{Mai}$ & Picada & 77,92 & 127,44 & 9,99 \\
\hline Nov & $\mathrm{Mai}$ & Inteira & 76,03 & 125,82 & 9,70 \\
\hline Nov & Jul & Picada & 76,99 & 147,42 & 11,40 \\
\hline Nov & Jul & Inteira & 77,99 & 147,08 & 11,50 \\
\hline Nov & Set & Picada & 72,06 & 154,97 & 11,19 \\
\hline Nov & Set & Inteira & 71,13 & 153,41 & 10,91 \\
\hline Nov & Nov & Picada & 62,76 & 140,64 & 8,75 \\
\hline Nov & Nov & Inteira & 59,86 & 141,41 & 8,47 \\
\hline Jan & $\mathrm{Mai}$ & Picada & 81,99 & 126,61 & 10,41 \\
\hline Jan & $\mathrm{Mai}$ & Inteira & 78,78 & 128,14 & 10,06 \\
\hline Jan & Jul & Picada & 81,92 & 147,33 & 12,12 \\
\hline Jan & Jul & Inteira & 80,16 & 148,46 & 11,93 \\
\hline Jan & Set & Picada & 78,00 & 155,00 & 12,07 \\
\hline Jan & Set & Inteira & 74,19 & 154,43 & 11,41 \\
\hline Jan & Nov & Picada & 66,46 & 145,12 & 9,53 \\
\hline Jan & Nov & Inteira & 66,60 & 145,70 & 9,60 \\
\hline M ar & $\mathrm{Mai}$ & Picada & 79,82 & 126,22 & 10,15 \\
\hline M ar & $\mathrm{Mai}$ & Inteira & 81,60 & 129,30 & 10,58 \\
\hline M ar & Jul & Picada & 75,28 & 147,36 & 11,14 \\
\hline M ar & Jul & Inteira & 74,68 & 146,56 & 10,98 \\
\hline M ar & Set & Picada & 75,73 & 155,55 & 11,77 \\
\hline M ar & Set & Inteira & 76,18 & 154,05 & 11,73 \\
\hline M ar & $\mathrm{Nov}$ & Picada & 63,72 & 144,66 & 9,13 \\
\hline M ar & Nov & Inteira & 61,97 & 144,36 & 8,87 \\
\hline $\mathrm{Mai}$ & $\mathrm{Mai}$ & Picada & 83,22 & 124,87 & 10,49 \\
\hline $\mathrm{Mai}$ & Mai & Inteira & 80,84 & 124,65 & 10,15 \\
\hline Mai & Jul & Picada & 74,22 & 146,73 & 10,91 \\
\hline Mai & Jul & Inteira & 73,68 & 145,71 & 10,76 \\
\hline $\mathrm{Mai}$ & Set & Picada & 77,48 & 153,65 & 11,86 \\
\hline $\mathrm{Mai}$ & Set & Inteira & 74,51 & 153,29 & 11,41 \\
\hline $\mathrm{Mai}$ & Nov & Picada & 66,16 & 143,47 & 9,38 \\
\hline $\mathrm{Mai}$ & Nov & Inteira & 63,00 & 143,87 & 9,01 \\
\hline
\end{tabular}


As figuras 138, 139 e 140, a seguir, mostram, respectivamente, a evolução de TCH, ATR e TAH médias das safras de 1986, 1987 e 1988 para as épocas de plantio e de colheita.

Resultados de TCH - Média das Safras 1986/87/88 corte 2 - épocas de plantio e colheita

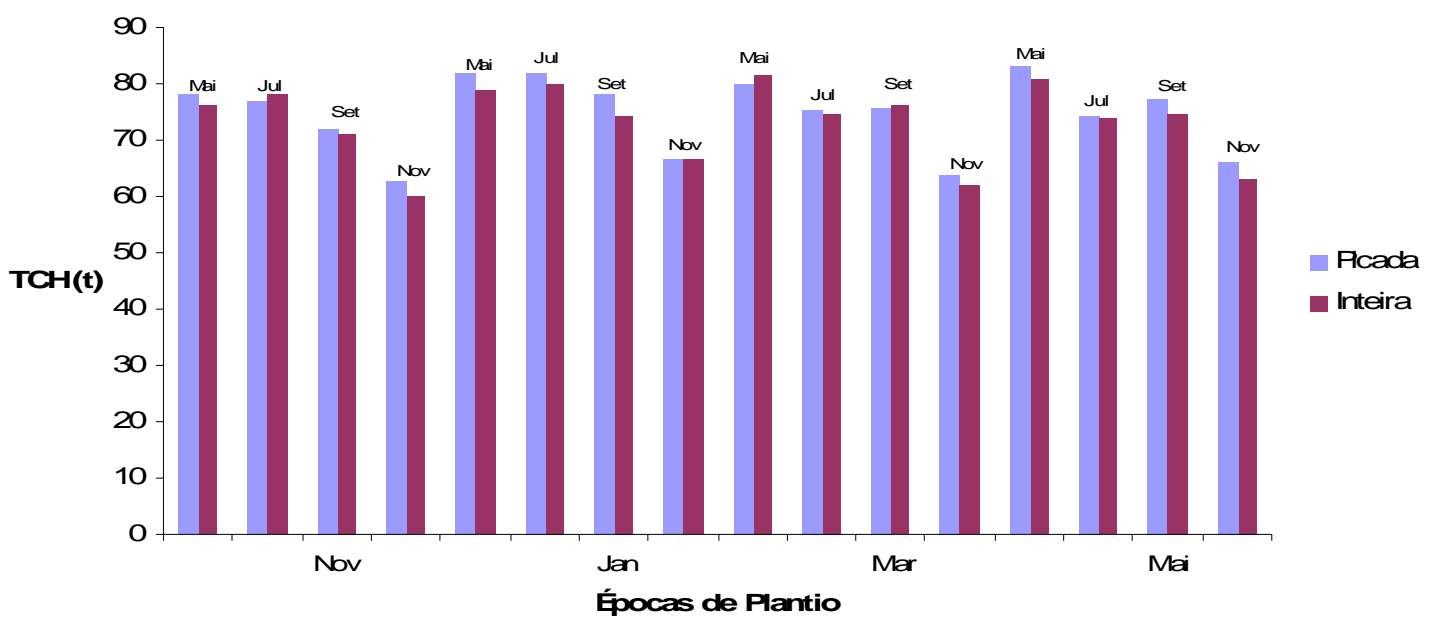

Figura 138 - Resultados médios de TCH para a variedade NA 56-79 nas safras 1986/87/88, no $2^{\circ}$ corte e nas épocas de plantio e colheita

Resultados de ATR- Média das Safras 1986/87/88 corte 2 - épocas de plantio e colheita

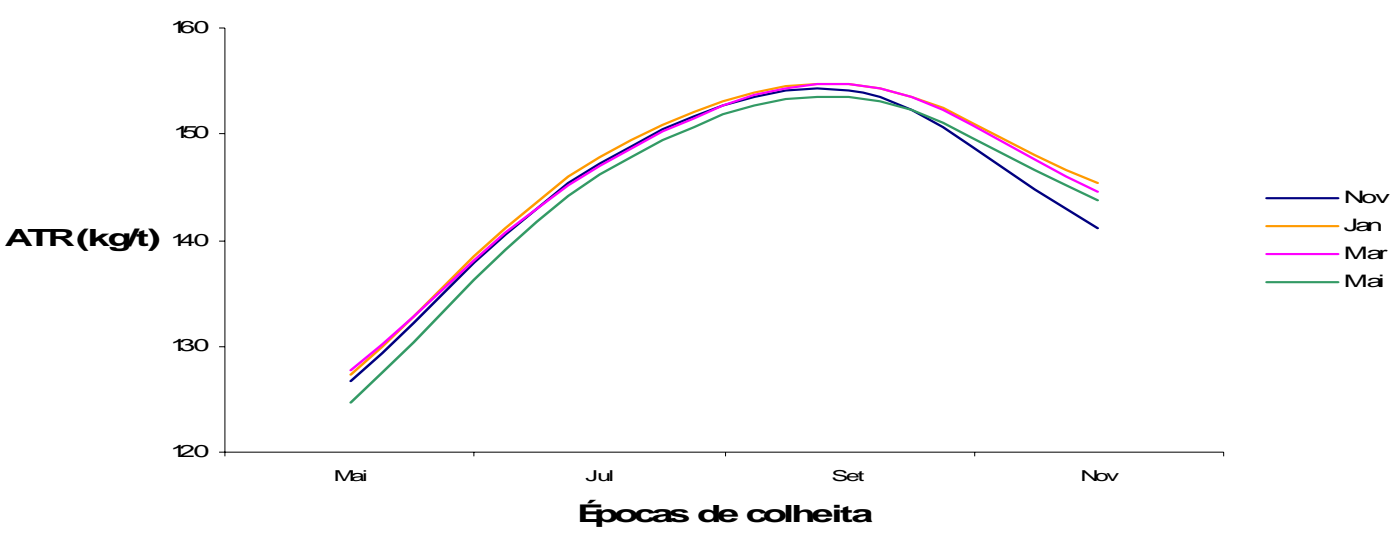

Figura 139 - Resultados médios de ATR para a variedade NA 56-79 nas safras 1986/87/88, no $2^{\circ}$ corte e nas épocas de plantio e colheita 
Resultados de TAH- Média das Safras 1986/87/88 corte 2 - épocas de plantio e colheita

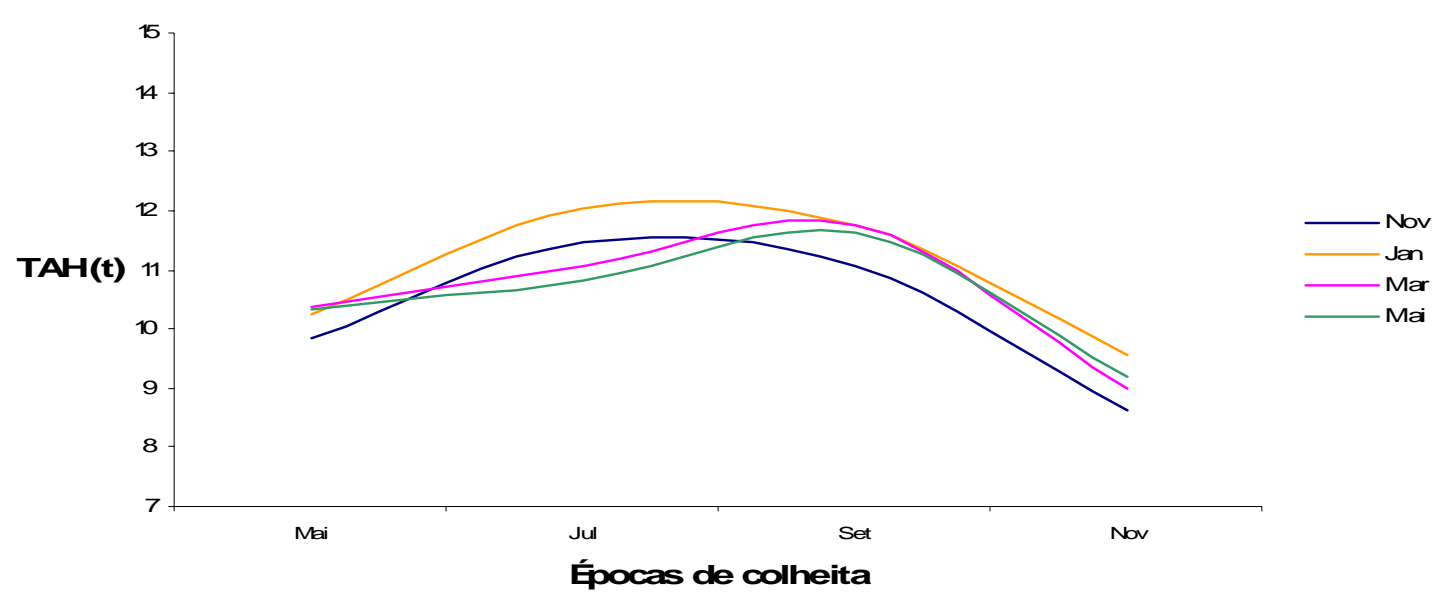

Figura 140 - Resultados médios de TAH para a variedade NA 56-79 nas safras 1986/87/88, no $2^{\circ}$ corte e nas épocas de plantio e colheita

\subsection{Variedade SP 71-1406 $-1^{\circ}$ corte}

São apresentados na tabela 64 , a seguir, os resultados obtidos no primeiro corte nas safras de 1985, 1986 e 1987, para toneladas de cana por ha (TCH), açúcar total recuperável (ATR) em kg de açúcar por tonelada de cana e (TAH) toneladas de açúcar por ha, para a variedade SP 71-1406. 
Tabela 64. Valores obtidos de TCH, ATR e TAH para a variedade SP 71-1406, no primeiro corte e nas safras de 1985, 1986 e 1987, em várias combinações de épocas de plantio e de colheita e sob os tratamentos muda picada e inteira no sulco de plantio

\begin{tabular}{|c|c|c|c|c|c|c|c|c|c|c|c|}
\hline \multicolumn{12}{|c|}{ SP 71-1406 } \\
\hline \multirow[b]{2}{*}{$\begin{array}{l}\text { Ep } \\
\text { PI }\end{array}$} & \multirow[b]{2}{*}{$\begin{array}{l}\text { Ep } \\
\text { Colh }\end{array}$} & \multirow[b]{2}{*}{ Trat } & \multicolumn{3}{|c|}{ Safra 1985 - corte 1} & \multicolumn{3}{|c|}{ Safra 1986 - corte 1} & \multicolumn{3}{|c|}{ Safra 1987 - corte 1} \\
\hline & & & $\begin{array}{l}\text { Rend } \\
\text { Cana } \\
(\mathrm{TCH})\end{array}$ & ATR & $\begin{array}{l}\text { Rend } \\
\text { açúcar } \\
\text { (TAH) }\end{array}$ & $\begin{array}{l}\text { Rend } \\
\text { Cana } \\
(\mathrm{TCH})\end{array}$ & ATR & $\begin{array}{l}\text { Rend } \\
\text { açúcar } \\
\text { (TAH) }\end{array}$ & $\begin{array}{l}\text { Rend } \\
\text { Cana } \\
(\mathrm{TCH})\end{array}$ & ATR & $\begin{array}{l}\text { Rend } \\
\text { açúcar } \\
\text { (TAH) }\end{array}$ \\
\hline Nov & Mai & Picada & 109,60 & 128,04 & 14,03 & 122,91 & 117,26 & 14,42 & 144,38 & 136,00 & 19,61 \\
\hline Nov & Mai & Inteira & 102,29 & 127,92 & 13,09 & 120,45 & 115,27 & 13,92 & 151,53 & 135,74 & 20,56 \\
\hline Nov & Jul & Picada & 106,81 & 140,89 & 15,08 & 117,41 & 141,55 & 16,61 & 150,05 & 150,85 & 22,64 \\
\hline Nov & Jul & Inteira & 119,12 & 144,15 & 17,17 & 118,50 & 139,28 & 16,47 & 153,72 & 147,99 & 22,74 \\
\hline Nov & Set & Picada & 103,07 & 149,93 & 15,43 & 123,57 & 142,35 & 17,62 & 158,15 & 156,28 & 24,70 \\
\hline Nov & Set & Inteira & 101,76 & 142,41 & 14,49 & 126,43 & 145,45 & 18,34 & 160,10 & 157,94 & 25,30 \\
\hline Nov & Nov & Picada & 135,41 & 161,98 & 21,92 & 131,10 & 146,32 & 19,12 & 155,91 & 145,87 & 22,72 \\
\hline Nov & Nov & Inteira & 130,31 & 159,17 & 20,77 & 122,38 & 150,55 & 18,41 & 157,53 & 145,24 & 22,86 \\
\hline Jan & Mai & Picada & 112,15 & 125,95 & 14,12 & 105,95 & 110,88 & 11,71 & 143,38 & 129,57 & 18,54 \\
\hline Jan & Mai & Inteira & 112,41 & 127,53 & 14,34 & 106,29 & 109,28 & 11,64 & 129,43 & 128,90 & 16,66 \\
\hline Jan & Jul & Picada & 113,88 & 146,56 & 16,67 & 113,24 & 133,28 & 15,08 & 140,05 & 149,04 & 20,85 \\
\hline Jan & Jul & Inteira & 119,12 & 145,91 & 17,39 & 111,67 & 134,57 & 15,04 & 142,43 & 149,53 & 21,31 \\
\hline Jan & Set & Picada & 104,38 & 144,75 & 15,11 & 119,91 & 149,11 & 17,86 & 145,86 & 158,48 & 23,11 \\
\hline Jan & Set & Inteira & 99,79 & 145,30 & 14,37 & 117,43 & 151,78 & 17,82 & 142,91 & 159,23 & 22,75 \\
\hline Jan & Nov & Picada & 133,46 & 166,47 & 22,16 & 124,15 & 154,11 & 19,11 & 148,29 & 144,67 & 21,52 \\
\hline Jan & Nov & Inteira & 139,86 & 162,21 & 22,71 & 119,43 & 153,32 & 18,33 & 155,24 & 143,79 & 22,32 \\
\hline Mar & Mai & Picada & 117,10 & 119,82 & 14,03 & 96,55 & 96,55 & 9,31 & 119,43 & 125,22 & 14,91 \\
\hline Mar & Mai & Inteira & 111,95 & 117,31 & 13,13 & 97,91 & 96,08 & 9,39 & 119,76 & 122,60 & 14,69 \\
\hline Mar & Jul & Picada & 132,41 & 139,99 & 18,54 & 100,50 & 129,56 & 12,98 & 125,24 & 148,26 & 18,56 \\
\hline Mar & Jul & Inteira & 124,29 & 137,52 & 17,09 & 99,36 & 129,06 & 12,81 & 125,43 & 146,46 & 18,38 \\
\hline Mar & Set & Picada & 135,46 & 147,74 & 19,98 & 111,10 & 151,32 & 16,81 & 139,00 & 158,18 & 21,97 \\
\hline Mar & Set & Inteira & 128,07 & 142,68 & 18,25 & 107,76 & 152,47 & 16,39 & 122,19 & 160,19 & 19,54 \\
\hline Mar & Nov & Picada & 156,67 & 169,43 & 26,51 & 118,91 & 157,56 & 18,73 & 127,67 & 146,44 & 18,65 \\
\hline Mar & Nov & Inteira & 130,03 & 166,08 & 21,58 & 118,15 & 160,30 & 18,94 & 120,43 & 149,61 & 18,02 \\
\hline Mai & Mai & Picada & 98,36 & 99,76 & 9,83 & 73,19 & 76,31 & 5,58 & 96,95 & 102,63 & 9,95 \\
\hline Mai & Mai & Inteira & 97,36 & 97,58 & 9,52 & 79,24 & 81,69 & 6,46 & 85,81 & 100,48 & 8,61 \\
\hline Mai & Jul & Picada & 123,60 & 128,36 & 15,83 & 89,69 & 119,96 & 10,79 & 104,72 & 137,47 & 14,40 \\
\hline Mai & Jul & Inteira & 108,53 & 127,13 & 13,78 & 88,48 & 121,37 & 10,73 & 85,48 & 139,88 & 11,96 \\
\hline Mai & Set & Picada & 99,03 & 137,32 & 13,58 & 94,19 & 146,56 & 13,78 & 111,86 & 155,52 & 17,40 \\
\hline Mai & Set & Inteira & 102,60 & 142,88 & 14,68 & 98,57 & 144,65 & 14,22 & 107,57 & 155,12 & 16,69 \\
\hline Mai & Nov & Picada & 117,10 & 168,25 & 19,66 & 105,34 & 155,55 & 16,37 & 119,34 & 145,83 & 17,41 \\
\hline Mai & Nov & Inteira & 121,10 & 165,63 & 20,06 & 105,95 & 156,15 & 16,55 & 105,81 & 145,69 & 15,39 \\
\hline
\end{tabular}


Tabela 65. Resumo dos quadros de análise de variância dos dados obtidos para a variedade SP 71-1406, no primeiro corte e com plantio no ano de 1983/84, em relação às variáveis dependentes ATR, TCH e TAH em várias combinações de épocas de plantio e de colheita e sob os tratamentos cana picada e inteira no sulco de plantio

\begin{tabular}{|c|c|c|c|c|}
\hline C. Variação & $G L$ & $\begin{array}{c}\mathrm{TCH} \\
Q M\end{array}$ & $\begin{array}{c}\text { ATR } \\
Q M\end{array}$ & $\begin{array}{c}\mathrm{TAH} \\
Q M\end{array}$ \\
\hline$B L O C O$ & 4 & -- & -- & -- \\
\hline EPCOL & 3 & 5399,956 * * & 14859,838 ** & 583,511 ** \\
\hline Resíduo (a) & 12 & 490,386 & 26,104 & 9,890 \\
\hline EPPLA & 3 & 3214,054 * * & 1225,612 * * & $110,735^{* *}$ \\
\hline Resíduo (b) & 12 & 439,574 & 16,515 & 8,037 \\
\hline TRAT & 1 & 388,628 & $88,655^{*}$ & 15,813 \\
\hline$E P C O L{ }^{\star} E P P L A$ & 9 & 367,366 & $474,648^{* *}$ & $10,841^{*}$ \\
\hline$E P C O L{ }^{*} T R A T$ & 3 & 27,772 & 17,006 & 2,183 \\
\hline$E P P L A{ }^{*} T R A T$ & 3 & 362,857 & 20,229 & 12,094 \\
\hline $\begin{array}{l}\text { EPCOL * EPPLA }{ }^{*} T R A T \\
\text { Resíduo (c) }\end{array}$ & $\begin{array}{c}9 \\
100\end{array}$ & $\begin{array}{l}225,523 \\
211,473\end{array}$ & $\begin{array}{l}30,436 \\
19,380\end{array}$ & $\begin{array}{l}5,903 \\
5,109\end{array}$ \\
\hline Total & 159 & -- & -- & -- \\
\hline
\end{tabular}

A tabela 65, apresentada, mostra os valores da análise de variância, para as variáveis TCH, ATR e TAH, da variedade SP 71-1406, no primeiro corte ano de 1983/84.

Como se pode observar, houve efeito significativo de épocas de plantio e de épocas de colheita para as variáveis TCH, ATR e TAH. O tratamento muda picada e inteira no sulco de plantio apresentou efeito significativo apenas para a variável ATR.

Houve interação de épocas de plantio dentro de épocas de colheita para as variáveis ATR e TAH, indicando diferenças significativas entre as épocas de plantio para cada época de colheita. Não houve qualquer outra interação. 
Tabela 66. Valores médios de TCH para a variedade SP 71-1406 das médias de épocas de plantio, no ano de 1983/84, no $1^{\circ}$ corte

\begin{tabular}{ccc}
\hline EPPLA & $T C H$ & $($ MÉDIA) \\
\hline Mar & 129,497 & $\mathrm{a}$ \\
Jan & 116,880 & $\mathrm{ab}$ \\
Nov & 113,547 & $\mathrm{~b}$ \\
Mai & 108,458 & $\mathrm{~b}$ \\
\hline
\end{tabular}

Médias seguidas das mesmas letras não diferiram estatisticamente entre si.

$\mathrm{Na}$ tabela 66, observa-se que para a variedade SP 71-1406, no primeiro corte e ano de plantio 1983/84, houve diferença estatisticamente significativa entre as médias TCH nas épocas de plantio. A média da época de plantio Março diferiu estatisticamente das médias das épocas Novembro e Maio. As maiores médias foram obtidas para a época de plantio Março. As menores produções foram obtidas nas épocas de plantio Novembro e Maio.

A Figura 141, a seguir, mostra a evolução de TCH nas épocas de plantio.

ResultadosdeTCH

Safra1985-corte1

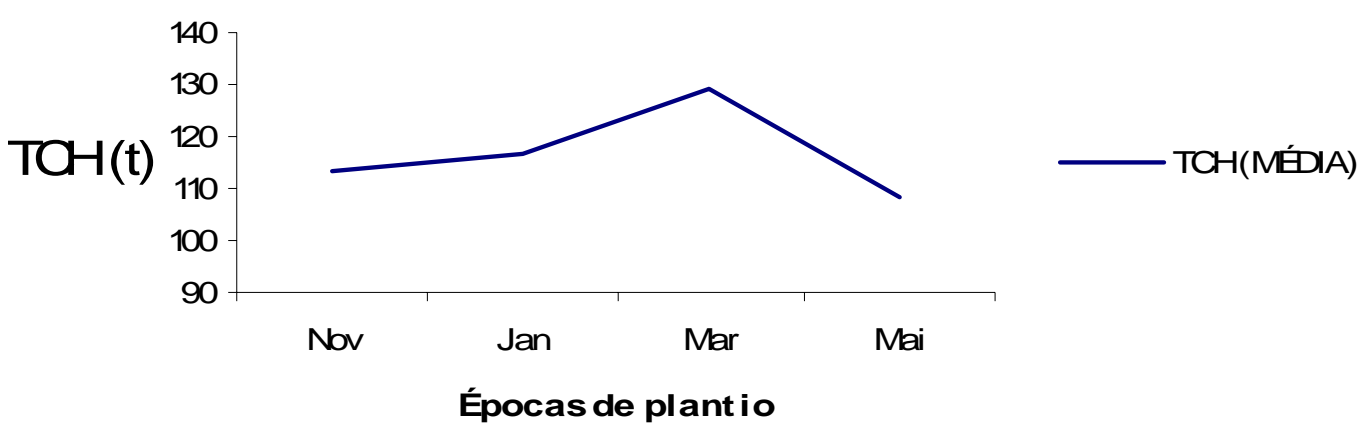

Figura 141 - Resultados de TCH para a variedade SP 71-1406 na safra 1985 , no $1^{\circ}$ corte e nas épocas de plantio 
Tabela 67. Valores médios de TCH para a variedade SP 71-1406 das médias de épocas de colheita, no ano de 1983/84, no $1^{\circ}$ corte

\begin{tabular}{|c|c|c|}
\hline EPCOL & \multicolumn{2}{|c|}{$T C H$ (MÉDIA) } \\
\hline Nov & 132,991 & $a$ \\
\hline Jul & $118,47 \mathrm{C}$ & $a b$ \\
\hline Set & 109,271 & b \\
\hline Mai & 107,65 & $\mathrm{~b}$ \\
\hline
\end{tabular}

Médias seguidas das mesmas letras não diferiram estatisticamente entre si.

Na tabela 67, observa-se que para a variedade SP 711406, no primeiro corte e ano de plantio 1983/84, houve diferença estatisticamente significativa entre as médias $\mathrm{TCH}$ das épocas de colheita. A média da época de colheita Novembro diferiu estatisticamente das médias das épocas Setembro e Maio, sendo que estas não diferiram entre si. A maior média foi obtida na época Novembro e as menores produções foram obtidas nas épocas de colheita Maio e Setembro.

A Figura 142, a seguir, mostra a evolução de $\mathrm{TCH}$ nas épocas de colheita.

Resultadosde TCH

Safra1985-corte1

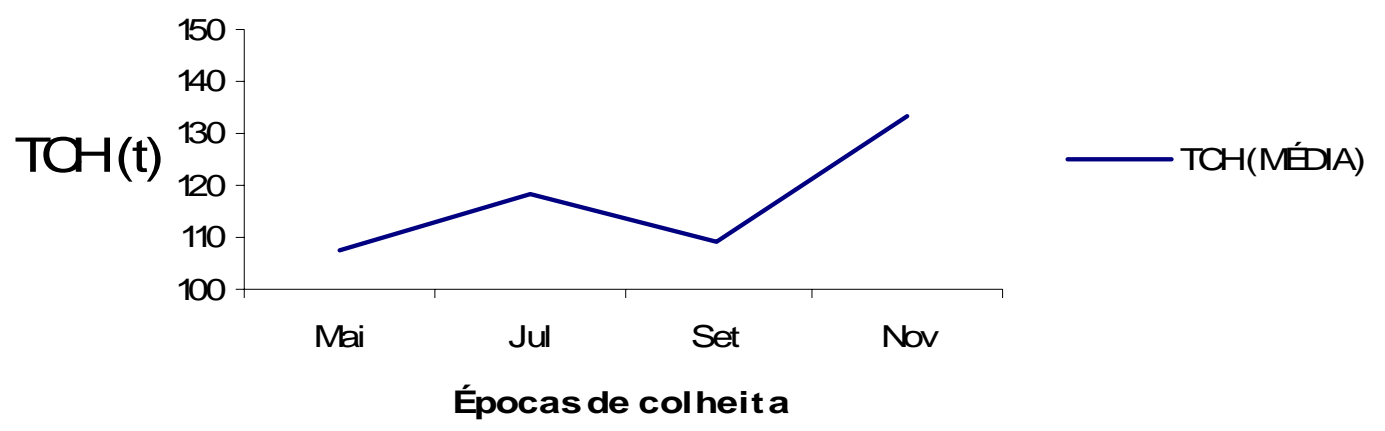

Figura 142 - Resultados de TCH para a variedade SP 71-1406 na safra 1985, no $1^{\circ}$ corte e nas épocas de colheita 
Tabela 68. Valores médios de ATR para a variedade SP 71-1406 nas interações de épocas de plantio dentro de épocas de colheita, no ano de $1983 / 84$, no $1^{\circ}$ corte

\begin{tabular}{|c|c|c|c|}
\hline$\overline{E P P L A}$ & EPCOL & \multicolumn{2}{|c|}{ ATR (MÉDIA) } \\
\hline Mar & Nov & $167,751 \mathrm{a}$ & \\
\hline Mai & Nov & 166,939 a & \\
\hline Jan & Nov & 164,343 a & \\
\hline Nov & Nov & 160,573 & b \\
\hline Jan & Jul & 146,236 & c \\
\hline Nov & Set & 146,175 & c \\
\hline Mar & Set & 145,211 & $\mathrm{~cd}$ \\
\hline Jan & Set & 145,026 & $\mathrm{~cd}$ \\
\hline Nov & Jul & 142,517 & $\mathrm{~cd}$ \\
\hline Mai & Set & 140,103 & $c d$ \\
\hline Mar & Jul & 138,759 & d \\
\hline Nov & Mai & 127,978 & $\mathrm{e}$ \\
\hline Mai & Jul & 127,747 & e \\
\hline Jan & Mai & 126,741 & $\mathrm{e}$ \\
\hline Mar & Mai & 118,568 & $f$ \\
\hline Mai & Mai & 98,671 & $\mathrm{~g}$ \\
\hline
\end{tabular}

Médias seguidas das mesmas letras não diferiram estatisticamente entre si.

$\mathrm{Na}$ tabela 68 , observa-se que para a variedade SP 71-1406, no primeiro corte e ano de plantio 1983/84, houve diferença estatisticamente significativa entre as médias de ATR para a interação épocas de plantio dentro das épocas de colheita.

Os resultados obtidos mostraram que para a variedade SP 71-1406, no $1^{\circ}$ corte, em relação à variável ATR para qualquer época de plantio a época de colheita Novembro apresentou os maiores valores. As épocas de colheita Maio com plantio em Maio, Março, Janeiro e Novembro e época de colheita Julho com plantio em Maio apresentaram os menores valores. 
Tabela 69. Valores médios de ATR para a variedade SP 71-1406 das médias de tratamentos (muda picada e inteira no sulco de plantio), com plantio no ano de $1983 / 84$, no $1^{\circ}$ corte

\begin{tabular}{|c|c|}
\hline TRATAMENTOS & ATR (MÉDIA) \\
\hline muda picada & $142,203 \quad a$ \\
\hline muda inteira & 140,714 \\
\hline
\end{tabular}

Médias seguidas das mesmas letras não diferiram estatisticamente entre si.

$\mathrm{Na}$ tabela 69 , observa-se que para a variedade SP 71-1406, no primeiro corte e ano de plantio 1983/84, houve diferença estatisticamente significativa entre as médias dos tratamentos (muda picada e inteira no sulco de plantio), mostrando que mudas picadas no sulco de plantio resultaram em maior valor de ATR.

As figuras 143, 144, 145 e 146, a seguir, mostram a evolução de ATR onde se pode verificar o efeito das épocas de colheita sobre as épocas de plantio.

\section{Resultados de ATR- Safra 1985 \\ corte 1 - época de plantio Novembro}

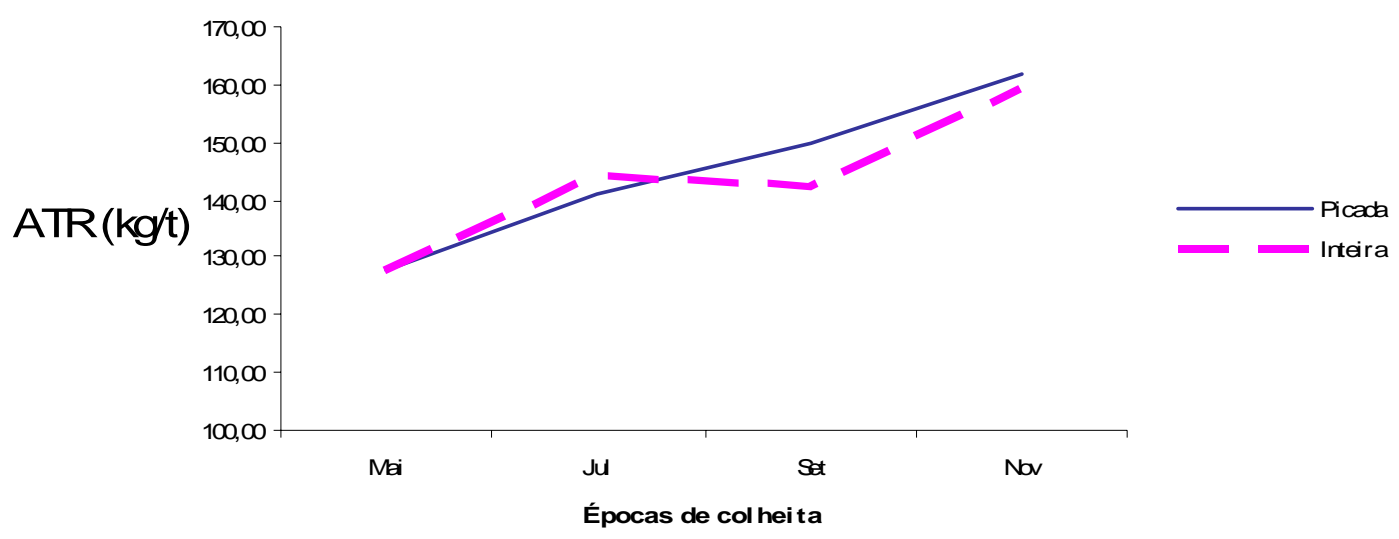

Figura 143 - Resultados de ATR para a variedade SP 71-1406 na safra 1985, no $1^{\circ}$ corte e na época de plantio Novembro 
Resultados de ATR- Safra 1985

corte 1 - época de plantio Janeiro

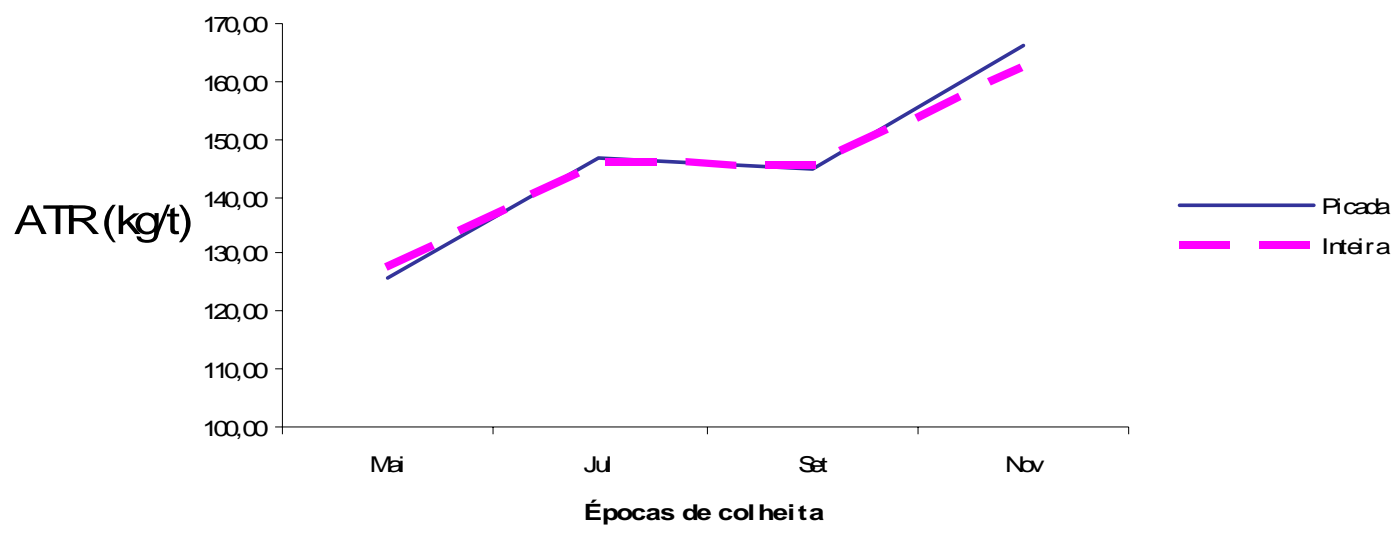

Figura 144 - Resultados de ATR para a variedade SP 71-1406 na safra 1985 , no $1^{\circ}$ corte e na época de plantio Janeiro

\section{Resultados de ATR- Safra 1985}

corte 1 - época de plantio Março

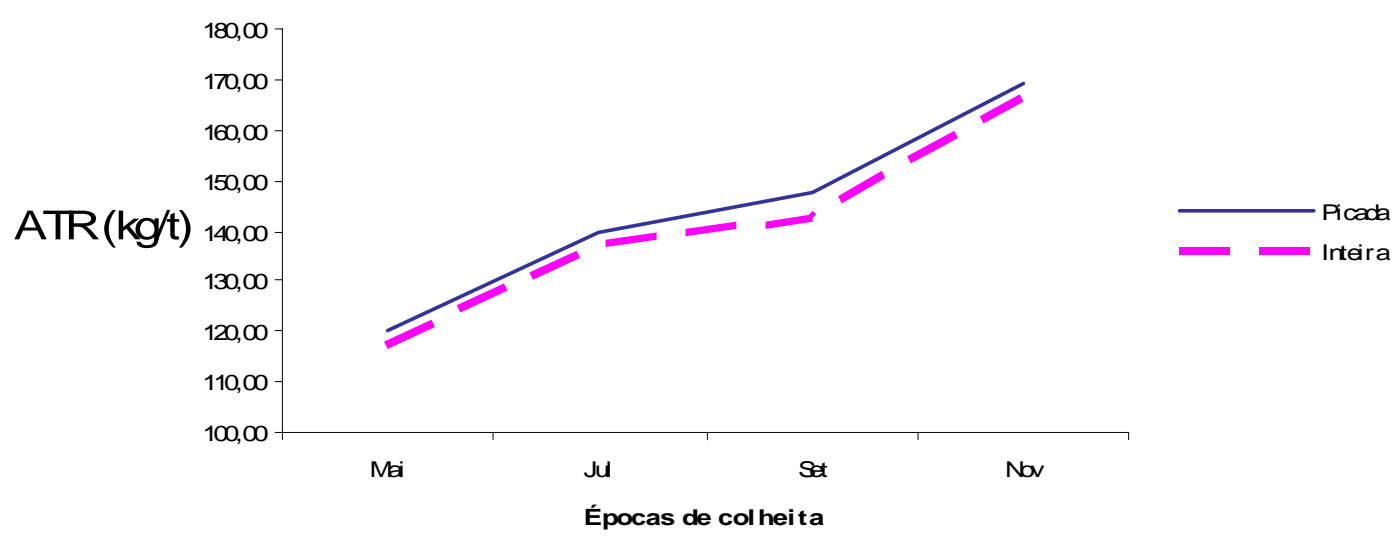

Figura 145 - Resultados de ATR para a variedade SP 71-1406 na safra 1985, no $1^{\circ}$ corte e na época de plantio Março 


\section{Resultados de ATR- Safra 1985}

corte 1 - época de plantio Maio

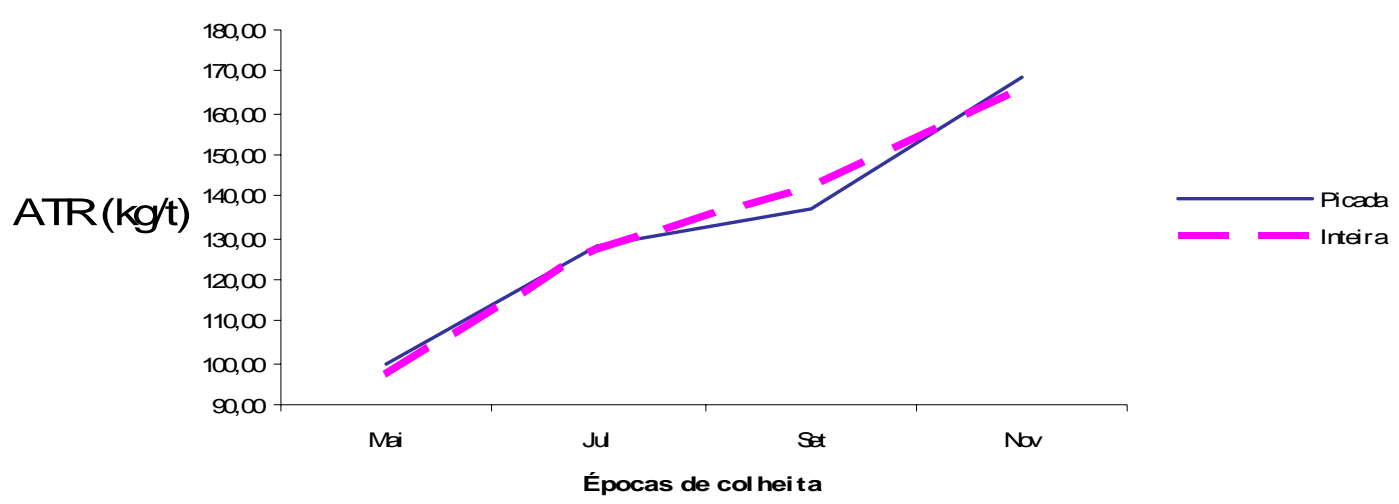

Figura 146 - Resultados de ATR para a variedade SP 71-1406 na safra 1985, no $1^{\circ}$ corte e na época de plantio Maio

Tabela 70. Valores médios de TAH para a variedade SP 71-1406 nas interações de épocas de plantio dentro de épocas de colheita, no ano de $1983 / 84$, no $1^{\circ}$ corte

\begin{tabular}{cccc}
\hline EPPLA & EPCOL & TAH (MÉDIA) \\
\hline Mar & Nov & 24,046 a & \\
Jan & Nov & 22,436 ab & \\
Nov & Nov & 21,343 abc \\
Mai & Nov & 19,856 & bcd \\
Mar & Set & 19,115 & bcde \\
Mar & Jul & 17,812 & cdef \\
Jan & Jul & 17,032 & defg \\
Nov & Jul & 16,127 & efg \\
Nov & Set & 14,956 & fg \\
Mai & Jul & 14,803 & fg \\
Jan & Set & 14,737 & fg \\
Jan & Mai & 14,229 & $\mathrm{~g}$ \\
Mai & Set & 14,131 & $\mathrm{~g}$ \\
Mar & Mai & 13,579 & $\mathrm{~g}$ \\
Nov & Mai & 13,561 & $\mathrm{~g}$ \\
Mai & Mai & 9,675 & $\mathrm{~h}$ \\
\hline
\end{tabular}

Médias seguidas das mesmas letras não diferiram estatisticamente entre si. 
$\mathrm{Na}$ tabela 70 , observa-se para a variedade SP $71-1406$, no primeiro corte e ano de plantio 1983/84, que houve diferença estatisticamente significativa entre as médias de TAH para a interação épocas de plantio dentro das épocas de colheita. Os resultados mostram que para qualquer época de plantio a época de colheita Novembro apresentou os maiores valores, ainda, dentro da época de colheita Novembro a época de plantio Maio mostrou menor resultado que Março. O menor valor foi obtido nas épocas de colheita Maio com plantio em Maio.

As figuras 147, 148, 149 e 150, a seguir, mostram a evolução de TAH onde se pode verificar o efeito das épocas de colheita sobre as épocas de plantio.

\section{Resultados deTAH- Safra 1985 \\ corte 1 - época de plantio Novembro}

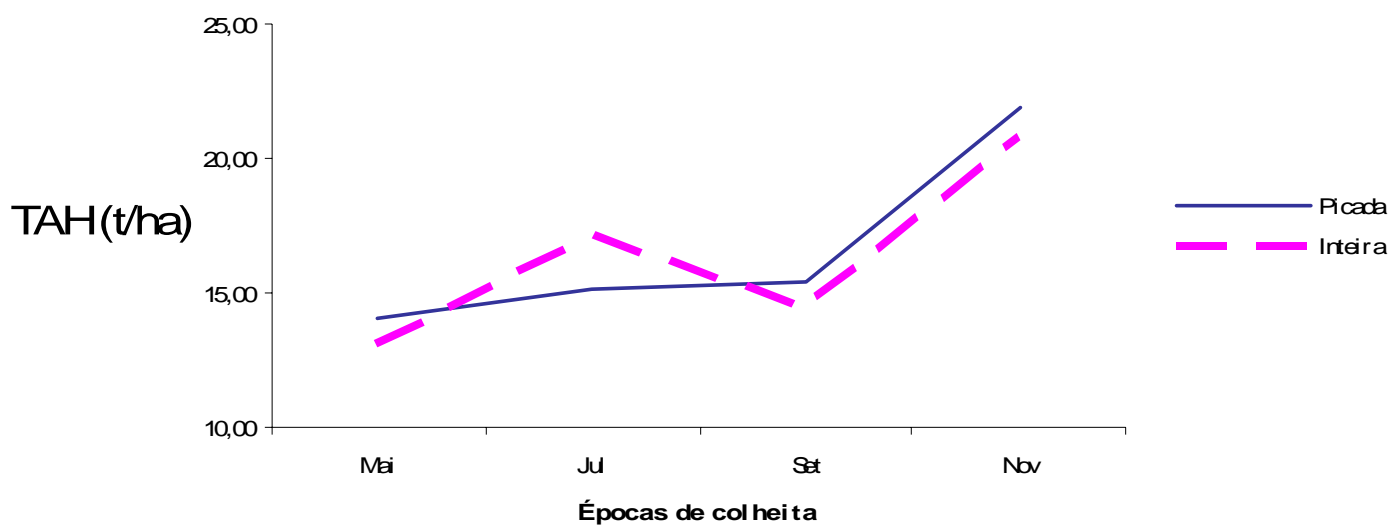

Figura 147 - Resultados de TAH para a variedade SP 71-1406 na safra 1985, no $1^{\circ}$ corte e na época de plantio Novembro 


\section{Resultados deTAH- Safra 1985}

corte 1 - época de plantio Janeiro

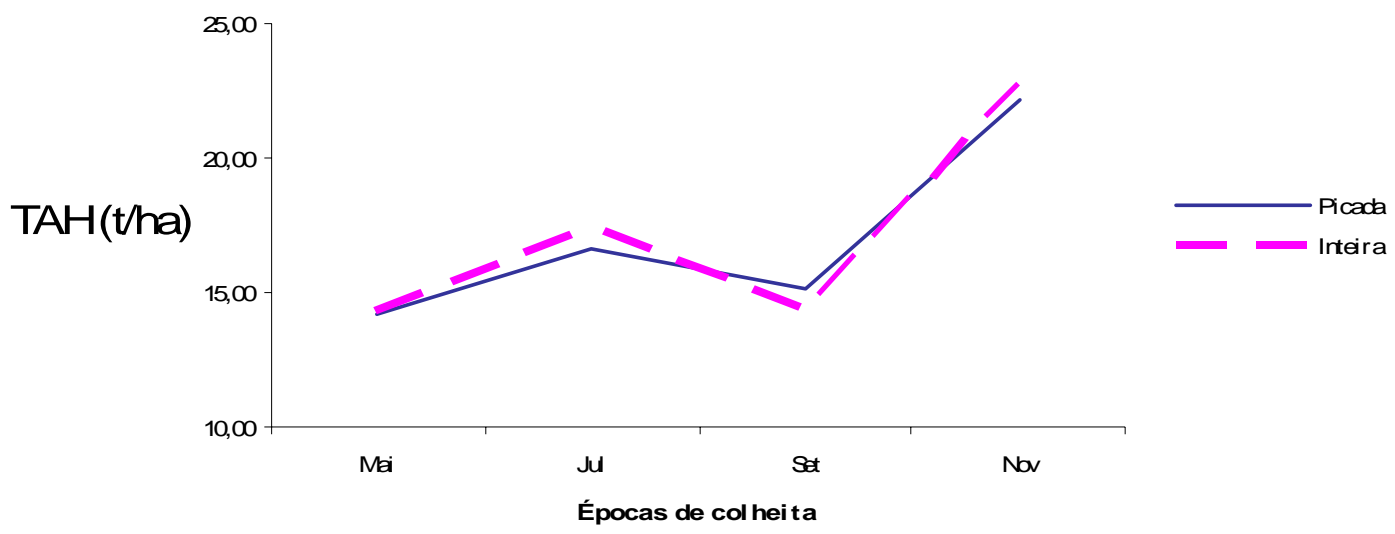

Figura 148 - Resultados de TAH para a variedade SP 71-1406 na safra 1985, no $1^{\circ}$ corte e na época de plantio Janeiro

\section{Resultados deTAH- Safra 1985 \\ corte 1 - época de plantio Março}

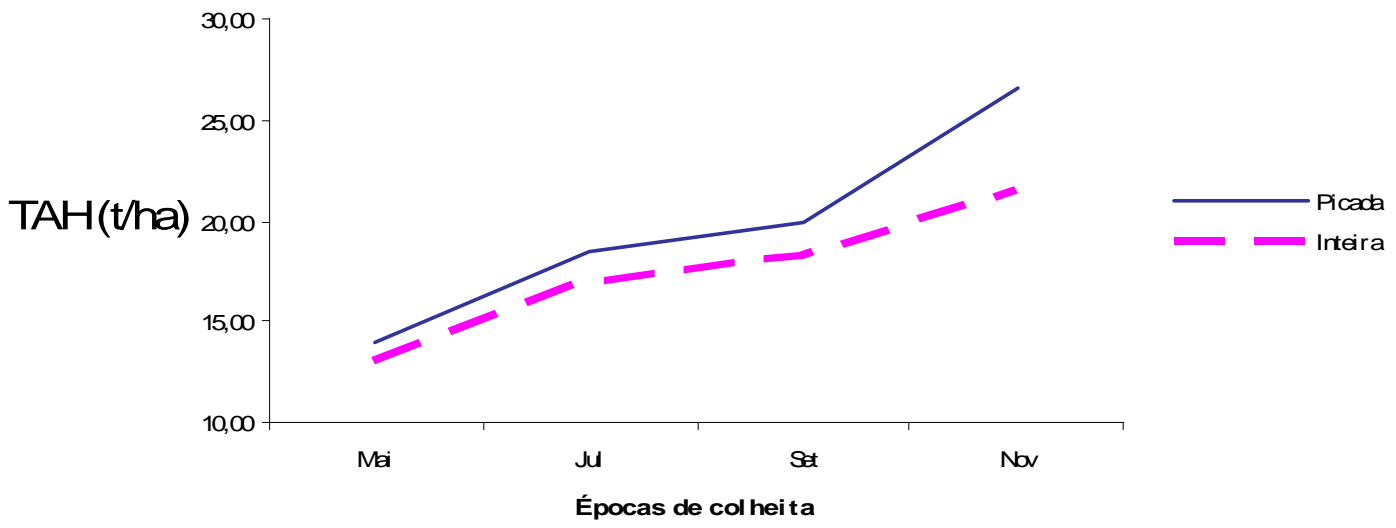

Figura 149 - Resultados de TAH para a variedade SP 71-1406 na safra 1985, no $1^{\circ}$ corte e na época de plantio Março 


\section{Resultados deTAH- Safra 1985 \\ corte 1 - época de plantio Maio}

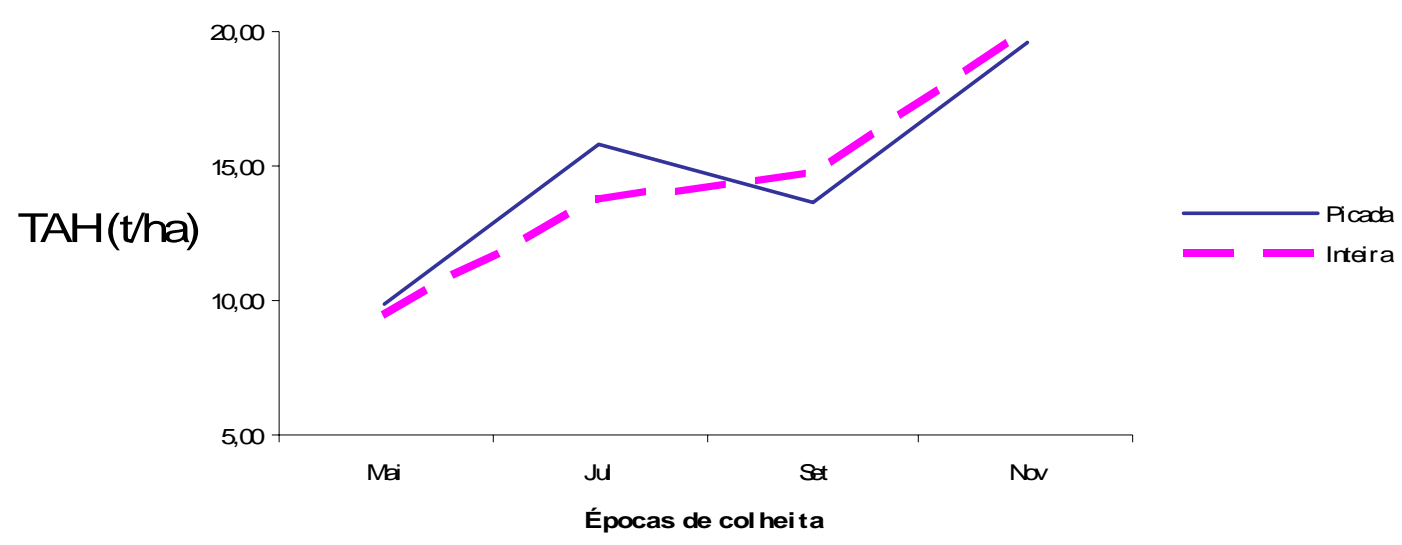

Figura 150 - Resultados de TAH para a variedade SP 71-1406 na safra 1985 , no $1^{\circ}$ corte e na época de plantio Maio

Tabela 71. Resumo dos quadros de análise de variância dos dados obtidos para a variedade SP 71-1406, no primeiro corte e com plantio no ano de 1984/85, em relação às variáveis dependentes TCH, ATR e TAH em várias combinações de épocas de plantio e de colheita e sob os tratamentos cana picada e inteira no sulco de plantio

\begin{tabular}{lcccc}
\hline \multicolumn{1}{c}{ C. Variação } & GL & TCH & ATR & TAH \\
\hline BLOCO & 4 & QM & QM & QM \\
EPCOL & 3 & $2509,288^{* *}$ & $23192,046^{* *}$ & $479,623^{* *}$ \\
Resíduo (a) & 12 & 70,313 & 52,799 & 1,475 \\
EPPLA & 3 & $7025,806^{* *}$ & $1260,512^{* *}$ & $191,700^{* *}$ \\
Resíduo (b) & 12 & 357,299 & 36,243 & 5,865 \\
TRAT & 1 & 14,677 & 26,520 & 0,025 \\
EPCOL ${ }^{*}$ EPPLA & 9 & $202,247^{* *}$ & $834,397^{* *}$ & $13,315^{*}$ \\
EPCOL ${ }^{*}$ TRAT & 3 & 41,386 & 6,307 & 0,412 \\
EPPLA ${ }^{*}$ TRAT & 3 & 44,026 & 1,643 & 0,709 \\
EPCOL ${ }^{*} E P P L A^{*} T R A T$ & 9 & 23,977 & 20,183 & 0,506 \\
Resíduo (c) & $10 \odot$ & 70,872 & 21,811 & 1,530 \\
Total & 159 & -- & -- & -- \\
\hline
\end{tabular}


A tabela 71, apresentada, mostra os valores da análise de variância, para as variáveis TCH, ATR e TAH, da variedade SP 71-1406, no primeiro corte e com plantio no ano de 1984/85.

Como se pode observar, houve efeito significativo de épocas de plantio e de épocas de colheita para as variáveis TCH, ATR e TAH. O tratamento muda picada e inteira no sulco de plantio não apresentou efeito significativo para as variáveis estudadas.

Houve interação de épocas de plantio dentro de épocas de colheita para as variáveis $\mathrm{TCH}$, ATR e TAH, indicando diferenças significativas entre as épocas de plantio para cada época de colheita. Não houve qualquer outra interação.

Tabela 72. Valores médios de TCH para a variedade SP 71-1406 nas interações de épocas de plantio dentro de épocas de colheita, com plantio no ano de $1984 / 85$, no $1^{\circ}$ corte

\begin{tabular}{|c|c|c|c|}
\hline$E P P L A$ & EPCOL & \multicolumn{2}{|c|}{$T C H$ (MÉDIA) } \\
\hline Nov & Nov & 126,741 & $\mathrm{a}$ \\
\hline Nov & Set & 125,002 & $a b$ \\
\hline Jan & Nov & 121,789 & $a b c$ \\
\hline Nov & Mai & 121,680 & $a b c$ \\
\hline Jan & Set & 118,669 & abcd \\
\hline Mar & Nov & 118,527 & abcd \\
\hline Nov & Jul & 117,955 & abcd \\
\hline Jan & Jul & 112,453 & bcde \\
\hline Mar & Set & 109,431 & cdef \\
\hline Jan & Mai & 106,122 & def \\
\hline Mai & Nov & 105,644 & def \\
\hline Mar & Jul & 99,929 & efg \\
\hline Mar & Mai & 97,228 & $\mathrm{fg}$ \\
\hline Mai & Set & 96,384 & $\mathrm{fg}$ \\
\hline Mai & Jul & 89,086 & gh \\
\hline Mai & Mai & 76,216 & $\mathrm{~h}$ \\
\hline
\end{tabular}

Médias seguidas das mesmas letras não diferiram estatisticamente entre si.

$\mathrm{Na}$ tabela 72 , observa-se para a variedade SP $71-1406$, no primeiro corte e ano de plantio 1984/85, que houve diferença estatisticamente 
significativa entre as médias de TCH para a interação de épocas de plantio dentro das épocas de colheita. Os maiores valores foram obtidos nas colheitas de Novembro, Setembro, Maio e Julho com plantios em Novembro; nas colheitas de Novembro e Setembro com plantios em Janeiro e, ainda, nas colheitas de Novembro com plantios em Março. Os menores valores foram obtidos nas colheitas de Maio, Julho e Setembro com plantios em Maio e nas colheitas de Maio e Julho com plantios em Março.

As figuras 151, 152, 153 e 154, a seguir, mostram a evolução de TCH onde se pode verificar o efeito das épocas de colheita sobre as épocas de plantio.

\section{Resultados de TCH- Safra 1986 corte 1 - época de plantio Novembro}

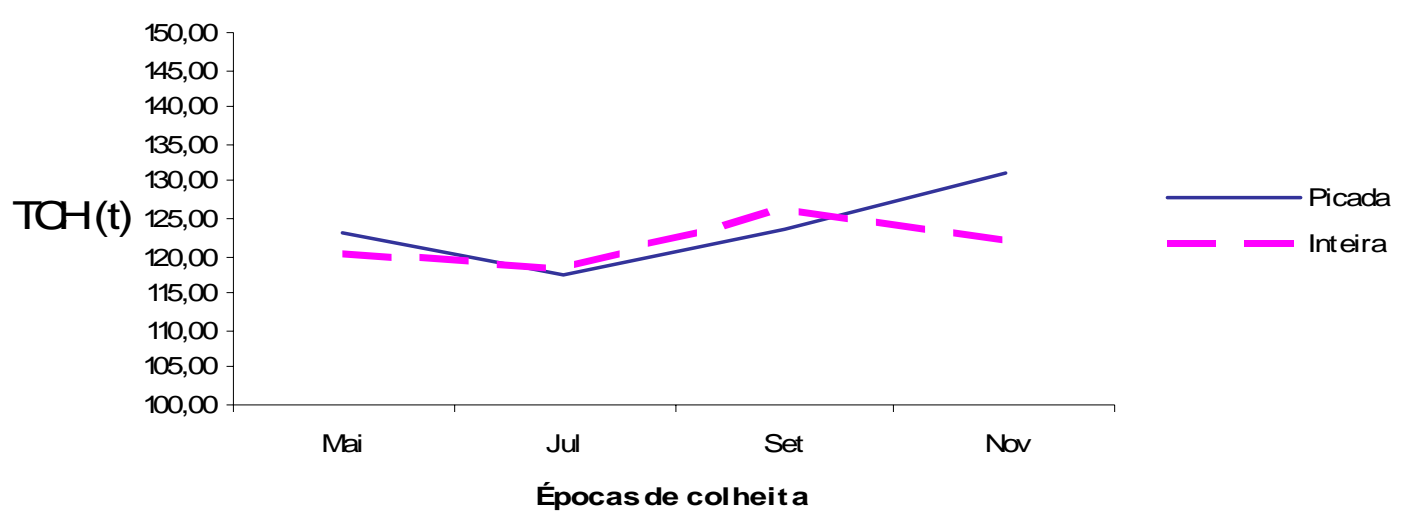

Figura 151 - Resultados de TCH para a variedade SP 71-1406 na safra 1986, no $1^{\circ}$ corte e na época de plantio Novembro 


\section{Resultados de TCH-Safra 1986 \\ corte 1 - época de plantio Janeiro}

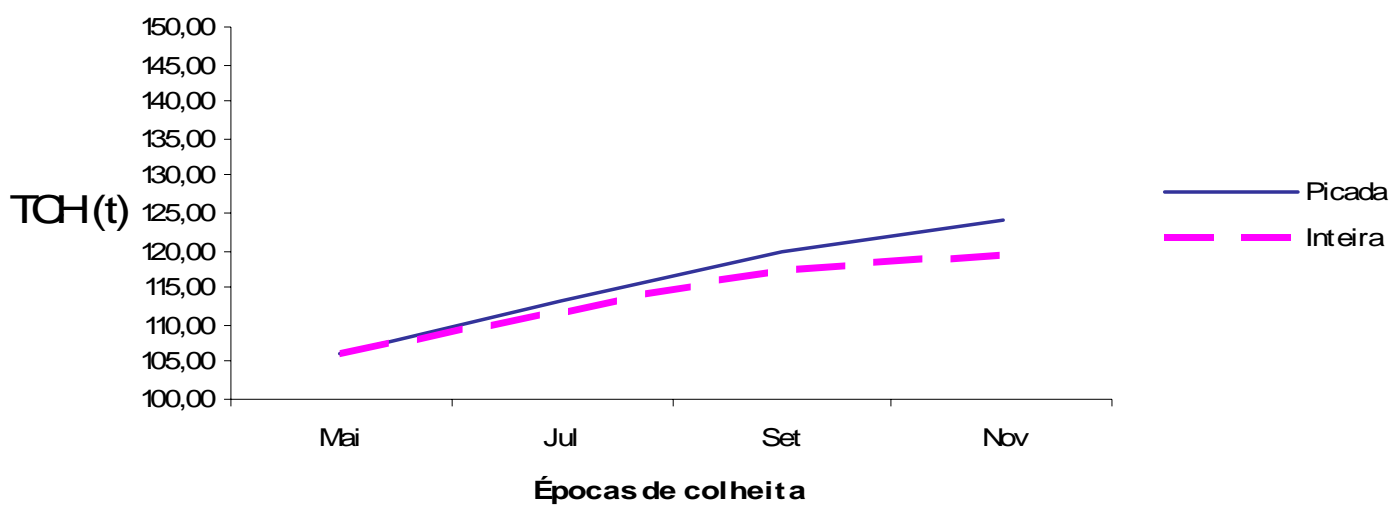

Figura 152 - Resultados de TCH para a variedade SP 71-1406 na safra 1986, no $1^{\circ}$ corte e na época de plantio Janeiro

Resultados de TCH- Safra 1986

corte 1- época de plantio Março

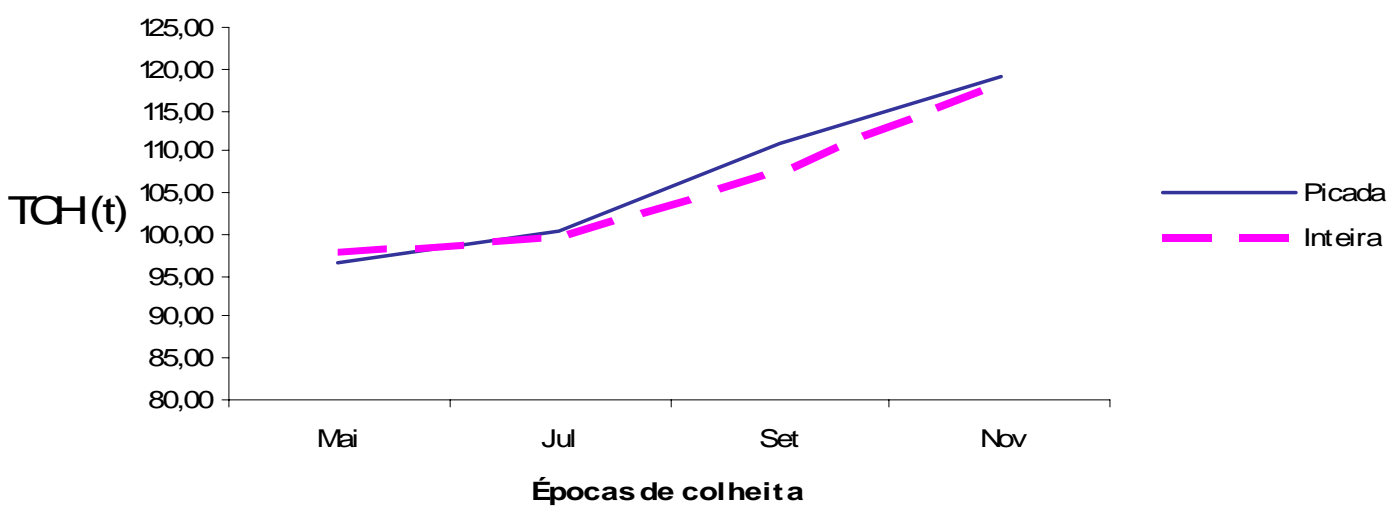

Figura 153 - Resultados de TCH para a variedade SP 71-1406 na safra 1986, no $1^{\circ}$ corte e na época de plantio Março 
Resultados de TCH- Safra 1986

corte 1 - época de plantio Maio

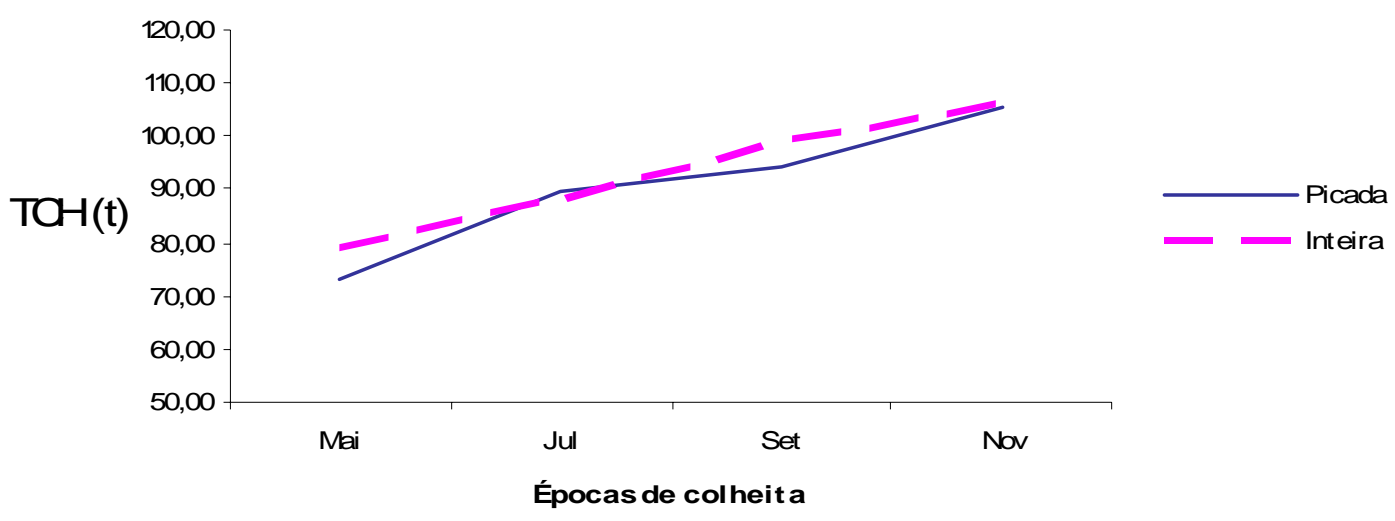

Figura 154 - Resultados de TCH para a variedade SP 71-1406 na safra 1986, no $1^{\circ}$ corte e na época de plantio Maio

Tabela 73. Valores médios de ATR para a variedade SP 71-1406 nas interações de épocas de plantio dentro de épocas de colheita, com plantio no ano de 1984/85, no $1^{\circ}$ corte

\begin{tabular}{|c|c|c|c|}
\hline EPPLA & EPCOL & \multicolumn{2}{|c|}{ ATR (MÉDIA) } \\
\hline Mar & Nov & 158,930 & a \\
\hline Mai & Nov & 155,852 & $a b$ \\
\hline Jan & Nov & 153,712 & $a b c$ \\
\hline Mar & Set & 151,894 & abcd \\
\hline Jan & Set & 150,445 & bcde \\
\hline Nov & Nov & 148,434 & cde \\
\hline Mai & Set & 145,603 & def \\
\hline Nov & Set & 143,903 & ef \\
\hline Nov & Jul & 140,418 & $f g$ \\
\hline Jan & Jul & 133,919 & $g$ \\
\hline Mar & Jul & 129,310 & g \\
\hline Mai & Jul & 120,664 & $\mathrm{~h}$ \\
\hline Nov & Mai & 116,265 & $i$ \\
\hline Jan & Mai & 110,080 & i \\
\hline Mar & Mai & 96,313 & j \\
\hline Mai & Mai & 79,002 & k \\
\hline
\end{tabular}

Médias seguidas das mesmas letras não diferiram estatisticamente entre si. 
$\mathrm{Na}$ tabela 73 , observa-se para a variedade SP $71-1406$, no primeiro corte e ano de plantio 1984/85, que houve diferença estatisticamente significativa entre as médias de ATR para a interação de épocas de plantio dentro das épocas de colheita. Os maiores valores de ATR foram obtidos nas épocas de colheita Novembro com plantios em Março, Maio e Janeiro e épocas de colheita Setembro com plantios em Março e Janeiro. Os menores valores foram obtidos nas épocas de colheita Maio com plantios em Maio, Março, Janeiro e Novembro.

As figuras 155, 156, 157 e 158, a seguir, mostram a evolução de ATR onde se pode verificar o efeito das épocas de colheita sobre as épocas de plantio.

\section{Resultados de ATR- Safra 1986 \\ corte 1 - época de plantio Novembro}

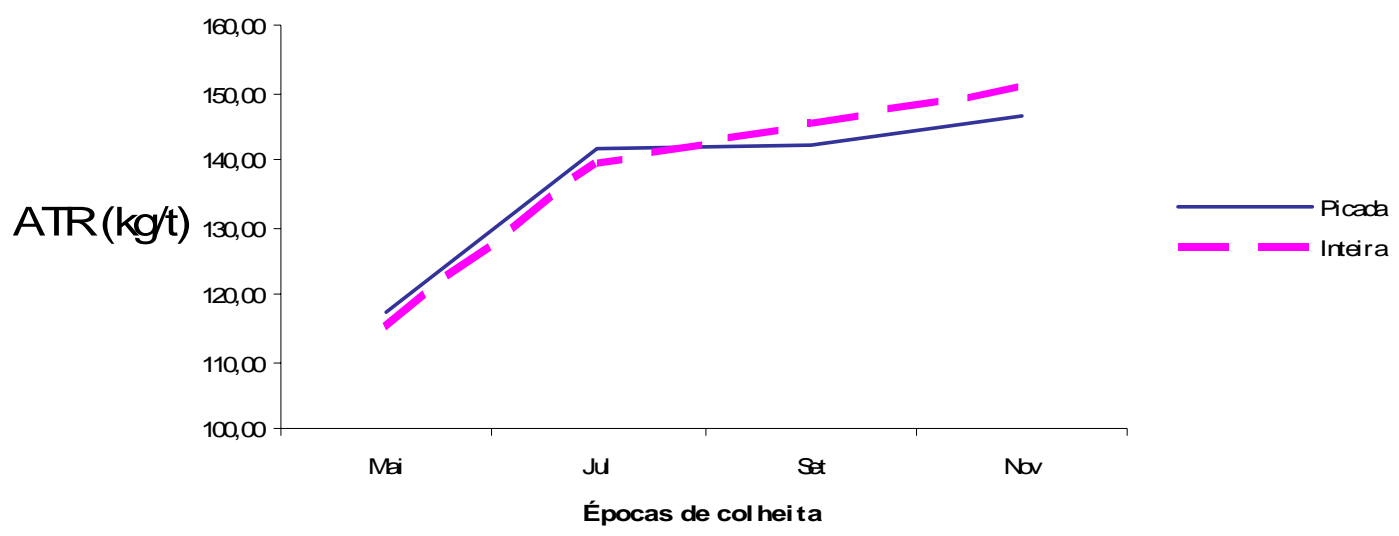

Figura 155 - Resultados de ATR para a variedade SP 71-1406 na safra 1986, no $1^{\circ}$ corte e na época de plantio Novembro 
Resultados de ATR- Safra 1986

corte 1 - época de plantio Janeiro

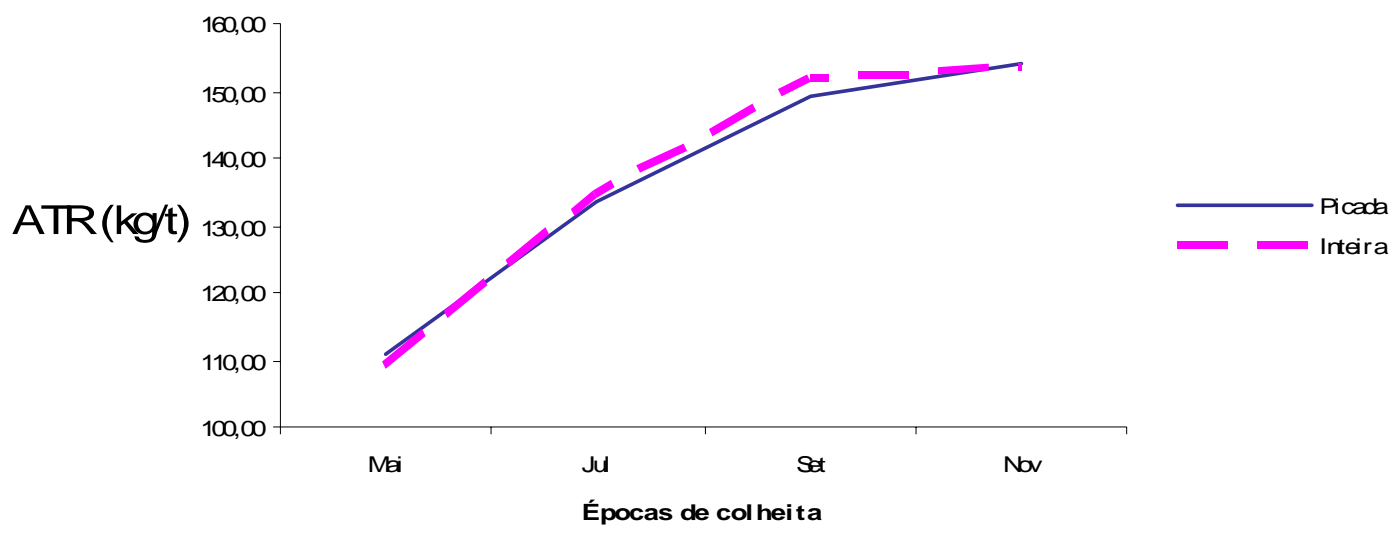

Figura 156 - Resultados de ATR para a variedade SP 71-1406 na safra 1986, no $1^{\circ}$ corte e na época de plantio Janeiro

Resultados de ATR- Safra 1986

corte 1 - época de plantio Março

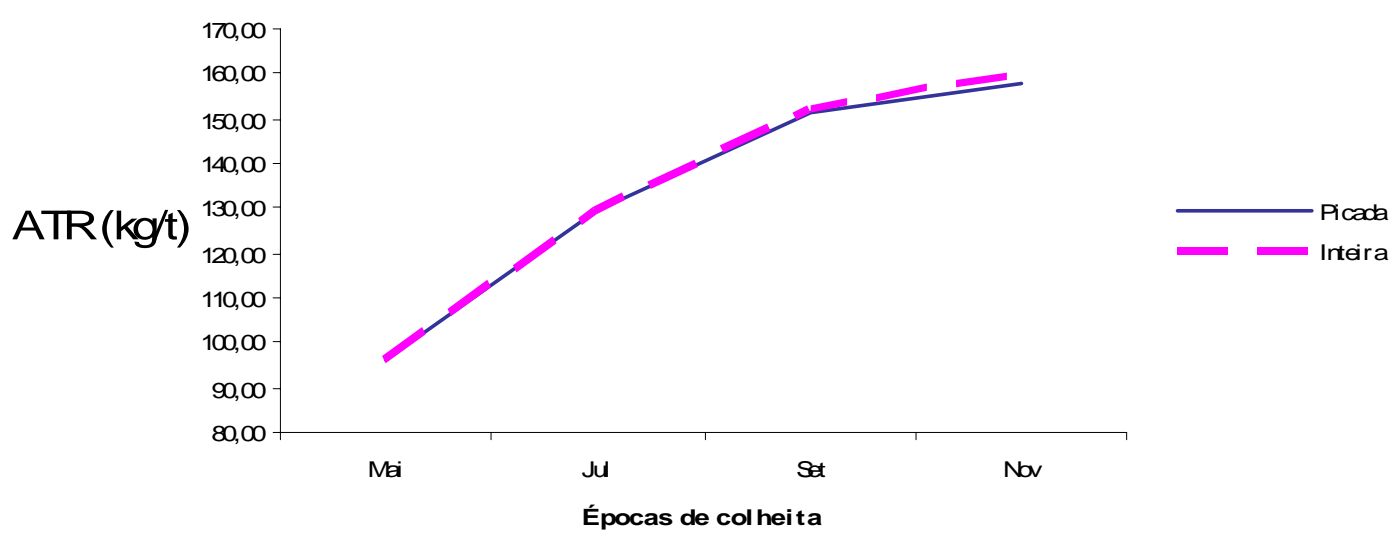

Figura 157 - Resultados de ATR para a variedade SP 71-1406 na safra 1986, no $1^{\circ}$ corte e na época de plantio Março 


\section{Resultados de ATR- Safra 1986}

corte 1 - época de plantio Maio

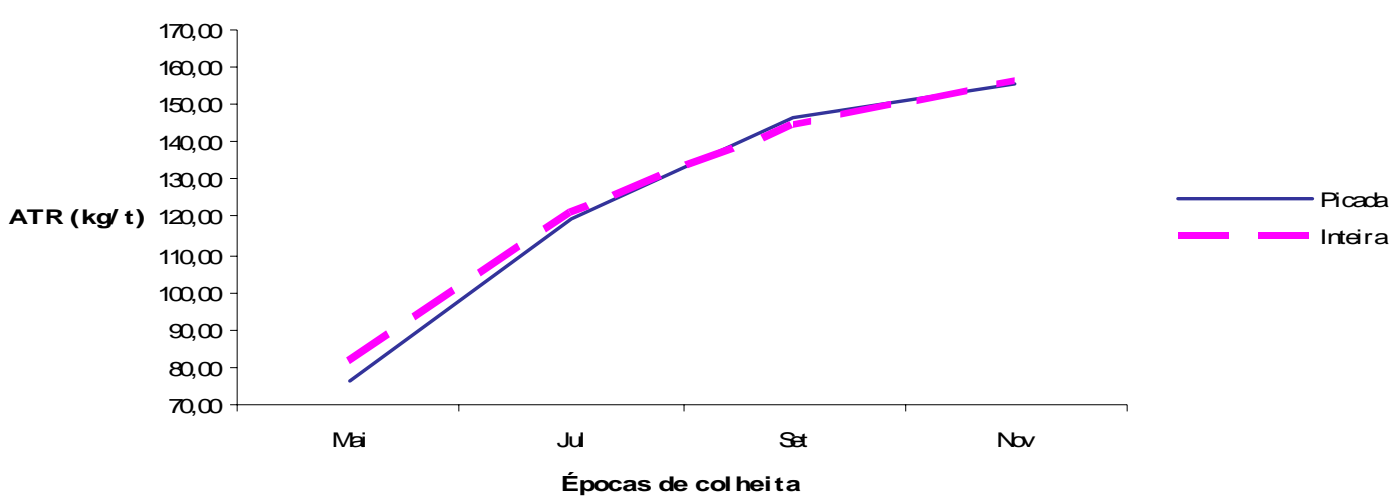

Figura 158 - Resultados de ATR para a variedade SP 71-1406 na safra 1986, no $1^{\circ}$ corte e na época de plantio Maio

Tabela 74. Valores médios de TAH para a variedade SP 71-1406 nas interações de épocas de plantio dentro de épocas de colheita, com plantio no ano de $1984 / 85$, no $1^{\circ}$ corte

\begin{tabular}{cccc}
\hline EPPLA & EPCOL & TAH (MÉDIA) \\
\hline Mar & Nov & 18,839 a \\
Nov & Nov & 18,768 a \\
Jan & Nov & 18,720 a \\
Nov & Set & 17,980 ab \\
Jan & Set & 17,844 ab \\
Mar & Set & $16,599 \quad$ bc \\
Nov & Jul & 16,538 bc \\
Mai & Nov & 16,460 & bc \\
Jan & Jul & 15,061 & cd \\
Nov & Mai & 14,171 & de \\
Mai & Set & 14,001 & de \\
Mar & Jul & 12,892 & ef \\
Jan & Mai & 11,674 & fg \\
Mai & Jul & 10,758 & gh \\
Mar & Mai & 9,350 & $\mathrm{~h}$ \\
Mai & Mai & 6,020 & $\mathrm{i}$ \\
\hline Médias seguidas das mesmas letras não diferiram estatisticamente entre si.
\end{tabular}

Médias seguidas das mesmas letras não diferiram estatisticamente entre si. 
$\mathrm{Na}$ tabela 74 , observa-se para a variedade SP 71-1406, no primeiro corte e ano de plantio 1984/85, que houve diferença estatisticamente significativa entre as médias de TAH para a interação épocas de plantio dentro das épocas de colheita. Os maiores valores foram obtidos nas colheitas de Novembro e Setembro com plantios em Março Novembro e Janeiro. Os menores valores foram obtidos nas épocas de colheita de Maio com plantios em Maio, Março e Janeiro e, ainda, nas colheitas de Julho com plantios em Maio e Março.

As figuras 159, 160, 161 e 162, a seguir, mostram a evolução de TAH onde se pode verificar o efeito das épocas de colheita sobre as épocas de plantio.

\section{Resultados deTAH- Safra 1986 \\ corte 1 - época de plantio Novembro}

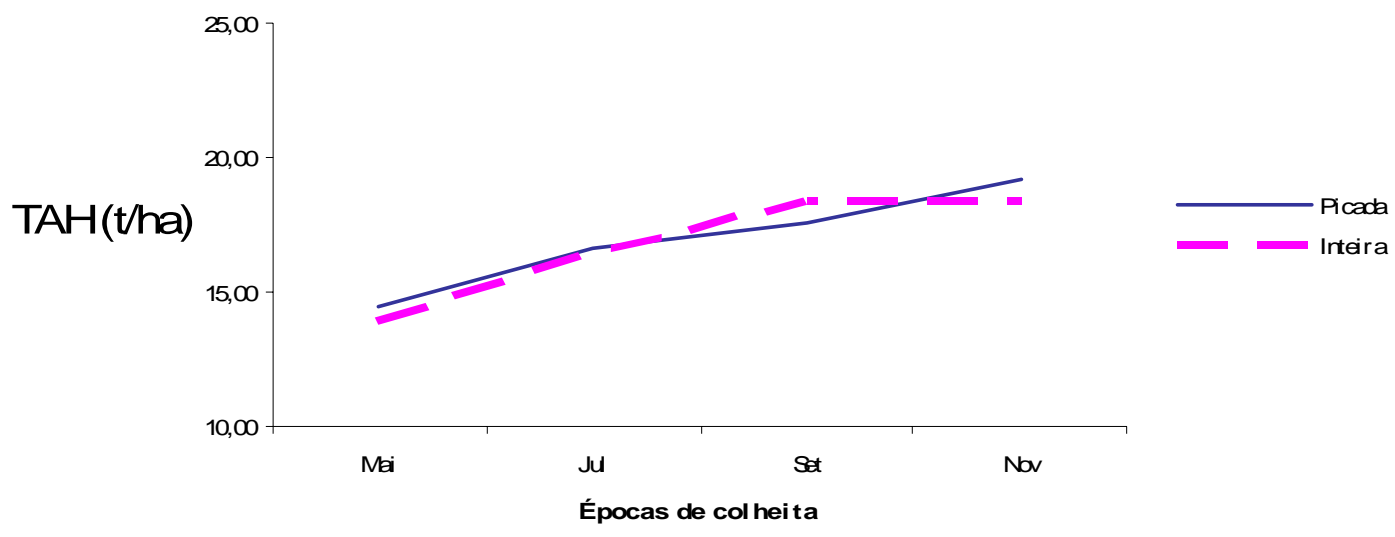

Figura 159 - Resultados de TAH para a variedade SP 71-1406 na safra 1986, no $1^{\circ}$ corte e na época de plantio Novembro 


\section{Resultados deTAH- Safra 1986 \\ corte 1 - época de plantio Janeiro}

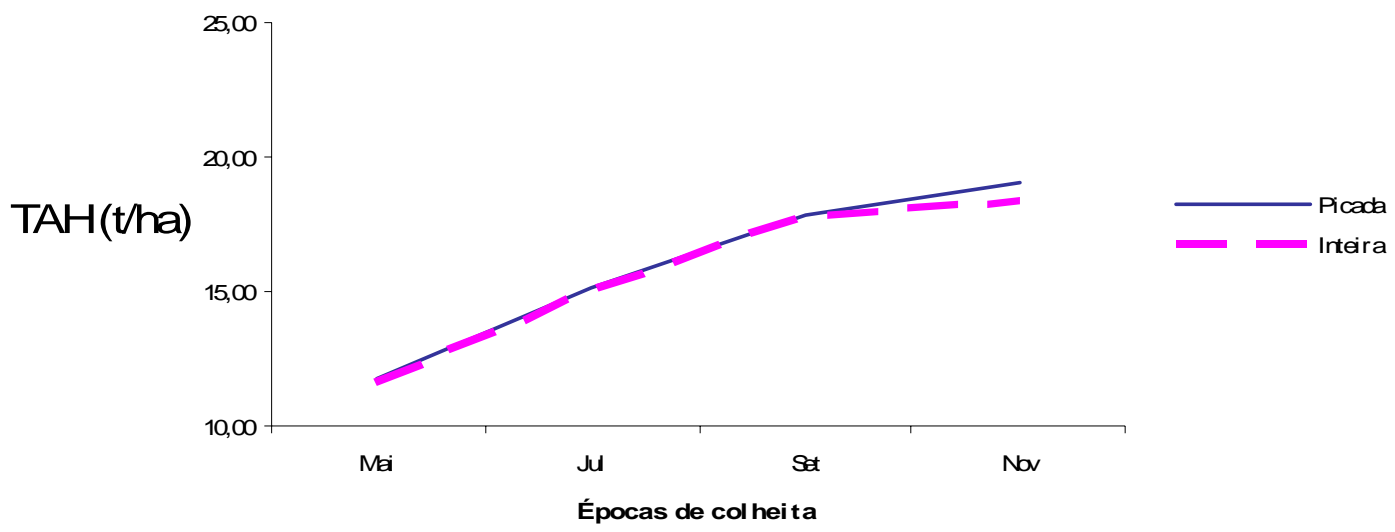

Figura 160 - Resultados de TAH para a variedade SP 71-1406 na safra 1986, no $1^{\circ}$ corte e na época de plantio Janeiro

\section{Resultados deTAH- Safra 1986 \\ corte 1 - época de plantio Março}

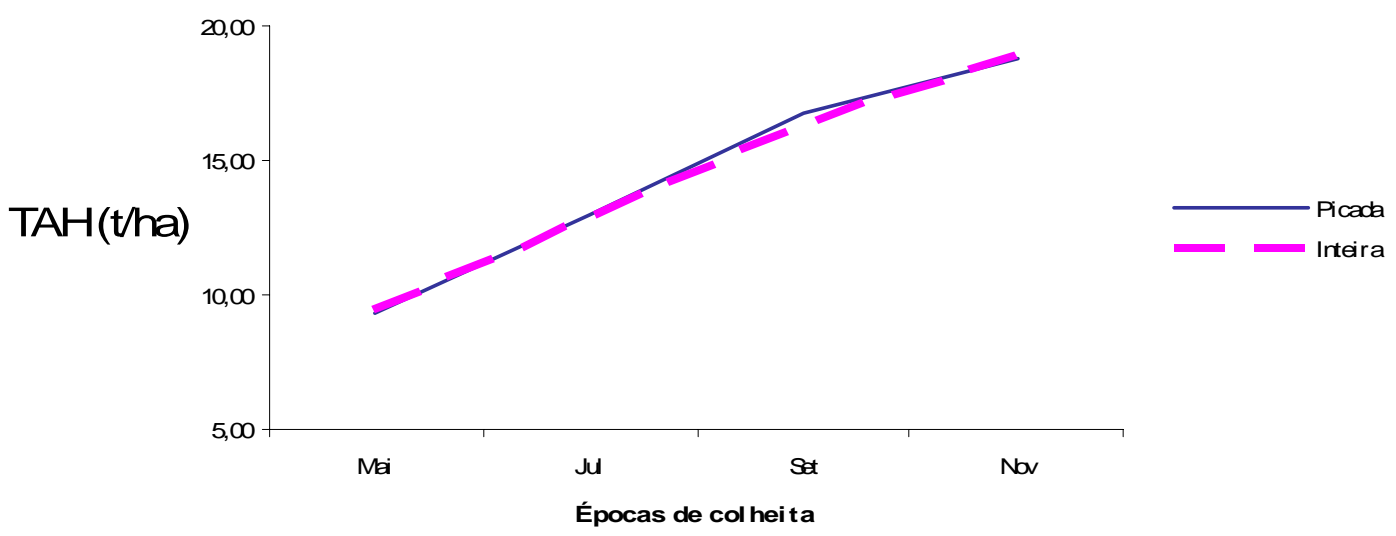

Figura 161 - Resultados de TAH para a variedade SP 71-1406 na safra 1986 , no $1^{\circ}$ corte e na época de plantio Março 


\section{Resultados deTAH- Safra 1986 corte 1 - época de plantio Maio}

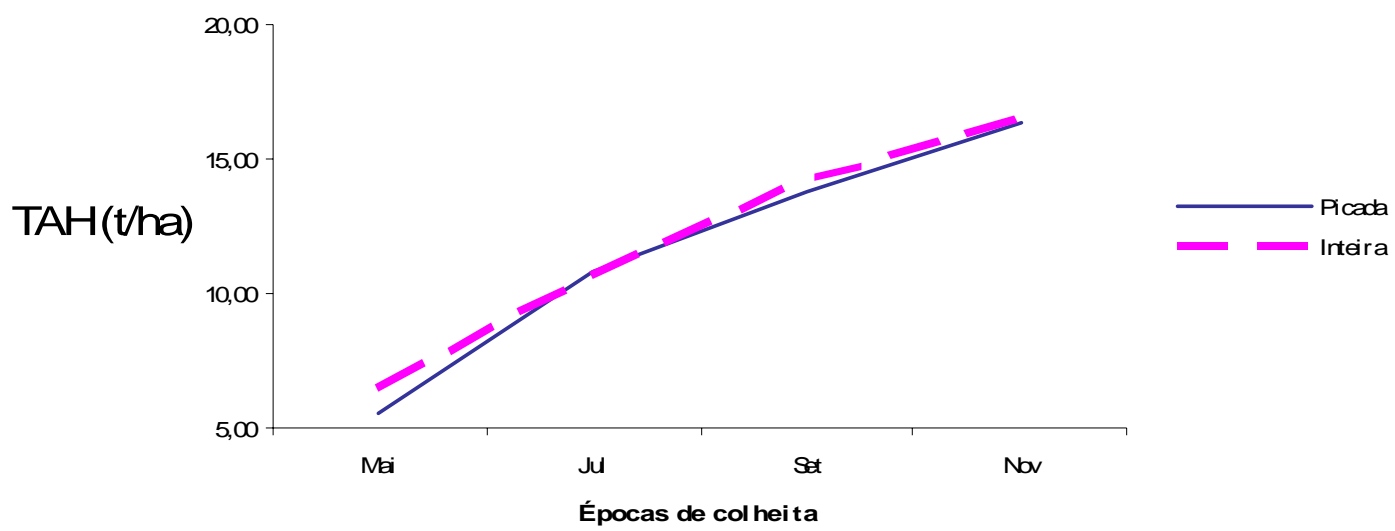

Figura 162 - Resultados de TAH para a variedade SP 71-1406 na safra 1986 , no $1^{\circ}$ corte e na época de plantio Maio

Tabela 75. Resumo dos quadros de análise de variância dos dados obtidos para a variedade SP 71-1406, no primeiro corte e com plantio no ano de 1985/86, em relação às variáveis dependentes TCH, ATR e TAH em várias combinações de épocas de plantio e de colheita e sob os tratamentos cana picada e inteira no sulco de plantio

\begin{tabular}{|c|c|c|c|c|}
\hline C. Variação & $G L$ & $\begin{array}{c}\text { TCH } \\
Q M\end{array}$ & $\begin{array}{c}\text { ATR } \\
Q M\end{array}$ & $\begin{array}{c}\text { TAH } \\
Q M\end{array}$ \\
\hline$B L O C O$ & 4 & -- & -- & -- \\
\hline EPCOL & 3 & $1473,066^{* *}$ & 8621,453 * * & 257,221 ** \\
\hline Resíduo (a) & 12 & 295,916 & 27,321 & 6,788 \\
\hline$E P P L A$ & 3 & $20632,413^{*} *$ & 1108,226 * * & $570,845^{* *}$ \\
\hline Resíduo (b) & 12 & 696,024 & 43,840 & 11,402 \\
\hline TRAT & 1 & $658,370^{*}$ & $\odot, 570$ & 13,059 \\
\hline$E P C O L{ }^{*} E P P L A$ & 9 & 166,933 & $474,248 * *$ & $7,885^{*}$ \\
\hline$E P C O L{ }^{*} T R A T$ & 3 & 13,144 & 11,048 & $\odot, 161$ \\
\hline$E P P L A{ }^{*} T R A T$ & 3 & 434,722 * & $\odot, 878$ & 7,795 \\
\hline $\begin{array}{l}\text { EPCOL *EPPLA*TRAT } \\
\text { Resíduo (c) }\end{array}$ & $\begin{array}{c}9 \\
10 \odot\end{array}$ & $\begin{array}{l}155,105 \\
154,140\end{array}$ & $\begin{array}{r}9,350 \\
15,717\end{array}$ & $\begin{array}{l}2,677 \\
3,556\end{array}$ \\
\hline Total & 159 & -- & -- & -- \\
\hline
\end{tabular}


A tabela 75 , mostra os valores da análise de variância para as variáveis TCH, ATR e TAH da variedade SP 71-1406, no primeiro corte e ano de plantio 1985/86.

Como se pode observar, houve efeito significativo de épocas de plantio e de épocas de colheita para as variáveis TCH, ATR e TAH. O tratamento muda picada e inteira no sulco de plantio apresentou efeito significativo apenas para a variável TCH.

Houve interação de épocas de plantio dentro de épocas de colheita para as variáveis ATR e TAH, indicando diferenças significativas entre as épocas de plantio para cada época de colheita. Houve, também, interação de tratamentos dentro de épocas de plantio para $\mathrm{TCH}$, indicando diferenças significativas entre os tipos de mudas (inteira ou picada no sulco de plantio) para cada época de plantio. Não houve qualquer outra interação.

Tabela 76. Valores médios de TCH para a variedade SP 71-1406 nas interações de tratamento dentro de épocas de plantio, com plantio no ano de $1985 / 86$, no $1^{\circ}$ corte

\begin{tabular}{ccc}
\hline EPPLA & Tratamento & TCH (MÉDIA) \\
\hline Nov & Muda inteira & $155,717 \mathrm{a}$ \\
Nov & Muda picada & $152,122 \mathrm{a}$ \\
Jan & Muda picada & $144,396 \mathrm{a}$ \\
Jan & Muda inteira & $142,503 \mathrm{a}$ \\
Mar & Muda picada & $127,836 \mathrm{~b}$ \\
Mar & Muda inteira & $121,954 \mathrm{~b}$ \\
Mai & Muda picada & $108,216 \mathrm{c}$ \\
Mai & Muda inteira & $96,168 \mathrm{~d}$ \\
\hline
\end{tabular}

Médias seguidas das mesmas letras não diferiram estatisticamente entre si.

$\mathrm{Na}$ tabela 76, observa-se que para a variedade SP 71-1406, no primeiro corte e ano de plantio 1985/86, houve diferença estatisticamente significativa entre as médias de $\mathrm{TCH}$ para a interação de tratamentos (muda inteira ou picada no sulco de plantio) dentro da época de plantio. Os maiores valores de TCH foram obtidos nas épocas de plantio Novembro e Janeiro. Os 
menores valores foram obtidos na época de plantio Maio onde os tratamentos apresentaram diferenças estatisticamente significativas entre si, sendo significativamente superior o desempenho da muda de cana picada para essa variedade.

A Figura 163, a seguir, mostra a evolução de TCH para as épocas de plantio onde se pode verificar o efeito dos tratamentos (muda inteira ou picada no sulco de plantio) sobre os valores observados.

A Figura 08, já apresentada, mostra o balanço hídrico para o período estudado onde se pode observar que a partir do mês de abril até julho ocorreram baixas precipitações e queda na temperatura (Figura 09), considerando que Maio é uma época de plantio com condições climáticas menos favoráveis para a cana, caracterizada por declínio na temperatura e déficit hídrico, os resultados obtidos para esta variedade de cana contradizem os resultados obtidos para a variedade SP 70-1143 (tabelas 04 e 08, já apresentadas) que coincidiram com os resultados de Lee et al. (1984), que notaram que quando ocorre um período de déficit hídrico, o plantio de cana inteira em comparação com toletes de três gemas apresenta falhas menores e o "stand" final melhor.

Resultados de TCH

Safra1987-corte 1

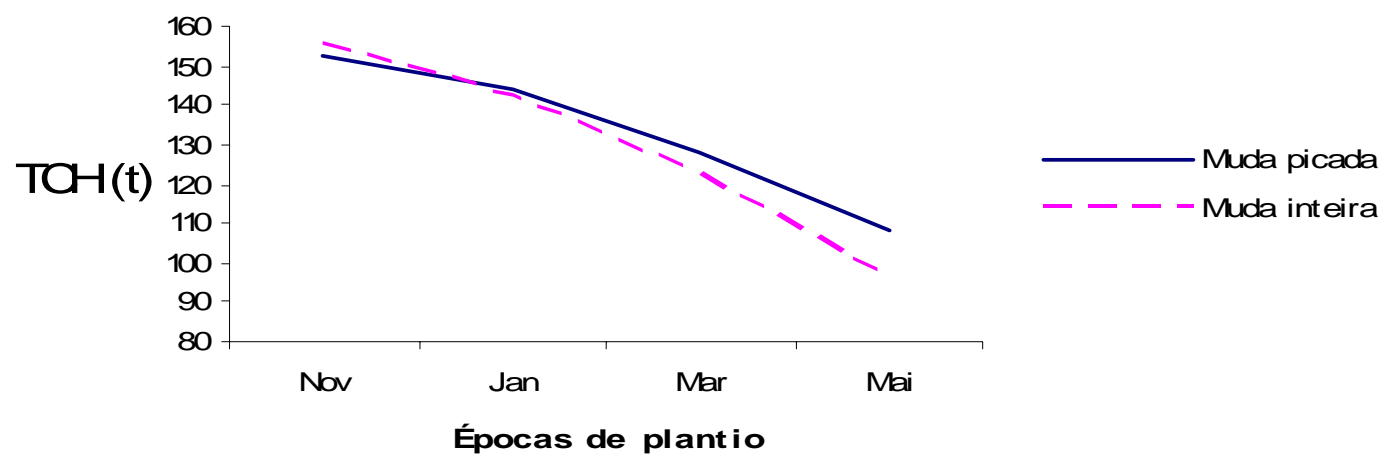

Figura 163 - Resultados de TCH para a variedade SP 71-1406 na safra 1987, no $1^{\circ}$ corte nas épocas de plantio 
Tabela 77. Valores médios de $\mathrm{TCH}$ para a variedade SP 71-1406 nas épocas de colheita, com plantio no ano de $1985 / 86$, no $1^{\circ}$ corte

\begin{tabular}{ccc}
\hline EPCOL & $T C H$ (MÉDIA) \\
\hline Nov & 136,277 & $\mathrm{a}$ \\
Set & 135,955 & $\mathrm{a}$ \\
Jul & 128,390 & ab \\
Mai & 123,836 & b \\
\hline
\end{tabular}

Médias seguidas das mesmas letras não diferiram estatisticamente entre si.

$\mathrm{Na}$ tabela 77, observa-se que para a variedade SP 71-1406, no primeiro corte e ano de plantio 1985/86, houve diferença estatisticamente significativa entre as médias de TCH para as épocas de colheita. Os maiores valores de TCH foram obtidos nas épocas de colheita Novembro, Setembro e Julho. Os menores valores foram obtidos na época de colheita Maio.

A Figura 164, a seguir, mostra a evolução de TCH para as épocas de colheita. A Figura 08, já apresentado, mostra o balanço hídrico nos anos estudados onde se pode observar que na safra de 1987 ocorreram chuvas bem distribuídas durante o período acrescido de quedas menores na temperatura (Figura 09, já apresentada), assim, houve condições climáticas favoráveis para a variedade de cana estudada manter sua taxa de crescimento e acumular massa. 
Resultados de TCH

Safra1987-corte 1

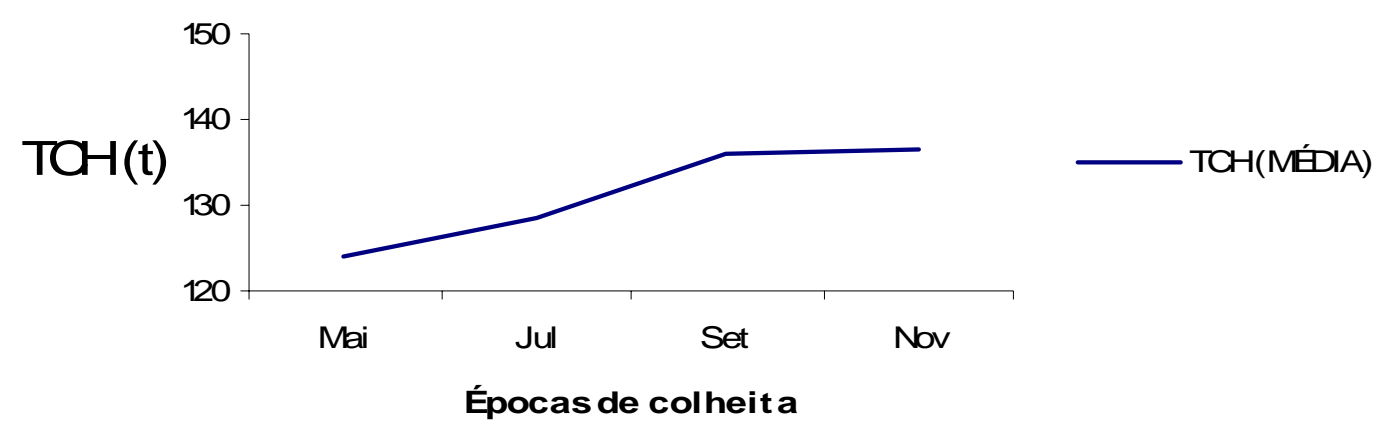

Figura 164 - Resultados de TCH para a variedade SP 71-1406 na safra 1987, no $1^{\circ}$ corte nas épocas de colheita

Tabela 78. Valores médios de ATR para a variedade SP 71-1406 nas interações de épocas de plantio dentro de épocas de colheita, no ano de $1985 / 86$, no $1^{\circ}$ corte

\begin{tabular}{|c|c|c|c|}
\hline EPPLA & EPCOL & \multicolumn{2}{|c|}{ ATR (MÉDIA) } \\
\hline Mar & Set & 159,185 & $\mathrm{a}$ \\
\hline Jan & Set & 158,856 & a \\
\hline Nov & Set & 157,114 & a \\
\hline Mai & Set & 155,321 & $a b$ \\
\hline Nov & Jul & 149,416 & bc \\
\hline Jan & Jul & 149,285 & bc \\
\hline Mar & Nov & 148,020 & C \\
\hline Mar & Jul & 147,359 & C \\
\hline Mai & Nov & 145,759 & C \\
\hline Nov & Nov & 145,558 & C \\
\hline Jan & Nov & 144,226 & $\mathrm{~cd}$ \\
\hline Mai & Jul & 138,676 & de \\
\hline Nov & Mai & 135,869 & e \\
\hline Jan & Mai & 129,232 & $f$ \\
\hline Mar & Mai & 123,911 & $f$ \\
\hline Mai & Mai & 101,558 & g \\
\hline
\end{tabular}

Médias seguidas das mesmas letras não diferiram estatisticamente entre si. 
$\mathrm{Na}$ tabela 78, observa-se que para a variedade SP 71-1406, no primeiro corte e ano de plantio 1985/86, houve diferença estatisticamente significativa entre as médias de ATR para a interação épocas de plantio dentro das épocas de colheita.

Os maiores valores de ATR foram obtidos nas épocas de colheita Setembro com plantios em Março, Janeiro, Novembro e Maio. Os menores valores foram obtidos nas épocas de colheita Maio com plantios em Maio, Março, Janeiro e Novembro.

As figuras 165, 166, 167 e 168, a seguir, mostram a evolução de ATR onde se pode verificar o efeito das épocas de colheita sobre as épocas de plantio.

Resultados de ATR- Safra 1987 corte 1 - época de plantio Nbvembro

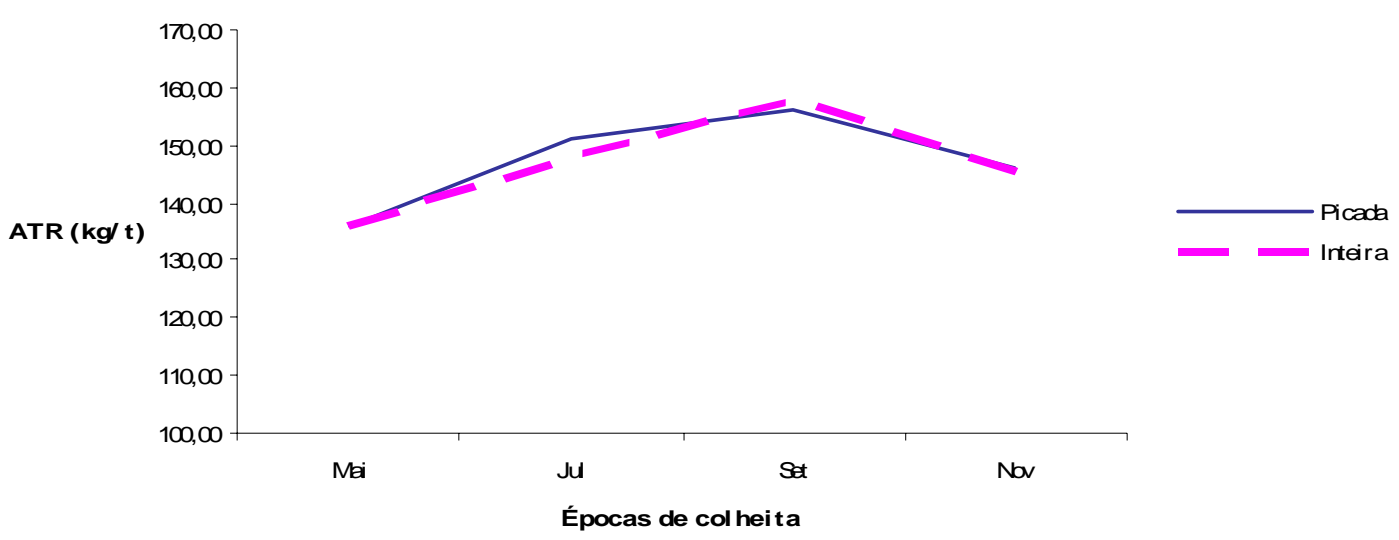

Figura 165 - Resultados de ATR para a variedade SP 71-1406 na safra 1987, no $1^{\circ}$ corte e na época de plantio Novembro 
Resultados de ATR- Safra 1987

corte 1 - época de plantio Janeiro

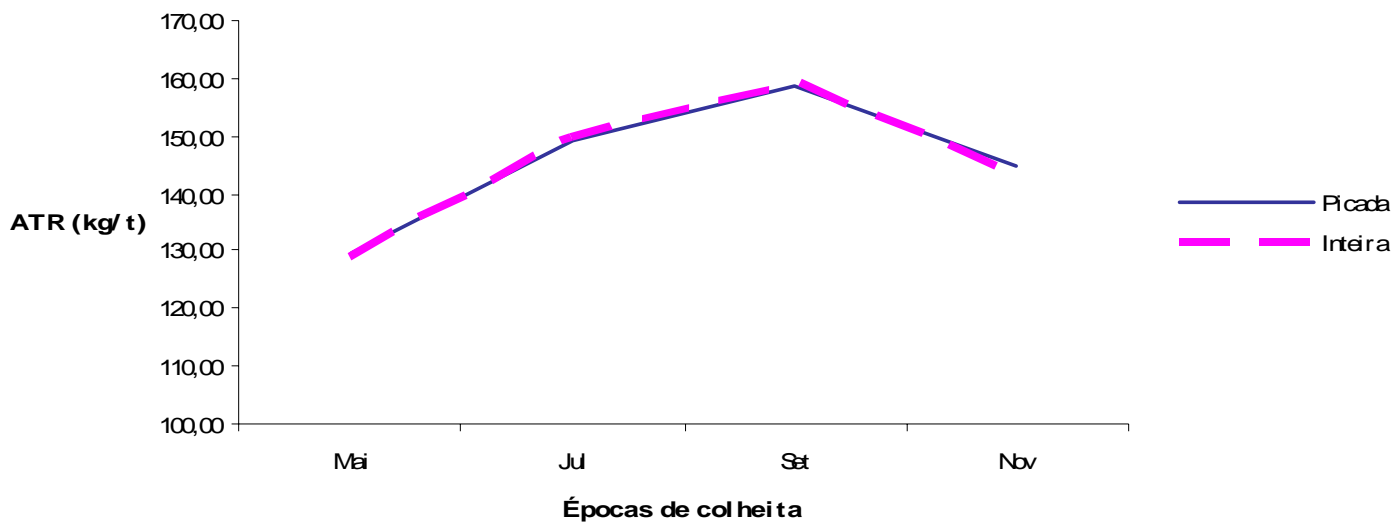

Figura 166 - Resultados de ATR para a variedade SP 71-1406 na safra 1987, no $1^{\circ}$ corte e na época de plantio Janeiro

\section{Resultados de ATR- Safra 1987} corte 1 - época de plantio Março

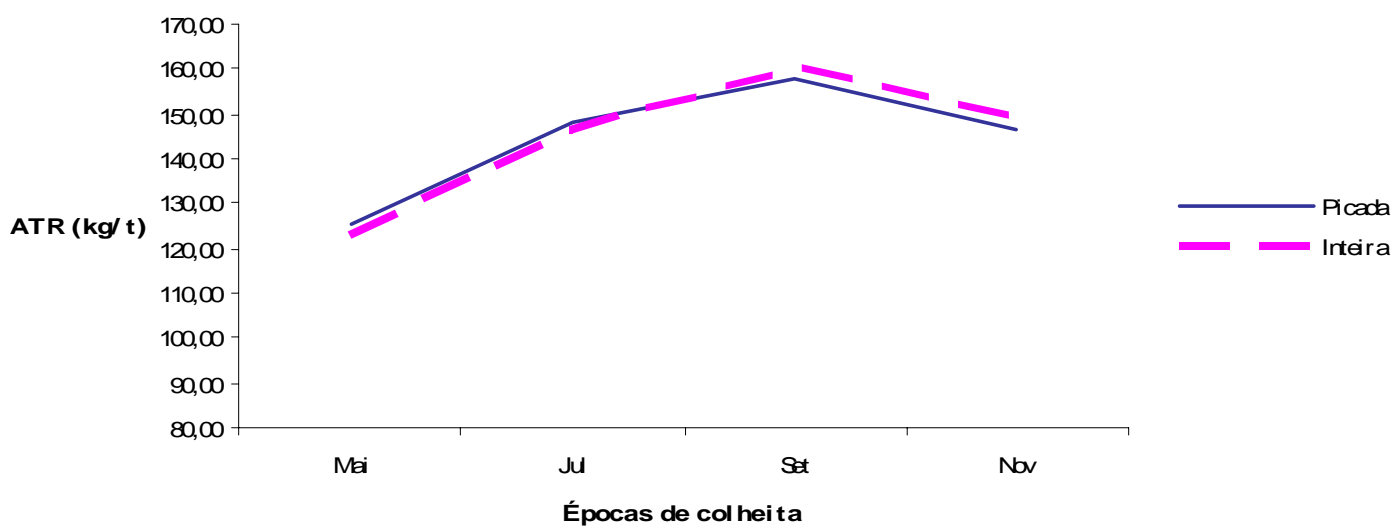

Figura 167 - Resultados de ATR para a variedade SP 71-1406 na safra 1987, no $1^{\circ}$ corte e na época de plantio Março 


\section{Resultados de ATR- Safra 1987 corte 1 - época de plantio Maio}

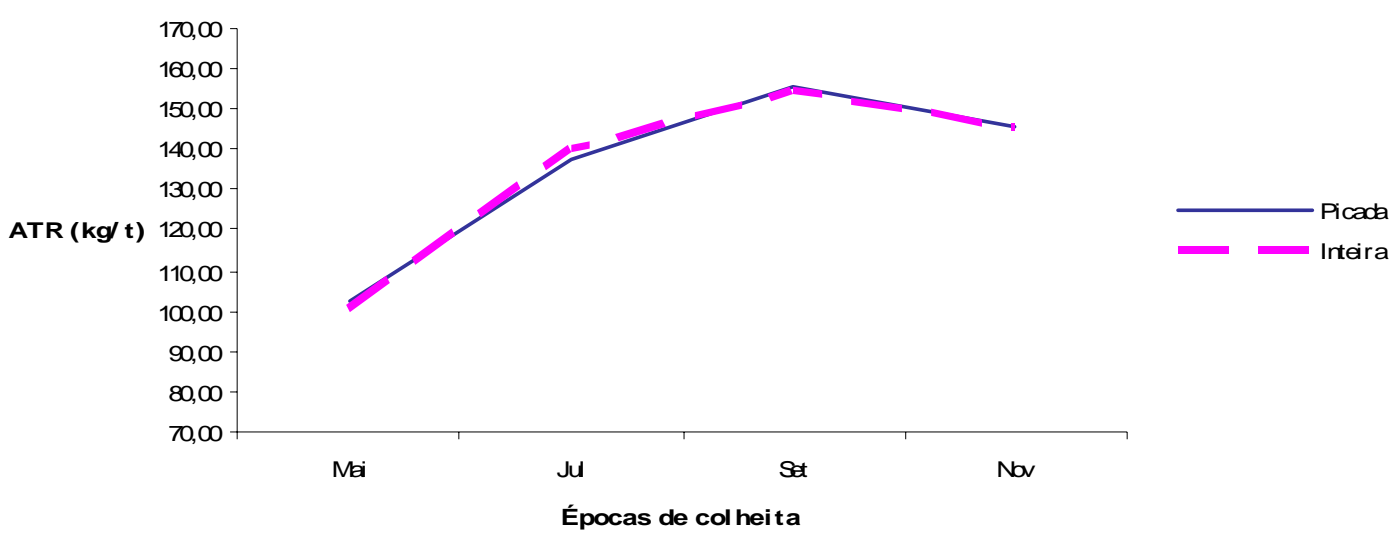

Figura 168 - Resultados de ATR para a variedade SP 71-1406 na safra 1987, no $1^{\circ}$ corte e na época de plantio Maio

Tabela 79. Valores médios de TAH para a variedade SP 71-1406 nas interações de épocas de plantio dentro de épocas de colheita, com plantio no ano de 1985/86, no $1^{\circ}$ corte

\begin{tabular}{|c|c|c|c|}
\hline EPPLA & EPCOL & \multicolumn{2}{|c|}{ TAH (MÉDIA) } \\
\hline Nov & Set & 25,000 & $a$ \\
\hline Jan & Set & 22,928 & $a b$ \\
\hline Nov & Nov & 22,791 & $a b$ \\
\hline Nov & Jul & 22,692 & $a b$ \\
\hline Jan & Nov & 21,921 & b \\
\hline Jan & Jul & 21,080 & bc \\
\hline Mar & Set & 20,756 & bc \\
\hline Nov & Mai & 20,086 & bcd \\
\hline Mar & Jul & 18,466 & cde \\
\hline Mar & Nov & 18,337 & cde \\
\hline Jan & Mai & 17,602 & def \\
\hline Mai & Set & 17,046 & ef \\
\hline Mai & Nov & 16,402 & ef \\
\hline Mar & Mai & 14,800 & $\mathrm{fg}$ \\
\hline Mai & Jul & 13,181 & $g$ \\
\hline Mai & Mai & 9,285 & h \\
\hline
\end{tabular}

Médias seguidas das mesmas letras não diferiram estatisticamente entre si. 
$\mathrm{Na}$ tabela 79, observa-se que para a variedade SP 71-1406, no primeiro corte e ano de plantio 1985/86, houve diferença estatisticamente significativa entre as médias de TAH para a interação épocas de plantio dentro das épocas de colheita. Os maiores valores foram obtidos nas épocas de colheita Setembro, Novembro e Julho com plantios em Novembro e, ainda colheitas de Setembro, Novembro e Julho com plantios em Janeiro. O menor valor de TAH foi obtido na época de colheita Maio com plantio em Maio.

As figuras 169, 170, 171 e 172, a seguir, mostram a evolução de TAH onde se pode verificar o efeito das épocas de colheita sobre as épocas de plantio.

\section{Resultados deTAH- Safra 1987 \\ corte 1 - época de plantio Novembro}

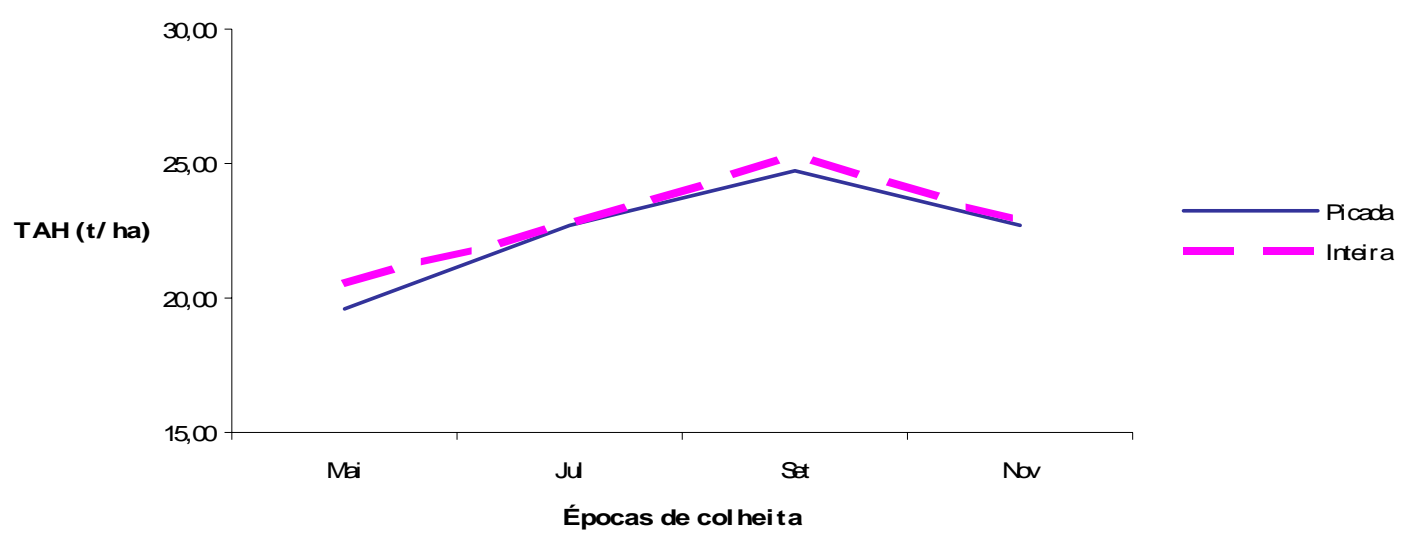

Figura 169 - Resultados de TAH para a variedade SP 71-1406 na safra 1987 , no $1^{\circ}$ corte e na época de plantio Novembro 


\section{Resultados deTAH- Safra 1987 \\ corte 1 - época de plantio Janeiro}

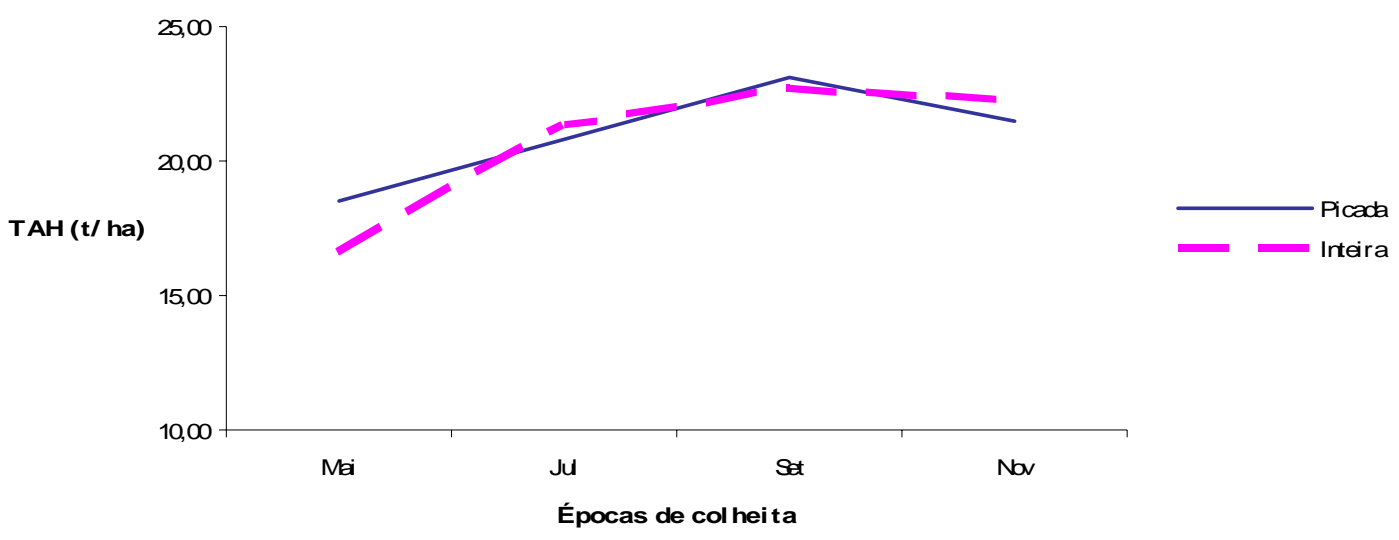

Figura 170 - Resultados de TAH para a variedade SP 71-1406 na safra 1987, no $1^{\circ}$ corte e na época de plantio Janeiro

Resultados deTAH- Safra 1987

corte 1 - época de plantio Março

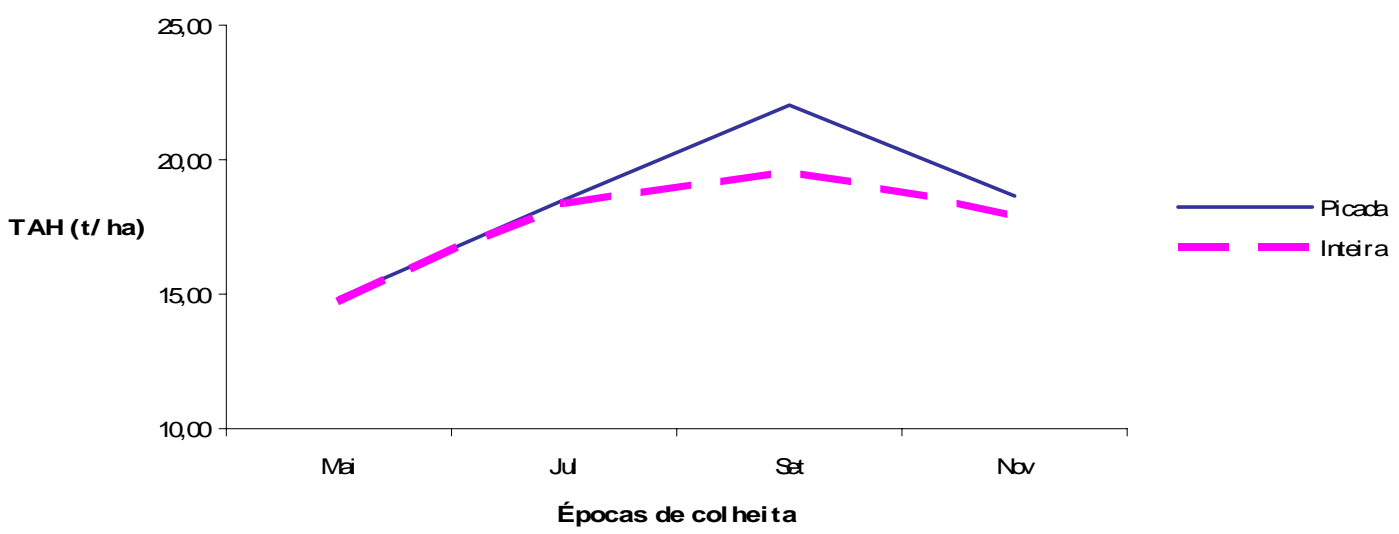

Figura 171 - Resultados de TAH para a variedade SP 71-1406 na safra 1987, no $1^{\circ}$ corte e na época de plantio Março 


\section{Resultados deTAH- Safra 1987}

corte 1 - época de plantio Maio

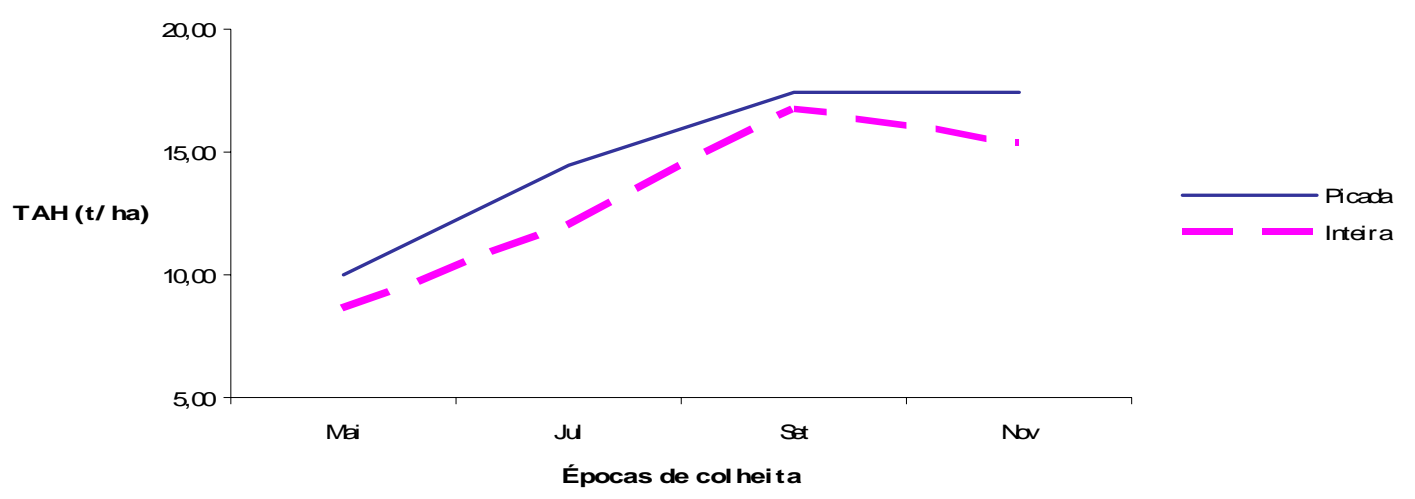

Figura 172 - Resultados de TAH para a variedade SP 71-1406 na safra 1987, no $1^{\circ}$ corte e na época de plantio Maio

$\mathrm{Na}$ tabela 80, a seguir, mostram-se os valores médios das safras de 1985, 1986 e 1987, para TCH, ATR e TAH da variedade SP 71-1406, no primeiro corte, nas várias combinações de épocas de plantio e de colheita e nos tratamentos muda picada e inteira no sulco de plantio.

Comparando as os resultados ano a ano, observa-se que na safra 85 , ano de plantio 1983/84, houve efeito significativo de épocas de plantio e de colheita para as variáveis TCH, ATR e TAH. O tratamento muda picada e inteira no sulco de plantio apresentou efeito significativo apenas para a variável ATR. Houve interação de épocas de plantio dentro de épocas de colheita para as variáveis ATR e TAH.

No ano de 1984/85, safra 86, houve efeito significativo de épocas de plantio e de épocas de colheita para as variáveis TCH, ATR e TAH. O tratamento muda picada e inteira no sulco de plantio não apresentou efeito significativo para as variáveis estudadas. Houve interação de épocas de plantio dentro de épocas de colheita para as variáveis TCH, ATR e TAH.

No ano de plantio 1985/86, safra 87, houve efeito significativo de épocas de plantio e de épocas de colheita para as variáveis TCH, ATR e TAH. 
O tratamento muda picada e inteira no sulco de plantio apresentou efeito significativo apenas para a variável TCH. Houve interação de épocas de plantio dentro de épocas de colheita para as variáveis ATR e TAH, houve, também, interação de tipos de mudas (inteira ou picada no sulco de plantio) para cada época de plantio para $\mathrm{TCH}$.

Para os três anos estudados a variedade SP 71-1406, apresentou efeito significativo de época de plantio e de colheita para as variáveis TCH, ATR e TAH. O tipo de muda (picada e inteira no sulco de plantio) apresentou efeito significativo para a variável ATR no primeiro ano (safra 85), e para a variável TCH na safra 87. Houve interação de épocas de plantio dentro de épocas de colheita para as variáveis ATR e TAH na safra 85, para as variáveis TCH, ATR e TAH na safra 86 e para as variáveis ATR e TAH na safra 87, quando houve, também, interação de tipos de mudas (inteira ou picada no sulco de plantio) para cada época de plantio para $\mathrm{TCH}$.

Observa-se que no geral os resultados das variáveis TCH, ATR e TAH nos anos safra estudados sempre evoluíram do início para o final da safra com os picos localizados no mês de novembro com destaque para a época de plantio Maio que sempre apresentou os menores valores iniciais. 
Tabela 80. Valores médios de TCH, ATR e TAH para a variedade SP 71-1406, no primeiro corte e nas safras de, 1985, 1986 e 1987, em várias combinações de épocas de plantio e de colheita e sob os tratamentos muda picada e inteira no sulco de plantio

\begin{tabular}{|c|c|c|c|c|c|}
\hline $\begin{array}{l}\text { Ep } \\
\text { PI }\end{array}$ & $\begin{array}{l}\text { Ep } \\
\text { Colh }\end{array}$ & dia das & $\begin{array}{c}1-1406 \\
1985 / 86 \\
\text { Rend } \\
\text { Cana } \\
\text { (TCH) }\end{array}$ & - corte 1 & $\begin{array}{l}\text { Rend } \\
\text { açúcar } \\
\text { (TAH) }\end{array}$ \\
\hline Nov & Mai & Picada & 125,63 & 127,10 & 16,02 \\
\hline Nov & Mai & Inteira & 124,76 & 126,31 & 15,86 \\
\hline Nov & Jul & Picada & 124,76 & 144,43 & 18,11 \\
\hline Nov & Jul & Inteira & 130,45 & 143,80 & 18,79 \\
\hline Nov & Set & Picada & 128,26 & 149,52 & 19,25 \\
\hline Nov & Set & Inteira & 129,43 & 148,60 & 19,38 \\
\hline Nov & Nov & Picada & 140,80 & 151,39 & 21,25 \\
\hline Nov & Nov & Inteira & 136,74 & 151,65 & 20,68 \\
\hline Jan & Mai & Picada & 120,49 & 122,13 & 14,79 \\
\hline Jan & Mai & Inteira & 116,04 & 121,90 & 14,21 \\
\hline Jan & Jul & Picada & 122,39 & 142,96 & 17,54 \\
\hline Jan & Jul & Inteira & 124,41 & 143,34 & 17,91 \\
\hline Jan & Set & Picada & 123,38 & 150,78 & 18,69 \\
\hline Jan & Set & Inteira & 120,04 & 152,11 & 18,31 \\
\hline Jan & Nov & Picada & 135,30 & 155,08 & 20,93 \\
\hline Jan & Nov & Inteira & 138,18 & 153,10 & 21,12 \\
\hline Mar & Mai & Picada & 111,03 & 113,86 & 12,75 \\
\hline Mar & Mai & Inteira & 109,88 & 112,00 & 12,40 \\
\hline Mar & Jul & Picada & 119,38 & 139,27 & 16,69 \\
\hline Mar & Jul & Inteira & 116,36 & 137,68 & 16,09 \\
\hline Mar & Set & Picada & 128,52 & 152,41 & 19,59 \\
\hline Mar & Set & Inteira & 119,34 & 151,78 & 18,06 \\
\hline Mar & Nov & Picada & 134,42 & 157,81 & 21,30 \\
\hline Mar & Nov & Inteira & 122,87 & 158,66 & 19,51 \\
\hline Mai & Mai & Picada & 89,50 & 92,90 & 8,45 \\
\hline Mai & Mai & Inteira & 87,47 & 93,25 & 8,20 \\
\hline Mai & Jul & Picada & 106,00 & 128,60 & 13,67 \\
\hline Mai & Jul & Inteira & 94,16 & 129,46 & 12,16 \\
\hline Mai & Set & Picada & 101,69 & 146,47 & 14,92 \\
\hline Mai & Set & Inteira & 102,91 & 147,55 & 15,20 \\
\hline Mai & Nov & Picada & 113,92 & 156,54 & 17,81 \\
\hline Mai & Nov & Inteira & 110,95 & 155,82 & 17,33 \\
\hline
\end{tabular}

As figuras 173, 174 e 175, a seguir, mostram, respectivamente, a evolução de TCH, ATR e TAH médias das safras de 1985, 1986 e 1987 para as épocas de plantio e colheita. 
Resultados de TCH- Média das Safras 1985/86/87 corte 1 - épocas de plantio e colheita

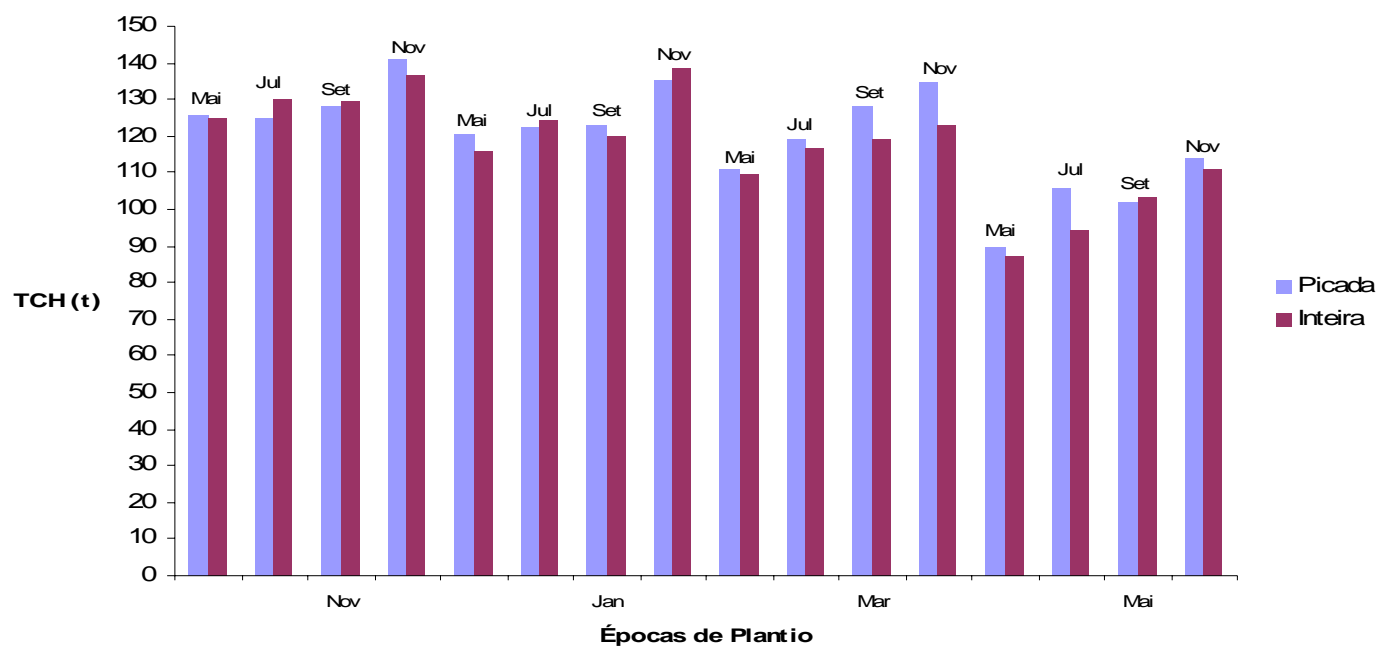

Figura 173 - Resultados médios de TCH para a variedade SP 71-1406 nas safras $1985 / 86 / 87$, no $1^{\circ}$ corte e nas épocas de plantio e colheita

\section{Resultados de ATR - Média das Safras 1985/86/87 corte 1 - épocas de plantio e colheita}

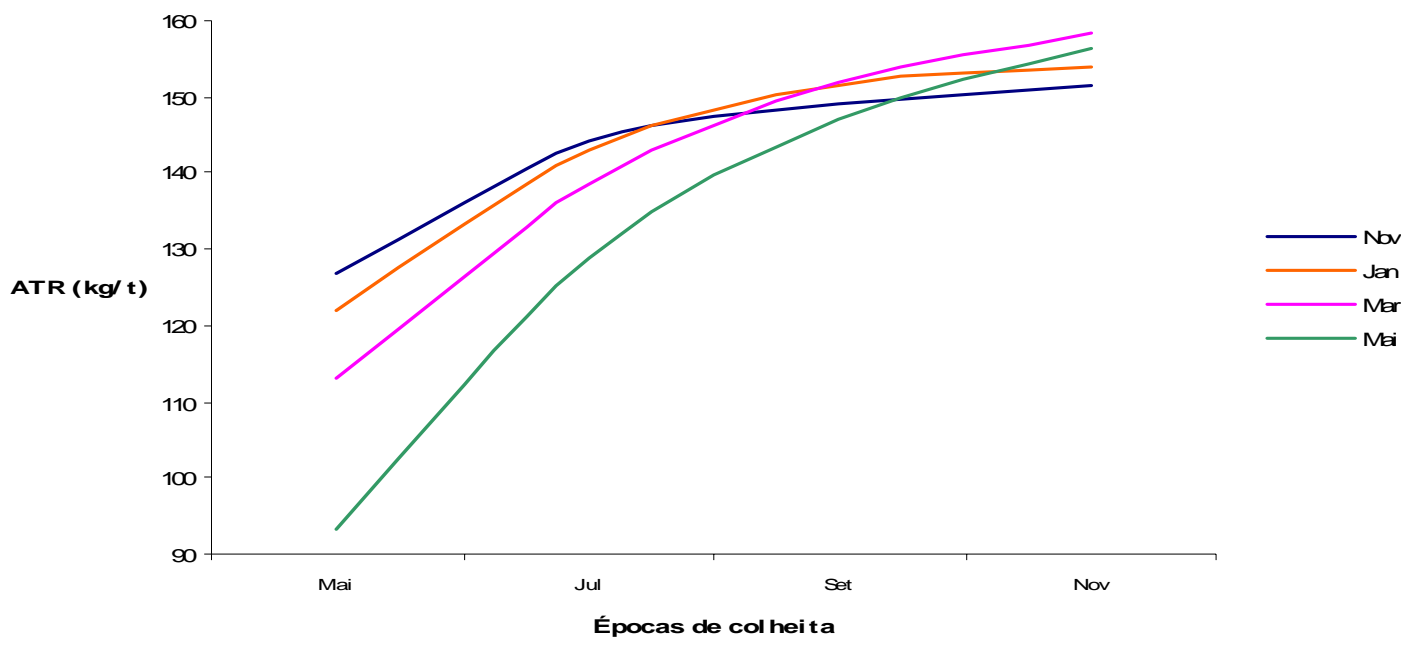

Figura 174 - Resultados médios de ATR para a variedade SP 71-1406 nas safras 1985/86/87, no $1^{\circ}$ corte e nas épocas de plantio e colheita 


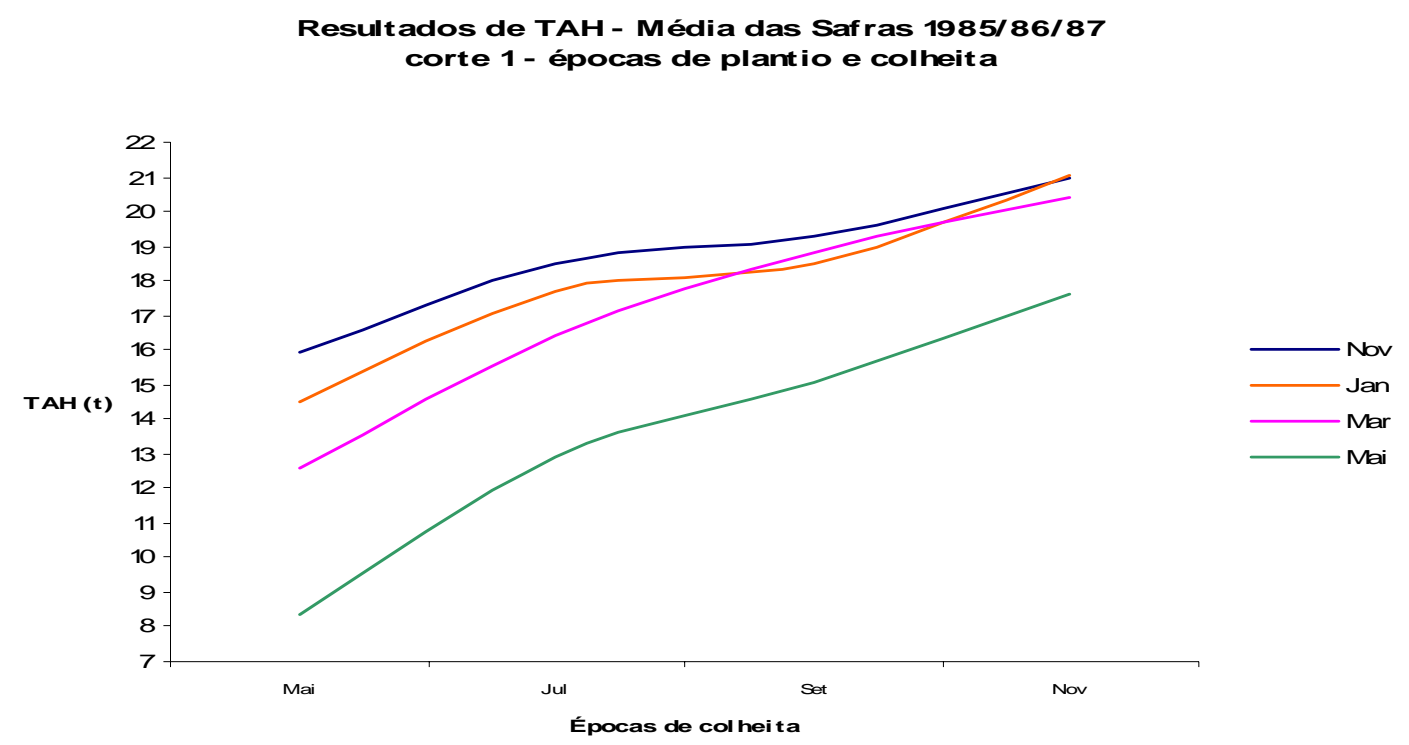

Figura 175 - Resultados médios de TAH para a variedade SP 71-1406 nas safras $1985 / 86 / 87$, no $1^{\circ}$ corte e nas épocas de plantio e colheita

\subsection{Variedade SP 71-1406 - $2^{\circ}$ corte}

São apresentados na tabela 81 , a seguir, os resultados obtidos no segundo corte nas safras de 1986, 1987 e 1988, para toneladas de cana por ha (TCH), açúcar total recuperável (ATR) em kg de açúcar por tonelada de cana e (TAH) toneladas de açúcar por ha, para a variedade SP 71-1406. 
Tabela 81. Valores obtidos de TCH, ATR e TAH para a variedade SP 71-1406, no segundo corte e nas safras de 1986, 1987 e 1988, em várias combinações de épocas de plantio e de colheita e sob os tratamentos muda picada e inteira no sulco de plantio

\begin{tabular}{|c|c|c|c|c|c|c|c|c|c|c|c|}
\hline \multicolumn{12}{|c|}{ SP 71-1406 } \\
\hline \multirow[b]{2}{*}{$\begin{array}{l}\text { Ep } \\
\text { PI }\end{array}$} & \multirow[b]{2}{*}{$\begin{array}{l}\text { Ep } \\
\text { Colh }\end{array}$} & \multirow[b]{2}{*}{ Trat } & \multicolumn{3}{|c|}{ Safra 1986 - corte 2} & \multicolumn{3}{|c|}{ Safra 1987 - corte 2} & \multicolumn{3}{|c|}{ Safra 1988 - corte 2} \\
\hline & & & $\begin{array}{l}\text { Rend } \\
\text { Cana } \\
(\mathrm{TCH})\end{array}$ & ATR & $\begin{array}{l}\text { Rend } \\
\text { açúcar } \\
\text { (TAH) }\end{array}$ & $\begin{array}{l}\text { Rend } \\
\text { Cana } \\
(\mathrm{TCH})\end{array}$ & ATR & $\begin{array}{l}\text { Rend } \\
\text { açúcar } \\
\text { (TAH) }\end{array}$ & $\begin{array}{l}\text { Rend } \\
\text { Cana } \\
(\mathrm{TCH})\end{array}$ & ATR & $\begin{array}{l}\text { Rend } \\
\text { açúcar } \\
\text { (TAH) }\end{array}$ \\
\hline Nov & Mai & Picada & 81,57 & 95,09 & 7,73 & 84,81 & 118,24 & 10,05 & 86,53 & 110,54 & 9,58 \\
\hline Nov & Mai & Inteira & 79,43 & 94,77 & 7,52 & 81,33 & 117,07 & 9,52 & 85,14 & 110,92 & 9,42 \\
\hline Nov & Jul & Picada & 70,64 & 125,43 & 8,87 & 82,72 & 146,28 & 12,11 & 85,81 & 138,21 & 11,85 \\
\hline Nov & Jul & Inteira & 75,41 & 126,48 & 9,54 & 75,72 & 145,92 & 11,06 & 91,29 & 138,08 & 12,57 \\
\hline Nov & Set & Picada & 87,34 & 161,19 & 14,08 & 84,81 & 156,46 & 13,27 & 70,24 & 164,31 & 11,54 \\
\hline Nov & Set & Inteira & 87,76 & 163,10 & 14,32 & 85,05 & 158,73 & 13,50 & 76,24 & 161,10 & 12,29 \\
\hline Nov & Nov & Picada & 105,00 & 157,87 & 16,57 & 78,76 & 146,69 & 11,56 & 60,76 & 156,79 & 9,54 \\
\hline Nov & Nov & Inteira & 97,24 & 157,60 & 15,32 & 75,81 & 146,25 & 11,09 & 61,05 & 159,29 & 9,76 \\
\hline Jan & Mai & Picada & 85,24 & 91,94 & 7,81 & 78,72 & 120,48 & 9,48 & 88,53 & 111,18 & 9,86 \\
\hline Jan & Mai & Inteira & 86,79 & 93,47 & 8,10 & 81,72 & 119,90 & 9,79 & 86,48 & 111,52 & 9,66 \\
\hline Jan & Jul & Picada & 66,29 & 129,86 & 8,61 & 78,95 & 144,34 & 11,38 & 91,19 & 137,51 & 12,54 \\
\hline Jan & Jul & Inteira & 73,36 & 127,75 & 9,37 & 78,48 & 145,35 & 11,40 & 86,19 & 140,19 & 12,08 \\
\hline Jan & Set & Picada & 89,53 & 164,54 & 14,74 & 93,67 & 157,87 & 14,78 & 83,67 & 155,60 & 13,05 \\
\hline Jan & Set & Inteira & 89,10 & 162,30 & 14,48 & 88,14 & 157,61 & 13,90 & 81,05 & 162,50 & 13,17 \\
\hline Jan & Nov & Picada & 106,38 & 159,28 & 16,93 & 84,19 & 148,24 & 12,48 & 63,86 & 158,03 & 10,10 \\
\hline Jan & Nov & Inteira & 105,19 & 158,40 & 16,65 & 81,95 & 146,79 & 12,03 & 56,00 & 153,52 & 8,60 \\
\hline Mar & Mai & Picada & 83,38 & 94,43 & 7,90 & 90,72 & 120,72 & 10,92 & 86,72 & 107,96 & 9,36 \\
\hline Mar & Mai & Inteira & 84,60 & 94,96 & 8,05 & 93,14 & 117,61 & 10,92 & 92,00 & 110,43 & 10,16 \\
\hline Mar & Jul & Picada & 73,14 & 127,10 & 9,31 & 71,81 & 142,61 & 10,23 & 86,86 & 137,16 & 11,92 \\
\hline Mar & Jul & Inteira & 80,12 & 129,46 & 10,38 & 82,53 & 144,38 & 11,92 & 88,38 & 137,87 & 12,17 \\
\hline Mar & Set & Picada & 89,14 & 163,57 & 14,61 & 94,05 & 156,75 & 14,73 & 81,95 & 163,02 & 13,38 \\
\hline Mar & Set & Inteira & 93,95 & 164,08 & 15,42 & 91,24 & 157,07 & 14,32 & 82,57 & 156,78 & 13,00 \\
\hline Mar & Nov & Picada & 106,05 & 159,81 & 16,96 & 83,62 & 144,14 & 12,04 & 66,95 & 158,47 & 10,60 \\
\hline Mar & Nov & Inteira & 104,76 & 156,16 & 16,36 & 85,76 & 146,17 & 12,57 & 58,81 & 154,46 & 9,10 \\
\hline Mai & Mai & Picada & 83,64 & 92,40 & 7,73 & 86,29 & 118,37 & 10,19 & 94,00 & 111,12 & 10,49 \\
\hline Mai & Mai & Inteira & 88,57 & 99,37 & 8,81 & 89,67 & 117,43 & 10,53 & 97,67 & 111,66 & 10,88 \\
\hline Mai & Jul & Picada & 82,24 & 127,12 & 10,46 & 84,43 & 144,64 & 12,23 & 99,10 & 140,75 & 13,96 \\
\hline Mai & Jul & Inteira & 81,36 & 130,15 & 10,60 & 84,86 & 147,08 & 12,48 & 93,00 & 138,86 & 12,91 \\
\hline Mai & Set & Picada & 91,76 & 164,74 & 15,13 & 89,24 & 158,33 & 14,11 & 83,57 & 165,13 & 13,80 \\
\hline Mai & Set & Inteira & 83,48 & 162,58 & 13,58 & 98,14 & 155,93 & 15,30 & 83,76 & 165,33 & 13,85 \\
\hline Mai & Nov & Picada & 114,81 & 151,90 & 17,43 & 91,67 & 146,21 & 13,39 & 67,57 & 159,73 & 10,79 \\
\hline Mai & Nov & Inteira & 108,10 & 157,51 & 17,02 & 79,05 & 145,52 & 11,50 & 69,00 & 159,02 & 10,98 \\
\hline
\end{tabular}


Tabela 82. Resumo dos quadros de análise de variância dos dados obtidos para a variedade SP 71-1406, no segundo corte e com plantio no ano de 1983/84, em relação às variáveis dependentes TCH, ATR e TAH em várias combinações de épocas de plantio e de colheita e sob os tratamentos cana picada e inteira no sulco de plantio

\begin{tabular}{lcccc}
\hline \multicolumn{1}{c}{ C. Variação } & GL & TCH & ATR & TAH \\
\hline BLOCO & 4 & QM & QM & QM \\
EPCOL & 3 & $6627,505^{* *}$ & $39739,620^{* *}$ & $665,500^{* *}$ \\
Resíduo (a) & 12 & 238,991 & 21,580 & 4,389 \\
EPPLA & 3 & 274,450 & 7,320 & 5,421 \\
Resíduo (b) & 12 & 123,470 & 27,390 & 2,621 \\
TRAT & 1 & 1,459 & 22,070 & 0,063 \\
EPCOL ${ }^{*}$ EPPLA & 9 & 91,146 & 22,170 & 1,394 \\
EPCOL ${ }^{*}$ TRAT & 3 & 135,290 & 13,370 & 3,265 \\
EPPLA ${ }^{*}$ TRAT & 3 & 67,911 & 34,400 & 0,623 \\
EPCOL ${ }^{*}$ EPPLA*TRAT & 9 & 30,853 & 17,990 & 1,161 \\
Resíduo (c) & $10 \odot$ & 57,945 & 16,670 & 1,391 \\
Total & 159 & -- & -- & -- \\
\hline
\end{tabular}

A tabela 82, apresentada, mostra os valores da análise de variância, para as variáveis TCH, ATR e TAH, da variedade SP 71-1406, no segundo corte e com plantio no ano de 1983/84.

Como se pode observar, houve apenas efeito significativo de épocas de colheita para as variáveis TCH, ATR e TAH. Épocas de plantio e tratamentos (muda picada e inteira no sulco de plantio) não apresentaram efeito significativo para as variáveis estudadas. Não houve qualquer efeito de interação.

Tabela 83. Valores médios de TCH para a variedade SP 71-1406 das médias de épocas de colheita, no ano de 1983/84, no $2^{\circ}$ corte

\begin{tabular}{ccc}
\hline EPCOL & $T C H$ (MÉDIA) \\
\hline Nov & 105,943 & a \\
Set & 89,008 & b \\
Mai & 84,153 & bc \\
Jul & 75,320 & c
\end{tabular}

Médias seguidas das mesmas letras não diferiram estatisticamente entre si. 
$\mathrm{Na}$ tabela 83, observa-se que para a variedade SP 711406, no segundo corte e ano de plantio 1983/84, houve diferença estatisticamente significativa entre as médias de $\mathrm{TCH}$ nas épocas de colheita. Os resultados apresentaram diferenças entre si, sendo o maior valor de TCH obtido na época de colheita Novembro e os menores nas épocas Julho e Maio.

Tabela 84. Valores médios de ATR para a variedade SP 71-1406 das médias de épocas de colheita, no ano de $1983 / 84$, no $2^{\circ}$ corte

\begin{tabular}{crc}
\hline EPCOL & ATR & (MÉDIA) \\
\hline Set & 163,262 & $\mathrm{a}$ \\
Nov & 157,316 & $\mathrm{~b}$ \\
Jul & 127,918 & $\mathrm{C}$ \\
Mai & 94,553 & $\mathrm{~d}$ \\
\hline
\end{tabular}

Médias seguidas das mesmas letras não diferiram estatisticamente entre si.

$\mathrm{Na}$ tabela 84, observa-se que para a variedade SP 711406, no segundo corte e ano de plantio 1983/84, houve diferença estatisticamente significativa entre as médias de ATR nas épocas de colheita. Os resultados apresentaram diferenças entre si, sendo o maior valor de ATR obtido na época de colheita Setembro e o menor na época Maio.

Tabela 85. Valores médios de TAH para a variedade SP 71-1406 das médias de épocas de colheita, no ano de $1983 / 84$, no $2^{\circ}$ corte

\begin{tabular}{crc}
\hline EPCOL & TAH & (MÉDIA) \\
\hline Nov & 15,558 & $\mathrm{a}$ \\
Set & 14,543 & $\mathrm{~b}$ \\
Jul & 9,542 & $\mathrm{c}$ \\
Mai & 7,958 & $\mathrm{~d}$ \\
\hline
\end{tabular}

Médias seguidas das mesmas letras não diferiram estatisticamente entre si.

$\mathrm{Na}$ tabela 85 , observa-se que para a variedade SP 711406 , no segundo corte e ano de plantio 1983/84, houve diferença estatisticamente 
significativa entre as médias de TAH nas épocas de colheita. Os resultados apresentaram diferenças entre si, sendo o maior valor de TAH obtido na época de colheita Novembro e o menor na época Maio.

As figuras 176, 177 e 178, a seguir, mostram, respectivamente, a evolução de TCH, ATR e TAH para a variedade SP 71-1406 nas épocas de colheita.

Resultados de TCH

Safra1986-corte 2

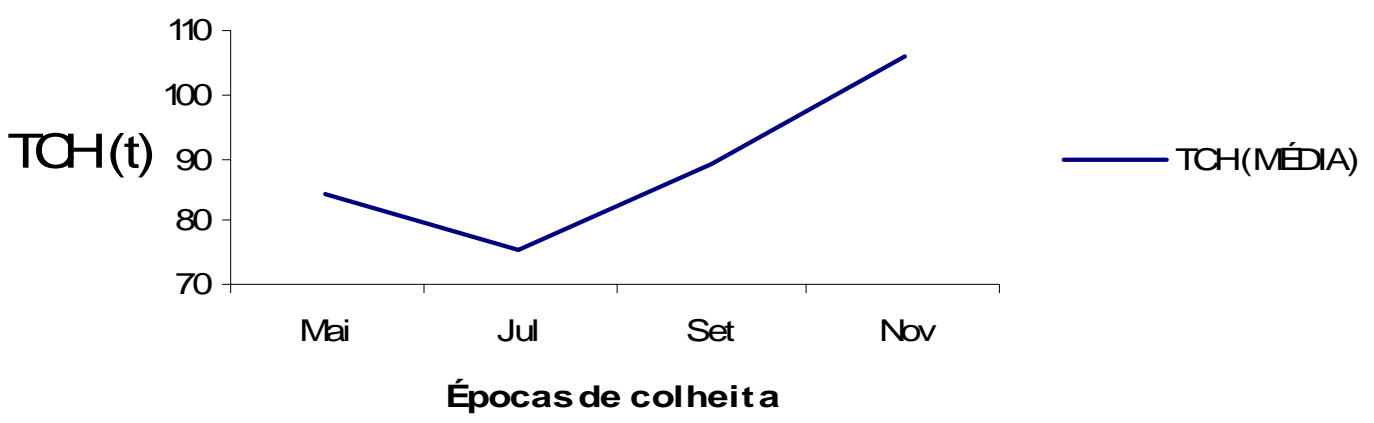

Figura 176 - Resultados de TCH para a variedade SP 71-1406 na safra 1986, no $2^{\circ}$ corte nas épocas de colheita

Resultados de ATR

Safra1986- corte 2

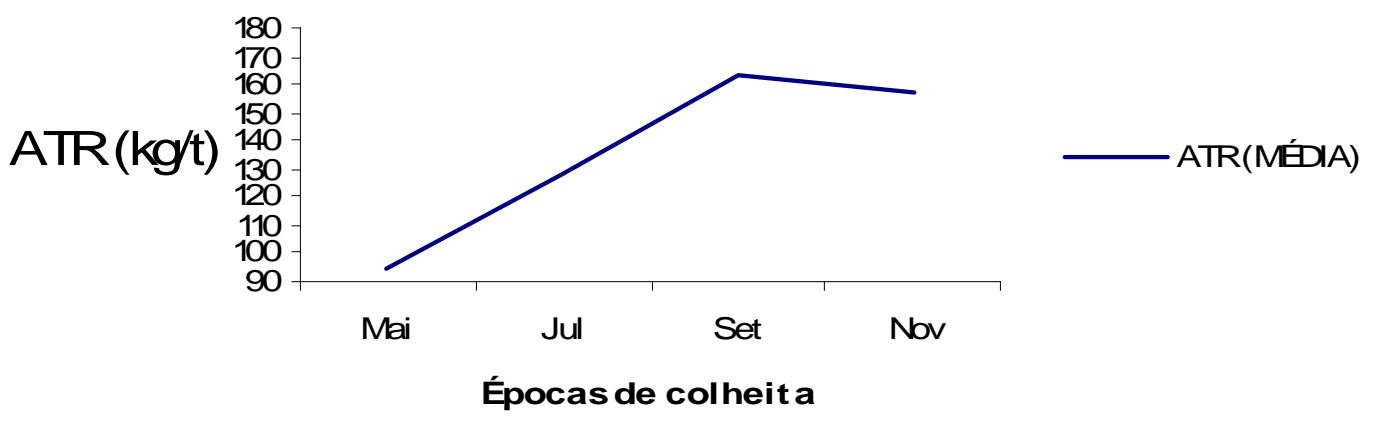

Figura 177 - Resultados de ATR para a variedade SP 71-1406 na safra 1986, no $2^{\circ}$ corte nas épocas de colheita 
Resultados de TAH

Safra1986- corte 2

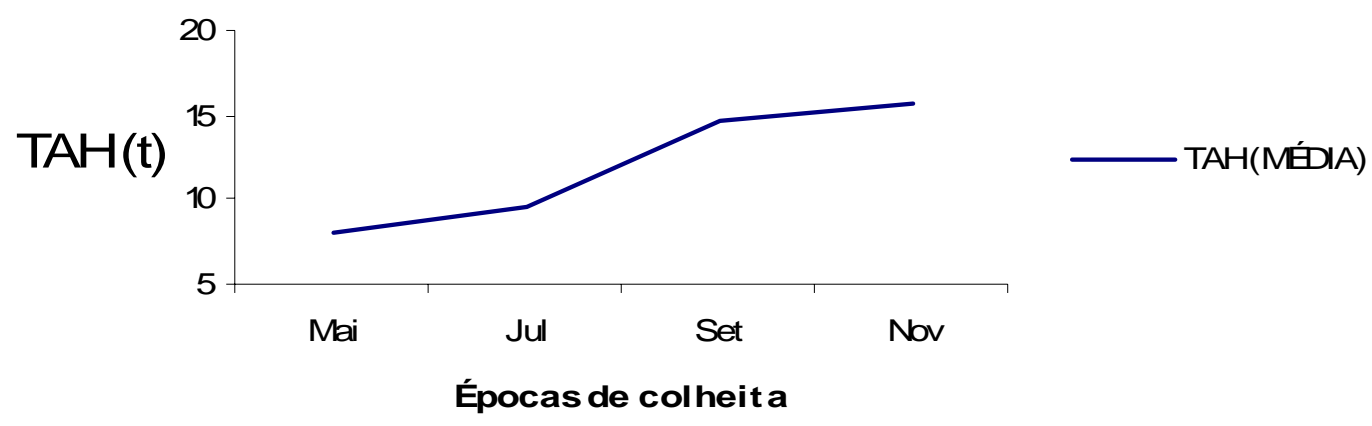

Figura 178 - Resultados de TAH para a variedade SP 71-1406 na safra 1986, no $2^{\circ}$ corte nas épocas de colheita

Tabela 86. Resumo dos quadros de análise de variância dos dados obtidos para a variedade SP 71-1406, no segundo corte e com plantio no ano de 1984/85, em relação às variáveis dependentes ATR, TCH e TAH em várias combinações de épocas de plantio e de colheita e sob os tratamentos cana picada e inteira no sulco de plantio

\begin{tabular}{lcccc}
\hline \multicolumn{1}{c}{ C. Variação } & GL & TCH & ATR & TAH \\
\hline BLOCO & 4 & QM & QM & QM \\
EPCOL & 3 & $832,589 * *$ & $10727,391^{* *}$ & $113,378^{* *}$ \\
Resíduo (a) & 12 & 83,800 & 12,105 & 1,780 \\
EPPLA & 3 & 385,981 & 13,421 & 6,603 \\
Resíduo (b) & 12 & 445,305 & 10,138 & 8,137 \\
TRAT & 1 & 5,358 & 0,382 & 0,203 \\
EPCOL ${ }^{*} E P P L A$ & 9 & 92,737 & 8,686 & 1,949 \\
EPCOL ${ }^{*} T R A T$ & 3 & 58,190 & 11,819 & 1,191 \\
EPPLA*TRAT & 3 & 72,612 & 0,973 & 1,513 \\
EPCOL ${ }^{*} E P P L A^{*} T R A T$ & 9 & 94,095 & 6,936 & 2,199 \\
Resíduo (c) & 100 & 71,470 & 7,647 & 1,634 \\
Total & 159 & -- & -- & -- \\
\hline
\end{tabular}

A tabela 86, mostra os valores da análise de variância para as variáveis TCH, ATR e TAH da variedade SP 71-1406, no segundo corte e ano de plantio 1984/85. 
Como se pode observar, houve apenas efeito significativo de épocas de colheita para as variáveis TCH, ATR e TAH. Épocas de plantio e tratamentos (muda picada e inteira no sulco de plantio) não apresentaram efeito significativo para as variáveis estudadas. Não houve qualquer efeito de interação.

Tabela 87. Valores médios de TCH para a variedade SP 71-1406 das médias de épocas de colheita, com plantio no ano de 1984/85, no $2^{\circ}$ corte

\begin{tabular}{cc}
\hline EPCOL & $T C H$ (MÉDIA) \\
\hline Set & 90,544 a \\
Mai & 85,800 ab \\
Nov & $82,603 \quad$ b \\
Jul & $79,936 \quad$ b \\
\hline Médias seguidas das mesmas letras não diferiram estatisticamente entre
\end{tabular}
si.

$\mathrm{Na}$ tabela 87, observa-se que para a variedade SP 71-1406, no segundo corte e ano de plantio 1984/85, houve diferença estatisticamente significativa entre as médias TCH das épocas de colheita. Os maiores valores foram obtidos nas épocas de colheita Setembro e Maio; sendo que apenas a média da época Setembro diferiu estatisticamente das médias das épocas Novembro e Julho.

Tabela 88. Valores médios de ATR para a variedade SP 71-1406 das médias de épocas de colheita, com plantio no ano de $1984 / 85$, no $2^{\circ}$ corte

\begin{tabular}{|c|c|c|}
\hline EPCOL & ATR (ME & $D I A)$ \\
\hline Set & 157,344 & $\mathrm{a}$ \\
\hline Nov & 146,253 & b \\
\hline Jul & 145,076 & b \\
\hline Mai & 118,727 & c \\
\hline
\end{tabular}
si. 
$\mathrm{Na}$ tabela 88, observa-se que para a variedade SP 71-1406, no segundo corte e ano de plantio 1984/85, houve diferença estatisticamente significativa entre as médias de ATR das épocas de colheita. O maior valor foi obtido para a época de colheita Setembro e os menores valores foram apresentados pela época de colheita Maio.

Tabela 89. Valores médios de TAH para a variedade SP 71-1406 das médias de épocas de colheita, com plantio no ano de 1984/85, no $2^{\circ}$ corte

\begin{tabular}{cc}
\hline EPCOL & $T A H \quad($ MÉDIA) \\
\hline Set & 14,239 a \\
Nov & $12,081 \quad$ b \\
Jul & $11,603 \quad$ b \\
Mai & $10,176 \quad$ c \\
\hline Médias seguidas das mesmas letras não diferiram estatisticamente entre
\end{tabular}

si.

$\mathrm{Na}$ tabela 89, observa-se que para a variedade SP 71-1406, no segundo corte e ano de plantio 1984/85, houve diferença estatisticamente significativa entre as médias de TAH das épocas de colheita. O maior valor foi obtido para a época de colheita Setembro e os menores valores foram apresentados pela época de colheita Maio.

As figuras 179, 180 e 181, a seguir, mostram, respectivamente, a evolução de TCH, ATR e TAH para as épocas de colheita. 
Resultados de TCH

Safra1987-corte 2

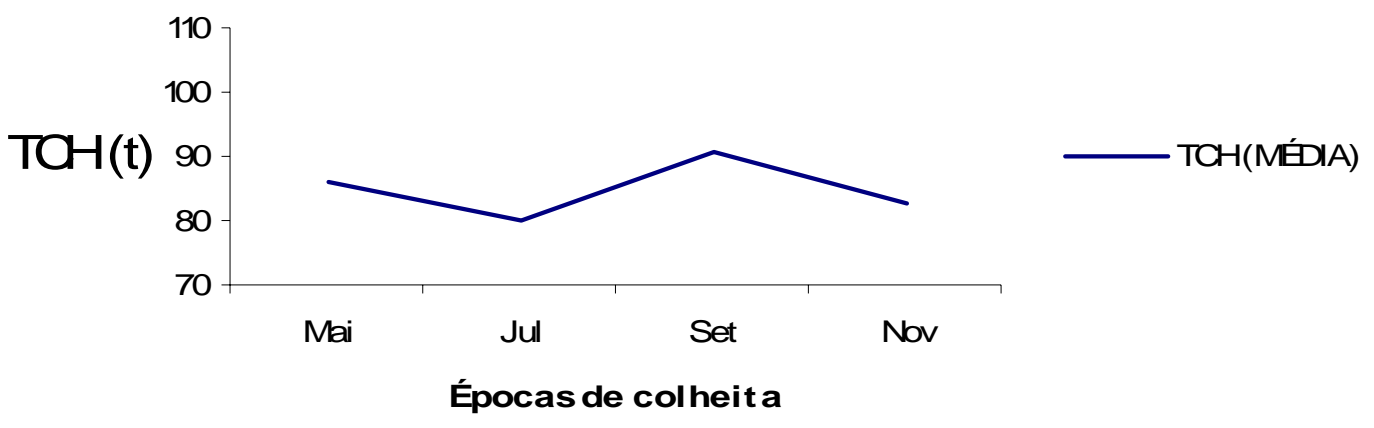

Figura 179 - Resultados de TCH para a variedade SP 71-1406 na safra 1987, no $2^{\circ}$ corte nas épocas de colheita

Resultados de ATR

Safra1987-corte 2

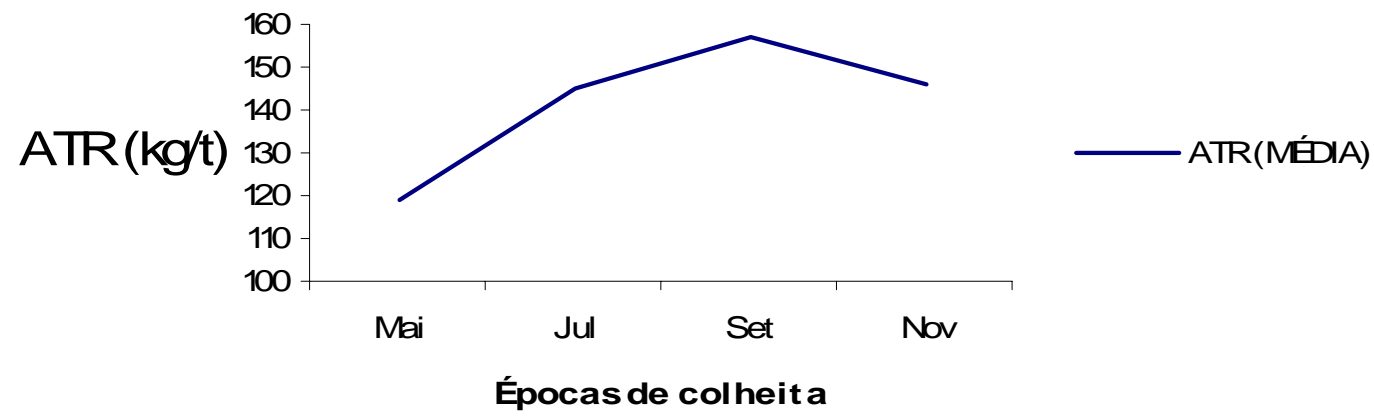

Figura 180 - Resultados de ATR para a variedade SP 71-1406 na safra 1987, no $2^{\circ}$ corte nas épocas de colheita 
Resultados de TAH

Safra1987- corte 2

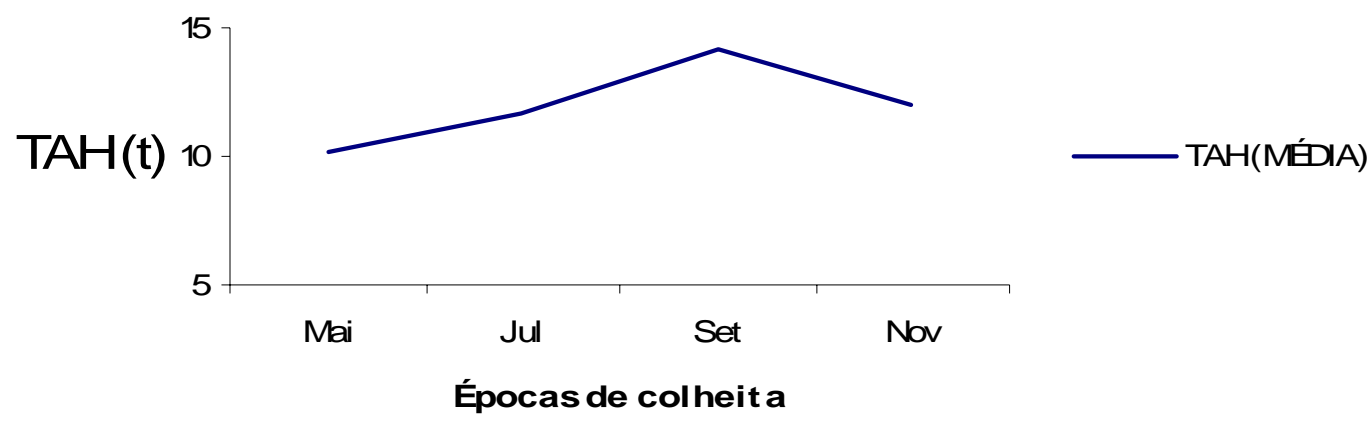

Figura 181 - Resultados de TAH para a variedade SP 71-1406 na safra 1987, no $2^{\circ}$ corte nas épocas de colheita

Tabela 90. Resumo dos quadros de análise de variância dos dados obtidos para a variedade SP 71-1406, no segundo corte e com plantio no ano de 1985/86, em relação às variáveis dependentes ATR, TCH e TAH em várias combinações de épocas de plantio e de colheita e sob os tratamentos cana picada e inteira no sulco de plantio

\begin{tabular}{|c|c|c|c|c|}
\hline C. Variação & $G L$ & $\begin{array}{c}\mathrm{TCH} \\
Q M\end{array}$ & $\begin{array}{c}\text { ATR } \\
Q M\end{array}$ & $\begin{array}{c}\text { TAH } \\
Q M\end{array}$ \\
\hline BLOCO & 4 & - & - & -- \\
\hline EPCOL & 3 & $6451, \odot 45^{* *}$ & 21599,396 ** & $108,158 * *$ \\
\hline Resíduo (a) & 12 & 192,381 & 61,660 & 4,193 \\
\hline EPPLA & 3 & 553,916 ** & 79,985 & 14,448 ** \\
\hline Resíduo (b) & 12 & 132,855 & 59,015 & 2,839 \\
\hline TRAT & 1 & 11,729 & 2,478 & $\odot, 474$ \\
\hline$E P C O L{ }^{*} E P P L A$ & 9 & 53,640 & 15,152 & 1,017 \\
\hline$E P C O L{ }^{*} T R A T$ & 3 & 52,164 & $13, \odot 49$ & 1,506 \\
\hline$E P P L A{ }^{*} T R A T$ & 3 & 82,765 & 16,431 & 1,372 \\
\hline$E P C O L{ }^{*} E P P L A{ }^{*} T R A T$ & 9 & 41,355 & 33,782 & 1,232 \\
\hline Resíduo (c) & 100 & 71,609 & 28,746 & 1,726 \\
\hline Total & 159 & -- & -- & -- \\
\hline
\end{tabular}


A tabela 90, mostra os valores da análise de variância para as variáveis TCH, ATR e TAH da variedade SP 71-1406, no segundo corte e ano de plantio 1985/86.

Como se pode observar, houve efeito significativo de épocas de colheita para as variáveis TCH, ATR e TAH. Houve, também, efeito de épocas de plantio para as vaiáveis TCH e TAH. Tratamentos (muda picada e inteira no sulco de plantio) não apresentaram efeito significativo para as variáveis estudadas. Não houve qualquer efeito de interação.

Tabela 91. Valores médios de TCH para a variedade SP 71-1406 das médias de épocas de plantio, com plantio no ano de $1985 / 86$, no $2^{\circ}$ corte

\begin{tabular}{cc}
\hline EPPLA & TCH (MÉDIA) \\
\hline Mai & $85,960 \mathrm{a}$ \\
Mar & $80,531 \mathrm{ab}$ \\
Jan & $79,621 \mathrm{ab}$ \\
Nov & $77,132 \mathrm{~b}$ \\
\hline Médias seguidas das mesmas letras não diferiram estatisticamente entre si.
\end{tabular}

$\mathrm{Na}$ tabela 91, observa-se que para a variedade SP 71-1406, no segundo corte e ano de plantio 1985/86, houve diferença estatisticamente significativa entre as médias $\mathrm{TCH}$ nas épocas de plantio. $\mathrm{O}$ valor obtido na época de plantio Maio foi superior ao valor obtido na época de plantio Novembro.

Tabela 92. Valores médios de TCH para a variedade SP 71-1406 das médias de épocas de colheita, com plantio no ano de $1985 / 86$, no $2^{\circ}$ corte

\begin{tabular}{cc}
\hline EPCOL & $T C H$ (MÉDIA) \\
\hline Jul & 90,227 a \\
Mai & $89,633 \mathrm{a}$ \\
Set & 80,382 b \\
Nov & $63,002 \quad$ C \\
\hline Médias seguidas das mesmas letras não diferiram estatisticamente entre si.
\end{tabular}

Médias seguidas das mesmas letras não diferiram estatisticamente entre si. 
$\mathrm{Na}$ tabela 92, observa-se que para a variedade SP 71-1406, no segundo corte e ano de plantio 1985/86, houve diferença estatisticamente significativa entre as médias TCH nas épocas de colheita. Os maiores valores foram obtidos nas épocas de colheita Julho e Maio, e o menor valor foi obtido na época de colheita Novembro.

As figuras 182 e 183, a seguir, mostram, respectivamente, a evolução de TCH para as épocas de plantio e de colheita.

Resultados de $\mathrm{TCH}$

Safra1988 - corte 2

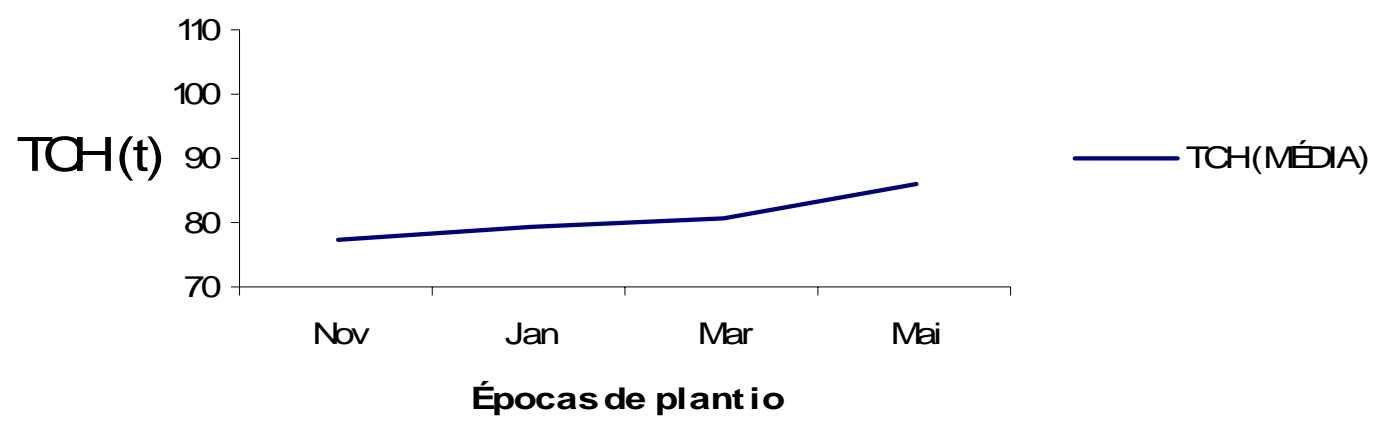

Figura 182 - Resultados de TCH para a variedade SP 71-1406 na safra 1988 , no $2^{\circ}$ corte nas épocas de plantio 
Resultados de TCH

Safra1988- corte 2

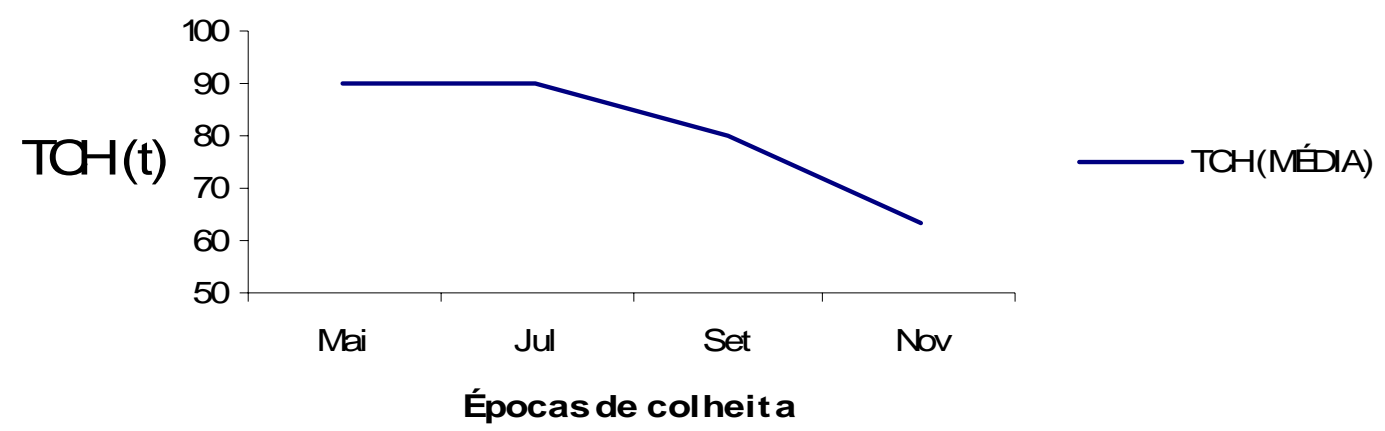

Figura 183 - Resultados de TCH para a variedade SP 71-1406 na safra 1988, no $2^{\circ}$ corte nas épocas de colheita

Tabela 93. Valores médios de ATR para a variedade SP 71-1406 das médias de épocas de colheita, com plantio no ano de $1985 / 86$, no $2^{\circ}$ corte

\begin{tabular}{cl}
\hline$E P C O L$ & $A T R($ MÉDIA) \\
\hline Set & $161,722 \mathrm{a}$ \\
Nov & $157,412 \mathrm{a}$ \\
Jul & $138,580 \mathrm{~b}$ \\
Mai & $110,666 \quad \mathrm{c}$ \\
\hline Médias seguidas das mesmas letras não diferiram estatisticamente entre si.
\end{tabular}

$\mathrm{Na}$ tabela 93, observa-se que para a variedade SP 71-1406, no segundo corte e ano de plantio 1985/86, houve diferença estatisticamente significativa entre as médias de ATR nas épocas de colheita. Os maiores valores de ATR foram obtidos nas épocas de colheita Setembro e Novembro e o menor valor foi obtido na época de colheita Maio.

A Figura 184, a seguir, mostra a evolução de ATR para a época de colheita. 
Resultados de ATR

Safra1988- corte 2

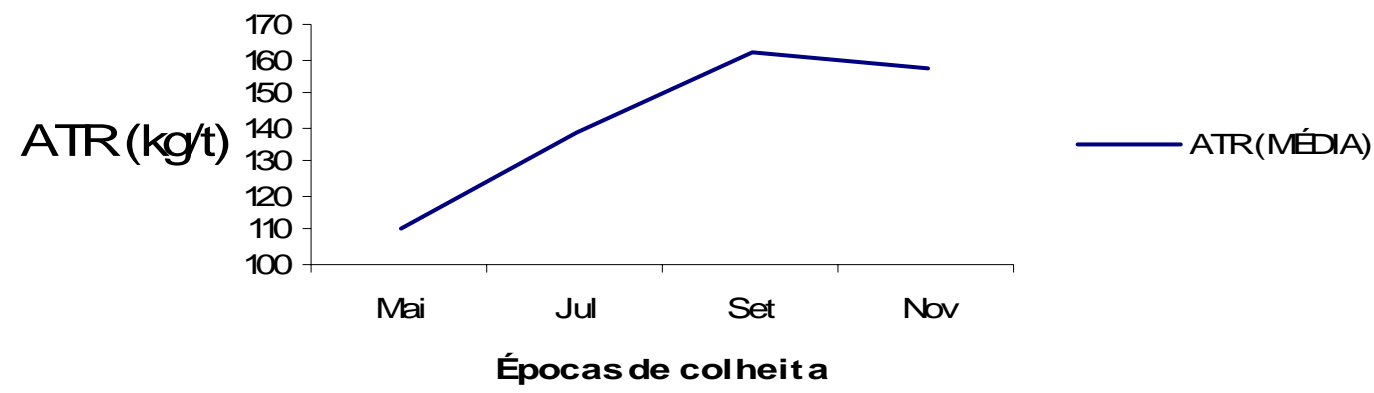

Figura 184 - Resultados de ATR para a variedade SP 71-1406 na safra 1988 , no $2^{\circ}$ corte nas épocas de colheita

Tabela 94. Valores médios de TAH para a variedade SP 71-1406 das médias de épocas de plantio, com plantio no ano de $1985 / 86$, no $2^{\circ}$ corte

\begin{tabular}{cc}
\hline EPPLA & TAH (MÉDIA) \\
\hline Mai & $12,207 \mathrm{a}$ \\
Mar & $11,209 \mathrm{ab}$ \\
Jan & $11,132 \mathrm{ab}$ \\
Nov & $10,819 \mathrm{~b}$ \\
\hline
\end{tabular}

Médias seguidas das mesmas letras não diferiram estatisticamente entre si.

$\mathrm{Na}$ tabela 94, observa-se que para a variedade SP 71-1406, no segundo corte e ano de plantio 1985/86, houve diferença estatisticamente significativa entre as médias TAH nas épocas de plantio. $\mathrm{O}$ valor obtido na época de plantio Maio foi superior ao valor da época de plantio Novembro.

Tabela 95. Valores médios de TAH para a variedade SP 71-1406 das médias de épocas de colheita, com plantio no ano de $1985 / 86$, no $2^{\circ}$ corte

\begin{tabular}{|c|c|}
\hline EPCOL & TAH (MÉDIA) \\
\hline Set & $13,010 \quad a$ \\
\hline Jul & $12,499 \quad a$ \\
\hline Nov & 9,933 \\
\hline Mai & 9,926 \\
\hline
\end{tabular}

Médias seguidas das mesmas letras não diferiram estatisticamente entre si. 
$\mathrm{Na}$ tabela 95, observa-se que para a variedade SP 71-1406, no segundo corte e ano de plantio 1985/86, houve diferença estatisticamente significativa entre as médias de TAH nas épocas de colheita. Os maiores valores foram obtidos nas épocas Setembro e Julho e os menores nas épocas Maio e Novembro.

As figuras 185 e 186, a seguir, mostram, respectivamente, a evolução de TAH para as épocas de plantio e de colheita.

Resultados de TAH

Safra1988-corte 2

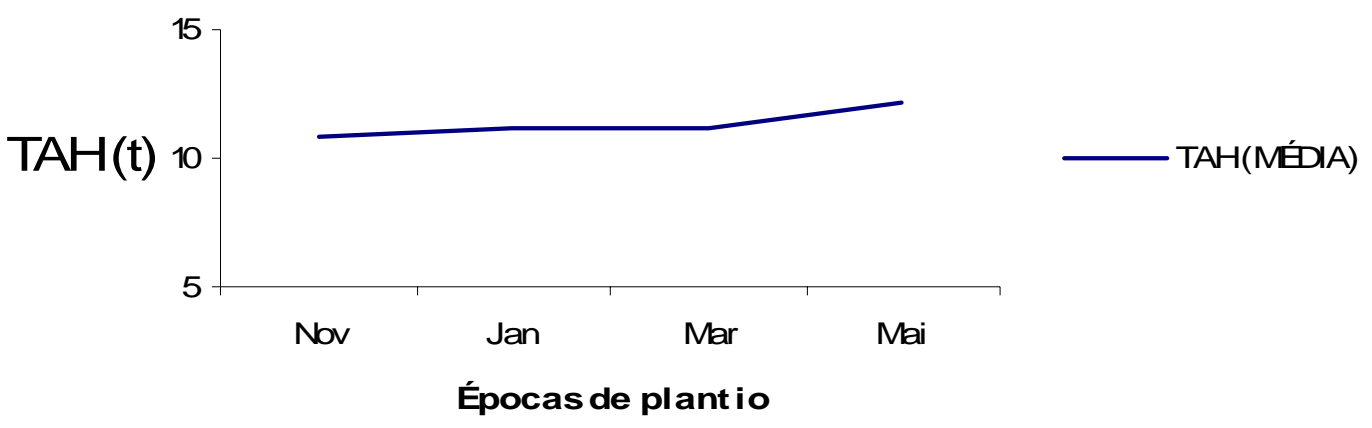

Figura 185 - Resultados de TAH para a variedade SP 71-1406 na safra 1988 , no $2^{\circ}$ corte nas épocas de plantio 
Resultados de TAH

Safra1988-corte 2

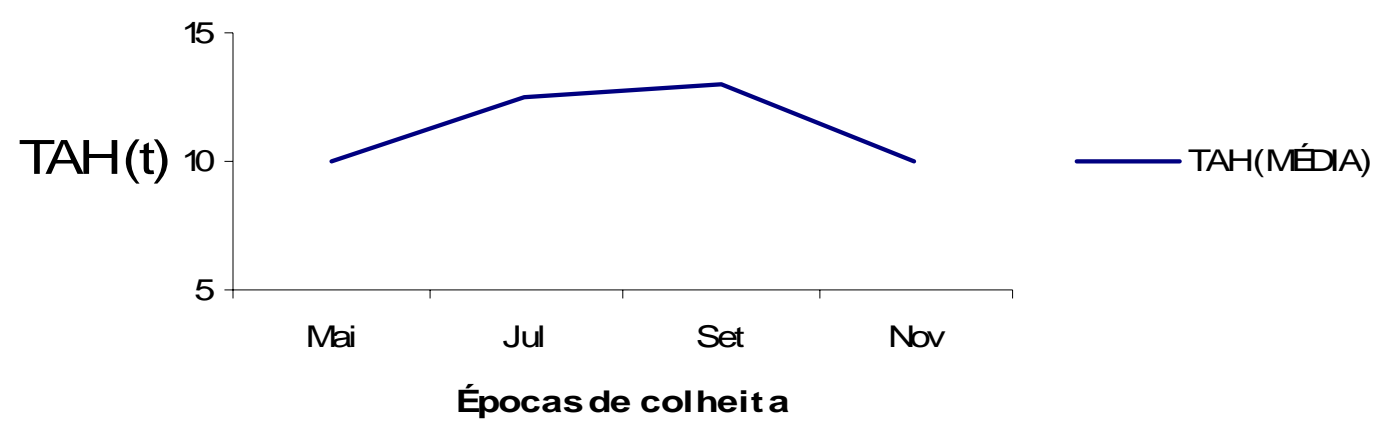

Figura 186 - Resultados de TAH para a variedade SP 71-1406 na safra 1988 , no $2^{\circ}$ corte nas épocas de colheita

Na tabela 96, a seguir, mostram-se os valores médios das safras de 1986, 1987 e 1988, para TCH, ATR e TAH da variedade SP 71-1406, no segundo corte, nas várias combinações de épocas de plantio e de colheita e nos tratamentos muda picada e inteira no sulco de plantio.

Comparando as os resultados ano a ano, observa-se que na safra 86 , ano de plantio 1983/84, houve efeito significativo apenas de épocas de colheita para as variáveis TCH, ATR e TAH. Épocas de plantio e tratamentos (muda picada e inteira no sulco de plantio) não apresentaram efeito significativo para as variáveis estudadas e não houve qualquer efeito de interação.

Na safra 87, ano de plantio 1984/85, também houve efeito significativo somente de épocas de colheita para as variáveis TCH, ATR e TAH. Épocas de plantio e tratamentos (muda picada e inteira no sulco de plantio) não apresentaram efeito significativo para as variáveis estudadas e não houve qualquer efeito de interação

Na safra 88, ano de plantio 1985/86, houve efeito significativo de épocas de colheita para as variáveis TCH, ATR e TAH e, efeito de épocas de plantio para as vaiáveis $\mathrm{TCH}$ e $\mathrm{TAH}$. Tratamentos (muda picada e inteira no 
sulco de plantio) não apresentaram efeito significativo e não houve qualquer efeito de interação

Para os três anos estudados a variedade SP 71-1406, apresentou efeito significativo de época de colheita para as variáveis TCH, ATR e TAH. O efeito de épocas de plantio somente ocorreu na safra 88 para as variáveis TCH e TAH. O tratamento muda picada e inteira no sulco de plantio não apresentou efeito significativo em nenhum dos anos estudados e, não houve qualquer efeito de interação nos três anos estudados.

Em todos os anos estudados, os resultados de ATR sempre evoluíram do início para o final da safra com os picos localizados no mês de setembro e ligeira queda no mês de novembro. TAH sempre acompanhou as curvas de ATR sendo influenciado por TCH.

Para a variedade SP 71-1406 repetiu-se o fato de que no $2^{\circ}$ corte onde as idades foram igualadas, $\mathrm{TCH}$ mostrou-se mais influenciado pelas condições climáticas do ano do que pelo manejo em si. 
Tabela 96. Valores médios de TCH, ATR e TAH para a variedade SP 71-1406, no segundo corte e nas safras de 1986, 1987 e 1988, em várias combinações de épocas de plantio e de colheita e sob os tratamentos muda picada e inteira no sulco de plantio

\begin{tabular}{|c|c|c|c|c|c|}
\hline & & dia das & $\begin{array}{l}1-1406 \\
1986 / 8\end{array}$ & - corte 2 & \\
\hline & & & Rend & & Rend \\
\hline $\mathrm{Ep}$ & Ep & & Cana & & açúcar \\
\hline $\mathrm{PI}$ & Colh & Trat & $(\mathrm{TCH})$ & ATR & $(\mathrm{TAH})$ \\
\hline$\overline{\text { Nov }}$ & Mai & Picada & 84,30 & 107,96 & 9,12 \\
\hline Nov & Mai & Inteira & 81,97 & 107,59 & 8,82 \\
\hline Nov & Jul & Picada & 79,72 & 136,64 & 10,94 \\
\hline Nov & Jul & Inteira & 80,80 & 136,82 & 11,06 \\
\hline Nov & Set & Picada & 80,80 & 160,65 & 12,96 \\
\hline Nov & Set & Inteira & 83,02 & 160,98 & 13,37 \\
\hline Nov & Nov & Picada & 81,51 & 153,78 & 12,56 \\
\hline Nov & Nov & Inteira & 78,03 & 154,38 & 12,06 \\
\hline Jan & Mai & Picada & 84,16 & 107,87 & 9,05 \\
\hline Jan & Mai & Inteira & 84,99 & 108,30 & 9,19 \\
\hline Jan & Jul & Picada & 78,81 & 137,24 & 10,84 \\
\hline Jan & Jul & Inteira & 79,34 & 137,76 & 10,95 \\
\hline Jan & Set & Picada & 88,95 & 159,34 & 14,19 \\
\hline Jan & Set & Inteira & 86,10 & 160,80 & 13,85 \\
\hline Jan & Nov & Picada & 84,81 & 155,18 & 13,17 \\
\hline Jan & Nov & Inteira & 81,05 & 152,91 & 12,43 \\
\hline Mar & Mai & Picada & 86,94 & 107,70 & 9,40 \\
\hline Mar & Mai & Inteira & 89,91 & 107,67 & 9,71 \\
\hline Mar & Jul & Picada & 77,27 & 135,63 & 10,49 \\
\hline Mar & Jul & Inteira & 83,68 & 137,24 & 11,49 \\
\hline Mar & Set & Picada & 88,38 & 161,11 & 14,24 \\
\hline Mar & Set & Inteira & 89,26 & 159,31 & 14,24 \\
\hline Mar & Nov & Picada & 85,54 & 154,14 & 13,20 \\
\hline Mar & Nov & Inteira & 83,11 & 152,26 & 12,67 \\
\hline Mai & Mai & Picada & 87,98 & 107,29 & 9,47 \\
\hline Mai & Mai & Inteira & 91,97 & 109,48 & 10,07 \\
\hline Mai & Jul & Picada & 88,59 & 137,50 & 12,22 \\
\hline Mai & Jul & Inteira & 86,41 & 138,70 & 12,00 \\
\hline Mai & Set & Picada & 88,19 & 162,74 & 14,35 \\
\hline Mai & Set & Inteira & 88,46 & 161,28 & 14,24 \\
\hline Mai & Nov & Picada & 91,35 & 152,62 & 13,87 \\
\hline Mai & Nov & Inteira & 85,38 & 154,02 & 13,17 \\
\hline
\end{tabular}


As figuras 187, 188 e 189, a seguir, mostram, respectivamente, a evolução de TCH, ATR e TAH médias das safras de 1986, 1987 e 1988 para as épocas de plantio e colheita.

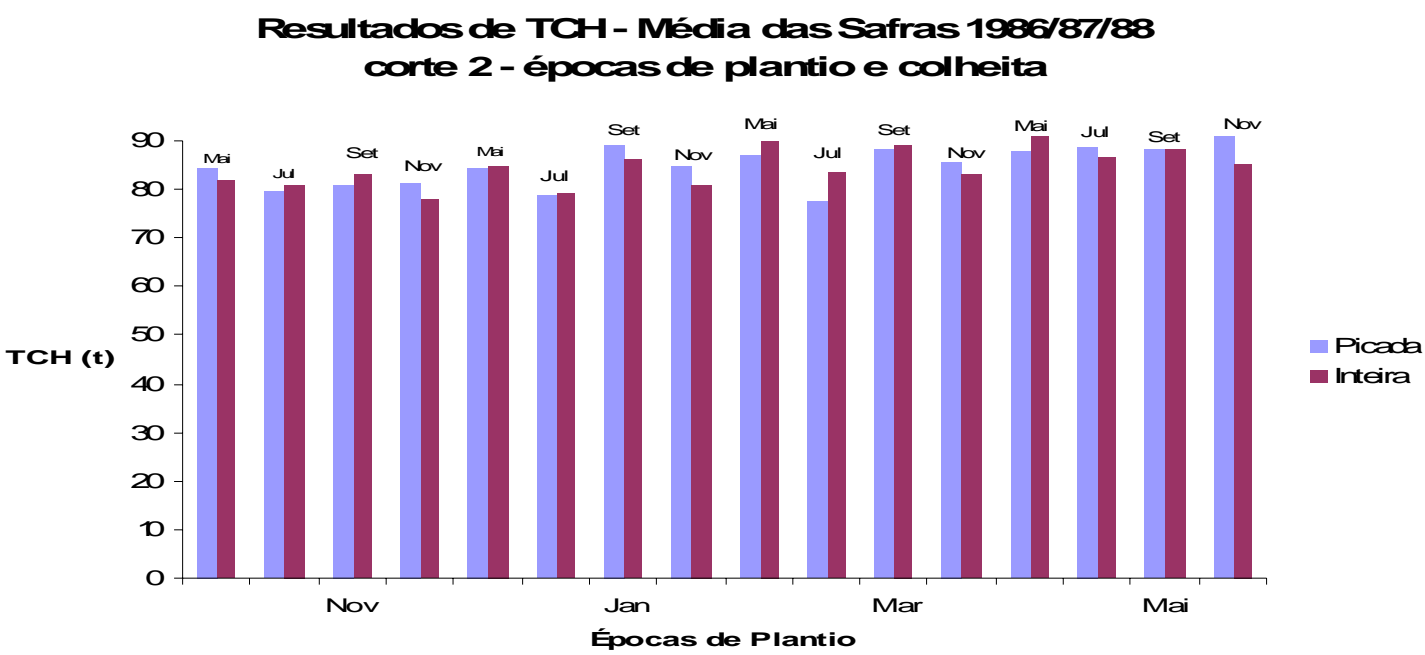

Figura 187 - Resultados médios de TCH para a variedade SP 71-1406 nas safras 1986/87/88, no $2^{\circ}$ corte e nas épocas de plantio e colheita

Resultados de ATR- Média das Safras 1986/87/88 corte 2 - épocas de plantio e colheita

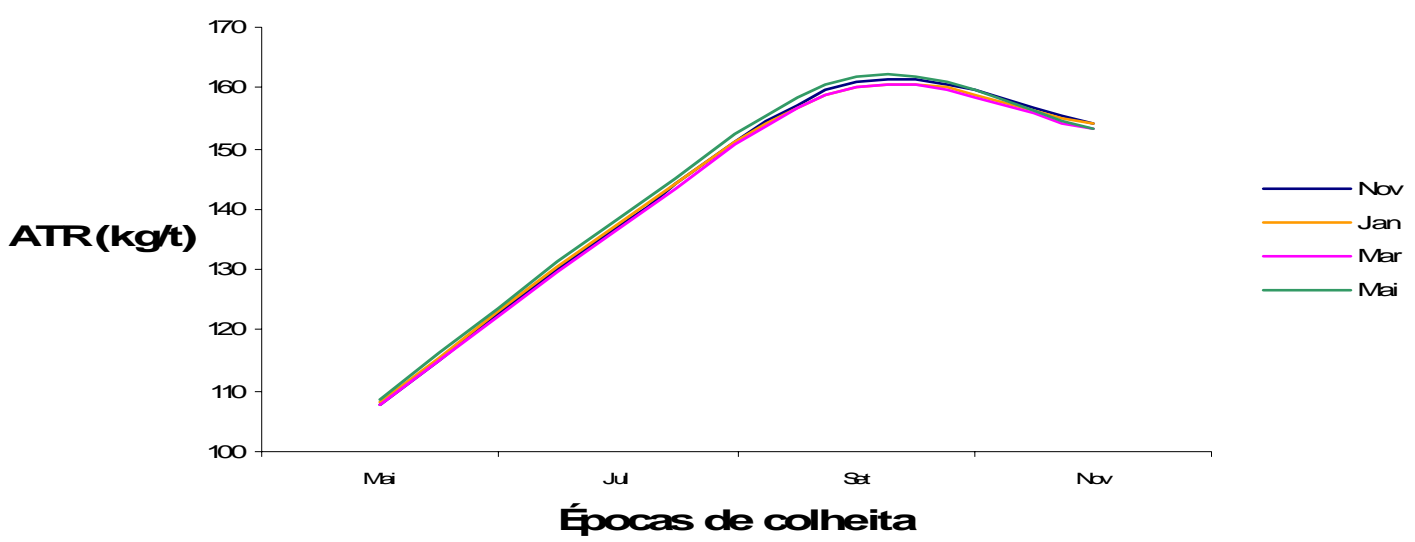

Figura 188 - Resultados médios de ATR para a variedade SP 71-1406 nas safras 1986/87/88, no $2^{\circ}$ corte e nas épocas de plantio e colheita 
Resultados de TAH- Média das Safras 1986/87/88 corte 2 - épocas de plantio e colheita

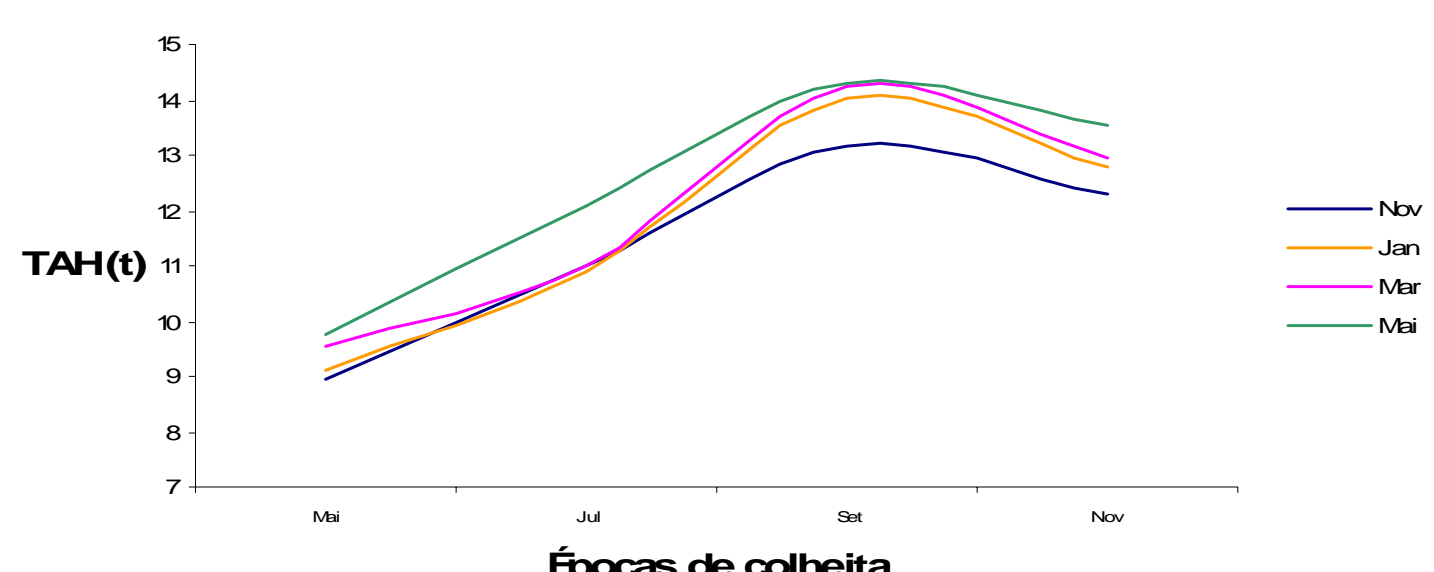

Figura 189 - Resultados médios de TAH para a variedade SP 71-1406 nas safras 1986/87/88, no $2^{\circ}$ corte e nas épocas de plantio e colheita

\subsection{Resumo das variedades SP 70-1143, NA 56-79 e SP 71-1406 - $1^{\circ}$ e $2^{\circ}$ cortes}

As figuras 190 e 191, a seguir, mostram, respectivamente, a evolução de TCH média das variedades SP 70-1143, NA 56-79 e SP 71-1406 no $1^{\circ}$ corte, representando as safras de 1985, 1986 e 1987 e no $2^{\circ}$ corte representando as safras de 1986, 1987 e 1988 para as épocas de plantio e colheita.

Observa-se que entre as variedades estudadas a SP 71-1406 apresentou valores de $\mathrm{TCH}$ superiores no $1^{\circ}$ corte em relação às demais variedades estudadas. As variedades SP 70-1143 e NA 56-79 apresentaram valores de $\mathrm{TCH}$ semelhantes ao longo do estudo. 


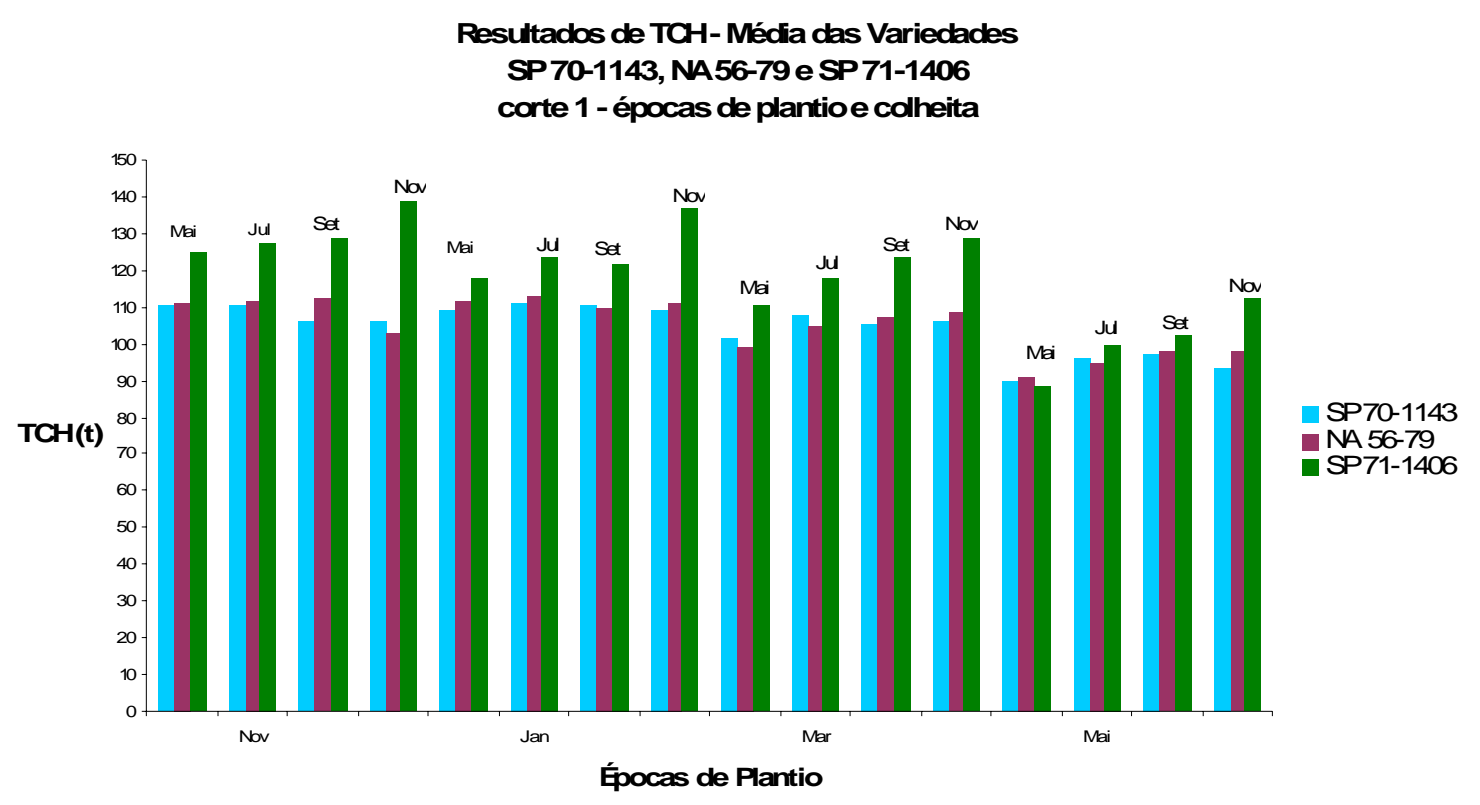

Figura 190 - Resultados médios de TCH média das variedades SP 70-1143, NA 56-79 e SP 71-1406, $1^{\circ}$ corte, safras 1985/86/87, nas épocas de plantio e colheita
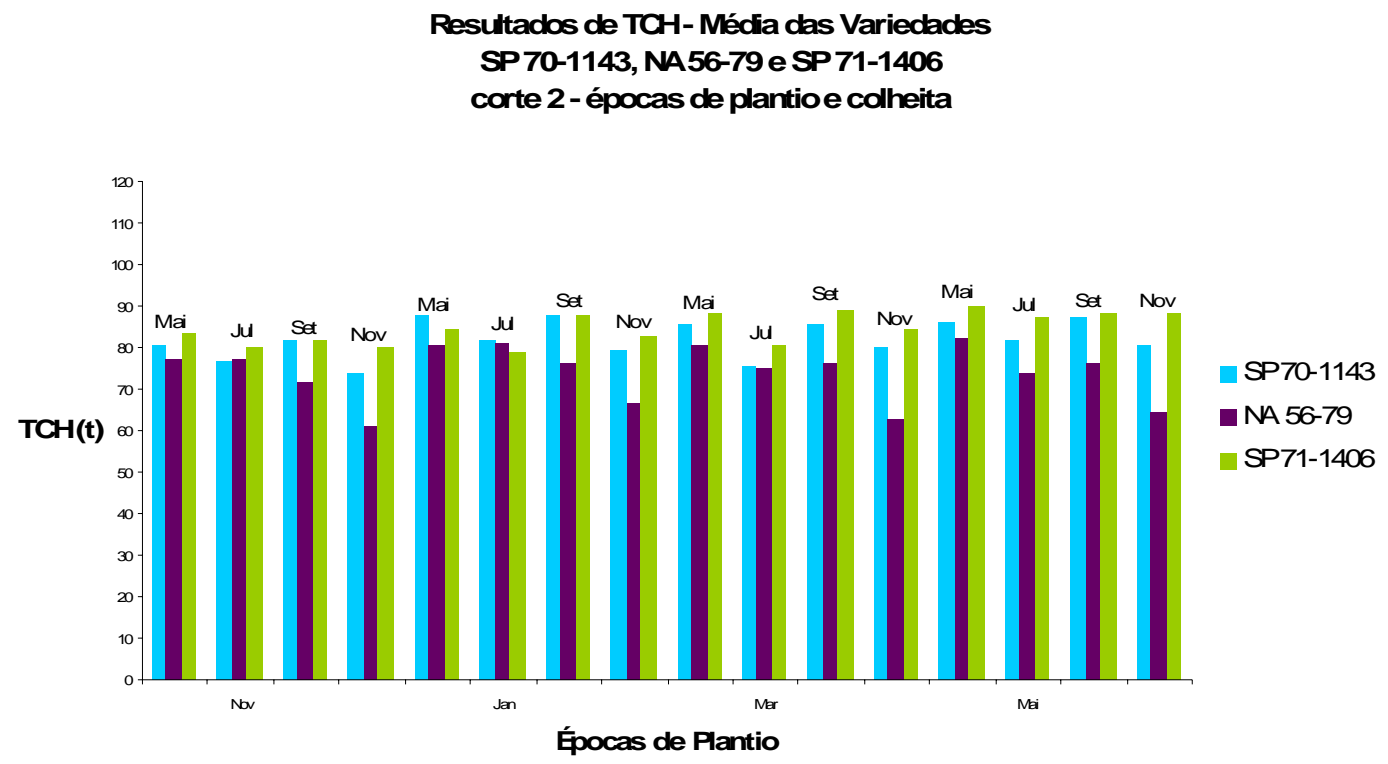

Figura 191 - Resultados médios de TCH média das variedades SP 701143, NA 56-79 e SP 71-1406, $2^{\circ}$ corte, safras 1986/87/88, nas épocas de plantio e colheita 
As figuras 192 e 193 a seguir, mostram, respectivamente, a evolução de ATR média das variedades SP 70-1143, NA 56-79 e SP 71-1406 no $1^{\circ}$ corte, representando as safras de 1985,1986 e 1987 e no $2^{\circ}$ corte representando as safras de 1986, 1987 e 1988 para as épocas de plantio e colheita. Pode-se observar que a variedade NA 56-79 apresenta valores iniciais de ATR mais altos sem no entanto atingir os valores máximos das demais.

\section{Resultados de ATR- Média das Variedades \\ SP70-1143, NA56-79 e SP71-1406 \\ corte 1 - épocas de colheita}

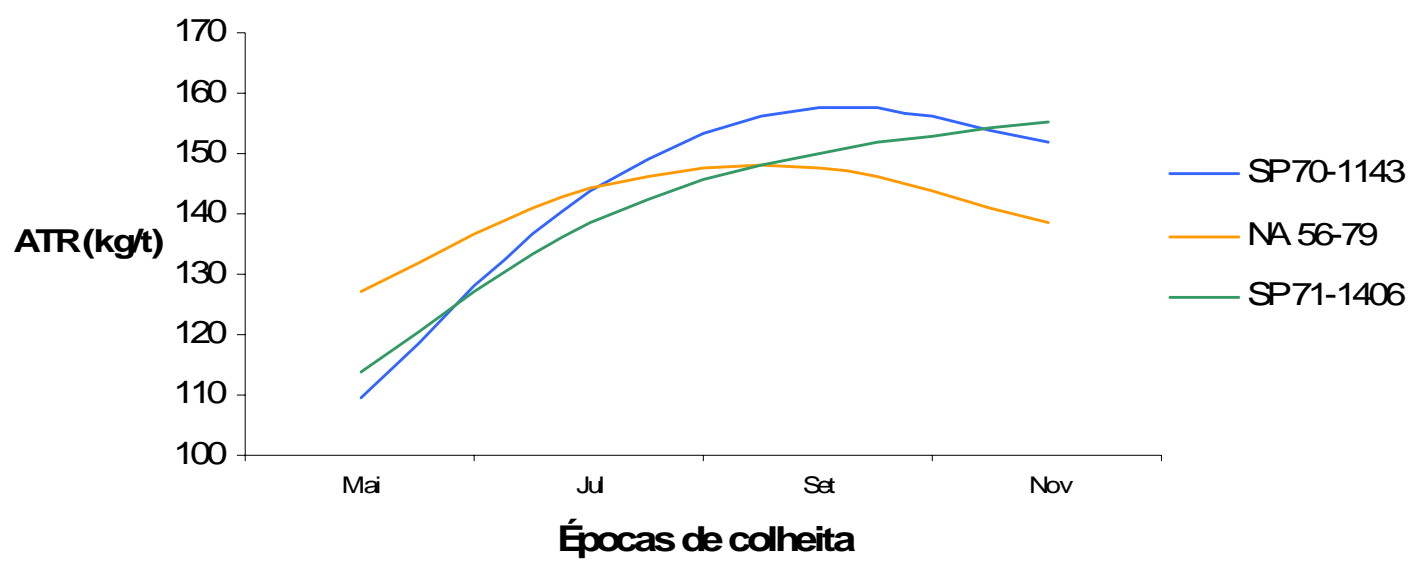

Figura 192 - Resultados médios de ATR para as variedades SP 70-1143, NA 56-79 e SP 71-1406, $1^{\circ}$ corte, safras 1985/86/87, nas épocas de colheita 


\section{Resultados de ATR- Média das Variedades \\ SP 70-1143, NA56-79 e SP 71-1406 \\ corte 2 - épocas de colheita}

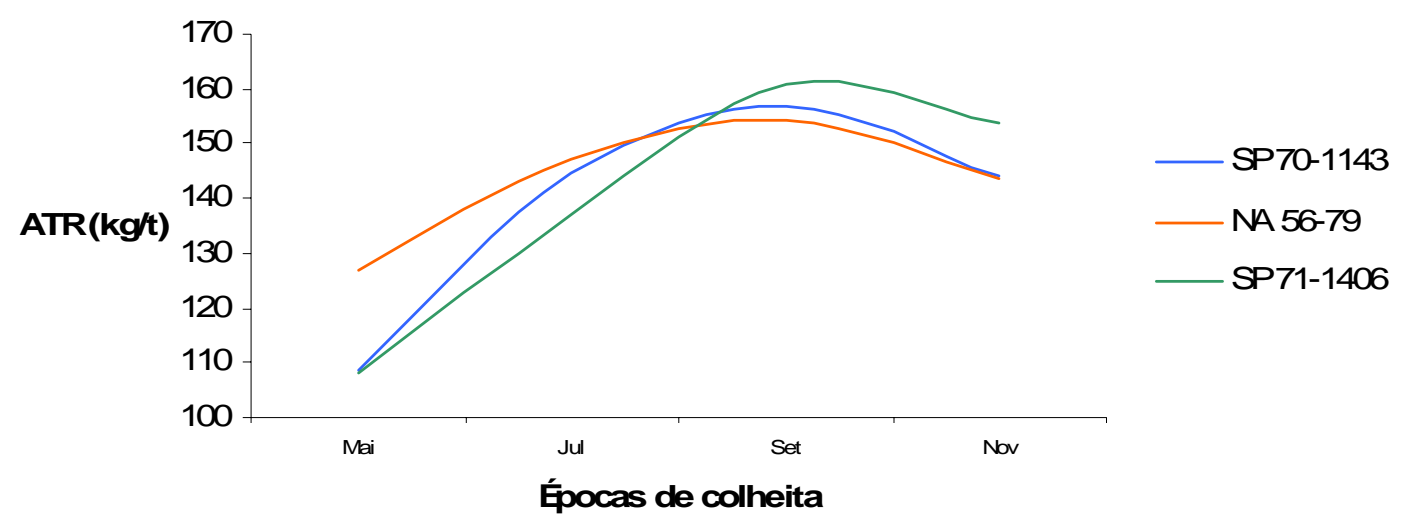

Figura 193 - Resultados médios de ATR para as variedades SP 70-1143, NA 56-79 e SP $71-1406,2^{\circ}$ corte, safras 1986/87/88, nas épocas de colheita

As figuras 194 e 195, a seguir, mostram, respectivamente, a evolução de TAH média das variedades SP 70-1143, NA 56-79 e SP 71-1406 no $1^{\circ}$ corte, representando as safras de 1986, 1987 e 1988 e no $2^{\circ}$ corte representando as safras de 1987, 1988 e 1989 para as épocas de plantio e colheita. A variedade SP 71-1406 apresentou os maiores valores no $1^{\circ}$ corte, principalmente nas épocas de colheita Setembro e Novembro, em função de seu alto desempenho de TCH e ATR. 


\section{Resultados de TAH- Média das Variedades \\ SP 70-1143, NA56-79 e SP 71-1406 \\ corte 1 - épocas de collheita}

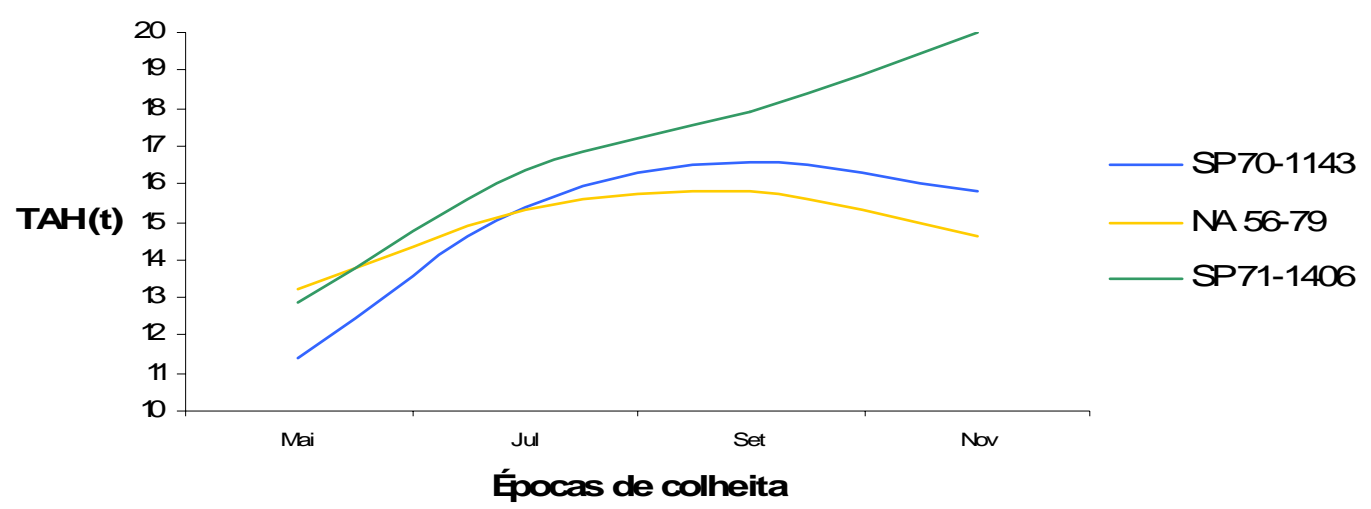

Figura 194 - Resultados médios de TAH para as variedades SP 701143, NA 56-79 e SP 71-1406, $1^{\circ}$ corte, safras 1985/86/87, nas épocas de colheita

\section{Resultados de TAH- Média das Variedades SP 70-1143, NA56-79 e SP 71-1406 corte 2 - épocas de collheita}

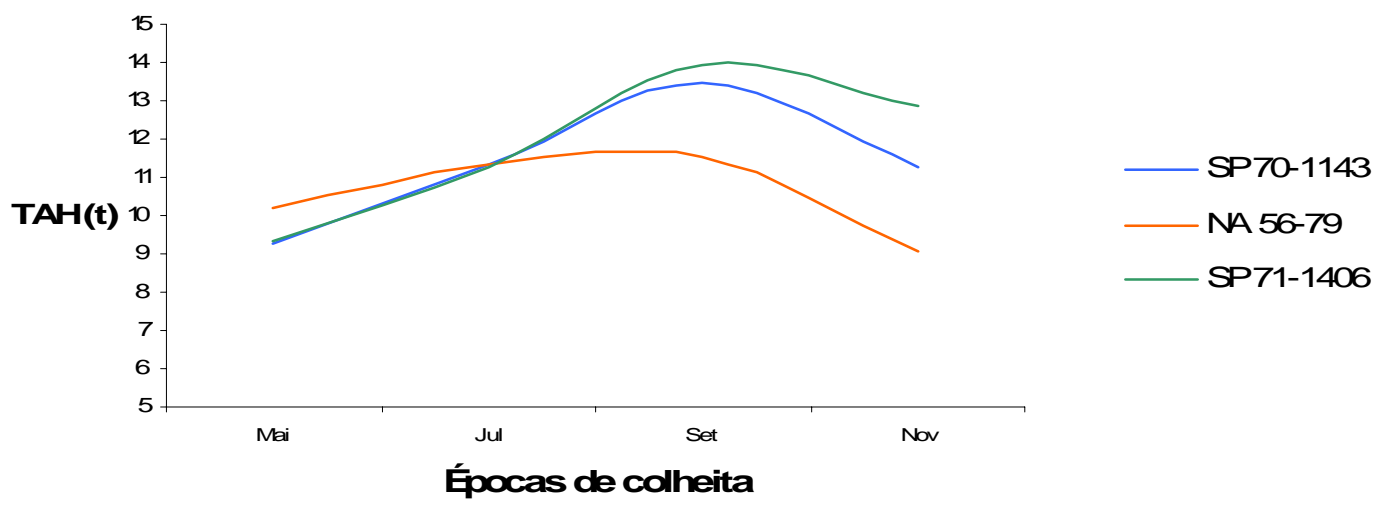

Figura 195 - Resultados médios de TAH para as variedades SP 70-1143, NA 56-79 e SP 71-1406, $2^{\circ}$ corte, safras 1986/87/88, nas épocas de colheita 


\section{CONCLUSÕES}

Épocas de plantio afetaram TCH, ATR e TAH nas canas planta;

Tipo de muda somente afeta a produção na cana planta e em determinadas situações climáticas;

Épocas de corte afetaram TCH pelo tempo de vegetação (idade), ATR pela curva de maturação e TAH como conseqüência das anteriores, nas canas planta e soqueiras;

Plantios tardios atrasam a maturação no primeiro corte;

O clima influencia os resultados de épocas de plantio;

O clima influencia os resultados de tipos de mudas na cana planta para a variedade SP 70-1143;

Para todas as variedades estudadas a época de plantio Maio deve ser evitada;

A variedade NA 56-79 deve ser colhida partir de julho, as demais a partir de Setembro;

A variedade SP 71-1406 foi a única a apresentar resultados superiores com o uso de muda picada, mesmo em épocas adversas;

Os tratamentos estudados não tiveram efeito residual no $2^{\circ}$ corte. 
ANEXOS 


\section{ANEXO A}

\section{Esquema do campo experimental}

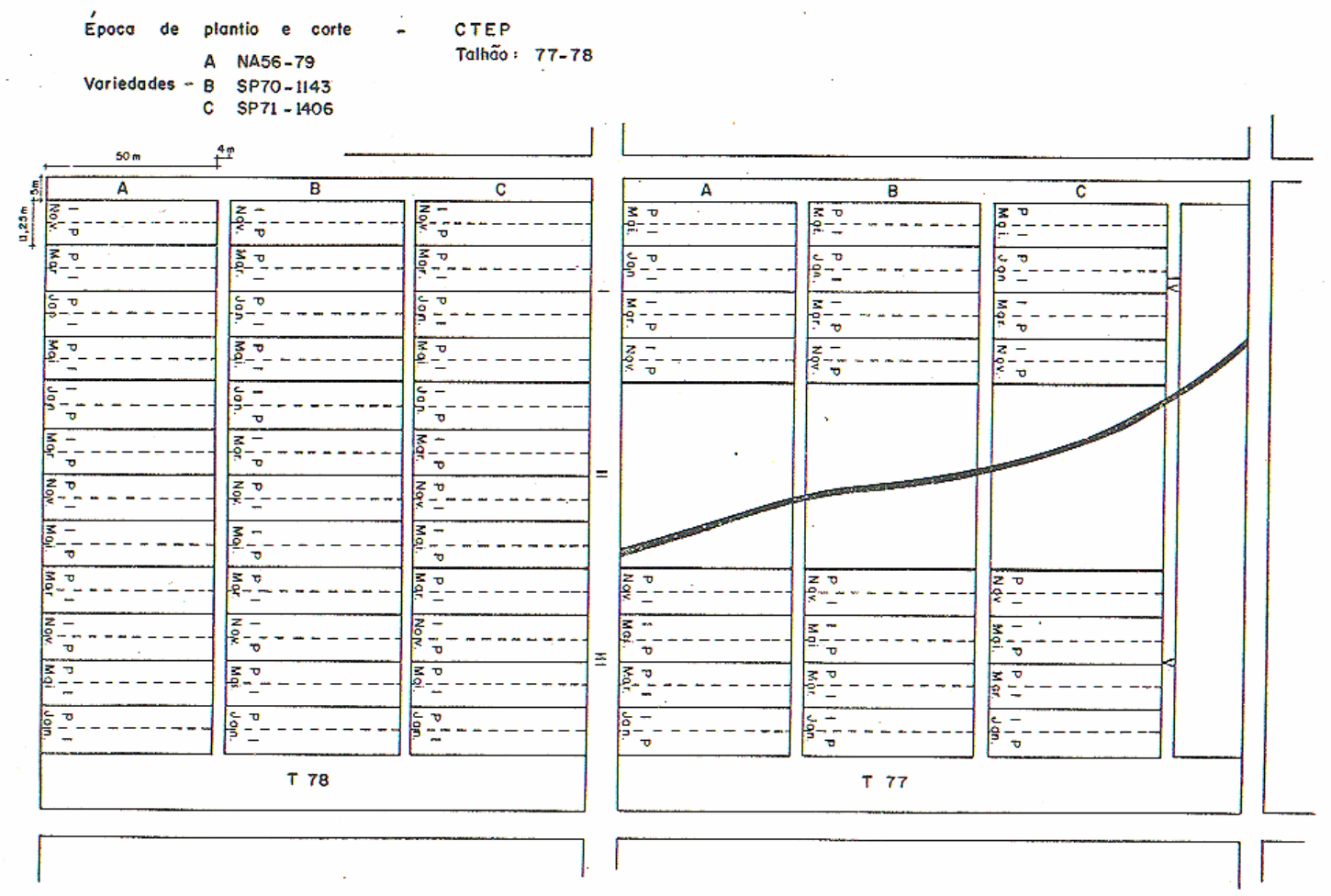




\section{REFERÊNCIAS BIBLIOGRÁFICAS}

AHMED, M. A.; MARIOTTI, J. Caña de azúcar: La época de corte afecta el rendimiento y la producción. Avance Agroindustrial, v. 3, n. 12, p.5-8, 1983.

ALEXANDER, A. G. Sugarcane physiology: a comprehensive study of the Saccharum source-to-sink system. Amsterdam: Elsevier, 1973. 725p.

ARCENAUX, G. Studies of some practical means of increasing the germination of sugarcane under Louisiana conditions. Sugar Bulletin, n. 26, p.389-395, 1948.

BACCHI, O.S. Balanço hídrico no Estado de São Paulo para a cana-deaçúcar. Araras: PLANALSUCAR - Coordenadoria Regional Sul - SP, 1978. $36 p$.

BACCHI, O.S. Geadas: procedimento com a cana-de-açúcar atingida. Piracicaba: PLANALSUCAR - Coordenadoria Regional Sul, 1982. 36p.

BARBIERI, V.; VILLA NOVA, N. A. Climatologia e a cana-de-açúcar. Araras: PLANALSUCAR - Coordenadoria Regional Sul - COSUL. Climatologia, 1977. p. 1-22. 
BARBIERI, V. Condicionamento climático da produtividade potencial da canade-açúcar (Saccharum spp.): Um modelo matemático-fisiológico de estimativa. Piracicaba, 1993. 140p. Tese (Doutorado) - Escola Superior de Agricultura "Luiz de Queiroz", Universidade de São Paulo.

BARNES, A. C. The sugar cane. London: Leonard Hill, 1964. p.210-234: Propagation of the cane.

BASTOS, C. R. et al. Efeito da geada nas características tecnológicas de algumas variedades de cana-de-açúcar. Pesquisa Agropecuária Brasileira, v. 18, n. 6, p. 565-574, 1983.

BEAUCLAIR, E.G.F. de. Relações entre algumas propriedades químicas do solo e a produtividade da cana-de-açúcar (Saccharum spp.), através de regressão linear múltipla. Piracicaba, 1991. 90p. Dissertação (Mestrado) Escola Superior de Agricultura "Luiz de Queiroz", Universidade de São Paulo.

BEAUCLAIR, E.G.F. de. Produtividade da cana-de-açúcar em função de alguns macronutrientes presentes no caldo e no solo. Piracicaba, 1994. 98p. Tese (Doutorado) - Escola Superior de Agricultura "Luiz de Queiroz", Universidade de São Paulo.

BEAUCLAIR, E. G. F. de; PENTEADO, C. R. Cronograma de corte da cana-deaçúcar através da programação linear. In : SEMINÁRIO DE TECNOLOGIA AGRONÔMICA, 2., Piracicaba, 1984. Anais. Piracicaba: Centro de Tecnologia Copersucar, 1984. p. 424 - 434. 
BEAUFILS, E.R. Diagnosis and recommendations integrated system (DRIS); a general scheme for experimentation and calibration based on principles developed from research in plant nutrition. Soil Science Bulletin, v. 1, p. 132, 1973.

BONNET, J. A. Chemical concept about sucrose formation and maturity status of harvested sugarcane in Puerto Rico. Sugar Journal, v. 25, n. 1, p. 45-46, 49-50, 54 e 76, 1962.

BRIEGER, F.O.; PARANHOS, S.B. Técnica cultural. In: INSTITUTO BRASILEIRO DA POTASSA. Cultura e adubação da cana-de-açúcar. São Paulo, 1964. p.138-190.

BRITO, S. A. de. Efeito de tamanhos de toletes e de cana inteira, com e sem desponte, na produção da cana-de-açúcar. Viçosa, 1988. 50p. Dissertação (Mestrado) - Universidade Federal de Viçosa.

CALÇA, S. A.; COLLETTI, L. A.; GLÓRIA, N. A. da. Ciclo da cana - um dos fatores da maior lucratividade da lavoura canavieira. Piracicaba,SP: STAB. Açúcar, Álcool e Subprodutos, v. 6 , n. 1, set/out, p. 9-10, 1983.

CAMARGO, A. P. Contribuição para a determinação da evapotranspiração potencial no Estado de São Paulo. Bragantia, v. 21, n. 12, p. 163-213, 1962.

CAMARGO, P. N. Fisiología de la caña de azúcar. Serie Divulgación Técnica, v. 1, n. 6., p. 1-60, 1976.

CASTRO, P. R. C. Maturadores químicos em cana-de-açúcar. In: SEMANA DA CANA-DE-AÇÚCAR DE PIRACICABA, 4., Piracicaba, 1999. Anais. Saccharum, v. 1, p. 12-16, 1999. 
CHANG, H.; WANG, J. S., HO, F. W. The effect of different pan ratio for controlling irrigation of sugarcane in Taiwan. In: INTERNATIONAL SOCIETY OF SUGAR CANE TECHNOLOGISTS, 13., Formosa, 1968. Proceedings. Formosa: Lianjing, 1968. v. 13, p. 652-663.

CHEN, R. S.; TSE, C. G. Effect of planting time and planting density on the yield of plant and ratoon of autumn-planted sugarcane. Report of Taiwan Sugar Research Institute. v. 16, n. 1, p. 20-23, 1969.

CHOW, N. P. Number of buds per seed piece in relation to germination, growth and yield of sugarcane. Report of Taiwan Sugar Research Institute. n. 5, p. 91-108, 1949.

CLEMENTS, H. F. Factors affecting the germination of sugar cane. Hawaiian Planters Record, v. 44, p. 117-146, 1940.

CONSELHO DOS PRODUTORES DE CANA-DE-AÇÚCAR, AÇÚCAR E ÁLCOOL DO ESTADO DE SÃO PAULO. Manual de instruções. ConsecanaSP, Piracicaba, SP: CONSECANA, 2002. 120p.

COOPERATIVA CENTRAL DOS PRODUTORES DE AÇÚCAR E ÁLCOOL DO ESTADO DE SÃO PAULO. Amostragem e análise da cana-de-açúcar. São Paulo, 1980. 37 p.

COOPERATIVA CENTRAL DOS PRODUTORES DE AÇÚCAR E ÁLCOOL DO ESTADO DE SÃO PAULO. Controle de produção integrado aplicado à canade-açúcar: Sistema Copi. In: SEMINÁRIO DE TECNOLOGIA AGRONÔMICA 1., Piracicaba, 1982. Anais. Piracicaba: Copersucar,1982. p. 193-209. 
COOPERATIVA CENTRAL DOS PRODUTORES DE AÇÚCAR E ÁLCOOL DO ESTADO DE SÃO PAULO. Variedades SP: recomendações e manejo. In: REUNIÃO TÉCNICA COPERSUCAR: Variedades de cana-de-açúcar e suas implicações na lavoura canavieira. São Paulo: Copersucar, 1983. p. 44-56.

DOOREMBOS, J.; PRUITT, W. O. Crop water requirements. Rome: FAO, 1975. 179p. (FAO. Irrigation and Drainage Paper, 24).

DOOREMBOS, J.; KASSAM, A. H. Efectos del agua sobre el rendimiento de los cultivos. Roma: FAO, 1979. 212p. (FAO. Riego y Drenaje, 33).

EMPRESA BRASILEIRA DE PESQUISA AGROPECUÁRIA. Centro Nacional de Pesquisa e solos. Sistema brasileiro de classificação de solos. Brasília: Embrapa Produção de Informação; Rio de Janeiro: Embrapa Solos, 1999. $412 p$.

FAUCONIER, R.; BASSEREAU, D. La caña de azúcar. Barcelona: Blume, 1975. 433p.

FERNANDES, A. C.; FURCO, A. M. Deterioração de cana-de-açúcar após a geada de 1981. Boletim Técnico Copersucar, n. 24, p. 5-12, 1983.

FERRARI, S.E. Comportamento da variedade de cana-de-açúcar CB 41-76, atingida pela geada com relação à qualidade tecnológica e à fermentação alcoólica. Saccharum, v. 7, n. 33, p. 34-8, 1984.

FNP CONSULTORIA E COMÉRCIO. AGRIANUAL 99: anuário da agricultura brasileira. São Paulo, 1999. 413 p. 
GASCHO, G. J.; SHIH, S. F. Sugarcane. In: TEARE, I. D.; PEET, M. M. (Ed.). Crop-water relations. New York: John Wiley, 1983. p. 445-479.

GEMENTE, A .C.; PINAZZA, A. H.; BRUGNARO, C.; GUIMARÃES, E.; OLIVEIRA NETO, G. R. de; KRUGLIANSKAS, I.; SBRAGIA, R. Planejamento agrícola. In: BRUGNARO, C.; SBRAGIA, R. Gerência agrícola em destilarias de álcool. 2. ed. Piracicaba: IAA/PLANALSUCAR, 1986. p. 29-83 (Coleção PLANALSUCAR, 1).

GHELLER, A. C. A. Fatores que afetam o desempenho de maturadores e reguladores de crescimento em cana-de-açúcar. In: SEMANA DA CANA-DEAÇÚCAR DE PIRACICABA, 4., Piracicaba, 1999. Anais. Piracicaba: Saccharum, 1999. p. 16-19.

GHELLER, A. C. A. Técnica para o controle da podridão abacaxi em cana-deaçúcar e modelo para a estimativa de perdas. Piracicaba, 1995. 115p. Dissertação (Mestrado) - Escola Superior de Agricultura "Luiz de Queiroz", Universidade de São Paulo.

HARTT, C. E. Effects of moisture supply upon translocation and storage of $\mathrm{C}^{14}$ in sugarcane. Plant Physiology, v. 42, p. 338-346, 1967.

HARTT, C. E.; BURR, G. O. Factors affecting photosynthesis in sugarcane. INTERNATIONAL SOCIETY OF SUGAR CANE TECHNOLOGISTS, 12., 1967. Proceedings, Cartegena de Indias: Celam, 1967. p. 590-609.

HSIAO, T. C. Plant response to water stress. Plant Physiology. n. 24, p. 519$570,1973$. 
HSU, E. R. H.; KAO, Y. C. Review of sugarcane planting using whole stalk seed cane in Huwei District Sugar Factory. Journal of the Agricultural Association of China. v. 115, p. 42-50, 1981.

HUMBERT, H. P. The growing of sugarcane. Amsterdam: Elsevier, 1968. $779 p$.

IDE, B. Y.; BANCHI, A. D. Influência do clima na produtividade da cana-deaçúcar. In: SEMINÁRIO DE TECNOLOGIA AGRONÔMICA, 2., Piracicaba, 1984. Anais. São Paulo: COPERSUCAR, 1984. p. 196-204.

IDE, B. Y.; OLIVEIRA, M. A. de. Efeito do clima na produção da cana-de-açúcar. In: SEMINÁRIO DE TECNOLOGIA AGRONÔMICA, 3., Piracicaba, 1986. Anais. São Paulo: COPERSUCAR, 1986. p. 573-583.

KANWAR, R. S.; SHARMA, H. L.; AULAKH, M. S. Effect of piece size on germination and yield of sugar cane. Sugar News, v. 6, n.9, p.3-11, 1975.

LEE, T. S. G. Efeitos e procedimentos com a cana-de-açúcar atingida pela geada antes da maturação. Saccharum, v.6, n.28, p. 12-19, 1983.

LEE, T. S. G. Efeito do plantio de cana inteira na germinação, no desenvolvimento e na produção de cana-de-açúcar. Cadernos Planalsucar, v.3, n.1. p.13-23, 1984.

LEE, T. S. G.; SILVA, M. R. Pré-tratamento para plantio de cana inteira. Brasil Açucareiro, v.105, n.4,5/6. p.8-12. 1987. 
LEE, T. S. G.; MARTINS, J.; MATSUOKA, S.; MAGALHÃES, P. M.; CASTILHO, H. J.; FURLANI NETO, V. L. Plantio de cana inteira - Viabilidade e recomendações. STAB. Açúcar, Álcool e Subprodutos, v.2, n.6. p.10-11, 1984.

LEE, T. S. G.; MARTINS, J.; MATSUOKA, S.; MAGALHÃES, P. M.; CASTILHO, H. J.; FURLANI NETO, V. L. Plantio de cana inteira: viabilidade e recomendações. Saccharum, v. 9, n.43, p.20-23, 1986.

LiMA, A. F. P. de; CASAGRANDE, A. A.; BARBOSA, J. C.;NEME, L. H. Comportamento de variedades de cana-de-açúcar, no município de Dumont$\mathrm{SP}$, com a ocorrência de déficits hídricos no período de desenvolvimento. STAB. Açúcar, Álcool e Subprodutos, v. 9, n. 12. p. 31-38, set/dez. 1990.

LONSDALE, J. E. Planting depth and seed material for establishment of sugarcane. In: CONGRESS OF THE INTERNATIONAL SOCIETY OF SUGARCANE TECHNOLOGISTS, 16., São Paulo, 1978. Proceedings. São Paulo: ISSCT, 1978. v.2, p.945-961.

LONSDALE, J. E.; GOSNELL, J. M. Growth and quality of four sugarcane varieties as influenced by age and season. In: ANNUAL CONGRESS SOUTH AFRICAN TECHNOLOGISTS ASSOCIATION, 50., Mount Edgecombe, 1976. Proceedings. Mount Edgecombe: Wendell, 1976. p.1-5.

MA, Y. C. Planting the whole stalk seed cane TSC plantation. Report of Taiwan Sugar Research Institute, v. 27, n.4, p.130, 1980.

MACHADO, E. C. Fisiologia da produção da cana-de-açúcar. Crescimento. In: PARANHOS, S. B. Cana-de-açúcar: cultivo e utilização. Campinas: Fundação Cargill, 1987. v. 1, p. 56-87. 
MAGALHÃES, A. C. N. Ecofisiologia da cana-de-açúcar: aspectos do metabolismo do carbono na planta. In: CASTRO, P. R. C.; FERREIRA, S. O.; YAMADA, T. (Ed.). Ecofisiologia da produção agrícola. Piracicaba: Potafós, 1987. p. 113-118.

MAIA, N. B.; BEAUCLAIR, E. G. F. Utilização da metodologia do sistema copi na determinação dos fatores limitantes da produtividade. In: SEMINÁRIO DE TECNOLOGIA AGRONÔMICA, 2., Piracicaba, 1984. Anais. São Paulo: Copersucar, 1984. p. 151-161.

MALAVOLTA, E., HAAG, H. P. Fisiologia. In: INSTITUTO BRASILEIRO DE POTASSA. Cultura e adubação da cana-de-açúcar. São Paulo, 1964. p.221-236.

MENDES, A.; GIÚDICE, R. M. del; MARCIANO, N.;THIÈBAUT, J. T. L.; VIEIRA, J. M.; TELES, F. F. F. Estudo da viabilidade de ampliação do período de safra da cana-de-açúcar para a produção de etanol. STAB. Açúcar, Álcool e Subprodutos, v. 5, n. 3. p. 50-53, jan/fev., 1987.

MENDONÇA, J. R. de. Efeito da geada de julho de 1981 nas características tecnológicas da diferentes variedades e clones de cana-de-açúcar. Boletim Técnico Copersucar, n.24, p. 16-21, 1983.

MENDONÇA, J. R. de; NOCITI, P. R. H.; DEOTTI, R. C. Estudo de diferentes épocas de corte em cana-de-açúcar. In: SEMINÁRIO DE TECNOLOGIA AGRONÔMICA, 2., Piracicaba, 1984. Anais. Piracicaba: Centro de Tecnologia Copersucar, 1984. p. 140-149. 
MONGELARD, J. C.; NICKELL, J.W.; GASCHO, G.J. The sugar cane in the soils plant - atmosphere continuum. In: CONGRESS OF THE INTERNATIONAL SOCIETY OF SUGARCANE TECHNOLOGISTS, 14., Louisiana, 1971. Proceedings. Louisiana: ISSCT, 1971. p. 827-840.

MOURÃO, M. G. Influência do período de armazenamento das mudas e do número de gemas por toletes na produção da cana-de-açúcar (Saccharum sp.), 1 corte. Lavras, 1991. 48p. Dissertação (Mestrado) - Escola Superior de Agricultura de Lavras.

NAQVI, H. A.; QAYYUM, R. Effect of drought on sugarcane. Integral Sugar Journal, v.75, p. 168-9, 1973.

NASCIF, A. E.; TULLER, V. V.; SOUZA, D.; AZEVEDO, A. J. Influência da época de plantio e corte no rendimento agroindustrial da cana-de-açúcar. In: CONGRESSO NACIONAL DA STAB, 2., Rio de Janeiro, 1981. Anais. Rio de Janeiro: STAB, 1981. p. 230-46.

NICKELL, L. G. Water utilization. Basic plant water studies. In: INTERNATIONAL SOCIETY OF SUGAR CANE TECHNOLOGISTS, 13., Formosa, 1968. Proceedings. Formosa: Lianjing, 1968. p. 38-48.

NUNES JÚNIOR, S. M.; SCHOUCHANA, D. T. Determinação do valor econômico de variedade de cana-de-açúcar em função das épocas de corte e das distancias da Usina. Boletim Técnico Copersucar, n. 25, p.2-10, 1984.

OMETTO, J.C. An equation for the estimation of agro-industrial sugarcane yield in the Piracicaba region. In: INTERNATIONAL SOCIETY OF SUGAR CANE TECHNOLOGISTS CONGRESS, 16., São Paulo, 1978. Anais. São Paulo: Editora Ceres, 1978. p.899-905. 
OMETTO, J. C. Parâmetros meteorológicos e a cultura da cana-de-açúcar. Piracicaba: ESALQ. 1980. 17p.

OMETTO, J.C. Bioclimatologia Vegetal. São Paulo: Editora Ceres, 1981, $440 p$.

ORLANDO FILHO, J. Nutrição e adubação de cana-de-açúcar no Brasil. Piracicaba: Instituto do Açúcar e do Álcool/Planalsucar, 1983. 369 p.

ORTOLANI, A. A.; PAES de CAMARGO, M. B. Influência dos fatores climáticos na produção. In: CASTRO, P. R. C.; FERREIRA, S. O.; YAMADA, T. (Ed.) Ecofisiologia da produção agrícola. Piracicaba: Associação Brasileira para a Pesquisa da Potassa e do Fosfato, 1987. p. 71-79.

PANJE, R. R.; GILL, P. S.; SINGH, B. Studies on germination of sugarcane; gradients and interations in the germination of buds. In: CONGRESS INTERNATIONAL SOCIETY OF SUGAR CANE TECHNOLOGISTS, 11., Mauritius, 1962. Proceedings. Mauritius: ISSCT, 1962. p. 267-273.

PAO, T. P., SHIAH, F. Y. A study of the effect of the orientation of the setts on the germination characteres of sugarcane. I seed bed investigation. Report of the Taiwan Sugar Experimental Statistics. n.22, p. 1-50, 1960. Resumo em Horticultural Abstracts, v.32, n.1, p.256, 1962.

PARANHOS, S.B. (Coord.). Cana-de-açúcar: cultivo e utilização. Campinas: Fundação Cargill, 1987. v.2, 856p.

PENNMAN, H. L. Natural evaporation from open water, bare soil and grass. THE ROYAL SOCIETY, London, 1948. Proceedings, p.120-146. 
PINAZZA, A.H. Implicações da gerência agrícola nas usinas e destilarias. Brasil Açucareiro, v. 103, p.26-27, 1985.

PIRES, C. E. L. S.; BARBOZA, G. P.; FARIAS, S. O.;MELO, M. M. Influência da época de colheita na qualidade da variedade de cana-de-açúcar RB 72454 florescida. STAB. Açúcar, Álcool e Subprodutos, v. 6, n. 2, p. 36-38, nov/dez. 1987.

PLANA, R.; DOMINI, M. E.; ESPINOSA, R. Influencia de las precipitaciones y la temperatura sobre la brotadura de dos variedades de caña de azucar (Saccharum sp híbrido) plantadas en diferentes meses. Cultivos Tropicales. v.9, n.3, p. 19-24, 1987.

QUINTELA, A. C. R. Avaliação do plantio convencional e de cana inteira, com e sem desponte, e da compactação pós-cobertura, em duas variedades de cana-de-açúcar. Lavras, 1996. 37p. Dissertação (Mestrado) - Universidade Federal de Lavras.

RICAUD, R. B.; COCHRAN, M. Methods of planting sugarcane for sugar and biomass production in Louisiana. In: CONGRESS OF INTERNATIONAL SOCIETY OF SUGAR CANE TECHNOLOGYSTS, 17., Lousiana, 1980. Proceedings. Lousiana: ISSCT, 1980. p. 118-120.

ROCHA, A. M. C. Emergência, perfilhamento e produção da cana-de-açúcar (Saccharum spp.) em função das épocas de plantio no Estado de São Paulo. Piracicaba, 1984. 138p. Dissertação (Mestrado) - Escola Superior de Agricultura "Luiz de Queiroz", Universidade de São Paulo. 
ROSENFELD, U.; LEME, F. J. A. Produtividade da cana-de-açúcar irrigada por aspersão: estudo de épocas de irrigação. In: CONGRESSO NACIONAL DA STAB, 3., São Paulo, 1984. Proceedings. São Paulo: STAB, 1984. p. 18.

SANTOS, A. M. C. Emergência, perfilhamento e produção de colmos de canade-açúcar (Saccharum sp.), em função das épocas de plantio no Estado de São Paulo. Piracicaba, 1983. 154p. Dissertação (Mestrado) - Escola Superior de Agricultura "Luiz de Queiroz", Universidade de São Paulo.

SEGALLA, A. L.; OLIVEIRA, H. D.; POMER, C. V.; SPIRONELO, A.; BASTOS, C. R. Determinação do período de colheita de variedades de cana-de-açúcar através de suas curvas de maturação. In: CONGRESSO NACIONAL DA STAB, 2., Rio de Janeiro, 1981. Anais. Rio de Janeiro: STAB, 1981. p.227245.

SEGALLA, A. L.; TOKESHI, H. Variedades de cana-de-açúcar para o Brasil; adaptação e recomendação das variedades de cana-de-açúcar para as diversas regiões do País. Brasil Açucareiro. v. 98, n. 6, p. 34-40, 1981.

SHAW, M. E. A.; INNES, R. F. The growth pattern and yield of annual cane planted at different seasons and effects of nitrogen treatments. In: CONGRESS INTERNATIONAL SOCIETY OF SUGAR CANE TECHNOLOGISTS, 12., San Juan, 1965. Proceedings. Amsterdam: ISSCT, 1965. p.401-428.

SILVA, G.L.S.P. da. Efeitos das condições do tempo sobre a produtividade da cana-de-açúcar no Estado de São Paulo. STAB. Açúcar, Álcool e Subprodutos, v.5, n.1. p.19-24, 1986. 
SINGH, H.; SINGH, H. Seasonal planting of sugarcane in Punjab (India). In: CONGRESS INTERNATIONAL SOCIETY OF SUGAR CANE TECHNOLOGISTS, 9., New Delhi, 1956. Proceedings, New Delhi: ISSCT, 1956. p. 283-301.

STOLF, R. Transplantio de soqueira de cana-de-açúcar como técnica de renovação da cultura. Piracicaba, 1983. 100p. Tese (Doutorado) - Escola Superior de Agricultura "Luiz de Queiroz", Universidade de São Paulo.

STOLF, R. Metodologia de avaliação de falhas nas linhas de cana-de-açúcar. STAB. Açúcar, Álcool e Subprodutos, v. 4, n. 6, p. 22-36, 1986.

STOLF, R.; IAIA, A. M.; LEE, T. S. G. Índice de falha segundo o método de STOLF; correlação com rendimento agrícola em cana planta. Brasil Açucareiro, v.104, n.5/6, p. 44-50, 1986.

STOLF, R.; IAIA, A. M.; LEE, T. S. G. Índice de falha segundo o método de STOLF; correlação com rendimento agrícola em cana planta. Álcool \& Açúcar, v.11, n.58, p. 12-16, 1991.

THOMPSON, G. D. Water use by sugarcane. South African Sugar Cane Journal, v. 60, n. 11, p.592-600 e n.12, p.627-635, 1976.

THORNTHWAITE, C. W.; MATHER, J. R. The water balance. Centerton: Drexel Institute of Technology, 1955. 104p.

TOMER, P. S. Better germination of sugar cane and high yield. Indian Sugar, v.18, n.10, p. 765-766, 772, 1969. 
VAN DILLEWIJN, C. Botany of sugarcane. Waltham: The Chronica Botanica, 1952. $371 \mathrm{p}$.

VILLA NOVA, N. A.; PEDRO JÚNIOR, M. J.; PEREIRA, A. R.; OMETTO, J. C. Estimativa de graus-dia acumulados acima de qualquer temperatura base, em função das temperaturas máxima e mínima. Caderno de Ciência da Terra, n.30, p. 8, 1972.

WALDRON, J. C.; GLASZIOU, K. T.; BULL, T. A. The physiology of sugar cane. IX. Factors affecting photosynthesis and sugar storage. Australian Journal of Biological Sciences, v. 20, n.6, p. 1043-52, 1967.

WOOD, R. A. Cane deterioration as affected by billet size, delay in milling and other factors. SOUTH AFRICAN, SUGAR TECHNOLOGISTS ASSOCIATION, 50., 1976. Tropical Agricultive, v.3, n.2, p.134, 1987.

WORDEN, W. W. Experimental one-eye seed cutter. Sugar News, v.39, n.10, p.650-652, 1962.

YANG, P. C.; LO, C. C.; HO, F. C.; YIN, S. A. A study of planting whole-stalk seed cane, its germination, growth and sugar cane yield. Report of Taiwan Sugar Research Institute, n.94, p.19-32, 1981.

ZAMBELLO JÚNIOR, E.; ORLANDO FILHO, J. Diagnosis and recommendations integrated system (DRIS) applied to various sugarcane tissues. In: CONGRESS INTERNATIONAL SOCIETY OF SUGAR CANE TECHNOLOGISTS, 17., Manila, 1980. Proceedings, Manila: ISSCT, v. 1, p. 446-57. 